Universidade de São Paulo

Faculdade de Filosofia, Letras e Ciências Humanas

Departamento de História

Programa de Pós-Graduação em História Social

\title{
Confrontos políticos e redes de sociabilidade, Bahia (1821-1823)
}

\author{
Argemiro Ribeiro de Souza Filho
}

Orientadora: Prof ${ }^{a}$. Dr ${ }^{\mathrm{a}}$. Miriam Dolhnikoff

São Paulo - SP

2010 
Universidade de São Paulo

Faculdade de Filosofia, Letras e Ciências Humanas

Departamento de História

Programa de Pós-Graduação em História Social

\section{Confrontos políticos e redes de sociabilidade, Bahia (1821-1823)}

\section{Argemiro Ribeiro de Souza Filho}

Tese apresentada ao programa de pós-graduação em História Social do Departamento de História da Faculdade de Filosofia, Letras e Ciências Humanas da Universidade de São Paulo, para obtenção do título de Doutor em História.

Orientadora: Prof ${ }^{a}$. Dr ${ }^{\mathrm{a}}$. Miriam Dolhnikoff

São Paulo - SP 
Autorizo a reprodução e divulgação total ou parcial deste trabalho, por qualquer meio convencional ou eletrônico, para fins de estudo e pesquisa, desde que citada a fonte.

Catalogação na Publicação

Serviço de Biblioteca e Documentação

Faculdade de Filosofia, Letras e Ciências Humanas da Universidade de São Paulo

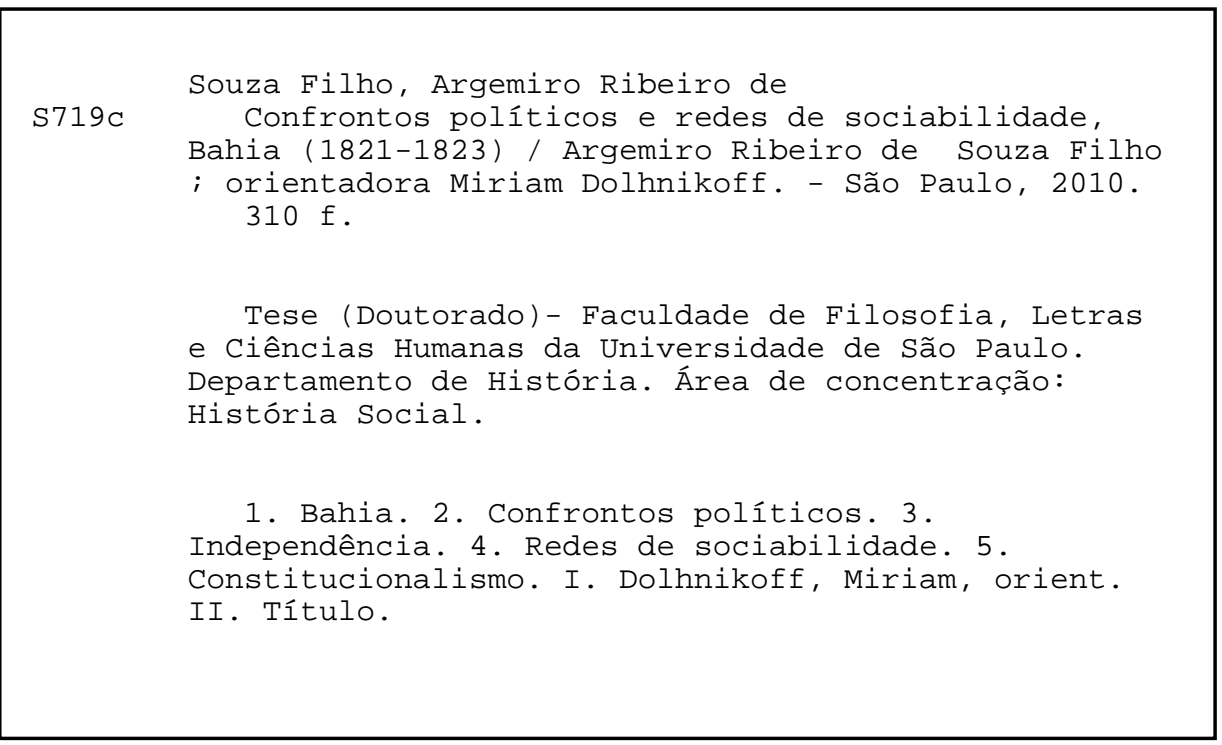




\section{Resumo}

A pesquisa discute as amplas alterações políticas ocorridas na província da Bahia nos anos 1821-1823 decorrentes da crise do Antigo Regime português na América. Com base em fontes documentais e bibliográficas, procura-se reafirmar que a materialização da conjuntura crítica em território luso-americano adquiriu desdobramentos específicos em suas várias partes, cujos habitantes passaram a experimentar formas de organização e de participação condizentes com uma nova cultura política difundida no período. No caso da Bahia, as condições peculiares de organização político-econômica possibilitaram distintas percepções de encaminhamento da crise. Em função disso, diferentes alternativas foram apresentadas como expressão de projetos individuais ou coletivos em busca da realização de anseios até então contidos pelas autoridades da monarquia de Bragança. Os desafios vivenciados na província durante a Guerra de Independência (1822-1823) não somente serviram como aprendizado político para os habitantes, como também propiciou que alguns deles se tornassem lideranças importantes na construção do Estado imperial. Dessa maneira, o estudo propõe investigar os variados caminhos percorridos por uma parte da classe dominante oriunda da província baiana na montagem de um arranjo institucional com o poder central sediado na corte, assegurado por meio da manutenção de uma estrutura econômica escravista e excludente como fundamento da nação brasileira em formação.

Palavras-chave: Bahia, Confrontos políticos, Independência, Redes de sociabilidade, Constitucionalismo.

\section{Abstract}

This research discusses the broad political changes that occurred in the province of Bahia in the years 1821-1823 as a consequence of the crisis of the Old Portuguese Regime in America. Based on documentary and bibliographical sources, it seeks to reaffirm that the materialization of a critical political context in the Portuguese-American territory resulted in specific developments in its various parts where inhabitants began to experience forms of organization and participation consistent with a new political culture widespread in the period. In the case of Bahia, the unique conditions of political-economic organization enabled the development of different perceptions on how to deal with the crisis. As a result, different alternatives were presented as expressions of individual and group projects towards the achievement of expectations so far restrained by the authorities of the monarchy of Braganza. The challenges experienced in the province during the War of Independence (1822-1823) not only served as political learning for the inhabitants, but also allowed some of them to become important leaders in the construction of the Imperial state. Thus, this study proposes the investigation of the numerous paths taken by a segment of the ruling class from the province of Bahia in setting up an institutional organization with central power headquartered at the imperial court. The survival of this organization was ensured by maintaining an economic structure of slavery and exclusion as the basis for the Brazilian nation in formation.

Keywords: Bahia, Political clashes, Independence, Networks of sociability, Constitutionalism. 
Para todos os jovens, conterrâneos e conhecidos, vitimados pela violência na minha cidade natal, Vitória da Conquista - Bahia. 


\section{Agradecimentos}

Nos anos dedicados à realização deste doutorado beneficiei-me de apoios importantes e, sem os quais, não teria aqui chegado. Do mestre, e agora saudoso, István Jancsó, recebi o estímulo para ingressar no Programa da Pós-Graduação da Universidade de São Paulo e, por quase quatro anos, tive o privilégio de contar com a sua habilitada e cuidadosa orientação. A dor da sua perda, na reta final deste trabalho, só não foi maior devido aos seus ensinamentos refletidos não apenas no cultivo da "boa História", mas em ter sabido congregar pessoas em redes de sociabilidade que extrapolaram o universo acadêmico.

A prestimosa acolhida da Prof ${ }^{a}$. Dra ${ }^{a}$. Miriam Dolhnikoff na continuidade da orientação da pesquisa deu-me tranquilidade e, simultaneamente, subvencionou o refinamento teórico da abordagem. Ainda a Miriam, bem como ao Prof. Dr. André Machado, agradeço as contribuições quando da banca de qualificação, pois suas inserções foram decisivas para ancoragem e redirecionamento da pesquisa.

Ter a oportunidade do convívio no espaço do Projeto Temático Fundação do Estado e da nação: Brasil c.1780-1850, financiado pela FAPESP, revelou-se igualmente fundamental no aguçamento teórico-metodológico da pesquisa. Dentre aqueles que tornaram o seu ambiente intelectualmente profícuo e de trato cotidiano aconchegante, destaco, para além do István, da Miriam e do André, João Paulo Pimenta, Andréa Slemian, Valdei Araújo, Ana Rosa Cloclet e Wilma Peres Costa. Tanto no âmbito do Temático, quanto nos cursos oferecidos na Pós, os professores Márcia Berbel, Rafael Marquese e Cecília Helena de Salles Oliveira sustentaram debates, promoveram discussões e forneceram materiais importantes para o meu amadurecimento acadêmico e para o encaminhamento da pesquisa. Ainda no quesito sala de aula, foi fascinante a experiência de ter frequentado o descontraído e fecundo curso de História e Historiografia do Brasil, coordenado por Fernando Antônio Novais.

Durante a estada em São Paulo, instituímos a nossa comunidade de baianos congregando, à época, os pós-graduandos Francisco Carlos, Rosângela Cardoso, Rubens Mascarenhas, Jânio Diniz, Suzane Tosta, João Diógenes, Cristina Pina, Gildásio Santana e Dulce. A morte da Prof ${ }^{a}$. e amiga Albertina Vasconcelos, minha mestra na Iniciação Científica na UESB, deixou igualmente um sentimento de dor e de orfandade.

Ainda em São Paulo, contei com os amigos de longa data, Rita Duca, a quem sou grato pela empatia, boas conversas e pela leitura crítica dos capítulos da tese, e Loreto Trujillo. Ambos fizeram da sua a nossa casa. Amizades novas também foram construídas e, 
cada qual a sua maneira, abrandaram a árdua rotina dos estudos. São desta cepa Maraisa, Creuza, Ana Cláudia, Jomar, Januari, Rosângela Marques e Elpídio.

Em Vitória da Conquista, onde regressei e morei nos últimos dois anos, manifesto muita gratidão a minha família. De maneira singular e carinhosamente menciono a minha mãe, Cleusa Andrade, pelo apoio e os cuidados para que eu pudesse dedicar-me aos estudos. Recebi também carinho e atenção de muitas pessoas queridas, particularmente registro os de Cecília, Henrique, Dolores, Mônica, Renato, Rafael, Telma, Laurita, Cerilla, Preto, Tânia, Lú, Weslei, Mércia, Naíra, Neto, Cotinha, Diana, Camila e Jefinho. À minha companheira Maria Aparecida devo o incessante incentivo, muita cumplicidade de vida e, notadamente, a crítica teórico-metodológica de uma excelente historiadora e leitora atenta e muito exigente. Nossa parceria, por certo, ainda renderá muitos e bons frutos.

Para a minha imensa satisfação, convivi com muitas crianças nesta trajetória. À cabeceira sempre esteve o meu amado Caio que, sem dúvida, tornou a feitura da tese menos árdua. Curtimos muito, especialmente os nossos descobrimentos em São Paulo. Filho, sou enormemente agradecido por sua alegre e carinhosa existência. Desfrutamos de bons momentos em nossos encontros com João, Marcéu, Yanne, Anna Clara Piau, João Pedro, Ana Clara Trujillo, Pedro Henrique, Carlinhos, Kaiodê, Guilherme, Vinícius, Artur, Diogo e Gabriel.

A todos, muito obrigado. 


\section{Sumário}

Página

$\begin{array}{lc}\text { Introdução } & 8\end{array}$

Capítulo 1 Compromissos, acomodações e tensões: A Bahia na crise do Antigo 14 Regime português

$1.1 \mathrm{O}$ monarca na Bahia: a política de reordenamento do Império português 27

1.2 Indícios de descontentamentos na Bahia e revoluções na América hispânica $\quad 38$

1.3 Corte para o Rio de Janeiro e compensações para a Bahia 53

Capítulo 2 Autonomias políticas e espaços de experiência: A Revolução 73 Constitucionalista na Bahia

2.1 Construção da aliança liberal entre os habitantes de Portugal e do Brasil no $\quad 77$

contexto revolucionário

2.2 A Revolução Constitucionalista na Bahia e suas implicações para a América $\quad 88$ portuguesa

$\begin{array}{ll}2.3 \text { Projetos divergentes na Bahia constitucionalista } & 101\end{array}$

Capítulo 3 Entre a Bahia e o Rio de Janeiro: o reordenamento da política 138

3.1 A adesão da classe senhorial na Bahia ao projeto político das províncias $\quad 139$

coligadas

3.2 Disputas internas e reacomodações entre representantes da classe senhorial na 168

Bahia

3.3 A construção de um espaço de experiência: o Conselho Interino de Governo 177

Capítulo 4 Compromissos e acomodações na formação da nação brasileira 208

4.1 Rearranjos político-militares na Bahia pós-Independência 208

4.2 Felisberto Caldeira Brant: visão política em período de crise 219

4.3 Deputados baianos na Assembleia Constituinte de $1823 \quad 248$

4.4 Da Bahia para representantes da nação 280

Conclusão 293

$\begin{array}{lr}\text { Fontes Documentais e Bibliográficas } & 297\end{array}$ 


\section{Introdução}

Em 11 de junho de 1822, Felisberto Caldeira Brant Pontes de Oliveira Horta (17721842), futuro marquês de Barbacena, enviou uma carta ao presidente da Junta de Pernambuco, que enfrentava dificuldades para assegurar a estabilidade política na província, na qual expressava a sua compreensão do que deveria ser o pacto contratualista a ser firmado entre as províncias do Brasil:

[...] garantida a integridade do Brasil, que todos desejam ver dividido, não pode haver a menor dúvida que cada uma das Províncias há de ter sua particular administração, e que os homens de saber e virtude acharão campo vasto para promover a felicidade da Pátria. Neste momento de crise o que sobretudo convém é a estreita união com o Rio, e Vossa Excelência bem conhece quanto embaraça aos Portugueses estar o Herdeiro da Coroa à testa da confederação Brasileira.

[...] A revolução de 1817 fez persuadir a toda gente que os Pernambucanos desejam fazer de sua Província uma República independente, e supondo isso possível que consideração política teria no Mundo? Para os ignorantes não há razão que baste, mas Vossa Excelência de certo conhece as vantagens de um Estado que abrange do Prata ao Amazonas, e por isso espero em Deus que por todos os meios a seu alcance se esforçará por conservar a integridade do Brasil. ${ }^{1}$

Poucos dias após esse contato, era a vez da Bahia ingressar em uma guerra civil cujas motivações passavam por profundas divergências no que se referia à conformação da nação portuguesa, aprofundadas à medida que a superação da crise política materializava novas condições jurídico-políticas de organização da sociedade, composta dali por diante não mais por portugueses, mas sim brasileiros. ${ }^{2}$ A historiografia recente tem demonstrado como esse movimento de construção do Estado e da nação, no que se refere sobretudo às primeiras décadas do pós-Independência, fora tortuoso e complexo. E essa complexidade demanda reabrir ou colocar novas questões no âmbito das esferas política, econômica e social que envolveram o movimento de Independência. Ainda mais se parte da perspectiva de situar este processo no interior das alterações mais amplas que sacudiram o mundo ocidental em fins do

\footnotetext{
${ }^{1}$ Carta a Gervásio Pires Ferreira, em 11 de junho de 1822. Cartas sobre a Independência, de 1822 a 1823. ARQUIVO NACIONAL. Livro dos termos: homenagens e assentos. Rio de Janeiro: Typografia do Arquivo Público Nacional. $1947 . \quad$ p. $258 . \quad 2$ Disponível $\quad$ em: http://www.archive.org/stream/livrodostermosh00bragoog\#page/n13/mode/1up>. Acesso em 15 de maio de 2009. p. 254.

${ }^{2}$ SLEMIAN, Andréa; PIMENTA, João Paulo G. $O$ “nascimento político do Brasil”. As origens do Estado e da nação (1808-1825). Rio de Janeiro: Ed. DP \& A, 2003.
} 
XVIII e início do século XIX. ${ }^{3}$ Perspectiva que, ao mesmo tempo em que permite apreender a dimensão da crise política do Antigo Regime e em seu interior do Sistema Colonial, permite também conhecer os desdobramentos em regiões específicas, sem perder de vista suas próprias dinâmicas e possibilidades. É nesse movimento incessante dos processos históricos que residem as relações complexas entre homens e mulheres, sujeitos do devir histórico.

Afirmar que a província da Bahia constituiu um celeiro de alternativas políticas em meio à instabilidade que assolou o mundo luso-americano nos anos 1820 pode não se constituir em grande novidade. Felizmente, nos últimos anos, o tema tem despertado o interesse de pesquisadores, somados a estudos clássicos, que avançam na compreensão de questões importantes sobre o período. ${ }^{4}$ Todavia, a despeito desses estudos, dos quais esta pesquisa muito se valeu, as mediações interpostas pelas elites dirigentes da província para assegurar a aliança desse território ao Império liderado por d. Pedro I ainda permanecem obscuras. Este estudo propõe discutir os diversos caminhos trilhados pelas lideranças baianas - naturais ou residentes na província - nos anos de consolidação da Independência do Brasil. Parte-se do pressuposto que as ideias constitucionalistas resultantes da adesão ao vintismo português em fevereiro de 1821, não somente abriram um fértil campo de experimentação política para grande parte dos habitantes da província, como também possibilitou que alguns dentre estes pudessem alçar à condição de estadistas importantes, cujas ações e formulações seriam essenciais na projeção do Estado imperial a ser erigido. Quando Caldeira Brant, na correspondência acima, afirma que a união com o Rio de Janeiro era essencial à manutenção

\footnotetext{
${ }^{3}$ NOVAIS, Fernando Antônio; MOTA, Carlos Guilherme. A independência política do Brasil. 2. ed. São Paulo: Hucitec, 1996.

${ }^{4}$ SILVA, Ignácio Accioli Cerqueira e. Memórias Históricas e Políticas da Província da Bahia. Anotado por Braz do Amaral. Bahia: Imprensa Oficial do Estado, 1919-1931, v. 3 e 4; AMARAL, Braz do. História da Independência na Bahia. Salvador: Progresso, 1957; MORTON, F. W. O. The Consertative Revolution of Independence: Economy, society and politics in Bahia (1790-1840). Thesis Submitted to the Board of the Faculty of Modern History in Partial Fulfilment of the Requirements for the Degres of D. Phil, University of Oxford, Oxford, 1974; SILVA, Eduardo; REIS João José. O jogo duro do dois de Julho: o "Partido Negro" na Independência da Bahia. In: Negociação e conflito: a resistência negra no Brasil escravista. São Paulo: Companhia das Letras. p. 79-98, 1989; WISIAK, Thomas. A 'Nação partida ao meio': tendências políticas na Bahia na crise do Império luso-brasileiro. Dissertação (Mestrado em História) - Universidade de São Paulo, São Paulo, 2001; COELHO, Hilton Barros. "Authoridades" e "Anarchistas" no "Império da desordem": conflitos e reconfigurações do poder dominante na Bahia da guerra à consolidação da Independência. Dissertação (Mestrado em História) - Universidade Federal da Bahia, Salvador, 2003; SOUZA FILHO, Argemiro Ribeiro de. A guerra de Independência na Bahia: Manifestações políticas e violência na formação do Estado nacional (Rio de Contas e Caetité). Dissertação (Mestrado em História) - Universidade Federal da Bahia, Salvador, 2003; GUERRA FILHO, Sérgio Armando Diniz. O povo e a Guerra: Participação das camadas populares nas lutas pela Independência do Brasil na Bahia. Dissertação (Mestrado em História) - Universidade Federal da Bahia, Salvador, 2004; TAVARES, Luís Henrique Dias. Independência do Brasil na Bahia. Salvador: Edufba, 2005; SILVA, Daniel Afonso da. Histórias de Bahia. Histórias de Brasil. Apontamentos para o estudo da crise política do Primeiro Reinado na Bahia (1828-1831). Dissertação (Mestrado em História) - Universidade de São Paulo, São Paulo, 2007 e SOUSA, Maria Aparecida Silva de. Bahia: de capitania a província, 1808-1823. Tese (Doutorado em História Social) - Universidade de São Paulo, São Paulo, 2009.
} 
da integridade do Brasil, tinha em mira, do alto da sua experiência, que a arrematação desse projeto exigiria concessões, conciliações e, por conseguinte, a eliminação de indivíduos e de propostas divergentes. De fato, ao analisar a conturbada conjuntura política da Bahia nos anos 1821-1823, algumas perguntas são inevitáveis: que projetos políticos se expressaram nesses anos? Como se construiu a adesão da Bahia à proposta de unidade capitaneada pelo Rio de Janeiro? Qual o modelo de Estado defendido pelas lideranças adesistas?

Embora a pesquisa não avance no tempo de modo a acompanhar os desdobramentos políticos, procurou-se validar a importância política e econômica da Bahia no movimento de afirmação do Estado independente e de conformação do Império do Brasil. Essa constatação remete para uma análise na qual as articulações políticas necessitam ser apreendidas em sua vinculação com os interesses materiais da classe dirigente. Sem dúvida, os confrontos manifestados no período da Independência realçaram ainda mais esses interesses, cujas bases assentavam-se em uma estrutura de tipo mercantilista de organização política e econômica que, todavia, conhece as primeiras fissuras em princípios do Oitocentos. Com efeito, a transferência da sede do Império português para a América, em 1808, alterou profundamente as condições em que portugueses europeus e americanos viviam e se relacionavam até então. É fato que essas mudanças foram sentidas de maneira mais contundente no Rio de Janeiro, nova sede da monarquia bragantina, e nas áreas no seu entorno. No entanto, as exigências postas por essa nova condição da antiga colônia americana, que em 1815 é elevada à categoria de Reino Unido de Brasil, Portugal e Algarves, impuseram alterações importantes inclusive nas capitanias do Norte, seja no que se refere às políticas de fortalecimento dos laços entre os súditos americanos e o monarca português, seja na imposição de medidas de cunho econômico visando à sustentação da sede da Corte e dos seus novos habitantes. As capitanias da Bahia e de Pernambuco, maiores produtoras de cana-de-açúcar, então principal produto da balança comercial, e sob as quais recaíam as mais altas taxações de impostos, irão se ressentir dessa assimetria, registrando uma queixa recorrente em documentos da época e que estará na base das discussões sobre a autonomia das províncias no Império. Ademais, internamente essas regiões enfrentavam amplas desigualdades decorrentes de uma sociedade escravista, além dos distintos padrões de riqueza material e de posição social entre os homens livres. Situação que demandava uma vigilância constante por parte das autoridades e que, mesmo assim, não evitou sobressaltos ao poder. Ainda mais em tempos de crise.

Em razão disso, quando as primeiras notícias sobre a vitória da Revolução Liberal do Porto chegaram à Bahia em princípios de 1821, momentaneamente as lideranças de distintas posições políticas acordaram que era preciso dar encaminhamento às soluções 
propostas pelos liberais vintistas. A análise das fontes documentais evidencia que o desejo por algum tipo de alteração nas estruturas políticas do Império português era latente. As circunstâncias históricas possibilitaram a sua manifestação de maneira surpreendente, inclusive para muitas lideranças do movimento. O desafio maior seria, então, conseguir conciliar posições divergentes sem colocar em risco a segurança das pessoas livres e das suas propriedades, como bem recomendava os pilares do pensamento liberal, ao mesmo tempo em que a crise política dava vazão a ressentimentos de variada natureza. Essa tarefa revelou-se de difícil execução nas províncias do Norte. Na Bahia, em especial, a velocidade dos acontecimentos, própria de momentos críticos, denota que pouco mais de dois anos fevereiro de 1821 a julho de 1823 - foram suficientes para sacudir a província de alto a baixo, dos sertões à capital. Naqueles anos, a esfera pública esteve alargada, permitindo que amplos setores ocupassem a cena, cada qual a vislumbrar uma saída mais viável para os seus anseios. Liberdade, República, Nação, Pátria, Constituição, Cidadãos, Soberania Popular são termos que adquirem concretude e significados próprios de uma época em ebulição e de importantes mudanças políticas. $\mathrm{O}$ aprofundamento da instabilidade vai exigir de parte da classe dirigente local e do governo central articulações que acenavam para a consolidação da monarquia constitucional em torno de d. Pedro de Alcântara, príncipe regente em abril de 1822. Os confrontos políticos ocorridos na província, nos quais a formação de uma Junta de Governo provisório (Salvador) e de um Conselho Interino (Recôncavo) forjarão lideranças importantes na conformação do pacto político demandado pela classe dominante. Não à toa, a movimentação de alguns desses indivíduos entre a Bahia e o Rio de Janeiro selarão um projeto de Estado e de Nação brasileiros em busca de sua legimitidade. Compreende-se, desse modo, que a busca pela construção da unidade nacional foi um objetivo intensamente perseguido não apenas pelos segmentos políticos arraigados ao poder central detentores de uma visão comum sobre a nação desejada. Pelo contrário, a montagem de um arranjo institucional contou com a indispensável participação das elites locais, que nem sempre atuavam como um bloco homogêneo, haja vista a própria Guerra de Independência (18221823) ocorrida na província, assim como as divergências entre as lideranças sediadas no Recôncavo e nos Sertões, o que pressupõe investigar os variados caminhos percorridos nessa intricada relação entre poderes central e local, como anteriormente apontou Miriam Dolnhikoff. ${ }^{5}$ É esta dinâmica da política baiana nos anos de 1821-1823 e os processos de articulação que extrapolam as fronteiras da província que constituem o arcabouço deste

\footnotetext{
${ }^{5}$ DOLHNIKOFF, Miriam. O Pacto Imperial: origens do federalismo no Brasil do século XIX, 2005.
} 
trabalho. Para dar conta das questões propostas, recuamos no tempo de modo a compor um quadro da Bahia nos anos que antecederam o movimento constitucionalista. Desse modo, a pesquisa foi estruturada em quatro capítulos.

No primeiro, propõe-se analisar as transformações políticas ocorridas na província em fins do século XVIII e princípios do seguinte, quando o aprofundamento da crise sistêmica do Antigo Regime português, em meio às ameaças das revoluções liberais, levaram a Coroa de Bragança a intensificar os reajustamentos administrativos e econômicos, enquanto recursos que favorecessem uma melhor integração entre o Estado e as classes dominantes locais. Explorando as contradições internas de uma sociedade arraigada ao mundo da escravidão, o eixo norteador da discussão será direcionado para o acompanhamento das grandes realizações da Coroa em território baiano, bem como a identificação dos diversos mecanismos pelos quais se fundamentavam a política de compromissos e acomodações envolvendo a família real e os súditos residentes na Bahia. Por fim, serão examinadas as tensões e os conflitos verificados na província que punham em alerta as autoridades régias.

Tendo em vista a forma como se processou a aliança política no interior do Império português após a vitória da Revolução Liberal no Reino europeu, o enquadramento geral do segundo capítulo objetiva demonstrar o quanto a adoção do constitucionalismo na Bahia revelou-se decisivo para os acontecimentos subsequentes na América portuguesa. As práticas comportamentais que suscitaram sérias dissidências entre os defensores da Revolução Constitucionalista (1821) foram aqui problematizadas, uma vez que atestam o alargamento das disputas envolvendo variados projetos políticos comprometidos com a superação do governo absoluto. O objetivo do capítulo é demonstrar que a busca de alternativas políticas para a superação da crise do Antigo Regime português na Bahia envolveu não apenas setores vinculados às classes dominantes e intermediárias, mas também indivíduos de baixa extração social que, não raras vezes, forçariam os marcos referenciais de regeneração política estabelecidos pelas classes dirigentes.

O terceiro capítulo concentrou-se no processo de realinhamento político da Bahia com o Rio de Janeiro facilitado pelas redes de sociabilidade construídas entre lideranças baianas residentes nessas duas províncias, o que descortina outra dimensão do movimento de Independência. A análise também busca dar conta da constituição das juntas governativas na Bahia, enquanto espaços de experiência sob a direção da classe senhorial, capacitando-a para outros desafios. Importou, então, compreender as interações e as divergências entre os representantes das classes dominantes que enfrentaram a Guerra de Independência e como 
algumas das suas lideranças ajudaram a implementar o governo monárquico centralizado que caracterizou todo o Primeiro Reinado (1822-1831).

A situação da província no pós-Independência marcada pelos rearranjos políticomilitares em um cenário ainda de instabilidade é o que discute o quarto e último capítulo. Aqui também se enfatiza a figura de Felisberto Caldeira Brant, último comandante das armas na Bahia antes da Revolução Constitucionalista. O exame da sua correspondência no período ajuda a entender a capacidade de análise e de articulação de um súdito da monarquia portuguesa interessado na adoção de algumas mudanças como recurso para o encaminhamento da crise política sem colocar em risco os privilégios das elites locais. $\mathrm{O}$ capítulo destaca ainda o posicionamento dos representantes da província da Bahia durante a Assembleia Constituinte de 1823 e após a sua dissolução pelas tropas imperiais, dando ênfase na influência exercida por alguns baianos na elaboração do projeto constitucional que redundou na Carta de Constituição outorgada por d. Pedro I, em 1824, a qual, dentre outras prerrogativas, demarcou a discriminação entre "cidadãos" e "não cidadãos" e deixou espaço para a preservação da instituição escravista. Será averiguado igualmente o quanto a província baiana tornou-se essencial para a consecução da monarquia centralizada e para a unidade do Império brasileiro, atestada na influência e no papel exercido por parte de alguns indivíduos, agora vistos e tidos como representantes da nação. 


\section{Capítulo 1}

\section{Compromissos, acomodações e tensões: A Bahia na crise do Antigo Regime português}

Na expectativa de conseguir escapar ao ímpeto das revoluções liberais que no último quartel do Setecentos ameaçava diretamente a sobrevivência dos governos absolutos no mundo atlântico, inclusive pela irrupção das primeiras contestações sistêmicas ao poder régio em possessões ultramarinas - vide as conspirações mineira de 1789 e a baiana de 1798 -, a Coroa bragantina lançou mão de um projeto ambicioso aos padrões da economia mercantilista tradicional e à própria noção de poder que legitimava o Antigo Regime. Longe de negar as linhas gerais da política pombalina (1750-1777), a qual principiara todo um conjunto de práticas reformistas de caráter ilustrado, a Coroa decidiu por aprofundar o desenvolvimento e a integração da economia e da sociedade metropolitana e colonial como potentes recursos com os quais o Império ambicionava superar as suas graves defasagens frente às modernas nações europeias da Era Industrial. ${ }^{1}$

A esse conjunto de medidas concernente ao mercantilismo ilustrado posto em marcha pela intelligentsia portuguesa, ressaltou-se que em termos práticos o que se experimentou foi o "caráter de abrandamento do exclusivo e de incentivo da produção colonial, combinado com uma política manufatureira e de reformas na metrópole".2 Já se observou também que a execução desse projeto suscitou uma consistente política de compromissos e acomodações no interior do Império português. ${ }^{3}$ Conquanto a mobilização de novas correntes de ideias para executar as reformas revelasse mesmo uma necessidade, imprescindível também fora selecionar no conjunto da nova mentalidade aqueles setores que mais se adaptavam à situação emergente nos domínios de Portugal. ${ }^{4}$ Na colônia americana, essa diretriz favoreceu diretamente aos grandes proprietários que, de forma inequívoca, passaram a ser tratados como parceiros privilegiados da Coroa no melhoramento prático a ser implementado e de cujo sucesso presumiu-se assegurar não apenas a manutenção do Sistema Colonial, mas a própria sobrevivência do Antigo Regime.

\footnotetext{
${ }^{1}$ Cf. NOVAIS, Fernando Antônio. Portugal e Brasil na crise do Antigo Sistema Colonial (1777-1808). 2. ed. São Paulo: Hucitec, 1983.

${ }^{2}$ Idem, ibidem. p. 236.

${ }^{3}$ KENNEDY, John Norman. Bahian Elites, 1750-1822. Hispanic American Historical Review - Hahr, v. 53, n. 3. p. 415-439, 1973; MORTON, F. W. O. The Consertative Revolution of Independence: Economy, society and politics in Bahia (1790-1840). Thesis Submitted to the Board of the Faculty of Modern History in Partial Fulfilment of the Requirements for the Degres of D. Phil, University of Oxford, Oxford, 1974 e MAXWELL, Kenneth R. A geração de 1790 e a idéia do império luso-brasileiro. In: MAXWELL, Kenneth R. Chocolate, piratas e outros malandros. Ensaios tropicais. São Paulo: Paz e Terra. p. 157-207, 1999.

${ }^{4}$ NOVAIS, Fernando Antônio, op. cit. p. 223.
} 
Parte inerente do enquadramento do Sistema Colonial e dotada de condições essenciais para desfrutar do esforço anteriormente promovido pelo consulado pombalino, a capitania da Bahia viu-se, então, capacitada para aproveitar as novas oportunidades que a Coroa lhe apresentava. Essa conjunção de fatores, somadas às mudanças na economia mundial, permitiu que a capitania adentrasse em uma fase positiva de crescimento econômico que se estenderia até $1820 .^{5}$ Estimulados, os grandes proprietários já vinham ampliando a produção e dinamizando a pauta de exportação com proveito no mercado internacional. Em vista disso, a nova política da Coroa veio, a rigor, potencializar um ambiente econômico em desenvolvimento. A grande novidade, então, era o chamamento ao compromisso político com acesso facilitado à burocracia do Estado. ${ }^{6}$

Circunscrito ainda na esfera comercial, o resultado dessa implementação foi logo sentido. De modo que, ao final do Setecentos, a capitania apresentava uma pauta agrícola bastante diversificada com 61 produtos destinados à exportação, posição que na América portuguesa só foi ultrapassada pela concorrência do Rio de Janeiro. Entretanto, se for considerado apenas o montante das exportações entre os anos de 1796 a 1807, a capitania baiana assumiu a posição de líder com a soma monetária de 36.465:000\$000 (Trinta e Seis Mil Quatrocentos e Sessenta e Cinco Contos de Réis) referente à receita das mercadorias que deixaram o porto da capital Salvador rumo ao comércio exterior. ${ }^{7}$ Convém realçar que, além dos artigos tradicionais (a exemplo do açúcar, fumo e couros), a expansão da Revolução Industrial na Europa abrira espaço para o algodão, artigo que ocupou a terceira posição no cômputo das exportações da Bahia no período. Cultivada nas áreas sertanejas e com o grosso da produção nas vilas de Rio de Contas e de Caetité, o cultivo algodoeiro revelou-se também importante à medida que ampliou o envolvimento de novas fronteiras agrícolas à atividade de

\footnotetext{
${ }^{5}$ MATTOSO, Kátia M. de Queirós. Os escravos na Bahia no alvorecer do século XIX (Estudo de um grupo social). Revista de História. São Paulo, Jan-março, v. 47, n. 97, ano XXV. p. 109-135, 1974.

${ }^{6}$ A íntima colaboração entre as classes dominantes do Brasil e de Portugal, especialmente no que dizia respeito ao 'elitismo burocrático' favorecido pelo Estado entre fins do Setecentos e princípios do século seguinte foi também destacado por DIAS, Maria Odila Silva. A interiorização da metrópole. In: MOTA, Carlos Guilherme (Org.). 1822: Dimensões. São Paulo: Perspectiva, 1972. p. 181. Para essa análise, no entanto, a conclusão é distinta a aqui defendida, visto considerar que a formação do Estado nacional brasileiro "nada teria de revolucionário", sendo, portanto, "a monarquia, a continuidade da ordem existente [...] as grandes preocupações dos homens que forjaram a transição para o império". Idem, ibidem. p. 180.

${ }^{7}$ No mesmo período, o Rio de Janeiro exportou 32.729:000\$000 e Pernambuco 32.004:000\$000. Para a situação econômica da Bahia e sobre as taxas de exportação aqui apresentadas, ver LUGAR, Catherine. The Merchant community of Salvador - Bahia 1780-1830. These (doctorate). University of New York at Stony Brook, 1980, tabela 2.17. p. 100
} 
exportação. ${ }^{8}$ Todavia, o seu impacto na economia baiana só não foi maior devido às longas distâncias até os portos de embarque e às precárias condições das estradas e dos transportes.

Outros fatores exerceram grande influência para que a fase de prosperidade adquirisse maior relevância com evidentes benefícios para uma parcela dos habitantes residentes na capitania, sobretudo em se tratando da aristocracia proprietária, capitaneada pelos poderosos senhores de engenho. Emblemático, nesse sentido, foi o caso da retumbante revolta de escravos e libertos em São Domingos (atual Haiti) que, a partir de 1791, privou o mundo de uma magnífica produção açucareira. Ao colapso da produção canavieira naquela que até então era considerada a jóia da coroa francesa, seguiu-se a desorganização da economia da colônia inglesa da Jamaica, retirando de cena outro importante concorrente do açúcar a nível mundial. Sendo ambos os acontecimentos consequências diretas e indiretas da Revolução Francesa, é crível afirmar que sem dependerem totalmente dos seus esforços, em fins do século XVIII o continente do Brasil e a capitania espanhola de Cuba tornaram-se detentores quase absolutos de um produto de primeira necessidade no mercado internacional. ${ }^{9}$

$\mathrm{Na}$ Bahia, essas conjunções favoráveis adquiriram status comparáveis a de um renascimento econômico. ${ }^{10}$ Com os preços do açúcar mantendo-se elevados, cresceu a procura de novas terras para a exploração canavieira, os engenhos multiplicaram-se e o funcionamento do complexo açucareiro requereu uma busca frenética pela mão-de-obra escrava que, ao ser paga em África com o tabaco produzido na capitania, impulsionou outros elos da economia, incluindo-se aí o próprio tráfico de escravos. Acresce a essa relação de complementaridade

\footnotetext{
${ }^{8}$ Cf. MATTOSO, Kátia M. de Queirós, op. cit. p. 114-115; JANCSÓ, István. Na Bahia, contra o Império: História do ensaio de sedição de 1798. São Paulo: Hucitec; Salvador: EDUFBA, 1996. Cap. 2 e BARICKMAN, Bert J. Um contraponto baiano: açúcar, fumo, mandioca e escravidão no Recôncavo, 1780-1860. Rio de Janeiro: Civilização Brasileira, 2003. No tocante à relevância do algodão baiano nesse período, ver PRADO JÚNIOR, Caio. Formação do Brasil contemporâneo. 22. ed. São Paulo: Brasiliense, 1992. p. 134 e passim e NEVES, Erivaldo Fagundes. Uma comunidade sertaneja: da sesmaria ao minifúndio (um estudo de história regional e local). Salvador: Edufba; Feira de Santana: UEFS, 1998. Ver ainda do mesmo autor Estrutura Fundiária e dinâmica mercantil: Alto Sertão da Bahia séculos XVII e XIV. Salvador: EDUFBA; Feira de Santana: UEFS, 2005.

${ }^{9}$ Cf. MATTOSO, Kátia M. de Queirós, op. cit. p. 114. Estabelecida em 1764 e mantendo-se vinculada à Espanha até 1898, a capitania cubana veio a ser, juntamente com o Brasil, um dos maiores consumidores de mão-de-obra escrava traficada da África entre fins do Setecentos e princípios do século seguinte, o que lhe permitiu ampliar consideravelmente a sua produção açucareira. Com a intensificação dos conflitos europeus, especialmente a eclosão da guerra entre britânicos e franceses em 1803 e, seus desdobramentos imediatos no Caribe - com destaque para a Independência do Haiti (1804) -, os grandes proprietários da ilha destacar-se-iam pela maneira como conseguiram manter-se relativamente afastados dos grandes acontecimentos políticos que atingiam a vizinhança controlada, até então, pelos impérios coloniais da Espanha, França, Grã-Bretanha e Holanda. Para uma análise geral sobre os conflitos políticos no Caribe desse período, ver BLACKBURN, Robin. A queda do escravismo colonial 1776-1848. Rio de Janeiro/São Paulo: Record, 2002. A posição geopolítica de Cuba e a opção da classe proprietária escravocrata em aproveitar as turbulências internacionais para reafirmar sua lealdade ao império espanhol são assuntos visitados em estudo recente de SLEMIAN, Andréa e PIMENTA, João Paulo G. A corte e o mundo: Uma história do ano em que a família real portuguesa chegou ao Brasil. São Paulo: Ed. Alameda, 2008. Cap. 4.

${ }^{10}$ MAXWELL, Kenneth, op. cit. p. 171.
} 
entre o mercado interno e externo, ${ }^{11}$ a excepcional conjuntura econômica internacional que, entre os anos de 1787 e 1817, apresentou seus melhores resultados. Então, ao levar-se em conta tão somente o ponto de vista dos grandes proprietários da capitania, não há por que discordar que a Bahia desse período experimentasse uma época de felicidade. Percepção que - importa ainda registrar - esteve fortemente atada ao universo mental da era enciclopedista, pois à medida que o conhecimento acumulava-se e a Razão iluminava o mundo, e não apenas as coisas, mas os homens, os governos, as sociedades, o tempo da felicidade não tinha porque tardar. $^{12}$

A euforia econômica concentrada nas atividades de exportação facilitava ambições diversas. Revelando-se dispostos a não desperdiçarem as oportunidades, principalmente porque ocorriam no interior de uma colônia, muitos proprietários na capitania puderam enviar, com maiores comodidades, alguns dos seus filhos às universidades europeias, sobretudo a de Coimbra em Portugal e Montpellier na França. ${ }^{13}$ No momento em que a Coroa tomava sob sua responsabilidade um programa de reformas com envergadura suficiente para atender tanto ao desenvolvimento econômico da metrópole, quanto à exploração racionalizada da produção do Ultramar, ter um herdeiro diplomado bacharel nas áreas do direito, da medicina e da filosofia podia fazer diferença na projeção da família rumo aos negócios da burocracia estatal. Ao investigar as academias coloniais, Iris Kantor realçou a trajetória de uma ilustração luso-americana cujos integrantes, seguindo caminhos variados, passaram a ter acesso a distintos postos no aparato do Estado português. E, a partir dessa inserção, sentiram-

\footnotetext{
${ }^{11}$ A ideia de complementaridade entre os mercados interno e externo advém do entendimento de que se em fins do Setecentos e princípios do século seguinte a exploração colonial já se intensificara a ponto de poder atender as necessidades do mercado doméstico, como atestam as capitanias de Minas Gerais, São Paulo e Rio Grande de São Pedro. Também é inegável que porquanto vigorou o Sistema Colonial na América portuguesa, em nenhum momento esse domínio deixou de se comportar como uma colônia de exploração que satisfazia, sempre em primeiro plano, as necessidades da metrópole. Nesse sentido, mantêm-se extremamente atualizados os estudos de PRADO JÚNIOR, Caio, op. cit. e NOVAIS, Fernando Antônio, op. cit. No que concerne à dinâmica do mercado interno, ver FRAGOSO, João Luís Ribeiro. Homens de Grossa Aventura. Acumulação e hierarquia na praça mercantil do Rio de Janeiro (1790-1830). 2. ed. Rio de Janeiro: Civilização Brasileira, 1998; FRAGOSO, João Luís Ribeiro; FLORENTINO, Manolo. O arcaismo como projeto: Mercado Atlântico, sociedade agrária e elite mercantil no Rio de Janeiro, 1790-1840. Rio de Janeiro: Editora Diadorim, 1993. Igualmente indispensável para se compreender a formação do mercado interno no Brasil em princípios do Oitocentos é o estudo de DIAS, Maria Odila da Silva, op. cit. e LENHARO, Alcir. As tropas da moderação: o abastecimento da Corte na formação política do Brasil, 1808-1842. São Paulo: Símbolo, 1979.

${ }^{12}$ No que concerne ao ideal de felicidade nesse período, ver NOVAIS, Fernando Antônio, op. cit. p. 217.

${ }^{13}$ Esse também era um meio do Estado absolutista compensar as classes privilegiadas no Brasil, pois a expulsão dos padres jesuítas (1759), e por consequência o fechamento dos seus colégios pelo marquês de Pombal, significou, de fato, uma redução nas oportunidades de formação educacional no interior da América portuguesa. E, ao contrário da monarquia de Espanha na América Ibérica, a administração portuguesa, em todo o período anterior a 1808, se recusara terminantemente a implantar qualquer centro de formação de ensino superior no Brasil; a solução da Coroa bragantina fora franquear a ida de filhos dos colonos abastados para complementarem seus estudos no Velho Mundo. Cf. FREYRE, Gilberto. Casa-grande \& senzala: formação da família brasileira sob o regime da economia patriarcal. 30. ed. Rio de Janeiro: Record, 1995. p. 388, nota 39.
} 
se impelidos a firmar uma cultura política que informasse o Brasil enquanto unidade prenhe de história, conquanto esses representantes mantivessem incólume a diretriz de subordinação colonial. De qualquer modo, importa aqui é registrar que: “A crescente importância dos domínios americanos para a conservação do Império lusitano, ampliava a capacidade de barganha política dos vassalos luso-americanos na luta pela concessão de mercês e ofícios públicos". 14

Foi, portanto, em meio a esse programa de realizações próprio do Século das Luzes e alicerçado em alianças de compromissos e acomodações que d. Rodrigo de Sousa Coutinho (1755-1812) assumiu o ministério das Relações Exteriores de Portugal (1796-1803). A passagem desse afilhado do marquês de Pombal pela pasta ministerial, com efeito, aprofundou a participação dos portugueses americanos em funções de mando e subordinação no aparato governamental. Detentor de uma compreensão alargada sobre as possibilidades do Império português, o futuro conde de Linhares optou pela valorização da meritocracia, estimulando, por isso, a formação ilustrada entre os residentes na América portuguesa. Não por acaso, ao implementar um programa de política fiscal eficaz à realidade luso-brasileira, d. Rodrigo testou uma de suas propostas, a qual sustentava que "luminosas reformas" deveriam ser executadas "por homens inteligentes e capazes de formar sistemas bem-organizados, e cuja utilidade seja por todos sentida e experimentada". ${ }^{15}$ Essa iniciativa pavimentou, por assim dizer, o caminho por onde passaria a geração ilustrada luso-americana com papel decisivo no Brasil dos anos de $1820 .^{16}$

No que respeita particularmente à Bahia de fins do Setecentos, a implementação econômica centrada na produção e na exportação das atividades agrícolas direcionadas ao mercado internacional ocorreu em detrimento do plantio de alimentos em geral, acarretando,

\footnotetext{
${ }^{14}$ KANTOR, Iris. Esquecidos e Renascidos: Historiografia acadêmica luso-americana, 1724-1759. São Paulo: Hucitec; Salvador: Centro de Estudos Baianos/UFBA, 2004. p. 34. Entretanto, como ensinara István Jancsó, dessa inflexão da ideologia da ilustração americana nos negócios de Estado "não deve induzir à ideia de alguma suposta coesão das elites luso-americanas. Elas eram múltiplas, tinham interesses eventualmente conflitantes, como também eram diferentes os níveis de sedimentação das experiências históricas que conformavam suas memórias, ainda que todas elas tenham resultado do mesmo mecanismo básico envolvendo a combinação de duas trajetórias simultâneas, mas de diversa abrangência”. JANCSÓ, István. Brasil e brasileiros: notas sobre modelagem de significados políticos na crise do Antigo Regime português na América. Estudos avançados. v. 22, n. 62, São Paulo, p. 257-274, jan./abr. 2008.

${ }^{15}$ Apud MAXWELL, Kenneth, op. cit. p. 182. Depois de deixar o governo em 1803, d. Rodrigo fora novamente convocado em 1808, quando acumulou as pastas ministeriais dos Negócios Estrangeiro e da Guerra. LYRA, Maria de Lourdes Viana. A utopia do poderoso império: Portugal e Brasil: bastidores da política, 1798-1822. Rio de Janeiro: Sette Letras, 1994. p. 129. A atuação política e administrativa do futuro conde de Linhares é analisada, em profundidade, pela autora; ver, especialmente, o capítulo 3.

${ }^{16}$ Sobre o papel preponderante no quadro da geração ilustrada no processo de Independência do Brasil, ver COSTA, Emília Viotti da. Introdução ao estudo da emancipação política. In: MOTA, Carlos Guilherme. Brasil em Perspectiva. 19. ed. Rio de Janeiro: Ed. Bertrand Brasil, 1990. p. 64-125; MAXWELL, Kenneth, op. cit. e DIAS, Maria Odila da Silva, op. cit.
} 
por isso, a incidência de vários momentos de carestia e escassez nos gêneros de primeira necessidade entre baianos. ${ }^{17}$ Os altos preços das commodities - mercadorias tais como açúcar, tabaco e algodão - que possuíam cotação no mercado internacional, levaram, como já mencionado, à exploração e valorização das melhores terras para atender aos interesses externos e, por isso, deram margens para que a segurança alimentar da maioria da população fosse ameaçada. Em vista disso, a estreia em território baiano da ideologia que apregoava a regulamentação da economia pela mão invisível do mercado teve como contrapartida a insatisfação do amplo e dinâmico estrato social formado por aqueles que não eram nem senhores nem escravos. Essa gente do comum ressentia-se não somente da crescente falta da farinha de mandioca em suas refeições, mas também do milho e do feijão, alimentos que com a carne constituíam as fontes protéicas por excelência da população na América portuguesa. ${ }^{18}$

Outros fatores que tenderam a açular a fome entre os estratos de ínfima condição social foram as intempéries climáticas, principalmente em se tratando da ocorrência das secas que, periodicamente, atingiram algumas localidades do Recôncavo e das áreas sertanejas. ${ }^{19}$ Ao se ter em conta que a produção de alimentos encontrava-se pressionada para as áreas exteriores ao rico solo de massapé, ou seja, para fora do Recôncavo imediato à cidade de Salvador, a carestia e a escassez de produtos, inclusive pelas distâncias, dificuldades nos transportes e má conservação das estradas só tendiam a recrudescer as ameaças de fome. Compreende-se, assim, que a lógica do laissez-faire, frente às melhores possibilidades de lucro nos gêneros de exportação, tendeu a relegar a produção alimentícia como atividade menor, secundária e em nada modificando a característica de subsistência, como demonstrou Caio Prado Júnior. ${ }^{20}$

Não foi à toa que ante as persistências regulamentárias, como a decisão do capitãogeneral da capitania, d. Rodrigo José de Menezes, em implantar um celeiro público em Salvador (1785), somadas às relutâncias da Coroa em não abdicar de todo a sua capacidade de intervenção na economia, que anos mais tarde (1807) o ilustrado Manoel Ferreira da Câmara Bittencourt e Sá, proprietário do engenho da Ponta, em Iguape, pronunciaria a famosa

${ }^{17}$ SILVA, Ignácio Accioli de Cerqueira. Memórias Históricas e Políticas da Província da Bahia. Anotado por Braz do Amaral. Bahia: Imprensa Oficial do Estado, 1919-1931, v. 3. p. 72. SCHWARTZ, Stuart B. Segredos internos: Engenhos e escravos na sociedade colonial - 1550/1835. São Paulo: Companhia das Letras, 1995. p. 353.

${ }^{18}$ Sobre a situação alimentar da Bahia neste período, ver VILHENA, Luís dos Santos. Recopilação de notícias soteropolitanas e brasílicas. Bahia: Imprensa oficial do Estado, 1921, v. 1. p. 125 e segs.

${ }^{19}$ Em fins do século XVIII e princípios do XIX, o fenômeno das secas manifestou-se sobretudo nos anos de 1791-1793 (a grande seca),1819-1821, 1824-1825 e 1830-1831. Cf. REIS, João José. Rebelião escrava no Brasil: a história do levante dos malês em 1835. Edição rev. e amp. São Paulo: Companhia das Letras, 2003. p. 36.

${ }^{20}$ PRADO JÚNIOR, Caio, op. cit. 
sentença pela qual prevenira: "não planto um pé de mandioca para não cair no absurdo de renunciar à melhor cultura do país pela pior que nele há". ${ }^{21}$ Manifestações como essas são também relevantes à medida que servem de indicativo de que no interior da aliança de compromissos e acomodações entre a Coroa e a classe proprietária vinculada às atividades de exportação havia resistências irremediáveis.

Foi, portanto, numa Bahia de contrastes, marcada pela opulência e pela ameaça de fome, que entre 1797 e 1798 a cidade de Salvador transformou-se em palco privilegiado para a ocorrência de práticas cujo caráter político era inequívoco. Ocorrências de conversas, reuniões, leituras e traduções de textos franceses contra a autoridade do governo absoluto tornaram-se, de fato, manifestas. ${ }^{22}$ Ludibriosos pasquins apareceram afixados ao patíbulo público e, em princípios de 1798, a forca misteriosamente amanheceu queimada. Neste exercício contestatório, nem mesmo os símbolos e a autoridade religiosa foram poupados de ataques, o que revela a dimensão do quanto a ordem do Antigo Regime encontrou-se confrontada. $^{23}$

Não obstante os planos dos rebeldes terem sido frustrados, suas ações, como advertira István Jancsó, revelaram-se audaciosas já que na trama revolucionária alguns representantes de condições sociais extremas, como o senhor e o escravo, intercambiaram experiências sobre como por fim ao governo absoluto. ${ }^{24}$ Destaca-se o comprometimento de protagonistas oriundos dos segmentos intelectuais e, sobretudo, a participação de libertos, soldados e pequenos artesãos que, conjuntamente, propunham outra era de felicidade, onde a Liberdade é a doçura da vida fundada e sustentada pelo "Poderoso e Magnífico Povo Bahinense Republicano desta cidade da Bahia Republicana". ${ }^{25}$ Expressão política de uma das possibilidades de aliança de classes, o ensaio sedicioso foi também importante à medida que aprofundou o processo de acumulação de experiência política, de âmbito individual e coletivo, com o qual se pode melhor compreender o viver em colônia em fins do século XVIII. ${ }^{26}$ Assim, ao tempo em que uma parte dos homens manejando o instrumental ilustrado

\footnotetext{
${ }^{21}$ Carta II, M[anoel] F[erreira] da C[âmara]. In: BRITO, João Rodrigues de. Cartas Econômico-políticas: sobre a agricultura e comércio da Bahia. Lisboa: Imprensa Nacional, 1821 (Reeditada pelo Governo do Estado da Bahia no ano de 1924). p. 100.

${ }^{22}$ TAVARES, Luís Henrique Dias. História da Bahia. 10. ed. rev. e aum. São Paulo: UNESP. Salvador: Edufba, 2001. p. 181 e JANCSÓ, István. A sedução da liberdade: cotidiano e contestação política no final do século XVII. In: SOUZA, Laura de Mello e (Org.). História da vida privada no Brasil: cotidiano e vida privada na América portuguesa. São Paulo: Companhia das Letras, p. 387-437, 1997, v. 1.

${ }^{23}$ JANCSÓ, István, 1996, op. cit.

${ }^{24}$ Idem, ibidem.

25 “Aviso ao Povo Bahinense” n. ' 3, citado por JANCSÓ, István, 1996, op. cit. p. 123.

${ }^{26}$ MOTA, Carlos Guilherme. A ideia de revolução no Brasil (1789-1801): Estudo das formas de pensamento. 4. ed. São Paulo: Ática, 1996 (Série Fundamentos, 116). Cap. 1.
} 
tencionava ampliar sua participação nos projetos imperiais modificando o caráter monopolista da metrópole, havia também aqueles que explicitavam o desejo de alteração radical do vínculo colonial. $^{27}$

Observa-se, então, que embalada pelo jogo de contradições característico da crise do Antigo Regime, a sociedade escravista na América portuguesa em fins do período colonial foi prodigiosa em apresentar práticas comportamentais que, ao nível da mentalidade, assinalaram uma crescente "tomada de consciência do processo histórico vivido". ${ }^{28}$ A complexa tessitura societária manifesta na Bahia de 1797 e 1798 evidenciava que a alta difusão da mão-de-obra escrava disseminada entre os habitantes da capitania facilitara a subversão dos fundamentos da ordem estamental em benefício de outras formas organizativas que agregassem personagens de variada condição social. Nesse sentido, o ensaio sedicioso de 1798 ilustra bem como diferentes segmentos empenharam-se na busca generalizada de alternativas capazes de solucionar uma crise que, apesar dos esforços da Coroa, apresentava-se cada vez mais irredutível. ${ }^{29}$ Além do mais, compreende-se que a trama política ali distendida dificulta falar em dualidade de atuação na qual representantes dos estratos sociais inferiores, objetivando a transformação radical da sociedade, assumiram práticas políticas eminentemente subversivas, enquanto indivíduos pertencentes ou, ao menos, protegidos pela classe senhorial em formação restringiram seus comportamentos a atos transgressivos de natureza cultural. ${ }^{30}$

Impulsionadas por mecanismos estruturais, todas as conspirações que vicejaram na América portuguesa em fins dos Setecentos e princípios do século seguinte - Inconfidência

\footnotetext{
${ }^{27}$ Idem, ibidem loc cit.

28 Ibidem. p. 17 (grifos do autor).

${ }^{29}$ Para uma análise sobre a crise do Antigo Regime português compreendida como processo que transcorridas as fases errática, contínua, sistêmica tornou-se, por fim, irredutível, consultar JANCSÓ, István; PIMENTA, João Paulo Garrido. Peças de um mosaico (ou apontamentos para o estudo da emergência da identidade nacional brasileira). In: MOTA, Carlos G. (Org.). Viagem Incompleta. A experiência brasileira (1500-2000). Formação: histórias. São Paulo: Senac, p. 127-175, 2000. E para a compreensão dos variados segmentos sociais implicados no ensaio de sedição de 1798, ver JANCSÓ, István, 1996, op. cit.

${ }^{30}$ JANCSÓ, István. Bahia 1798: A hipótese de auxílio francês ou a cor dos gatos. In: FURTADO, Júnia Ferreira (Org.). Diálogos oceânicos: Minas Gerais e as novas abordagens para uma história do Império Ultramarino Português. Belo Horizonte: ed. UFMG, 2001. p. 361-387 e MOREL, Marco. Cipriano Barata na Sentinela da Liberdade. Salvador: Academia de Letras da Bahia: Assembleia Legislativa do Estado da Bahia, 2001. p. 60. No que concerne à análise diferenciada sobre as perspectivas dos envolvidos com a Conspiração de 1798 ver, por exemplo, TAVARES, Luís Henrique Dias. Da Sedição de 1798 à Revolta de 1824 na Bahia: Estudos sobre a Sedição de 12 de agosto de 1798, o soldado Luís Gonzaga das Virgens, os escravos no 1798, Francisco Agostinho Gomes, Cipriano Barata e Levante dos Periquitos. Salvador: Edufba; São Paulo: Unesp, 2003 e MAXWELL, Kenneth. A Devassa da devassa: a Inconfidência Mineira: Brasil e Portugal - 1750/1808. 3. ed. Rio de Janeiro: Paz e Terra, 1985. Reduzida em seu leque de alianças, a "conjuração baiana", segundo Maxwell, levou a punição contra "os artesãos mulatos, os soldados, os parceiros destituídos de propriedade e os professores assalariados", os quais "tanto se opunham aos brasileiros ricos quanto ao domínio português". 1985, op. cit. p. 244-245. A categoria classe senhorial em formação é tomada emprestada das análises de NOVAIS, Fernando Antônio; MOTA, Carlos Guilherme. A independência política do Brasil. 2. ed. São Paulo: Hucitec, 1996.
} 
Mineira (1789), Conjura do Rio de Janeiro (1794), Sedição da Bahia (1798), Conspiração dos Suassuna em Pernambuco (1801) - nuançam a conjuntura revolucionária sob a qual a Coroa portuguesa encontrou-se diretamente envolvida. Ao contrário dos movimentos da América portuguesa de outros tempos, a ação desses insurretos tomou nova direção. Extravasaram, inclusive, o caráter subversivo de súditos contra a autoridade dos funcionários do rei. Doravante, as principais dissensões da população colonial manifestavam-se na forma de luta antiabsolutista, anticolonial, antimonopolista e em defesa da liberdade comercial. ${ }^{31}$

Sob qualquer ângulo, a novidade era considerável. De desagrados periódicos que pontilharam a história do Sistema Colonial, os planos dos descontentes se deslocaram, então, dos aspectos acessórios da política administrativa para concentrarem-se na crítica radical à estrutura de poder do Estado. A expressão viva o rei, morra o mau governo deixou de plasmar a inclinação contestatória de maior gravidade; não bastava apenas restaurar a ordem, a subversão dos seus fundamentos passava, cada vez mais, a representar uma promissora alternativa de futuro, ainda que suas manifestações continuassem desconexas e circunscritas aos limites regionais. De fato, o isolamento das conspirações ensaiadas nos espaços coloniais derivava da bem-sucedida estratégia da Coroa que soube, por um lado, concentrar o poder discricionário na metrópole, e, por outro, empenhou-se em manter as relações entre os centros de poderes americanos sempre independentes uns dos outros e verticalizados em sua dependência para com as decisões régias. ${ }^{32}$

Entretanto, ao principiar o Oitocentos e tendo por cenário um conturbado continente europeu no qual a ascensão de Napoleão Bonaparte ao trono francês (1804) exacerbara as ameaças às monarquias tradicionais do Ocidente, os Bragança sentiram-se praticamente obrigados a reforçarem as políticas de reajustamentos administrativos e econômicos na falta de outros meios que lhes facilitassem a integração dos benefícios para o conjunto da nação portuguesa. ${ }^{33}$ Com a crescente disputa de ordem política e econômico-industrial envolvendo os impérios contemporâneos - com destaque para a Grã-Bretanha e a França - a Coroa portuguesa, bem como a de Espanha, via-se forçada também a assumir, sem maiores evasivas, a sua incômoda posição de potência de segunda ordem. Mas essa não era essencialmente uma situação nova, pois desde meados do século XVII, quando a prosperidade da Península Ibérica passou a depender das riquezas no Ultramar, mormente do que se produzia nas colônias

\footnotetext{
${ }^{31}$ COSTA, Emília Viotti da, op. cit. p. 73.

${ }^{32}$ HOLANDA, Sérgio Buarque de. A herança colonial - Sua desagregação. In: HOLANDA, Sérgio Buarque de (Dir.). História geral da civilização brasileira. São Paulo: Difel, 5. ed., tomo II. 1985. p. 09. Ver também JANCSÓ, István, 1997, op. cit.

${ }^{33}$ Cf. SLEMIAN, Andréa; PIMENTA, João Paulo G., op. cit. p. 43.
} 
americanas, os países de Portugal e de Espanha deixaram efetivamente de representar a vanguarda do que havia de mais promissor na economia dos tempos modernos. ${ }^{34}$

Ressalta-se, porém, que a intensificação dos reajustes promovidos pelo reformismo ilustrado com vistas a fomentar a integração social e comercial entre as diversas partes da nação portuguesa já surtia, naqueles anos, algum resultado. No plano econômico, os anos de 1776 e 1777 haviam sido marcados em Portugal por um superávit global deficitário na balança comercial. Isso se explicava porque enquanto a transação comercial para com as colônias portuguesas mantinha-se superavitária em 1.177:159\$491, o mesmo tipo de relação com as nações estrangeiras apresentava um déficit de 618:230\$895. Foi justamente por não desprezarem esse desequilíbrio e ao mesmo tempo por ambicionarem revertê-lo que os estadistas portugueses dedicaram-se ao aperfeiçoamento da política de incentivos e reajustes conduzida anteriormente por Sebastião José de Carvalho e Melo, o marquês de Pombal, ministro dos Negócios Estrangeiros e da Guerra no governo de d. José I (1750-1777).

Se a fase posterior ao consulado pombalino para a nação portuguesa deve ser compreendida pelo "aperfeiçoamento prático" verificado nas áreas econômicas, sociais e governamentais, não há como negar que o impacto decisivo dessa política aconteceu na possessão americana do Império. ${ }^{35} \mathrm{O}$ cenário internacional, com as Independências das treze colônias inglesas na América (1776), a Revolução Francesa (1789) e a Revolução em São Domingos (1791), distendia a pressão para que a Coroa bragantina aprofundasse mais e mais os reajustamentos administrativos e econômicos como recursos que, em última instância, deveriam salvaguardar a ordem no vasto Portugal.

Os efeitos dessa resolução podem ser acompanhados, por exemplo, por intermédio dos dados econômicos para o período. Entre 1796 e 1807 - ano que antecede o fim do exclusivismo colonial -, registrou-se importante viragem na economia portuguesa que conseguiu alterar uma situação anterior de déficit no comércio mundial para uma posição superavitária nessa mesma relação, cujo montante alcançaria a cifra de 20.399:909\$937. ${ }^{36}$ Entretanto, o acumulado total no comércio entre Portugal e suas colônias produziu, naqueles

\footnotetext{
${ }^{34}$ No que concernem às motivações que fizeram de Portugal e de Espanha potências de segunda ordem, ver NOVAIS, Fernando, op. cit. p. 17 e passim.

35 A partir da sociedade baiana, o historiador inglês Frederic W. Orde Morton analisa, com propriedade, os variados mecanismos dessa política. MORTON, F. W. O., op. cit.

${ }^{36}$ Os resultados apresentados nesse parágrafo fundamentaram-se em NOVAIS, Fernando Antônio. Notas para o estudo do Brasil no comércio internacional do fim do século XVIII e início do século XIX (1796-1808). In: NOVAIS, Fernando Antônio. Aproximações: estudos de história e historiografia. São Paulo: Casacnaify, 2006. p. 105-126. Para se chegar às cifras mencionadas foram confrontadas as tabelas número $1,3,5$ e 6 , as quais encontram-se, respectivamente, nas páginas 113, 114 e 115. Para uma compreensão geral da economia da América portuguesa no período deve-se consultar também ARRUDA, José Jobson de. O Brasil no comércio colonial, 1796-1808. São Paulo: Ática, 1980 e LUGAR, Catherine, op. cit.
} 
mesmos anos, um déficit comercial contabilizado em $17.874: 415 \$ 835$. Isso porque a participação do continente do Brasil gerou sozinho um saldo positivo entre exportações (141.355:229\$759) e importações (118.437:224\$070) de 22.918:005\$689. Admite-se, então, que a América portuguesa figurou-se como a grande responsável pela reversão da tendência econômica em favor da Coroa, possibilitando que - não obstante o comércio colonial passasse a ser visivelmente deficitário em relação à metrópole - a nível mundial o conjunto da nação portuguesa apresentasse uma balança comercial positiva. De resto, deve-se considerar que esses resultados deixavam de fora tanto o contrabando (que desde fins dos Setecentos alastrava-se pela costa colonial, especialmente no caso do Brasil, pois se tratava, obviamente, de uma atividade ilícita), quanto o tráfico de escravos, realizado nos próprios espaços coloniais através de África e América.

A ampliação nos números de navios que aportaram ou zarparam do porto da capital baiana entre os anos 1798 e 1810, corroboram a assertiva de que o comércio americano experimentava uma fase de crescimento e dinamização. 


\section{TABELA 1}

\section{Movimento de navios no porto de Salvador (1798-1810)}

\begin{tabular}{|l|l|l|}
\hline Anos & Entradas & Saídas \\
\hline 1798 & 291 & 280 \\
\hline 1799 & 315 & 328 \\
\hline 1800 & 298 & 268 \\
\hline 1801 & 309 & 283 \\
\hline 1802 & 272 & 282 \\
\hline 1803 & 325 & 262 \\
\hline 1804 & 306 & 276 \\
\hline 1805 & 381 & 351 \\
\hline 1806 & 420 & 388 \\
\hline 1807 & 360 & 353 \\
\hline 1808 & 364 & 285 \\
\hline 1809 & 439 & 380 \\
\hline 1810 & 453 & 396 \\
\hline
\end{tabular}

Fonte: SILVA, Ignácio Accioli de Cerqueira, op. cit., v. 3, p. 51-52. ${ }^{37}$

Por tudo isso, as exportações e importações americanas viabilizaram uma alavancagem do comércio português que, no quadro da crise geral do Antigo Regime, asseguraria algum conforto para uma monarquia obrigada a abandonar a sua posição de neutralidade ante a Europa crivada pela ampliação dos confrontos beligerantes envolvendo os impérios da Grã-Bretanha e da França napoleônica. Após ter testado ao limite suas reais possibilidades, o príncipe regente d. João (1767-1826) - que em razão da doença mental de sua mãe, d. Maria I (1734-1816), respondia pelos atos da Coroa -, finalmente, decidiu-se sobre quem apoiaria na aguda conjuntura de hostilidades que se apresentava na Europa. Optou pela aliança luso-britânica, a qual foi oficialmente convencionada em 22 de outubro de 1807.

A partir daí, seguiram-se as negociações para que toda a família real, sob a proteção da marinha inglesa, fosse transferida ao Brasil, território aonde se pressupunha a monarquia estaria mais protegida dos efeitos das revoluções liberais. De qualquer forma, as autoridades portuguesas precisavam agir rápido, visto que a França e a Espanha - nação recém-anexada ao domínio napoleônico - assinaram o Tratado de Fontainebleau, em 27 de outubro de 1807, que, dentre outros fatores, permitiu o livre acesso do exército francês, comandado pelo general Jean-Androche Junot (1771-1813), à cidade de Lisboa. Com efeito, a principal missão

\footnotetext{
${ }^{37}$ Esses dados foram anteriormente utilizados por LUGAR, Catherine, op. cit. p. 76 e MATTOSO, Kátia M. de Queirós. Bahia, século XIX: uma província no Império. Rio de Janeiro: Nova Fronteira, 1992. p. 474.
} 
das tropas francesas consistia em destituir do trono e tornar prisioneira a dinastia dos Bragança. $^{38}$

Em 4 de novembro, d. João reuniu os conselheiros de Estado e anunciou o estabelecimento da corte na América. Daí por diante, os preparativos para a travessia atlântica extrapolaram de vez os aposentos palacianos. Representantes da nobreza, copiosa criadagem, oficiais do exército e altos funcionários passaram a dividir suas funções cotidianas com encaixotamentos e transportes das alfaias. Dez dias depois, a esquadra britânica que escudaria a corte real até o Brasil adentrou na barra do Tejo. E no dia 19, o exército francês invadia o território português pela Beira Baixa. Inevitavelmente, os rumores da iminente chegada da força napoleônica espalharam-se por Lisboa. Passados mais cinco dias, os franceses passaram a controlar Abrantes, confirmando a fragilidade da autoridade dos Bragança.

Em meio àquela atmosfera de forte tensão, o Conselho de Estado reuniu-se mais uma vez, no dia 26, quando aprovou, por unanimidade, a transferência de toda a família real para o Rio de Janeiro. Na mesma ocasião, d. João proclamou ao povo a resolução de partir do Reino e que nomearia uma Regência, a qual responderia pelos atos da administração enquanto durasse a sua ausência. Com isso, o príncipe regente despediu-se dos súditos europeus e, a exemplo do procedimento dos seus futuros companheiros de viagem, procurou acomodações no interior de um dos navios preparados para ir ao Novo Mundo. As más condições do tempo, no entanto, retiveram a partida daquela frota. Tomados pela angústia, a distinta tripulação teve que aguardar, até que no dia 29 os navios portugueses e ingleses, finalmente, puderam alçar velas e zarpar para o Brasil. Ato contínuo, Lord Strangford na condição de comandante da esquadra inglesa participou ao governo britânico:

Tenho a honra de anunciar-vos que o Príncipe Regente de Portugal efetuou a sua sábia e magnânima resolução de se retirar de um Reino, que não podia conservar por mais tempo, senão reduzindo-se a vassalo da França; e que S. A. Real e família, acompanhado pela maior parte de suas naus de guerra, e por grande multidão de seus fiéis vassalos, partiu hoje de Lisboa e se acha em viagem para o Brasil, debaixo da escolta de uma esquadra inglesa. Este grande e memorável acontecimento foi o resultado do sistema constante de confiança e moderação, adotado por $\mathrm{S}$. $\mathrm{M}$. a respeito deste país e porque me tinha feito responsável, em observância das vossas instruções. ${ }^{39}$

Ao se perceber em alto-mar e, portanto, cada vez mais distante daquele que durante tanto tempo fora o seu inseparável Portugal, d. João certamente sentiu-se mais aliviado, pois não ignorava que, por muito pouco, havia escapado ao encontro com o temido exército

\footnotetext{
${ }^{38}$ SLEMIAN, Andréa; PIMENTA, João Paulo G., op. cit. p. 47-48.

${ }^{39}$ Apud SILVA, Ignácio Accioli de Cerqueira, op. cit., v. 3. p. 46.
} 
francês. Realmente, no dia 30 o general Junot foi visto em Lisboa. Mas a velha capital já não era a mesma e não faltava quem ainda ressentisse com as novidades dos dias anteriores. ${ }^{40}$

Para a pesquisa aqui apresentada, fundamental é realçar que o aprofundamento, em fins do Setecentos, das reformas ilustradas levadas adiante pela Coroa portuguesa alargaram efetivamente as possibilidades de participação das classes dominantes radicadas na América portuguesa nos negócios do Estado. E que, apesar da importância, esse melhoramento prático não se revelara suficiente para conter a crise do Antigo Regime. Prova disso, foi que, em 1807, a família real viu-se obrigada a abandonar seus domínios europeus a procura de refúgio em terras americanas. Desafiada então em sua capacidade diretiva, a Casa de Bragança reagira e, assim que pisou no Novo Mundo, principiou a empreender uma série de mudanças visando dotar a nova sede do governo de condições político-administrativa que pudessem bem representar a importância do Império português. ${ }^{41}$ Situação que indubitavelmente firmou-se como um marco redefinidor da relação entre metrópole-colônia, pois a magnitude dessa viragem permitiu, dentre outros fatores, aos próprios contemporâneos adquirem gradativamente consciência de que um tempo diferente e novo começava a ser inaugurado. ${ }^{42}$ Portanto, é sobre o impacto dessas mudanças na Bahia que, a primeira parte desse estudo, pretende debruçar-se.

\subsection{O monarca na Bahia: a política de reordenamento do Império português}

A despeito de todas as providências cabíveis, a travessia do Atlântico não deixaria de ser feita com certa apreensão entre aquele conjunto de tripulantes que a todo tempo deveria permanecer atento às coordenadas da esquadra britânica que lhes fazia proteção. Seguir com as embarcações alinhadas em um único e grande comboio era - não restam dúvidas - a melhor forma de evitar tanto uma eventual surpresa por parte dos franceses que se arriscassem em mar alto, quanto um possível encontro com navios piratas que àquela época, diziam-se, os

\footnotetext{
${ }^{40}$ Para uma compreensão geral sobre a conjuntura europeia na qual a família real portuguesa transmigrou-se para o Brasil, ver SLEMIAN, Andréa; PIMENTA, João Paulo G., op. cit. Cap. 2 e CALMON, Pedro. História do Brasil. Século XIX, o império e a ordem imperial. v. 4, 1959.

${ }^{41}$ Cf. SODRÉ, Nelson Werneck. As razões da independência. Rio de Janeiro: Civilização Brasileira, 1965.

${ }^{42}$ A definição de tempo histórico aqui adotado procura interagir com a análise de Reinhart Koselleck quando, por exemplo, nos alerta que: "Um critério infalível desta modernidade são seus conceitos de movimento - como indicadores de mudança social e política e como elementos linguísticos de formação da consciência, da crítica ideológica e da determinação do comportamento". KOSELLECK, Reinhart. Futuro Passado: contribuição à semântica dos tempos históricos. Rio de Janeiro: Contraponto: Ed. PUC-Rio, 2006. p. 303.
} 
mares estavam infestados. ${ }^{43}$ Contudo, foi de novo o mau tempo o responsável pelas maiores tensões entre os nobres viajantes. Por conta de um temporal ocorrido em noite de 9 de dezembro diversas embarcações acabaram separadas. A maioria conseguiria posteriormente reunir-se e, assim, manteria sua rota de viagem rumo ao Rio de Janeiro. Já a nau capitânia que conduzia o príncipe regente d. João - juntamente com três navios ingleses e alguns portugueses, onde também estavam a rainha d. Maria e outros Bragança - só veio dar notícia de seu paradeiro quando, em 22 de janeiro de 1808, chegou arribada no porto da cidade de Salvador.

Após ser certificado de que toda a família real partira em viagem para a América portuguesa, o capitão-general e governador da Bahia (1805-1809), d. João de Saldanha da Gama Mello e Torres Guedes de Brito, $6^{\circ}$. conde da Ponte, sabedor afinal da menor distância da capitania baiana em relação a Lisboa, tratou de recomendar "toda vigilância para que o governo fosse com antecedência avisado da aproximação da frota [régia], no caso de vir aqui arribar". ${ }^{44}$ Isso explica o fato da comitiva que transportava parte dos tripulantes ter sido recepcionada com um tratamento que pode ser considerado condigno aos dignatários reais do Antigo Regime. Assim, quando na primeira vez que uma monarquia europeia chegou à América não deixou de haver, disparos de canhões, procissões, Te-Deum, beija-mão; além do que residências foram iluminadas e providências foram dadas visando as melhores acomodações e alimentações para a realeza que, ao menos momentaneamente, podia se esquecer dos grandes problemas e azáfamas experimentados nos últimos meses. Bafejado também desde muito cedo por tantas promessas, d. João, finalmente, tinha a oportunidade de verificar in loco a tão decantada prosperidade do Novo Mundo.

Não obstante as avaliações de parte a parte, as expectativas entre o futuro rei e os primeiros súditos americanos encontrados reservariam negociações que, ainda hoje, merecem apreciações. Antiga sede dos vice-reis, a Bahia procuraria na visita inusitada uma oportunidade de melhorar sua situação no interior da América portuguesa. Sem perder tempo, o corpo de comércio da capital enviou uma representação a d. João pela qual requisitava que o mesmo revisse qualquer outro plano e, então, optasse pela capitania Baiense para o restabelecimento da monarquia no Brasil. Ao justificarem os motivos para uma solicitação

\footnotetext{
${ }^{43}$ Accioli informou que em fins do Setecentos (1776) numerosos corsários franceses atuavam na região costeira da capitania baiana. SILVA, Ignácio Accioli de Cerqueira, op. cit., v. 3. p. 27. Os navios corsários foram uma ameaça constante no Atlântico Sul entre esse período até, pelo menos, os primeiros anos de 1820.

${ }^{44}$ PINHO, Wanderley. A abertura dos portos. Cairu. Os Ingleses. A Independência. Salvador: Publicações da Universidade da Bahia, 1961. p. 49. Sobre a estada de d. João em Salvador e a densa tessitura que envolveu a dissolução do Antigo Regime na Bahia, ver SOUSA, Maria Aparecida Silva de. Bahia: de capitania a província, 1808-1823. Tese (Doutorado em História Social) - Universidade de São Paulo, São Paulo, 2009.
} 
como essa, os negociantes afiançavam ao futuro soberano que a capitania era detentora de um "incomparável porto" marítimo; situava-se também no "centro das colônias de V. A. que dominando a África, lhe abre uma comunicação tanto mais fácil e breve com a Ásia, como com as nações aliadas da Europa, quanto fica sendo o seu comércio mais ativo, na reprodução dos variados ramos da sua agricultura". 45

Sem se afastar dos planos traçados com seus conselheiros reais, o príncipe regente manteve a decisão de ir residir no Rio de Janeiro. Mas para não frustrar completamente os interesses dos suplicantes, concedera-lhes diversos benefícios que comprovariam a necessidade régia em compensar e inserir a Bahia na rota das modernizações econômicas, sociais e culturais que o governo empreenderia no Novo Mundo com o intuído de assegurar um mínimo de estabilidade política. Mas a despeito de todo esse esforço em encontrar recursos para encaixar a antiga sede dos vice-reis na equipagem modernizadora, ficava, irremediavelmente, a descoberto as imperfeições governamentais cuja proximidade da Coroa tornava aguda sua responsabilização direta pelos diversos mecanismos de dominação e exploração, aos quais não deixariam de estar submetidos à maioria dos súditos naqueles anos. $^{46}$

Em pesquisa recente, Maria Aparecida Silva de Sousa salientou que não obstante a menor distância entre a realeza e os súditos americanos potencializasse a ascensão econômico-social de uma parcela da população que se revelou apta a usufruir dos benefícios da modernização bragantina, isso não fora suficiente para alterar as condições de existência do amplo e menos favorecido contingente populacional sob o qual pesava a ascendente taxação de impostos. ${ }^{47}$ Prevalecendo essas condições, não demorou a conformar-se entre habitantes das diversas regiões americanas a compreensão, um tanto exacerbada, de que, com a instalação da Corte portuguesa, o Rio de Janeiro não apenas fora elevada à cabeça do "vasto" e "poderoso império", mas igualmente passara a se comportar como a nova fonte de propagação dos abusos da justiça, da "administração dos áulicos", enfim, do poder despótico,

\footnotetext{
${ }^{45}$ Apud SILVA, Ignácio Accioli de Cerqueira, op. cit., v. 3. p. 231-232, nota 27.

${ }^{46}$ Ao avaliar o valor simbólico e prático da transferência da corte para a América portuguesa, Sérgio Buarque de Holanda destacou que "a presença, agora, e naturalmente o convívio e trato forçado, de numerosos estrangeiros, nos ramos mais diversos de ocupação, há de ajudar os naturais, mesmo quando procedam das classes ínfimas, a julgar os seus dominadores como melhor senso de realidade". HOLANDA, Sérgio Buarque de, op. cit. p. 11.

${ }^{47}$ SOUSA, Maria Aparecida Silva de, op. cit. p. 11. O historiador canadense F. W. O. Morton também dera atenção ao peso das taxações sobre os habitantes da Bahia em fins do período colonial, registrando, por exemplo, que: "Em 1799, um imposto de exportação adicional (então chamado novo subsídio) foi fixado para o açúcar, tabaco e algodão, especialmente sobre o último o qual pagava $\$ 600$ [Seiscentos Réis] por arroba". Outras tarifas foram criadas, como a do selo (criada em 1804), cujos papéis legais ficavam obrigados a portar. Em boa proporção, essas taxas tiveram consequências diretas sobre a elevação dos custos de exportação nos principais produtos da Bahia, o que indubitavelmente complicava a competição com os rivais estrangeiros. Cf. MORTON, F. W. O., op. cit. p. 176 (Grifos do autor. Tradução livre).
} 
tal qual a representação mental que, até pouco tempo, vinha sendo atribuída a Lisboa. Basta dizer que nos meses subsequentes à deflagração da Revolução Constitucionalista, ocorrida na Bahia em 10 de fevereiro de 1821, muito se receou do poder discricionário da corte fluminense e a própria ferocidade do sistema tributário ali praticado não seria facilmente esquecida, tanto que, em 1822, o Diário Constitucional assim rememorava:

[...] Todos sabem que a Bahia pagava a iluminação do Rio de Janeiro, e que depois do Dia 10 de Fevereiro [de 1821] não foi mais cumprida essa remessa, ainda ditada pela subversiva Administração daquela Corte [...]. Logo: porque não aplicamos em nosso benefício aquilo que, de boa mente, dávamos ao benefício alheio? [...]. ${ }^{48}$

Em pouco mais de um mês em que permaneceu entre os baianos, o príncipe d. João revelou-se muito solícito às reformas liberais de cariz econômico. Assim, a primeira grande decisão da regência contemplou desde os negócios da América portuguesa aos interesses estrangeiros - especialmente os da Grã-Bretanha -, pois com o bloqueio continental promovido por Napoleão na Europa e, sobretudo, com a invasão de Portugal, os navios mercantes em todo o Brasil estavam, direta ou indiretamente, impedidos de realizar as suas atividades comerciais com a antiga metrópole. Em razão desses acontecimentos e atendendo às orientações governamentais, o conde da Ponte havia, em $1^{\circ}$ de janeiro de 1808 , proibido que as embarcações aportadas em Salvador partissem em direção à Europa. Como essa situação, de fato, não podia perdurar, quatro dias após a comitiva real desembarcar na capital baiana os negociantes locais encaminharam a d. João uma representação solicitando a suspensão dos embargos sobre a livre navegação e atividades de comércio com os portos estrangeiros. A linguagem explicitada no documento recomendava pronto recurso por parte do governante, visto que as medidas pleiteadas "não pode[ria]m sofrer delongas sobre sua concessão" pela simples razão de produzirem "prejuízo do Comércio, perda iminente da Lavoura, miséria, e necessidade imediata dos habitantes e estagnação dos rendimentos reais". 49

Acostumado, de certa forma, a encontrar saídas para conjunturas igualmente difíceis, o príncipe regente lançou mão da única medida que, a rigor, poderia contornar a grave situação que o grande comércio enfrentava "em razão das críticas e públicas circunstâncias da Europa", mormente porque do seu funcionamento dependiam, como

\footnotetext{
${ }^{48}$ Diário Constitucional, n. 05, quarta-feira, 13 de fevereiro de 1822. Tipografia da Viúva Serva e Carvalho, 1821-1822. Exemplar da coleção do IEB/Usp.

${ }^{49}$ Apud PINHO, Wanderley, 1961, op. cit. p. 26-27.
} 
lembrava a representação, as principais arrecadações financeiras da "Real Fazenda". ${ }^{50}$ Por tudo isso, d. João logo se decidiu pela extinção do exclusivismo comercial na sua mais rica possessão colonial, visto ter sido isso o que verdadeiramente se verificou depois da publicação da carta régia de 28 de janeiro de $1808 .{ }^{51}$ De fato, o que importava para a Coroa bragantina era romper o isolamento aos produtos portugueses ante a ocupação francesa dos principais portos a que Portugal tinha acesso, pois, como observou Antonio Penalves Rocha, a abertura dos Portos americanos ao comércio internacional afiançava a continuidade das relações entre a nova sede do Império e os mercados europeus. ${ }^{52}$

Ainda que o príncipe explicitasse ser essa inédita medida uma solução "interina e provisória”, o certo é que, dali por diante, os portos alfandegários da América portuguesa ficaram autorizados a admitir "todos e quaisquer gêneros, fazendas e mercadorias transportadas em navios estrangeiros das potências que se conser[va]vam em paz e harmonia" com a "Real Coroa", sendo o mesmo assegurado às demais embarcações portuguesas. Em contrapartida, essas relações mercantis obrigar-se-iam ao pagamento dos impostos de $24 \%$ de entrada sobre bens e produtos importados, conquanto $20 \%$ se referissem a "direitos grossos" e $4 \%$ a título de "donativos". Resguardava-se também o princípio de que quando se tratasse da aquisição de "vinhos, aguardente e azeites doces", a contribuição seria paga em "dobro" e, assim, procurou-se assegurar vantagens comerciais aos mais importantes gêneros oriundos de Portugal. Em segundo lugar, franqueava não só aos portugueses, mas também aos súditos estrangeiros a autorização para exportarem "todos e quaisquer gêneros e produtos coloniais" para os portos que melhor lhes parecessem. ${ }^{53}$

Relacionado a essa postura da Coroa em prol da liberdade comercial na sua mais próspera colônia, importa observar que, por determinação do próprio príncipe regente, o conde da Ponte havia encaminhado ao Senado da Câmara de Salvador um questionário datado de 12 de maio do ano anterior que, dentre outros "importantes objetos relativos aos interesses presentes, e futuros desta capitania", indagava sobre a prevalência de "alguma causa opressiva

\footnotetext{
${ }^{50}$ Carta Régia de 28 de janeiro de 1808. In: SILVA, Ignácio Accioli de Cerqueira, op. cit., v. 3. p. 49.

${ }^{51}$ A decisão de abolir o monopólio colonial no Brasil não foi uma medida inédita que a Coroa Portuguesa punha em execução, pois, entre 1765 e 1795, toda a América hispânica passou a ser beneficiária de uma série de providências que praticamente livrou o seu comércio do controle monopolístico dos reis de Espanha. SLEMIAN, Andréa; PIMENTA, João Paulo G., op. cit. p. 74.

${ }^{52}$ ROCHA, Antonio Penalves. Economia Política e Política no Período Joanino. In: SZMRECSÁNYI, Tamás; LAPA, José Roberto do Amaral (Orgs.). História Econômica da Independência e do Império. 2. ed. revista. São Paulo: Hucitec/Associação Brasileira de Pesquisadores em História Econômica/ Edusp /Imprensa Oficial, 2002. p. 30-31.

${ }^{53}$ As exceções ficavam por conta da continuidade da proibição do comércio de Pau Brasil, o qual continuava a ser produto de monopólio real, "ou outros [gêneros] notoriamente estancados". Carta Régia de 28 de janeiro de 1808. In: SILVA, Ignácio Accioli de Cerqueira, op. cit., v. 3. p. 49.
} 
contra a lavoura; qual seja esta causa, e o meio dela se evitar"; também desejou saber: "Se o comércio sofre algum vexame, qual ele seja, e se será conveniente ao mesmo comércio particular desta praça, desoprimi-lo dele sem risco de outro maior dano". ${ }^{4}$ Expostas as demais questões, o documento finalizava com uma mensagem à qual devia merecer atenção das autoridades consultadas, pois recomendava que: "As respostas a cada um destes artigos se devem restringir a hipóteses do estado atual dos Rendimentos Reais, sem que se exija a reorganização de um sistema novo, e imaginário, mas sim o meio mais apropriado às circunstâncias, e capaz de produzir os resultados mais vantajosos à lavoura, e ao comércio desta capital". ${ }^{55}$ Ao se verificar o estado conturbado da Europa naquele momento e as alterações que se seguiriam com a transferência da família real para o Brasil, parece crível admitir que a Coroa estivesse, desde algum tempo, inclinada a modificações mais sérias no sistema de exploração colonial americano. A inclusão dessa proposição ajudaria, ao menos, explicar a rapidez com que d. João sintetizou e apresentou a resolução que impactaria consideravelmente a economia do Brasil em relação ao comércio mundial. ${ }^{56}$

De todo o modo, a abertura dos portos teve, conforme aludiria José da Silva Lisboa (1756-1835), futuro visconde de Cairu, uma importância prática ainda maior, pois significou a suspensão do Sistema Colonial no Brasil. ${ }^{57}$ Não por acaso, seria justamente em torno das questões vinculadas a essa liberdade comercial que, dali por diante, manifestar-se-iam as maiores tensões envolvendo portugueses radicados nos dois lados do Atlântico, as quais se estenderiam, pelo menos, até o processo de Independência política do Estado e nação brasileiros em 1822-1823. Isso porque, com a abertura comercial, a antiga metrópole e os grandes negociantes portugueses, que, até então, controlaram o grosso do comércio nesta parte da América, logo perceberam a efetiva perda do monopólio nas realizações das mercadorias saídas do Brasil. Dimensionaram ainda o alargamento nas participações de comerciantes, inclusive estrangeiros, que, disputando apoios entre a classe senhorial nascida majoritariamente em território americano, ficaram livres para exportarem e importarem bens e

\footnotetext{
${ }^{54}$ Naqueles dias, interessava ao príncipe compreender: "Se a mesma lavoura tem recebido progressivo aumento, de que tanto depende a prosperidade do comércio desta capital, e qual o motivo favorável, ou desfavorável a este respeito"; "Se os diferentes exames sobre a boa qualidade dos gêneros de exportação desta colônia, e mais cautelas, que se praticam a respeito dos mesmos gêneros, se podem considerar úteis, ou nocivos ao progresso do comércio" e, finalmente: "Se o lavrador desobrigado destes exames, e o negociante na liberdade de convencionar-se nos preços dos gêneros com o mesmo lavrador promoverão melhor seus recíprocos interesses". Oficio do conde da Ponte ao Senado da Câmara de Salvador, apud BRITO, João Rodrigues de, op. cit. p. 26.

${ }_{55}^{55}$ Apud idem, ibidem, loc cit.

${ }^{56}$ Essa possibilidade foi considerada em estudo de TAVARES, Luís Henrique Dias. História da Bahia. 10. ed. rev. e aum. São Paulo: UNESP. Salvador: Edufba, 2001. p. 210-211.

${ }^{57}$ Para Silva Lisboa, a transferência da corte para o Rio de Janeiro "marca uma grande era nos anais da civilização, pela suspensão do sistema colonial [e a adoção de] um liberal sistema econômico". Apud ROCHA, Antonio Penalves, op. cit. p. 30.
} 
mercadorias em direção às rotas comerciais que lhes apresentassem mais "vantajosas às suas especulações". 58

Nota-se que, se por um lado, esta inserção no comércio internacional asseguraria a continuidade dos rendimentos que, até então, fazia a felicidade do Brasil, e por extensão da monarquia, com a vantagem de garantir os vínculos da Coroa e de uma maior proporção de súditos portugueses com os mercados europeus. Por outro, a forma como se deu a regulamentação desse processo passou a desagradar, já em 1808, uma parcela importante dos negociantes concentrados no grande comércio, os quais não se contentaram apenas com as taxas preferenciais sobre os principais produtos de exportação de Portugal. Formado majoritariamente por portugueses nascidos em território europeu, esse agrupamento sentir-seia ameaçado, seja pela concorrência em geral, seja pela competição da Grã-Bretanha em particular; posto que os agentes britânicos da Era Industrial estivessem verdadeiramente empenhados na conquista de novos mercados para os seus variados produtos manufaturados.

Nos dias seguintes à publicação da carta régia que autorizara a abertura dos Portos, grandes negociantes residentes em Salvador levaram ao príncipe regente uma representação em que esperavam obter medidas protecionistas mais seguras frente à concorrência estrangeira. O alvo central das suas queixas dirigia-se ao "sistema" de comércio praticado pelos representantes da Grã-Bretanha que a princípio "vendem [...] barato e compram caro" na perspectiva de provocar o "desfalecimento" da "produção do país" e, logo que esse é assegurado, invertem a situação e adotam "o sistema contrário", cujo ordinário é observar os "comerciantes nacionais depaupera[re]m" e os rivais enriquecerem. ${ }^{59}$ Ao que parece, essa tentativa corporativista dos negociantes de grosso trato em Salvador não logrou sucesso, haja vista que, conforme o Almanaque para a cidade da Bahia, para o ano de 1812 havia 12 firmas estrangeiras, a maioria de origem britânica, para outras 154 registradas em nomes de portugueses europeus e americanos. E nove anos mais tarde, as casas comerciais dedicadas às atividades de exportação e importação de mercadorias passaram ao número de 22 , sendo

\footnotetext{
${ }^{58}$ A citação pertence à Representação dos negociantes da Bahia ao príncipe regente d. João, em 27 de janeiro de 1808. Apud PINHO, Wanderley, 1961, op. cit. p. 27. Sobre as questões gerais discutidas aqui, ver ROCHA, Antonio Penalves, op. cit. p. 41-43. No lado das colônias hispânicas, igualmente, as funções administrativas e comerciais mais disputadas foram, em grande proporção, monopolizadas pelos reinóis, se bem que no tocante à propriedade fundiária o acesso da população crioula revelavou-se mais facilitado. Cf. BENEDICT, Anderson R. Pioneiros crioulos. In: BENEDICT, Anderson R. Comunidades Imaginadas: reflexões sobre a origem e a difusão do nacionalismo. São Paulo: Companhia das Letras, p. 84-106, 1998.

${ }^{59}$ Apud SILVA, Maria Beatriz Nizza da. A primeira gazeta da Bahia: Idade d'Ouro do Brazil. 2. ed. revista e ampliada. Salvador: Edufba, 2005. p. 150.
} 
dezoito britânicas e as demais francesas e alemãs, que controlavam dois estabelecimentos cada. $^{60}$

Então, se não bastasse ter regulamentado a liberdade de comércio aos padrões mais apropriados à ideologia liberal em forte ascensão no mundo ocidental de princípios do Oitocentos, as ações subsequentes do príncipe regente na sua curta permanência em território baiano priorizaram a dinamização e integração comercial em favor do desenvolvimento americano. Dentre as concessões anunciadas, convém mencionar a criação da primeira Companhia de Seguros e Comércio Marítimo, a abertura de estradas - inclusive porque previa recursos para que a Bahia e o Rio de Janeiro se interligassem por vias terrestres de fácil acesso - e a permissão para que uma fábrica de vidros fosse instalada. Esse procedimento, no entanto, abria importante precedente contra o alvará de 1785 que proibira atividades manufatureiras no Brasil; e quiçá indicava, uma vez mais, os planos futuros da monarquia que, efetivamente, suspenderia tamanha interdição com a carta régia de $1^{\circ}$ de abril de $1808 .{ }^{61}$

Durante a estada do príncipe regente em Salvador, verificou-se ainda a autorização para que uma Escola Médico-Cirúrgica fosse estabelecida na cidade. Decerto, além de incentivar os estudos médicos entre os filhos das classes proprietárias, essa iniciativa poderia impactar positivamente o tratamento da saúde, ao menos, entre as famílias mais abastadas da capital e Recôncavo baianos já que, além das "aulas práticas" cirúrgicas, permitiu-se igualmente a criação das cadeiras de anatomia e obstetrícia. ${ }^{62}$ Em termos mais particulares, mas não menos significativos à lógica de distribuição de graças e mercês característica do Antigo Regime, a visita bragantina serviu, finalmente, para conferir comendas e títulos, atender interesses de desembargadores e militares, abrandar penas e dar indultos a criminosos, ${ }^{63}$ verticalizando, portanto, a atuação régia entre uma maior proporção de súditos, o que, em última instância, visava reafirmar os preceitos tradicionais das monarquias absolutas.

\footnotetext{
${ }^{60}$ SILVA, Maria Beatriz Nizza da. op. cit. p. 151.

${ }^{61}$ CALMON, Pedro, op. cit. p. 1372. Para a situação da Bahia nesse período, ver também. PINHO, Wanderlei de A. A Bahia - 1808-1856. In: HOLANDA, Sérgio Buarque de (Org.). História Geral da Civilização Brasileira. 6. ed. São Paulo: Difel, 5 ed., p. 242-311, tomo II. 1985, v. 2. e CAVALCANTE, Zélia. O processo de Independência na Bahia. In: MOTA, Carlos Guilherme (Org.), 1972, op. cit. p. 231-250.

${ }^{62}$ CALMON, Pedro, op. cit. p. 1371-1372. Passados sete anos (1815), essas cadeiras de "aulas práticas" cederiam lugar à implantação de um curso completo de cirurgia, com duração de cinco anos, período em que seus estudantes poderiam dedicar-se aos conhecimentos de anatomia, química farmacêutica, princípios e prática médico-cirúrgica, fisiologia, higiene, patologia, terapêutica e obstetrícia. Esse também seria núcleo das disciplinas que, posteriormente, daria origem à Faculdade de Medicina da Bahia, a qual cumpriria papel de alguma relevância no ensino médico e na cultura humanista brasileira do século XIX. TAVARES, Luís Henrique Dias, op. cit., 212-213.

${ }^{63}$ PINHO, Wanderley, 1961, op. cit. p. 19.
} 
Contudo, percebe-se que a postura geral da Coroa indicava que as relações entre a autoridade monárquica e seus súditos experimentavam surpreendentes alterações. Em suma, passados quase três séculos de exploração colonial americana, as pressões externas e internas que propiciaram a sua maior integração e dinamização econômica e social engendraram também a crítica ao próprio sistema e, no limite, apontavam para a sua superação. ${ }^{64}$ Mas, como a monarquia portuguesa não negligenciava o intricado mosaico que dava forma e sentido à sua autoridade no contexto crítico do Antigo Regime, ela trazia perto de si um corpo de assessores, os conselheiros de Estados, cujas funções exigiam-lhes estar informados, tanto das conjunturas e dos interesses internacionais, quanto das necessidades e aspirações internas nos domínios da nação. ${ }^{65}$

Quando desembarcou em Salvador, d. João pôde contar com, pelo menos, dois conselheiros régios nas pessoas de d. Fernando José de Portugal (1852-1817), depois marquês de Aguiar, e do marquês de Bellas, José Luiz de Vasconcellos e Sousa. ${ }^{66}$ O primeiro era bastante conhecido e conhecedor da Bahia e de vários dos seus habitantes já que por treze anos (1788-1801) exercera o alto posto de capitão-general e governador da capitania. Foi, como se sabe, na sua administração que se organizou e espraiou o ensaio sedicioso que tinha por pretensão a instauração da República Bahinense. Descoberta e devassada a conspiração, d. Fernando resolveu hierarquizar as culpas de modo a "capacitar que nestes atentados nem entravam pessoas de consideração, nem de entendimento, ou que tivessem conhecimento e luzes", sendo, isso sim, negócios de homens de baixa condição social, "de péssima conduta e faltos de religião". ${ }^{67}$ Sugestão que, na época, foi rigorosamente acatada pela Coroa. Então, depois de tudo que viu e viveu na capitania, o futuro marquês de Aguiar bem que poderia oferecer algum tipo de experiência ao príncipe regente, inclusive sugerindo ou censurando propostas e nomes de pessoas no intuito de secundar a Coroa no fortalecimento dos vínculos políticos e sociais em uma parte influente da possessão americana.

Reputa-se ter sido por intermédio desse conselheiro, ainda que auxiliado também pelo conde da Ponte, que o então deputado e secretário da Mesa de Inspeção, José da Silva

\footnotetext{
${ }^{64}$ NOVAIS, Fernando Antônio, 1983, op. cit. e COSTA, Emília Viotti da, op. cit. p. 84.

${ }^{65}$ SOUSA, Maria Aparecida Silva de, op. cit.

${ }^{66}$ PINHO, Wanderlei, 1961, op. cit. p. 21. Nos dias seguintes à chegada do príncipe regente à Bahia, outros conselheiros e integrantes da corte portuguesa, cujas embarcações haviam igualmente se desgarrado do restante da comitiva que seguira para o Rio de Janeiro, começaram a aportar em Salvador. Dentre estes, Antônio de Araújo, depois conde da Barca, José Egídio Alves de Almeida, futuro secretário particular de d. João VI e marquês de Santo Amaro - que, por sinal, era baiano - e o desembargador Tomás Antonio Corte Real. Cf. Idem, ibidem. p. 20.

${ }^{67}$ Apud JANCSÓ, István, 1996, op. cit. p. 151. A hipótese sobre a hierarquização das culpas dos implicados em 1798 foi demonstrada nesta análise. Idem, ibidem. p. 152-153.
} 
Lisboa conseguiria aproximar-se do príncipe regente. ${ }^{68}$ Baiano e legítimo representante da formação ilustrada, o futuro visconde de Cairu ingressara nos cursos de ciências jurídicas da Universidade de Coimbra (1774-1778), formando-se em Cânones. ${ }^{69}$ Após muitos anos de serviços como funcionário público na Bahia, ele gozava de muito prestígio junto às várias autoridades da capitania. Em razão das suas ideias e conhecimentos, especialmente na área de economia política, d. João convidou-lhe para seguir viagem com a comitiva real e servir à alta burocracia imperial no Centro-Sul. ${ }^{70}$ Ao chegar ao Rio de Janeiro, Silva Lisboa foi logo nomeado desembargador do Paço e da Consciência e Ordens, cuja atribuição principal exerceria como Censor Régio. Seis meses na nova corte foram suficientes para que o futuro visconde de Cairu conquistasse o muito ambicionado posto de deputado na Real Junta de Comércio, Agricultura, Fábricas e Navegação. Seus vínculos com a Bahia, no entanto, continuaram ativos. Em outubro de 1808 fora nomeado desembargador da Relação da Bahia; em 1823, ocupou primeiro a vaga de deputado Constituinte pela província natal e, três anos depois, era senador vitalício do Império do Brasil. ${ }^{71}$

Reaver a trajetória desse baiano ilustrado no interior do Estado português e, posteriormente, no Estado imperial do Brasil torna-se importante em virtude de ele servir para demarcar uma tendência de mudança de residência para a corte fluminense naqueles anos, seguida por outros indivíduos nascidos na Bahia, aonde novas e melhores oportunidades exerciam um poder de fascínio considerável. ${ }^{72}$ A rigor, o deslocamento de habitantes da capitania para o Rio de Janeiro não era novo, já que ocorria com alguma evidência desde 1763, quando a cidade de Salvador perdeu para os fluminenses a sede dos vice-reis do Brasil. Todavia, com a instalação da família real em 1808, o Rio de Janeiro tornou-se efetivamente rota migratória de grande apelo não apenas para a Bahia, mas para todo o Império

\footnotetext{
${ }^{68}$ PINHO, Wanderlei, 1961, op. cit. p. 22.

${ }^{69}$ Sobre a trajetória intelectual do futuro visconde de Cairu ambientada no torvelinho político do Antigo Regime português, ver ARRUDA, José Jobson de Andrade; NOVAIS, Fernando Antônio, op. cit.

${ }^{70}$ As contribuições de José da Silva Lisboa na defesa do livre-comércio como recurso capaz de realizar a conciliação de interesses entre a Coroa e seus súditos são discutidas por ROCHA, Antonio Penalves, op. cit.

${ }^{71}$ ROCHA, Antonio Penalves. Introdução. CAIRU, Visconde de. Visconde de Cairu. Organização e introdução de Antonio Penalves Rocha. São Paulo: Ed. 34, p. 7-50, 2001.

${ }^{72}$ Maria Odila Silva Dias registrou a inclinação das classes dominantes em apegar-se à corte nos anos em que a família real residiu no Rio de Janeiro. Dentre as explicações que encontrou para isso estavam as perspectivas políticas e a necessidade de afirmação diante de facções rivais. Outros foram tocados pelas vaidades pessoais, ambições de títulos e honrarias e ou, simplesmente, por sentirem-se estimulados pelo "nepotismo do príncipe". Havia ainda aqueles que desejavam entabular negócios com os portugueses europeus recém-chegados ao Rio de Janeiro e que traziam da antiga metrópole algum cabedal. Entretanto, a historiadora compreendeu que boa parte desses deslocamentos também poderia ser esclarecida pela conduta dos segmentos dominantes: "ansiosos de assegurar sua autonomia local sobre a proteção e sanção do poder central que viria afirmar sua posição em meio à população escrava, ou pior, a turbulência de mestiços que não eram proprietários". DIAS, Maria Odila da Silva, op. cit. p. 177.
} 
português. ${ }^{73}$ Com o agravamento da crise política em princípios dos anos 1820 , muitos desses baianos permaneceram na corte, quando então passaram a influir diretamente nas atividades políticas relacionadas ao processo de formação do Estado e nação brasileiros, questões que serão aprofundadas ao longo desse estudo.

Ao deixar a cidade de Salvador e embarcar para a capital fluminense, aos 26 de fevereiro de 1808, a monarquia portuguesa havia traçado um esboço mais ou menos preciso de como pretendia redesenhar o equilíbrio político, econômico e social capaz de englobar uma maior proporção de súditos que, de fato, eram os legítimos interessados em construir alternativas para a superação da aguda crise. Por isso, o futuro monarca fez da Bahia um campo de experiência importante pelo qual pôde testar algumas das políticas que serviriam de base para a reinvenção do Império português. ${ }^{74}$ Nesse sentido, convém enfatizar que o território americano não apenas abrigaria a corte transmigrada, mas nele também - e a começar pela Bahia - realizar-se-iam concessões e erguer-se-iam instituições administrativas próprias de um Estado que, se por um lado, tencionava continuar absoluto; por outro, mostrava-se apto em promover mudanças e inovações com graus variados de modernização, ainda que seu custo, contraditoriamente, pudesse por em risco a sobrevivência do próprio sistema que procurava preservar. Em todo o caso, a América portuguesa adquiriria melhores condições para expressar seus potenciais no interior do império. Situação que, por seu turno, seria acompanhada de reveses entre os portugueses defensores das velhas prevalências e hierarquias no âmbito imperial, os quais teriam motivos para se sentirem mais e mais preteridos ante o que acontecia no Brasil. ${ }^{75}$

\footnotetext{
${ }^{73}$ SLEMIAN, Andréa. Vida política em tempo de crise: Rio de Janeiro (1808-1824). São Paulo: Hucitec, 2006.

${ }_{75}^{74}$ Cf. SOUSA, Maria Aparecida Silva de, 2009, op. cit.

${ }^{75}$ Sempre na expectativa de reduzir as reformas aos limites do livre comércio e frustrar a todo o custo uma possível convocação de Cortes Gerais, em dezembro de 1808, d. Rodrigo endereçara uma correspondência a d. Fernando José de Portugal alertando-o que "S. A. R. está convencida de que o único meio de evitar o péssimo efeito das Cortes é ganhar o afeto do povo com justas concessões, e avançando aqueles estabelecimentos úteis com que os demagogos hão de querer depois fazer-se valer". Estas suas preocupações iriam se justificar ante a consulta posta por alguns governadores em Portugal considerando a convocação de Cortes Gerais para aquele Reino. Antevendo os perigos para a forma de poder absoluto, em agosto do ano seguinte, o já nobilitado conde de Linhares (1808) aconselhava, em tons um tanto austero, ao príncipe d. João: "Estas lembranças [de Cortes Gerais] dos governadores deve ser fortemente rebatida, e um tal princípio pode ter as mais sérias consequências para a autoridade de V. A. R. e para a Monarquia, e quem a lembrou é mais traidor do que aqueles que à cara descoberta atacam a Monarquia”. Apud LYRA, Maria de Lourdes Viana, op. cit. p. 133-134 (para ambas as citações).
} 


\subsection{Indícios de descontentamentos na Bahia e revoluções na América hispânica}

Nos últimos anos dos Setecentos, o governo de Lisboa esteve informado sobre os potenciais efeitos da propaganda revolucionária na capitania baiana, especialmente, após a conspiração de 1798, quando segmentos das tropas demonstraram-se afetados pelos novos ideais de soldado-cidadão ainda em construção no continente europeu. Já no que diz respeito ao período em que a monarquia portuguesa residiu na América, o recurso preventivo mais fartamente adotado passou, tanto pela exortação para os governadores manterem-se vigilantes frente aos descontentamentos potenciais, quanto pela adoção sistemática da regra colonial portuguesa matizada em fórmulas tradicionais, como: "Cooptação das elites locais por meio de postos e honras; estímulos de rivalidades entre elas favorecendo uma minoria de portugueses europeus e o uso de procedimentos burocráticos designados para ampliar o valor da grande legitimidade da Coroa" ${ }^{76}$

A fixação da monarquia portuguesa entre os fluminenses, embora produzisse uma forte percepção de que o Estado ampliava a sua política de compromissos e acomodações tendo em vista novos rearranjos de poder no interior do Império, revelava-se, ainda assim, incapaz de neutralizar os principais efeitos da crise do Antigo Regime. Afinal de contas, a conjuntura europeia de princípios do Oitocentos ao mesmo tempo que obrigou a corte portuguesa a procurar refúgio no Brasil, produziu a abertura do ciclo revolucionário na América espanhola, impondo novos desafios à monarquia de Bragança. Então, ainda mais consciente de que novos empuxos insurrecionais poderiam atravessar as fronteiras da América portuguesa, coube-lhe redobrar os cuidados administrativos e militares na expectativa de assim preservar o seu legado tradicional.

Se, por um lado, a declaração de guerra à França permitiu a conquista militar da província de Caiena (Guiana Francesa) pelo governo português (1809) que, assim, passou a exercer controle sobre a difusão dos ideais napoleônicos em um território contíguo ao Brasil via a capitania do Pará; por outro, a decisão da América hispânica de optar pela criação de juntas governativas e, finalmente, pela dissolução dos laços políticos com a Espanha não iria assegurar nem ao exército da Grã-Bretanha nem ao de Portugal - ambos com interesses expansionistas na região - preencher o vazio de poder que se estabelecera em razão dos franceses terem ocupado a Península Ibérica. ${ }^{77}$ Isso porque as alterações políticas em território

\footnotetext{
${ }^{76}$ MORTON, F. W. O. , 1974, op. cit. p. 79 (tradução livre).

${ }^{77}$ Em consequência da guerra na Europa, o exército da Grã-Bretanha invadiu a região do Prata em junho de 1806 e em julho do ano seguinte. Em ambas as ocasiões, no entanto, os britânicos foram obrigados a abandonar suas posições devido à resistência empreendida pelas milícias urbanas comandadas por chefes locais e que recebiam
} 
americano partiram do princípio segundo o qual, e a exemplo dos procedimentos verificados em cidades espanholas (sobretudo Aranjuez, Servilha e Cádiz), os súditos da América podiam organizar-se política e, se necessário, militarmente, para melhor defender os direitos do monarca espanhol, Fernando VII, então, cativo de Napoleão e cuja coroa havia sido usurpada pelo Império francês. ${ }^{78}$

Bem entendido, a maioria dos ayuntamientos americanos fora instalado tendo por proposição fundamental "a retroversão da soberania aos povos, em nome do rei”, conquanto as práticas autonomistas daí derivadas se mostrarem, já nas origens, contrárias ao preceito primário a ser protegido. ${ }^{79}$ Em outras palavras, ao se estruturarem politicamente, tanto os súditos peninsulares quanto os ultramarinos, negaram a realeza como fonte de poder única e inviolável, abrindo, assim, o caminho para que a ação política garantidora da autonomia da América, ante o domínio francês, pudesse também ser estendida à própria potestade de Espanha de quem, na realidade, não tardaram em decidir a proclamar-se independentes na forma de novos Estados nacionais. ${ }^{80}$

A experiência revolucionária desses vizinhos americanos, certamente, colocava em vigilância a monarquia absoluta luso-americana que chegada ao Rio de Janeiro, em 7 de apoios expressivos entre a maioria da população. O Império português, por seu turno, procurou respaldar a presunção de d. Carlota Joaquina, esposa de d. João, em reclamar direitos dinásticos sobre a América-hispânica, em razão da Espanha ter caído sob o controle francês. O projeto carlotista propunha assumir o poder e com o apoio das coroas portuguesa e britânica enfrentar ao inimigo comum. Ou seja, se antepor ao bonapartismo considerado uma ameaça aos princípios de organização do Estado e sociedades do Antigo Regime. Embora travasse contatos e chegasse mesmo a enviar interlocutores a algumas regiões hispânicas, os propósitos do carlotismo só adquiriram consistência na região do Prata, muito por conta das intensas atividades comerciais e interesses que essa localidade vinha estabelecendo com o território do Brasil naqueles anos. Sobre o assunto, ver PIMENTA, João Paulo Garrido. Estado e Nação no fim dos Impérios Ibéricos no Prata (1808-1828). São Paulo: Hucitec; Fapesp, 2002. Para a conjuntura geral da América hispânica nesse período, consultar JANCSÓ, István. A construção dos Estados Nacionais na América Latina: Apontamentos para o estudo do Império como projeto. In: SZMRECSÁNYI, Tamás; LAPA, José Roberto do Amaral (Orgs.), op. cit. p. 3-26.

${ }^{78}$ Em março de 1808, uma revolução palaciana obrigou o rei de Espanha Carlos IV a abdicar ao poder em favor do seu filho, Fernando. Logo depois, os franceses ocuparam Madri e Napoleão Bonaparte conseguiu que os Bourbons Carlos e Fernando VII viajassem para Bayonne. Ali, aos 5 dias deste mês, o imperador francês forçouos a renunciar ao trono espanhol, favorecendo, com isso, que no mês seguinte José Bonaparte, irmão do corso francês, fosse proclamado rei de Espanha e das Índias. LYNCH, John. As origens da Independência da América Espanhola. In: BETHELL, Leslie (Org.). História da América Latina: Da Independência a 1870. São Paulo: Edusp/Imprensa Oficial do Estado de São Paulo; Brasília: Fundação Alexandre de Gusmão, 2004, v. 3. p. 71.

${ }^{79}$ SLEMIAN, Andréa; PIMENTA, João Paulo G., op. cit. p. 148. Resultado direto do recrudescimento da crise do Antigo Regime, em 1810, os cabildos abiertos de Caracas (19 de abril); Buenos Aires (22 de maio); Alto do Peru (em 25 de maio e, posteriormente, em outubro quando a junta de Quito logrou pleno êxito); Santa Fé de Bogotá (20 de julho) e Santiago do Chile (18 de setembro) instituíram suas próprias juntas de governo em substituição aos representantes designados pela metrópole espanhola. CHUST, Manuel. La cuestión nacional em las Cortes de Cádiz (1810-1814). Valencia: Centro Francisco Tomás y Valiente UNED Alzira-Valencia, Fundación Instituto Historia Social, 1999 (Col. Biblioteca História Social). p. 40.

${ }^{80}$ Depois da promulgação da Constituição elaborada nas Cortes de Cádis (1812), diversas populações da América hispânica promoveram seus próprios ensaios constitucionais que, ao fim e ao cabo, provocaram a ruptura política entre esses povos e a nação de Espanha. São exemplos desses processos os acontecimentos verificados no Peru (1812-1814), em Quito (1812), na Província Oriental (1813) e no Paraguai (1813), Rio da Prata (em 1813 e 1819), México (1814), Chile (1818) e na Colômbia (1819). Cf. Idem, ibidem. 
março de 1808, reunia esforços não apenas para uma possível intervenção na região, mas sobretudo porque estava disposta a assegurar um maior equilíbrio entre as diferentes partes da nação portuguesa. ${ }^{81}$ Apesar das precauções, a viabilidade da revolução hispano-americana, enquanto alternativa para a superação do Antigo Regime, constituiria, doravante, em um novo e profundo mecanismo de transformação e de aprendizado político por parte dos habitantes no interior de um continente que fora escolhido pela Casa de Bragança justamente para servir de abrigo ante as turbulências do século.

Pode-se afirmar que esse era um processo de mão dupla visto que a simples presença da família real na América cumpriria, outrossim, a função de contrabalançar o campo de atuação do projeto revolucionário hispano-americano, obrigado pelas próprias especificidades conjunturais manifestas nos dois lados do Atlântico a concentrar todas as suas forças nas dinâmicas disputas em aberto. Sobrava, de todo o modo, o exemplo subversivo, cuja propagação envolvia uma gama variada de recursos, incluindo-se aí manifestações subliminares que na maioria dos casos tinha por função primordial embaraçar a atuação do aparato governamental repressivo. Nesse aspecto, a força moral do exemplo revolucionário constituía-se, desde sempre, uma promessa, a um só tempo, importante e iminente. ${ }^{82} \mathrm{E}$, não por acaso, os indicativos de subversão firmaram-se no universo mental das autoridades portuguesas de princípios do Oitocentos como os principais desvios de conduta e comportamento a serem vigiados e combatidos.

Não obstante as especificidades que individualizavam as trajetórias e experiências do Reino europeu e da capitania baiana, o alinhavar de perspectivas recíprocas se fazia manifesto, especialmente após 1807 com a transferência da família real para a América portuguesa. Os estreitos laços comerciais e de parentescos que os portugueses europeus radicados na antiga capital dos vice-reis no Brasil mantinham com Portugal propiciou a conformação de alguma sociabilidade política entre essas duas partes do império bragantino. Daí a ocorrência de uma dada simetria envolvendo o que passou a ser denominado de

\footnotetext{
${ }^{81}$ Maria de Lourdes Viana Lyra sumariou que, entre fins do Setecentos e princípios do século seguinte, o "reformismo ilustrado" português primou por realizar as "[...] reformas eficientes na máquina administrativa para desentravar o sistema, estimular a atividade produtiva e interdependente de todas as partes do império. $\mathrm{O}$ objetivo era sedimentar a unidade e sustar o processo revolucionário. Para D. Rodrigo [de Sousa Coutinho], o peso excessivo da carga tributária constituía o problema fundamental, vendo-o não apenas como entrave ao desenvolvimento de exploração da riqueza, mas também como adubo fértil ao germe dos movimentos de libertação colonial ". Op. cit. p. 81.

${ }^{82}$ A força moral das revoluções contra o Antigo Regime não era necessariamente nova, pois, como se sabe, os ensaios sediciosos em Minas Gerais (1789) e na Bahia (1798), tornaram-se também dignos de atenção para os próprios contemporâneos pela forma com que os seus implicados procuraram inspirações e contatos entre os respectivos representantes dos eventos revolucionários dos Estados Unidos de 1776 e da França de 1789. Para o primeiro e o segundo casos, ver respectivamente MAXWELL, Kenneth, 1985, op. cit. e JANCSÓ, István, 2001, op. cit.
} 
interesses nacionais conjugando, em certa proporção, as expectativas de futuro entre os dois importantes territórios portugueses. Realmente, nos anos subsequentes à instalação da corte fluminense, a população reinol sentiu-se abandonada pela monarquia e entregue à administração de protetores ingleses, enquanto habitantes da Bahia também se frustravam com a recusa do convite feito ao futuro rei para ali fixar residência, sendo que, logo se viriam compelidos a contribuir na implantação da infraestrutura necessária ao funcionamento da nova sede do Império. ${ }^{83}$

Para além de entreter relações com o governo centralizado no Rio de Janeiro - o qual bem cedo revelou apreciável capacidade em drenar recursos financeiros e quadros diretivos para a sua órbita -, o Reino de Portugal, bem como a província da Bahia passaram a experimentar uma acirrada concorrência promovida pelos negociantes ingleses. Conjuntura que, decerto, propiciava um fator de instabilidade política para o Império, pois gradativamente fariam coincidir os interesses daquelas duas praças comerciais que encontrariam sérios motivos para desconfiarem das medidas advindas do principal centro de convergência do novo Império. ${ }^{84}$ Afinal, a considerável alteração no tradicional equilíbrio das partes no interior da nação portuguesa acarretava relevantes possibilidades de disputas, dentre as quais, faz-se necessário compreender como a repentina transferência do mais importante centro de convergência imperial para o Rio de Janeiro impactou as relações, mormente as comerciais, que capitanias como o Pará, Maranhão e a própria Bahia mantinham secularmente com Portugal. ${ }^{85}$ Mesmo considerando que as especificidades das suas localizações geográficas, principalmente em se tratando das duas primeiras regiões, propiciavam o contato mais fácil com Portugal, todos logo descobriram que enquanto a corte bragantina permanecesse no Sul

\footnotetext{
${ }^{83}$ Os efeitos desta insatisfação para com a preponderância do Rio de Janeiro sobre as economias tradicionais da antiga colônia do Brasil parecem ter sido consideráveis. Caso contrário, como explicar, por exemplo, o tremendo esforço, inclusive financeiro, que grandes comerciantes em Salvador aplicaram para tentar manter a vinculação da província baiana aos desígnios de Portugal? Para o substancial gasto que os comerciantes portugueses europeus empregaram durante os anos de 1821 a 1823 na expectativa de serem conservados os destinos da Bahia e Portugal, ver SILVA, Ignácio Accioli de Cerqueira, op. cit., v. 3-4 e MORAES, Alexandre de Mello. História do Brasil-Reino e do Brasil-Império. Belo Horizonte: Itatiaia; São Paulo: Ed. Universidade de São Paulo, 1982, t. 2.

${ }^{84}$ No que diz respeito às insatisfações políticas em Portugal após a vinda da família real para a América portuguesa, ver ALEXANDRE, Valentim. Os sentidos do Império. - questão nacional e questão colonial na crise do Antigo Regime português. Porto: Afrontamento, 1993.

${ }^{85}$ A intenção aqui é explorar e, se possível, problematizar algumas das sendas investigativas sugeridas por István Jancsó e João Paulo G. Pimenta quando observaram que: "O tradicional equilíbrio político entre as capitanias ou, mais exatamente, entre os grandes centros de convergência do espaço luso-americano, cada qual ligado a Lisboa onde se realizava a unidade do todo por eles formado, foi bruscamente substituído por outro que instaurava uma hierarquia entre espaços sociais que anteriormente relacionavam-se horizontalmente, alteração que, subordinando as outras regiões ao Rio de Janeiro, tinha imediato sentido prático”. JANCSÓ, István; PIMENTA, João Paulo Garrido, op. cit. p. 154. No que se refere à conformação de novas relações econômicas nas províncias do Centro e do Sul do Império português a partir da fixação da corte joanina no Rio de Janeiro, ver o estudo pioneiro de LENHARO, Alcir, op. cit.
} 
do continente do Brasil estariam obrigadas a voltar, ao menos, parte das suas atenções para os novos pólos articuladores em plena afirmação nas cercanias fluminense. ${ }^{86}$

Situações como essas possibilitaram a Maria Odila da Silva Dias concluir que: "Para governadores e funcionários das várias capitanias parecia a mesma coisa dirigirem-se para Lisboa ou para o Rio". ${ }^{87}$ Registre-se, no entanto, que essa inédita subversão no direcionamento da principal rota de peregrinação da nação portuguesa não envolveu apenas perdas para o conjunto das populações americanas, visto o esforço sincero da Coroa bragantina em levar adiante uma política de modernizações, compensações e cooptações que, com efeito, serviu de anteparo e, se ao menos não conseguiu anular os descontentamentos, retardou os seus efeitos.

Influenciado, por certo, pelos resultados dessa complexa tessitura, cuja principal característica parecia ser a provisoriedade, o redator português europeu Joaquim José da Silva Maia difundiria, tempos depois no número inaugural do periódico Sentinella Bahiense, em 21 de junho de 1821, uma acerba crítica contra as principais inovações promovidas pela monarquia durante a sua estada na América portuguesa. Não obstante o real objetivo desse periódico consistisse em incensar a resistência no tocante ao ajustamento político da província baiana à corte fluminense, ele denunciava a infraestrutura, bem como os recursos simbólicos e culturais que fundamentavam o poder de base da Coroa bragantina naqueles delicados anos:

O Rio de Janeiro, aonde o Despotismo havia assentado seu trono, no longo espaço de 13 anos; e aonde uma corrompida Corte, transplantada de um País velho, com todas as manhas e defeitos inveterados, para um País novo; pretendendo livrar-nos do opressivo estado de Colônia, franqueado o Brasil a todas as Nações, nos lançou ainda mais pesadas cadeias. A substância das Províncias era absorvida por aquela voragem, que nos reduziu ao estado de acanhamento, em que hoje estamos: apensou o nosso comércio, aniquilou a marinha; estuporou todos os ramos de indústria: tanto mais deve merecer a nossa execração que tendo todas as proporções para fazer este País florescente, animar e promover a agricultura, as artes; fez o contrário [...] e ainda fez mais desmoralizou-nos!!! As enormes somas que lhes forneciam as Províncias, em vez de se empregarem no melhoramento das estradas, no encanamento dos rios; em promover à marinha, eram dissipadas escandalosamente por estúpidos e corrompidos petimestres. [...] Em paga do muito dinheiro, que a ávida Corte recebia das Províncias, por multiplicados Impostos, nos fizeram vaidosos e fátuos enchendo-nos de fitas, que deviam

\footnotetext{
${ }^{86}$ Para os indicativos de como as províncias do Pará e do Maranhão resistiram, por algum tempo, a se alinhar ao poder do Rio de Janeiro no contexto da Independência, ver MACHADO, André Roberto de A. A quebra da mola real das sociedades: a crise política do Antigo Regime português na Província do Grão-Pará (1821-1825). Tese (Doutorado em História Social) - Universidade de São Paulo, São Paulo, 2006. No que respeita ao desenvolvimento do mercado interno voltado para atender a dinâmica da corte fluminense, ver FRAGOSO, João Luís Ribeiro, op. cit. e a análise pioneira de LENHARO, Alcir, op. cit.

${ }^{87}$ DIAS, Maria Odila da Silva, op. cit. p. 182.
} 
ser a distinção e paga do merecimento, e que as prodigalizando a toda a casta de gente, perderam toda a estima. Multiplicou os Tribunais e os Empregados, que, complicando os negócios das partes, fazendo os dispendiosos, oprimiam o Povo: não satisfeita ainda de nos iludir com penduricalhos, que tornavam vazias as bolsas e as cabeças daqueles que as recebiam, também nos iludiu com vãos títulos, que bens nenhuns na realidade traziam consigo; com a Categoria de Reino!!! Como se este título pudesse fazer alguns bens no Brasil, quando as Leis eram ineficazes, quando o luxo nos tinha arruinado, a virtude ultrajada; quando finalmente o Despotismo mais estendia sobre nós a sua vara de ferro!!! [...]. ${ }^{88}$

Se no decurso de pouco mais de um decênio em que a Coroa bragantina se ausentara de Portugal, os residentes na América portuguesa deixaram registradas poucas denúncias sobre as condutas e práticas administrativas, simbólicas e culturais, esse retesamento encontrou, enfim, condições para extravasar durante os conturbados anos em que se processou a desagregação do Antigo Regime. ${ }^{89}$ Afinal de contas, mesmo considerando todos os recursos de acomodação, ou simples repressão que o aparato português pudesse lançar mão à época para manter sob controle os seus vassalos não há como negar que os coevos vivenciavam uma época de profundas mudanças, na qual a busca e a circulação de informações e de experiências constituíam-se fenômenos em célere expansão.

Portanto, tendo que se contrapor à força política dos ideais de revolução sujeitos a manifestar-se, tanto na esfera da vida privada, quanto nos espaços públicos, a Coroa portuguesa adotou algumas medidas preventivas quando esteve sediada na América. ${ }^{90} \mathrm{Em}$ se tratando especificamente da Bahia, que desde fins do Setecentos ampliara de maneira considerável os contatos comerciais com a região do Prata, o período após a abertura dos

\footnotetext{
${ }^{88}$ Sentinella Bahiense, n. 1, sexta-feira, 21 de junho de 1822. Bahia: Tipografia da Viúva Serva e Carvalho (grifos no original). Exemplar do acervo do Centro de Estudos Baianos da UFBA. Silva Maia fora também o proprietário e redator do periódico Semanário Cívico, órgão que se manteve vinculado à regeneração política tal qual preconizava o projeto vencedor nas Cortes de Lisboa (1821-1823). Sobre a profusão de títulos honoríficos, honrarias e dignidades que o governo joanino distribuiu durante sua permanência na América, e que fora por esse periódico duramente criticado, ver ARMITAGE, John. História do Brasil: desde o período da chegada da família de Bragança, em 1808 até a abdicação de D. Pedro I, em 1831, compilada à vista dos documentos públicos e outras fontes originais formando uma continuação da história do Brasil, de Southey. Belo Horizonte: Itatiaia; São Paulo: Edusp, 1981. p. 34.

${ }^{89}$ Em estudo recente, Valdei Araújo observou que, da forma como fora instituído por d. João, a categoria de Reino do Brasil padeceu de fortes questionamentos no contexto em que o monarca foi obrigado a retornar à Europa. As céleres mudanças obrigavam, de fato, a uma reorientação, notada inclusive em discursos de figuras de proa da ilustração no Brasil, como se verifica nos escritos do próprio José Bonifácio de Andrada e Silva, o qual defendeu que o novo Portugal não se encontraria pela via da regeneração do velho Portugal, mas em sua regeneração no Novo Mundo: "[...] pois a fundação da Monarquia Brasílica fará uma época na História futura do Universo". Apud ARAÚJO, Valdei Lopes de. A experiência do tempo: conceitos e narrativas na formação nacional brasileira (1813-1845). São Paulo: Hucitec, 2008. p. 54.

${ }^{90}$ MOREL, Marco. As transformações dos espaços públicos: Imprensa, atores políticos e sociabilidades na cidade imperial (1820-1840). São Paulo: Hucitec, 2005.
} 
portos exigiria cuidados especiais por parte das autoridades. ${ }^{91}$ Convém realçar que com a repentina morte do conde da Ponte, em 24 de maio de 1809, a administração da capitania teve que ser confiada a um governo interino, enquanto se aguardava a Coroa nomear um novo governador e capitão general. ${ }^{92}$ A escolha do príncipe d. João sobre quem deveria ocupar esse eminente posto recaiu sobre d. Marcos de Noronha e Brito (1771-1828), $8^{\circ}$ conde dos Arcos de Valdevez, um funcionário régio de prestígio entre os Bragança. Dentre os serviços prestados, havia dirigido a capitania do Pará e de São José do Rio Negro (1802-1805) e fora o último vice-rei da América portuguesa (1805-1808). ${ }^{93}$

Em 30 de setembro de 1810, o conde dos Arcos assumiu o governo da Bahia com a missão de preservar a prosperidade e a modernização acelerada vivida por uma parcela da população da capitania. ${ }^{94}$ Sua administração deveria igualmente dedicar-se ao bom funcionamento de uma sociedade escravista, marcada por fortes dessemelhanças sociais e que, por essa razão, acarretava profundos ressentimentos entre aqueles que se sentiam desprivilegiados com as diretrizes do Antigo Regime. Para melhor ilustrar essa questão, cabe retomar a análise do historiador João José Reis que, por meio de 395 inventários de pessoas que morreram em Salvador entre os anos de 1800 e 1850, apontou como os habitantes do período enfrentavam uma situação econômica de forte desigualdade social. Segundo seus cálculos, os $10 \%$ mais ricos concentravam $66,9 \%$ dos bens materiais. Classificando apenas dez dos indivíduos que detinham grandes cabedais, o estudo apontou que os mesmos possuíam $37 \%$ da riqueza, não obstante só representassem $2,3 \%$ dos inventariados pesquisados. Como reverso dessa condição, João Reis verificou que $60 \%$ dos arrolados retinham $6,7 \%$ dos patrimônios e, destes, $30 \%$ possuíam mísero $1,1 \%$ em bens avaliados. Por fim, os últimos $30 \%$ dos inventariados, situados entre a extremidade superior e inferior da

\footnotetext{
${ }^{91}$ Accioli demonstrou que para os anos 1798 e 1810 as relações comerciais envolvendo a Bahia, o Rio Grande e a região do Rio Prata propiciaram a importação de mercadorias no valor de 5.373:746\$000, enquanto as exportações dessas regiões para a capitania baiana alçaram a soma de 4.225:120\$000. SILVA, Ignácio Accioli de Cerqueira, op. cit., v. 3 (esses dados constam das tabelas nas páginas 50 e 51). Segundo Catherine Lugar, depois das cidades de Lisboa e do Porto, os domínios portugueses na África e no Sul do Brasil eram os principais destinos do comércio marítimo da Bahia de fins do Setecentos, sendo que, a partir 1801, alguns importantes comerciantes residentes na capitania passariam a traficar números consideráveis de escravos africanos diretamente para o Rio Grande e Rio do Prata. Cf. LUGAR, Catherine, op. cit. p. 75. Sobre o assunto, ver também SLEMIAN, Andréa; PIMENTA, João Paulo G., op. cit. p. 95.

${ }_{92}$ Compusera o governo interino o arcebispo d. frei José de Santa Escolástica, o chanceler Antônio Luiz Pereira da Cunha e o marechal João Batista Vieira Godinho. SILVA, Ignácio Accioli de Cerqueira, op. cit., v. 3. p. 52.

${ }^{93}$ Natural de Lisboa e com ancestralidade na nobreza de Portugal, o conde dos Arcos aportou na América aos 32 anos de idade. Três anos depois, na condição de vice-rei, foi o responsável por providenciar os primeiros cuidados para a recepção da família real que chegara transmigrada ao Rio de Janeiro. MORTON, F. W. O. The governorship of the Count of Arcos in Bahia, 1810-1818. Enlightened despotism in an age of revolution, Toronto, outubro de 1986 (mimeog.). A respeito das providências do governo do vice-rei quando da chegada dos Bragança à capitania fluminense, ver SLEMIAN, Andréa, 2006, op. cit.

${ }^{94}$ MORTON, F. W. O., 1986, op. cit. p. 4.
} 
amostra, controlavam $26,4 \%$ do total de recursos, o que sugere que os segmentos de menor condição social também se distinguiam internamente por diferentes padrões de riqueza material. $^{95}$

Outros fatores que merecem ser observados para a Bahia de princípios do Oitocentos são as atitudes comportamentais que informam a existência de variados segmentos sociais articulando-se para expressar, em níveis coletivos, críticas e reivindicações ante o funcionamento de importantes instituições da sociedade da América portuguesa. Nesse sentido, chama atenção o requerimento datado em 31 de julho de 1807 e enviado diretamente ao príncipe regente pelos "Vivandeiros e Condutores da Capitania da Bahia" e mais alguns "habitantes de diversas classes", no qual elencavam queixas e propostas "contra a falta de economia pública e contra os abusos" propiciadas "especialmente pela indolência e tolerância da Câmara da dita Cidade". 96

Constando de 41 signatários, o documento sustentava que apesar do alvará régio de 1799 ter autorizado isenções sobre as cobranças "das taxas nos víveres", tudo continuara como antes, pois "não queria a mesma Câmara que ele [alvará] fosse aplicável". Realçava, então, que se combinada com as determinações anteriores, aquela medida teria sido o "bastante para o total alívio e sossego dos suplicantes", firmando-se, assim, "uma verdadeira execução, segundo as Pias Intenções de V. A. R., porém, sinistros interpretes das Leis justas ou, para melhor dizer, atorvadores [sic] da felicidade pública têm feito inúteis aos suplicantes os benefícios a eles liberalizados por V. A. R.”. Com isso, os peticionários denunciavam que a maioria das posturas municipais proferidas pelo Senado da Câmara de Salvador continha mixórdias dignas das mais graves contradições. ${ }^{97}$

Datava de longa tradição no Império português o estabelecimento das posturas municipais como instrumentos de leis pelos quais os senados das câmaras regulamentavam as

\footnotetext{
95 REIS, João José, 2003, op. cit. p. 32-33.

96 Requerimento dos vivandeiros, condutores e mais habitantes de diversas classes de Cidadãos da Bahia, dirigido ao Príncipe Regente, contra a falta de economia pública e contra os abusos pelos quais sofrem vexames. Bahia, 31 de julho de 1807. 1 documento. Arquivo Público do Estado da Bahia - APEB. Setor de Microfilmes (Fontes do catálogo 68 - constantes do acervo da Biblioteca Nacional do Rio de Janeiro - Documento, 905). Em pesquisa de mestrado, Avanete Pereira Sousa observou que, em consonância às determinações previstas nos códigos de leis do Império português, a exemplo das Ordenações Afonsina (1446), Manuelina (1521) e Filipina (1603), o estabelecimento e a administração da ordem nas cidades e vilas nos variados domínios régios constituíam em atribuições primordiais do poder camarário. Em se tratando especificamente da situação da cidade de Salvador setecentista, este estudo salienta que o Senado da Câmara da capital exercia forte controle sobre o meio urbano, atingindo mais diretamente os setores "ligados ao abastecimento e à oferta de serviços à população, quais sejam: os vendedores de porta, os pequenos vendeiros e os oficiais mecânicos". SOUSA, Avanete Pereira. Poder local e cotidiano: a Câmara de Salvador no século XVIII. Dissertação (Mestrado em História) - Universidade Federal da Bahia, Salvador, 1996. p. 100.

${ }^{97}$ Idem, ibidem. Sob um ângulo próprio de análise, esse requerimento fora também analisado por SOUSA, Maria Aparecida Silva de, 2009, op. cit. p. 186-188.
} 
diversas atividades comerciais e de serviços ocorridas nos espaços urbanos. $\mathrm{Na}$ América portuguesa, foi por meio das posturas que os vereadores asseguraram, por exemplo, que o comércio, inclusive o ambulante, fosse regulado via expedição e renovação anual das licenças de funcionamento expedidas pelas câmaras municipais, assim como fixavam multas e sanções em caso de infrações cometidas nesses empreendimentos. ${ }^{98}$ Mas não eram somente os estabelecimentos "de portas abertas" que permaneciam legalmente sujeitos aos mecanismos das posturas, visto que para realizar reformas nas casas, o estabelecimento de novas construções e outros tantos procedimentos ocorridos no interior das vilas e cidades, seus responsáveis precisavam estar atentos às similares disposições legais.

No requerimento ora analisado, é digna de nota a maneira como se esboçou uma defesa a favor dos interesses corporativistas dos vivandeiros que se consideravam em desvantagem pela comercialização concorrencial praticadas, tanto pelos proprietários das tabernas, como entre as "pretas regateiras", livres ou escravas, que pelas ruas da cidade comercializavam uma enorme variedade de produtos alimentícios e outras miudezas. Essa situação pode ser apreendida na seguinte indagação:

Esta confusa determinação da Câmara na execução daquele Alvará faz notar: que se esse compreende só os vivandeiros - tomados pelos que conduzem de fora os víveres para vender - [mas] como inclui ela na isenção das taxas os Taberneiros e as pretas vendedeiras da terra que são rigorosas regatas e depois manda que aqueles fiquem almotaçando as aguardentes da terra? ${ }^{99}$

Esses questionamentos tornam-se ainda mais importantes na medida em que se sabe que, ao término dos anos de 1790, Luís dos Santos Vilhena havia dedicado parte do seu tempo tratando justamente de assuntos como os levantados pelo requerimento dos vivandeiros. À época, o português europeu e professor de grego na Bahia deixou claro, entre outras coisas, que as atividades comerciais desenvolvidas na cidade de Salvador articulava um vasto tecido social, servindo, inclusive, de meio de subsistência efetivo a uma grande quantidade de

\footnotetext{
${ }^{98}$ No caso do comércio ambulante realizado por escravo, muito comum em cidades como a capital baiana de princípios do Oitocentos, o seu dono era quem deveria providenciar a licença e a renovação dessa, quando necessária. Também era de sua responsabilidade dar satisfação às autoridades sobre eventuais penas ou faltas cometidas pelo cativo no exercício comercial. No que concerne à discussão dessas questões, consultar SOUSA, Avanete Pereira, op. cit.

99 Requerimento..., op. cit. Na defesa de direitos corporativistas frentes aos seus demais concorrentes, os peticionários reclamavam que as determinações da Câmara “[...] isentava[m] da pensão das almotaçarias indistintamente a todas as pessoas que vendiam comestíveis e que tão-somente se ficassem tirando as Licenças e Regimentos do estilo; o mais, dali a poucos dias, mandou que os Taverneiros continuassem nas almotaçarias" recolhendo licenças a cada "bimestre das aguardentes de cana e [do] mel, coco de beber água etc., ficando entre estes mesmos Taberneiros sem" obrigação de pagarem "taxa[s]" sobre "a manteiga de porco; toucinhos, carnes do sertão etc.", assim como igualmente isentara as atividades das "pretas regateiras [no tocante a] todos os grãos, legumes e mais comestíveis que se usam vender”. Idem, ibidem.
} 
"negros" que dependiam de "contratos e negociações" com outros comerciantes de Salvador para

vender pelas ruas, a pregão, as coisas mais insignificantes e vis: como sejam iguarias de diversas qualidades v. g. Mocotós, isto é, mãos de vaca, carurus, vatapás, mingaus, pamonhas, canjicas [...] de milho, acassás, acarajés, abarás, arroz de coco, feijão de coco, angus, pão-de-ló de arroz, o mesmo de milho, roletes de cana, queimados, isto é, rebuçados [bombons] a 8 por um vintém, e doces de infinitas qualidades. ${ }^{100}$

Embora Vilhena procurasse dar a impressão de que todos esses acepipes não passassem de repastos "insignificantes e vis", a forma como soube detalhá-los sugere algum grau de conhecimento sobre tantas "iguarias", cujas famas, ainda hoje, muito contribuem com a culinária e cultura baianas. ${ }^{101}$ Entretanto, o que mais importa é que a sua leitura não apenas facilita o entendimento de como as ramificações comerciais urdiram uma rede de negócios impressionante na capital, mas também faz ver o quanto as práticas consideradas lícitas e ilícitas apresentavam-se justapostas ou, quando muito, separadas por uma linha muito tênue bem ao gosto de uma fiscalização deliberadamente complacente em favor das "casas poderosas". 102

O professor régio antecipou, assim, em quase dez anos a exposição de motivo relativa aos desmandos, privilégios e algumas das corrupções manifestas na atividade comercial varejista da cidade de Salvador que, por não terem recebido as devidas providências, reapareciam, quase que integralmente, nas denúncias de 1807, posto que, ainda das

mesmas casas [de comércio] que não só tem o seu negócio em grosso, como vendem das suas lojas por miúdo, a côvado e vara, saem turmas de negras com caixinhas cheias de fazendas [tecidos], a maior parte de contrabando, tirados por alto ou comprados em Navios que aqui aportam e saem carregados de Dinheiro; outros vindos das feitorias das costas de Guiné e Mina, furtando desta forma os direitos de S. Majestade, e iludindo as suas saudáveis Leis, que o vedam, pela venalidade dos guardas, não só paisanos, como ainda militares; alguns dos quais se julgam bem-aventurados quando lhes chega uma destas funções; excetuando contudo muito que há honradíssimos. Trazem as mesmas negras outras fazendas da ordem das que

\footnotetext{
${ }^{100}$ VILHENA, Luís dos Santos, op. cit., v. 2. p. 131.

101 Outrossim, ao acrescentar que esta era uma atividade "privativa da repartição dos pobres", Vilhena generalizou a situação, pois era significativa a presença de escravo - geralmente alugado ou de ganho desempenhando a mesma função. Idem, ibidem. p. 132.

${ }^{102}$ Como apontou Wilma Peres Costa: “A máquina arrecadadora metropolitana era uma via de mão dupla, fazendo reverter às camadas favorecidas parte substancial da arrecadação”. COSTA, Wilma Peres. Do domínio à nação: os impasses da fiscalidade no processo de Independência. In: JANCSÓ, István (Org.). Brasil: Formação do Estado e da Nação. São Paulo: Hucitec; Ed. Unijuí; Fapesp, 2003. p. 151.
} 
admitem despacho na Alfândega; e ninguém pois se embaraça com elas, nem lhes pede contas, pelo respeito às casas poderosas a que pertencem, salvoconduto este que as livra de todo o perigo, e triste será a sorte de quem bulir com elas. As negras porém que não pertencem às casas da primeira ordem, tiram uma licença do Senado para poderem vender, livres das ciladas do vigilante Rendeiro do ver. ${ }^{103}$

Linha a linha, Vilhena matizava uma das razões pela qual a sociedade escravocrata desse período distinguia-se em sua profunda dessemelhança percebida ante a prosperidade econômica de uma minoria e a pobreza material de uma imensa coletividade para quem o poder das autoridades era - como não podia deixar de sê-lo - extremamente "vigilante". Quanto à "Política e economia" prevalecentes na capital baiana, o professor informava que delas se poderiam "igualmente ajuizar" a partir do procedimento do mesmo rendeiro no cumprimento "das funções do seu emprego". Então, explicava:

Quando este vai lançar na renda já leva contadas todas as vendas e Tabernas que há por toda a cidade e subúrbios; faz conta do ajuste que há de fazer com cada um, de forma que daquelas avenças leve já segura a renda, e ganhe não pouco; com este cálculo feito de antemão, lança, arremata e lavra-se-lhe o termo com as cláusulas do estilo, com fiadores abonados: o que acabado, sai a fazer os mencionados ajustes com os vendeiros e taberneiros, convencionando-se em que os não perseguirá por aquele ano, se lhe derem tanto:

O comum são $12 \$ 000$ rs. para mais.

Celebrada que seja aquela avença, ai fica o vendelhão habilitado para furtar a salvo, entrando logo no ajuste o avisá-lo, quando houver correição geral. ${ }^{104}$

Com a perspectiva de estimar qual deveria ser o rendimento proporcionado somente em se tratando dessa amostragem da economia baiana, Vilhena considerou a existência de 250 vendas em toda a cidade de Salvador de fins do Setecentos. Então concluiu que, a um custo por estabelecimento de $12 \$ 000$ (Doze Mil Réis), os vendeiros e taberneiros pagavam anualmente "só para o rendeiro" a pequena fortuna de 3:000\$000 (Três Contos de Réis). No que concernia à avença contratada ao vendelhão, imputava que o valor a ser pago pelos mesmos proprietários precisaria ser "dobrado", ou seja, teriam que dispor de mais um montante de 6:000\$000 (Seis Contos de Réis). Por fim, no que dizia respeito às atividades das "numerosas" "negras regateiras", ele presumiu que cada uma deveria incrementar a receita do mencionado contratador em mais " 3 , 4, 5 mil réis" a depender dos objetos do seu "tráfico". 105

A falta de isonomia entre diferentes tipos de contribuidor continuaria sem solução ainda em 1821. Circunstância que favoreceu ao redator do periódico pró-lusitano, Semanário

\footnotetext{
${ }^{103}$ VILHENA, Luís dos Santos, op. cit. p. 132.

${ }^{104}$ Idem, ibidem. p. 132-133.

105 Ibidem. p. 133.
} 
Cívico, interpor junto aos seus leitores algum conhecimento sobre os fundamentos da economia. Para tanto considerava, que: “[...] Sendo princípio certo que os impostos devem proporcionar-se às posses dos contribuintes para que todos concorram conforme as suas possibilidades [...]", caberia, por certo, indagar como poderia: "Uma loja de fazendas [tecidos] que vende grosso cabedal paga[r] anualmente $12 \$ 800$, e um pequeno botequim, [uma] taberna etc, paga[r] o mesmo. Outro tanto acontece com os saveiros, barcos, lanchas, sumacas, navios, etc., que pagam em desproporção considerável uns dos outros [...]". ${ }^{106}$ Portanto, em situações extorsivas como essas nas quais as cobranças dos impostos recaiam desproporcionalmente sobre o grande e o pequeno comerciante obrigados a recolherem à Fazenda Régia o mesmo tributo, deduz-se acertadamente que os preços finais das mercadorias eram quase sempre exorbitantes à população. E foi justamente a carestia uma das questões que não escapou aos peticionários de 1807. Na oportunidade, eles não apenas retrataram esse problema, como também apontaram a prevalência de condutas que, na prática, dificultavam a livre concorrência no comércio de produtos locais. Segundo avaliavam, era flagrantemente "contraditório" que:

dando V. A. R. no dito Alvará as taxas por causas da carestia dos víveres, fosse da Mente de V. A. R. ficassem conservadas as ditas taxas para a mesma carestia nas aguardentes, [nos] cocos, abanos e rolos de cera, gêneros do comércio isentos para "identidade de razão", quando não fosse por tantas Leis gerais relativas à liberdade do mesmo comércio.

E ainda mais [...], se os Alvarás de 12 de Maio de 1757 proíbem as taxas, entradas, amostras e outras pensões nos grãos, legumes, farinha, lenha, louças, telha, tijolo, cal etc., como temerariamente continua a Câmara em obrigar os condutores destes gêneros a pedir-lhe para as suas embarcações os Regimentos do seu Edital e Posturas que são papéis de taxas para os referidos Gêneros e para fretes de passageiros com um só preço para diversas distâncias: assim como para todos os Oficiais da terra, que, além de constituírem um verdadeiro comércio com as suas mãos-de-obra, trabalhando em gêneros alfandegados não devem sofrer esses Regimentos, ou taxas da Câmara inúteis e nulos por todos os princípios? ${ }^{107}$

Responsáveis por abastecer a população com produtos alimentícios trazidos de fora da cidade, os vivandeiros e demais peticionários procuravam, acima de tudo, proteção para não serem tributados em mais de uma ocasião, visto que atribuíam à profusão de taxas, em forma de posturas, editais e requerimentos, "parte das extorsões" praticadas pelos camaristas "com a falsa máscara do zelo público". Questionavam também que:

106 Semanário Cívico, n. 5, de 29 de março de 1821. Apud SILVA, Maria Beatriz Nizza da. Semanário Cívico: Bahia, 1821-1823. Salvador: Edufba, 2008. p. 69.

${ }^{107}$ Requerimento..., op. cit. "Acrescendo, de mais a mais, a falta de observância [...] a mesma relutância que sempre se achou [...]" na "Bahia [em] respeito à liberdade de comércio e economia pública”. Ibidem. 
se a Câmara tem a Postura n. 43 pela qual nenhum oficial mecânico possa abrir tenda pública sem ser examinado e, na falta do exame, sem Licença, a qual, contudo, não compreende os Cabeleireiros, Imaginários, Pintores, Escultores, Entalhadores etc., por serem Artistas; com confusa e indistintamente obriga ela pelos Almotacés e Rendeiros aos donos e Mestres das Lanchas, ou [de] barcos do seu Termo, e de fora dele a tirarem todos os anos essas Licenças, contra as quais já estão cansados de clamar perante a mesma Câmara, mostrando que a navegação é Arte e não Ofício mecânico de porta aberta, [...] que os Suplicantes são de diversos termos e comarca, que não há na Câmara Postura que obrigue ainda aos do seu termo a semelhantes Licenças, se para navegar incompetentes e se para conduzir, ou vender, contrárias às Leis, que dão aos Lavradores e Condutores livres acesso a qualquer parte, onde vão com os seus efeitos? ${ }^{108}$

Dessa maneira, os peticionários tanto reforçavam o ressentimento com as autoridades camaristas, quanto revelavam o quão difícil podia ser a vida dos pequenos comerciantes em uma sociedade cindida pela tradicional forma de organização plasmada na estratificação social com arraigados privilégios e outra que, pouco a pouco, vinha afirmandose via a contraposição de direitos e deveres de ordem classista. Nesse sentido, deve-se observar que se, por um lado, os "suplicantes" continuavam recorrendo à estrutura do próprio Antigo Regime em busca de soluções para os seus problemas, por outro, não deixavam de demonstrar que a situação vivida encontrava-se no limite. Portanto, mensagens como as que lembravam ao próprio monarca que a "felicidade pública, [era] objeto inseparável do trono de V. A. R" deveriam merecer séria reflexão por parte de quem as recebia. Afinal de contas, esse era um meio indireto de os peticionários informarem à entidade real sobre a possibilidade de reação contra atitudes que "temerariamente" ocorriam em uma capitania estratégica à manutenção do poder e prestígio da Coroa bragantina em território americano.

Então, a despeito de manter uma exposição de razões pautada em recorrentes súplicas, a tessitura deste requerimento constituía, do início ao fim, em acérrima crítica à instituição mais importante do mundo ibérico, ainda que a sua análise aparecesse circunscrita à cidade de Salvador. Não por acaso, a Câmara Municipal da capital baiana, conforme o entendimento dos peticionários, não correspondia aos "verdadeiros princípios da boa economia": "antes [estava] pronta em ceder, por dinheiro, as ruas públicas e [os] lugares de beira-mar próprios dos condutores". Com procedimentos como esses, tornava-se patente a

\footnotetext{
108 Ibidem. Associados estreitamente aos interesses dos vivandeiros, os responsáveis pelas pequenas embarcações que conduziam, diuturnamente, alimentos essenciais à cidade de Salvador, como a farinha de mandioca, os legumes e as frutas frescas, enxergavam-se diretamente atingidos pelas cobranças dessas taxas. E isso, obviamente, guardava suas influências sobre a escassez crônica e a carestia nos gêneros alimentícios tão frequentes na capital baiana. Sobre a atuação dos oficiais mecânicos na Bahia no transcurso da crise do Antigo Regime português, ver JANCSÓ, István, 1996, op. cit.
} 
"impostura na sustentação de caprichos e na confusão das suas deliberações para melhor aumento das suas rendas, e utilidade do seu Escrivão, Porteiro e Aferidores poderosos" que, associados aos próprios camaristas, tornavam-se beneficiários à custa dos "miseráveis povos pelo interesse de sua renda". Enfim, os "suplicantes" enfatizavam que essa não era uma situação nova, visto a preexistência de um "axioma antigo no povo que é causar debalde, ou malhar em ferro frio, pretender da Câmara decisão clara e favorável ao público com tais opositores". 109

Convém aqui ressaltar que a instituição camarária na América portuguesa constituiu-se desde o princípio em um espaço privilegiado de poder formal controlado pela classe proprietária local. No Senado da Câmara de Salvador de fins do Setecentos e princípios do século seguinte, por exemplo, a presença de representantes da classe senhorial em formação fora sempre expressiva, especialmente em se tratando dos senhores de engenho, tais como Cristóvão da Rocha Pita, Salvador Pires de Carvalho e Albuquerque, José Pires de Carvalho e Albuquerque e seu irmão Francisco Elesbão Pires de Carvalho e Albuquerque. Dentre esses, também se encontrava o senhor de terras em Nossa Senhora do Monte do Recôncavo e futuro deputado às Cortes de Lisboa pela província baiana, Alexandre Gomes Ferrão Castelo Branco, que havia ocupado a cadeira de vereança em Salvador em duas legislaturas diferentes, em 1805 e em $1815 .^{110}$

Diante do exposto, os vivandeiros insistiam que "só da Piedade" da monarquia aguardariam as condições de pôr termo a todas aquelas "promiscuidades" e "extorsões", visto que a simples soma das posturas municipais excedia "em número para mais de 200". Cômputo esse que os signatários consideravam abusivo, mencionando inclusive a "repetição de Postura sobre uma mesma matéria". Ao final das contas, afiançavam que de todo o compêndio de leis, normas e regulamentos existente, apenas uma compilação composta de "40 a 50" posturas seria o bastante para conformar a "felicidade pública". ${ }^{111} \mathrm{E}$, em outra passagem, afirmaram:

Os Suplicantes, que já representaram a V. A. R. contra os absurdos expostos, e que sabem, que não sendo duvidados na sua existência e veracidade [...] não deixam de representar a $\mathrm{V}$. A. que os meios ordinários para se dissiparem abusos sem número tão impróprios e difíceis a embarcadiços, Condutores, Vivandeiros e pessoas miseráveis e muito mais contra interesses

\footnotetext{
${ }^{109}$ Requerimento..., op. cit.

110 Ao analisar a situação da capitania baiana entre 1750 e 1822, John Norman Kennedy concluiu que a ocupação de cargos burocráticos na estrutura administrativa era um meio seguro de as "elites" proprietárias facilitarem a prosperidade dos seus negócios. Op. cit. p. 418-419.

${ }^{111}$ Requerimento..., op. cit.
} 
dos poderosos da Cidade, havendo um tão fácil como o da Reforma das Posturas que a mesma Lei faculta. ${ }^{12}$

E para não haver dúvidas sobre o porquê ocupavam a monarquia com questões dessa natureza, os "suplicantes" declararam-se convencidos de "que da Câmara da Bahia, relutante e aferrada em sistemas reprovados, e [acostumada as] desculpas frívolas e paliativas jamais" se deveria esperar "deferimento favorável" ao exame geral sobre um assunto decididamente controverso. A única saída, arremataram, era o príncipe regente "mandar examinar as ditas Posturas" e, "de seu Moto Próprio", determinar que "a Câmara da Bahia [...] aceite e ponha em execução" um código de leis municipais satisfatoriamente reformado. Devendo também a instituição estar obrigada a oferecer "impreterível conta" ao mesmo príncipe sobre esses novos atos, "pois, se assim não for, estão os suplicantes desenganados de melhoramentos e [...], em deplorável jugo de opressões, sem outra alguma esperança, que na Imediata Patronal Providência de V. A. R., a cujos pés, submissamente prostrados, Suplicam Justiça e Mercê". 113

Não foi possível saber como reagira d. João perante a um requerimento com acusações e exigências tão diretas proferidas por súditos coloniais que, decididamente, davam passos em direção ao enfrentamento contra a conduta do Senado da Câmara entrelaçada aos interesses dos "poderosos da Cidade". Ademais, procedimento como os destacados acima deviam incomodar a monarquia absoluta que, naturalmente, exigia mesmo entre os seus mais distintos funcionários um alto grau de deferência e distanciamento que os "Suplicantes" poderiam, se nada fosse feito, simplesmente deixar de invocar. Essa era, então, outra modalidade de advertência que os interessados na manutenção da ordem do Antigo Regime precisavam dar resposta.

De qualquer forma, a provisoriedade política começaria, por esse período, a estar presente também no universo colonial das Américas hispânica e portuguesa. Certamente depois de pessoalmente ter passado pela Bahia, d. João deveria estar ainda mais inteirado das potencialidades e dos problemas que essa capitania experimentava. Dessa maneira, a nomeação de uma liderança com o grau de experiência administrativa do conde dos Arcos pode ser efetivamente compreendida como meio da Coroa tentar reforçar a sua presença entre os habitantes da Bahia, em um período no qual o projeto de Revolução demonstrava sua

\footnotetext{
${ }^{112}$ Ibidem.

${ }^{113}$ Ibidem.
} 
capacidade de romper fronteira, passando, a ameaçar mais e mais a monarquia dos Bragança. $^{114}$

Invertido o principal pólo de convergência do espaço luso-americano ante a retirada da corte bragantina de Portugal, uma nova hierarquia espacial foi instaurada no interior da América portuguesa. Portanto, é relevante ter-se em conta que o corolário imediato dessas alterações manifestou-se na ruptura do equilíbrio entre as capitanias do continente do Brasil que, um tanto abruptamente, deixaram de se relacionar horizontalmente com a antiga metrópole, para disputarem a influência política do novo eixo dinamizador de poder assentado no Rio de Janeiro. ${ }^{115}$ Como se verifica para a Bahia, a concentração de poder nas cercanias fluminense abriria, por um lado, possibilidades de reiteração entre adventícios da ilustração americana que procuravam na nova sede imperial condições de ascensão política e social sem abandonar, ao menos de imediato, suas raízes e interesses regionais, já que não deixaram de retroalimentá-los via a afirmação das redes de sociabilidade. Por outro, a implementação de uma infraestrutura moderna na recém-elevada capital do império português exigira adaptações econômicas que, inegavelmente, retirara de muitos parceiros tradicionais da Coroa a preeminência comercial tal qual existira entre os portugueses europeus radicados na Bahia e seus semelhantes em Portugal. Neste último caso, as condições históricas características da Era das Revoluções ${ }^{116}$ propiciaram que uma parcela significativa da classe mercantil residente na Bahia se sentisse irremediavelmente solidária aos segmentos congêneres que, a partir da cidade do Porto, teceram uma ampla aliança de classes visando não apenas limitar o governo absoluto, mas restaurar, por meio do constitucionalismo, a outrora proeminência da nação portuguesa.

\subsection{Corte para o Rio de Janeiro e compensações para a Bahia}

Reforçar a presença do Estado e propiciar um arranjo vantajoso que beneficiasse a classe proprietária constituíram os principais mecanismos da Coroa para contrapor-se às variadas adversidades em tempos de aceleradas transformações. Por isso, enquanto assentava sua corte no Rio de Janeiro, a monarquia colocaria em andamento na Bahia uma política de modernização e compensações que propiciaria significativas alterações no cotidiano de uma

\footnotetext{
${ }^{114}$ A respeito da administração do conde dos Arcos na Bahia, ver MORTON, F. W. O., 1986, op. cit. e SOUSA, Maria Aparecida Silva de, 2009, op. cit. Cap. 2.

${ }^{115}$ Essa inversão de poder no interior do Império português foi demonstrada com rigor e clareza por JANCSÓ, István; PIMENTA, João Paulo Garrido, op. cit.

${ }^{116}$ A categoria Era das Revoluções deve ser compreendida nos termos postulados por: HOBSBAWM, Eric J. A Era das revoluções: Europa 1798-1848. 16. ed. revisada. São Paulo: Paz e Terra, 2002.
} 
parcela privilegiada da sua população. Posto que, com o fim do exclusivismo comercial, como era de se esperar, houve um despertar de grandes oportunidades e o comércio veio a ser um meio eficiente pelo qual os mercadores ampliaram sua participação na sociedade escravocrata baiana. $^{117}$

Portanto, com a economia ainda mais florescente, esse segmento social se afirmou como o principal agente do financiamento da agricultura, seja diretamente, via, por exemplo, a construção de engenhos, seja indiretamente com a ampliação da importação e fornecimentos, a prazos prefixados, de escravos à classe senhorial. ${ }^{118}$ Por outro lado, famílias bem estabelecidas na capitania viram na instalação da monarquia no Rio de Janeiro um apelo muito forte para estreitarem ainda mais as suas relações com os fluminenses. ${ }^{119}$ Muitos simplesmente trocaram de residências e foram habitar na corte, propiciando, assim, uma presença mais ativa de indivíduos que, mudando da Bahia, ajudariam a fomentar a importância e a dinamização da nova sede do Império português.

Para reforçar essa asserção, observemos a trajetória do baiano, bacharel em direito, Antônio Luís Pereira da Cunha (1760-1837), haja vista que bem representa a mobilidade horizontal de vassalos na América portuguesa. ${ }^{120}$ Depois de deixar o cargo de chanceler da Relação da Bahia, em 1808, Pereira da Cunha foi residir na corte fluminense e, em princípios de 1818, fora agraciado com a condecoração da Ordem de Cristo. Naquele momento, ocupava o posto de juiz almotacel do Rio de Janeiro. Mas isso não lhe bastava. Interessado em perseguir os meios de ter maior ascensão ao poder, solicitou a graça de ser proprietário do

${ }^{117}$ Como também possuía interesse na participação formal e informal na estrutura burocrática da América portuguesa, a própria "elite" mercantil disputou e obteve concessão, via decreto régio de 1740, que lhe assegurou tanto o direito de elegibilidade para postos de vereança, quanto o de vir a ser nomeada para cargos administrativos no território do Brasil. Ao que parece, no entanto, essa conquista serviu mais para ampliar o status de reconhecimento aos negociantes, do que para exacerbar a concorrência entre esses e os representantes da classe senhorial no controle dessas funções. Em termos gerais, senhores e mercadores com atividades na capitania baiana compartilharam interesses econômicos similares e, disso, estiveram relativamente conscientes até, pelo menos, estourarem os primeiros choques de opiniões políticas em razão dos desdobramentos da Revolução Constitucionalista do Porto (1820). Questão que será mais bem examinada adiante. Para o imbricamento de alianças (familiares, comerciais, patronais) que possibilitaram a esses dois segmentos sociais atuarem, na maioria das vezes, de forma coesa, cf. KENNEDY, John Norman, op. cit. p. 421 e KRAAY, Hendrik. Race, State and Armed Forces in Independence-Era Brasil, Bahia, 1790's-1840's. Stanford: Stanford University Press, 2002. Cap. 1. Para as oportunidades de comércio na Bahia após a vinda da família real, ver SOUSA, Maria Aparecida Silva de, 2009, op. cit.

${ }^{118}$ MORTON, F. W. O., 1974, op. cit. p. 41.

${ }^{119}$ Segundo Isabel Lustosa, a população total da capital fluminense saltou de apenas 50 mil habitantes em 1808 para algo em torno de 110 mil em 1830. Desse implemento imigratório, 24 mil compunha-se de portugueses europeus. LUSTOSA, Isabel. D. Pedro I: um herói sem nenhum caráter. São Paulo: Companhia das Letras, 2006.

${ }^{120}$ Sobre a importância do "intercâmbio regional" em fins do Antigo Regime, ver o excelente artigo de MELLO, Evaldo Cabral de. Andanças coloniais. Folha de São Paulo, São Paulo, 25 maio 2003. Caderno Mais! p. 12-13. Antônio Luís Pereira da Cunha formou-se em Direito na Universidade de Coimbra em 1787. Nessa instituição acadêmica cursou também matemática e filosofia. BARATA, Alexandre Mansur. Maçonaria, sociabilidade ilustrada e independência do Brasil. Juiz de Fora: Ed. UFJF; São Paulo: Annablume, 2006. p. 320. 
ofício de escrivão de protesto, ou a de tornar-se oficial de uma das Secretarias de Estado, afirmando ficar contente com outra função equivalente. Conforme verificou Andréa Slemian, para justificar os seus pleitos junto à Coroa, Pereira da Cunha "alega a decadência de seu comércio após ter sacrificado todas as suas rendas em benefício dos interesses do Senado, além de fazer avultadas despesas para 'se conservar na decência de seu cargo"". ${ }^{21}$ Ao ser nomeado para administrador dos asseios das ruas, praças e praias, declinou da oferta justificando problemas de saúde. Outras oportunidades surgiram para Pereira da Cunha em fevereiro de 1821, depois do Rio de Janeiro aderir à revolução constitucionalista, quando passou a ocupar a intendência-geral de Polícia. Consta ainda que alcançara a distinta função de desembargador do Paço. No alvorecer do Primeiro Reinado, Antônio Luís Pereira da Cunha seria eleito deputado pelo Rio de Janeiro (1823) e, dissolvida a Assembléia Constituinte, d. Pedro o conservaria entre o seleto grupo escolhido para elaborar um novo projeto de Constituição, do qual seria um dos seus principais redatores, sendo, então, contemplado com um título nobiliárquico, o de marquês de Inhambupe. Adiante, serão apresentados outras trajetórias que confirmam como a residência na corte poderia, em muitos casos, trazer bons frutos àqueles que ambicionavam acesso aos padrões de riqueza material, mando e subordinação de terceiros.

Em razão dos vassalos estarem cada vez mais conscientes de que o Brasil passava a se constituir na principal rota de imigração para os que desejassem melhores condições na obtenção de graças e mercês junto à monarquia, muitos portugueses europeus também optaram em vir residir no Rio de Janeiro e mesmo na Bahia consolidando, dessa maneira, a posição dessas duas capitanias para os que precisassem aportar desse lado do Atlântico após 1808. Na análise de Manuel Bomfim, “o Brasil era, naquela época, a única verdadeira colônia portuguesa, e para cá vinham quase todos os que, no reino, não obtinham viver diretamente ou indiretamente do Tesouro real". ${ }^{122}$ Entretanto, esse tipo de imigração, especialmente para atender às atividades do comércio, não se constituía em uma novidade para os habitantes das capitanias como a Bahia, Pernambuco e o Rio de Janeiro, pois desde as reformas do período pombalino esse processo imigratório experimentou incentivos diversos. O que importa aqui realçar é que o deslocamento interno de residentes na Bahia em direção à corte ocorrera em

\footnotetext{
${ }^{121}$ Boa parte dos dados expostos nesse parágrafo consta do estudo de SLEMIAN, Andréa, 2006, op. cit. p. 3839. Era relativamente comum a prestação de serviço nas principais instituições representativas do poder régio como recurso à obtenção de nomeações para ocupar cargos de variado relevo na administração portuguesa ou ainda títulos de nobreza, horárias e sesmarias.

122 BOMFIM, Manoel. A América Latina: males de origem. Rio de Janeiro: Topbooks, 1993. p. 227. Sobre o pensamento radical de Manoel Bomfim, considerado o primeiro interprete do Brasil no século 20, ver o artigo de CÂNDIDO, Antonio. Radicalismos. Estudos avançados, v. 4, n. 8, São Paulo, p. 4-18, jan./abr. 1990.
} 
concomitância ao ingresso de outros agentes na capitania vindos à procura de novas oportunidades, incluindo-se aí desde os portugueses europeus, mas também os ingleses e alguns franceses. Em se tratando exclusivamente da afluência de portugueses na cidade de Salvador, o visconde de Cairu chegaria a dizer que, por volta dos anos de 1820, essa "Praça" era “quase uma Colônia do Minho". ${ }^{123}$

Destacado pela Coroa de Bragança como aquele que deveria empreender um novo ímpeto nas relações de caráter reformista na administração da Bahia, o conde dos Arcos (1810-1818) mostrar-se-ia desde o início da gestão disposto a facilitar o entrelaçamento de interesses entre os habitantes da capitania e a corte do Rio de Janeiro. Em seu governo, novos setores também passaram a se beneficiar das oportunidades surgidas na América portuguesa no momento em que a família real ali se instalou. Esse parece ter sido o caso do comerciante português Manoel Antônio da Silva Serva que residia na capitania desde 1897. Atento às possibilidades para o estabelecimento de novos negócios, ainda em 1809, ele retornou à Europa, aonde adquiriu uma tipografia e mais materiais necessários à impressão de jornais. De volta a Salvador, Silva Serva principiou a publicação da gazeta Idade d'Ouro do Brazil, inaugurando, em 4 de maio de 1811, a imprensa baiana. ${ }^{124}$

Como o Rio de Janeiro e a Bahia foram as únicas capitanias da América portuguesa a obter concessões do governo absoluto para possuir veículos de imprensa, admite-se, portanto, a importância desses dois centros enquanto gestores e difusores de conteúdos destinados à nascente opinião pública no Brasil. ${ }^{125}$ Do ponto de vista da monarquia, as liberalizações conferidas, finalmente, aos americanos deveriam cumprir uma função estratégica à medida que os proprietários desses periódicos comprometiam-se pela divulgação, em suas gazetas, de matérias e notícias relativas aos interesses do governo e,

${ }^{123}$ LISBOA, José da Silva. História dos principais sucessos políticos do Império do Brasil dedicada ao senhor d. Pedro I. Rio de Janeiro: Tipografia imperial e Nacional, 1927, parte X. p. 44. Embora muito inferior ao número registrado para a cidade de Salvador, a presença de portugueses europeus em vilas baianas como as de Nazaré, Rio de Contas e Caetité, merecem atenção, mesmo porque durante as lutas de Independência, e em momentos críticos do Primeiro Reinado, as populações locais e as imigradas de Portugal enredaram-se em graves confrontos políticos. Para as dissensões políticas envolvendo os protagonistas destas duas últimas vilas, ver SOUZA FILHO, Argemiro Ribeiro de. A guerra de Independência na Bahia: Manifestações políticas e violência na formação do Estado nacional (Rio de Contas e Caetité). Dissertação (Mestrado em História) Universidade Federal da Bahia, Salvador, 2003.

${ }^{124}$ A trajetória de Manoel Antonio da Silva Serva e o balanço temático sobre a Gazeta Idade d'Ouro no Brazil (1811-1823) foram objetos de análise de SILVA, Maria Beatriz Nizza da, op. cit.

${ }^{125}$ Em 1808, a Coroa autorizara a publicação da Gazeta do Rio de Janeiro que somada, posteriormente, com a Idade d'Ouro do Brazil na Bahia tornaram-se os únicos periódicos da América portuguesa até a explosão da imprensa periodista (1821-1823) ocorrida após a afirmação da Revolução Constitucionalista no interior do Império português, que teve como imediata consequência o direito à liberdade de imprensa aplicada a todo o Brasil, conforme termos da carta régia de 28 de agosto de 1821. Idem, ibidem. Para a afirmação da opinião pública nesse período, ver MOREL, Marco, op. cit. 
assim sendo, a primeira missão dos editores seria reforçar os vínculos dinásticos entre a Coroa e os súditos bragantinos. Em contrapartida, a simples necessidade de uma imprensa atesta a capacidade de circulação de ideias na América portuguesa. ${ }^{126} \mathrm{E}$, como o periodismo não poderia furtar-se ao imperativo da opinião pública, tornava-se imprescindível que ele discutisse e ampliasse os modelos de sociabilidade e práticas políticas existentes. Mas ao lidarem com assuntos tão sensíveis, os que tinham na informação um negócio rentável e mais ainda a monarquia, incorriam no risco de, mesmo a contragosto, acabarem patrocinando mudanças indesejáveis, pois a possibilidade de revolução pairava no horizonte exigindo, tanto das instituições consagradas, quanto da estreante, muita atenção.

$\mathrm{Na}$ tentativa de melhor controlar as informações veiculadas na gazeta Idade d'Ouro do Brazil, o conde dos Arcos divulgou uma série de regras a ser seguida pelo periódico, o qual também teria um censor nomeado pelo governo sendo, então, responsável pela aprovação ou reprovação das matérias e artigos de cada número levado ao conhecimento público. Editada em 5 de maio de 1811, entre outras condutas, essas normas determinavam que:

Deverá a Idade d'Ouro publicar todos os escritos ministeriais e econômicos, cujo conhecimento convier publicar, discorrendo sobre o interesse público, que deflui das disposições e medidas que neles se contêm. [...]

Deverá contar as notícias políticas sempre da maneira mais singela, anunciando simplesmente os fatos, sem interpor quaisquer reflexões que tendam direta ou indiretamente a dar qualquer inflexão à opinião pública. [...]

Deverá finalmente a Idade d'Ouro fazer menção dos despachos civis e militares, particularmente desta capitania, e escrever os avisos que forem remetidos a seu redator; convenientes à maior facilidade e viveza do comércio. $^{127}$

Vê-se, assim, como a imprensa absolutista tinha a sua liberdade circunscrita aos interesses da preservação do statu quo governamental. Situação que se patenteia no restrito controle sobre a difusão das "notícias políticas" a serem transmitidas ao público de maneira simplista, factual, ausente de "quaisquer reflexões" e que, por fim, se recusasse a dar vazão à “opinião pública". A rigor, em se tratando dos acontecimentos políticos adversos à ordem vigente, independentes se estes fossem internos ou externos ao Império português, não

\footnotetext{
${ }^{126}$ Sobre a difusão das ideias na América portuguesa de fins do Antigo Regime, JANCSÓ, István, 1997, op. cit.; VILLALTA, Luis Carlos. O que se fala, o que se lê: língua, instrução e leitura. In: SOUZA, Laura de Mello e (Org.). História da vida privada no Brasil: cotidiano e vida privada na América portuguesa. São Paulo: Companhia das Letras, p. 332-385, 1997, v. 1.

${ }^{127}$ Apud, SILVA, Maria Beatriz Nizza da, op. cit. p. 22.
} 
haveria outro comportamento: a sua divulgação necessariamente haveria de ser domesticada no sentido de extrair dele qualquer experiência positiva. ${ }^{128}$

Não havia dúvida de que o tempo era de grandes conturbações políticas e todo cuidado era esperado por parte dos mandatários que deveriam saber dispor dos mecanismos que pudessem favorecer uma espécie de propaganda a favor da ordem. E para isso, nada melhor do que apostar nos dados que demonstrassem a "facilidade e viveza do comércio". E nesse esteio, o conde dos Arcos mostrar-se-ia habilitado. Favorecido pela dinâmica comercial e incentivado pela política de compensações facultada pela Coroa, a sua administração empenhou-se na realização de melhorias públicas que procurava dotar a Bahia e, de maneira muito especial, o espaço urbano de Salvador, de um ambiente de ares "civilizado", conforme padrões europeus valorizados entre os contemporâneos. Foi, portanto, num clima de renovação cultural e material que a capital baiana recebeu importantes edifícios públicos, como a Biblioteca (1811) que reuniu um acervo de sete mil livros de várias áreas do conhecimento e um teatro, o Real de São João (1812). Cadeiras de aulas públicas de comércio, agricultura e arquitetura naval com seus respectivos professores foram fundadas, facultando, assim, o acesso qualificado a uma parcela da população. A presença do Estado também se verificou na ampliação do aparato destinado à segurança da capitania, tanto que os efetivos dos regimentos de infantaria foram ampliados para 1.200 praças e criados dois esquadrões de cavalaria. ${ }^{129} \mathrm{Em} 1816$, diversos habitantes foram convidados à inauguração da Faculdade de Medicina e, no ano seguinte, o conde dos Arcos fez a entrega oficial da Praça e do Prédio de Comércio em reconhecimento e para servir de estímulo aos comerciantes que transacionavam seus negócios na Bahia. ${ }^{130}$ Até mesmo um passeio público e um obelisco comemorativo à chegada da família real no Brasil passaram a integrar a paisagem urbanística da capital que, a despeito de ser proporcionalmente inferior aos investimentos alocados naqueles anos para a nova sede da monarquia, vinha alcançando vantagens relativas à sua infra-estrutura como há tempos não se verificava. ${ }^{131}$

\footnotetext{
${ }^{128}$ Para Koselleck: "A experiência é o passado atual, aquele no qual acontecimentos foram incorporados e podem ser lembrados" e, sobretudo, repetidos. Daí, então, o esforço dos representantes da Coroa em extrair das experiências políticas qualquer empuxo positivo. Cf. KOSELLECK, Reinhart, op. cit. p. 308 e passim.

${ }^{129}$ RUY, Affonso. História política e administrativa da cidade de Salvador. Evolução histórica da cidade de Salvador. Salvador: Tipografia Beneditina Ltda (Publicação da Prefeitura Municipal do Salvador; Comemorativa do IV Centenário da Cidade), 1949. p. 352.

${ }^{130}$ MORTON, F. W. O., 1986, op. cit.

${ }^{131}$ Maria Aparecida aprofunda as discussões e implicações ocorridas na capitania baiana nesse período. SOUSA, Maria Aparecida Silva de, 2009, op. cit. No que concerne às profundas mudanças ocorridas na cidade fluminense no período em que ali residiu a monarquia de Bragança, ver SLEMIAN, Andréa, 2006, op. cit.
} 
Paralelo a isso, o governador mostrou ser um grande entusiasta do modelo de formação de caráter ilustrado facultado aos filhos das classes proprietárias que podiam estudar na Europa. Ao longo da sua administração ampliou-se a porção de estudantes que se ausentou da Bahia e, algum tempo depois, retornou trazendo em suas bagagens individuais, ao menos, um diploma acadêmico. Entre os anos de 1811 e 1821, a capitania baiana superou todas as demais concorrentes da América portuguesa no número de estudantes enviados a centros universitários do Velho Mundo. Não por acaso, o governo conde dos Arcos seria lembrado, anos mais tarde, em comentários elogiosos pela maneira com que procurou valorizar a educação. Dados relevantes a esse respeito são encontrados no periódico Semanário Cívico no qual o seu redator Joaquim José da Silva Maia recordou, por exemplo, que:

Em 1810 chegou a esta cidade por governador o conde dos Arcos e a instrução pública tomou nova face. Este general animou e promoveu a educação da mocidade. Privilegiou as Aulas, concedendo aos estudantes as maiores imunidades, a ponto que na desgraça acontecida em Pernambuco em 1817, quando toda a cidade se fez militar e se criaram alguns Regimentos milicianos, os estudantes nem mesmos nas Milícias sentaram praça. Com tão decidida proteção a mocidade refluía de todas as comarcas desta província para estudarem, certos que não eram mais violentados para os recrutamentos. Muitos seguiram adiante os seus estudos, indo a Coimbra formar-se em diversas Faculdades e, entre estes, alguns, por falta de meios, por subscrição. ${ }^{132}$

No que diz respeito ao ensino superior, Mello Moraes forneceu uma listagem por meio da qual é possível identificar os estudantes de sete influentes capitanias da América portuguesa diplomados pela Universidade de Coimbra nos anos de 1818, 1821 e 1822. Nela, se observa que para a Bahia retornaram 31 indivíduos formados em Ciências Jurídicas, dois em medicina e outros dois em Ciências Médicas; para Pernambuco chegaram nove diplomados em Ciências Jurídicas e três em Cânones; o Rio de Janeiro, por sua vez, teve quatro habitantes titulados em Ciências Jurídicas e um em Cânones; o Maranhão pode contar com o retorno de cinco indivíduos diplomados em Ciências Jurídicas; Mato Grosso, um habitante com formação em Ciências Jurídicas e, por fim, o Pará que também recebeu apenas um egresso da referida instituição que na Europa realizou exames, embora o autor não registrasse qual fora. ${ }^{133}$ Além do mais, por não contemplar os dados referentes a outras

\footnotetext{
132 Semanário Cívico, n. 2, de 08 de março de 1821. Apud SILVA, Maria Beatriz Nizza da, 2008, op. cit. p. 39.

133 MORAES, Alexandre de Mello, op. cit., t. 2. p. 281-283. Na tentativa de estabelecer uma escala de comparação sobre a formação acadêmica para as Américas hispânica e portuguesa, Sérgio Buarque de Holanda assegurou que somente a Universidade do México no período de 1775 até a Independência formou 7.850 bacharéis e 473 doutores e licenciados, enquanto os indivíduos oriundos no Brasil que se diplomaram durante o mesmo período em Coimbra (1775-1821) redundou em 720. Ou seja, apenas um vice-reino hispânico formou
} 
universidades e não trazer informações sobre a realidade dos estudantes das demais capitanias, esse levantamento deve ser visto com ressalvas.

Para a pesquisa que ora se apresenta, no entanto, seus dados são bastante úteis. Logo de partida, eles robustecem a hipótese de que a classe proprietária vinha conferindo importância à formação de caráter ilustrado, especialmente em se tratando das Ciências Jurídicas; segundo, indica que os recém-formados estavam retornando às suas capitanias/províncias de origem em um período no qual se revelaria decisivo à história do Brasil e, finalmente, mediante os inventários é possível identificar nominalmente quem foram os diplomados e suas respectivas capitanias. Para a Bahia, de fato, é interessante reaver toda a listagem, pois, como se discutirá mais à frente, nela encontra-se uma porção de indivíduos que desempenharão funções proeminentes no decurso da Revolução Constitucional (1821) e ao longo do primeiro decênio do intricado processo de formação do Estado e da nação brasileiros (1821-1831). Nesse sentido, são apresentados no quadro abaixo os nomes desses diplomados, assim como os cursos que realizaram em Coimbra.

dez vezes mais quadros acadêmicos do que toda a América portuguesa, o que diferencia o quanto o modelo de colonização de Portugal fora centralizado a partir de onde residia a sede da monarquia. HOLANDA, Sérgio Buarque de. Raízes do Brasil. 26. ed. São Paulo: Companhia das Letras, 1995. p. 119. 


\section{QUADRO 1}

Egressos da Universidade de Coimbra entre os anos de 1818, 1821, 1822 (Bahia)

\begin{tabular}{|l|l|}
\hline Nomes & Formação \\
\hline Antonio de Araújo Ferreira & Ciências Jurídicas \\
\hline Francisco Gomes Brandão Montezuma & Ciências Jurídicas \\
\hline Gustavo Adolfo de Aguilar Pantoja & Ciências Jurídicas \\
\hline João Francisco de Borja Pereira & Ciências Jurídicas \\
\hline Joaquim José Ribeiro & Ciências Jurídicas \\
\hline José Emídio dos Santos Tourinho & Ciências Jurídicas \\
\hline José Maria Monteiro de Barros & Ciências Jurídicas \\
\hline Miguel Calmon du Pin e Almeida & Ciências Jurídicas \\
\hline Rodrigo de Sousa Silva Pontes Malheiro & Ciências Jurídicas \\
\hline Antonio de Cerqueira Lima & Ciências Jurídicas \\
\hline Francisco de Sousa Paraíso & Ciências Jurídicas \\
\hline Joaquim José Pinheiro de Vasconcelos & Ciências Jurídicas \\
\hline José Carlos Pereira de Almeida Torres & Ciências Jurídicas \\
\hline José da Costa Carvalho Júnior & Ciências Jurídicas \\
\hline Cassiano Esperidião de Melo e Matos & Ciências Jurídicas \\
\hline Francisco Aires de Almeida Freitas & Ciências Jurídicas \\
\hline Miguel Joaquim de Castro Mascarenhas & Ciências Jurídicas \\
\hline Bernardino José de Melo & Ciências Jurídicas \\
\hline Manoel Antonio Galvão & Ciências Jurídicas \\
\hline Antonio Ferreira Lima & Ciências Jurídicas \\
\hline Domingos Martins Ribeiro & Ciências Jurídicas \\
\hline José Libânio de Sousa & Ciências Jurídicas \\
\hline João Martiniano Barata & Ciências Jurídicas \\
\hline João Ricardo da Costa Dormund & Ciências Jurídicas \\
\hline Nicolau da Silva Lisboa & Ciências Jurídicas \\
\hline Clemente Alves de Oliveira Mendes & Ciências Jurídicas \\
\hline Joaquim Marcelino de Brito & Ciências Jurídicas \\
\hline Manoel dos Santos Martins Velasques & Ciências Jurídicas \\
\hline Antonio Calmon du Pin e Almeida & Ciências Jurídicas \\
\hline José Nunes Barbosa Madureira & Ciências Jurídicas \\
\hline Manoel José Teixeira de Sá & Ciências Jurídicas \\
\hline Joaquim José Frederico Gomes & Ciências Médicas \\
\hline Antonio Policarpo Cabral & Ciências Médicas \\
\hline José Elói Pessoa & Ciências Matemáticas \\
\hline Eustáquio Adolfo de Melo & Ciências Matemáticas \\
\hline & cit \\
\hline
\end{tabular}

Fonte: MORAES, Alexandre de Mello, op. cit., v. 3, p. 281-282.

Tendo ainda como perspectiva a administração do último vice-rei do Brasil, o Semanário Cívico continuou a enaltecer a maneira como a educação superior fora alentada na Bahia, a ponto de registrar: "Desta província foram a Coimbra, nestes seis anos, mais estudantes do que tinham ido noutro tempo no espaço de um século! Pela matrícula na Universidade consta que excederam a mais de 60, entre os quais mais de 12 foram por meio 
de subscrições, e para todos havia concorrido generosamente o conde dos Arcos". ${ }^{134}$ Claro está que toda essa efervescência de bagagem cultural não devia somente à fase de prosperidade econômica vivida na capitania baiana, dela dependeu também a decisão dos homens de Estado, enquanto representantes imediatos da Coroa, em motivar a formação de quadros entre os filhos das classes dominantes. Nesse aspecto a Bahia poderia sentir-se bastante privilegiada por essa política que, sem dúvida, visava fortalecer os compromissos entre vassalos indispensáveis à manutenção da autoridade do governo absoluto em tempos de revolução.

No tocante às inovações materiais, cumpre observar que depois de ter recebido solicitações por parte dos principais negociantes da capital baiana, d. João resolveu intervir ainda mais no processo de modernização da economia baiana. Para tanto, autorizou, via carta régia de 16 de fevereiro de 1816, que fosse ali implantada uma Caixa de Descontos, filiada ao Banco do Brasil, a qual já em princípios do ano seguinte iniciou as suas operações comerciais. ${ }^{135}$ Alguns anos antes, em 1810, a Coroa bragantina havia convencionado com a Grã-Bretanha o Tratado de Aliança e Comércio pelo qual as mercadorias daquela nação passaram a ser importadas à América portuguesa a uma taxa alfandegária de $15 \%$, enquanto as mercadorias de Portugal ficavam obrigadas a taxação de $16 \%$ em suas importações. ${ }^{136}$

Porém, como acontecera anteriormente com a abertura dos Portos, essa era um tipo de política que, apesar de beneficiar uma parcela importante da população americana a qual passava imediatamente a ter mais facilidades no acesso aos produtos europeus, trazia também efeitos negativos. Em capitanias onde o grande comércio era firmemente controlado por negociantes de Portugal, como ocorria na Bahia, os antigos beneficiários sentiam-se bastante incomodados ante a concorrência direta e indireta que os investimentos britânicos provocavam. Em última instância, essa ampliação da abertura comercial era percebida como prejudicial a diversos mercadores radicados nos dois lados do Atlântico que tendiam a atribuir as ameaças sob as suas atividades monopolísticas à estada da monarquia no Brasil. Situação

\footnotetext{
${ }^{134}$ Semanário Cívico, n. 2, de 08 de março de 1821. Apud SILVA, Maria Beatriz Nizza da, 2008, op. cit. p. 39. Com base nesse periódico, Maria Beatriz Nizza demonstrou que, enquanto no período anterior a 1810 o número de estudantes cursando matérias preparatórias para o exercício profissional de alguma qualificação ou para o ingresso na universidade era de 139 na capitania baiana, no ano subsequente ao encerramento da administração do conde dos Arcos (1810-1818) fora possível arrolar um total de 664 alunos nessas condições. Idem, ibidem. p. 40.

${ }^{135}$ Depois de chegar ao Rio de Janeiro, d. João resolveu criar o Banco do Brasil, conforme as normas estatuídas no decreto régio de 12 de outubro de 1808.

${ }^{136}$ O Tratado Amizade, Aliança e Comércio assinado no Rio de Janeiro, em fevereiro de 1810, impactara a vida comercial da nação portuguesa. Devido a isso, na cidade de Salvador em 1815, José Felipe dos Santos anunciava na gazeta Idade d'Ouro do Brazil que possuía cópias publicadas deste em sua "loja" para quem desejasse adquiri-la. Idade d'Ouro do Brazil, n. 69, de 29 de agosto de 1815. Bahia: na Tipografia de Manoel Antônio da Silva Serva. Consta do acervo do APEB. Setor de Microfilmes.
} 
que se agravaria muito depois de 1812, quando as tropas napoleônicas foram expulsas de toda a península ibérica e não havia mais razões a impedir o retorno da Coroa de Bragança à antiga cabeça do Império. ${ }^{137}$

Todavia, a instalação de um centro de poder na América portuguesa em fase de desenvolvimento econômico ascendente e a própria noção de que uma nova rota de peregrinação imperial acompanhara a Coroa serviam, efetivamente, de desestímulo ao regresso da monarquia à Europa. Além disso, depois de tantos proselitismos políticos, diversos quadros imbuídos da ideologia da ilustração, nascidos no Brasil e com experiência europeia, estavam em suas antigas capitanias. E a melhor coisa que o governo poderia fazer era, decerto, acomodá-los bem no interior da burocracia do Estado, com a firme perspectiva de vir, assim, a canalizar o que havia ali de impulso renovador em favor da manutenção do governo absoluto. Mas para que isso ocorresse a contento era preciso, dentre outros fatores, um ambiente com um mínimo de estabilidade política, condição que aparentemente a América portuguesa ainda oferecia. Desse modo, por que a monarquia deveria abortar o audacioso projeto de erguer um poderoso Império a partir do Brasil? Em resumo, entre as potencialidades e frustrações plausíveis a se verificarem na Europa ou na América, d. João e sua corte dia-a-dia revelavam suas escolhas que, inegavelmente, indicavam a sua preferência em permanecer no Novo Mundo. ${ }^{138}$

A situação se tornou ainda mais salutar depois que a Coroa decidiu-se pela elevação do Brasil à condição de Reino Unido em 16 de dezembro de $1815{ }^{139}$ Resolução essa que adensaria os descontentamentos das classes dominantes muito identificadas à tradicional hegemonia do Reino de Portugal sobre as demais partes do Império. E uma vez admitida que tanto a abertura dos portos (1808), quanto o subsequente Tratado de Comércio com a GrãBretanha (1810) foram medidas que golpearam o comércio monopolista controlado pelo capital português, a nova e imponente categoria política do Brasil passaria a ser interpretada como prova definitiva da inversão dos papéis no interior do espaço imperial. Entretanto, essa

\footnotetext{
${ }^{137}$ Com a conjuntura de guerra europeia e a consequente fuga da monarquia de Bragança para o Brasil, as atividades comerciais de Portugal entraram em uma fase de forte declínio econômico. Na opinião de um contador oficial do governo, os dados da junta do comércio português com as nações estrangeiras referentes ainda ao ano de 1808, de tão reduzidos, poderiam encontrar-se reunidos em um único volume de anotações. SLEMIAN, Andréa; PIMENTA, João Paulo G., op. cit. p. 76. Sobre as restrições das receitas fiscais em Portugal nesse período, ver também ALEXANDRE, Valentim, op. cit.; COSTA, Wilma Peres, op. cit. p. 177.

${ }^{138}$ Sobre os investimentos materiais da nobreza e dos altos funcionários do Estado português na cidade do Rio de Janeiro, ver SLEMIAN, Andréa, 2006, op. cit.

${ }_{139}$ Carta de Lei de 16 de Dezembro de 1815. In: AMARAL, Braz do. História da Independência na Bahia. Salvador: Progresso, 1957. p. 22-23. Sobre o impacto da elevação do Brasil a categoria de reino, ver LYRA, Maria de Lourdes Viana, op. cit. No que concerne aos significados da criação do Brasil Reino entre os baianos, ver SOUSA, Maria Aparecida Silva de, 2009, op. cit.
} 
tomada de consciência, além de não ter sido linear, atingira de forma desigual os envolvidos, evitando, assim, imediatas reações entre os que deveriam sentir-se prejudicados com a medida concertada.

Grande parte desse resultado pode, certamente, ser atribuído à maneira como a Coroa bragantina empenhou-se em fornecer o mínimo de visibilidade no interior do Império português a uma alteração de tanta magnitude. Para isso, o príncipe d. João cuidou somente de divulgar a carta régia pela qual anunciava, sem maiores alardes, que o Brasil havia sido elevado à categoria de Reino Unido a Portugal e Algarves. A intenção, com efeito, não podia ser outra do que dar a impressão de que a mudança no status político da América portuguesa era algo de reduzida significância, conquanto o conselheiro régio Silvestre Pinheiro Ferreira acabasse, posteriormente, registrando que, apesar da distinta medida passar desapercebida a muitos súditos, "os políticos encararam desde logo como um ato de emancipação". ${ }^{140}$ Interpretação que, a contragosto do futuro rei, iria ser potencializada entre os habitantes de Portugal, pavimentando, então, o caminho para que importantes segmentos sociais, a exemplo dos militares e grandes mercadores, procurassem no liberalismo um meio seguro de regenerar a antiga hegemonia de Portugal. ${ }^{141}$

Outra inovação que a ascensão do Brasil à posição de Reino Unido acabaria propiciando diz respeito ao sentimento identitário, pois, dali por diante, a matriz lusoamericana mostrar-se-ia apta a adotar uma característica comportamental ainda mais individualizada, autonomizada, a ponto de poder afirmar-se brasileira. ${ }^{142}$ Por razões distintas, a criação do Reino do Brasil implicaria em desdobramentos sérios para o futuro da monarquia portuguesa. ${ }^{143}$ Contudo, as consequências daí resultantes só podem ser compreendidas quando se tem em vista a complexa busca de alternativas para a superação da crise sistêmica do Antigo Regime.

\footnotetext{
${ }^{140}$ Apud JANCSÓ, István. Independência, independências. In: JANCSÓ, István (Org.). Independência: História e historiografia. São Paulo: Hucitec; Fapesp, p. 18-48, 2005. p. 42. Para as formulações de Silvestre Pinheiro Ferreira apresentadas a d. João em 1814 no intuito de se evitar a eclosão do processo revolucionário e, por extensão, conduzir ao fim da monarquia e do novo império em formação, ver LYRA, Maria de Lourdes Viana, op. cit. p. 149-153.

${ }^{141}$ Para a presente discussão, ver ALEXANDRE, Valentim, op. cit. No que diz respeito ao sentimento dos habitantes do Rio de Janeiro sobre a possibilidade da corte ali permanecer, ver SLEMIAN, Andréa, 2006, op. cit. ${ }^{142}$ A reflexão sobre a virtualidade identitária brasileira a partir da elevação do Brasil à condição de Reino Unido é empreendida por JANCSÓ, István; PIMENTA, João Paulo Garrido, op. cit. p. 154-155. Conforme observam, "o recurso cada vez mais frequente ao conceito de Império no vocabulário político desta época revela a necessidade de uma fórmula que expressasse a nova configuração do Estado bragantino cuja sede do poder deixava de ser equivalente à condição de metrópole, subordinadora de um vasto leque de colônias díspares na América." Idem, ibidem. p. 154, nota 42.

${ }^{143}$ LYRA, Maria de Lourdes Viana, op. cit.
} 
Dessa maneira, a decisão da Coroa portuguesa em fundar o Reino do Brasil deve ser compreendida, antes de tudo, como uma resposta ao processo de céleres mudanças ocorridas na Europa, especialmente depois do exército francês ter ali sofrido derrotas importantes. Realmente, a alteração da conjuntura internacional viabilizou a orquestração de um novo arranjo político em favor das potências que vinham se sagrando vitoriosas no continente. Nos meses anteriores à batalha de Waterloo que, em 18 de junho 1815, selou os planos imperiais de Napoleão Bonaparte, representantes diplomáticos de várias nações, com destaque para a Grã-Bretanha, Rússia, Áustria e Prússia, principiaram a organização de um congresso em Viena.

Os temas centrais a serem deliberados pelos plenipotenciários diziam respeito, principalmente, à redefinição geopolítica de uma Europa pós-napoleônica, à restauração dos governos tradicionais - sob a forma de monarquias absolutas - e os meios de se restabelecer um período de paz duradoura no continente. Mas a persistência da monarquia portuguesa em enviar para ali um maior número de representantes devia-se também a outras motivações. Naquele período, d. João se sentia muito pressionado a apresentar soluções sobre questões específicas ao Império, a exemplo de ter de negociar um tratado, estipulando prazos e condições, para a definitiva supressão do tráfico de escravos, como queria a Coroa britânica. ${ }^{144}$ Por tudo isso, a elevação do Brasil à categoria de Reino Unido a Portugal e Algarves, foi um recurso com o qual a monarquia bragantina pôde efetivamente ter a seu serviço três plenipotenciários, a saber: conde de Palmela - d. Pedro de Sousa e Holstein - , d. Antonio de Saldanha da Gama e d. Joaquim Lôbo da Silveira, com os quais procuraram defender os interesses de todo o Império português enquanto vigorou o Congresso de Viena. ${ }^{145}$ Mas essas providências, obviamente, não poderiam sanar as graves tensões e

\footnotetext{
144 Desde a última década do Setecentos o governo da Grã-Bretanha esteve submetido a fortes pressões para por fim ao tráfico de escravos, inclusive porque havia toda uma mobilização na Câmara dos Comuns disposta a passar um projeto que tornasse ilegal o comércio atlântico de escravos africanos para os domínios britânicos. Vencidas as maiores resistências, esse projeto foi, finalmente, aprovado pelo parlamento em $1^{\circ}$ de janeiro de 1808. A partir de então, as autoridades britânicas encamparam a missão de fazer com que o comércio africano de escravo viesse a ser definitivamente extinto pelas demais nações comprometidas com a escravidão. Portanto, em 1815, a Coroa portuguesa estava convencida da impossibilidade de se furtar completamente à ostensiva campanha pró-abolicionista da Grã-Bretanha. Todavia, ela revelou toda a sua disposição em acordar um tratado que lhe permitisse concessões. Por isso, à medida que soube tirar proveito do trabalho dos seus plenipotenciários no Congresso de Viena, Portugal conseguiu, pelo tratado de 21 de Janeiro de 1815 assinado com a Grã-Bretanha, que a extinção do comércio negreiro ficasse restrita ao norte do Equador. Embora reduzisse a área geográfica do tráfico africano, milhares de súditos portugueses ainda poderiam beneficiar-se do comércio negreiro por mais alguns anos. Ademais, como é sabido, a decisão final sobre o tráfico africano só seria plenamente resolvida bem mais à frente, na década de 1850, quando o próprio Império do Brasil já se encontrasse consolidado. No que concerne à política abolicionista da Grã-Bretanha, consultar BLACKBURN, Robin, op. cit. Especialmente o cap. 8. Para a situação do Brasil nesse contexto, ver RODRIGUES, Jaime. O infame Comércio: proposta e experiências no final do tráfico de africanos para o Brasil (1800-1850). Campinas, SP: Unicamp/Cecult, 2000.

${ }^{145}$ Cf. CALMON, Pedro, op. cit., v. 4. p. 1404-1405.
} 
contradições percebidas por um número crescente de súditos radicados nos dois lados do Atlântico, os quais se mostravam, gradativamente, mais interessados nos ideais do liberalismo político, notados como a melhor forma de se superar a irredutível crise que a todos envolvia.

Deve-se igualmente ressaltar que se, por um lado, as relações das capitanias do Norte para com as do Centro-Sul ampliaram a possibilidade de ascensão social para uma gama maior de famílias e indivíduos radicados na América portuguesa. Por outro, essa interdependência se manifestou de forma muito desigual. Nesse sentido, enquanto a Coroa implantava toda uma máquina administrativa no Rio de Janeiro e, simultaneamente, modernizava a infraestrutura da cidade fluminense elevada à cabeça do Império, tradicionais economias e sociedades como a de Pernambuco, do Maranhão e da própria Bahia encontravam-se cada vez mais na contingência de terem que arcar com o grosso dos impostos destinados à "Real Fazenda".

Não obstante a Coroa tenha empreendido diversas concessões para a Bahia, a visibilidade e o impacto dessas melhorias foram mais bem percebidos por quem transitava pela capital e os beneficiários dos novos serviços revelavam-se pouco representativos em relação à maioria dos moradores da cidade de Salvador e mesmo insignificantes quando comparados ao conjunto dos habitantes da capitania. Já a cobrança do fisco atingia indiscriminadamente toda a população livre e mesmo uma parcela dos escravos urbanos, como no caso dos regateiros e de muitos escravos de ganho que laborando no comércio a varejo, como mencionado acima, não podiam escapar das malhas da fiscalidade. Outrossim, a dependência da monarquia bragantina para com a receita tributária americana revelava-se nas mais diferentes situações e, pior, deixava indícios que deveria ser duradoura. Tendo somente em vista a recuperação dos danos que a guerra causara a Portugal, em 1811 a Coroa determinou que, no decorrer de quarenta anos e após satisfazerem as suas obrigações ordinárias, as alfândegas da Bahia, de Pernambuco e do Maranhão ficariam responsáveis pelo repasse anual de cento e vinte mil cruzados. ${ }^{146} \mathrm{~A}$ forma de arrecadar esse montante logo foi estipulada pela monarquia bragantina na carta régia de 17 de outubro de 1812 ao determinar que das capitanias da Bahia e de Pernambuco fosse recolhido um montante mensal de 35:000\$000 e a do Maranhão fornecesse, pelo mesmo processo, a importância de

\footnotetext{
${ }^{146}$ LYRA, Maria de Lourdes Viana, op. cit. p. 165. Para Maria Odila Silva Dias, a incidência desses novos impostos sobre as capitanias do Norte tornava-se "ilustrativo da continuidade da política fiscal" recrudescente que a Coroa impunha "a financiar ao custeio do seu funcionamento e de obras públicas" necessários ao aprofundamento da base de poder imperial na América. DIAS, Maria Odila Silva, 1972, op. cit. p. 173, nota 29 (Grifos da autora).
} 
25:000\$000. ${ }^{147}$ Essa disposição entraria em vigor em janeiro de 1813 e, sob nenhuma hipótese, poderia ser aplicada para "fazer pagamento algum de qualquer natureza que seja pertencente às despesas da mesma capitania, sem que esta quantia mensal [...] se ache completa no cofre, e à disposição do meu Real Erário". ${ }^{148}$ Não obstante o processo de Independência do Brasil, essa austera fiscalidade continuaria a querer drenar recursos das províncias em direção ao Rio de Janeiro. Tanto assim que, em julho de 1823, o baiano Cipriano José Barata de Almeida (1762-1838) denunciava as intenções do novo governo que continuava exigindo dos pernambucanos as escandalosas somas "de dinheiros tributários, que são os 35 contos mensais que já pediram e até mais de dois milhões atrasados, posto que não foram [enviadas] e me parece nenhuma Província mandará, salvo se for[em] povoada de patetas e escravos, ou de bestas de carga, ou de porcos que criem toucinho para os do Rio comerem". ${ }^{149}$ Insatisfações com esse teor de radicalidade contra o governo centralizado de d. Pedro I serão discutidas com mais vagar no capítulo a seguir.

Por ora, interessa notar que o programa de reformas ilustradas implementado desde a segunda metade do Setecentos pressupunha que os incrementos econômicos levariam necessariamente a uma maior arrecadação tributária. No entanto, as racionalizações da produção e de tributação ocorreram em compassos bastante distintos. Ao que tudo indica, a criação de subsídios, taxas e impostos revelou-se o meio mais cômodo da Coroa dos Bragança responder às crises e conturbações características da Era das Revoluções. Não por acaso, as extinções dos monopólios régios como o da pesca da baleia (1798) e o do sal (1801), foram logo acompanhadas de novas tributações. ${ }^{150}$ As altas taxas que incidiram sobre a produção de alguns gêneros de exportação refletem bem a situação. Desenvolvida pelas principais

${ }^{147}$ Carta Régia de 17 de outubro de 1812 - Determina as soma mensais em dinheiro que as capitanias da Bahia, Pernambuco e Maranhão devem remeter ao Real Erário (disponível em www.camara.org.br).

148 Apud SOUSA, Maria Aparecida Silva de, 2009, op. cit. p. 132. Na acepção contemporânea de Francisco Sierra y Mariscal, a transmigração da família real "para o Brasil fez da Corte do Rio de Janeiro o receptáculo de todas as Riquezas do Império Português. Os pretendentes para lá levaram somas consideráveis. Os Generais das Províncias de Retorno de seus Governos lá gastaram quanto tinham adquiridos neles. Nas causas do foro que lá iam por apelação lá gastavam somas incríveis. O Erário Régio de Portugal sofria saques avultadíssimos. As Províncias do Brasil sofriam uns saques de 400 contos, outras mais, e outras menos. Os viajantes das diversas Nações, os Ministros das Cortes estrangeiras, e os emigrados de diversos pontos da América Espanhola, lá gastaram somas muito fortes”. SIERRA Y MARISCAL, Francisco de. Idéias gerais sobre a Revolução do Brasil e suas consequências. Anais da Biblioteca Nacional. v. 43-44. p. 51-81, Rio de Janeiro, 1931. p. 60.

${ }^{149}$ Sentinela da Liberdade na Guarita de Pernambuco Alerta!, n. 11, quarta-feira, 2 de julho de 1823 . Recife, Tipografia de Cavalcante e Carvalho. In: BARATA, Cipriano. Sentinela da Liberdade e outros escritos (18211835). Organização e edição de Marco Morel. São Paulo: Edusp, 2008. p. 306. Manoel Bomfim também iria ensinar que declarada a Independência, sendo substituídos os representantes do Estado português dos postos mais importantes: "os impostos deixaram de ir para o tesouro da coroa de Ultramar; mas o Estado, em si, permanece qual era [...]" preso às "tradições governamentais". BOMFIM, Manoel, op. cit. p. 191 .

${ }^{150}$ De forma lapidar, Wilma Peres Costa concluiu que: "O furor tributário caracterizou de tal forma a estada da família real na América, que não escaparam nem os pecados dos fiéis já que se taxavam até mesmo os bilhetes de confissão”. Op. cit. p. 171. 
capitanias do Norte - especialmente por Maranhão, Pernambuco e Bahia -, a cultura algodoeira tinha progredido sem nenhum tipo de assistência oficial, mas tornou-se um dos produtos mais sobrecarregados em tributos da América portuguesa de princípios do Oitocentos. $^{151}$

Em razão de todas essas vicissitudes, as manifestações de descontentamento logo apareceram. Em fins de março de 1817, a corte fluminense viu-se surpreendida com as primeiras notícias de que um sistema de governo republicano havia sido deflagrado em Pernambuco e que emissários estavam sendo enviados às capitanias vizinhas em busca de adesões e mais apoios à Revolução principiada. ${ }^{152}$ Decidida a reprimir com viva força militar os rebeldes e seus ideais liberais, a monarquia portuguesa encontrou no governo do conde dos Arcos um aliado importante. E embora diversos insurgentes tivessem considerado, por algum tempo, que lideranças influentes da Bahia levantar-se-iam em franco auxílio, tornando aquela Revolução uma causa comum, esses supostos aliados dos pernambucanos mantiveram-se passivos, em silêncio; e nem, ao menos, conseguiram que o religioso José Inácio Ribeiro de Abreu e Lima - o padre Roma, como era conhecido - escapasse à prisão e ao impetuoso castigo ministrado pelo governo baiano desde o momento em que ele aportou na praia de Itapõa, em Salvador, no dia 26 de março.

O padre Roma fora um arauto da Revolução que se processava em Pernambuco. A bordo de uma jangada, ele percorreu, naqueles dias, a costa marítima pernambucana, indo a

${ }^{151}$ MORTON, F. W. O., 1974, op. cit. p. 167. Ciente de que para a Bahia os tributos sobre o sal rendiam anualmente a importância de 54:000\$000, a Coroa, antes mesmo de expedir a carta régia de 24 de abril de 1801 que autorizaria a supressão dessa receita, publicou o decreto de 19 de maio de 1799 pelo qual determinava a d. Fernando José de Portugal, então governador da capitania, a reformulação das taxas tributárias existentes para, assim, cobrir o desfalque prenunciado (SILVA, Ignácio Accioli de Cerqueira, op. cit., v. 3. p. 24). A diligência sobre esse assunto fora notável, haja vista que, em 15 de abril de 1801, o príncipe d. João felicitou o governo baiano pelo "louvável zelo e inteligência" com que fixara "a cobrança provisionaria dos mesmos novos impostos, enquanto não vos chegava a [...] Real aprovação". No entanto, o sistema de arrecadação em vigor só seria parcialmente aproveitado pela Fazenda, visto que "algumas alterações" foram exigidas pelo seguinte critério de tributação: 60 réis para cada arroba do açúcar branco; 30 réis por arroba do açúcar mascavo; 40 réis por arroba para o tabaco "aprovado" e 20 réis sobre o "reprovado"; $3 \$ 000$ réis cobrado por cada escravo exportado, mas isso provisoriamente para - conforme dizia - não sobrecarregar a produção agrícola, devendo, em breve, ser substituído por outro imposto no mesmo valor individual e pago pelos detentores de "escravos de luxo", considerando nessa acepção todos os cativos ocupados na cidade de Salvador, ainda que só encontrasse ali em ocasiões excepcionais; por fim, a Coroa ordenava que fosse arrecadado "sobre o algodão 160 rs, por cada arroba, e não 100 rs. [...] proposto". A justificativa do futuro monarca para exigir uma tributação $266 \%$ maior para a produção algodoeira do que a extraída do açúcar residia-se no fato do ônus de 160 réis encontrar-se já "estabelecido no Maranhão, deve[ndo] ser uniforme em todo o Brasil, e pago nas mesas de inspeção, pois tem por principal objeto a inspeção do governo, de que tanto benefício resulta ao seu valor e crédito nos mercados da Europa”. Carta Régia de 15 de abril de 1801. In: SILVA, Ignácio Accioli de Cerqueira, op. cit., v. 3. p. 24-28, nota 87, os grifos constam da versão do documento consultado.

${ }^{152}$ A Revolução de 1817 pode ser considerada, entre outras questões, como uma forma de reação das elites regionais da capitania de Pernambuco e suas anexas, ante a crescente centralização do poder no Rio de Janeiro, o que poderia explicar a existência de muitos simpatizantes em território baiano ao projeto insurgente desencadeado em Pernambuco. Cf. BERNARDES, Denis Antônio de Mendonça. $O$ patriotismo constitucional: Pernambuco, 1820-1822. São Paulo: Hucitec: Fapesp. Recife: Ed. Universitária da UFPE, 2006. 
Alagoas, onde conquistou adesões essenciais à causa revolucionária. De volta à balsa, tomou a direção da capital baiana. Consta que ele trazia consigo cartas nominais, manifestos e mais informações sobre os últimos acontecimentos na antiga capitania a serem repassadas aos contatos que na Bahia aguardavam por notícias. Ao se aproximar da praia, contudo, o padre percebeu a movimentação das tropas legalistas, supondo que as mesmas encontravam-se à sua espera, cuidou, então, de submergir sob as águas de Itapoã todos os papéis embarcados, livrando-se, ao menos em parte, de maiores detalhamentos acerca de um repertório que bem poderia ser comprometedor. ${ }^{153}$

No Rio de Janeiro, alguns indicavam, de maneira mais ou menos explícita, que na Bahia o conde dos Arcos agia como uma espécie de patrono de diversos indivíduos interessados em alternativas revolucionárias, como a que, por coincidência ou não, começava a ser testada em Pernambuco. ${ }^{154} \mathrm{O}$ certo, porém, é que conhecida a proclamação de um sistema dissidente na capitania vizinha, o último vice-rei do Brasil nem ao menos aguardou autorização real para principiar a repressão que, com maior ou menor violência, atingiria uma parte expressiva da população residente no território pernambucano e demais áreas sob influência dos mesmos insurgentes. ${ }^{155}$ Ambiguidades políticas como essas marcariam, como se verá, o futuro de d. Marcos de Noronha e Brito na América portuguesa.

Entretanto com a prisão do padre Roma em Itapoã, o conde dos Arcos passou a demarcar como deveria ser o procedimento das autoridades baianas para com os que se deixassem influenciar com os acontecimentos em desenvolvimento na capitania vizinha. Levado à prisão no forte de São Pedro, o padre Roma foi, imediatamente, submetido a um

\footnotetext{
${ }^{153}$ Braz do Amaral apontou outra versão para essa prisão, recomendando ser pretensamente "mais segura" do que as, até então, conhecidas. Nesse caso, o padre Roma chegou à Bahia em uma pequena embarcação que transportava cocos. Depois de vencer a Barra da Baía de Todos os Santos, o meio marítimo no qual viajava "fundeou entre os fortes S. Diogo e Santa Maria e [...] um tripulante [foi] a terra para fazer compras na taverna de Simplício Manoel da Costa”. Informado sobre a carga alimentícia constante da embarcação e interessando-se pela oportunidade do negócio, o taberneiro foi examiná-la "e lá encontrou o padre Roma e um fillho" deste. Descoberto, o padre logo fora conduzido ao Forte de São Pedro, na capital, e entregue às autoridades militares que, naquele momento, já haviam destacado uma escolta para ir à Barra capturá-lo. A explicação, todavia, em nada esclarece sobre os possíveis documentos que o padre Roma trazia consigo. Além do mais, a suposta inação desse emissário - seja quando permaneceu na embarcação depois dessa ter chegado ao destino, seja quando ele se deixou levar até as autoridades, sem que se diga, inclusive, quantos os coagiram a um percurso que, ao fim, lhe seria fatal -, certamente, não condiz com a fama de agitador político adquirida desde, pelo menos, a sua passagem precedente por Alagoas; e que fizera dele um procurado pelas forças legalistas. AMARAL, Braz do. Anotações feitas à Terceira Seção das Memórias Históricas e Políticas da Bahia, pelo Prof. Braz do Amaral, correspondendo ao período que vai desde o governo do Conde Pavolide até a elevação do Brasil a Reino Unido ao de Portugal e dos Algarves. In: SILVA, Ignácio Accioli de Cerqueira e, op. cit., v. 3. p. 249.

${ }^{154}$ Idem, ibidem. p. 248-249.

155 O estudo de Carlos Guilherme Mota sobre a participação das diferentes capitanias do Norte nos acontecimentos de 1817 continua fundamental já que aponta para a multiplicidade política refletida em uma gradação de posicionamentos que inclui desde as tendências mais radicais às de maior moderação. MOTA, Carlos Guilherme. Nordeste 1817: estruturas e argumentos. São Paulo: Perspectiva, 1972.
} 
conselho militar, presidido pelo governador e tendo por demais integrantes os majores Manuel Pedro de Freitas Guimarães, Manoel Gonçalves da Cunha, o tenente-coronel José Antonio de Matos, os coronéis Joaquim José de Souza Portugal e Antonio Frutuoso de Menezes e Doria e os brigadeiros Felisberto Caldeira Brant e Manoel Joaquim de Matos. Depois de passar apenas duas noites no forte, o eclesiástico já teria condições de saber que, por votos unânimes, a comissão o sentenciara à pena de morte. E, já no dia seguinte, um fuzilamento punha fim à sua vida.

Inusual até mesmo para os padrões do Antigo Regime, a grande urgência com a qual o veredicto e a sentença acima foram consumados emanava de um poder que, em nome da monarquia, procedia em termos absolutos. Diante disso - obviamente - a comissão deliberadamente resolveu não consultar, a priori, qual seria a opinião de d. João acerca desse julgamento. Como a monarquia experimentava, de fato, um momento muito peculiar, visto que o herdeiro da Coroa estava prestes a se tornar efetivamente rei do Império português e que, em condições assim, a ritualística da sagração real envolvia, normalmente, gestos magnânimos e indulgentes promovidos pelo aspirante ao trono, um perdão como aquele poderia ter sido plenamente justificável. Porém, nem mesmo as recém-concluídas e muito celebradas exéquias pela morte de uma rainha - d. Maria I - que, durante anos, esteve demente exerceram qualquer influência sobre a condenação à qual o conde dos Arcos e seus subordinados submeteram o padre Roma. ${ }^{156}$ Além disso, esse governador decidiu vencer os limites jurisdicionais da capitania baiana, facilitando, com isso, que as forças militares saídas de Salvador em direção a Pernambuco se destacassem pela violência com que foram autorizadas a tratar os acusados de conspiração contra a ordem vigente. Razão pela qual, elas não tardaram em comunicar ao governo da Bahia que, depois de um bem-sucedido ataque realizado em território pernambucano, encontrava-se de posse de importantes prisioneiros e, inclusive, que haviam capturado a "bandeira revolucionária, ficando, outrossim, sobre o terreno quase todos os cadáveres dos rebeldes". ${ }^{157}$ Estimado pelos altos serviços prestados à

\footnotetext{
${ }^{156}$ Contando 81 anos de idade, d. Maria I faleceu no Rio de Janeiro em 19 de março de 1816 . No dia seguinte, o marquês de Aguiar comunicava ao governo da Bahia tanto o óbito ocorrido, quanto as determinações do príncipe d. João no tocante às "demonstrações do justo sentimento de tão grande perda; ordenando que nas terras desse governo mande V. Exa. fazer todas as honras fúnebres que são do estilo em semelhantes ocasiões. E o luto geral que o Mesmo Senhor mandou que se tomasse há de ser por tempo de um ano, seis meses rigorosos e seis meses aliviado". Apud SOUSA, Maria Aparecida Silva, 2009, op. cit. p. 110.

${ }^{157}$ Apud SILVA, Ignácio Accioli de Cerqueira, op. cit., v. 3. p. 70, nota 111. Uma análise recente sobre o grau de violência das forças legalistas contra os rebeldes de 1817 encontra-se em BERNARDES, Denis Antônio de Mendonça, op. cit. Detalhes igualmente interessantes acerca das perseguições e violências contra os suspeitos de participação da Revolução de 1817, podem também ser encontradas nos escritos jornalísticos de Cipriano Barata, os quais vieram novamente a público em publicação editada e cuidadosamente enriquecida de notas e esclarecimentos elaborados pelo historiador Marco Morel. Cf. BARATA, Cipriano, 2008, op. cit.
} 
Coroa o conde dos Arcos encerrou suas atividades administrativas na capitania baiana, em 26 de janeiro de 1818 , e seguiu para a corte do Rio de Janeiro, aonde continuaria servindo ao Império português.

Não se deve também deixar de mencionar que enquanto os defensores da Coroa enviavam forças militares para combater os rebeldes de 1817, outra conspiração irrompia em Lisboa. Nesse caso, os objetivos fundamentais dos insurgentes passavam pela destituição do oficialato inglês que, desde a transmigração da família real, controlava os principais cargos militares. Esses insurgentes defendiam igualmente a instauração do sistema monárquicoconstitucional de governo nos moldes da agenda liberal e, por fim, preconizavam a reorganização do comércio imperial em benefício do Reino de Portugal. Não obstante a derrota dos projetos de matrizes liberais ter sido imposta nos dois lados do Atlântico pelos defensores do Antigo Regime, a monarquia portuguesa devia ficar precavida sobre o fato da sua consagrada e reiterada política de cooptação e compensações começar a emitir fortes sinais de exaustão. Realmente, a persistência da crise e o consequente desequilíbrio fiscal favoreciam as graves dissidências que, em contato com outros fatores, começavam a mobilizar setores vinculados às classes dominantes de diferentes regiões que, em definitivo, poderiam desenvolver uma aliança em busca de alternativas conjuntas para os graves e persistentes dilemas políticos do Império português.

Na outra ponta, a atuação do, então, rei d. João VI - visto que com a derrota dos diferentes projetos liberais de 1817 e a consequente reunificação do Império foi, com pompa e circunstância, coroado monarca do Brasil, de Portugal e dos Algarves em 6 de fevereiro de 1818 - não assinalava significativa mudança de direção. ${ }^{158}$ Compreende-se, assim, que a monarquia havia se tornado, ao menos temporariamente, refém da política de compensações em benefício das classes dominantes e favorecedoras de eventuais inovações para algumas áreas referenciais, a exemplo do que se verificou para os centros urbanos de Rio de Janeiro e Salvador. As contradições inerentes a esses processos, no entanto, continuavam avolumandose.

No mesmo ano em que d. João foi coroado no Brasil, reuniões clandestinas passaram a ocorrer em intervalos regulares em Portugal. Por meio delas, adquiriu consistência a necessidade dos liberais possuírem uma organização diretiva que conformasse "um corpo

${ }^{158}$ Um mês antes da coroação de d. João, a Câmara Municipal de Salvador enviou à corte os comendadores Felisberto Caldeira Brant Pontes Júnior e Francisco José de Mattos Ferreira e Lucena, os quais assistiriam a cerimônia de aclamação "[...] e aos pés do Trono renovar[iam] os Juramentos de Obediência e de Fidelidade, que o Senado, e o Povo da Bahia consagra[va]m [...]" ao novo monarca dos reinos de Portugal, Brasil e Algarves. Idade d'Ouro do Brazil, n. 42, de 26 de maio de 1817. Bahia: na Tipografia de Manoel Antônio da Silva Serva. Consta do acervo do APEB. Setor de Microfilmes. 
compacto [...] para dirigir o movimento a prol do País, e da liberdade", pois vaticinavam, premonitoriamente, que "necessariamente revoltas e anarquia" logo voltariam a convulsionar o Reino e, na primeira ocasião, pretendiam estar capacitados para assumirem a direção do movimento. ${ }^{159}$ Ao que tudo indica, essa concepção tática altamente refinada no interior do grupo liberal fez a diferença, uma vez que não tardou para estar à frente da Revolução Constitucionalista do Porto, em 24 de agosto de 1820, contribuindo, assim, para um profundo processo de modificações no curso da história de Portugal e Brasil.

159 Apud SOUZA, Iara Lis Franco Schiavinatto Carvalho. Pátria coroada: o Brasil como corpo político autônomo - 1780-1831. São Paulo: UNESP, 1999. p. 79-80. 


\section{Capítulo 2}

\section{Autonomias políticas e espaços de experiência: A Revolução Constitucionalista na Bahia}

As notícias relativas à queda da Regência em Portugal e à convocação das Cortes Gerais para elaboração de uma constituição chegaram a Salvador em fins de outubro de 1820. Sendo amplamente difundidas entre os habitantes, essas informações despertaram entusiasmo em diferentes estratos sociais que, a partir das suas próprias experiências, formavam opiniões sobre o que acabara de acontecer no reino europeu. Embora seja difícil detectar o momento exato em que a política reformista e de conciliação da Coroa de Bragança tenham perdido a hegemonia entre as classes dominantes da capitania, essa viragem aconteceu.

$\mathrm{Na}$ expectativa de explicar as motivações essenciais que levavam a Bahia a se comportar como o território que mais "agita[va] o Brasil", Francisco Sierra y Mariscal sintetizava bem a situação político-social da capitania às vésperas do constitucionalismo. Publicado em 10 de novembro de 1823 na cidade de Lisboa, o seu testemunho coevo registrara:

A Província da Bahia era a que parecia ser mais opulenta em Razão das suas Rendas, era a que tinha em si mais elementos da Revolução; ela deveria primeiro que nenhuma outra dar sinal seguindo o movimento e aceitando o convite, que se fizera de Portugal, por isso que era a que mais Relações comerciais tinha com a Metrópole. As rendas principais daquelas Províncias consistem em Dízimos e Alfândega. A Província da Bahia tem perto de 500 engenhos, porém esta Província é essencialmente mais pobre que Minas [Gerais], São Paulo e Rio Grande [do Sul], porque estas três Províncias têm em si de que subsistir, o que a Bahia não tem; porque sendo todos os seus produtos artigos de exportação, os Ingleses, e mais estrangeiros carregam com eles, e mesmo com o dinheiro em circulação, deixando-lhe em câmbio trapos e bonecos. O Comércio da Praça da Bahia era composto todo de Portugueses Europeus; este Comércio comprava aos estrangeiros suas mercadorias e fazia vir de Inglaterra as Máquinas e utensílios para as serventias dos Engenhos, mas quase tudo era fiado. Fazia vir da costa da África escravatura, do Rio Grande as Carnes, e de outras partes Farinhas. Toda a ação e movimento daquele Comércio, se dirigia a proporcionar-se artigos e meios para poder suprir e adiantar fundos aos Srs. de Engenho, estes recebiam adiantado quanto precisavam para o andamento de suas fábricas, hipotecando aos Negociantes Portugueses [que] ato contínuo a hipotecavam aos estrangeiros, para pagamento dos gêneros e Máquinas que lhes tinham tomado fiadas. O Sistema depravado de economia dos Senhores de Engenho, fazia com que Recebem [sic] cada ano muito mais do que a importância de sua Safra, acontecendo quase sempre, que as hipotecavam a 
três e a quatro [financiadores] ao mesmo tempo, passando contudo miseravelmente, e sendo isto um foco de querelas e de demandas. ${ }^{1}$

Avaliava, assim, que as atividades comerciais na Bahia careciam de consistência e de "capitais reais" e não de um amontoado de títulos em dívidas. ${ }^{2}$ Fundando-se igualmente nos privilégios concedidos aos senhores de engenhos, o periódico Semanário Cívico, de 29 de novembro de 1821, denunciava que:

[...] O governo passado persuadiu-se que, concedendo aos proprietários de engenho o privilégio de considerar-se a sua fábrica, escravos, bois, cavalos e terras indivisíveis para não serem penhorados, em separado, por qualquer credor, seria o meio mais eficaz de promover o aumento da safra de açúcar. Nesta errônea persuasão publicou uma lei ordenando que os engenhos e todos os seus acessórios se reputassem um todo que não poderiam sofrer execução senão quando a dívida excedesse ao seu total valor, e apenas seriam obrigados a pagar pelo rendimento da terça parte do seu produto. ${ }^{3}$

Perante as dificuldades dos credores em reaverem os capitais empatados junto aos senhores de engenho, Sierra y Mariscal asseverava que "o Comércio e a lavoura da Bahia estavam de fato quebrados". Previdente ainda arrematara: “Apesar de tantos males quem não meditava afundo o estado das coisa[s] e se entretinha só pela superfície, via na Província da Bahia um véu de opulência que encobria uma miséria real e, que ao menor transtorno político, todo aquele esplendor fictício deveria desaparecer". 4

Não obstante os problemas de iminente insolvência que rondavam a agroindústria açucareira no Recôncavo, não se deve menosprezar a influência política da Bahia frente ao futuro imediato do Brasil no transcurso da dissolução do Antigo Regime português. Para tanto, cabe aqui realçar os aspectos demográficos da província baiana tendo como referência a população livre e os escravos. Nesse sentido, verifica-se que o índice populacional na Bahia por este período era considerável. Somente a cidade de Salvador contabilizava cerca de 60 mil habitantes em 1822, enquanto a população total da província podia ser calculada em 671.922

\footnotetext{
${ }^{1}$ SIERRA Y MARISCAL, Francisco de. Idéias gerais sobre a Revolução do Brasil e suas consequências. Anais da Biblioteca Nacional. v. 43-44. Rio de Janeiro, 1931. p. 60-61.

${ }^{2}$ Idem, ibidem, p. 61.

${ }^{3}$ Semanário Cívico, n. 40, de 29 de fevereiro de 1821. Apud SILVA, Maria Beatriz Nizza da. Semanário Cívico: Bahia, 1821-1823. Salvador: Edufba, 2008. p. 60. Passados menos de quatros meses dessa denúncia, na sessão das Cortes de Lisboa de 8 de março de 1822, o deputado baiano Domingos Borges de Barros apresentou requerimento assinado por negociantes da Bahia, solicitando "abolição do privilégio dos senhores de engenho". A agenda liberal, portanto, forcejava meios de controlar o poderio da terra sobre as demais atividades produtivas, especialmente para com o comércio. $O$ Independente, n. 9, sábado, 9 de março de 1822 [p. 526]. In: 〈http://books.google.com.br/books?id= vovAAAAYAAJ\&printsec=frontcover\#v=onepage\&q\&f=false> (Acesso em 21 de novembro de 2009). Para uma análise, ainda hoje válida, de como os privilégios dos senhores de engenho atuaram sobre o desenvolvimento econômico da América portuguesa, ver FURTADO, Celso. Formação econômica do Brasil. 17. ed. São Paulo: Ed. Nacional, 1980. Em especial, o capítulo 8.

${ }^{4}$ SIERRA Y MARISCAL, Francisco de, op. cit. p. 61.
} 
indivíduos em 1823. Deste conjunto, a população livre totalizava 434.464 habitantes e a cativa 237.458 indivíduos. ${ }^{5}$ Percebe-se, então, que para cada duas pessoas livres à época na antiga sede dos vice-reis, havia uma que subsistia no sistema econômico da escravidão. Arrancados de uma estreita faixa de terra no golfo de Benin, em princípios do século XIX, para serem conduzidos por embarcações asfixiantes, os africanos desembarcavam no porto marítimo de Salvador para logo serem comercializados. A origem étnica desses imigrantes forçados era constituída por nagôs, jejes e haussás muçulmanos, os quais, gradativamente, procuravam refazer suas vidas incorporando e modificando a cultura baiana. ${ }^{6}$

No interior da sociedade baiana, grandes proprietários de terras e de escravos, negociantes de grosso cabedal, altos funcionários do Estado, da Igreja e, por fim, oficiais de elevada patente militar atingiam mais facilmente a proeminência no que concerne ao padrão de riqueza material, poder de mando e a subordinação de terceiros. Sob qualquer ângulo, esses indivíduos e, em vários casos, seus familiares conformavam os estratos sociais dominantes na Bahia. Em seguida, encontravam-se os segmentos sociais que ocupavam os escalões secundários às atividades aqui descritas. No entanto, os cargos e as funções desempenhados por essa camada intermediária tornaram-se, com o passar do tempo, muito disputados pelas pessoas de cor - geralmente crioulas, cabras, mulatas e pardas - as quais compunham a maioria dos habitantes da Bahia em fins do Antigo Regime. ${ }^{7}$ É crível, pois, afirmar que desde a segunda metade do século XVIII este complexo e dinâmico segmento de classes populares tornou-se tão expressivo que, somente com graves riscos, seria desconsiderado nos cálculos políticos e sociais em qualquer projeto de futuro.

$\mathrm{Na}$ base da sociedade baiana encontrava-se um espesso substrato de escravos expropriados das suas vontades e pessoas, que subsistiam reduzidos aos locais destinados à agricultura - sobretudo em torno do complexo açucareiro em áreas do Recôncavo - e aos espaços urbanos, mormente na cidade de Salvador. Compreende-se, assim, que a matriz estruturante da sociedade e da economia na Bahia de fins do Setecentos e durante longos anos

\footnotetext{
${ }^{5}$ Para os resultados censitários citados, ver MATTOSO, Kátia M. de Queirós. Ser escravo no Brasil. São Paulo: Brasiliense, 1982. p. 64. Esses dados demográficos são aproximativos aos índices adotados por JANCSÓ, István. Independência, independências. In: JANCSÓ, István (Org.). Independência: História e historiografia. São Paulo: Hucitec; Fapesp, 2005. p. 22-23; REIS, João José. Rebelião escrava no Brasil: a história do levante dos malês em 1835. Edição rev. e amp. São Paulo: Companhia das Letras, 2003. p. 20-24; BARICKMAN, Bert J. Um contraponto baiano: açúcar, fumo, mandioca e escravidão no Recôncavo, 1780-1860. Rio de Janeiro: Civilização Brasileira, 2003. p. 98 e SCHWARTZ, Stuart B. Segredos internos: Engenhos e escravos na sociedade colonial - 1550/1835. São Paulo: Companhia das Letras, 1995. p. 352.

MATTOSO, Kátia M. de Queirós. Ser escravo no Brasil. São Paulo: Brasiliense, 1982, p. 64.

${ }^{6}$ SCHWARTZ, Stuart. op. cit, p. 354.

7 Cf. ARAÚJO, Ubiratan Castro de. A política dos homens de cor no tempo da independência. In: DOMINGUES, Carlos Vasconcelos et al (Orgs.). Animai-vos, Povo Bahiense! A conspiração dos Alfaiates. Salvador: Omar G. Editora, 1999. p. 100-113.
} 
do século seguinte residiria na exploração do elemento servil. Finalmente, ao maciço societário de cativos assemelhavam-se, às vezes mesmo em piores condições sociais, os vagabundos e mendigos que conformavam os restos da sociedade escravocrata, cuja composição incluía: "marinheiros velhos ou aleijados, prostitutas, mulatos e negros exescravos abandonados pelos senhores na velhice, índios desgarrados das aldeias, negros fugidos do eito, brancos e mestiços pobres com trabalho irregular, ciganos e degredados europeus". 8 De todo este amálgama, reunido na base societária, resultava em cálculo de proporções apreciáveis de indivíduos que viviam no limiar da pobreza na multissecular urbe baiana. 9

Mas esse intricado mosaico social não se deixava compreender a primeira olhadela, posto que do proprietário abastado ao indivíduo em cativeiro fora extensa a gama dos senhores a beneficiar-se da instituição escravista na Bahia. ${ }^{10}$ Além do mais, o estrato escravista em todo o Brasil vivera desde sempre em permanente contiguidade com a sociedade dos brancos, propiciando assim o que Gilberto Freyre denominou de miscibilidade entre cativos (iniciada já com os indígenas e conservada "gostosamente" com os africanos) e seus senhores, o que explica a forte miscigenação característica daquela sociedade. ${ }^{11}$

Para consubstanciar os indícios de que o período fora de elevadas contradições e conflitos na sociedade baiana de fins do Antigo Regime, cumpre salientar que as rebeliões escravas tornaram-se ali endêmicas, o que amplificaram as tensões e impuseram às autoridades senhoriais a dura missão de controlar a "crioulada". Desencadeadas, especialmente, na capital baiana e nas áreas do Recôncavo entre os anos de 1807 e 1821, o ciclo das insurreições entre cativos dessa fase reforçou a tradição de audácia e contestação na Bahia das primeiras décadas do Oitocentos. ${ }^{12}$ Nesse sentido, é preciso não perder de vista que as circunstâncias imediatas que concorreram para as revoltas escravistas residiam especialmente na ampliação da economia canavieira, no aumento do tráfico negreiro, nas tentativas de racionalização do trabalho compulsivo, nas crises periódicas de produção de

\footnotetext{
${ }^{8}$ MOREL, Marco. Cipriano Barata na Sentinela da Liberdade. Salvador: Academia de Letras da Bahia: Assembleia Legislativa do Estado da Bahia, 2001. p. 30.

9 MATTOSO, Kátia M. de Queirós. Bahia, século XIX: uma província no Império. Rio de Janeiro: Nova Fronteira, 1992. Sobre a pobreza na Bahia de fins do período colonial, ver também VILHENA, Luís dos Santos. Recopilação de notícias soteropolitanas e brasílicas. Bahia: Imprensa oficial do Estado, 1921, v. 2.

${ }^{10}$ REIS, João José, 2003, op. cit.

11 FREYRE, Gilberto. Casa-grande \& senzala: formação da família brasileira sob o regime da economia patriarcal. 30. ed. Rio de Janeiro: Record, 1995.

${ }^{12}$ Para fins analíticos, João Reis dividiu as revoltas escravas na Bahia desse período em dois ciclos. O primeiro, ocorrido entre os anos 1807 a 1821; e o segundo que se manifestou "na Bahia independente", cujas insurreições iniciadas já em 1822 teriam o seu ápice em 1835 na famosa Revolta dos Malês. REIS, João José, 2003, op. cit.
} 
alimentos e, ainda, na percepção mais aguçada em torno dos confrontos de interesses entre os segmentos livres da população. ${ }^{13}$

No contexto das revoluções liberais, a composição dos cativos e das pessoas de cor ao representarem mais de dois terços dos habitantes da Bahia adquiria, por certo, um aspecto político de grande envergadura, já que abria a possibilidade de uma insurreição generalizada envolvendo a escravatura e a população livre, amplamente mestiça. Porém, essa potencialidade, em nenhum momento, traduzir-se-ia em paralisia do sistema. Pelo contrário, mesmo a Bahia experimentando o mencionado ciclo de revoltas escravistas e em plena recessão econômica, o tráfico negreiro alcançaria média anual superior a 7 mil escravos ao longo de todo o decênio de $1820 .{ }^{14}$ Foi, portanto, em meio a um cenário de graves tensões, contradições que a Revolução Constitucionalista eclodiu na Bahia em 10 de fevereiro de 1821, vinculando, assim, a administração da província às Cortes Constituintes de Lisboa que do outro lado do Atlântico tomaram a iniciativa de romper com o governo absoluto. Fixa-se aqui um primeiro referencial a ser aprofundado nesse capítulo que é o de compreender como o movimento constitucionalista, desencadeado sob a influência da Revolução Liberal do Porto, ampliou as possibilidades de intervenção política dos habitantes da província baiana.

\subsection{Construção da aliança liberal entre os habitantes de Portugal e do Brasil no contexto revolucionário}

A ampliação da presença de portugueses europeus na Bahia vinha sendo favorecida, conforme mencionado, desde a transferência da corte e da abertura dos portos. Em riqueza e população, a antiga capital da colônia era a segunda capitania da América portuguesa, sendo a cidade de Salvador, em 1820, um dos maiores centros urbanos do Novo Mundo. Geograficamente bem posicionada, detentora de vasta e segura baía e comunicando-se pelo interior com importantes regiões, o peso político que o território baiano exercia sob o Império não poderia ser menosprezado. Por todas essas razões, a Coroa ver-se-ia pressionada a

${ }^{13}$ Cf. REIS, João José, 2003, op. cit. parte I e SCHWARTZ, Stuart, op. cit. parte IV.

${ }^{14}$ Cf. SCHWARTZ, Stuart B., op. cit.; BARICKMAN, B. J., op. cit. Calcula-se que para a toda a América portuguesa a média anual do tráfico de escravos, entre 1785 e 1815, fez desembarcar um patamar superior a 25.000 africanos por ano. Por esses dados, conhece-se que de cada quatro escravos aportados no Brasil, um serviu ao senhoril na Bahia. Para estes cálculos do tráfico na América portuguesa, ver ARRUDA, José Jobson de Andrade; NOVAIS, Fernando Antônio. Prometeus e Atlantes na forja da Nação. Revista Economia e Sociedade, Campinas, v. 12, n. 2, jul./dez. 2003. p. 242-243. (disponível em <http://www.eco.unicamp.br/docdownload/publicacoes/instituto/revistas/economia-e-sociedade/V12-F2-S21/05Novaes\%20Jobson.pdf> Acesso em 12 de novembro de 2009). Para o que diz respeito à fase de recessão econômica da província da Bahia na década de 1820, ver MATTOSO, Kátia M. de Queirós. Os escravos na Bahia no alvorecer do século XIX (Estudo de um grupo social). Revista de História. São Paulo, Jan-março, v. 47, n. 97, ano XXV. p. 109-135, 1974. 
acompanhar de perto os potenciais efeitos da propaganda revolucionária do vintismo sobre aqueles habitantes, inclusive pela possibilidade dos empregados institucionais se engajarem no projeto liberal já bastante desenvolvido no outro lado do Atlântico.

Naqueles anos, o aprofundamento da crise e as contradições políticas da Coroa tornaram-se ainda mais perceptíveis, sobretudo, para os habitantes das capitanias mais distantes da corte do Rio de Janeiro. Nesse contexto, a Bahia começara a ressentir-se com maior impaciência diante do tratamento que a monarquia vinha lhe dispensando, especialmente depois dela ter tido contribuição relevante para a derrota do governo dissidente que se organizava a partir de Pernambuco. Registre-se também que na fase final do governo do conde dos Arcos os grandes investimentos públicos escassearam, elevando, por certo, os descontentamentos para com as rendas extraídas da capitania por meios tributários. Paralelo a isso, a presença do Estado fazia-se mais ostensiva em sua capacidade repressiva, pois, com a justificativa de auxiliar os combates aos rebeldes pernambucanos e seus aliados, em 1817, a Coroa transferiu de Portugal para a capital baiana um contingente de oficiais e soldados que se reuniram às demais tropas ali existentes. ${ }^{15}$

Importa, ainda, destacar que a permanência do batalhão de artilharia número 12 na cidade de Salvador, para além da segurança oficial, colaboraria na ampliação da comunidade de portugueses europeus residentes na capitania, conquanto também contribuísse para agudizar as tensões no interior de uma corporação militar em que europeus e filhos da terra estavam cada vez mais dispostos a rivalizarem entre si em busca das patentes mais graduadas. ${ }^{16}$ Nesse caso, os convívios diários de soldados e oficiais nascidos na América com os militares oriundos de Portugal contribuíram para eles atestarem que, do fardamento às promoções, o tratamento no interior do Exército beneficiava aos contingentes de origem europeia. Além do mais, o maior volume de informações chegadas do Ultramar no contexto pós-1808, permitia que o conjunto da guarnição comparasse a sua situação ao novo paradigma

\footnotetext{
${ }^{15}$ Em 30 de setembro de 1817, a gazeta Idade d'Ouro do Brazil assim anunciava: "Tem entrado e continuam a entrar neste porto várias embarcações de transporte que trazem tropa de Lisboa para esta cidade [de Salvador]. Domingo já ficavam aqui 160 homens do Batalhão número 12. Os soldados são de Chaves e do Porto e formam ao todo 2 batalhões. Saíram mais embarcações que levam tropa para o Rio de Janeiro". Idade d'Ouro do Brazil, n. 77, de 30 de setembro de 1817. Bahia: na Tipografia de Manoel Antônio da Silva Serva. Consta do acervo do APEB. Setor de Microfilmes.

${ }^{16}$ John Armitage assinalara que em razão da conspiração de 1817, "um corpo de tropas de Portugal, composto de quatro batalhões de infantaria, um de caçadores, e uma brigada de artilharia", foi transferido ao Brasil; sendo que um batalhão ficara destacado em Pernambuco, um segundo na Bahia, retirando-se os demais contingentes para a corte fluminense. ARMITAGE, John. História do Brasil: desde o período da chegada da família de Bragança, em 1808 até a abdicação de D. Pedro I, em 1831, compilada à vista dos documentos públicos e outras fontes originais formando uma continuação da história do Brasil, de Southey. Belo Horizonte: Itatiaia; São Paulo: Edusp, 1981. p. 34. Para a crescente disputa entre europeus e filhos da terra pela ocupação dos melhores postos militares nesse período, ver KRAAY, Hendrik. Race, State and Armed Forces in Independence-Era Brasil, Bahia, 1790's-1840's. Stanford: Stanford University Press, 2002.
} 
do soldado-cidadão, cuja visibilidade na era napoleônica e nos subsequentes processos de independência na América espanhola, a partir de 1810, deu-lhe concretude. ${ }^{17}$

Dentre os entusiasmados com as mudanças políticas no Reino de Portugal, encontraram-se os grandes mercadores que atuavam na praça comercial da Bahia. ${ }^{18}$ Mas não apenas eles. Ainda no topo da hierarquia social baiana, uma porção de magistrados, a maioria dos militares e parte considerável da classe senhorial passaram a enxergar nos novos acontecimentos a oportunidade para resolução efetiva de muitos dos seus problemas. Para os presos políticos que, na cadeia do Aljube em Salvador, respondiam pela participação na Revolução de 1817, somados aos sobreviventes do ensaio de sedição de 1798, as perspectivas em curso eram também inspiradoras.

De todo o modo, as bases de sustentação da autoridade do governo absoluto encontravam-se tão desgastadas na capitania que nem mesmo o então governador e capitãogeneral, conde da Palma, d. Francisco de Assis Mascarenhas (1779-1843), foi capaz de esboçar, ao menos, uma reação pública que dificultasse a conformação e o espraiamento de projetos contrários ao Antigo Regime português. Sem enfrentar maiores obstáculos, a ocorrência de reuniões e demais articulações para se discutir o papel da Bahia diante das mudanças principiadas em Portugal começavam a mobilizar diferentes segmentos sociais da capital, superando, dessa maneira, o período de inação que o Império português viu-se envolvido.

Ainda assim, os setores organicamente mais vinculados às classes dominantes, os quais, inegavelmente, possuíam os melhores privilégios e isenções no Antigo Regime,

\footnotetext{
${ }^{17}$ ARAÚJO, Ubiratan Castro de. A Guerra da Bahia. Salvador: Ceao/UFBA, 2001 (Série Capítulos). Salienta realçar que, a rigor, o paradigma soldado-cidadão já se fazia presente desde o ensaio sedicioso de fins do Setecentos. Neste sentido, o historiador canadense Hendrik Kraay registrou a declaração de um soldado que afirmara ter conversado privativamente com o tenente Hermógenes Francisco de Aguillar Pantoja quando os dois patrulhavam o porto da cidade de Salvador, e o último observando o calção roto do soldado, lastimou "[...] o miserável estado da Tropa Portuguesa, o pouco soldo que percebiam os soldados, e a grande sujeição em que viviam, o que não sentia a Milícia Francesa, pois cada um soldado percebendo um soldo avultado, só viviam sujeitos [à legislação militar] na ocasião e fora dela tinham toda liberdade e igualdade”. Apud KRAAY, Hendrik, 2002, op. cit., p. 47 (tradução livre).

18 Enfatize-se, uma vez mais, que em influentes zonas portuárias da América portuguesa, como era a cidade de Salvador de princípios do Oitocentos, a concorrência crescente do comércio inglês vinha se tornando tão acentuada que, em alguns casos, podia-se até dispensar os produtos lusitanos, daí a animação manifesta entre os negociantes portugueses com as promessas políticas suscitadas pela Revolução do Porto. Encontrando-se na capital baiana em fevereiro de 1821, Sierra y Mariscal, posteriormente, anotou: "Ao monstruoso tratado de 1810, se deve atribuir em grande parte, e como causa imediata a Revolução do Brasil. Depois deste tratado, eu tenho visto nas vizinhanças do Rio de Janeiro, vilas reduzidas a ruínas, e desertas; o mesmo acontece no Recôncavo da Bahia”. SIERRA Y MARISCAL, Francisco de. Ideias gerais sobre a Revolução do Brasil e suas consequências. Anais da Biblioteca Nacional. v. 43-44. p. 51-81, Rio de Janeiro, 1931. p. 56. Para o contexto mais geral do Brasil frente às revoluções liberais no Ocidente, ver. GODECHOT, Jacques. Independência do Brasil e a Revolução do Ocidente. In: MOTA, Carlos Guilherme (Org.), 1972, op. cit. p. 27-37 e MAURO, Frédéric. A Conjuntura Atlântica e a Independência do Brasil. In: MOTA, Carlos Guilherme (Org.), 1972, op. cit. p. 38-47.
} 
preferiam não adotar, logo de início, posições que pudessem levar à ruína da autoridade vigente. Primeiro, queriam conhecer qual seria o posicionamento do monarca ante o novo sistema do governo adotado em Portugal, pois, acreditavam que d. João VI iria fatalmente condescender frente ao programa do vintismo, mesmo porque toda a porção territorial da antiga metrópole, o berço tradicional da monarquia portuguesa, já se encontrava sob autoridade constitucional. Presa a essa perspectiva, a gazeta Idade d'Ouro do Brasil declararia, posteriormente:

A Bahia esperava em modesto silêncio pela resolução do Rio de Janeiro à vista dos sucessos de Portugal; a Bahia não queria roubar aos ministros de S. M. a glória de fazerem por bem aquilo que necessariamente se havia fazer por mal, porque as baionetas que, no sistema florentino de Maquiavel, eram as últimas razões do povo. Do povo [...] que antes de se servir das baionetas se serviu de lágrimas e humildes representações que nem chegaram aos ouvidos do mais amável dos soberanos. ${ }^{19}$

Embora seja mais difícil determinar com alguma precisão o comportamento das classes sociais intermediárias da sociedade escravista nos últimos dias do Antigo Regime na capitania, os indícios são de que - tanto pelo peso numérico, quando pelos valores intrínsecos às suas próprias condições sociais - trabalharam para a conformação de uma ampla aliança política para, assim, assegurarem seus novos direitos constitucionais. Indicativo, desse posicionamento, revela-se na atuação das lideranças radicais que, pertencendo majoritariamente às camadas intermediárias, ampliaram a sua visibilidade política justamente ao ajudarem a desenvolver as ações conspiratórias até o momento no qual, pressupondo terem apoios suficientes, participaram da deflagração do processo que trouxe abaixo os principais representantes do governo absoluto na Bahia.

Mesmo levando-se em consideração as diferenças - pois elas existiram visto que nenhuma classe social pode ser compreendida como um todo coeso e livre de contradições -, o certo é que, com o passar do tempo, tanto os segmentos sociais mais vinculados às classes dominantes, quanto às intermediárias viram no modelo de aliança política adotado pelo vintismo português um padrão a ser seguido. ${ }^{20}$ Vale notar, no entanto, que a complexa organização societária da Bahia escravista exigia cuidados por parte dos segmentos societários que se propunham a capitanear o processo revolucionário, pois o exemplo de 1798

\footnotetext{
${ }^{19}$ Idade d'Ouro do Brazil, n. 13, sexta-feira, 13 de fevereiro de 1821. Exemplar do APEB. Setor de Microfilmes. ${ }^{20}$ Para o modelo de aliança do vintismo que em sua proposta de superação do Antigo Regime português amalgamou distintos segmentos sociais - profissionais liberais, integrantes do exército, da Igreja, dentre outros , ver ALEXANDRE, Valentim. Os sentidos do Império. - questão nacional e questão colonial na crise do Antigo Regime português. Porto: Afrontamento, 1993.
} 
- quando senhores, homens livres pobres e escravos foram acusados de tramar uma conspiração para deposição do Antigo Regime - poderia, mesmo a contragosto, voltar a ocorrer. Admite-se, então, que tanto o horizonte de expectativa das classes proprietárias, quanto o da maioria das lideranças das camadas intermediárias padecia de sérias limitações políticas. ${ }^{21}$ Em ambos os casos, portanto, a possibilidade de supressão da instituição escravista e a efetiva participação política dos estratos sociais formados por aqueles que não eram nem senhores, nem escravos, figuravam como temas altamente dissonantes e que, por isso, não deveriam aparecer nos debates públicos. ${ }^{22}$

Ao que tudo indica, esse entendimento tácito delineou, com precisão, a confluência de toda uma gama de interesses que permitiria a atuação conjunta das camadas dominantes e intermediárias contra um adversário poderoso. $\mathrm{O}$ interessante aqui, no entanto, é observar que na antessala da Revolução, as principais lideranças desses estratos sociais agiram com cautela no tocante às manifestações públicas, especialmente porque viram, logo cedo, que parte significativa das classes intermediárias de baixa extração social, formadas predominantemente por negros, crioulos e mulatos livres, estava muito disposta a participar mais autonomamente da redefinição do pacto político e social no interior da nação portuguesa. Neste caso, eles temiam, com razão, que o envolvimento ativo das classes intermediárias de caráter eminentemente popular nas lutas políticas acabasse apontando para uma direção mais consequente do que a acordada na agenda liberal. ${ }^{23}$ Admite-se, assim, que os conflitos de interesses envolvendo as classes dominantes, a contrapelo das suas vontades, favoreceram as lutas populares no período da Independência. ${ }^{24}$

\footnotetext{
${ }^{21}$ Sobre o horizonte de expectativa enquanto categoria histórica, ver KOSELLECK, Reinhart, op. cit. Cap. 14.

${ }^{22}$ A obra de Caio Prado Júnior continua sendo um eixo referencial importante para se aprofundar essa análise. Ver, por exemplo, PRADO JÚNIOR, Caio. Evolução Política do Brasil. 6. ed. São Paulo: Brasiliense, 1966.

${ }^{23}$ Demonstrar como os grupos ou classes populares se posicionaram frente à desagregação do Antigo Regime português e ao processo subsequente de Independência do Brasil tem sido um campo de investigação ainda pouco explorado pela historiografia. Dentre as iniciativas que têm buscado compreender o papel dos segmentos populares no cenário político dos anos de 1820, destacam-se as recentes pesquisas de Hendrik Kraay para quem: "Ainda se sabe muito pouco sobre a participação popular no processo de independência e como esta foi compreendida pelas classes populares. Ademais, a história da independência nas províncias do então Norte, notadamente a Bahia, mas também Pernambuco - onde a participação popular na política daqueles anos era mais visível -, ainda permanece mal-incorporada às histórias da independência". KRAAY, Hendrik. Muralhas da independência e liberdade do Brasil: a participação popular nas lutas políticas (Bahia, 1820-1825). In: MALERBA, Jurandir (Org.). A independência brasileira: novas dimensões. Rio de Janeiro: Ed. FGV, 2006. p. 307. Para o contexto hispânico do conceito e influência da soberania popular em princípios do século XIX, ver GUERRA, François-Xavier, Modernidad e independências: Ensayos sobre las revoluciones hispánicas. México: Fondo de Cultura Económica, 1995. Especialmente o cap. 10. Para a participação popular em Pernambuco durante o processo de Independência, consultar SILVA, Luís Geraldo. Aspirações barrocas e radicalismo ilustrado. Raça e nação em Pernambuco no tempo da Independência (1817-1823). In: JANCSÓ, István (Org.). Independência: História e historiografia. São Paulo: Hucitec; Fapesp, p. 915-934, 2005.

${ }^{24}$ PRADO JÚNIOR, Caio, 1966, op. cit.
} 
Nesse sentido, O cônsul da França na Bahia, Jacques Guinebaud, sintetizou o ambiente político-social dos habitantes de Salvador, entre fins de 1820 e princípios do ano seguinte, considerando que depois da divulgação dos acontecimentos liberais em Portugal:

Muito se conspirou, mas, no geral, nota-se uma tranquilidade e uma submissão à posição que adotará o rei, mesmo entre os mais radicais. Esta mudança de disposição deve-se ao medo que inspiravam os negros e os mulatos livres que já manifestaram o seu espírito de desordem, que deve inquietar os proprietários e os negociantes. ${ }^{25}$

Se, no entanto, essa avaliação mostrar-se-ia logo equivocada quanto à perspectiva subordinada da capitania aos desígnios da Coroa, ela acertou ao demonstrar que o envolvimento das classes populares nas disputas políticas inspirava fortes receios em outros segmentos sociais da sociedade escravista da Bahia. Apesar disso, as tentativas da gente do comum em participar das questões políticas tornar-se-iam uma constante do cotidiano baiano ao longo da agitada década que, apenas, se iniciava. ${ }^{26}$ Defrontando-se, portanto, com uma conjuntura na qual as tendências políticas tendiam a afirmar-se de maneira acelerada, a Coroa mantinha fortes interesses em conhecer o que se passava nas diferentes partes do Império português, particularmente em se tratando de pontos considerados estratégicos, como era a capitania da Bahia.

Sensível a essa situação, o conde de Palmela, então ministro das Relações Exteriores do Império, depois de ter testemunhado a mudança na ordem governamental em Portugal, desembarcou em Salvador, em $1^{\circ}$ de dezembro de 1820, antes de reencontrar com d. João VI

\footnotetext{
${ }^{25}$ Apud ARAÚJO, Ubiratan Castro de, 2001, op. cit. p. 12. Também nas lutas pela independência na América hispânica, ou em termos mais precisos na Venezuela, no México e Peru, o elemento catalisador envolveu sempre “o medo de mobilizações políticas das 'classes baixas': a saber, as revoltas dos índios ou dos escravos negros”. BENEDICT, Anderson R. Comunidades Imaginadas: reflexões sobre a origem e a difusão do nacionalismo. São Paulo: Companhia das Letras, p. 84-106, 1998. p. 86 (Grifos do autor). No que concerne especificamente ao caso da Venezuela, ver IZARD. Miguel. El miedo a la revolucion: La lucha por la libertad em Venezuela (17771830). Madrid: Editoria Tecnos, 1979.

26 Ao analisar a província do Pará e Maranhão entre os anos de 1821 a 1825, André Machado constatou como os milhares de tapuios - compreendidos regionalmente como índios não tribalizados, "civilizados", ou ainda caboclos - provocaram verdadeiros alinhamentos políticos entre as classes dirigentes locais e o Rio de Janeiro imperial ante as suas insistências em participar da vida política paraense. Amparado por boa documentação, o historiador teve a oportunidade de enfatizar que, a despeito de serem juridicamente livres, os tapuios não raramente viam-se compelidos a empreender trabalhos compulsórios ocasionais, situação na qual a difusão de direitos constitucionais passou a gerar graves instabilidades político-sociais entre franco opositores. MACHADO, André Roberto de A. A quebra da mola real das sociedades: a crise política do Antigo Regime português na Província do Grão-Pará (1821-1825). Tese (Doutorado em História Social) - Universidade de São Paulo, São Paulo, 2006. Para as tentativas de maior participação política dos sertanejos baianos no tempo da Independência, ver SOUZA FILHO, Argemiro Ribeiro de. A guerra de Independência na Bahia: Manifestações políticas e violência na formação do Estado nacional (Rio de Contas e Caetité). Dissertação (Mestrado em História) - Universidade Federal da Bahia, Salvador, 2003.
} 
no Rio de Janeiro. ${ }^{27}$ Após ter se inteirado minimamente do que se passava na capital baiana, reuniu-se com autoridades e alguns representantes dos setores influentes da sociedade local, inclusive comerciantes portugueses europeus. ${ }^{28}$ Convencido de que a capitania poderia, se nada fosse feito, renunciar às diretrizes do governo absoluto, o ministro Palmela procurou travar um acordo mínimo com as lideranças. De fato, os indícios apontam que ele antecipou aos presentes, ao menos em linhas gerais, um parecer que apresentaria a João VI, segundo o qual aconselharia o monarca outorgar uma carta constitucional, a exemplo do que realizara Luís XVIII na França (1814). O intuito do ministro era fazer ver ao rei a "tendência geral de todas as nações da Europa para a forma de governo representativo" como o melhor recurso para evitar a vertigem revolucionária, mormente na sua forma democrática. ${ }^{29}$ Defendia, portanto, que fosse adotada uma Carta de Constituição, cuja base de representação legislativa se assentasse sobre duas Câmaras, baixa e alta - sendo esta última, composta de nobres e aristocratas com mandatos hereditários - permanecendo, outrossim, d. João VI no Brasil.

Ao contatar distintos representantes da sociedade na Bahia, o conde de Palmela apostava na conciliação como meio de apaziguar os ânimos, afastando, assim, o risco da antiga sede dos vice-reis e reduto privilegiado dos comerciantes lusitanos, de se solidarizar com a Revolução Liberal instalada no Reino europeu. Na prática, porém, nada disso aconteceu. Ao contrário, o clima político em Salvador tornou-se mesmo difícil quando, de um navio chegado da corte fluminense, foi divulgada a informação de que o governo joanino estava terminantemente decidido a não reconhecer a convocação de Cortes Gerais Constituintes em Portugal. Descontentes, as tropas de linha, cuja prevalência de portugueses europeus em seus contingentes era apreciável, colocaram-se em estado de sobreaviso e as milícias passaram a conduzir consigo as suas armas. Convencido de que a capitania baiana poderia renunciar às diretrizes da Coroa, o ministro apressou sua partida e, no dia 2 de dezembro, embarcou para o Rio de Janeiro.

27 Para a eclosão e repercussão do movimento constitucional vintista em Portugal, consultar ALEXANDRE, Valentim, op. cit.

${ }^{28}$ Sobre a passagem do conde de Palmela pela Bahia em fins de 1820, ver ARAÚJO, Ubiratan Castro de, op. cit. e AMARAL, Braz do, 1957, op. cit. p. 12.

${ }^{29}$ Apud SILVA, Maria Beatriz Nizza da. Repercussões do movimento constitucional português de 1820 na Bahia e no Rio de Janeiro. ANAIS do Arquivo Público do Estado da Bahia, v. 51, p. 179-189, 1994, SalvadorBahia. p. 187. Como um dos resultados de sua passagem pela Bahia, o conde de Palmela teria recebido uma correspondência do marechal Felisberto Caldeira Brant Pontes, sugerindo que a Coroa apressasse suas decisões ante a iminente possibilidade do processo revolucionário se instalar no Reino americano, pois "qualquer favor concedido antes da revolução será recebido com entusiasmo, e todos os bons se deitarão nos braços de Sua Majestade, mas depois da revolução tudo parece necessidade, e sabe Deus que caráter desenvolverá ela em um país de tantos negros e mulatos!" Esse tipo de preocupação sobre a população profundamente marcada pela diversidade racial e suas demandas revolucionárias, mereceria outros comentários do futuro marquês de Barbacena, como se verá, adiante. Carta de Felisberto Caldeira Brant ao conde de Palmela em 21 de dezembro de 1820. Apud JANCSÓ, István; PIMENTA, João Paulo Garrido, op. cit. p. 169. 
Ao desembarcar no Rio de Janeiro, em 23 de dezembro de 1820, o conde de Palmela estava bem informado acerca dos acontecimentos em Portugal, bem como conhecia a predisposição da segunda capitania mais importante na América portuguesa abandonar, a qualquer momento, a orientação do governo absoluto. Reunindo-se imediatamente com o rei, Palmela considerou que a única solução ainda capaz de conservar a "existência e dignidade da Coroa" era d. João VI outorgar uma Carta Constitucional para o Império. ${ }^{30}$ Com o intuito de reforçar a sua posição, concluiu a sua ponderação para com o monarca em termos que marcavam o grave potencial da situação: "O fogo revolucionário vem aproximando-se rapidamente e, se V. M. não conseguir dar-lhe uma direção conveniente, em breve se achará envolvido por todos os lados pelo incêndio". ${ }^{31}$

Àquela época, o próprio d. João detinha algum conhecimento do que se passava na Bahia. Dias antes, ele havia consultado outros conselheiros régios em busca de soluções capazes de evitar que a capitania escapasse ao seu controle. Um dos conselheiros consultados foi o influente ministro Tomás Antônio Vilanova Portugal (1755-1839) que, apoiando-se na experiência recente da administração em Portugal, a qual não conseguira interpor à vitória da Revolução Liberal, manifestou ser de opinião que o posto de governador da Bahia passasse ao comando do conde de Vila Flor, Antônio José de Sousa Manuel de Meneses Severim de Noronha, pois, avaliava que, naquela conjuntura, somente um "governador soldado" - como o indicado - poderia ainda reconquistar a confiança da tropa, assim como extinguir a “combinação dos maçons" que, segundo informações, espalhava-se rapidamente por aquela sociedade. $^{32}$

\footnotetext{
30 Apud SILVA, Maria Beatriz Nizza. Movimento constitucional e separatismo no Brasil (1821-1822). Lisboa: Livros Horizonte, 1988 (Coleção Horizonte Histórico). p. 8. Segundo Cairu, o conde de Palmela chegou ao Rio de Janeiro em 23 de dezembro, depois de ter saído de Lisboa em 6 de outubro. Um dos motivos do seu regresso ao Brasil, era porque "vinha a tomar posse do Lugar para que havia sido despachado por El-Rei de Ministro dos Negócios Estrangeiros". LISBOA, José da Silva, op. cit., p. 33, nota s/n.

${ }^{31}$ Apud SILVA, Maria Beatriz Nizza, 1988, op. cit. p. 9-10. A concepção de revolução desde os acontecimentos da França de 1789 era percebida pelos homens de Estado portugueses numa acepção muito negativa e não raramente associada a incêndios destruidores e provocadores das maiores tragédias humanas. Situação que se tornava ainda mais evidente no vocabulário dos ministros da monarquia de Bragança depois das mudanças políticas ocorridas na América espanhola após 1808. Sobre a implicância em torno do vocábulo revolução nesse contexto ver, PIMENTA, João Paulo Garrido. A política hispano-americana e o Império Português. In: JANCSÓ, Jancsó (Org.). Brasil: Formação do Estado e da Nação. São Paulo: Hucitec; Ed. Unifuí; Fapesp, 2003. p. 123-139.

32 Apud VARNHAGEN, Francisco Adolfo de. Províncias: Bahia. In: VARNHAGEN, Francisco Adolfo de. História da Independência do Brasil: Até ao reconhecimento pela antiga metrópole compreendendo, separadamente, a dos sucessos ocorridos em algumas províncias até essa data. Anotada pelo Barão de Rio Branco e por uma comissão do Instituto Histórico e Geográfico Brasileiro. 4. ed. Revisada e anotada pelo Prof. Helio Vianna. São Paulo: Melhoramentos, 1957. p. 24. Diria o visconde de Cairu que na Bahia: "A Cabala Maçônica se precipitou a fazer (quanto antes) a explosão da Cratera Revolucionária da predominante sociedade correspondente do Grande Oriente". Conforme se verá adiante, foi realmente de alguma importância a relação
} 
Quando tudo parecia acertado para ser essa a resolução da monarquia, o conde dos Arcos interpôs um parecer contrário. E, como se tratava de um funcionário experiente e que, além disso, havia firmado contatos administrativos e pessoais por oito anos na Bahia, o monarca quis rever a decisão. Tomás Antônio, contudo, retrucou assegurando que o opositor "nada diz de razões: diz que não, porque entende que não, e contenta-se com impugnar". Em linguagem cada vez mais penetrante, o antigo ministro alertou ao rei que o deliberado "de ir o Conde de Vila Flor é muito justo e acertado; $e$, se não o fizer, expõe-se a perder a Bahia, e principiar a revolução no Brasil". E, por fim, arrematou: "É conhecida de V. M. a manobra da Bahia; todo o mundo conhece e teme, e pergunta por que não se dá providência. Precisa, pois dar as providências já ponderadas, - e não perder tempo porque eles [os residentes na Bahia] não o perdem". 33

Imediatamente d. João confirmou a designação do conde de Vila Flor para substituir o conde da Palma no governo da província baiana. Porém, a vacilação manifestou-se nas atitudes do nomeado. Inicialmente, Vila Flor solicitou informações sobre qual deveria ser a sua conduta à frente dessa nova administração. E, adiante, quis saber como proceder se chegando à Bahia o sistema constitucional já tivesse sido proclamado, ou mesmo se durante a sua gestão, e apesar dos seus esforços, o processo revolucionário viesse a concretizar-se. No conjunto, esse era um tipo de questionamento incômodo ao poder multissecular da Coroa de Bragança, visto que as principais respostas, fatalmente, demandavam um posicionamento que levasse em consideração o começo do fim do Antigo Regime português na América.

Embora o governo absoluto dos Bragança tivesse sido instado a agir com a urgência e determinação ante a iminência de uma situação política extremamente adversa, o que se verificou foi uma perda avassaladora na capacidade operacional da realeza. A rigor, d. João VI não conseguiria embarcar nem o conde de Vila Flor nem qualquer autoridade para o, outrora disputado, cargo de capitão-general e governador da Bahia. O que significa dizer que o esboroamento do Antigo Regime português no território do Brasil era já um dado e, portanto, podia ser apreendido antes mesmo de um poder alternativo encontrar-se definitivamente instalado. Portanto, com a queda do sistema na parte peninsular, bastou a ameaça de que diferentes estratos sociais estavam cada vez mais predispostos a aglutinar forças para, coletivamente, confrontar outro enclave do Império - a capitania baiana -, para que os governantes postarem em flagrante posição defensiva, de quase imobilidade.

da loja maçônica Grande Oriente do Brasil, sediada no Rio de Janeiro, com a província baiana. LISBOA, José da Silva, op. cit. p. 43 (Grifos do autor).

${ }^{33}$ Apud VARNHAGEN, Francisco Adolfo de, op. cit., loc cit. (Os grifos aparecem na obra citada). 
Depois da monarquia bragantina ter se refugiado por treze anos na colônia justamente para escapar ao ímpeto revolucionário encampado pelos ideais liberais -, informaram-lhe que o seu direito divino havia sido derrogado no Reino de Portugal e, ademais, que a aceitação da autoridade bragantina dependeria do imediato retorno da família real, assim como da plena aceitação da Carta Constitucional de Espanha, enquanto as Cortes Gerais elaborassem a Constituição da nação portuguesa. E isso não era tudo, posto que o melhoramento prático levado a efeito pelo reformismo ilustrado, inclusive com o empenho da Coroa no pós-1808, aprofundou as inter-relações estruturais que, desde a segunda metade dos Setecentos, ampliara o sentido da própria concepção do Império. Já para os habitantes da América portuguesa encontravam-se igualmente amadurecidas as condições para a propagação de novos valores societários, os quais - resguardados as especificidades, especialmente no que se referia aos interesses dos beneficiados com a instituição escravista poderiam ser expressos doravante pela construção de alianças políticas, em moldes semelhantes aos que permitiram a ascensão do movimento vintista. E, como se notou, essa possibilidade efetivamente não podia mais ser desconhecida em fins de 1820 , visto que sobre ela estavam muito conscientes o rei e seus altos funcionários.

Sob qualquer perspectiva, o quadro político nos meses finais de 1820 e começos de 1821 apresentava-se pouco aprazível à Coroa. Em Portugal, as suas opções previam, por um lado, negociações com os governantes liberais e, por outro, fiar-se "na esperança de virem [dali] notícias mais agradáveis". ${ }^{34}$ Ainda que desejasse se precaver das alianças e dos projetos políticos favoráveis à adesão do Reino do Brasil ao sistema constitucional, os procedimentos da monarquia na Bahia, no Pará e até mesmo no Rio de Janeiro - onde a autoridade régia era mais visível - atestam que d. João VI pouco pôde fazer.

Todavia, a corte joanina continuou informada sobre as proposições políticas manifestas na Bahia. Para o ministro Tomás Antônio, o monarca deveria aproveitar o "intervalo de sossego" oferecido por essa capitania para agir, pois notícias recentes davam conta que somente "a falta de dinheiro de um chefe é que impediu o tumulto" a ser promovido contra a administração local. ${ }^{35} \mathrm{Nada}$, porém, foi providenciado, o que contribuiu para que pessoas próximas ao rei apresentassem certo desânimo no tocante às circunstâncias imediatas em território americano. O então ministro da Repartição dos Estrangeiros, Silvestre Pinheiro Ferreira, exemplificava bem a situação, pois ao saber que deixaria o Rio de Janeiro para ir, em missão governamental, aos Estados Unidos da América, considerou como "particularmente

\footnotetext{
${ }^{34}$ Apud VARNHAGEN, Francisco Adolfo de, op. cit. p. 22 (Grifo meu).

${ }^{35}$ Idem, ibidem. p. 27.
} 
agradável" a sua nova atribuição uma vez que "proporciona[r-lhe-ia] os meios de sair decorosamente deste País e desta Corte antes daqui se verificar a explosão que há muito se receia, e que agora, depois de feita a Revolução em Portugal, é impossível se não realize dentro em muito pouco tempo". ${ }^{36}$

É importante observar que, embora ativos, os projetos políticos articulados na Bahia objetivando a instalação de um governo constitucional não reuniram rapidamente todas as condições para implementar um plano de ação que assegurasse a conquista do poder. Dentre os fatores que favoreceram a esse alongamento na fase conspiratória - o qual o ministro Tomás Antônio compreendeu como sendo um "intervalo de sossego" - foi decisiva a abertura do ciclo das festas religiosas celebradas na capital baiana ocorrido entre os dias de dezembro de 1820 e janeiro de $1821 .^{37}$ Nessa época, transcorriam também os recessos na administração e alfândega. Por fim, era comum notar um relaxamento tácito na disciplina, inclusive o controle privado sobre os escravos tornava-se menos rígido em período de festas prolongadas e sempre mais oportuno às atividades de lazer, de descanso.

Nesse sentido, seja para as classes dominantes, seja para as intermediárias, àquela época do ano não parecia a mais propícia a consertar grandes alterações políticoadministrativas. ${ }^{38}$ Assim, não se constitui exagero pensar que idiossincrasias culturais possam ter contribuído para que o Antigo Regime, embora cambaleante, prosseguisse na Bahia por um tempo já difícil de ser aproveitado até mesmo pelos defensores da Coroa portuguesa, como anteriormente mencionado.

De qualquer modo, quando a Revolução Liberal triunfou em Portugal e suas notícias se tornaram fecundas neste lado do Atlântico, o monarca teve dificuldades de levar adiante uma reação planejada e implementada em termos racionais contra os agentes constitucionais que, por isso, tiveram uma margem de tempo razoável para construírem virtuais pontes políticas em localidades essenciais da América portuguesa. Sendo, com efeito, a situação da capitania baiana paradigmática no que respeita à construção e execução de um projeto

\footnotetext{
${ }^{36}$ FERREIRA, Silvestre Pinheiro. Memórias e cartas biográficas (?) sobre a revolução popular, e o seu ministério no Rio de Janeiro desde 26 de fevereiro de 1821 até o regresso de S. M. o Sr. d. João VI com a corte para Lisboa, e os votos dos homens d'Estado que acompanharam a S. M. Carta I. In: Annaes da Bibliotheca Nacional do Rio de Janeiro. 1876-1877, v. 2, fascículo n. 1. Rio de Janeiro: Typ. G. Leuzinger \& Filhos, 1877. p. 253.

${ }^{37}$ Oficialmente católico - mas também adaptado às tradições das comunidades africanas -, o calendário religioso da capitania baiana atingia o auge festivo entre o último e primeiro mês do ano. Em dezembro, comemoravam-se Santa Bárbara (04), Nossa Senhora da Conceição (08), Santa Luzia (13) e o Natal (25). Em janeiro, no AnoNovo $\left(1^{\circ}\right)$, ocorria a procissão marítima em louvor ao Senhor dos Navegantes; seguiam-se depois o Dia de Reis (06), a festa do Senhor do Bonfim (segundo domingo do mês) e o Entrudo. Seguindo o calendário litúrgico, nos anos de 1821 e 1822 a festa do Entrudo acorreu, respectivamente, nos dias 4 a 6 de março e 17 a 19 de fevereiro. Cf. MATTOSO, Kátia M. de Queirós, 1992, op. cit. p. 205.

${ }^{38}$ Cf. ARAÚJO, Ubiratan Castro de, 2001, op. cit. p. 11.
} 
constitucionalista compatível ao modelo do vintismo português, mas que não deve ser tomado como o reflexo imediato deste. Como notara Caio Prado Júnior, as notícias dos sucessos do movimento liberal na Bahia conduziram à polarização das forças políticas em face aos objetivos revolucionários que integraram o processo político iniciado em Portugal aos desdobramentos sucedidos na América portuguesa. ${ }^{39}$

\subsection{A Revolução Constitucionalista na Bahia e suas implicações para a América portuguesa}

Na cidade de Salvador, entre os sobrados da Rua da Praia, reduto comercial dos portugueses europeus, e a cadeia do Aljube, onde se encontravam presos alguns dos rebeldes de 1817, sinuosos apresentaram-se os caminhos por onde se teceram planos contra o despótico governo. Radical de longa data, o cirurgião prático Cipriano José Barata de Almeida organizou "diversos Clubs", bem ao estilo da França de 1789, com o objetivo de tornar vitorioso o projeto revolucionário. ${ }^{40}$ Relatos igualmente coevos distinguem a sua postura radical como uma das maiores responsáveis pelo desenrolar da sublevação para a tomada do governo baiano. Francisco Sierra y Mariscal, por exemplo, recomendava a leitura crítica dos "papéis [...] do Sanscolote [sic] Barata" como meio de melhor atestar o estado subversivo da Bahia no período. ${ }^{41}$ Enquanto o visconde de Cairu destacaria ter sido Cipriano um dos grandes "Corifeus" da Revolução Constitucionalista na província. ${ }^{42} \mathrm{O}$ certo é que, entre meados de dezembro de 1820 e janeiro do ano seguinte, tanto se fez que o governador obteve denúncia formal de que uma grande conspiração estava prestes a ocorrer. Os propósitos dos segmentos sociais descontentes foram, então, antecipados e, através de uma ampla aliança de classes, a Revolução Constitucionalista efetivou-se. Assim, no alvorecer de

\footnotetext{
39 PRADO JÚNIOR, Caio, 1966. p. 181-183. Ao analisar as fortes impressões do constitucionalismo na província de Pernambuco, Denis Bernardes também considerou que a agenda liberal possuiu uma dinâmica própria na América portuguesa. Dessa forma, as informações da convocação das Cortes Gerais e a subsequente divulgação e conhecimento das Bases da Constituição Política da Monarquia Portuguesa constituíram tãosomente "o eixo de referência" para as mobilizações subsequentes que modificaram profundamente a face do Império português em princípios de 1820. BERNARDES, Denis Antônio de Mendonça, 2006, op. cit. Para essa discussão, ver, especialmente, o cap. 4.

${ }^{40}$ SILVA, Ignácio Accioli de Cerqueira. Memórias Históricas e Políticas da Província da Bahia. Anotado por Braz do Amaral. Bahia: Imprensa Oficial do Estado, 1919-1931, v. 3. p. 267.

${ }^{41}$ SIERRA Y MARISCAL, Francisco de, op. cit. p. 59.

${ }^{42}$ LISBOA, José da Silva. História dos principais sucessos políticos do Império do Brasil dedicada ao senhor d. Pedro I. Rio de Janeiro: Tipografia imperial e Nacional, 1927. p. 44. A trajetória política de Cipriano José Barata de Almeida foi bem traçada em estudo biográfico de MOREL, Marco, 2001, op. cit. O autor ressaltou o fato de diversos historiadores apontarem para a existência de "uma agremiação acadêmica, nos moldes dos clubes secretos ou até mesmo maçônicos, chamados "Cavaleiros da Luz" que funcionou em 1792 ou 1797 na cidade de Salvador. Idem, ibidem. p. 49.
} 
10 de fevereiro de 1821, os revolucionários, unindo-se à tropa de artilharia, tomaram ruas e praças da capital, de onde anunciaram a abertura de um tempo extraordinário para a Bahia, a qual se declarava como província politicamente autônoma que, por isso, adotava os princípios de uma "liberal constituição", conforme os critérios proclamados pelas Cortes Gerais da nação portuguesa.

Em seu primeiro pronunciamento às tropas, os revolucionários julgaram os procedimentos preventivos adotados pelo Rio de Janeiro como uma traição à Bahia, enfatizando que os males e motivos que levaram Portugal à Revolução eram bem conhecidos dos habitantes da província. Sem mencionar diretamente o monarca, o manifesto condenou a política dispensada à agricultura, ao comércio e à navegação, cujas atividades consideraram arruinadas. Em seguida, a crítica recaiu sobre os "violentos tributos arbitrados, corrupção dos magistrados, pobreza dos povos, misérias dos soldados e toda a casta de opressão, despotismo e tirania". ${ }^{43}$ Essa gradação dos motivos é ainda importante à medida que ajuda a entender a intricada aliança de classes necessária para pôr termo ao governo absoluto em território baiano. ${ }^{44}$

Percebe-se, então, que a busca de alternativas políticas para a superação da crise do Antigo Regime português na Bahia não se constituiu em um movimento circunscrito às classes dominantes e intermediárias com mais acessos e facilidades ao mundo letrado. Se, por um lado, a Revolução Constitucionalista agregou comerciantes portugueses, senhores de engenho, traficantes de escravos, militares pertencentes aos médios e altos escalões, profissionais liberais e homens da Igreja, por outro, teve que lidar com a participação dos segmentos de baixa extração social. Razão pela qual, no contexto das revoluções liberais, os segmentos "Tropa e Povo" expressavam, com propriedade, a sobrepujança da soberania popular que, a um só tempo, garantia e respaldava, em termos morais, a superação do Antigo Regime. ${ }^{45}$ Todavia, diante das graves contradições da sociedade e economia-escravista, a influência política desses segmentos elevaria, por vezes, a sua capacidade irruptiva em direção ao extravasamento dos marcos referenciais estabelecidos pelo modelo de revolução que as classes dirigentes estavam dispostas a suportar.

\footnotetext{
${ }^{43}$ Cf. Proclamação de 10 de fevereiro de 1821 aos soldados. In: SILVA, Ignácio de Accioli Cerqueira e, op. cit., v. 3. p. 268-269.

${ }^{44}$ A rigor, essa heterogeneidade de interesses não era uma invenção baiana já que estava totalmente de acordo com a conduta do movimento vintista português (Cf. ALEXANDRE, Valentim, op. cit.). E, com efeito, foi a referência para as adesões subsequentes que se verificaram em diversas partes do Brasil em 1821. Para a situação política do Grão-Pará, por exemplo, ver MACHADO, André Roberto de A., op. cit.

${ }^{45}$ Cf. GUERRA, François-Xavier, op. cit.
} 
$\mathrm{Na}$ madrugada do dia 10 de fevereiro, Cipriano Barata e seus companheiros deflagraram a ação revolucionária com a tomada do forte de São Pedro, alcançada após a deposição e prisão do comandante do corpo de artilharia Antonio Luiz Pires Borralho, cujo posto recairia doravante sob o tenente-coronel Manuel Pedro de Freitas Guimarães. Reforçando a atitude revolucionária, os presos da fortaleza - inclusive os ex-integrantes da Revolução de 1817 - conquistaram a liberdade, podendo, assim, engrossar as fileiras dos que anunciavam o fim do despotismo na Bahia. ${ }^{46}$ Aderente à causa dos sublevados, o regimento de artilharia, sob a liderança de Manuel Pedro, ganhou as ruas levando consigo diversas peças do arsenal de guerra para serem dispostas em locais estratégicos da cidade. A maioria do contingente sublevado, no entanto, marchou em direção ao Palácio do governo, onde pretendia expulsar o capitão-general e governador da capitania. Foi somente nesse momento que se esboçou uma tentativa de reação consequente por parte do conde da Palma, já que autorizou ao então marechal Felisberto Caldeira Brant, comandante do $1^{\circ}$ regimento de infantaria e da legião de caçadores, a retomada da fortaleza de São Pedro.

É interessante observar que o embate entre defensores da ordem vigente e da derrocada do Antigo Regime português na Bahia envolveu - para além do conde da Palma tão somente as forças arregimentadas na América portuguesa, incluindo aí os próprios comandantes militares. Dessa maneira, a artilharia sob as ordens do tenente-coronel Manuel Pedro, bem posicionada e guarnecida, respondeu ao assédio de uma coluna de cavalaria enviada pelo marechal Caldeira Brant, vencendo-a. Neste embate, caiu sem vida o major Hermógenes Francisco de Aguillar Pantoja (1770-1821) que lutava em defesa do governo. ${ }^{47}$ Denota-se aí algo paradoxal, visto que Aguillar Pantoja, a exemplo de Cipriano Barata, fora um dos implicados no ensaio sedicioso de 1798, mas que, indubitavelmente, seguiu o tortuoso

\footnotetext{
${ }^{46}$ De todos os que se encontravam encarcerados, somente o soldado Félix Dias declinou o convite para ser libertado. Por outro lado, pouco mais de noventa soldados sentenciados não apenas aceitaram a liberdade, como imediatamente passaram a integrar as forças revolucionárias (SILVA, Ignácio de Accioli Cerqueira e, op. cit., v. 3. p. 268; 270). Por meio dessa situação é possível estimar o quão opressivo fora o Antigo Regime português para os homens livres pobres, pois nem mesmo a prestação de serviços militares parecia assegurar-lhes algum privilégio, senão como explicar que quase uma centena de soldados cumprisse suas penas criminais em uma única fortaleza em Salvador? Quanto à natureza dos crimes cometidos pelos soldados, pode-se considerar que em sua grande maioria devia-se a deserção, explicada, sobretudo, pelo recrutamento forçado e as péssimas condições que aqueles homens enfrentavam no Exército. Sobre a situação dessa coletividade social no Exército português, ver KRAAY, Hendrik, 2002, op. cit.

${ }^{47}$ Para além do major Aguillar Pantoja - o qual descendia de uma sólida família de militares e cujo filho, Gustavo Adolfo de Aguillar Pantoja, diplomara-se em Direito na Universidade de Coimbra por essa época -, consta que as forças da ordem perderam dezesseis soldados naquele embate. CALOGERAS, João Pandiá. $O$ marquês de Barbacena. 2. ed. São Paulo: Companhia Editora Nacional, 1936. p. 22. Ainda sobre o assunto, ver a carta de William Pennel, cônsul inglês na Bahia, de 10 de fevereiro de 1821, citada por BANDEIRA, Luiz Alberto Moniz. O feudo: A Casa da Torre de Garcia d'Ávila: da conquista dos sertões à independência do Brasil. Rio de Janeiro: Civilização Brasileira, 2000. p. 375-376.
} 
caminho legalista naquele momento. ${ }^{48}$ Vencida a força armada da resistência, o marechal Luís Paulino Pinto de Oliveira França (1771-1823), português americano, apresentou-se como mediador entre os oponentes, apaziguando os ânimos e contribuindo para um desfecho favorável ao sistema constitucional à medida que neutralizou o governador conde da Palma. ${ }^{49}$

A Revolução Constitucionalista triunfara na capital baiana. As aclamações aos princípios constitucionais e contra o governo despótico ecoaram em diferentes freguesias de Salvador. Àquela altura dos acontecimentos, “já grande número de paisanos da Cidade Baixa fazia causa comum com os partidários do sistema proclamado". ${ }^{50}$ Digno de registro é que tanto o corpo do comércio, dominado pelos portugueses europeus, quanto as tropas oriundas de Portugal só ingressaram, de fato, no movimento quando a instalação de uma junta governativa já podia ser dada como certa. Esta tardança sugere, no mínimo, maior disposição das lideranças rebeldes e dos militares nascidos no Brasil em arriscarem as suas vidas pela vitória do constitucionalismo na Bahia. ${ }^{51}$

A entrada em cena da classe mercantil da Rua da Praia alcançou, sem nenhuma dúvida, peso relevante. Marcadamente a influência dos portugueses europeus radicados na Bahia fez-se sentir especialmente pela sua disponibilidade em financiar o governo civil e militar que se instituía na província. Toda essa disposição, no entanto, exigiria contrapartidas claras dos governantes em defesa dos interesses políticos e comerciais envolvendo Portugal. De fato, considerando a heterogeneidade de projetos políticos em disputa na Bahia desse período, os praistas revelaram-se bastante empenhados em ajustar os ideais de mudança político-social às estritas decisões emanadas das Cortes de Lisboa. Não foi à toa que no dia subsequente à instalação do governo constitucional, uma proclamação, detalhadamente formulada para granjear a simpatia e obediência da tropa, anunciara:

Ilustres oficiais e valorosos soldados [...] não duvideis: vosso exemplo será imitado e seguido por todas as províncias do Brasil [...] O governo, em nome da Pátria, está ansioso para vos dar uma demonstração de quanto está satisfeito de vós: conhece que para militares portugueses, o primeiro incentivo de heróicos feitos é o amor da glória [...]; mas, conhecendo ao mesmo tempo que é do seu dever o mais sagrado não consentir que daqui

\footnotetext{
48 Devido sua implicação no ensaio sedicioso, o então primeiro tenente Hermógenes Aguillar Pantoja fora sentenciado e cumprira um ano de prisão. KRAAY, Hendrik, 2002, op. cit. p. 47.

${ }^{49}$ Para o detalhamento de como se processou a Revolução Constitucionalista na Bahia, ver SILVA, Ignácio de Accioli Cerqueira e, op. cit., v. 3 e AMARAL, Braz do, 1957, op. cit. Indico também a consulta a ARAÚJO, Ubiratan Castro de, 2001, op. cit.

${ }^{50}$ SILVA, Ignácio de Accioli Cerqueira e, op. cit., v. 3. p. 271. Bairro comercial da capital baiana, a Cidade Baixa ainda hoje subsiste, mas há muito deixou de ser o principal eixo de referência das atividades mercantis na cidade de Salvador, tal qual exercera até meados do Oitocentos.

${ }^{51}$ SILVA, Ignácio de Accioli Cerqueira e, op. cit., v. 3. p. 271-272.
} 
avante a tropa desta Província continue a viver em penúria, com os diminutos soldos que ora tem, satisfaz aquele ardente desejo, participandovos que as mais precisas ordens se vão passar à estação competente, para que desde o dia 10 se paguem os vossos soldos pela tarifa que o governo fixar, a qual, por via da imprensa, se fará pública.

Ilustres oficiais e valorosos soldados! o governo espera de vós e vos recomenda a mais exata disciplina: dela depende a segurança dos vossos concidadãos e o bom êxito da santa causa que no dia 10 perfilhartes. Viva a Religião! Viva el-rei! Vivam as cortes de Portugal e a Constituição que as mesmas fizerem $!^{52}$

Realmente para os que aderiram mais tarde ao processo revolucionário, predominava a aflição em controlar o ímpeto das lideranças políticas mais exaltadas e, especificamente, o da tropa de artilharia sob o comando e a grande influência do então brigadeiro Manuel Pedro de Freitas Guimarães. ${ }^{53}$ Para aplacar a confessada ansiedade, os comerciantes da Praia organizaram logo uma subscrição voluntária que recolheu e dividiu igualmente entre oficiais de baixa patente militar e demais soldados a significativa quantia de 12:380\$120 (Doze Contos, Trezentos e Oitenta Mil e Cento e Vinte Réis). A Junta Governativa, de fato, autorizou um aumento real nos soldos e nas etapas que recebiam as tropas (16/02/1822). E, alguns dias depois (21/02/1822), uma comissão foi encarregada a contrair um empréstimo junto à corporação comercial. ${ }^{54}$ Dali por diante estava instalada uma acérrima disputa sobre quais deveriam ser os rumos da Revolução: contentar-se tão somente com a proposta de "regeneração" aludida pela fração dominante do liberalismo português ou pautar-se também pela preservação de sua autonomia política a ser negociada no âmbito das Cortes Gerais e Constitucionais.

Enquanto isso, os segmentos sociais vinculados à "Tropa" e ao "Povo" plasmavam a coletividade que exercendo a soberania popular tornava-se indispensável à legitimação da Revolução Constitucionalista. Se, por um lado, as lideranças liberais e autoridades decaídas do Antigo Regime, doravante decididas a sustentar o novo sistema, podiam ser "convocadas

\footnotetext{
${ }^{52}$ Idem, Ibidem. p. 278-279.

${ }^{53}$ Sublinhe-se que o tenente-coronel Freitas Guimarães fora o único oficial cujos integrantes do movimento constitucionalista na Bahia promoveram, por aclamação, a um novo posto militar, no seu caso, o de brigadeiro. Rompia-se, assim, a tradição, visto ser a promoção militar, em última instância, uma prerrogativa exclusiva do monarca, o que atesta - tal qual a libertação dos presos políticos e criminais - o pleno exercício da soberania popular nos primeiros gestos da Revolução Constitucionalista em território baiano. Cf. Ibidem e AMARAL, Braz do, op. cit.

${ }^{54}$ Ibidem. p. 280, nota 14. A presteza da classe mercantil frente à atuação da tropa para os sucessos da Revolução Constitucionalista visando colaborar francamente para a consolidação do novo governo repercutiu na imprensa baiana. Nesse sentido, o Semanário Cívico assinalaria: "Uma subscrição de 12:000\$000 que ofertaram os negociantes desta praça aos generosos soldados que cooperaram para a nossa regeneração no memorável dia 10 foi obra de dois dias. Todos os negociantes vão com a porfia oferecer ao novo governo os seus navios e todos os seus bens”. Semanário Cívico, n. 2, de 08 de março de 1821. Apud SILVA, Maria Beatriz Nizza da, 2008. p. 31.
} 
por avisos pessoais" para se dirigirem à Câmara Municipal onde seriam indicados os membros da Junta Governativa da província; por outro, o "incessante toque do sino da Cidade" conclamava aos demais segmentos sociais livres para também participarem daquele ato magnânimo. ${ }^{55}$

Dessa maneira, a fase revolucionária, que para se afirmar enquanto força irresistível ganhara as ruas e praças públicas, entrou em outro estágio de realização à medida que se recolheu aos espaços institucionais para tornar-se governo. A hierarquia social também se faria imediatamente sentir com renovada evidência, pois, enquanto muitas lideranças e autoridades teriam acesso facilitado ao interior da instituição camarária, a grande maioria dos que realmente conformava a soberania popular, simbolizada pela "Tropa" e pelo "Povo", ficaria do lado de fora, na praça pública, e somente dali deveriam exercer alguma influência no processo.

Em síntese, nesse novo estágio de realização da Revolução Constitucionalista, a intenção das autoridades era que os debates sobre os rumos e a estruturação da Junta Governativa ocorressem no interior da Câmara Municipal de onde sairiam os nomes dos novos governantes da província. Seguindo os critérios já adotados pelo vintismo português, o governo contaria com representantes do clero, da milícia, do comércio, da agricultura e da cidade que, depois de indicados pelo plenário camarário, seriam imediatamente confirmados pelas saudações do povo e da tropa reunidos em praça pública. Todavia, essa forma de escolha das autoridades, somente "com os conhecidos sinais de levantarem as mãos para o ar, e com vozes", não satisfez uma parcela significativa dos que se encontravam do lado de fora do prédio da Câmara. ${ }^{56}$

Em consequência, parte dos descontentes irrompeu a inédita sessão "gritando em altas vozes no meio de aclamações e de vivas que queria também por membro do governo o tenente-coronel Manuel Pedro de Freitas Guimarães", o qual, na madrugada daquele mesmo dia 10 de fevereiro de 1821, estivera no comando da tropa de artilharia em favor da Revolução. $^{57}$ Não obstante a exigência ter sido acatada, os rumos posteriores dos

\footnotetext{
${ }^{55}$ Idem, ibidem. p. 272.

${ }^{56}$ Ata do Senado da Câmara Municipal de Salvador, em 10 de fevereiro de 1821. In: SILVA, Ignácio de Accioli Cerqueira e, op. cit., v. 3. p. 273. A Junta de Governo Provisório da Bahia contou, inicialmente, com os seguintes representantes: do clero o reverendo deão José Fernandes da Silva Freire; da milícia os tenentes-coronéis Francisco de Paula e Oliveira e Francisco José Pereira; do comércio Francisco Antonio Filgueiras e José Antonio Rodrigues Vianna; da agricultura Paulo José de Melo. Para presidente foi, do mesmo modo, escolhido pela parte da cidade o desembargador da Relação da Bahia, Luiz Manoel de Moura Cabral e, finalmente, como secretários José Caetano de Paiva e José Lino Coutinho. Convém ainda observar que entre os integrantes da Junta havia naturais tanto de Portugal quanto da Bahia. Idem, ibidem. p. 272-273.

${ }^{57}$ Idem, ibidem. p. 273.
} 
acontecimentos políticos pareciam indicar que, pelo desejo das autoridades constituídas, a participação dos segmentos subalternos deveria restringir-se ao âmbito institucional sob a direção das classes dominantes. Entretanto, a conjuntura político-social na capital baiana nos meses e anos posteriores evidencia que houve fortes resistências nesse sentido.

Naquele dia de 10 de fevereiro de 1821, nem todas as principais lideranças liberais encontravam-se reunidas no interior da Câmara para a escolha dos membros da Junta Governativa. Conforme diria o visconde de Cairu: "Neste ato de tumulto e pavor se distinguia, respirando ameaças e vinganças, contra o Governo Real, o acima dito [Cipriano] Barata, ostentando-se como Cabeça de Motim, e fazendo-se notar na Praça burlescamente armado à sertaneja com espada a tiracolo e cinto de pistolas". ${ }^{58}$ Ao que tudo indica, essa liderança parece ter optado por animar a tropa e o povo ficando, então, do lado de fora da Câmara. Sabe-se que desde a noite anterior, quando as ruas da capital "foram tomadas de ebulição", uma "multidão significativa dirigiu-se à Praça do Palácio misturando civis e militares. O cortejo, impregnado de gente da plebe, era encabeçado por três pessoas: o tenente-coronel Manuel de Freitas Guimarães, o desembargador Luis Manoel de Moura Cabral e o cirurgião Cipriano José Barata de Almeida". 59

De fato, a biografia política de Cipriano Barata o apontava como radical de longa tradição. Há indícios de que fora uns dos integrantes do clube secreto, de inspiração maçônica e ramificações francesas, denominado Cavaleiros da Luz que funcionou na cidade de Salvador em fins do Oitocentos. ${ }^{60}$ Sabe-se também que Cipriano Barata interrompera a pregação de um padre barbadinho (português europeu) - que incursionava em missão no distrito de São Francisco do Conde - ao proferir um discurso tão ríspido contra a religião que o arcebispo da Bahia decidiu intervir solicitando a sua expulsão daquelas terras. ${ }^{61}$ Implicado nos ensaios de sedição republicana de 1798, Cipriano Barata apareceu como um dos oito brancos constante do rol dos 32 réus presos e processados pela Coroa portuguesa. ${ }^{62}$ Situação que o levaria, anos

\footnotetext{
${ }^{58}$ LISBOA, José da Silva, op. cit. p. 46-47.

${ }^{59}$ MOREL, Marco, 2001, op. cit. p. 120. Em 1827, o visconde de Cairu achava desnecessário declinar os nomes dos principais envolvidos com os acontecimentos que levaram a Revolução Constitucionalista na Bahia, pois "hoje os que antes eram os preeminentes no frenesi político, parecem de boa fé contritos e reformados, seguindo invariavelmente a Causa do Império do Cruzeiro". Mas, em seguida, dizia ser "impossível não declarar alguns dos Corifeus [...] para execração da posteridade" e aí aponta a influente participação das três lideranças citadas acima. LISBOA, José da Silva, op. cit. p. 44.

${ }^{60}$ MOREL, Marco, 2001, op. cit. p. 49.

${ }^{61}$ Cf. Ruy, Affonso. A primeira revolução social brasileira (1798). 2. ed. São Paulo: Ed. Nacional, 1978 (Brasiliana; v. 217). p. 42-43; JANCSÓ, István. Na Bahia, contra o Império: História do ensaio de sedição de 1798. São Paulo: HUCITEC; Salvador: EDUFBA, 1996. p. 116. Nessa ocasião, Cipriano Barata atuava como lavrador de cana em terras no distrito de São Francisco que arrendara junto ao rico proprietário Joaquim Inácio de Siqueira Bulcão.

${ }^{62}$ MOREL, Marco, 2001, op. cit. p. 55.
} 
mais tarde, a declarar ter suportado uma prisão em "segredo" na qual: “[...] por bem da Pátria eu estive nu em suores, com um grande bispote [pinico] no nariz; com um monte de correntes por travesseiros, e uns chinelos que foram de um Enforcado por fronha; e o meu rosto achou tudo bem macio, e mais uns grilhões aos pés com 36 carretéis de peso; roído de piolhos, percevejos, ratos; picados de lacrais etc" ${ }^{63}$ Por ocasião da Revolução de 1817, quando a repressão tomava as providências para a execução do padre Roma, Cipriano foi conduzido ao Palácio do governo, onde o conde dos Arcos duramente lhe advertira nos termos seguintes: "Sei de toda sua vida em Abrantes e na cidade; por todos os lugares tenho vigiado; mude de vida, senão the hei de mandar cortar a cabeça!"64 Em 1821, o arguto e experimentado Cipriano Barata - com quase seus sessenta anos de idade -, apresentou-se triunfante à cena política com o garbo de quem, finalmente, vencia o Antigo Regime português em sua província natal, denominada de "Pátria". 65

Testemunha do que se passava na cidade de Salvador aos 10 dias de fevereiro de 1821, Sierra y Mariscal descreveu o cenário político encontrado com o apuro de investigador social que vai a campo coletar as evidências de uma pesquisa:

Neste dia eu lá me achava, quem anda envolto nas massas do povo como eu, é que observa o como aquilo se fez; havia três partidos [...]. O Europeu queria seguir o partido de Portugal fosse ele qual fosse, porque [seus afiliados, os comerciantes lusitanos] era quem tinha mais a perder, e queria procurar proteção contra a anarquia que a Revolução deveria produzir. O Democrata era muito numeroso, mas não tinha nem dinheiro, nem cabeça, ele queria os Governos Provinciais independentes. O Aristocrata era fraco e pobre, e ainda não era bem conhecido, ele queria um Governo no Rio de Janeiro independente de Portugal com Constituição e duas Câmaras, e no qual se concentrasse o Brasil [...]. ${ }^{66}$

À semelhança de outros relatos coetâneos, os quais serão aqui cotejados, Sierra y Mariscal, interpretou os eventos ocorridos na capital baiana, pelo prisma da atuação política coletiva, ainda que essa não se constituísse em ação partidária estatutária, de tipo moderno. Entretanto, torna-se evidente que, a despeito das suas graves dissensões ideológicas, as

\footnotetext{
${ }^{63}$ Sentinela da Liberdade na Guarita de Pernambuco Alerta!, n. 63, sábado, 8 de novembro de 1823. Recife, Tipografia de Cavalcante e Carvalho. In: BARATA, Cipriano. Sentinela da Liberdade e outros escritos (18211835). Organização e edição Marco Morel. São Paulo: Edusp, 2008. p. 554.

${ }^{64}$ Apud MOREL, Marco, 2001, op. cit. p. 95.

${ }^{65}$ Embora possuísse alguns escravos, Cipriano Barata nunca amealhou grande fortuna material. Nesse sentido, observou Marco Morel: "Cipriano Barata subsistiu em termos econômicos e sustentou sua família de várias formas: como profissional liberal através da medicina, com aulas particulares, por uma botica (farmácia), como lavrador arrendatário de um grande senhor de engenho, recebendo algum subsídio governamental quando esteve preso, pela venda de jornais que redigia e por auxílio solidário de amigos pessoais e políticos". MOREL, Introdução. In: BARATA, Cipriano, 2008. Sentinela da Liberdade e outros escritos (1821-1835). Organização e edição Marco Morel. São Paulo: Edusp, 2008. p. 16.

${ }^{66}$ SIERRA Y MARISCAL, Francisco de, op. cit. p. 63.
} 
coletividades uniram forças para assegurar a derrocada do Antigo Regime português. Realmente, algumas linhas adiante, o autor das "Ideias gerais sobre a Revolução do Brasil e suas consequências" salientaria que: "Para fazer a Revolução de 10 de Fevereiro se uniram o partido Europeu e [o] Democrata", mas consumada a "Revolução, o partido Europeu teve poder bastante para suplantar o Democrata", simultaneamente, a facção do "partido Aristocrata do Rio de Janeiro" se fortaleceria, não tardando para convidar os descontentes na Bahia para seguir-lhes a direção. ${ }^{67}$

Sem saber, no entanto, que a Revolução Constitucionalista tornara-se vitoriosa em Salvador, a monarquia continuava a procura de uma solução providencialista para os males do governo absoluto, confiante de que as consagradas formas de poder voltassem a funcionar, ou algo inusitado ocorresse em favor da Coroa. No plano objetivo, porém, uma forte alteração política ia se afirmando na América portuguesa, como atesta a situação vivida pelo Pará desde $1^{\circ}$ de janeiro de 1821, quando as principais autoridades vinculadas a d. João VI foram destituídas e os paraenses tornaram-se os primeiros habitantes do Brasil a aderir às Cortes Constituintes de Lisboa. Não obstante a enorme relevância dessa viragem, o seu impacto para os rumos do Império português não pôde ser devidamente mensurado, visto que regiões importantes tardaram a conhecer o que ali se passava. Por outro lado, em 17 de fevereiro, informações precisas sobre a adesão da Bahia ao sistema constitucional adotado por Portugal chegaram à corte do Rio de Janeiro e, logo, esses sucessos foram difundidos aos mais variados portos do Império.

A avaliação de Silvestre Pinheiro Ferreira sobre os últimos acontecimentos divulgados na corte fluminense confirma a importância política da província baiana na arquitetura da nação portuguesa, visto que com a Revolução Constitucionalista: "Decidiu-se enfim a sorte do Brasil: Quebrou-se o nexo que unia suas Províncias a um centro comum: e com a dissolução do Brasil se consumou a dissolução da Monarquia [...]. A Bahia acaba de [se] desligar da obediência de Sua Majestade com o pretexto de aderir ao sistema das Cortes de Lisboa". Deduzia, então, o ministro que com a difusão de um reposicionamento de tal envergadura: "Provavelmente há esta hora tem feito outro tanto Pará, Maranhão e Pernambuco", cumprindo, por certo: "As demais Províncias segui-las de perto". ${ }^{68}$ Razão pela qual, o reposicionamento político da Bahia revelara-se, desde o início, decisivo para a redefinição do Império português.

\footnotetext{
${ }^{67}$ Cf. Idem, Ibidem, loc cit.

${ }^{68}$ FERREIRA, Silvestre Pinheiro, op. cit., Carta IV. p. 260.
} 
Impresso logo depois da vitória do constitucionalismo na Bahia, a gazeta Idade d'Ouro do Brazil, no já citado número de 13 de fevereiro de 1821, sublinhara a singularidade política deste evento como algo predestinado que marcaria a importância da província para o futuro imediato do Brasil.

O título de Idade d'Ouro, imposto à gazeta em sua primeira publicação, era um título figurativo, que augurava de longe o para sempre memorável dia 10 de fevereiro de 1821, dia em que esta briosa cidade repercutiu o há muito suspirado eco da regeneração do caráter português, que soou tão altamente nas margens do Douro e do Tejo. O Brasil inteiro chorou com santa inveja por seus irmãos da Europa, no momento em que os viu sair com glorioso denodo dos ferros do despotismo, mas a sorte guardava a Bahia na sua imperscrutável urna para se a redentora do Brasil, como havia guardado o Porto para redentor de Portugal. ${ }^{69}$

$\mathrm{Na}$ expectativa de que somente a Bahia havia vinculado a sua administração política às Cortes Gerais, d. João VI pretendeu isolar todo o território da América portuguesa frente à influência do governo constitucional. Para tanto, lançou o decreto régio de 18 de fevereiro no qual anunciou o envio do príncipe regente, d. Pedro de Alcântara, a Portugal, munido de autoridade e instruções para lidar com as demandas das Cortes e auxiliar-lhes na consolidação da Constituição. No que dizia respeito ao Brasil, o monarca se propôs adequar as partes da Constituição que fossem adotáveis e convenientes à estabilidade do Reino Unido. ${ }^{70}$ D. João chegou a nomear uma comissão para preparar as averiguações prometidas. Nesse sentido, é sintomático observar que dentre os designados pela Coroa para começar a apontar os melhoramentos úteis ao Brasil encontravam-se os juristas baianos José Egídio Álvares de Almeida (1767-1832) - barão de Santo Amaro -, os conselheiros e desembargadores do Paço Luís José de Carvalho e Melo (1764-1826), depois visconde da Cachoeira, e Antônio Luís Pereira da Cunha e José da Silva Lisboa, inspetor geral dos estabelecimentos literários. ${ }^{71}$ A

\footnotetext{
${ }^{69}$ Idade d'Ouro do Brazil, n. 13, sexta-feira, 13 de fevereiro de 1821. Exemplar do APEB. Setor de Microfilmes.

${ }^{70}$ Decreto Régio de 18 de fevereiro de 1821. In: SILVA, Ignácio Accioli Cerqueira e, op. cit., v. 3. p. 283-284, nota 18. Para o tema, ver também AMARAL, Braz do, 1957, op. cit. p. 34.

${ }^{71}$ Decreto Régio de 23 de fevereiro de 1821. In: MORAES, Alexandre de Mello. História do Brasil-Reino e do Brasil-Império. Belo Horizonte: Itatiaia; São Paulo: Ed. Universidade de São Paulo, 1982, t. 1. p. 59. Convêm igualmente salientar que a comissão contou com quinze componentes, sendo presidida pelo marquês de Alegrete, e tendo ainda como membros alguns dos proeminentes nomes da ilustração portuguesa em terras americanas: a exemplo de José Severiano Maciel da Costa (futuro marquês de Queluz), Mariano José Pereira da Fonseca (futuro marquês de Maricá) e Manuel Jacinto Nogueira da Gama (futuro marquês de Baependi). Idem, Ibidem, loc cit. O futuro marquês de Caravelas habitara no Rio de Janeiro desde, pelo menos, 1810, quando ali fora agraciado com a comenda da Ordem de Cristo. Nessa ocasião, ele também acumulara os prestigiados cargos de conselheiro e desembargador do Paço. Ainda na cidade de Salvador, o futuro barão de Santo Amaro - nobilitado ainda no governo de d. João - "obteve em 1808 o cargo de provedor da Alfândega em duas vilas. Em 1809 foi nomeado conselheiro do recém-criado Conselho da Fazenda, com ordenado 1:800\$000 e os emolumentos que pertenciam ao cargo. Além disso, a propriedade do ofício de meirinho do mar da Alfândega da Bahia foi-lhe
} 
rigor, essas nomeações conferiam importância à formação ilustrada desta cepa de baianos residentes na corte fluminense, pois, ante a decisiva conjuntura, o próprio ministro Tomás Antônio fora de parecer que d. João VI indicasse para essa comissão indivíduos capazes, "para não parecer paixão, mas só desejo de acertar". ${ }^{72}$

Ao adotar a consagrada tática do aperfeiçoamento prático, a administração joanina quis, de fato, minimizar a redução do seu poder enquanto governo absoluto, já que sendo aceitas as propostas da eminente comissão o rei permaneceria na parte americana do território português, realizando ali apenas as reformas limitadas às circunstâncias locais. Entretanto, esses decretos produziram efeito diverso do desejado por d. João VI. A falta de consenso entre os próprios conselheiros régios sobre como a Coroa deveria se portar ante a crescente força dos revolucionários nos dois lados do Atlântico contribuiu para que, entre fins de $1820 \mathrm{e}$ fevereiro de 1821, as decisões governamentais fossem, temporariamente, afrouxadas. No Rio de Janeiro, esse abrandamento na autoridade favoreceu a articulação de novas alianças liberais com a intenção de acelerar a definitiva adesão de todo o Império português ao governo constitucional. Com efeito, no âmbito da corte fluminense, os agentes das operações mercantis com a Europa e as principais províncias do Brasil forneciam informações sobre os avanços da Revolução Liberal. A Imprensa Régia também apresentava sua versão sobre os acontecimentos liberais. E bastante intensa para a época revelavam-se a troca de correspondência entre parentes e representantes dos interesses comerciais, permitindo, assim, o aperfeiçoamento das redes de informações que beneficiava o intercâmbio político, com alguma vantagem para as principais províncias da América portuguesa. ${ }^{73}$

Por tudo isso, as reiterações por parte dos fluminenses sobre a vitória constitucionalista na Bahia fortaleceram o ânimo liberal na corte. Reuniões conspiratórias contra o governo absoluto passaram, então, a contar com o franco patrocínio dos grandes do Rio de Janeiro e não demorou a que homens do Estado português revelassem simpatias para com os que se empenhavam para ver aceitas, de uma vez, as exigências constitucionais pela monarquia, posição sobre a qual até d. Carlota Joaquina já envidava algum apoio. ${ }^{74}$ Outra prova da pujança dos ideais liberais no interior do Império português encontra-se no fato do

dada em 1810". SILVA, Maria Beatriz Nizza da. Ser nobre na Colônia. São Paulo: Editora da Unesp, 2005b. p. 288, p. 301.

72 Apud LIMA, Manuel de Oliveira. O movimento da Independência: 1821-1822. 5. ed. São Paulo: Melhoramentos; Conselho Estadual de Cultura, 1972. p. 47.

${ }^{73}$ Uma boa análise sobre o processo de articulação política visando à adesão do Rio de Janeiro ao vintismo português encontra-se no estudo de OLIVEIRA, Cecília Helena L. de Salles. A astúcia Liberal: Relações de mercado e projetos políticos no Rio de Janeiro (1820-1824). Bragança Paulista: Ed. Edusf; Ícone, 1999. Ver, especialmente, o cap. 3 .

${ }^{74}$ LIMA, Manuel de Oliveira, op. cit. p. 49. 
príncipe d. Pedro ter decidido de vez pelo auxílio ao movimento constitucional depois de ficar inteirado da proclamação dos baianos. ${ }^{75}$

De fato, as novas ideias anunciando o que se passara em Portugal e na Bahia repercutiram junto ao príncipe regente d. Pedro de Alcântara. Jovem ambicioso e admirador dos feitos de Napoleão Bonaparte, o herdeiro presuntivo da Coroa bragantina mostrara-se, em fevereiro de 1821, cada vez mais convencido de que "era vão e perigoso não seguir o espírito do século", de acordo o registro do visconde de Cairu. ${ }^{76}$ Atento ao que se passava no interior das casas reais, mas igualmente interessado no ânimo advindo das ruas, a conduta de d. Pedro, por essa época, procurava romper o isolamento político que d. João VI e a maioria dos seus ministros vinha lhes dispensando. É sabido que dentre as figuras de maior preeminência na corte bragantina, d. Pedro mantinha frequentes contatos justamente com d. Marcos de Noronha e Brito, o $8^{\circ}$ conde dos Arcos. ${ }^{77} \mathrm{O}$ cultivo dessa empatia não era recente, visto que desde a época que o menino d. Pedro habitava em Portugal, o último vice-rei do Brasil já incumbira-se de, periodicamente, enviar-lhes presentes apreciáveis. ${ }^{78}$ Com o refúgio da família real na corte fluminense, as relações de amizade entre os dois consolidaram-se. E ocorrendo a ampla difusão das notícias sobre a Revolução no interior do Império português, d. Pedro e o conde mantiveram a correspondência em dia, tratando inclusive dos assuntos e das decisões tomadas pelos conselheiros régios. Acompanhando os procedimentos do ministro Tomás Antônio de Vila Nova e Portugal e do intendente Paulo Fernandes Viana, escreveu o príncipe regente:

Meu conde e meu amigo, sinto infinito dar-lhe esta parte. Saiba: Tomás Antônio e o intendente maquinam por todos os modos fazerem-lhe a sua desgraça e por consequência a minha. Querem, parece-me, deitá-lo fora do ministério [...] porque dizem que eles e o conde me têm metido na cabeça uma indiferença pelas coisas sucedidas, mas que por ora não os prenderão porque têm medo que eu faça alguma tarramontana e dizem que esperam forças inglesas para então poderem fazer com segurança. Veja a que ponto a intriga pode chegar que eu sou julgado contra mim, mas não importa, o

\footnotetext{
${ }^{75}$ Cf. VARNHAGEN, Francisco Adolfo de, op. cit. p. 43. Sobre a influência da Bahia para o futuro do Império português, Oliveira Lima registrou: "As notícias do pronunciamento da Bahia alcançaram Lisboa a 15 de abril de 1821 e pelo fato de tratar-se da mais importante e rica das capitanias brasileiras do tempo, apenas excedida em população por Minas Gerais, decidiam virtualmente da adesão do Brasil ao regime constitucional, como depressa se verificaria pelo ocorrido no Rio de Janeiro a 26 de fevereiro”. LIMA, Manuel de Oliveira, op. cit. p. 42.

${ }^{76}$ As palavras exatas do visconde de Cairu a respeito do entendimento de d. Pedro nesse período foram: "[...] o herdeiro da coroa sendo de alto entendimento, tinha o bom senso de reconhecer que era vão e perigoso não seguir o espírito do século. [...]". A respeito da atuação do príncipe regente neste período, ver LUSTOSA, Isabel. D. Pedro I: um herói sem nenhum caráter. São Paulo: Companhia das Letras, 2006.

${ }^{77}$ Cf. VARNHAGEN, Francisco Adolfo de, op. cit. Cap. 1.

${ }^{78}$ LUSTOSA, Isabel, op. cit. p. 43-44.
} 
tempo e a nação me despicarão. Deste seu amigo. Pedro. ${ }^{79}$

Neste contexto de dissensões e de intrigas que não poupavam proeminentes homens de Estado não é desarrazoado aceitar como tendo sido considerável a influência do conde dos Arcos sobre o ânimo político de d. Pedro. O certo é que bastaram apenas nove dias após a corte fluminense ter conhecimento das ocorrências na Bahia para que, em 26 de fevereiro, eventos análogos se manifestassem na cidade do Rio de Janeiro obrigando d. João VI a jurar a Constituição de Espanha e, antecipadamente, a que viesse a ser elaborada nas Cortes Gerais, Extraordinárias e Constituintes da Nação Portuguesa instalada, em 9 de janeiro de $1821 .^{80}$ Ao comentar sobre a ação nos bastidores que cercaram esses acontecimentos, possivelmente referindo-se ao último vice-rei do Brasil, Palmela assegurava:

O príncipe real mostrou naquela ocasião maior desembaraço e presença de espírito e mesmo muita fidelidade, porque a tropa quis sem dúvida aclamálo [rei em lugar d. João VI], e ele sempre atalhou esse último desaforo gritando "viva el-rei, nosso senhor, viva meu pai". Há, contudo, muita gente que supõe que ele estava instruído de antemão do que se meditava, e é certo que se deixa rodear e aconselhar por má gente. ${ }^{81}$

No que diz respeito particularmente ao território baiano, a concretização de um projeto para superação da crise do Antigo Regime colocou para muitos contemporâneos a necessidade de compreender, ou ainda redefinir e levar a efeito, uma série de concepções que, a partir de então, ampliaria o espaço da política. Constitucionalismo, soberania, representação e nação seriam alguns desses vocábulos que, pouco a pouco, acabariam por transmudar a própria ideia de emancipação, tornando factível a formação do Estado e da nação brasileiros. ${ }^{82}$

\footnotetext{
${ }^{79}$ Carta de D. Pedro para o conde dos Arcos. Arquivo Conde dos Arcos. Apud MARTINS, Rocha. O último vice-rei do Brasil. Lisboa: Edição do autor, s.d. p. 120. A respeito das relações entre d. Pedro e d. Marcos de Noronha e Brito, diria Alexandre de Moraes: "O Conde dos Arcos e os partidistas das novas ideias constitucionais se insinuaram de tal modo no ânimo do Príncipe, que ele se tornou entusiasta da liberdade, e então era instruído de todos os movimentos indo aos clubes que se faziam em várias partes, e mesmo, disfarçadamente, ao que se formava em São Cristovão”. MORAES, Alexandre de Mello, op. cit., t. 1. p. 137.

${ }^{80}$ Para o funcionamento e principais debates nas Cortes Gerais e Constituintes de Lisboa, ver ALEXANDRE, Valentim, op. cit. e BERBEL, Márcia Regina. A nação como artefato: deputados do Brasil nas cortes portuguesas (1821-1822). São Paulo: Hucitec, 1999.

81 Apud LUSTOSA, Isabel, op. cit. 105.

82 Conforme observou João Paulo Garrido Pimenta: “a dicionarização dos vocábulos dá-se em décadas posteriores à sua utilização, pois o tempo do registro não consegue acompanhar o tempo da transformação político-social". Processo esse que, inegavelmente, começaria a se firmar no continente do Brasil de princípios dos anos 1820. PIMENTA, João Paulo Garrido, 2003, op. cit. p. 131. Para o destacado papel da imprensa periodista na difusão de um novo vocabulário político, ver NEVES, Lúcia Maria Bastos Pereira. Corcundas e Constitucionais: A cultura política da Independência (1820-1822). Rio de Janeiro: Ed. Faperj; Revan, 2003. Especialmente o cap. 6.
} 


\subsection{Projetos divergentes na Bahia constitucionalista}

O ambiente político da Bahia no contexto subsequente à Revolução Constitucionalista aponta para a prevalência de graves dissidências e rivalidades envolvendo diferentes projetos de futuro. Em parte, isso se devia ao fato da própria adesão da província ao constitucionalismo ter elevado a percepção entre os seus habitantes de que a dissolução do Antigo Regime possuía significado variado. Para muitos contemporâneos passou a ser cada vez mais importante não apenas identificar a forma como os protagonistas tomavam partido por uma determinada causa política, mas também interessava perceber o quanto desejavam concorrer pela sua realização. ${ }^{83}$ Essa propensão agravou-se à medida que uma parcela significativa da população começou a ter dúvidas sobre a conduta das Cortes lisboeta em relação ao Brasil. Tanto, assim, que a $1^{\circ}$ de maio de 1821, o cônsul Guinebaud informava ao governo francês que as tropas militares da capital baiana voltaram ao estado de mobilização depois de ter sido divulgado um boato sobre as intenções dos deputados de Portugal em aprovarem medidas contrárias à liberdade comercial para o Brasil. ${ }^{84}$

Dessa maneira, verifica-se que nem bem as Cortes de Lisboa iniciara a primeira apreciação sobre o projeto visando a regulamentação das relações mercantis entre Portugal e Brasil na sessão de 25 de abril de 1821 - projeto esse que jamais seria totalmente aprovado -, na Bahia o debate sobre os seus possíveis resultados já era público. E, a bem dizer, as intenções comerciais dos deputados de Portugal apresentaram-se desde cedo eivadas de tensões o que revelava precocemente as insuperáveis dificuldades que as Cortes encontrariam em formular e aprovar uma proposta capaz de efetivamente "pôr em harmonia os interesses e [a] prosperidade do Brasil com os interesses e [a] prosperidade de Portugal". ${ }^{85}$ Os distúrbios político-militares envolvendo as tropas de Portugal e as oriundas da América portuguesa na província baiana no decorrer dos anos 1822 e 1823 corroborariam, em definitivo, para a forte aceitação entre os coevos de que o verdadeiro projeto dos liberais na antiga metrópole era ver o Brasil novamente reduzido à classe de colônia. De tudo isso resultou a afirmação da

\footnotetext{
${ }^{83}$ Sobre a conformação de tendências políticas na Bahia desse período, ver WISIAK, Thomas. A 'Nação partida ao meio': tendências políticas na Bahia na crise do Império luso-brasileiro. Dissertação (Mestrado em História) Universidade de São Paulo, São Paulo, 2001.

${ }^{84}$ Araújo, Ubiratan de Castro, op. cit. p. 25.

${ }^{85}$ Indicação do deputado Bento Pereira do Carmo na Sessão das Cortes de Lisboa de 15 de março de 1822. Apud ROCHA, Antonio Penalves. A economia política na desagregação do Império português. In: CARDOSO, José Luís (Coord.). A economia política e os dilemas do Império luso-brasileiro (1790-1822). Lisboa: Comissão nacional para as comemorações dos descobrimentos portugueses, p. 149-197, 2001, (Coleção Outras Margens). p. 163.
} 
"retórica da recolonização", a qual lançou profundas raízes no universo mental dos filhos da terra já em princípios de $1822 .^{86}$

No contexto das incertezas causadas pela provisoriedade política que envolvia a desagregação do Antigo Regime português, oficiais e soldados nascidos na Bahia - a maior proporção dos quais homens mulatos e pardos - observavam consternados o fato de seus pares europeus terem alcançado as melhores promoções em reconhecimento ao apoio decisivo que a "Tropa" prestou ao sucesso da Revolução Constitucionalista. ${ }^{87}$ Nesse aspecto, os ressentimentos entre os oficiais e soldados oriundos do Brasil em relação aos de Portugal, embora não fossem necessariamente novos, recrudesceram à medida que a Coroa reforçou o aparato de segurança, ampliando a presença de filhos da terra nos contingentes de defesa do Estado durante o governo do conde dos Arcos, como registrado acima. ${ }^{88}$ Convêm ainda reforçar que depois de terem lutado nas guerras napoleônicas e peninsulares e se defrontado com o paradigma do soldado-cidadão, nos moldes vazados pelo exército nacional politizado pelos ideais da Revolução Francesa, os militares do batalhão número 12 nutriam algum sentimento de superioridade em relação ao restante da tropa aquartelada na capital baiana. ${ }^{89} \mathrm{O}$ próprio afastamento do convívio e dos valores do Velho Mundo devia contribuir para que o contingente lusitano sentisse a necessidade de auto-afirmar-se frente aos filhos da terra. Situação que se tornava visível até mesmo pelos novos uniformes que os soldados europeus ostentavam na Bahia.

\footnotetext{
${ }^{86}$ Conforme análise de Antonio Penalves Rocha, “[...] as Cortes não pretendiam recolonizar o Brasil, no sentido preciso de restaurar o exclusivo tal como existira no Brasil antes de 1808, porque o livre comércio seria mantido e todas as restrições a ele impostas derivariam de um 'pacto comercial' celebrado nas cortes". Nesse sentido, os resultados por ele encontrados apontam que a fundamentação do projeto discutido no Congresso sugeria "a criação de circuito comercial restrito, algo semelhante a um 'mercado comum' português construído nas brechas deixadas pelo Tratado de Navegação e Comércio de 1810". Logo em seguida, esse historiador salientou que: "Isso, não quer dizer, no entanto, que tal entidade econômica tenha sido idealizada para promover uma igual distribuição dos benefícios econômicos para ambos os países [sic] participantes, mesmo porque os sujeitos interessados na edificação desse circuito são os mesmos que estavam empenhados na 'regeneração' de Portugal". Já no que concernia especificamente às províncias: “[...] o projeto, sem sombra de dúvida, traria graves prejuízos por causa da queda da receita que derivaria da baixa geral dos tributos de importação e exportação, tanto que os próprios deputados preocuparam-se com a questão em nome do Reino Unido [...]”. ROCHA, Antonio Penalves, 2001, op. cit. p. 176-177. Para a construção do discurso político da recolonização no Brasil ainda em princípios de 1822 e a sua incorporação à historiografia, ver BERBEL, Márcia Regina. A retórica da recolonização. In: JANCSÓ, István (Org.). Independência: história e historiografia. São Paulo: Hucitec; Fapesp, p. 791-808, 2005.

${ }^{87}$ Depois de contribuir diretamente para o êxito do constitucionalismo na Bahia, inclusive de ter, à custa da vida de alguns oficias e soldados, batido as forças legalistas, a tropa da artilharia tinha, de fato, motivos para sentir-se afrontada com o fato de os militares oriundos de Portugal ser largamente favorecidos com os melhores postos da guarnição, como se fossem os grandes responsáveis pelo triunfo do governo constitucional na província. Sobre a distinta participação desses corpos militares nos acontecimentos de 10 de fevereiro, ver SILVA, Ignácio de Accioli Cerqueira e, op. cit., v. 3. p. 270-271 e AMARAL, Braz do, 1957, op. cit. p. 18-21.

${ }^{88}$ Para o assunto, ver KRAAY, Hendrik, 2002, op. cit. Cap. 2.

${ }^{89}$ Araújo, Ubiratan de Castro, op. cit. Sobre o paradigma do soldado-cidadão, consultar KRAAY, Hendrik. Identidade racial na política, Bahia, 1790-1840: o caso dos henriques. In: JANCSÓ, István (Org.). Brasil: formação do Estado e da Nação. São Paulo: Hucitec; Ed. Unifuí; Fapesp, p.521-546, 2003.
} 
Dessa maneira, foi já na expectativa de poder amenizar certas diferenciações em uma corporação que deveria ser reconhecida pelo alinhamento, disciplina e compostura, que o coronel e mais oficiais do regimento dos Henriques chegaram a requisitar, em 10 de setembro de 1816, que a Coroa lhes providenciasse fardamentos similares aos usados pelos regimentos de caçadores vindos de Lisboa. $^{90}$ Como assinalou Hendrik Kraay, em princípios do Oitocentos havia uma tendência à discriminação, fundada em critérios raciais, exercida pelos soldados lusitanos sobre os homens da terra. ${ }^{91}$ Essa era, ao menos, uma das questões caras aos militares e que parece ter se agravado na medida em que as prerrogativas necessárias ao exercício da cidadania passaram a ser referência obrigatória à afirmação do constitucionalismo.

Vistos então sob uma dada perspectiva, as animosidades na caserna em Salvador anunciaram dissensões mais sérias entre os liberalismos no interior do Império português. De fato, em 18 de fevereiro de 1821, a Junta Governativa da Bahia havia solicitado às Cortes de Lisboa o envio de novos contingentes militares para a defesa da província, pois, naquele momento, os seus membros sentiam-se na obrigação de estar protegidos caso o governo do Rio de Janeiro reagisse contra as decisões implementadas. Todavia, em um contexto de céleres mudanças políticas, as informações que chegaram à Bahia no mês de julho dando conta que uma expedição composta de 1.184 homens partira de Portugal e, em breve, desembarcaria em Salvador, provocaram sentimentos díspares entre a população.

Enquanto os defensores do liberalismo lusitano comemoravam o reforço das tropas europeias, a maioria dos filhos da terra reconhecia que a conjuntura inicial havia se alterado a tal medida que a mesma força militar de protetora passara, então, a ser reputada como ameaça premente. ${ }^{92}$ Nesse sentido, o Rio de Janeiro não representava mais perigo, seja porque os seus principais habitantes juraram acatar e defender a Constituição, seja pelo fato de d. João VI ter retornado ao seu antigo centro de poder, deixando no Brasil o príncipe regente d. Pedro de Alcântara o qual, pelas notícias recebidas na província, vinha portando-se de maneira muito constitucional. ${ }^{93}$

\footnotetext{
${ }^{90}$ A esse respeito, caberia a d. João pronunciar sobre o requerimento em que o "coronel e mais oficiais do $3^{\circ}$ regimento de milícias dessa cidade [Salvador], pedem permissão para fazerem fardas azuis para o serviço diário, à imitação das que usam os caçadores vindos de Lisboa". APEB. Seção Colonial e Provincial. Ano: 1816. Maço: 118.

${ }^{91}$ KRAAY, Hendrik, 2003, op. cit.

${ }^{92}$ Composta por dois batalhões de infantaria e uma companhia de artilharia, a expedição militar apresentou-se, em 23 de agosto de 1821, às autoridades da Bahia com a designação de Legião Constitucional Lusitana. SILVA, Ignácio de Accioli Cerqueira e, op. cit., v. 3. p. 281 e 287, nota 21. Ver também AMARAL, Braz do, 1957, op. cit. p. 38.

${ }^{93}$ ARMITAGE, John, op. cit. Cap. 1.
} 
A sociedade escravista na Bahia voltava a se encontrar profundamente dividida e os projetos políticos apontavam para as mais variadas posições. Em vista das divergências, as tensões passaram a ser extravasadas por meios de violentos confrontos. Nos quartéis, soldados europeus e americanos hostilizavam-se mutuamente. Tão melindrosa se apresentaram as dissensões que, em 12 de julho de 1821, o cônsul Guinebaud anotou: "Não fora a firmeza do coronel comandante do batalhão 12, composto por 400 portugueses, soldados da Europa, uma nova revolução teria eclodido, o governo teria sido parcialmente renovado e a República proclamada pelos brasileiros". ${ }^{94}$ Importa salientar que o Semanário Cívico também havia feito referência em seu periódico do dia 12 sobre a insurgência de correntes separatistas na Bahia. Para tanto, indagava:

Haverá ainda malvados que procurem espalhar a cizânia, querendo com pérfidas e refalsadas sugestões renovar entre nós vergonhosas e pueris rivalidades? Que vergonha! Que opróbrio! Quais seriam seus fins? Por ventura separarem-se de Portugal, estabelecerem alguma quimérica República de Platão, cujos resultados seriam uma guerra civil, e por fim sermos presa de alguma potência estrangeira. ${ }^{95}$

Posteriormente, o periódico Diário Constitucional quis informar sobre a inquietação pública desse dia, porquanto atribuísse as suas causas à "intriga" suscitada pelo militares de Portugal, cujos

[...] alaridos e mais agitação pública [...] encheram de horror e assombro o resto dos Cidadãos: as lojas, e Casas de Comércio se fecharam, e ninguém ousava sair à rua a inteirar-se do sucesso, receando a morte; continuou o alvoroço até dez horas da noite, e vendo os Europeus armados [...], dos quais tão somente os Militares corriam aos seus quartéis, e por esta forma reconhecendo o engano, em que haviam caído [...] se recolheram às suas casas. Mal foi, porém, encetar-se o pomo da discórdia para continuar sempre a laborar a intriga, e a se reproduzirem os males! ${ }^{96}$

Não obstante a historiografia apontar que a perspectiva de Independência do Brasil só se configurasse como alternativa política viável em princípios de 1822 , quando os ajustes no interior do projeto liberal de Portugal, de fato, passaram a encontrar fortes resistências, é

\footnotetext{
${ }^{94}$ Apud Araújo, Ubiratan de Castro, op. cit. p. 30-31. A agitação ocorrida em 12 de julho deveu-se ao fato de o coronel Inácio Luís Madeira de Mello, comandante do Regimento da Legião Constitucional Lusitana número 12, ter recebido uma correspondência anônima denunciando-o que "os brasileiros o queriam assassinar" Apud TAVARES, Luís Henrique Dias. Independência do Brasil na Bahia. Salvador: Edufba, 2005. p. 26. A divulgação dessa notícia pôs em marcha todo o mencionado regimento e muitos portugueses europeus armados a ele se incorporaram na expectativa de intimidar os filhos da terra. Cf. SILVA, Ignácio Accioli de Cerqueira, op. cit., v. 3. p. 292.

${ }^{95}$ Semanário Cívico, n. 20, de 12 de julho de 1821. Apud SILVA, Maria Beatriz Nizza da, 2008, op. cit. p. 79.

${ }^{96}$ Diário Constitucional, n. 21, quarta-feira, 13 de março de 1822. Tipografia da Viúva Serva e Carvalho, 18211822. Exemplar da coleção do IEB/Usp.
} 
interessante notar que, na percepção de alguns habitantes da Bahia, o separatismo político passou a ser cogitado desde meados do ano anterior. ${ }^{97}$ Outro fator talvez ainda mais importante é observar que tanto o cônsul francês, quanto o redator do Semanário Cívico alertavam para a possibilidade de uma República ser implantada na província. As confrontações desses registros parecem indicar que não se tratava de evocar a ideia republicana com vistas a "assustar seus leitores", posto que, efetivamente, esse não deveria ser o caso do agente consular da França, Jacques Guinebaud. De qualquer forma, a efêmera aliança de classe que permitira os sucessos da Revolução Constitucionalista se dissipara. Fora, de fato, substituída pela emergência e disputas de projetos políticos conflitantes, cuja afirmação poderia desembocar em "guerra civil" como deixava antever Silva Maia. Por meio de uma analogia aos movimentos cismáticos de caráter religioso, o Semanário revelava aos seus leitores os projetos em disputa.

Ao furor das seitas religiosas sucedeu, nestes últimos tempos, o furor das seitas políticas. Têm aparecido realistas puros, realistas constitucionais, aristocratas, democratas, jacobinos ou anarquistas. A maior parte destes sectários não tem sido nem menos ardentes e furiosos em suas perseguições e vinganças que os sectários religiosos. Enquanto os mais fortes proscrevem os mais fracos, estes excitam por meio da intriga a guerra civil. ${ }^{98}$

Foi, portanto, nesse clima de forte dissensão política, que dias depois - em 2 de setembro - o processo eleitoral para a escolha dos deputados da província para as Cortes de Lisboa foi concluído. ${ }^{99}$ A eleição dos deputados na Bahia recaiu somente sob lideranças que nasceram e habitavam a província, o que sugere dificuldades entre os portugueses europeus radicados na Bahia de se constituírem representantes genuínos de seu grupo político para a ocupação de cargos no Congresso lisboeta. ${ }^{100}$ Mas isso não significa que o partido da Praia não contasse com defensores dos seus direitos entre os deputados pela Bahia que tomariam assento nas Cortes. O que a população baiana logrou, de fato, foi exercer a hegemonia sobre a

\footnotetext{
${ }^{97}$ Embora se configurasse como apenas um dos diversos projetos políticos que disputavam o futuro do Império português, em 4 de outubro de 1821 apareceram afixados pelas ruas do Rio de Janeiro alguns panfletos dando conta de que a Independência seria declarada e o príncipe regente aclamado rei ou imperador do Brasil em 12 de outubro, data do seu aniversário. LUSTOSA, Isabel, op. cit. p. 117-118.

${ }^{98}$ Semanário Cívico, n. 21, de 19 de julho de 1821. Apud SILVA, Maria Beatriz Nizza da, 2008, op. cit. p. 79.

${ }^{99} \mathrm{O}$ processo de eleição para os representantes de Portugal asseguraram a escolha de cem deputados. O Brasil, adotando os mesmos critérios eleitorais, conseguiria eleger outros 94 deputados entre efetivos e suplentes. Entretanto, já em sua primeira sessão, em 26 de janeiro de 1821, as "Cortes Gerais Extraordinárias e Constituintes da Nação Portuguesa" contou com a presença de todos os deputados europeus, enquanto a dinâmica política, inclusive em razão do desencantamento sobre o liberalismo de Lisboa, só iria permitir que 45 deputados do hemisfério do Brasil tomassem posse de suas cadeiras. Para esses dados e suas implicações, ver BERBEL, Márcia Regina, 1999, op. cit.

${ }^{100}$ Maria Beatriz Nizza da Silva apontou que o periodismo na Bahia empreendeu uma verdadeira campanha pedagógica no sentido de instruir os eleitores para escolha de deputados compromissados com os interesses da província. Maria Beatriz Nizza da., op. cit.
} 
origem dos seus representantes, sendo, então, eleitos: o padre e rico proprietário Francisco Agostinho Gomes; o médico José Lino Coutinho; o cirurgião prático e também bacharel em filosofia Cipriano José Barata de Almeida; o proprietário de engenho e bacharel em filosofia e ciências naturais, Domingos Borges de Barros, o qual em 1815 havia sido vereador no Senado da Câmara de Salvador; o bacharel em direito e marechal de campo, Luís Paulino de Oliveira Pinto da França; Alexandre Gomes Ferrão Castelo Branco, agricultor em Nossa Senhora do Monte do Recôncavo e vereador da Câmara de Salvador por duas legislaturas (1805 e 1815); o comendador e grande negociante, Pedro Rodrigues Bandeira - um dos principais acionistas do Banco do Brasil na Bahia - e o vigário da Freguesia da Vitória, Marcos Antonio de Souza. ${ }^{101}$

Na interpretação de Sierra y Mariscal, "o partido Democrata" na Bahia "tinha dois chefes muito inquietos" que eram José Lino Coutinho (1784-1836) e Cipriano Barata. Nesse sentido, concluiu que suas eleições tiveram influências diretas do "partido Europeu [que] se desfez deles fazendo que saíssem deputados". Admite também que atividades parlamentares foram assumidas de bom grado pelos eleitos, visto que "eles aceitaram porque era o melhor que lhes restava a fazer por então". ${ }^{102}$ As condutas políticas destas duas lideranças, juntamente com a do deputado baiano Francisco Agostinho Gomes - todos identificados com a causa republicana - foram atacadas de forma ainda mais contundente pelo redator do Semanário Cívico que, em novembro de 1822, equiparava Cipriano Barata "ao abjeto Marat da revolução francesa"103; sendo Lino Coutinho apontado como "corifeu da revolução pernambucana de 1817”; e, finalmente, o padre Agostinho Gomes aparecia para os leitores deste periódico não apenas como “dissipador de uma fortuna de 600 mil cruzados”, recebidos

101 Ata da eleição dos deputados da província da Bahia às Cortes da nação portuguesa em 02 de setembro de 1821. Revista do Instituto Geográfico e Histórico da Bahia, ano VI, v. 6, n. 19, p. 85-90, 1889. Dos deputados eleitos pela Bahia, pelo menos, quatro haviam estudado na Universidade de Coimbra, sendo eles: Cipriano José Barata de Almeida, Domingos Borges de Barros, José Lino Coutinho e Luís Paulino de Oliveira Pinho da França. WISIAK, Thomas, op. cit. p. 88. Sobre os anos de formação de Cipriano Barata na Europa, ver MOREL, Marco, 2001, op. cit. E, finalmente, para o contexto geral que possibilitara a influência política da geração ilustrada na agenda liberal em curso nas primeiras décadas do Oitocentos, ver ainda NEVES, Lúcia Maria Bastos Pereira. Liberalismo Político no Brasil: Ideias, Representações e Práticas (1820-1823). In: GUIMARÃES, Lúcia M. Pascoal e PRADO, Maria Emília (Orgs.). Liberalismo no Brasil imperial. Origens, conceitos e prática. Rio de Janeiro: Revan/UERJ, 2001. p. 73-101.

102 SIERRA Y MARISCAL, Francisco de, op. cit. p. 63. Com efeito, a se considerar a forma como foi empreendida a intricada aliança política responsável pela derrocada do Antigo Regime português, tanto em Portugal como no território do Brasil, é plausível admitir que algumas lideranças radicais entendessem e aceitassem, ainda que tacitamente, a monarquia constitucional como avanço político a ser assegurado em termos francamente liberais. Cf. WISIAK, Thomas, 2001, op. cit.

${ }^{103}$ Jean-Paul Marat (1743-1793), médico e jornalista, foi um dos mais radicais líderes jacobinos da Revolução Francesa. Em 1793, foi assassinado por uma mulher que apoiava o grupo político contrário (os girondinos). 
de herança paterna de origem reinol, mas como fornicador pelos "costumes escandalosos muito repreensíveis em um eclesiástico". ${ }^{104}$

Embebido em matrizes políticas conservadoras, Sierra y Mariscal defendia que: "O governo que convém a Portugal e ao Brasil para estarem unidos é tal e qual o que existia, e se possível muito mais concentrado, ilustrado e vigoroso". ${ }^{105}$ Por outro lado, para Joaquim José da Silva Maia - redator do Semanário e também procurador da Câmara Municipal de Salvador - o novo pacto político entre a antiga metrópole e a América portuguesa só poderia ser cimentado via alterações nas relações comerciais, "tendo o comércio de Portugal no Brasil decididas vantagens sobre o dos estrangeiros". ${ }^{106}$ Portanto, foi em razão dos projetos defendidos que ambos escritores produziram discursos apontando a exaltação política de algumas lideranças na Bahia. Esse tipo de tratamento dispensado aos exponentes do liberalismo portadores de alguma radicalidade devia, por certo, municiar e prevenir os segmentos sociais que se identificavam com alternativas políticas de caráter conservador, ainda que matizadas em "princípios constitucionais".

Fosse devido ao perfil dos eleitos, fosse em razão das demais contradições que envolviam a construção do pacto constitucional, o certo foi que seguidas às eleições dos deputados na província baiana as desconfianças e as discórdias manifestas entre portugueses europeus e americanos intensificaram-se. Situação que se tornaria ainda mais aguda quando, em fins de outubro, foram difundidas as linhas gerais do projeto de 29 de setembro, transformado em decreto lei de $1^{\circ}$ de outubro de 1821, pelo qual o Soberano Congresso apresentou uma série de medidas cuja execução teria impactos diretamente no Brasil. Dentre estas resoluções, encontravam-se a abolição da regência de d. Pedro, o qual deveria seguir para Europa; a supressão dos tribunais e juízos (a exemplo do Desembargo do Paço, Mesa de Consciência e Ordens, Conselho da Fazenda, Junta de Comércio e Casa de Suplicação existentes no Rio de Janeiro); a criação de juntas provisórias independentes entre si e sujeitas às Cortes e ao governo de Lisboa e, sobretudo, o estabelecimento de governadores das armas de nomeação e subordinação adstritas exclusivamente às Cortes e ao rei. ${ }^{107}$ Contudo, ao ser

\footnotetext{
${ }^{104}$ Semanário Cívico, n. 89, de 13 de novembro de 1821. Apud SILVA, Maria Beatriz Nizza da, 2008, op. cit. p. 137.

105 SIERRA Y MARISCAL, Francisco de, op. cit. p. 52.

${ }^{106}$ Semanário Cívico, n. 39, de 22 de novembro de 1821. Apud SILVA, Maria Beatriz Nizza da, 2008, op. cit. p. 19. A situação econômico-social de Portugal era de grave decadência, sentida, sobretudo, em decorrência da guerra com os franceses e da extinção do monopólio comercial com o Brasil. Reaver, ao menos em parte, alguns dos privilégios econômicos dos portugueses europeus no Brasil era o que esperaram muitos daqueles que abraçaram as ideias liberais promovidas pelo vintismo.

107 Como as Cortes de Lisboa iniciaram seus trabalhos com cem deputados das províncias de Portugal e a representação do Brasil somente atingiria 45 deputados, como mencionado, a própria alternativa do pacto
} 
divulgado nas províncias, essas diretrizes serviram aos fins mais diversos, menos inviabilizar politicamente a regência do príncipe herdeiro dos Bragança no Brasil. ${ }^{108}$

No que concerne à Bahia, as primeiras informações sobre o decreto das Cortes amplificaram as rivalidades entre portugueses europeus e americanos, pois o cumprimento do mesmo implicaria em redução da autonomia não apenas para a província, mas para o Brasil como um todo. Contrafeitos com a ampla hegemonia exercida pelos lusitanos nos dois lados do Atlântico, um grupo de militares e civis ocupou, em 3 de novembro, o prédio da Câmara Municipal de Salvador e passou a exigir que os membros da Junta ali reunidos renunciassem imediatamente às funções governativas e convocassem novas eleições para a administração provincial. ${ }^{109}$ Não obstante o impacto daquela ação, os dissidentes não traziam consigo forças suficientes para concretizar seus objetivos, haja vista que nem mesmo as tropas subordinadas aos oficiais presentes no movimento compareceram ao evento. Em contrapartida, o batalhão de infantaria número 12 - que como já se disse era formado exclusivamente por europeus rapidamente alinhou-se para desbaratar a sublevação. Em pouco tempo, as forças legalistas, em uma ação bem coordenada, não apenas livraram a Junta como capturaram várias lideranças militares do movimento.

Entre os encarcerados encontravam-se os tenentes-coronéis José Egídio Gordilho de Barbuda Veloso (1773-1830) e Felisberto Gomes Caldeira; os majores Elói Pessoa da Silva, José Gabriel da Silva Daltro e José Maria da Silva Torres; o capitão João Antonio Maia e o coronel ajudante de ordens Salvador Pereira Costa. Preocupada com a manutenção desses prisioneiros políticos na Bahia, a Junta Governativa decidiu remetê-los a Lisboa. A justificativa para essa deportação, no entanto, não deixa de ser sintomática de uma nova conformação política que gradativamente parecia promover uma articulação passando pelo envolvimento de outras províncias, uma vez que sobre os dissidentes recaía a acusação de

constitucional a partir do Reino europeu tornar-se-ia ameaçada aos olhos de muitos habitantes americanos. Destaca-se igualmente que algumas províncias americanas encontraram também dificuldades para cumprir todos os ciclos eletivos para a escolha dos seus deputados. A Bahia, por exemplo, concluíra suas eleições sem aguardar o representante da comarca de Jacobina que não chegou à capital em tempo hábil para participar do processo eleitoral. Por fim, não se deve esquecer que quando o decreto de 29 de setembro começou a ser discutido nas Cortes Gerais, os representantes do Brasil nem sequer haviam chegado a Lisboa. Todavia, quando o projeto foi submetido à aprovação, os deputados pernambucanos e fluminenses já participavam das suas funções constituintes, mas nem por isso tiveram direito de reaver a discussão. BERBEL, Márcia Regina, 1999, op. cit. Para os dados do processo eleitoral na Bahia, ver WISIAK, Thomas, 2001, op. cit.

${ }^{108}$ As repercussões políticas no Rio de Janeiro após a divulgação desse decreto foram reexaminadas por SLEMIAN, Andréa, 2006, op. cit. Ver, em especial, o cap. 5.

${ }^{109}$ Essa primeira Junta Provisória esteve no comando do governo da província entre 10 de fevereiro de 1821 e princípios de fevereiro de 1822, quando ocorreram novas eleições ainda sob a hegemonia das Cortes de Lisboa. 
pretenderem separar o Brasil de Portugal. ${ }^{110}$ Mesmo considerando que nem para a deposição da Junta esse movimento conseguira reunir todas as condições necessárias, as reiteradas menções de uma ambição desta envergadura atestam a sua virtualidade, merecendo, por isso, a atenção dos contemporâneos. ${ }^{111}$ Ademais, com as prisões e perseguições efetuadas, o alarma tomou conta da cidade contribuindo para que diversas famílias deixassem suas ocupações e casas, iniciando a primeira de uma série de emigrações que, nos meses subsequentes, deslocaria cada vez mais dissidentes para o Recôncavo baiano.

$\mathrm{Na}$ perspectiva de acalmar os ânimos, e simultaneamente desqualificar os que considerava sediciosos, a Junta Provisória lançou aos habitantes da capital uma proclamação na qual acusava os arquitetos da malfadada destituição de serem "uns perdidos na opinião pública", cuja organização reunira tão somente "alguma gente da plebe, raros oficiais de linha e pouquíssimos paisanos sem representação civil". ${ }^{112}$ Embora distorcesse os fatos quando, deliberadamente, reduzia ao mínimo a presença dos militares e eliminava a participação dos demais funcionários da administração no movimento conspiratório, esse rol de culpados fortalece a hipótese de que na América portuguesa de princípios dos anos 1820 diversos estratos sociais estiveram comprometidos com a política. Admite-se, aqui, que a análise de confrontos como esses são relevantes não apenas por confirmarem a existência de outros projetos políticos no interior da Revolução Constitucionalista, mas também porque trazem à tona alguns termos que emolduraram as relações político-sociais na Bahia ao longo de toda a década de 1820. De fato, ao combaterem os perigos da "anarquia", dos "partidos" e dos "perturbadores do sossego público", ${ }^{113}$ as autoridades constituídas deixaram a descoberto os seus temores frente a uma transformação social que extrapolasse os limites do constitucionalismo português.

\footnotetext{
${ }^{110}$ Continuadas as expedições, foram também presos: o brigadeiro José Tomás Boccaciari - cujo caso será analisado adiante; os capitães Luís Antonio da Silva Horta (cavalaria), José António da Fonseca Machado (legião de caçadores), João Antonio Maria (cavalaria), João de Souza Neto (adido ao Estado-Maior) e Felipe Justiniano Costa Ferreira; os tenentes Francisco Rodrigues Gomes de Souza (artilharia) e João Francisco de Oliveira (sota-patrão da Ribeira); o cadete Inácio de Matos Teles de Menezes (cavalaria); alferes José Francisco d'Essa e Pinho (cavalaria); o secretário do $1^{\circ}$ regimento Francisco José da Silva Castro (2 ${ }^{\mathrm{a}}$ linha); o feitor da alfândega José Soares e João Carneiro da Silva Rego. Cf. SILVA, Ignácio de Accioli Cerqueira e, op. cit., v. 3. p. 289-292 e AMARAL, Braz do. História da Independência na Bahia. Salvador: Progresso, 1957. p. 39-40.

${ }^{111}$ No tocante às primeiras acusações desabridas sobre a Independência nesse período, é preciso salientar que nem por isso havia sido de todo superado o alerta de Sérgio Buarque de Holanda de que: "[...] No Brasil, seja como for, reflexões dessa ordem [separatistas] haveriam de ficar confinadas, ao menos antes de 1808, a uma camada muito rala de seus habitantes e, convém repeti-lo, uma camada sem meios para vir a formar opinião geral e ativa". Proposição ainda válida para 1821, com a diferença que a partir dali o debate se tornava público e o tempo histórico se acelerava ante as contradições do projeto constitucionalista predominante em Portugal. HOLANDA, Sérgio Buarque de. A herança colonial - Sua desagregação. In: HOLANDA, Sérgio Buarque de (Dir.). História geral da civilização brasileira. São Paulo: Difel, 5. ed., tomo II. 1985. p. 11.

${ }^{112}$ SILVA, Ignácio de Accioli Cerqueira e, op. cit., v. 3. p. 291-292, nota 23.

${ }^{113}$ SOUZA FILHO, Argemiro Ribeiro de, op. cit.
} 
Em 7 de dezembro de 1821, foram encaminhados à cadeia da cidade de Salvador o preto João Crioulo, escravo de Antonio José Pereira da Rocha, e o pardo Francisco Antonio de Souza. Embora encarceramentos de cativos e pessoas livres de cor não constituíssem novidade no Brasil escravista, as reclusões de João e Francisco tinham motivações outras que não as de ordem social. Deviam-se às suas práticas políticas. Semelhante ao caso dos envolvidos com o ensaio de sedição de 1798, ambos foram mandados à prisão sob a alegação de portarem e divulgarem "escritos infamatórios e sediciosos" contra as autoridades constituídas, sendo denunciados pela veiculação de três documentos produzidos com "o fim de amotinar, ou ao menos, aterrar os Povos". ${ }^{114}$

O primeiro destes escritos encontrados em mãos de escravo constituía uma "Proclamação assinada por João Primo" e datada de 3 de novembro de $1821 ;{ }^{115}$ o segundo, no qual se dizia constar a mesma caligrafia, trazia a data 14 do referido mês e era intitulado: “Cidadãos beneméritos e verdadeiros Constitucionais respondem às fabulosas Proclamações dos agonizantes Bachás! SENHORES DÉSPOTAS DO NOVO MODELO!'. Subscreveu-lhe: "os Amantes do bem público" e, finalmente, o terceiro tratava-se de uma carta dirigida, em $1^{\circ}$ de dezembro, "aos Observadores e Célebres Constitucionais". ${ }^{116}$ Ao longo da devassa instaurada para se averiguar os fatos, uma das testemunhas asseverou que outros exemplares dos papéis confiscados apareceram, dispersamente, nas ruas da capital baiana. Em termos legais, no entanto, as autoridades passaram a ter conhecimento do conteúdo desses textos a partir do momento em que o comerciante matriculado Manoel José Dias Correia, branco de 29 anos, morador na Cidade Baixa, conduziu-os, juntamente com o escravo João, à presença dos

\footnotetext{
${ }^{114}$ Devassa de escritos inflamatórios e Sediciosos encontrados em mãos de João Crioulo, escravo de Antonio José Pereira Rocha, e Francisco Antonio de Souza. Cópias de devassas - processos datilografados. APEB. Seção Colonial e Provincial. Ano: 1821-1823. Maço: 6023. A difusão de ideias políticas contestatórias por meio de pasquins ou afixadas em locais públicos aparece como uma característica desse período. Em mãos do próprio d. Pedro chegaram alguns escritos que haviam sido espalhados no Rio de Janeiro em princípios de 1821. Os indícios são de que o príncipe regente intercambiava esse material com o conde dos Arcos. Em um dos seus bilhetes remetido a d. Marcos dizia: "Aí lhe remeto a proclamação que lhe disse e farei diligências para ver se apanho mais alguma". Noutro registrou: "Aí lhe remeto esse archote aceso capaz de queimar todo o mundo. Estimarei que me mande mais algum". Apud SILVA, Maria Beatriz Nizza da. D. Pedro e o Processo de Independência do Brasil. In: Estudos em homenagem a Luís António de Oliveira Ramos, Faculdade de Letras da Universidade do Porto, p. 1011-1018, 2004, p. 1014, Biblioteca Digital. <http://ler.letras.up.pt/site/default.aspx?qry=id015id1128id2143\&sum=sim> (Acesso em 12 de fevereiro de 2010).

${ }^{115}$ Por constar a data da tentativa de destituição da Junta Governativa, presume-se ser este um dos escritos que "testemunhas oculares" disseram que João Primo espalhava pela capital baiana pouco antes de o Senado da Câmara de Salvador e do Palácio de Governo serem tomados pelos insurretos. Semanário Cívico, n. 37, sábado, 7 de novembro de 1821. Apud Maria Beatriz Nizza da Silva. A primeira gazeta da Bahia: Idade d'Ouro do Brazil. 2. ed. revista e ampliada. Salvador: Edufba, 2005. p. 323.

${ }^{116}$ Devassa de escritos inflamatórios e Sediciosos encontrados em mãos de João Crioulo, escravo de Antonio José Pereira Rocha, e Francisco Antonio de Souza. Cópias de devassas - processos datilografados. APEB. Seção Colonial e Provincial. Ano: 1821-1823. Maço: 6023 (Grifos meus).
} 
membros da Junta Governativa da Bahia, exigindo-lhe providências sobre as manifestações que conturbavam a capital baiana.

Indisfarçavelmente, as prisões do escravo João Crioulo e do pardo Francisco Antonio tinham relações estreitas com o ambiente político da Bahia no contexto subsequente à Revolução Constitucionalista. De fato, as prisões do escravo João Crioulo e do pardo Francisco Antonio de Souza, bem como a existência dos manifestos políticos apreendidos cuja autoria foi atribuída ao, também, pardo João Primo - corroboram a hipótese de que o pluralismo de opiniões esgarçava a tênue harmonia política e trazia à tona graves rivalidades entre alguns dos protagonistas do movimento de 10 de fevereiro na Bahia. ${ }^{117} \mathrm{Na}$ condição de um liberal radical, esse cadete foi um personagem constante dos principais acontecimentos políticos da província baiana entre o período que vai da instauração da Revolução Constitucionalista (1821), passando pela Levante Militar dos Periquitos (1824) e pelos motins políticos por ocasião da abdicação do imperador d. Pedro (1831), até, pelo menos, os movimentos federalistas na Bahia (1831-1833). ${ }^{118}$

Por ora, importa analisar os acontecimentos políticos que engendraram a crise e a superação do Antigo Regime português enquanto processos complexos que encontraram na

${ }^{117}$ A informação de que o cadete de artilharia João Primo era pardo encontra-se na dissertação de mestrado desenvolvida por PONTES, Kátia Vinhático. Mulatos: Políticos e Rebeldes Baianos. Dissertação (Mestrado em História) - Universidade Federal da Bahia, Salvador, 2000. p. 140. A autora analisa a trajetória de alguns "mulatos" que atuaram nas lutas pela Independência, dentre esses Antonio Pereira Rebouças, Francisco Sabino da Rocha Vieira e João Primo. Os dados sobre esse último indivíduo estão ainda dispersos e muito pouco se sabe sobre seus traços físicos. Em 1831, quando Cipriano Barata denunciou os estratagemas utilizadas por aqueles que desejavam ver incriminados a ele, João Primo e o barão de Itaparica (Antonio Teixeira de Freitas Barbosa), mencionou que assim como uma pessoa usando uma cabeleira solta fora vista durante a noite querendo se passar por ele, outra utilizou um "chapéu de couro" e foi "falar aos Soldados afirmando que era o Senhor João Primo". Portanto, pode concluir-se que da mesma forma como o gosto pela longa cabeleira branca fora um traço característico de Cipriano em princípios dos anos 1830, a indumentária do chapéu de couro - quiçá à moda dos vaqueiros, cujas presenças de homens pardos fora sempre significativa -, fosse também facilmente identificada a João Primo. Manifesto que ao respeitável público apresenta o cidadão Cypriano José Barata de Almeida sobre a sua súbita, tyranna razão na Bahia, e remessa violenta para esta corte, onde se acha prezo. Com várias ideias úteis ao Brazil inteiro, \&c. \&c., Rio de Janeiro, 20 de julho de 1831. Rio de Janeiro: Typographia de Torres, anno de 1831. Exemplar pertencente à Fundação Clemente Mariani - Salvador-BA. p. 13.

${ }^{118}$ Depois dos violentos motins ocorridos na cidade de Salvador, em fins de abril de 1831, quando da divulgação das notícias da abdicação do imperador d. Pedro I e subsequente destituição de importantes autoridades do governo baiano, receberam ordens de prisão, entre outros, João Primo e Cipriano Barata. As principais acusações que pesaram contra eles era a de defenderem o federalismo, oporem-se publicamente ao governo e às instituições monárquicas e de apoiarem "a República com levante de escravos" (MOREL, Marco, 2001, op. cit. p. 261). Sobre essas prisões e a densa conjuntura política da Bahia do período, ver SILVA, Daniel Afonso da. Histórias de Bahia. Histórias de Brasil. Apontamentos para o estudo da crise política do Primeiro Reinado na Bahia (18281831). Dissertação (Mestrado em História) - Universidade de São Paulo, São Paulo, 2007. Especialmente o cap. 1. Uma leitura inovadora da forma como se processaram os arranjos políticos e institucionais envolvendo as instâncias de poderes central e regionais para a adoção do pacto federativo no Brasil imperial encontra-se em DOLHNIKOFF, Miriam. O Pacto Imperial: origens do federalismo no Brasil do século XIX, 2005. No que diz respeito às tentativas de se levar adiante uma Revolução Federalista na Bahia entre os anos de 1831 e 1833 , ver ARAS, Lina Maria Brandão de. A Santa Federação Imperial: Bahia, 1831-1833. Tese (Doutorado em História Social) - Universidade de São Paulo, São Paulo, 1995. 
emersão do Estado e da Nação brasileiros uma das suas alternativas mais impactantes. Quanto às prisões do escravo João Crioulo e do pardo Francisco, bem como as apreensões das proclamações de João Primo, cumpre observar que devido às ações coletivas envolvendo diferentes classes da sociedade escravista, a Junta Provisional viu-se diante de uma incômoda resposta política. Com efeito, a distribuição destes escritos constituía-se elemento central da contrapropaganda política daqueles que se revelavam capazes de mobilizar até representantes do mundo da escravidão contra o governo.

Ainda que a atividade do cativo João Crioulo tenha sido excepcional, realizada em troca das "alvíssaras" prometidas, como ele declarara às autoridades, ${ }^{119}$ a sua participação nas disputas em torno dos projetos constitucionalistas é, de todo modo, relevante, pois, recuperava os componentes da intricada aliança de classes presentes no ensaio de sedição de 1798 , aonde prevaleceram os indícios de que os dois extremos da sociedade escravista - o senhor e o cativo - compartilharam suas expectativas sobre como fundar uma sociedade livre das amarras do Antigo Regime. ${ }^{120}$ Essas inter-relações políticas tornam-se ainda mais apreciáveis na medida em que se admite a possibilidade do cadete de artilharia João Primo ter sido proprietário de escravos e não somente um intermediário entre setores da classe senhorial descontente com a Junta Governativa e o escravo empregado na contrapropaganda política dos que participaram dos acontecimentos de 3 de novembro. ${ }^{121}$

Relativo às atividades comerciais favorecidas por João Primo, encontrou-se referências sobre seu envolvimento com o mercado estrangeiro. Segundo Maria Beatriz, por mais de cinco anos, ele atuara como caixeiro do norte-americano Henry Hill - que, à época, exercia o cargo de cônsul dos Estados Unidos na Bahia. Em 1816, deixara esta função e firmara, então, uma sociedade com George T. Rogers e Willian Bartlett "para o expediente de comissões", constituindo o estabelecimento G. T. Rogers e Companhia. ${ }^{122}$ Nesta companhia,

\footnotetext{
119 Existe também a possibilidade de, com essa declaração, João Crioulo desejar tão somente facilitar o abrandamento de uma sentença que, naquelas circunstâncias, era provável.

${ }^{120}$ Devassa de escritos inflamatórios e Sediciosos encontrados em mãos de João Crioulo, escravo de Antonio José Pereira Rocha, e Francisco Antonio de Souza. Cópias de devassas - processos datilografados. APEB. Seção Colonial e Provincial. Ano: 1821-1823. Maço: 6023. A simples convocação de um escravo para distribuir propaganda contra o governo tende a consubstanciar a hipótese central no estudo de István Jancsó sobre 1798. JANCSÓ, István, 1996, op. cit.

${ }^{121}$ Ainda não foi possível constatar se o cadete João Primo possuía ou não cativos. Os indícios, no entanto, apontam que ele participava ativamente do mundo da escravidão, sendo inclusive indicado em 1824 como o interposto de uma proprietária que desejava recuperar um escravo fugitivo, conforme se depreende de um aviso publicado no periódico Grito da Razão: "Há dois meses, que se acha fugido um pardo alfaiate, de nome Luís, escravo da viúva D. Maria Rosa da Trindade, moradora na Vila de Santo Amaro, cujo escravo é baixo e também usa do Ofício de Cabeleireiro, tem menos dois dentes adiante, e consta-lhe andar nesta Cidade; quem o prender, entregando-o a João Primo, será bem pago". Grito da Razão, n. 3, 20 de fevereiro de 1824, sexta-feira. Tipografia da Viúva Serva e Carvalho. Exemplar do Apeb - Setor de microfilmagem; filme 48.

${ }^{122}$ SILVA, Maria Beatriz Nizza da. Ser nobre na Colônia. São Paulo: Editora da Unesp, 2005b. p. 304.
} 
João Primo foi o responsável tanto pelo recebimento das mercadorias americanas, quanto pela sua negociação. Mercadejava a atacado e a varejo, com a expectativa de assegurar "preços cômodos com prazo ou a troca de frutos do país". O rol dos produtos por ele anunciado desperta a atenção devido à variedade: "papel de diversas qualidades, camas, espelhos, linha branca, aniagens, chumbo em pasta, amarras e cabos de linho, couros do Rio da Prata, copos de vidro, tábuas de pinho, botas, sapatos de homem e de mulher, alcatrão, piche, sabão de pedra, salmão, carne e peixe salgado, vinagre, azeite, manteiga e vinho engarrafado". ${ }^{123}$

A situação socioeconômica de João Primo era de prosperidade neste período, a ponto de ser um dos integrantes do seleto grupo de negociantes de grosso trato que na Bahia obtiveram matrícula na Real Junta do Comércio, sendo a sua efetivada em 12 de junho de 1819. ${ }^{124}$ É importante também ressaltar que as suas atividades comerciais não se reduziam ao mercado urbano da capital, visto ter possuído e posto à venda uma embarcação que navegava pelo rio Contiguiba. ${ }^{125}$ Em um mapa demonstrativo, publicado no periódico Grito da Razão, de 15 de dezembro de 1824, o comerciante João Primo aparece entre os que haviam realizado grandes compras com registros na Junta da Fazenda da Bahia. ${ }^{126}$ Isso demonstra que, depois da Independência, ele continuara dedicando-se ao comércio, conquanto desse preferência às novas mercadorias, a saber: "açúcar de variados tons, farinha de trigo, aletria, bolacha de várias qualidades, chá, chocolate, café moído, cerveja, ovos, marmelada, toucinho, vinho, milho e Sal". ${ }^{127}$

A indicação é que o pardo João Primo poderia possuir um armazém de porte mediano ou mesmo pequeno, com a venda de produtos diversificados. ${ }^{128}$ Este perfil socioeconômico é suficiente para se cogitar que João Primo estivesse inserido no extensíssimo rol dos que possuíam escravos em Salvador. De qualquer forma, detinha, ao menos, a condição social para tornar-se senhor, se assim desejasse. Portanto, a relação desse cadete e comerciante com um escravo que distribuía manifestos assinados contra o governo

\footnotetext{
${ }^{123}$ Apud SILVA, Maria Beatriz Nizza da, 2005b, op. cit. p. 304.

${ }^{124}$ SILVA, Maria Beatriz Nizza da, 2005b, op. cit. p. 304. No contingente dos negociantes matriculados na Real Junta de Comércio entre os anos de 1809 a 1822, a historiadora encontrou para o Rio de Janeiro a soma de 421 matrículas realizadas. Em seguida, a capitania da Bahia apareceu com 134 matriculados, enquanto o Rio Grande de São Pedro representou a terceira capitania com 62, o que não apenas atesta a importância dessas praças comerciais para o Império português, quanto distinguia aqueles negociantes que integraram a Real Junta de Comércio. Idem, ibidem. p. 301.

${ }^{125}$ PONTES, Kátia Vinhático, op. cit. p. 140.

126 Grito da Razão, n. 74, 15 de dezembro de 1824, quarta-feira. Tipografia da Viúva Serva e Carvalho. Exemplar do Apeb - Setor de microfilmagem; filme 48. Esses dados foram originariamente apontados por PONTES, Kátia Vinhático, op. cit. p. 140.

127 Grito da Razão, n. 74, 15 de dezembro de 1824, quarta-feira. Tipografia da Viúva Serva e Carvalho. Exemplar do Apeb - Setor de microfilmagem; filme 48.

${ }^{128}$ PONTES, Kátia Vinhático, op. cit. p. 140.
} 
deve ser mais bem examinada. Afinal de contas, João Primo havia sido um partícipe importante na frustrada tentativa de destituição da Junta, em 3 de novembro de $1821 .^{129}$ Todavia, ao contrário de outras lideranças, escapara à prisão e à desesperação de ser remetido a Portugal, que para alguns já causava verdadeiro pavor.

Importa aqui ressaltar que dentre os insurretos deportados pela Junta Governativa da Bahia, o capitão José Antonio da Fonseca Machado suicidara-se ao chegar a Lisboa e o brigadeiro José Tomás Boccaciari atirou-se ao mar quando a embarcação que o conduzia entrava no rio Tejo. Consta que, por isso, ele também perdera a vida. Os demais companheiros de conspiração e prisão, no entanto, parecem ter suportado relativamente bem às agruras da cadeia lisboeta. Após algum tempo, conseguiram a absolvição das Cortes Gerais, podendo, finalmente, retornar à América. Assunto que será examinado adiante com mais vagar. ${ }^{130}$

Por sua vez, o comportamento radical de João Primo era já demasiadamente conhecido em 1821, tanto que, quando dos acontecimentos de 3 de novembro, um grupo de portugueses europeus que chegara à praça junto com as tropas legalistas, decerto prevendo que o movimento seria subjugado, gritava: "morra João Primo, morra Gordilho fora revolucionários!”. ${ }^{131}$ Esse cadete fora, na avaliação coeva de Antonio Pereira Rebouças, um "entusiasta liberal" que, a despeito de se encontrar "suficientemente estabelecido" na função de "comerciante", decidira se alistar na tropa de $1^{\text {a }}$ linha. Informava, além disso, que João Primo, "por sua índole especial, era capaz de qualquer empresa arriscada", prestando, por isso, serviços relevantes para a expulsão das tropas lusitanas. Inquieto para "permanecer em algum ponto de defesa, ainda se lhe oferecendo o respectivo comando", durante a Guerra de Independência chegavam notícias suas em andanças por "todas as povoações do Recôncavo e, às vezes, dando lugar a alguns desgostos pela animadversão com que se havia com os naturais de Portugal, ainda achando-se eles ao serviço do próprio país”. ${ }^{132}$ Em outra ocasião, seria o

\footnotetext{
${ }^{129}$ Guardando alguma semelhança com o ensaio de sedição de 1798, o agrupamento ao qual pertencia João Primo parece ter mesclado o uso da propaganda com a ação política. Segundo Accioli, dois dias antes do movimento de 3 de novembro, proclamações foram afixadas em diferentes partes da capital baiana, "e principalmente nos aquartelamentos", com o objetivo de convencer a tropa e o povo a expulsarem a Junta Provisional. Mesmo com importantes lideranças na cadeia e outras sendo procuradas pelos agentes repressivos do governo, a prática e a propaganda política, portanto, continuavam. SILVA, Ignácio de Accioli Cerqueira e, op. cit., v. 3. p. 289.

${ }^{130}$ Cf. SILVA, Ignácio de Accioli Cerqueira e, op. cit., v. 3. p. 289-292 e AMARAL, Braz do, 1957, op. cit. p. 57 , nota 9.

${ }^{131}$ SILVA, Ignácio Accioli Cerqueira e, op. cit., v. 3. p. 289 (Grifos do autor).

${ }^{132}$ REBOUÇAS, Antonio Pereira. Recordações Patrióticas. 1821-22. Revista do Instituto Geográfico e Histórico da Bahia, n. 48, 1923. p. 462, nota 10. O desenrolar da Guerra de Independência na Bahia já foi analisado por vários autores e, por isso, só será aqui retomado alguns aspectos particulares do conflito, os quais, direta ou
} 
próprio João Primo quem declararia que a sua motivação em assentar praça deveu-se às razões políticas, posto que desejasse "rogar à tropa do país para não anuir no desembarque dos lobos lusitanos". 133

A trajetória do João Primo parece sintetizar a pressão que os segmentos sociais libertos e livres exerciam na Bahia no sentido de desbloquearem as vias de acesso às ocupações melhor remuneradas e menos fatigantes. ${ }^{134}$ Isso se comprova tanto pelo fato de um pardo, nascido na América portuguesa, ter alcançado o posto de cadete do exército, quanto por vencer todos os obstáculos para assegurar um lugar no seletíssimo corpo comercial da cidade. Ainda que reduzidas, ascensões sócio-profissionais como a de João Primo incomodavam, por certo, a muitos dos representantes da população branca, especialmente no caso de portugueses europeus que tradicionalmente ocuparam os melhores cargos e postos na organização societária instaurada no Brasil, propiciando o aparecimento de graves antagonismos entre as partes envolvidas. Em torno dessas disputas residem algumas das causas profundas que impulsionaram, por um lado, as hostilidades entre os portugueses europeus e, por outro, as revoltas antilusitanas, logo denominadas de mata-marotos.

Tendo como pai um major de artilharia, João Primo havia sido beneficiado pelo decreto régio de 24 de fevereiro de 1820, segundo o qual os filhos de oficiais de patente da tropa de linha podiam ser admitidos no Exército já como segundos cadetes. ${ }^{135}$ Privilégios desse tipo, no entanto, passaram a ser veementemente condenados pela maioria dos defensores do movimento constitucionalista, a ponto de, em 1822, ter sido publicada em Lisboa uma Memória sobre a utilidade da extinção dos cadetes, cuja existência parece repugnante ao sistema constitucional e nociva ao serviço da pátria. Embora ainda não seja possível saber em que momento e sob que circunstâncias João Primo se afastou do Exército, a validação do privilégio acima constitui, de fato, uma contradição, pois entre o oficialato

indiretamente, possam contribuir para se compreender o aprendizado político que a classe senhorial experimentava.

${ }^{133}$ Apud KRAAY, Hendrik. Muralhas da independência e liberdade do Brasil: a participação popular nas lutas políticas (Bahia, 1820-1825). In: MALERBA, Jurandir (Org.). A independência brasileira: novas dimensões. Rio de Janeiro: Ed. FGV, 2006. p. 313.

${ }^{134}$ Para o assunto, ver ARAÚJO, Ubiratan Castro de, 1999, op. cit.

${ }^{135} \mathrm{O}$ governo de d. João VI fixou uma regulamentação ampliando o ingresso ao posto de cadete no interior da carreira militar portuguesa aos filhos de oficiais do exército. Mas, segundo Hendrik Kraay, nem todos os jovens que reivindicavam o posto de cadete do exército almejavam seguir permanentemente as carreiras militares, visto que tornar-se militar era apenas uma opção entre outras franqueadas aos que podiam acessar com certa facilidade um aporte de projeção social no Império Português. Cf. KRAAY, Hendrik, 2002. Cap. 2. 
inferior agravavam-se os ressentimentos sobre uma prática considerada "intolerável", mormente "numa época constitucional". ${ }^{136}$

Depois das prisões do escravo João e a do pardo Francisco, a Junta Provisional determinou que o ouvidor geral do crime, desembargador José Gonçalves Marques, abrisse uma devassa sobre o conteúdo e a procedência daqueles escritos que, segundo afirmava, pretendiam "amotinar os povos". Reproduzidos ao longo dos autos, os papéis distribuídos "dispersamente" pela capital, constituíam, de fato, um ataque direto aos integrantes do governo. Embora não censurasse as Cortes lisboeta, um dos documentos apregoava:

Todo Cidadão é livre quando nasce, e um dos elementos da liberdade é o direito que cada um tem para manifestar a sua opinião contra a tirania [...] Senhores Proclamadores a causa que nos obrigastes no dia 3 do corrente mês [novembro] tentar solenemente reconquistar os nossos perdidos Direitos, vós não podeis deixar de ter em consideração! A ordem atual das coisas, e a falta de exatidão em vossa conduta, nos dão a força natural apoiada com sentimentos Constitucionais! Nós, ouvindo às queixas e ao descontentamento geral dos Habitantes desta Província, obramos como interpretes da vontade dos Cidadãos protegidos pelo Estandarte Municipal e pelo Direito humano! [...] Proclamadores, negareis estas verdades? Dizeinos se os Povos tiveram poder para obrigar a Sua Majestade Fidelíssima [d. João VI]... pela Constituição, por que não terão direito para depor péssimos membros da Junta Provisional, e logo depositar a sua Autoridade em beneméritos Portugueses eleitos pelos Eleitores de Paróquia [...]? Um homem tem direito de matar a quem o quer privar da vida; e os Povos não hão de ter Direito de livrar-se de meia dúzia de perversos, que atacam os Direitos e as relações sociais? Vós assentais que é a raça escolhida para nos governar, e que as outras classes são raças condenadas a vos obedecerem; e com essas lindas ideias quereis que o Povo, que vos aborrece, tome partido para vós, assegurem em vossas trementes e rapinarias mãos a vara de ferro com que o tendes regido! Sim, vós quereis que essa vara abrasada incendeie a Província para mais de uma guerra civil! Sabeis vós, nefandos Proclamadores, até aonde chegará este flagelo da humanidade! ${ }^{137}$

Essa passagem sintetiza o profundo aprendizado político, de caráter radical, ainda que fortemente atado aos Direitos do Homem e do Cidadão, característico da Era das

\footnotetext{
${ }^{136}$ Apud SILVA, Maria Beatriz Nizza da, 2005b, op. cit. p. 307. As informações sobre o referido decreto, bem como acerca da memória citada, encontram-se à página 307.

${ }^{137}$ Cidadãos beneméritos e verdadeiros Constitucionais respondem às fabulosas Proclamações dos agonizantes Bachás...! SENHORES DÉSPOTAS DO NOVO MODELO! Em 14 de novembro de 1821. Devassa de escritos inflamatórios e Sediciosos encontrados em mãos de João Crioulo, escravo de Antonio José Pereira Rocha, e Francisco Antonio de Souza. Cópias de devassas - processos datilografados. APEB. Seção Colonial e Provincial. Ano: 1821-1823. Maço: 6023. (Grifos meus). Convém ainda observar que, em 3 de novembro de 1821, o major Elói Pessoa da Silva estava igualmente a redigir um manifesto contra a Junta Provincial, quando a sua prisão impediu que o mesmo fosse concluído. Isso faz crer que uma das metas dos dissidentes da Revolução Constitucionalista era intensificar a contrapropaganda ao governo. AMARAL, Braz do, 1957, op. cit. p. 40.
} 
Revoluções, que, de forma inequívoca, manifestava-se em território baiano. Ainda que o manifesto acima não mencionasse diretamente a soberania popular, lembrava ao público que "os Povos tiveram poder para obrigar" ao monarca absoluto a jurar a Constituição. Com o mesmo estilo indireto, o documento trazia à tona as delicadas questões envolvendo as noções de raça e de classe social amalgamados à luta política. Situações como estas reforçam o entendimento de que, a exemplo do ensaio sedicioso de 1798, o afloramento do constitucionalismo na Bahia tornou as relações políticas sensivelmente complexas, já que questionaram as significâncias raciais e de distribuição de riquezas. ${ }^{138}$

Além do mais, o escrito alertava contra os perigos de se estabelecer na província "uma guerra civil", deixando entrevisto que a partir dali várias possibilidades estariam postas. O governo poderia aí vislumbrar os indícios de que João Primo e seus parceiros reabriam caminho para a defesa da separação definitiva entre o Brasil e Portugal? Se a indagação for relacionada com as acusações imputadas aos demais dissidentes enviados a Lisboa, é possível que a resposta sobre essa questão seja positiva.

Confrontado com a situação, em 10 de dezembro o ouvidor geral do crime ordenou a abertura de uma devassa, na qual foram ouvidas trinta testemunhas. Vários depoentes, ao depararem-se com os escritos recolhidos pelas autoridades, afiançaram estar diante da "letra e firma de João Primo”. Outros foram além e afirmaram possuir conhecimentos anteriores de parte das ideias ali contidas, pois presenciaram o próprio cadete defendê-las. ${ }^{139}$ Também não se pode deixar de observar que as apreensões dos escritos em mãos do escravo João ocorreram, coincidentemente, há exatos trinta dias do editor do periódico Semanário Cívico e também procurador da Câmara Municipal de Salvador ter informado aos seus leitores que entre os insurretos que participaram da frustrada destituição da Junta Governativa avistara “o

\footnotetext{
138 Esse imbricamento entre questões políticas, raciais e sociais tem, nos últimos anos, merecido atenção crescente por parte da historiografia. No tocante especificamente à Bahia, onde, sem dúvida, os eventos de 1798 atestam suas consistências, pode-se consultar, dentre outros, MORTON, F. W. O., 1974, op. cit. p. 109 e segs.; JANCSÓ, István, 1996, op. cit. e TAVARES, Luís Henrique Dias. Da Sedição de 1798 à Revolta de 1824 na Bahia: Estudos sobre a Sedição de 12 de agosto de 1798, o soldado Luís Gonzaga das Virgens, os escravos no 1798, Francisco Agostinho Gomes, Cipriano Barata e Levante dos Periquitos. Salvador: Edufba; São Paulo: Unesp, 2003. Em abordagem, ainda recente, István Jancsó e João Paulo Garrido Pimenta depararam-se novamente com as interseções políticas, raciais e sociais durante a dissolução do Antigo Regime português na América, salientando que: "A exigência programática de uma nova ordem na qual os "homens pardos e pretos [...] todos serão iguais' não politizou apenas a questão social, mas também a questão racial [...] entre os sediciosos baianos de 1798". Condições que, como se verifica, se mantiveram afloradas na densa conjuntura política de princípios dos anos de 1820 na Bahia. JANCSÓ, István; PIMENTA, João Paulo Garrido. Peças de um mosaico (ou apontamentos para o estudo da emergência da identidade nacional brasileira). In: MOTA, Carlos G. (Org.). Viagem Incompleta. A experiência brasileira (1500-2000). Formação: histórias. São Paulo: Senac, 2000. p. 146-147.

${ }^{139}$ Devassa de escritos inflamatórios e Sediciosos encontrados em mãos de João Crioulo, escravo de Antonio José Pereira Rocha, e Francisco Antonio de Souza. Cópias de devassas - processos datilografados. APEB. Seção Colonial e Provincial. Ano: 1821-1823. Maço: 6023.
} 
cadete de Artilharia João Primo, que espalhava várias proclamações incendiárias por ele assinadas". ${ }^{140}$ Mas, afinal de contas, qual teria sido a mensagem contida no manifesto de 3 de novembro de 1821 ? Considerando os autos da devassa, um desses panfletos dizia:

Proclamação

Amados Irmãos e Verdadeiros Concidadãos! Hoje consolidamos nossos mútuos interesses. A cara Pátria atraiçoada pela venalidade de perversos Bachás... é salva p[or] seus Beneméritos filhos! Desapareça a miserável desconfiança entre os Naturais de ambos os Mundos, que formam uma só Nação! Ligamos os enérgicos exemplos dos Heróis Regenerados da Mãe Pátria! Desterre-se a iniquidade e triunfe a virtude!!! Viva a nossa Religião! Viva as Cortes em Portugal! E a Constituição! Viva El-Rei Constitucional o fr[aterno] D. João 6! Viva o brioso Povo desta Província, Bahia, 3 de Novembro de 1821 , João Primo. ${ }^{141}$

Não obstante o teor contestatório dos escritos subsequentes ter sido mais incisivo sobre os procedimentos da Junta, a nível discursivo a proclamação do dia 3 de novembro primava pela conservação dos laços de união com a "Nação" portuguesa, a "Mãe Pátria". Almejava, portanto, a total substituição da Junta Governativa por outra que fosse capaz de reequilibrar os poderes entre os portugueses "Naturais de ambos os Mundos", reafirmando, assim, a autonomia política da Bahia. Por outro lado, mesmo que os rumos das averiguações em torno da devassa sobre os escritos inflamatórios prosseguissem avançados, o período não era o mais propício às investigações prolongadas, já que a provisoriedade política persistia. Novas informações, gradativamente, davam conta das mudanças nas Cortes de Lisboa, enquanto as províncias do Centro-Sul, tendo à frente o Rio de Janeiro, começavam a emitir sinais de que só uma autêntica autonomia interessava ao Brasil.

Nesse ínterim, divulgou-se na Bahia que as Cortes decidiram pela realização de nova eleição para as juntas provinciais. Essa resolução legitimava, mesmo que extraoficialmente, as reivindicações defendidas pelo cadete João Primo e seus companheiros. Marcadas as eleições para 31 de janeiro de 1822, os responsáveis pela devassa em andamento viram-se, por certo, na necessidade de encontrar uma solução que não se chocasse com a nova conjuntura. Assim, em 8 de janeiro, o ouvidor ditou ordens para que o escravo João Crioulo e o pardo Francisco Antonio de Souza fossem "averbados no rol dos culpados e recomendados prisão". Disposto sob medida, o veredicto atingia os que menos poderiam se defender no

\footnotetext{
${ }^{140}$ Semanário Cívico, n. 37, sábado, 7 de novembro de 1821, apud Maria Beatriz Nizza da Silva, 2005, op. cit. p. 323.

${ }^{141}$ Devassa de escritos inflamatórios e Sediciosos encontrados em mãos de João Crioulo, escravo de Antonio José Pereira Rocha, e Francisco Antonio de Souza. Cópias de devassas - processos datilografados. APEB. Seção Colonial e Provincial. Ano: 1821-1823. Maço: 6023.
} 
interior de uma sociedade arraigada à instituição escravista. Resta, no entanto, indagar: o pardo Francisco e, principalmente, o escravo João seriam leitores? Conheciam as ideias contidas na contrapropaganda ao governo ou teriam sido apenas mensageiros contatados para a propaganda política? Infelizmente estas questões não puderam ser esclarecidas. ${ }^{142}$

Algum tempo após esses acontecimentos, o Diário Constitucional levou a apreciação dos seus leitores um ofício expedido pela primeira Junta Governativa da Bahia com o objetivo de fornecer "prova irrefragável da Prepotência", com que a mesma havia se portado para "com muitos dos Cidadãos desta Província". ${ }^{143}$ No essencial, o documento procuraria justificar os motivos que levaram à prisão do brigadeiro José Tomás Boccaciari e a sua deportação para Portugal nos dias que se seguiram a tentativa frustrada de destituição da Junta em novembro de 1821, o qual, conforme se verificou, foi dado por morto depois de desaparecer nas águas do rio Tejo. Antes, no entanto, o órgão governativo deixara registrado que:

Depois de havermos expedido em 9 do corrente [novembro] a Fragata Príncipe D. Pedro, com 16 Presos, que mais se distinguiram no feito da sedição do dia 03, de que temos dado conta, julgamos ser necessário afastar daqui o Brigadeiro José Tomás Boccaciari, a quem a opinião Pública acusa como um dos principais Chefes dos conjurados, e na casa do qual se formavam os Clubs, e floriavam os planos.

Desde o dia 10 de Fevereiro este Oficial se mostrou sempre descontente da nova Ordem de coisas, e foi geral e constantemente tido por anticonstitucional: nem era possível, que deixasse de sentir a queda de um Governo, no qual sem outros serviços, que os da intriga, de que é hábil mestre, tinham voado de posto em posto, e tinham adquirido imenso cabedal com o manejo dos dinheiros públicos, que lhes eram confiados para as obras de que estava encarregado, com negociações de rebates, de créditos da Fazenda, que ele cobrava do cofre público principalmente, por conivência dos Oficiais dela interessados na mesma prevaricação.

Não obstante o documento ter sido produzido nitidamente como peça acusatória, é importante observar como a primeira Junta Governativa procurava respaldar seu discurso ancorando-se em uma parcela da "opinião Pública". Fornecia, com essa medida, elementos sobre interesses pessoais e materiais que, possivelmente, teriam sido prejudicados com o advento da Revolução Constitucionalista, motivos pelos quais havia quem se dispusesse a resistir à nova Ordem das coisas. Não menos interessante é notar que com a persistência em "atestar" a conduta subversiva do brigadeiro Boccaciari, a Junta deu "publicidade" a

${ }^{142}$ Idem, ibidem. A documentação consultada não permitiu também conhecer quanto tempo estes indivíduos permaneceram presos.

${ }^{143}$ Diário Constitucional, n. 8, sábado, 16 de fevereiro de 1822. Tipografia da Viúva Serva e Carvalho, 18211822. Exemplar da coleção do IEB/Usp. 
provisoriedade política vivenciada pelos contemporâneos da Revolução, cujo futuro era intensamente disputado. Para tanto, apegou-se, inicialmente, a dois fatores, para, enfim expressar sua opinião:

[...] $1^{\circ}$. Que poucos dias antes da sedição, estando aquele Oficial de serviço, às Ordens do Governo, procurou travar conversa com os dois membros desta Junta, Francisco Antonio Filgueiras e José Antonio Rodrigues Vianna, e nela trabalhou mais eficazmente para persuadi-los que o Governo Constitucional não podia durar muitos dias no Brasil, que este infalivelmente ia por se[r] independente de Portugal; e que assim mesmo não podia durar em Portugal, não só porque Portugal nada valia sem o Brasil; mas que não podia menos existir ali o estado atual das coisas contra a vontade das mais Potências da Europa, e das principais pessoas desse Reino: $2^{\circ}$. no dia e hora da sedição não estando de serviço apresentou-se logo neste palácio, esforçan[do]-se quanto pode para intimidar os membros do Governo com ideias de guerra civil, e rios de sangue, que ia a correr senão desistíssemos do Governo, pedindo nos com grandes instâncias que cedêssemos à pretensão dos sediciosos.

Conhecendo a grande habilidade deste homem para a intriga, apesar de ser fraquíssimo, julgamos indispensável afastá-lo; e, por isso, remetemos preso em custódia pelo Brigue [ilegível] que ali seja guardado como S. Majestade julgar mais justo e conveniente até que ali chegue a devassa, que o mostre culpado ou inocente. Mas, ou as testemunhas ou culpem ou não, nós não hesitamos em declarar que este homem, íntimo amigo de Felisberto Caldeira, não deve de modo algum voltar ao Brasil.

Ao lado dessa profunda indefinição política dando conta de que a Revolução continuava em movimento e que, portanto, seu rumo poderia alterado pelos protagonistas em cena, ${ }^{144}$ a primeira Junta Governativa da Bahia não hesitou em declarar, ao arrepio dos direitos constitucionais sob os quais alcançara o poder, a existência de um cidadão vetado de "voltar ao Brasil” em razão das suas posições políticas. Daí porque os redatores do Diário Constitucional terem optado por divulgar esse ofício como recurso para combater o comportamento político da primeira Junta Provisional. Embora relativamente extenso, o descortinar da discussão conduz ao entendimento de que os acontecimentos de 03 de novembro demandaram uma espessa articulação, chegando, inclusive, ao interior do Palácio do governo. Portanto, mesmo sem atingir o fim ultimado, essa sedição demarcou com bastante precisão as divisões internas dentre os defensores do constitucionalismo na província baiana. Nesse sentido, registrara o periódico:

\footnotetext{
${ }^{144}$ Paralelo à consciência de que um processo revolucionário de tipo moderno com potencialidade de ampliar ou ainda reduzir as experiências das convulsões político-sociais estava em curso, apresentavam-se reivindicações daqueles que se propunham envidar esforços para conter, ou mesmo reverter, a fulgurante Revolução. Sobre $o$ conceito moderno de Revolução, ver KOSELLECK, Reinhart, op. cit. Cap. 3.
} 
Em obséquio da verdade nós não podemos deixar de reflexionar sobre as muitas falsidades que se acham no Ofício acima; assim como sobre o espírito de vingança, que de todas as linhas aparece. Nós não sabemos se o Brigadeiro Boccacciari era um dos principais Chefes dos conjurados do dia 3, e se era em sua casa que se faziam os clubs: e o não sabemos porque todos os Cidadãos desta Cidade e grande número dos de fora dela eram Chefes da Ação popular do dia 3. Todos se achavam ofendidos, insultados e oprimidos pela finada Junta e, por isso era em casa de todos, nas ruas, praças, e lugares de reunião, que se tratava daquele movimento. $\mathrm{O}$ Brigadeiro Boccacciari portanto, como homem de bem, [...] era natural que sentisse conosco os nossos azares. ${ }^{145}$

Há nessa releitura sobre a tentativa de destituição da "finada Junta", a compreensão de que, para além dos oficiais militares implicados, sua preparação mobilizou um razoável número de atores sociais, a ponto de vir a ser caracterizada como ação popular, o que se confirma pelas proclamações e prisões já analisadas. Em ampla defesa do brigadeiro Boccaciari continuava o Diário Constitucional a questionar:

Que fosse anti-constitucional ninguém o prova; e a razão que dá o ofício é falsa; [...] este oficial tem 33 anos pouco mais ou menos de serviço militar e militou na Praça de Major com o Marquês da Lorna, segundo nos afirmam; $2^{\circ}$ ele veio para aqui há 12 anos, e já Coronel: logo como voou de posto em posto? [...] Enquanto ter ele enriquecido com os dinheiros públicos, não consta, nem aparecerá documento algum público que testifique o ter ele recebido da Fazenda Provincial somas para obras: quando foi incubido da obra da Alfândega não fazia os pagamentos era feitos por via do Provedor daquela casa: e sendo incumbido de receber $700 \$$ réis da Fazenda Provincial para comprar e remeter para os Destacamentos dos Rios da Salça e [do] Jequitinhonha as ferramentas e [os] instrumentos de Lavoura constantes de uma relação que se lhe deu; não os recebeu. Logo como enriqueceu com o tráfico e manejo dos dinheiros públicos? E de mais também é de notar a facilidade que teve a Junta em desacreditar e infamar os Oficiais da Fazenda, afirmando [ilegível] aquele Brigadeiro utilizava, por conivência dos Oficiais, sem que fundamente esta ultrajadora acusação!!

Mesmo sem conhecer o fatal destino que o oficial Boccaciari encontrara à entrada de Lisboa, os leitores do Diário Constitucional eram informados sobre as arbitrariedades e os rigores da sua prisão.

Vejamos agora os pontos em que se fundou a Junta para despoticamente desterrar um Cidadão benemérito, arrancando-o dos braços e seio de sua Família e mandando-o suportar os rigores de uma viagem perigosa e prolongada em tempo crítico, como é o de inverno na Costa de Portugal: sem que o competente Tribunal o julgasse criminoso, nem contra ele tivesse

${ }^{145}$ Diário Constitucional, n. 8, sábado, 16 de fevereiro de 1822. Tipografia da Viúva Serva e Carvalho, 18211822. Exemplar da coleção do IEB/Usp. 
indicado a menor suspeita: procedimento, não só contra tudo o que temos jurado de presente, mas até contrário às Leis, que mui expressamente proíbem aos Governadores do Ultramar o mandarem presos para o Reino de Portugal, ainda sendo culpados: pois assim o diz o Alvará de 18 de Janeiro de 1624 , coll. $1^{\text {a }}$ a Ord. L. 1. tt. 7. a. 1: Mas a Junta que era superior a tudo, Senhora absoluta; de braço e cutelo postergou esta e muitas outras determinações!!

Daqui por diante, essa redação do Diário Constitucional, que possivelmente saía da lavra do jovem bacharel em Direito, Francisco Gomes Brandão Montezuma (1794-1870), concentrou-se na discussão sobre os usos do vocabulário político vinculados aos direitos constitucionais, evidenciando, assim, o quanto o debate público repercutira na Bahia desse período.

Diz a Junta que o Brigadeiro conversara sobre o estado atual das coisas em Portugal e no Brasil. Nunca nos passou pela cabeça que era crime, e crime tão horroroso o conversar sobre as coisas do tempo, receando do bom êxito delas; se isto não é permitido a um Cidadão como dizem que o Patriotismo nenhuma outra coisa é senão o interesse que toma o Cidadão na coisa Pública? E como se há de tomar este interesse, sem que se converse e escute os prós e contras à Felicidade Pública? [...] Se o brigadeiro tivesse intenções sinistras; se estas fossem aventar ideias de desunião e fundamentar um Partido, que o ofício chama de Felisberto [Caldeira Brant], não teria todo o cuidado em guardar-se do Governo? Este é o homem hábil, mestre na intriga?

E, ao concluir, o Diário Constitucional voltava à carga para comprovar com algum sarcasmo o "despotismo" da "finada Junta" que melhor podia ser comprovado quando finalizava o seu "ofício dizendo que o Brigadeiro, ainda que não seja culpado, contudo, deve ser desterrado deste País por ser amigo de Felisberto. [...] Desterrar-se um homem somente porque é amigo de outrem!!! E isto em o tempo, em que se proclama a segurança pessoal, como um dos Direitos sagrados do Cidadão!!! Os maiores Tiranos do mundo ainda se não lembraram de tal. [...]". ${ }^{146}$

No contexto da eleição para a segunda Junta Governativa da Bahia determinada pelas Cortes de Lisboa, nota-se que os integrantes da primeira Junta se empenharam pela recondução ao órgão. A votação, no entanto, denota que os 261 eleitores de paróquia da província baiana exerceram ao limite o poder delegativo e, assim, renovaram todo o

\footnotetext{
${ }^{146}$ Diário Constitucional, n. 8, sábado, 16 de fevereiro de 1822. Tipografia da Viúva Serva e Carvalho, 18211822. Exemplar da coleção do IEB/Usp.
} 
governo. ${ }^{147}$ Ao comentar sobre o comportamento dos membros do primeiro governo, o Diário Constitucional denunciava:

Chega em $1^{\circ}$ de Dezembro a Carta de Lei do $1^{\circ}$ de Outubro, segundo a qual se deveriam organizar novas Juntas de Governo: hoc opus, hic labor est. Cartas se escreveram para fora; foram encarregadas pessoas de angariarem aqui na Cidade votos de Eleitores de Paróquia, finalmente deu-se o mais ativo movimento à máquina de cabala; a fim de que tornássemos a ficar governados pela finada Junta de boa memória. Vem aqui apelo lembrar, de corrida, a prepotência praticada com o Septuagenário Deão de Pernambuco, mandado daqui sair em 19 horas, somente porque escrevera umas lembrancinhas aos Eleitores de Paróquia sobre este assunto. ${ }^{148}$

A despeito das articulações políticas, pressões e intimidações diretas, os membros do primeiro governo não lograram êxito no sufrágio eleitoral. Dessa maneira, a presidência da Junta Provincial coube, então, ao rico proprietário e senhor de engenho Francisco Vicente Vianna (1754-1828), eleito com "a pluralidade absoluta de 237 votos"; as indicações dos vogais recaíram sobre o comerciante natural de Portugal, Francisco Martins da Costa Guimarães (176 votos); o senhor de engenho e capitão-mor Francisco Elesbão Pires de Carvalho e Albuquerque (139 votos); o desembargador Francisco Carneiro de Campos (secretário, 112 votos); o grande proprietário e tenente-coronel Manoel Inácio da Cunha e Menezes (102 votos); o cônego José Cardoso Pereira de Melo (102 votos) e, finalmente, o bacharel em direito e filosofia, desembargador Antônio da Silva Teles (92 votos). ${ }^{149}$ Mais uma vez, os portugueses europeus parecem ter encontrado dificuldades em assegurar que os representantes da sua comunidade de origem vencessem o pleito eleitoral, visto que somente um lusitano, justamente oriundo das atividades comerciais, obteve o mandato. ${ }^{150}$

Afastado qualquer risco da prevalência dos representantes da Rua da Praia, a composição da classe senhorial hegemonizou o governo civil da segunda mais importante província do Brasil. E, ao contrário da Junta Provincial anterior que somente reconhecia autoridade nas Cortes de Lisboa, seus componentes cuidaram para que um dos primeiros atos administrativos fosse participar ao príncipe regente a sua eleição: “aproveita[ndo] a ocasião

\footnotetext{
${ }^{147}$ Diário Constitucional, n. 1, de 8 de fevereiro de 1822. Tipografia da Viúva Serva e Carvalho, 1821-1822. Exemplar da coleção do IEB/Usp.

${ }^{148}$ Diário Constitucional, n. 21, quarta-feira, 13 de março de 1822. Tipografia da Viúva Serva e Carvalho, 18211822. Exemplar da coleção do IEB/Usp (grifos no original).

${ }^{149}$ Diário Constitucional, n. 1, de 8 de fevereiro de 1822. Tipografia da Viúva Serva e Carvalho, 1821-1822. Exemplar da coleção do IEB/Usp.

150 Sugestivo de que as instituições representativas eram levadas a sério pela classe mercantil da Rua da Praia seja o fato de o europeu Costa Guimarães ter sido o único, dentre os eleitos para a nova Junta Governativa, que efetivamente parece ter concorrido para ocupar ali o posto de presidente, sendo, no entanto, suplantado pelo quase septuagenário Vicente Vianna.
} 
para protestar muito solenemente os sentimentos de puro amor, fidelidade, adesão e entusiasmo para com o Soberano Congresso da Nação e Causa da Constituição; para a Sagrada Pessoa de S. Majestade e Augusta Dinastia da Casa de Bragança e muito positivamente para com V. A. R.”. ${ }^{151}$ Portanto, em um contexto no qual os principais agentes do liberalismo em Portugal exigiam o imediato retorno de d. Pedro à Europa, este reatamento nas comunicações governamentais, para além de assegurar o reconhecimento da autoridade da regência no Brasil, parecia hipotecar apoio e acatamento às últimas decisões do regente que, a despeito das determinações de Lisboa, declarou publicamente, em 9 de janeiro, que permaneceria no Brasil.

$\mathrm{Na}$ outra ponta, com a expectativa de justificarem-se perante as Cortes lisboeta os motivos da reiterada derrota dos portugueses europeus nos pleitos eleitorais ocorridos na Bahia, comerciantes oriundos de Portugal encaminharam um recurso no qual atribuíam os fracassos à influência que o "partido faccioso" e defensor do "sistema Republicano" exercera no processo eletivo. ${ }^{152}$ Estes "mil e cinquenta e dois constitucionais da notável e sempre fiel cidade da Bahia, por seu emissário o cidadão Francisco Mendes da Silva Figueiró" relataram ainda que, depois de finalizadas as eleições e empossada a nova Junta Governativa, a qual manteve no governo das armas o brigadeiro Manuel Pedro de Freitas Guimarães, ocorreram comemorações em que:

o povo molecal (a mando dos facciosos) lançaram ao ar muitos foguetes, dirigindo alguns para o Palácio, acompanhados de impropérios contra aquele [antigo] Governo, com as seguintes palavras - fora o Governo morra o Governo - fora marotos - morram os marotos - fora os carneiros apelidos estes, que haviam imposto à briosa tropa lusitana, por serem brancas as fardetas com que de ordinário fazem o serviço; fizeram acender duas fogueiras na referida praça, para satiricamente queimarem uma pele de carneiro; positivo ataque dirigido à tropa europeia, além de várias alusões que neste ato praticaram. ${ }^{153}$

\footnotetext{
${ }^{151}$ Ofício da Junta Governativa da Bahia a Sua Alteza e Príncipe Real do Reino Unido de Portuga Brazil e Algarves. In: Diário Constitucional, n. 1, de 8 de fevereiro de 1822. Tipografia da Viúva Serva e Carvalho, 1821-1822. Exemplar da coleção do IEB/Usp. Essa intenção de veiculação política da nova Junta Provincial à autoridade de d. Pedro seria frustrada quando o brigadeiro Inácio Luís Madeira de Mello assumiu o comando das armas da Bahia pouco dias depois de ter sido encaminhado para a corte fluminense o referido ofício de governo.

${ }^{152}$ Recurso e adendo ao mesmo que as soberanas Cortes de Portugal dirigem mil e cinquenta e dois constitucionais da notável, e sempre fiel cidade da Bahia, por seu emissário o cidadão Francisco Mendes da Silva Figueiró. Revista do Instituto Geográfico e Histórico da Bahia, v. 58, 1932. p. 293. Esse documento foi concluído para ser remetido às Cortes em 10 de julho de 1822. Já a eleição da Junta Governativa ocorreu nos dias $1^{\circ}$ e 2 de fevereiro de 1822. Para maiores informações acerca desse processo eletivo, ver WISIAK, Thomas, op. cit. p. 115-117.

${ }^{153}$ Recurso e adendo ao mesmo que as soberanas Cortes de Portugal dirigem mil e cinquenta e dois constitucionais da notável, e sempre fiel cidade da Bahia, por seu emissário o cidadão Francisco Mendes da Silva Figueiró, op. cit. p. 302-303.
} 
Verifica-se aqui uma das primeiras denúncias acerca das manifestações antilusitanas que na Bahia ficaram conhecidas como os mata-marotos, cujas incidências foram registradas ao longo de todo o agitado período político enfrentado pela província até, pelo menos, o fim do Primeiro Reinado. ${ }^{154}$ Havia, por certo, no comportamento daqueles manifestantes reunidos na Praça do Palácio uma clara resposta aos afrontamentos que os regimentos de Portugal praticavam para com muitos baianos. Tanto assim, que anos mais tarde, ao recordar as vexações que muitos dos habitantes da Bahia enfrentaram durante os anos finais do Antigo Regime, Cipriano Barata discorreria: "sobre os desaforos dos Marotos comandantes das nossas Tropas, que matavam incessantemente os Soldados (que eram tratados de Cabras e Bodes) com 300, 400, 500, 600, 700, varadas". ${ }^{155}$ Lembrava-se também do "tempo em que os Portugueses, governando o General Madeira, passeavam pelas ruas com uma bandeira que tinha a seguinte inscrição vermelha: 'Isto é sangue de Bode'". 156

Transplantado da fauna, o vocábulo "Cabra" foi utilizado no mundo da escravidão construído na América portuguesa para diferenciar, inicialmente, o indivíduo de pele mais retinta que um mulato e mais clara que um negro. Porém, no período da Independência, essa conotação racial pejorativa foi generalizada - inclusive com uma suposta distinção de gênero já que incorporou também os "bodes" - cujo propósito visava vilipendiar igualmente os "brancos da terra" em contraposição aos "brancos europeus". ${ }^{157}$ Ao repreender a falta de compostura dos peninsulares, a população americana respondia com troças que incluíam até mesmo as relações matrimoniais entre os portugueses e as mulheres do Brasil em versinhos como este:
Marinheiro, pé de chumbo,
Calcanhar de frigideira;
Quem te deu a confiança
De casar com brasileira? ${ }^{158}$

\footnotetext{
${ }^{154}$ Sobre as manifestações políticas contra os portugueses europeus nesse período, ver RIBEIRO, Gladys Sabina. A liberdade em construção: identidade nacional e conflitos antilusitanos no primeiro reinado. Rio de Janeiro: Relume Dumará, 2002. No que respeita a esse tipo de manifestação e sua forte conotação política em algumas vilas interioranas, ver SOUZA FILHO, Argemiro Ribeiro de, op. cit.

${ }^{155}$ Desengano ao Público ou Exposição dos Motivos da Minha Arbitrária Prisão na Província da Bahia, Rio de Janeiro, 20 de julho de 1831. Rio de Janeiro: Typographia de Torres, anno de 1831. Exemplar pertencente à Fundação Clemente Mariani - Salvador-BA. 1831. p. 11.

${ }^{156}$ Desengano ao Público ou Exposição dos Motivos da Minha Arbitrária Prisão na Província da Bahia, op. cit. loc cit.

${ }^{157}$ Sobre a carga política dessas expressões raciais à época da Independência, ver SILVA, Eduardo; REIS, João José. O jogo duro do dois de Julho: o "Partido Negro" na Independência da Bahia. In: SILVA, Eduardo; REIS, João José. Negociação e conflito: a resistência negra no Brasil escravista. São Paulo: Companhia das Letras, p. 79-98, 1989.

158 Apud SOUZA, Ricardo Luís. O antilusitanismo e a afirmação da nacionalidade. Politeia: História e Sociedade/Revista do Departamento de história da Universidade Estadual do Sudoeste da Bahia. Vitória da
} 
A moeda zoológica também foi replicada, tendo o português europeu recebido o apelido de "carneiro", como já visto, ou mesmo de "peru", uma vez que não era raro encontrar um antigo reinol com o dorso superior, o pescoço e as pregas inferiores do rosto avermelhados, divido à exposição ao radiante sol tropical, que ainda hoje particulariza a cidade da Bahia. Outros epítetos foram usados nesta guerra simbólica, a exemplo de "caiados" devido à brancura das peles dos peninsulares. ${ }^{159}$ A procura de alcunhas injuriosas, nesse período, alcançou magnitude tal que, certa feita, Joaquim José da Silva Maia sentiu a necessidade de fornecer aos leitores do seu jornal a definição de uma delas. Neste caso, o vocábulo foi o de "ceroulas":

Ceroulas é o nome que na Bahia têm as tropas que defendem o príncipe, hoje imperador do Brasil, que armadas em guerrilhas, como ele lhes encomendou, têm vindo algumas vezes incomodar as nossas linhas de defesa. Deu-se-lhes este nome porque todo o seu vestuário consiste em umas ceroulas curtas de algodão grosso, tecido do país, e uma camisa curta por cima, também do mesmo algodão, descalços, e com um chapéu de palha na cabeça. Eis aqui o seu uniforme. ${ }^{160}$

Reside, indisfarçavelmente, no cerne desse novo vocabulário, descortinado na Bahia no tempo da Independência, um virulento estranhamento entre os portugueses que, gradativamente, adquiriam consciência de que uma profunda ruptura estava em curso, sendo, possível distinguir o local de pertencimento de diferentes comunidades imaginadas com forças suficientes para engendrar, em definitivo, um patriotismo político incompatível entre os nascidos em Portugal e no Brasil. ${ }^{161}$

Não foi também por acaso, então, que os "mil e cinquenta e dois" signatários do recurso advertiam as Cortes de Lisboa que com a eleição da nova Junta Provincial e o comando das armas nas mãos de Freitas Guimarães uma "nova fase a favor das menções dos facciosos" adquiria concretude, a ponto de ter sido "João Primo, principal revolucionário, [...] elevado a tenente de artilharia de linha, estando, aliás, notado por desertor". ${ }^{162}$ Embora não tenha sido possível encontrar outras referências que corroborem essa promoção militar,

Conquista - Bahia: Edições Uesb, v. 5, n. 1, 2005. p. 141. A expressão marinheiro em Pernambuco tornara-se sinônimo de lusitano e assim persistira ao longo do Oitocentos.

${ }^{159}$ Desengano ao Público ou Exposição dos Motivos da Minha Arbitrária Prisão na Província da Bahia, op. cit. p. 11.

${ }^{160}$ Semanário Cívico, n. 85, 16 de outubro de 1822, apud Maria Beatriz Nizza da Silva, 2008, op. cit. p. 143-144.

${ }^{161}$ Para as experiências de intercambialidade que, em fins do Antigo Regime, passaram a estabelecer laços identitários na América hispânica conformadores da noção de pertencimento às comunidades imaginadas, ver BENEDICT, Anderson, op. cit. p. 93 e passim.

162 Recurso e adendo ao mesmo que as soberanas Cortes de Portugal dirigem mil e cinquenta e dois constitucionais da notável, e sempre fiel cidade da Bahia, por seu emissário o cidadão Francisco Mendes da Silva Figueiró, op. cit. p. 293. 
quando se comemorou "o primeiro aniversário em que o gigantesco esforço e inabalável denodo de seus oficiais e soldados, arrostando os maiores perigos, suplantou nesta província o despotismo", o governador das armas promoveu uma série de militares, nominalmente assinalados, para assumirem novos postos de comando. ${ }^{163}$

No que concerne aos seus antigos companheiros de artilharia, Manuel Pedro dizia ser necessário "fazer justiça" visto que foram fundamentais para a instauração da Revolução Constitucionalista na Bahia em ano anterior. Por isso, o governador das armas estava decidido a corrigir algumas distorções ocorridas na guarnição, pois, como já se registrou, as autoridades constitucionais em Lisboa haviam promovido diversos militares europeus para os postos de comando nas tropas em detrimento aos filhos da terra que, a propósito, constituíam a grande maioria dos artilheiros. Assim, Manuel Pedro aproveitou-se da prerrogativa do cargo, o qual tinha "a honra de ocupar", para assegurar que "todas as praças de oficiais, de que se compunha aquele distinto regimento no referido dia [10 de fevereiro de 1821] tenham a graduação do posto imediato ao em que estão servindo". E, finalmente, por estar convencido de que essas suas determinações mereceriam, "sem dúvida, a confirmação de S. M. o Sr. rei D. João VI", ordenou o imediato e "inteiro cumprimento" das suas novas decisões. ${ }^{164}$

Em que se considere o novo arranjo institucional exigido pelo liberalismo manifesto entre a maioria dos deputados em Lisboa, as relações dos baianos com os defensores da antiga metrópole deteriorava-se visivelmente. A crise política, por fim, adquiriu contornos decisivos em princípios de fevereiro de 1822, quando se soube que o militar nomeado por d. João VI e pelas Cortes para o governo das armas na Bahia era ninguém menos que o brigadeiro Inácio Luís Madeira de Mello (1755-1833), o qual, até então, comandava o batalhão de infantaria número 12 e que nutria sérias divergências com importantes segmentos civis, especialmente, com alguns corpos militares sob o comando dos filhos da terra. Consta-se, inclusive, que

\footnotetext{
${ }^{163}$ Relações dos oficiais promovidos pelos Exmo. Brigadeiro governador interino das armas desta província. In: MORAES, Alexandre de Mello, op. cit., t. 2. p. 79-80. Dentre os nomeados encontrava-se a referência a "João Ladislau de Figueiredo e Melo, promovido ao posto de coronel agregado a um dos regimentos da $2^{\mathrm{a}}$ linha desta cidade que escolher, por nomeação de 10 do dito mês e ano". Os peticionários denunciavam ter sido esse "Boticário" premiado "coronel de milícias" devido ele ser um dos facciosos que muito combateram a autoridade da antiga Junta de Governo. Recurso e adendo ao mesmo que as soberanas Cortes de Portugal dirigem mil e cinquenta e dois constitucionais da notável, e sempre fiel cidade da Bahia, por seu emissário o cidadão Francisco Mendes da Silva Figueiró, op. cit. p. 293.

${ }^{164}$ Oficiais do regimento de artilharia de linha promovidos às graduações dos postos imediatos por portaria de 10 de fevereiro de 1822. In: MORAES, Alexandre de Mello, op. cit., t. 2. p. 80-81. Contrário àquela decisão, o brigadeiro de origem europeia que as Cortes de Portugal viriam a nomear para o governo das armas da província achou "necessário prevenir qualquer despesa, que se possa fazer com os oficiais de próximo promovidos pelo Sr. brigadeiro governador interino das armas". Razão pela qual, em 26 de fevereiro, Madeira de Mello ordenava "que todos os ditos promovidos, tanto na efetividade de postos, como em graduações, fiquem por ora suspensos, e sem efeitos os seus vencimentos e exercícios, até a última decisão de Sua Majestade, a quem será presente todo este negócio". Ofício de Inácio Luís Madeira de Mello, brigadeiro governador das armas, ao Sr. vedor-geral das tropas, em 26 de fevereiro de 1822. In: MORAES, Alexandre de Mello, op. cit., t. 2. p. 87-88.
} 
Madeira de Mello não havia tomado parte ativa no pronunciamento de adesão da Bahia ao constitucionalismo, sendo o seu regimento persuadido pelo então tenente-coronel Manuel Pedro. Ao que parece, um tanto vexado pelo pouco caso que os subordinados fizerem com as suas ordens, Madeira de Mello teria decidido ir ao encontro dos revolucionários, tendo sido aclamado e convencido, ou mesmo constrangido, a participar do movimento pelos artilheiros do Batalhão número $12 .^{165}$

Depois dos acontecimentos de 12 de julho do ano anterior, Madeira de Mello tornara-se o maior defensor dos portugueses europeus na província, pois fora um dos principais protagonistas a impedir que outros projetos políticos mudassem os rumos do movimento constitucionalista na Bahia. ${ }^{166}$ Em contrapartida, eram muitos os baianos que viam nessa designação a prova irrefutável de desprezo que o projeto das Cortes reservava não apenas para o território baiano, mas para o Brasil como um todo.

Ao debaterem a nomeação do governador das armas, os vereadores da capital quiseram retardar ou mesmo impedir a sua posse, lembrando inclusive que na qualidade de órgão municipal e congresso do povo deviam decidir pelo que fosse melhor para o governo da província. ${ }^{167}$ Os militares também se posicionaram e, enquanto as tropas europeias se colocavam à disposição do brigadeiro português, os corpos de $1^{\circ}$ regimento de infantaria, artilharia e legião de caçadores recusavam terminantemente que o comando deixasse de pertencer a um filho da terra, no caso, Manuel Pedro de Freitas Guimarães.

Nessa conjuntura de grande tensão entre tropas armadas, o "gênio inquieto" de João Primo despertou, mais uma vez, a atenção dos contemporâneos, haja vista que esse cadete e outras lideranças radicais, a exemplo do capitão Joaquim Sátyro da Cunha, foram apontados como "os cabeças" da resistência às determinações das Cortes de Lisboa desde o momento que se soube da nomeação de um português europeu para o maior posto militar na Bahia. Encontrando-se João Primo reunido à tropa de artilharia no forte São Pedro, em 17 de fevereiro, esta declarou "publicamente que ainda que as autoridades dessem posse de Governador das Armas da Província ao Brigadeiro Madeira, não se devia reconhecer com tal". ${ }^{168}$ Sustentada a posição política dos artilheiros com o apoio dos dissidentes da Revolução

\footnotetext{
${ }^{165}$ LIMA, Manuel de Oliveira, op. cit., p. 188.

${ }^{166}$ Nesse sentido, aludiria $O$ Constitucional: “Chegou o Paquete, [...] apressemo-nos em noticiar que chegou nele o Diploma, ou Patente, pela qual foi despachado Brigadeiro e Governador das Armas desta Província, o Senhor Ignácio Luís Madeira, Pessoa a quem não conhecemos de hoje para desconfiarmos das suas qualidades Militares e Civis”. Diário Constitucional, n. 8, Sábado, 16 de fevereiro de 1822. Tipografia da Viúva Serva e Carvalho, 1821-1822. Exemplar da coleção do IEB/Usp.

167 BANDEIRA, Luiz Alberto Moniz, op. cit. p. 388.

168 Inquérito militar que mandou o General Madeira proceder sobre os acontecimentos do forte de São Pedro. AMARAL, Braz do, 1931, op. cit., v. 3. p. 488-519, nota 6. As citações constam das páginas 491 e 494 . Sobre a
} 
Constitucionalista, as provocações avolumaram-se e, entre os dias 18 e 21 de fevereiro, a cidade de Salvador foi sacudida por violentos combates envolvendo militares e civis, com "a perda de ambos os partidos a 200 homens, inclusive os feridos", conforme estimou Inácio Accioli. ${ }^{169}$ Devido às suas melhores condições, os soldados europeus forçaram a retirada dos batalhões resistentes para o Recôncavo; muitas outras famílias procuraram o mesmo destino e a capital caiu sob o domínio das tropas do brigadeiro Madeira de Mello.

Observa-se, então, que as dissensões armadas na capital, em fins de 1821 e princípios de 1822, abriram, em definitivo, a possibilidade de se levar adiante planos políticos mais audaciosos. Dentre os "projetos" favorecidos pelas disputas na província, consta que, logo após a rendição da cidade, outra denúncia, em forma de representação assinada por 848 "negociantes, proprietários, militares e mais cidadãos", sugeria que a resistência dos opositores visava a separação política entre Brasil e Portugal.

Tudo isso, senhor, talvez, tendia ao sinistro fim de ganharem tempo aqueles facciosos a executarem seus nefandos projetos; e, abusando do respeitável nome do príncipe real, unirem-se à corte do Rio de Janeiro, e por virtude de tão repreensível cilada tornar-nos perjuros aos solenes juramentos do dia 10 de fevereiro e 25 de março [juramento das Bases da Constituição portuguesa em Salvador] do ano próximo passado, e deste modo conseguirem fazer a mais escandalosa cisão entre o Brasil e Portugal, separando-nos dos nossos caros irmãos da Europa, e ilhas, o que certamente lhes obstava, existindo o comando das armas nas mãos do brigadeiro Inácio Luís Madeira de Mello, do qual a firmeza do seu caráter e cordial adesão à santa causa constitucional é dos facciosos o maior dos receios. ${ }^{170}$

Essa nova acusação somente reiterava as informações da primeira Junta Governativa sobre uma possível articulação pela Independência política organizada há algum tempo na Bahia, conforme mencionado. Por outro lado, não se pode deixar de destacar que essas divergências não se restringiam apenas à polarização entre portugueses e filhos da terra. Eram, de fato, muito mais complexas. No âmago de uma sociedade na qual o trabalho escravo constituía a mola-mestra da acumulação do capital mercantil, ${ }^{171}$ a classe senhorial não podia esquecer dos diferentes segmentos sociais que em 1798 tencionaram revolucionar a base

participação política das lideranças radicais na Bahia no pós-Independência, ver COELHO, Hilton Barros. "Authoridades" e "Anarchistas" no "Império da desordem": conflitos e reconfigurações do poder dominante na Bahia da guerra à consolidação da Independência. Dissertação (Mestrado em História) - Universidade Federal da Bahia, Salvador, 2003.

${ }^{169}$ SILVA, Ignácio de Accioli Cerqueira e, op. cit., v. 3. p. 330.

170 Representação, constando 848 assinaturas de negociantes, proprietários, militares e mais cidadãos, ao soberano congresso da nação e ao muito poderoso rei constitucional, o Sr. D. João VI. In: AMARAL, Braz, 1957, op. cit., p. 145, nota 9.

${ }^{171}$ Cf. FERNANDES, Florestan. A sociedade escravista no Brasil. In: IANNI, Octávio (Org.). Florestan Fernandes: sociologia crítica e militante. São Paulo: Ed. Expressão popular, 2004. p. 367. 
social e material daquela sociedade, bem como a série de revoltas escravas que desde o ano de 1807 ameaçava a paz dos senhores no entorno da capital e nas áreas do Recôncavo ${ }^{172}$ e, finalmente, não seria prudente de sua parte negligenciar a fato de os revolucionários de 1817 terem considerado, por algum tempo, a capitania baiana como área de influência para seus projetos.

Não por acaso, existia tanto da parte do governo da capital quanto da resistência que a partir do Recôncavo começava a organizar-se a preocupação para que não saíssem fortalecidos os interesses dos segmentos subalternos da sociedade escravista na Bahia. Grosso modo, escravos africanos e crioulos, e uma espessa população mestiça e pobre conformaram os segmentos sociais que, na perspectiva das autoridades, exigiriam o maior controle por parte do governo. Assim, em $1^{\circ}$ de julho de 1822, quando os conflitos entre lusitanos e filhos da terra extrapolaram o perímetro da capital para generalizar-se em verdadeiras lutas pela Independência, a Junta Provincial cuidou de precaver o brigadeiro Inácio Luís Madeira de Mello sobre o "quanto impolítica e tremenda seria para a segurança de toda esta província a tentativa de fazer o Recôncavo, recheado de castas perigosíssimas, teatro de uma guerra exterminadora". ${ }^{173}$ Sem demonstrar preocupação aparente, o militar português considerou ser este um problema para a classe senhorial solucionar, já que ela era portadora do "instrumento da desgraça" e, como se esquecesse que muitos dos escravos residiam no interior das suas casas, agia como se não percebesse que quaisquer exemplos subversivos para com as autoridades constituídas estavam sujeitos a propiciar a "imoralidade" dos cativos, os quais, aderindo à rebelião em curso, bem poderiam reduzir "a província a teatro da mais sanguinolenta e horrorosa cena". ${ }^{174}$

De fato, nos primeiros decênios do Oitocentos a figura legal do escravo na América portuguesa convivia com uma simbologia que tendia a discriminá-lo simultaneamente como um inimigo doméstico e um inimigo público. ${ }^{175} \mathrm{E}$ era justamente por manter um ambíguo convívio de vasta experiência com antagonistas desta natureza que a classe senhorial pressupunha conhecer até que ponto o perigo rondava-a. Nesse sentido, João José Reis situa bem a questão ao enfatizar que "o conflito é inerente à relação entre escravos e senhores", enquanto "a negociação é uma estratégia de resistência escrava, tanto quanto de dominação

\footnotetext{
${ }^{172}$ REIS, João José, 2003, op. cit. Especialmente o cap. 1.

${ }^{173}$ Correspondência da Junta Provisória de Governo da Bahia ao Ilmo. Exmo. Sr. brigadeiro governador das armas desta província, Inácio Luís Madeira de Mello, em $1^{\circ}$ de julho de 1822. In: SILVA, Ignácio de Accioli Cerqueira e, op. cit., v. 3. p. 353, nota 50 (Grifos meus).

${ }^{174}$ Idem, ibidem, loc cit.

175 Acerca dessa temática, ver FERNANDES, Florestan, op. cit.
} 
senhorial". Afinal de contas, a articulação entre esses dois pólos é que garantia um mínimo de consenso entre as partes. ${ }^{176}$

Por experimentar em princípios de 1822 um cenário político inédito, mas igualmente indeciso e deveras provisório, as classes diretivas tanto da capital, quanto do Recôncavo e interior da província, não menosprezaram a possibilidade do vocábulo liberdade, em seu sentido sócio-político, atingir a ordem societária escravista ou vir a favorecer uma revolução de caráter popular. Daí as constantes referências das autoridades quanto à fermentação política propiciada por facções anarquistas ou republicanas com articulações na capital e em algumas vilas do interior. No que se refere à condição dos escravos, em abril de 1822, a senhora do engenho Aramaré, Maria Bárbara Garcez Pinto da França, havia registrado que "a crioulada de Cachoeira", aproveitando-se da convocação de Cortes Gerais, chegou a enviar "requerimentos para serem livres". ${ }^{177}$ Conquanto, para ela, e mesmo para uma parcela dos segmentos dominantes da Bahia, o perigo real contra a ordem pública residia não nos cativos, ainda que esses tivessem nascido no Brasil, mas nos estratos de baixa condição social, representados, especialmente, pelas "classes de cor", as quais se mostravam dispostas a encontrar os meios que lhes assegurassem uma maior inserção político-social. Situação que marcaria profundamente o universo mental das classes proprietárias baianas que, para além de combaterem as tropas lusitanas estacionadas na cidade de Salvador, viram-se obrigadas a enfrentar os seus "inimigos internos". ${ }^{178}$

Nesse último caso, a guerra seria bem mais duradoura, pois, dentre os inimigos a serem controlados, as clivagens sociais que conformavam o grosso da população do Brasil exigiriam maior atenção por parte dos homens de Estado. Tanto assim que, em 16 de abril de 1823, as autoridades reunidas no Conselho Interino, na vila de Cachoeira, cuidaram de enviar aos ministros de Pedro I uma exposição de motivos considerando, dentre outras coisas:

\footnotetext{
176 MORAIS, José Geraldo Vinci de; REGO, José Márcio Rego. Conversa com historiadores brasileiros. [entrevistas concedida por] João José Reis. São Paulo: Ed. 34, 2002. p. 328. Ver também SILVA, Eduardo; REIS, João José. Negociação e conflito: a resistência negra no Brasil escravista. São Paulo: Companhia das Letras, 1989.

177 FRANÇA, António d'Oliveira Pinto da (Org.). Cartas baianas, 1821-1824: subsídios para o estudo dos problemas da opção na independência brasileira. São Paulo: Nacional; Rio de Janeiro: Núcleo Editorial da Universidade do Estado do Rio de Janeiro, 1980. p. 36.

${ }^{178}$ O enfrentamento coercitivo aos "inimigos internos" das classes dominantes na Bahia de princípios dos anos de 1820 aparece com clareza no Relatório dos trabalhos do Conselho Interino de Governo da província da Bahia, em prol da Regência e do Império de sua magestade imperial o senhor D. Pedro I e da Independência Política do Brasil, redigido e offerecido ao grande constitucional e defensor perpétuo do Brazil, e ao heróico povo da província da Bahia por Miguel Calmon d' Pin e Almeida. Bahia: Na Typographia Nacional, 1823. p. 1-24 (Disponível em: <http://www.crl.edu/content/brazil/BAH.htm> Acesso em 14 de agosto de 2008). A citação acima se encontra à página 17. Uma boa discussão sobre as possibilidades e limitações das classes sociais no período da Independência encontra-se em REIS, João José. A elite baiana face os movimentos sociais, Bahia: 1824-1840. Revista de História. São Paulo, Out-dezembro, v. 54, n. 108, ano XXVII. p. 341-384, 1976.
} 
Que as classes de cor têm no Brasil o maior ciúme por não entrarem promiscuamente nos empregos públicos, é verdade já incontestável e mais agora depois que o fratricídio lusitano tem sobre isto fundado a sua primeira defesa: ora não sendo isto fácil, nem de modo algum político conceder já aquela igualdade para aparecerem homens de cor nos primeiros empregos, é verdade que muito convém ter a maior política com a situação destas classes desarmando-as delicada e prudentemente.

E tanto mais quanto sendo estas classes as que menos têm [a] perder, e menos laços têm sociais, são as mais aptas para sustentarem empresas arrojadas e tresloucadas, mais subversivas. ${ }^{179}$

Os argumentos atestam, com precisão, que os maiores representantes da classe senhorial na Bahia anteviam a possibilidade de sublevação das classes populares e, mesmo enfrentando uma guerra contra os lusitanos, eram capazes de apontar uma estratégia para impedir a sua realização. Com efeito, não se constitui novidade afirmar que, depois de quase três centúrias de intensa miscigenação entre europeus, ameríndios e africanos, nenhum outro segmento social tornou-se tão representativo na Bahia oitocentista como os que se situavam entre a classe senhorial e os escravos, cuja clivagem étnica comportava majoritariamente crioulos, cabras, mulatos e pardos.

Em função disso, tanto as autoridades interioranas como as que dominavam na capital viram-se forçadas a considerar, para os cálculos políticos e sociais a ser implementados, a preponderância daquela camada societária. Mesmo porque, a crise irredutível do Antigo Regime, com seus vastos privilégios, mormente a reserva dos melhores empregos públicos para os bem-nascidos, havia atingido em cheio as camadas intermediárias da sociedade escravista, provocando divergências que, cada vez mais, ficavam difíceis de ser negadas. ${ }^{180}$ Enfim, com poucas alternativas para escapar à lógica asfixiante de um sistema estamental em ruínas, tornava-se factível aos homens e às mulheres desse segmento societário a criação de vínculos identitários, de redes de sociabilidade que melhor informassem acerca das suas condições sociais.

\footnotetext{
${ }^{179}$ Correspondência oficial do Conselho Interino de Governo na Cachoeira, em 16 de abril de 1823. Documentos históricos sobre a emancipação política da Bahia. Revista do Instituto Geográfico e Histórico da Bahia, ano V, v. 5, n. 17, 1898. p. 363-364. Uma análise pautada nessa correspondência do Conselho Interino foi empreendida por KRAAY, Hendrik. "Em outra coisa não falavam os pardos, cabras e crioulos." O "recrutamento" de escravos na Guerra de Independência na Bahia (1822-1823). Revista Brasileira de História. ANPUH/Humanitas, v. 22, $\mathrm{n}^{\circ}$ 43. p. 109-126, 2002.

${ }^{180}$ Cf. ARAÚJO, Ubiratan Castro de, 1999, op. cit.
} 
Após ter sido vencida militarmente pelas tropas lusitanas, entre 19 e 21 de fevereiro de 1822, uma parcela significativa dos descontentes com os rumos da Revolução Constitucionalista viu-se forçada a abandonar a capital baiana em direção ao interior da província. Dias depois, Madeira de Mello levou ao conhecimento das Cortes Gerais a existência de três tendências políticas em Salvador as quais, a exemplo dos seus contemporâneos, designava de "partidos".

Três são os partidos que existem nesta cidade: dos naturais de Portugal o partido quase geral é puramente constitucional; e a este alguns há, dos naturais do país, que se unem; dois são os partidos que estes seguem, a saber: os mais poderosos, já em posses e já em empregos de representação, ligados aos togados do Rio de Janeiro, querem uma constituição, em que, como lordes, figurem independentes do governo de Portugal, e por isso trabalham para a separação, é este motivo porque o poder legislativo de Vossa Majestade é ali atacado nos papéis públicos com o maior vilipêndio.

Os que pelas suas posses ou empregos não ombreiam com aqueles, querem uma independência republicana, em que só figurem os naturais do país; têm-se chocado ambos estes partidos até aqui, tendo sido o resultado favorável ao primeiro constitucional; porém agora, julgando-se ofendidos ambos os corpos por ser notado o geral americano por fraco e rebelde, trabalham a reunir-se; e se o conseguem, como é de esperar, é necessário força para o rebater [...]. ${ }^{181}$

Em boa medida, os rumos dos acontecimentos que se desenrolaram em território baiano a partir da tomada da capital pelas tropas lusitanas tendem a confirmar a avaliação acima. De um lado, a maioria dos portugueses europeus (sobretudo os vinculados ao grande comércio e ao exército) pertencia à tendência política disposta a implementar o projeto constitucionalista encampado pelas Cortes de Lisboa que ambicionava a sustação da autonomia política recém-conquistada pela Bahia. Na outra ponta, a conformação de nova aliança, facilitada pela imposição de Madeira de Mello, entre os agregados do "partido brasileiro", propositores de uma Constituição independente de Portugal, e os que defendiam uma ruptura ainda maior, denunciados pelos opositores como republicanos.

De fato, não se deve menosprezar que a instauração de uma República para o Brasil povoava o universo mental de muitos contemporâneos, como atestaria a Confederação do Equador em $1824 .{ }^{182}$ Todavia, também é preciso dizer, que a possibilidade de se instaurar

181 Ofício de Inácio Luís Madeira de Mello às Cortes de Lisboa em 7 de março de 1822. In: MORAES, Alexandre de Mello, op. cit., t. 2. p. 76-79. A citação encontra-se à página 79.

182 BERNARDES, Denis Antônio de Mendonça, op. cit. Ao examinar a conjuntura política na Bahia depois dos acontecimentos verificados na cidade Salvador em fevereiro de 1822 e diante da possibilidade de se instaurar um centro de poder executivo no Brasil, Braz do Amaral considerou que: "Os espíritos dos homens mais instruídos e 
uma "república com liberdade de escravos" era, como alertaria Cipriano Barata em 1831, "uma invenção tenebrosa"; um ardil do qual os governantes desde o Período Joanino muito se valeram para justificar a sistemática da violência física, especialmente a promovida pelo Estado contra os que questionassem o poder "unitário" e centralizado. ${ }^{183}$ Nesse sentido, a denúncia de Cipriano Barata é relevante à medida que descortina a tessitura ideológica subjacente à "ideia de república com sublevação e liberdade de Escravos", evidenciando, assim, o quanto no Brasil das primeiras décadas do Oitocentos as lutas políticas com proposições dissonantes da lógica imperial de "unidade" de territórios e centralidade do poder em um único centro decisório passaram a conviver com as fortes tentativas de instrumentalização e tipificação vinculada ao modelo de revolução ocorrida em São Domingos (1791-1794). ${ }^{184}$ Além do mais, revela a disputa de projetos divergentes, pois, o próprio processo que engendrou a crise sistêmica do Antigo Regime ampliou também as contradições das sociedades escravistas que possuíam cada vez mais gente escravizada e intensamente explorada.

Depois de fugir da Europa com outros cinco deputados do Brasil para não ter que assinar a Constituição que as Cortes de Lisboa concluíam para a nação portuguesa em 1823 , Cipriano Barata e o padre Agostinho Gomes aportaram na província de Pernambuco em princípios de abril de $1823 .{ }^{185} \mathrm{Na}$ ocasião em que o território do Brasil lutava para se tornar independente de Portugal, principiando, assim, a formação do Estado e da nação brasileiros, Cipriano passou a dedicar-se aos escritos jornalísticos de forte conotação política. Por meio de manifestos e, especialmente, via o jornal Sentinela da Liberdade, a conduta desviante deste

mais capazes os levavam ou para a república, ou para a monarquia com o príncipe regente D. Pedro, porque isso se lhes afigurava como o caminho mais curto para chegar à Independência”. AMARAL, Braz do, 1957, op. cit. p. 172.

${ }^{183}$ Manifesto que ao respeitável público apresenta o cidadão Cypriano José Barata de Almeida sobre a sua súbita, tyranna razão na Bahia, e remessa violenta para esta corte, onde se acha prezo. Com várias ideias úteis ao Brazil inteiro, \&c. \&c., op. cit. As citações encontram-se às páginas 2 e 4. Para o contexto político no pós-abdicação de d. Pedro I, em 7 de abril de 1831, e as motivações que levaram Cipriano Barata a escrever esse manifesto, ver MOREL, Marco, 2001, op. cit. p. 104 e 105 e SILVA, Daniel Afonso da, op. cit. p. 47 e segs.

${ }^{184}$ Uma discussão sobre haitinização enquanto retórica dos governantes e dos grandes proprietários para tentar controlar a agitação político-social no Brasil de princípios do século XIX encontra-se em RODRIGUES, Jaime. $O$ infame Comércio: proposta e experiências no final do tráfico de africanos para o Brasil (1800-1850). Campinas, SP: Unicamp/Cecult, 2000.

${ }^{185}$ Com as tensões que envolviam a ocupação da capital baiana pelas tropas de Portugal, Cipriano Barata justificaria ter escolhido ir para Pernambuco até a Bahia conseguir livrar-se das tropas inimigas (BARATA, Cipriano, 2008, op. cit.). Os sete deputados do Brasil que fugiram de Lisboa para não assinar a Constituição da nação portuguesa foram: Antônio Carlos Ribeiro de Andrada Machado e Silva, José Ricardo da Costa Aguiar e Andrada, Antônio Manuel da Silva Bueno e Diogo Antônio Feijó, representantes da Província de São Paulo e Cipriano José Barata de Almeida, Francisco Agostinho Gomes e José Lino Coutinho, deputados pela Bahia. JANCSÓ, István; PIMENTA, João Paulo Garrido, op. cit. p. 129. 
político radical entabulava um tenaz combate aos portugueses europeus que tomavam armas ou patrocinavam financeiramente a Guerra de Independência na Bahia. ${ }^{186}$

Dessa maneira, ao conhecer uma proclamação de Cipriano Barata, datada de 5 de abril de 1823, o redator do Semanário Cívico passou a classificar o seu autor com o mais radical dos adversários que: "Só deseja ver derramado o sangue, estabelecida a anarquia. Convida os brasileiros que façam cruel guerra a todos os portugueses europeus, que ensopem as mãos em seu sangue, que lhes trinquem o coração, diz-lhe que não se conciliem mais, e que exterminem do Brasil esta raça maldita". ${ }^{187}$ Em resposta, Silva Maia denunciava que o "malvado Barata" pretendia, outrossim, sublevar os escravos. "Muitas vezes este furioso o disse, e nós lho ouvimos na Praça do Comércio, 'que com um tição de fogo queimaria os canaviais, e com duas palavras armaria os negros para assassinarem seus bárbaros senhores' Quereis que este malvado realize seus infernais projetos?" "188 Talvez resida na retórica desse discurso a primeira associação entre as ideias políticas de Cipriano Barata com levante de escravos, conjunção da qual, em diversos momentos o autor da Sentinela da Liberdade viu-se obrigado a desvencilhar-se, afirmando tratar-se de "boatos" propalados pelos "corcundas" e demais agentes do "antigo servilhismo".

Importante também mencionar que quando Cipriano Barata denunciava, em 1831, as "armadilhas de república com levante de Escravo", o fazia, em primeiro lugar, como uma peça de defesa, pois, após longos anos circulando pelos navios-prisões e cárceres do Império do Brasil, via-se novamente encarcerado, devido à prisão promovida pelos que na Bahia revelavam-se aferrados ao "partido unitário e [à] centralização do governo" imperial. ${ }^{189} \mathrm{Em}$ segundo lugar, Cipriano usava a sua pena para reafirmar a posição política que adotou

\footnotetext{
${ }^{186}$ BARATA, Cipriano, 2008, op. cit.

${ }^{187}$ Semanário Cívico, n. 111, de 24 de abril de 1821. Apud SILVA, Maria Beatriz Nizza da, 2008, op. cit. p. 172. ${ }^{188}$ Semanário Cívico, n. 111, de 24 de abril de 1821. Apud SILVA, Maria Beatriz Nizza da, 2008, op. cit. p. 172. ${ }^{189}$ Manifesto que ao respeitável público apresenta o cidadão Cypriano José Barata de Almeida sobre a sua súbita, tyranna razão na Bahia, e remessa violenta para esta corte, onde se acha prezo. Com várias ideias úteis ao Brazil inteiro, \&c. \&c., op. cit. As citações encontram-se nas páginas 2 e 4. Em avançada idade, o cirurgião prático e, então, jornalista Cipriano José Barata de Almeida vivera, entre novembro de 1823 e o primeiro semestre de 1834 nos cárceres do Império do Brasil, totalizando dez anos e seis meses de prisão. Cf. MOREL, Marco, 2001, op. cit. p. 287 e 316. Em 1831, Cipriano Barata diria que "apesar da experiência" que seus conterrâneos na Bahia adquiriram ao longo de todo o Primeiro Reinado, "ainda vemos a teima de nos quererem os sequazes do erro enganar [...]; porque antes a luta e armadilhas de república com levante dos escravos eram para destruir a Independência e a Liberdade; e hoje parece ser para conservar o Governo Unitário ou Central, enganando o povo com medos a fim de apartar a Federação das províncias brasileiras. Manifesto que ao respeitável público apresenta o cidadão Cypriano José Barata de Almeida sobre a sua súbita, tyranna razão na Bahia, e remessa violenta para esta corte, onde se acha prezo. Com várias ideias úteis ao Brazil inteiro, \&c. \&c, op. cit. p. 6. Respeitado estudioso da conduta política desse liberal exaltado, Marco Morel ficou convencido da falsidade "das acusações de que Cipriano Barata estaria tramando uma sublevação de escravos para proclamar a República”. MOREL, Marco. As transformações dos espaços públicos: Imprensa, atores políticos e sociabilidades na cidade imperial (1820-1840). São Paulo: Hucitec, 2005. p. 73.
} 
publicamente logo que começaram os trabalhos legislativos da primeira Assembleia Constituinte do Brasil reunida no Rio de Janeiro em 3 de maio de 1823. Na ocasião, ele registrara na Sentinela da Liberdade que:

Cada província precisa de fazer suas Leis particulares, seus arranjos em separado, o que só deve ser organizado dentro delas pelos seus naturais e seus governos privativos; havendo em separado Leis Gerais que façam a união Imperial, e eis aqui a Federação. ${ }^{190}$

Coerente com esses princípios, em 1831, insistiria que a "república com levante dos Escravos [...] hoje parece ser para conservar o Governo Unitário, ou Central, enganando o povo com medos a fim de apartar a Federação das províncias brasileiras". ${ }^{191}$ Nesse aspecto, a defesa do projeto federalista mantinha-se ativa na Bahia após a abdicação do imperador ocorrida no Rio de Janeiro, em abril de 1831 período em que se intensificaram os motins envolvendo a tropa e paisanos armados que sacudiram a capital e algumas vilas baianas. Toda essa discussão vem a propósito porque na "trama" urdida dando conta de que uma grande sublevação envolvendo a participação da escravaria da capital e do Recôncavo estava prestes a ocorrer, Cipriano afirmara ser os agentes do governo os responsáveis pela difusão desse "perigoso boato, e fizeram-no bem espalhar, que era eu, João Primo", entre outros, "os capatazes dessa república de Pretos". ${ }^{192}$ Por isso, ambos foram presos na madrugada de 28 de abril de 1831. E seis dias depois seguiram, "em segredo", para o Rio de Janeiro, tendo como transporte um "Brigue sujo de carregar madeiras" e sem "os mantimentos precisos". Dizia ainda Cipriano que o pardo João Primo, seu companheiro de infortúnio era um "patriota estimável pelas suas ótimas qualidades, mas odiado pela oposição forte que fazia aos Marotos perniciosos", dando, assim, a entender ser esse o motivo porque o "Senhor João Primo" tornara-se igualmente vítima das "tramóias" dos grandes da província. ${ }^{193}$

Além da identificação das tendências políticas acima, outros elementos indicam que em princípios de 1822 já se encontrava em curso uma forte articulação entre residentes na província da Bahia e do Rio de Janeiro, objetivando a conformação de um projeto distinto do

${ }^{190}$ Sentinela da Liberdade na Guarita de Pernambuco, n. 14, 21 de maio de 1823 e n. 54, 8 de setembro de 1823, apud MOREL, Marco, 2001, op. cit. p. 188. Sobre a força desses arranjos federalistas a partir do período regencial, ver DOLHNIKOFF, Miriam, op. cit. Deve-se notar que Cipriano Barata deixava os portugueses europeus e outros estrangeiros de fora da organização direta do governo federativo que defendia.

${ }^{191}$ Manifesto que ao respeitável público apresenta o cidadão Cypriano José Barata de Almeida sobre a sua súbita, tyranna razão na Bahia, e remessa violenta para esta corte, onde se acha prezo. Com várias ideias úteis ao Brazil inteiro, \&c. \&c., op. cit. p. 5. Para o impacto do movimento federalista na Bahia, ver ARAS, Lina Maria Brandão, op. cit.

${ }^{192}$ Manifesto que ao respeitável público apresenta o cidadão Cypriano José Barata de Almeida sobre a sua súbita, tyranna razão na Bahia, e remessa violenta para esta corte, onde se acha prezo. Com várias ideias úteis ao Brazil inteiro, \&c. \&c., op. cit. p. 15.

${ }^{193}$ Idem, ibidem. p. 13 e 17 e também a nota 8 . 
proposto pelo constitucionalismo lisboeta. Questão essa que, a meu ver, não tem recebido a devida atenção por parte da historiografia. Um dos objetivos do próximo capítulo será analisar alguns indícios acerca da existência de uma rede de sociabilidade envolvendo representantes da classe senhorial baiana que, durante a dissolução do Antigo Regime português na América, conseguiram convergir delicados interesses entre as duas províncias mais importantes do Brasil para o projeto de monarquia constitucional capitaneado por d. Pedro I. 


\section{Capítulo 3}

\section{Entre a Bahia e o Rio de Janeiro: o reordenamento da política}

Resultado de um processo de múltiplas articulações, as classes senhoriais no Brasil das primeiras décadas do Oitocentos eram representadas, principalmente, por proprietários de terras, engenhos, plantações de gêneros de exportação, currais de gado e escravos, os quais, em muitos casos, usufruíam, diretamente ou por meio dos seus filhos, de cargos administrativos, jurídicos e militares no aparelho do Estado português. Com a implementação da política do reformismo ilustrado característico do último quartel do Setecentos e princípios do século seguinte, a transferência da família real e a subsequente implantação de importantes órgãos da administração imperial no Brasil, o acesso desse segmento social à máquina burocrática da administração régia fora muito facilitado. Contudo, a primazia nos postoschave da Coroa bragantina continuou sendo uma prerrogativa vedada à sua participação. Tanto assim que, em mais de treze anos na América, a monarquia não nomeou um único ministro nascido no Brasil. ${ }^{1}$

Não obstante a Coroa ter se empenhado pela consolidação de uma profícua aliança de compromissos com os setores dominantes na América portuguesa em fins do Antigo Regime, os mandatários régios mantiveram incólume o monopólio da legitimação política. Daí ter resistido às competições no interior da estrutura institucional, cabendo à realeza atuar como a medianeira nas resoluções das disputas por cargos, honrarias e mercês. ${ }^{2}$ Importa ainda observar que apesar do sentimento de pertença ao Reino do Brasil e à nação portuguesa adquirirem relativa consistência e houvesse sido compartilhado indistintamente pelos súditos da Coroa bragantina, ${ }^{3}$ a autonomia política conquistada em províncias como a Bahia e as graves contradições que apontavam para o obstrucionismo do pacto constitucional nas Cortes de Lisboa, tornaram factível a ocorrência de uma nova viragem política.

\footnotetext{
${ }^{1}$ É significativo observar que uma maior exclusão a favor dos europeus no acesso aos postos decisivos da Coroa parece ter sido a norma nas Américas até esse período, pois dos 170 vice-reis que a América hispânica possuiu até 1813, apenas quatro foram de origem crioula. BENEDICT, Anderson R. Pioneiros crioulos. In: BENEDICT, Anderson R. Comunidades Imaginadas: reflexões sobre a origem e a difusão do nacionalismo. São Paulo: Companhia das Letras, 1998. p. 96.

${ }^{2}$ Para o aprofundamento dessa análise, ver MORTON, F. W. O. The Consertative Revolution of Independence: Economy, society and politics in Bahia (1790-1840). Thesis Submitted to the Board of the Faculty of Modern History in Partial Fulfilment of the Requirements for the Degres of D. Phil, University of Oxford, Oxford, 1974. p. 60 e segs.

${ }^{3}$ JANCSÓ, István; PIMENTA, João Paulo Garrido. Peças de um mosaico (ou apontamentos para o estudo da emergência da identidade nacional brasileira). In: MOTA, Carlos G. (Org.). Viagem Incompleta. A experiência brasileira (1500-2000). Formação: histórias. São Paulo: Senac, p. 127-175, 2000.
} 
Indicativo dessa realidade é que, conforme se registrou, já em fins de 1821, havia autoridades baianas prendendo pessoas com o argumento de que elas arquitetavam uma aliança com o objetivo de assegurar o desenlace político de Brasil e Portugal. Simultâneo a isso, havia igualmente quem percebesse nas acusações de ruptura política sustentada, seja pela primeira Junta Provincial, seja pelos defensores do liberalismo predominante em Portugal, algo funesto que deliberadamente ajudava a propalar, com proposições "elegantes", ideias como as seguintes: "Querem independência, cuidado!... República!... Felisbertinos!... Carcundo-Austriaco-Russo-Realistas, e outras mais palavrinhas dignas de memória eterna". 4 Enfim, estes vocábulos substanciam a hipótese de que o constitucionalismo operava uma profunda alteração nas linguagens políticas e sociais em um contexto histórico-cultural em que se processava a definitiva superação do Antigo Regime e abria caminho ainda indefinido a culminar na formação do Estado e nação brasileiros.

$\mathrm{Na}$ medida em que as relações com o liberalismo português, no entanto, provocavam fortes dissidências entre os antigos construtores da Revolução Constitucionalista, as classes senhoriais na Bahia passaram gradativamente a reorientar as suas expectativas objetivando não apenas a consecução dos princípios constitucionais, como também conquistar, de vez, a hegemonia, enquanto classe diretiva primordial da sociedade escravista. Nesse sentido, uma reaproximação política com a regência do príncipe d. Pedro passava a ser muito apreciada, sobretudo porque diminuía, sensivelmente, a possibilidade de um projeto republicano vir a se confirmar.

\subsection{A adesão da classe senhorial na Bahia ao projeto político das províncias coligadas}

O realinhamento político envolvendo os representantes da classe senhorial estabelecida na Bahia e as autoridades do Rio de Janeiro seria ensejado, dentre outros motivos, porque as redes de sociabilidade políticas e comerciais mantiveram-se ativas, a despeito da ruptura oficial do governo baiano com as "províncias do Sul". Acresce a isso, o fato de que os confrontos político-militares de fevereiro de 1822 abriram caminho para a conjugação de interesses entre as duas províncias mais importantes do Brasil. A confirmação dessa tendência, no entanto, foi largamente favorecida quando, em princípios de maio de

\footnotetext{
${ }^{4}$ Diário Constitucional, n. 21, quarta-feira, 13 de março de 1822. Tipografia da Viúva Serva e Carvalho, 18211822. Exemplar da coleção do IEB/Usp. Interessante aqui é notar que as referências políticas não apenas davam conta de posturas emancipacionistas, mas também procuravam vincular os dissidentes do constitucionalismo português à política da Santa Aliança, representada, em seu conjunto, pela Áustria, Rússia, Inglaterra e Prússia, o que revela o embate de projetos políticos distintos em disputa na sociedade baiana.
} 
1822, chegara à Bahia, pelas mãos do recém-formado bacharel em Ciências Jurídicas, Miguel Calmon du Pin e Almeida (1796-1865), uma correspondência assinada por todos os deputados baianos enviados às Cortes lisboeta, os quais propunham que a Junta Governativa de Salvador, assim como as câmaras municipais se pronunciassem no tocante à seguinte questão:

1. ${ }^{\circ}$ Se convém à província da Bahia, que haja no Brasil uma delegação do Poder Executivo, para facilitar o recurso necessário aos povos desse Reino. 2. ${ }^{\circ}$ Se lhe convém que haja duas delegações em diferentes pontos do Brasil para o mesmo fim. 3..$^{\circ}$ Se lhe convém que o Poder Executivo resida só em El-rei, delegando este a cada uma Junta Governativa de cada Província a parte do mesmo poder, que necessária for para a pronta execução das leis, e recurso dos povos, como acontecia antigamente com os Capitães-Generais. $4^{\circ}$ Finalmente não convindo com os três precedentes arbítrios, qual seja aquele que julga a Província mais conveniente, ou útil ao seu bom regime e administração.

Em razão da densa dinâmica política em desenvolvimento no interior na antiga colônia americana, um poder executivo já vinha sendo exercido, extraoficialmente, pelo príncipe regente nas províncias do Sul (especialmente no Rio de Janeiro, em São Paulo e Minas Gerais), mormente depois da declaração do Fico, em 9 de janeiro de $1822 .{ }^{6}$ Atento a essa conjuntura, o Diário Constitucional narraria aos seus leitores, via a publicação de uma correspondência assinada pelo Amigo do Brazil, os pormenores dos acontecimentos na corte fluminense, quando uma representação popular com cerca de 8.000 assinaturas solicitara a permanência de d. Pedro no Brasil. ${ }^{7}$ Expunham também as dissensões com a divisão de tropa

\footnotetext{
${ }^{5}$ Carta dos Deputados desta Província dirigida à Câmara desta Cidade, e por ela mandada imprimir. $O$ Constitucional, n. 14, de 11 de maio de 1822. Tipografia da Viúva Serva e Carvalho, 1821-1822. Exemplar da coleção do IEB/Usp. Esse documento fora datado em 18 de março de 1822 e constava das assinaturas dos seguintes deputados: Alexandre Gomes Ferrão, Domingos Borges de Barros, Marcos Antonio de Souza, Pedro Rodrigues Bandeira, Luís Paulino de Oliveira Pinto da França, José Lino Coutinho, Francisco Agostinho Gomes e Cipriano José Barata de Almeida. Ainda neste número, e nos três subsequentes, $O$ Constitucional defendeu que fosse organizada uma assembleia, com novos representantes da província indicados a partir dos eleitores de paróquia, para se decidir sobre a consulta dos deputados baianos, pois somente assim iria ter consideração a vontade dos habitantes. Em termos gerais, apresentou-se como imprópria a decisão da segunda Junta que mandou consultar as Câmaras da Bahia sobre aquele parecer. Procurava-se, portanto, convencer aos leitores que, se nada fosse feito, o interesse do "partido", da "cabala", iria preponderar sobre a vontade da maioria dos cidadãos. Por fim, o periódico não deixou de enfatizar que a vontade do povo era a de enviar uma deputação para felicitar o príncipe regente pela sua decisão de permanecer no Brasil e, por isso, reivindicava que a Junta não protelasse ou contemporizasse acerca de tão importante decisão. Cf. $O$ Constitucional, n. 17, sábado, 17 de maio de 1822. Tipografia da Viúva Serva e Carvalho, 1821-1822. Exemplar da coleção do IEB/USP

${ }^{6}$ VARNHAGEN, Francisco Adolfo de. História da Independência do Brasil: Até ao reconhecimento pela antiga metrópole compreendendo, separadamente, a dos sucessos ocorridos em algumas províncias até essa data. Anotada pelo Barão de Rio Branco e por uma comissão do Instituto Histórico e Geográfico Brasileiro. 4. ed. Revisada e anotada pelo Prof. Helio Vianna. São Paulo: Melhoramentos, 1957. p. 94-95. Tanto assim que, em 04 de maio, d. Pedro ordenou que os decretos das Cortes de Lisboa somente fossem executados no Brasil com o Cumpra-se do regente. Idem, ibidem. p. 117.

${ }^{7}$ Diário Constitucional, n. 6, quinta-feira, 14 de fevereiro de 1822. Tipografia da Viúva Serva e Carvalho, 18211822. Exemplar da coleção do IEB/Usp.
} 
de Portugal estacionada na capital e comandada pelo general Jorge de Avilez, que se mostrava insatisfeita com a decisão do príncipe regente em não retornar à Europa, cujos resultados, como se sabe, levariam à sua expulsão pelas guarnições fiéis a d. Pedro, vindo uma parte dela fortalecer os contingentes militares europeus, sob a direção de Madeira de Mello, em Salvador. $^{8}$

Embora essa detalhada "correspondência" pudesse ser obra dos redatores do Diário na pessoa de Montezuma ou de Corte Real, escrita na expectativa de enfatizar junto aos leitores os acontecimentos políticos da capital fluminense, o que a torna singular para análise que aqui se empreende é a sua capacidade em revelar uma das formas atuantes das redes de sociabilidade entre a Bahia e o Rio de Janeiro. Situação essa que se explícita de todo pela declaração do autor do documento quando, assim, concluiu a narrativa: "Se com efeito estas e outras semelhantes notícias tiverem cabimento na sua Folha, que tanto se interessa na prosperidade do Brasil, continuarei a transmitir-lhas, segundo me forem chegando, por ter uma correspondência ativa com aquela Corte, e com pessoa assaz exata em transcrevê-la". 9 Essa declaração evidencia, então, o intercâmbio político entre setores sociais das duas províncias de maior importância na América portuguesa, e em um contexto no qual se avolumavam os descontentamentos entre os que discordavam do projeto liberal hegemônico em Portugal. Além do mais, inserções como essas procuravam ampliar a influência da regência de d. Pedro na província baiana, onde, não restam dúvidas, a defesa dos ideais liberais atinentes tão somente às Cortes de Lisboa tinha entre os grandes negociantes lusitanos e segmentos vinculados às tropas subordinadas a Madeira de Mello acérrimos defensores.

Por outro lado, com o retorno de d. João e de seus principais ministros a Portugal, em abril de 1822, foi se tornando cada vez mais evidente para a classe senhorial residente na Bahia que ela não tinha razões graves para temer a influência do Rio de Janeiro. Pelo contrário, o intercâmbio entre os segmentos dominantes, que ali começavam a coligar-se sob a liderança de um Bragança, deveria servir de suporte à definitiva conquista da hegemonia política de uma classe social que, na prática, já detinha a supremacia material em território do Brasil. ${ }^{10}$ Todo esse processo, no entanto, não foi algo linear ou mesmo previsível para as

\footnotetext{
${ }^{8}$ Com exceção do oficialato superior e do estado-maior, o desembarque na Bahia desse contingente militar europeu ocorreu em 27 de março de 1822. SILVA, Ignácio Accioli de Cerqueira. Memórias Históricas e Políticas da Província da Bahia. Anotado por Braz do Amaral. Bahia: Imprensa Oficial do Estado, 1919-1931, v. 3. p. 335-336.

${ }^{9}$ Diário Constitucional, n. 6, quinta-feira, 14 de fevereiro de 1822. Tipografia da Viúva Serva e Carvalho, 18211822. Exemplar da coleção do IEB/Usp.

${ }^{10}$ Em Raízes do Brasil, Sérgio Buarque alertou para o declínio do senhoriato rural que a partir de 1808 perdeu muito de sua ocupação privilegiada e singular pari passu à ascensão dos centros urbanos que passaram a abrigar outras ocupações, como as vinculadas à máquina administrativa, às profissões liberais e mesmo às funções
} 
partes envolvidas. Afinal, a busca por alternativas políticas para a superação do Antigo Regime, que a todos mobilizava, vinha sendo disputada em torno dos ideais liberais, conquanto os dissensos com relação ao formato do arranjo constitucional que a maioria dos deputados em Lisboa desejava legar ao conjunto da nação portuguesa se tornassem, a cada dia, mais difíceis de encontrar uma solução harmoniosa entre Brasil e Portugal. ${ }^{11}$

Já em princípios de janeiro de 1822 cinquenta distintos representantes da comunidade baiana residentes no Rio de Janeiro expressaram apoio formal à decisão de d. Pedro de não retornar a Europa como determinavam as Cortes Gerais. Para tanto, felicitaram:

Senhor, - Os naturais da província da Bahia residentes nesta corte, cheios do mais profundo respeito, vêm hoje de sua parte manifestar na augusta presença de V. A. R. os sentimentos da mais pura, sincera e cordial gratidão pelo incomparável benefício que de V. A. R. acabam de receber, resolvendo por ora demorar sua residência neste vasto, e rico continente. E será possível que os filhos da pátria, antevendo a série incalculável de males, que ia inundar o Brasil pelo regresso de V. A. R. à antiga sede da monarquia, deixassem de considerar este rasgo de profunda política, e sabedoria da parte de V. A. R., como o maior benefício concedido aos seus desejos, e como o único e verdadeiro meio da sua salvação e futura prosperidade.

Sim, augusto senhor, V. A. R., por esta resolução, verdadeiramente heróica, salvou a pátria dos horrores da anarquia, destruindo o gérmen das facções; tornou indissolúveis os laços, que unem um ao outro hemisfério Português; lançou os fundamentos de um império, que será em pouco tempo o assombro da Europa inteira.

Entretanto, senhor, que o soberano congresso, em cujas luzes e virtudes sobejamente confiam, se ocupa da nossa regeneração política, organizando uma constituição sábia, que realize tão altos destinos da nação Portuguesa; os abaixo assinados rogam a V. A. R. se digne de aceitar em testemunho da sua gratidão, zelo e fidelidade, a oferta que francamente fazem das suas pessoas e bens a favor da causa, que V. A. R. tem adotado. Rio de Janeiro, 15 de fevereiro de $1822 .^{12}$

Vinculada à capital fluminense, especialmente pelos altos cargos e privilégios que usufruíam na burocracia do Estado, essa comunidade encontraria na regência um sólido aporte contra o decreto lei de $1^{\circ}$ de outubro de 1821 que, entre tantas medidas, previa, conforme já se

políticas. Entretanto, é preciso não perder de vista que essa transição de poder da classe senhorial aos segmentos liberais citadinos se deu, em muitos casos, no interior do seio familiar; pois, como se tem aqui insistido, a maior participação das classes dominantes na direção do Estado, por exemplo, operou-se por meio dos seus filhos que, seja pela aquisição de um diploma acadêmico, seja pelos meios tradicionais, passaram mais facilmente a gerir maiores e melhores espaços na burocracia estatal também ascendente. Cf. HOLANDA, Sérgio Buarque de. Raízes do Brasil. 26. ed. São Paulo: Companhia das Letras, 1995. p. 82.

${ }^{11}$ BERBEL, Márcia Regina. A nação como artefato: deputados do Brasil nas cortes portuguesas (1821-1822). São Paulo: Hucitec, 1999.

${ }^{12}$ Felicitação dos Baianos residentes no Rio de Janeiro a S.A.R, em 15 de janeiro de 1822. Constitucional, n. 5, sábado, 20 de abril de 1822. Tipografia da Viúva Serva e Carvalho, 1821-1822. Exemplar da coleção do IEB/USP. 
disse, a supressão do aparato da administração imperial criado no Brasil depois de 1808 . Nesse sentido, o Diário Constitucional, cuja redação ficava a cargo de Francisco Corte Real, depois Corte Imperial, e do jovem bacharel em Direito, Francisco Gomes Brandão Montezuma, publicou uma carta do governo da província de São Paulo ao príncipe regente, datada de 24 de dezembro, que além de condenar a pretensa decisão das Cortes relativa a d. Pedro seguir "incógnito" pela Europa, questionara: "Como querem despojar o Brasil do Desembargo do Paço e Mesa de Consciência e Ordens, Conselho da Fazenda e Junta do Comércio, Casa da Suplicação e de tantos outros Estabelecimentos novos que já prometiam futura Felicidade?"13 Afinal de contas, era mexer em algo como dois mil empregos que acomodavam muitos filhos da terra e, dentre estes, muitos baianos. ${ }^{14}$

Não fora à toa que dentre os signatários da Felicitação dos Baianos que hipotecavam apoio à permanência de d. Pedro no Brasil se encontravam personagens - já conhecidos nesta pesquisa - como José da Silva Lisboa, os conselheiros e desembargadores do Paço, Luís José de Carvalho e Melo e Antônio Luís Pereira da Cunha. Ao lado destes, subscreveram igualmente o documento: os brigadeiros Domingos Alves Branco Moniz Barreto (1748-1831) - que encabeçava a assinatura do texto - e Manuel Ferreira de Araújo Guimarães (1777-1838), o desembargador do Paço e Honorário e Ajudante do Procurador da Coroa e Fazenda Nacional, Clemente Ferreira França (1774-1827), futuro marquês de Nazaré, e o jurista José Joaquim Carneiro de Campos (1768-1836), depois marquês de Caravelas. ${ }^{15}$ Com esse gesto político, a maioria desses indivíduos incontestavelmente procurava consolidar atribuições de prestigiados interlocutores da classe senhorial em um intricado processo político que culminaria na formação do Estado e da nação brasileiros.

Embora numerosa, faz-se necessário que seja apresentada toda a relação dos baianos que, na corte carioca, articularam-se para firmar apoio ao governo do príncipe regente, pois, como se constatará ao longo deste capítulo, vários sobrenomes dos signatários arrolados, fornecem pistas do quanto foram atuantes as redes de sociabilidade entre a Bahia e o Rio de Janeiro nos anos precedentes à derrocada do Antigo Regime na América portuguesa. Ademais, é perceptível a existência de relações familiares e, quiçá, de compadrios nesta comunidade baiana que fora tentar a sorte na corte fluminense. A felicitação a d. Pedro constava também das seguintes assinaturas: Pedro Nolasco Pereira da Cunha; Manoel

\footnotetext{
${ }^{13}$ Carta do Governo de São Paulo de 24 de dezembro de 1824. In: Diário Constitucional, n. 4, terça-feira, 12 de fevereiro de 1822. Tipografia da Viúva Serva e Carvalho, 1821-1822. Exemplar da coleção do IEB/Usp.

${ }^{14}$ BERNARDES, Denis Antônio de Mendonça. O patriotismo constitucional: Pernambuco, 1820-1822. São Paulo: Hucitec: Fapesp. Recife: Ed. Universitária da UFPE, 2006. p. 499-500, nota 222.

${ }^{15}$ Felicitação dos Baianos residentes no Rio de Janeiro a S.A.R. In: Constitucional, n. 5, sábado, 20 de abril de 1822. Tipografia da Viúva Serva e Carvalho, 1821-1822. Exemplar da coleção do IEB/USP.
} 
Carneiro de Campos; Marcellino Antonio de Sousa; José de O’Freire; Antonio Alves Branco Moniz Barreto; João Pereira de Andrade; Alexandre Moreira de Sousa Requião; Francisco Manoel da Cunha; José Ignacio Pinto Bulhões; Francisco Pinto Ribeiro de Sousa; Caetano José Barbosa do Cauto Brum da Silveira Corte Real; João Pinto Lacerda; Manoel Rodrigues dos Reis; João Carneiro de Campos; Joaquim Antonio Nunes Cardoso; Candido Caldeira de Sousa; Padre Manoel Alves de Meneses; Antonio Martins da Costa; Pedro Afonso de Carvalho; José Tavares França; Anselmo Alves Branco Moniz Barreto; João Pedro Ladislau de Figueiredo Lobo; Frei Pedro Nolasco da Sacra Família; Frei Rodrigo de S. José; Francisco Carvalho dos Passos; Manoel Maria Cabral; João Baptista de Carvalho; José Maria de Carvalho; Manoel Pacheco da Silva; José de Sousa Coelho; Theófilo de Mello, Intérprete da Comissão Mista e Curador dos Libertos Minas; Francisco Joaquim Alves Branco Moniz Barreto; Ernesto Alves Branco Moniz Barreto; Domingos Cardoso Marquês; Carlos Carneiro de Campos; Lopo José de Albuquerque Maranhão; Luiz Antonio de Freitas; Manoel José Tavares Pereira Portugal; Capitão João Egidio Calmon. Francisco Cardoso Pereira de Melo; Vicente Porfirio Soares Serpa Nogueira; Eusébio Gomes Barreiros; Cônego Alexandre de Gusmão Sodré; José Bernardino Ribeiro Diniz, Nomeado Secretário do Governo Geral das Ilhas do Príncipe e S. Tomé e, finalmente, José Felix. ${ }^{16}$

Observa-se também que nos mesmos dias em que a consulta dos deputados da Bahia sobre a necessidade ou não de se estabelecer "uma delegação do Poder Executivo" no Brasil tornou-se conhecida em Salvador, aconteceu de a Câmara Municipal fluminense conferir a d. Pedro o título de "Defensor Perpétuo do Brasil", oficializando, assim, a criação daquele poder executivo. ${ }^{17}$ Pouco depois, reuniões ocorreram no Recôncavo baiano com o objetivo de congregar um maior número possível de proclamações a partir das vilas interioranas, produzindo, assim, um fato político que hostilizava as autoridades militares da capital e, por extensão, as últimas decisões tomadas pelas Cortes de Lisboa em relação ao Brasil. ${ }^{18}$

\footnotetext{
${ }^{16}$ Idem, ibidem. Os sobrenomes assinalados em itálico, em alguns casos, apontam e, em outros, simplesmente sugerem relações de parentesco com representantes da classe senhorial atuante na Bahia.

17 A ideia de delegar ao príncipe regente o título de Defensor Perpétuo do Brasil foi primeiro articulada "nos clubes maçônicos" do Rio de Janeiro, precisamente em uma sessão da loja Grande Oriente ocorrida em princípios de maio de 1822 quando o baiano Domingos Alves Branco Moniz Barreto apresentou essa proposta na expectativa de que facilitaria "organizar no Brasil um governo perpetuamente livre". Aprovada a sugestão, Joaquim Gonçalves Ledo e o padre Januário da Cunha Barbosa redigiram, na mesma sessão, o discurso a ser lido na Câmara Municipal pelo irmão maçônico e também presidente do senado camarário José Clemente Pereira; VARNHAGEN, Francisco Adolfo de, op. cit. p. 85 e 117. Sobre a atuação da maçonaria para a afirmação da Independência, ver o recente estudo de BARATA, Alexandre Mansur. Maçonaria, sociabilidade ilustrada e independência do Brasil. Juiz de Fora: Ed. UFJF. São Paulo: Annablume, p.171-248, 2006.

${ }^{18}$ Cf. SILVA, Ignácio Accioli de Cerqueira e, op. cit. v. 3. p. 343.
} 
Ao analisar a Bahia desse período, Luís Henrique Dias Tavares atesta que o rico proprietário de terras, escravos e engenho e capitão-mor Joaquim Inácio de Siqueira Bulcão (1768-1829), depois barão de São Francisco, fora um dos "mais comprometidos com o reconhecimento da autoridade do príncipe dom Pedro". Razão pela qual, ele andava, naqueles dias, "confirmando reuniões conspirativas para a decisão da data em que as vilas do recôncavo aclamariam o príncipe dom Pedro regente único do Reino do Brasil". ${ }^{19} \mathrm{O}$ testemunho coevo de Antonio Pereira Rebouças também dá conta de que "a maior parte da força de $1^{\text {a }}$ linha [...] emigrada da capital" depois dos combates de fevereiro de 1822 encontrara abrigo nas propriedades do "patriota capitão-mor Bulcão". ${ }^{20}$

Se, por um lado, existia uma articulação de forças no sentido de não permitir que as tropas lusitanas extrapolassem os limites urbanos de Salvador. Por outro, deve-se insistir que a fase de prosperidade econômica vivenciada pela Bahia, especialmente nos anos de 1790 a 1820, favorecera consideravelmente a presença dos portugueses europeus no interior, agudizando, naquele momento, as divergências e, com elas, a troca de informações e de experiências políticas. ${ }^{21} \mathrm{E}$, a despeito da classe proprietária do Recôncavo ter tentado acordar para que as declarações das vilas sobre o reconhecimento da autoridade de d. Pedro ocorressem simultaneamente, ${ }^{22}$ o processo foi antecipado quando, em 14 de junho, a Câmara da vila de Santo Amaro aprovou as suas respostas às indagações dos deputados com uma proclamação que, entre outras questões, requisitava:

Que haja no Brasil um centro único de Poder Executivo; que este Poder seja exercitado por sua Alteza Real o Príncipe Real, segundo as regras prescritas em uma liberal Constituição; e que a Sede do mesmo Poder seja aquele

\footnotetext{
${ }^{19}$ TAVARES, Luís Henrique Dias. Independência do Brasil na Bahia. Salvador: Edufba, 2005. p. 97.

${ }^{20}$ REBOUÇAS, Antonio Pereira. Recordações Patrióticas. 1821-22. Revista do Instituto Geográfico e Histórico da Bahia, n. 48, 1923. p. 493. Acompanhando a trajetória de diversos integrantes da classe dominante na Bahia de fins do Setecentos até a consolidação do processo de Independência, Frederic W. Orde Morton destacou a atuação de Joaquim Inácio de Siqueira Bulcão, considerando-o "o mais típico representante da classe fundiária" e ilustrada da sociedade baiana. Siqueira Bulcão estudara agricultura na França e na Inglaterra e, tanto no ensaio de sedição de 1798, quando nas lutas pela Independência na Bahia, esteve implicado em assuntos políticos. MORTON, F. W. O., 1974, op. cit. A citação encontra-se à página 182.

${ }^{21}$ SOUZA FILHO, Argemiro Ribeiro de. A guerra de Independência na Bahia: Manifestações políticas e violência na formação do Estado nacional (Rio de Contas e Caetité). Dissertação (Mestrado em História) Universidade Federal da Bahia, Salvador, 2003 e GUERRA FILHO, Sérgio Armando Diniz. O povo e a Guerra: Participação das camadas populares nas lutas pela Independência do Brasil na Bahia. Dissertação (Mestrado em História) - Universidade Federal da Bahia, Salvador, 2004.

${ }^{22}$ A data para que se processasse uma declaração conjunta das vilas do Recôncavo reconhecendo a autoridade de d. Pedro era possivelmente 29 de junho - dia da festa de São Pedro. BANDEIRA, Luiz Alberto Moniz. O feudo: A Casa da Torre de Garcia d'Ávila: da conquista dos sertões à independência do Brasil. Rio de Janeiro: Civilização Brasileira, 2000. p 404.
} 
lugar que mais útil for ao seu bom Regime e administração do Reino. ${ }^{23}$

No dia 12 de junho, a presença ostensiva das tropas lusitanas no entorno da Câmara Municipal de Salvador já havia impedido que os seus vereadores se reunissem, em razão da suspeita de que a sessão camarária prevista para aquela data seria antecedida pelo toque do sino convocando o "Povo" para efetuar a proclamação do príncipe regente como Defensor Perpétuo do Brasil. ${ }^{24}$

Depois dos acontecimentos de fevereiro de 1822, Madeira de Mello mandara estacionar - via o rio Paraguaçu - uma barca canhoneira em frente à vila de Cachoeira, visto a importância dessa vila, não apenas por ser o maior entreposto econômico do interior da província, mas também por se firmar como o principal abrigo dos dissidentes da capital. Desde 21 de abril, entretanto, o brigadeiro podia estar informado de que "esta mesma vila" também careceria "de uma força armada", se quisesse "conter [as] Cabeças esquentadas" que desejavam a "União com o Rio de Janeiro"; pois, naquelas circunstâncias, tornara-se impossível prever até quando as tropas de ordenanças e milícias continuariam sustentando a vontade das autoridades da capital. ${ }^{25}$ Enfim, essa era a segunda vez, em menos de uma semana, que o capitão-mor de Cachoeira, José Antonio Fiuza de Almeida, levava ao conhecimento de Madeira de Mello o estado de convulsão política vivenciado na vila sob seu comando, visto que, em 16 de abril, havia transmitido-lhe informações sobre a prevalência ali de "três partidos revolucionários, a saber, um de Brasileiros, outro de Europeus e o terceiro de Negros". ${ }^{26}$

\footnotetext{
${ }^{23}$ Ata de vereação do Senado da Câmara de Santo Amaro da Purificação, em 14 de junho. In: AMARAL, Braz do. História da Independência na Bahia. Salvador: Progresso, 1957. p. 198-201 (a citação encontra-se à página 199). Acerca da proclamação em Santo Amaro e o papel das Câmaras Municipais do Recôncavo no processo de Independência, ver também AMORIM, Deolino. A Independência do Brasil e as Câmaras do Recôncavo baiano. Revista do Instituto Geográfico e Histórico da Bahia, n. 74, p. 213-222, 1947. Para o desdobramento desse processo no Alto Sertão, ver SOUZA FILHO, Argemiro Ribeiro de, op. cit.

${ }^{24}$ Ata da Câmara de Salvador, em 15 de junho de 1822. Documentos da Municipalidade de Salvador relacionados com a Independência do Brasil. 1821-1823. Salvador: Prefeitura Municipal/Departamento de Cultura da SMEC, 1972. p. 61. A predisposição do Senado da Câmara de Salvador em celebrar a união com o Rio de Janeiro havia sido confirmada depois da sessão de $1^{\circ}$ de junho, quando a sua vereança mandou "cumprir e registrar" a portaria, de 10 de maio, expedida pelo ministro José Bonifácio de Andrada e Silva, na qual determinava que fossem empregados todos os recursos para assegurar a aclamação da regência d. Pedro na província. Cf. Sentinella Bahiense, n. 7, quarta-feira de 14 de agosto de 1822. Tipografia da Viúva Serva e Carvalho. Exemplar da coleção do Centro de Estudos Baianos da Universidade Federal da Bahia. Ver também SILVA, Ignácio Accioli de Cerqueira e, op. cit., v. 3. p. 352 e segs. e AMARAL, Braz do, 1957, op. cit., 179.

${ }^{25}$ Correspondência do capitão-mor de Cachoeira, José Antonio Fiuza de Almeida ao governador das armas, Inácio Luís Madeira de Mello, em 21 de abril de 1822. In: AMARAL, Braz do, 1957, op. cit. p. 190, nota 2. As informações de que a barca de guerra lusitana fora destacada para Cachoeira logo depois que a capital caíra sob o domínio das tropas de Portugal constam das Recordações Patrióticas. REBOUÇAS, Antonio Pereira, op. cit. p. 472 .

${ }^{26}$ Correspondência do capitão-mor de Cachoeira, José Antonio Fiuza de Almeida ao governador das armas, Inácio Luís Madeira de Mello , em 16 de abril de 1822. In: AMARAL, Braz do, 1957, op. cit. p. 189, nota 2. João José Reis analisou, com propriedade, as duas dimensões do partido negro durante as lutas pela
} 
Nenhuma dessas prevenções, no entanto, conseguiu impedir que a aclamação à autoridade de d. Pedro fosse, finalmente, celebrada na vila de Cachoeira, em 25 de junho, quando a Câmara Municipal foi tomada por uma grande assembleia composta por vereadores, representantes dos segmentos proprietários, do clero e dos militares para consultarem

ao povo e [à] tropa [...] se eram contentes que se aclamasse a S. A. R. o Sr. D. Pedro de Alcântara, por Regente e Perpétuo defensor e protetor do Reino do Brasil, assim, na forma que foi aclamado na cidade do Rio de Janeiro; e logo pelo povo e [pela] tropa que se achavam na praça foi respondido - que sim -; lançando o Procurador o estandarte [da Câmara para] fora das janelas todos houveram (sic) por aclamado a S. A. Real o Sr. D. Pedro, na forma acima dita [...], dando muitos e repetidos vivas a S. A. Real, com grande alegria, conservando-se esta Vila e todo o seu distrito debaixo da sujeição, e obediência das autoridades constituídas nesta Vila, e da mesma forma às autoridades constituídas na Capital da Província, logo que essas tenham aderido ao sistema da Corte do Rio de Janeiro, que acabamos de proclamar $[\ldots] .{ }^{27}$

Sabe-se, no entanto, que das casas dos portugueses europeus Manoel Machado Nunes e Antonio Pinto de Lemos Bastos partiram alguns disparos, acompanhados de descargas de artilharia efetuadas pela canhoneira lusitana, em direção aos manifestantes favoráveis à união política com o príncipe regente. Mas como essas iniciativas não causaram maiores danos, o entusiasmo moral dos opositores ao governo militar da capital recresceu não apenas entre os segmentos dominantes e os milicianos, mas porque envolveu "indivíduos de todas as classes", ${ }^{28}$ inclusive alguns portugueses europeus que, ativamente, se colocaram $a$ favor da causa adotada no Rio de Janeiro.

No dia seguinte, "foram convocadas as Autoridades Constituídas e Cidadãos conspícuos desta mesma Vila [de Cachoeira] e seu termo" para "tomarem medidas tendentes à sustentação" das "mudanças políticas" ali ocorridas. ${ }^{29}$ Convém observar, no entanto, que essa reunião, em forma de assembleia deliberativa, não ocorreria em um espaço público, mas na

Independência na Bahia. À primeira dimensão correspondia "uma construção ideológica da elite", enquanto a outra dava conta de "um fenômeno absolutamente real". Por isso, considerou essa segunda bastante significativa aos "vários grupos negros-mestiços de escravos, libertos ou homens livres que, cada qual à sua maneira, tentavam negociar uma participação no movimento da Independência, ou subverter a própria ordem escravocrata no calor do conflito luso-brasileiro". SILVA, Eduardo; REIS, João José. Negociação e conflito: a resistência negra no Brasil escravista. São Paulo: Companhia das Letras, 1989. p. 80.

${ }^{27}$ Termo de vereações da aclamação do Príncipe Real, regente, perpétuo, defensor e protetor do Brasil. In: MORAES, Alexandre de Mello. História do Brasil-Reino e do Brasil-Império. Belo Horizonte: Itatiaia; São Paulo: Ed. Universidade de São Paulo, 1982, t. 2. p. 128-130. A citação encontra à página 129.

${ }^{28}$ SILVA, Ignácio Accioli de Cerqueira e, op. cit., v. 3. p. 345-346.

${ }^{29}$ Ata de criação e instalação da Junta Conciliatória e de Defesa, em 26 de junho de 1822. In: REBOUÇAS, Antônio Pereira, op. cit. p. 482-484, nota 42. A citação encontra-se à página 483. 
casa do padre Navarro, situada à praça do hospital S. João de Deus, onde foi decidida a criação de uma

"Junta Interina, Conciliatória e de Defesa", com tratamento de Mercê, tendo toda a Jurisdição necessária para conciliar entre si e defender de qualquer agressão os habitantes desta Vila, com superioridade às autoridades militares e [ao] povo, que ficam desde já obrigados, bem como o mesmo povo a obedecê-la às suas ordens; e isto somente durante a existência da mesma Junta, que se estenderá até quando as autoridades da Capital da Província reconhecerem e anuírem a Aclamação de Sua Alteza Real dando estas inteiro cumprimento a todas as ordens que dimanarem da Corte do Rio de Janeiro. ${ }^{30}$

Ainda nessa mesma assembleia, "procedeu-se a eleição" para composição da Junta

Conciliatória e de Defesa, sendo, com "votos por aclamação", nomeados para as funções de:

Presidente, o patriota, capitão [de milícia], Antonio Teixeira de Freitas Barbosa, vereador da Câmara Municipal, abastado negociante e proprietário urbano e rural; Secretário, Antonio Pereira Rebouças, e vogais, o patriota, capitão mandante das ordenanças, José Paes Cardoso da Silva, rico proprietário, o patriota [padre] Manoel José de Freitas, professor de cadeira pública de gramática e língua latina, e, o capitão das ordenanças, Antonio José Alves Bastos, proprietário e comerciante muito bem conceituado: este dois últimos naturais de Portugal. ${ }^{31}$

Essa Junta tornara-se mais completa pela aceitação do coronel José Garcia Pacheco de Moura Pimentel e Aragão no posto de "comandante-em-chefe de toda a força militar e no exercício das funções de governador das armas". 32 Os integrantes desse "governo" organizaram uma caixa de despesas militares para manutenção da tropa reunida no Recôncavo, as quais garantiam a autoridade do príncipe regente na Bahia. Depois de ser avariada pelos combatentes, a barca canhoneira se rendeu na noite do dia 28 de junho. Toda a sua tripulação - vinte e oito pessoas, das quais seis feridas - acabou, então, prisioneira e, possivelmente, teve como companhia de cadeia os mencionados portugueses europeus que no interior da vila quiseram resistir à aclamação de d. Pedro. Deve-se ainda realçar que a canhoneira lusitana não somente seria definitivamente subtraída do governo de d. João, como teria as suas peças de artilharia retiradas e espalhadas em pontos estratégicos de defesa pelo

\footnotetext{
${ }^{30}$ Idem, ibidem. p. 484.

${ }^{31}$ Idem, ibidem. p. 482. Sobre os componentes e as motivações para criação da Junta Conciliatória e de Defesa, ver também SILVA, Ignácio Accioli de Cerqueira e, op. cit., v. 3. p. 347.

${ }^{32}$ REBOUÇAS, Antônio Pereira, op. cit. p. 483-484.
} 
Recôncavo, ainda que no momento da captura estivesse tremulando no seu pavilhão uma bandeira da nação portuguesa. ${ }^{33}$

É curioso, igualmente, observar que os membros da "Junta Interina”, à imitação dos revolucionários franceses de 1789, deveriam receber o "tratamento de Mercê", o que denota uma tentativa de nivelamento das hierarquias sociais existentes. ${ }^{34}$ Esse horizonte de expectativa parece ter sido introduzido na ata de fundação da Junta pelo seu secretário, o mulato Antonio Pereira Rebouças. Nas Recordações patrióticas, ele referiu-se à maioria dos antigos colegas de governo chamando-os de "patriota", como verificado acima. Baiano da também próspera vila de Maragogipe, Pereira Rebouças contava com vinte e três anos de idade, quando, em 21 de fevereiro, emigrara "com sua mãe e cinco irmãs" para o Recôncavo, deixando atrás de si "os lusitanos armados, hostilmente assenhoreados" da cidade-porto da Bahia. ${ }^{35}$ Autodidata disciplinado e afeito às ideias liberais, em 1820 havia impetrado petição ao Tribunal do Desembargo do Paço no Rio de Janeiro para o exercício da função de advogado provisionado (rábula). Submeteu-se ao exame e foi então aprovado, podendo, assim, atuar em toda a província baiana. ${ }^{36}$

\footnotetext{
${ }^{33}$ Idem, loc cit. e SILVA, Ignácio Accioli de Cerqueira e, op. cit., v. 3. p. 347.

${ }^{34}$ Ata de criação e instalação da Junta Conciliatória e de Defesa, em 26 de junho de 1822. In: REBOUÇAS, Antônio Pereira, op. cit. p. 482-484, nota 42. As citações encontram-se à página 483.

${ }^{35}$ REBOUÇAS, Antônio Pereira, op. cit. p. 468-469. Nascido em 10 de agosto de 1798, Antonio Pereira Rebouças era o caçula dos nove filhos gerados da união legal entre o português europeu, branco e alfaiate, Gaspar Pereira Rebouças e a mulata liberta Rita Brasília dos Santos, natural de Salvador. No momento em que emigrara da capital com a sua mãe e as cinco irmãs - Escolástica, Luíza, Maria, Anna Rita e Eugênia Rebouças , Antonio ia também ao encontro do seu irmão Manoel Maurício que, em Cachoeira, exercia o ofício de escrevente de cartório. Na fazenda do Caminhoá, situada no povoado de Cruz das Almas (Recôncavo), estava o seu pai, já em idade avançada. Seu outro irmão, Manoel Pereira, emigrara da capital logo depois da organização da Junta Conciliatória e de Defesa. Manoel serviu por algum tempo na função de comissariado de boca das tropas defensoras da autoridade do príncipe regente e, depois disso, ingressou no batalhão de $1^{\mathrm{a}}$. linha n. 3 (Periquitos), na condição de soldado. Finalmente, sobre José Pereira Rebouças, filho mais velho do casal Gaspar e Rita Brasília, não se sabe, ao certo, nem onde habitava, nem se tomara parte ou não do processo de Independência. Entretanto, por algum tempo José esteve a serviço das tropas. Cf. REBOUÇAS, Antônio Pereira, op. cit. p. 469, nota 42. Para a trajetória política e social de Antonio Pereira Rebouças, ver PONTES, Kátia Vinhático, op. cit. Cap. 4 e GRINBERG, Keila. O fiador dos brasileiros: cidadania, escravidão e direito civil no tempo de Antônio Pereira Rebouças. Rio de Janeiro: Civilização Brasileira, 2002.

${ }^{36}$ Embora o filho caçula da liberta Rita Brasília continuasse ampliando as suas projeções intelectuais, políticas e sociais, o que ele tinha, em comparação a muitos ao seu redor naqueles dias vividos em Cachoeira, não era "prestígio por família e riqueza", mas uma certa dose de talento e grande obstinação com os quais aproveitaria para forcejar, com sucesso, diversos e recalcitrantes entraves de uma sociedade escravista em visível mudança. REBOUÇAS, Antônio Pereira, op. cit. p. 469. Cf. GRINBERG, Keila, op. cit. p. 69. Participando ativamente da vida política na província e na capital imperial - onde por várias legislaturas exerceu a função de deputado do Império -, a trajetória de Antonio Pereira Rebouças tornava-se, inegavelmente, um resultado-síntese da Era das Revoluções, posto que era um mulato que apostava na meritocracia como recurso para a superação do preconceito racial, o qual adquiria concretude na sociedade oitocentista, a partir dos anos 1820. Indo à corte do Rio de Janeiro, em 12 de outubro de 1823, ele recebeu do imperador d. Pedro a condecoração de Cavaleiro da Imperial Ordem do Cruzeiro e a nomeação para o cargo de Secretário do Presidente de província de Sergipe, função que passou a exercer em 1824. Nesse novo posto teria sustentado que: "[...] todo homem pardo, ou preto pode ser General". Posições contrárias ao privilégio de raças serviram para incompatibilizá-lo com os mais poderosos representantes das classes dominantes locais. Apud PONTES, Kátia Vinhático, op. cit. p. 126
} 
Depois de ter acomodado sua família em Maragogipe, onde a acolhida contou com a solidariedade de parentes paternos, Pereira Rebouças seguiu para Cachoeira. Ali conseguira "uma boa casa na Praça Municipal”, mas, faltando mobiliário e, presumivelmente, algum conforto financeiro para adquiri-lo, decidiu retornar "clandestinamente" à capital, onde embarcou os "móveis indispensáveis" que extraíra da sua antiga residência. De volta à vila, apresentou ao juiz de fora e presidente da Câmara Municipal, Antonio Cerqueira Lima, o documento provisional que lhe permitia advogar, razão pela qual, ficou logo "estabelecido no exercício de sua profissão de advogado no Foro da Vila de Cachoeira". ${ }^{37}$

Nessa "populosa" praça, contava com a amizade de algumas famílias proprietárias. O reencontro com antigos conhecidos que também emigraram da capital potencializava as suas possibilidades de sustento, em um período no qual a construção de alternativas políticas e institucionais de enfrentamento à autoridade das Cortes de Lisboa se revelava bem mais atrativa do que a defesa dos clientes particulares, posto que havia uma causa comum a ser atingida e financiamentos para isso não deixariam de aparecer.

Além disso, o autor das Recordações patrióticas não era um principiante na resistência ao projeto liberal que se tornara preponderante nas Cortes de Lisboa em meados de 1821. De acordo o seu relato autobiográfico, fora um dos partícipes da sublevação contra a primeira Junta Governativa da Bahia. Reportou-se às reuniões preparatórias, aos instantes em que a praça e as áreas internas da Câmara Municipal de Salvador e do Palácio de Governo foram tomadas pelos manifestantes e, ainda, como se processou a reação das autoridades que

(grifos da autora). Assim, Rebouças viu-se obrigado a regressar à província baiana no mês de fevereiro do ano seguinte. Em Salvador, fundaria o jornal O Baiano (1828-1831) e disposto a continuar na ardorosa defesa dos princípios liberais, especialmente dos direitos constitucionais, teria sérios embates políticos com antigos companheiros das lutas pela Independência, mas que, naquele momento, representavam os interesses do governo de d. Pedro, cuja sua aceitação ao constitucionalismo deixava margens a questionamentos. Dentre essas autoridades que, a partir da Bahia, contrapor-se-iam às posições de Rebouças estaria o próprio presidente da província José Egídio de Gordilho de Barbuda (1827-1830), personagem do qual se suspeitava integrasse o "Gabinete Secreto" que, tinha por objetivo, suscitar meios para a restauração do governo absoluto sob a liderança do imperador. Cf. SILVA, Daniel Afonso da. Histórias de Bahia. Histórias de Brasil. Apontamentos para o estudo da crise política do Primeiro Reinado na Bahia (1828-1831). Dissertação (Mestrado em História) Universidade de São Paulo, São Paulo, 2007. Cap. 2 e 4. A denúncia sobre as ramificações na Bahia do "Gabinete Secreto", subordinado ao imperador, foi apontada por Cipriano Barata. Manifesto que ao respeitável público apresenta o cidadão Cypriano José Barata de Almeida sobre a sua súbita, tyranna razão na Bahia, e remessa violenta para esta corte, onde se acha prezo. Com várias ideias úteis ao Brazil inteiro, \&c. \&c., Rio de Janeiro, 20 de julho de 1831. Rio de Janeiro: Typographia de Torres, anno de 1831. Exemplar pertencente à Fundação Clemente Mariani - Salvador-BA. p. 7. A figura controversa de Gordilho de Barbuda será discutida adiante.

${ }^{37}$ REBOUÇAS, Antônio Pereira, op. cit. p. 471-472. Para o transporte de ida e vinda da capital, Pereira Rebouças serviu-se da barca a vapor, "a primeira introduzida na província e também no Brasil", em 1818, pelo rico proprietário e brigadeiro Felisberto Caldeira Brant Pontes de Oliveira Horta. Idem, ibidem. p. 471. 
culminara nas prisões do dia 3 de novembro, narrando estes fatos sempre na terceira pessoa. ${ }^{38}$ Coerente para com a "verve legalista que o caracterizou em toda sua trajetória política",39 Pereira Rebouças sustentou ainda que, quando das reuniões conspiratórias, defendera, por mais de uma vez, a eleição de uma nova Junta, por entender ser esse o meio mais legítimo de substituir aquele governo. Em defesa de um procedimento o mais próximo possível da legalidade chegara a dizer que: "Não menos bem lhe pareceu que se deixasse de ter feito uma proclamação em regra, e se estivessem espalhando quartos de papel escrito por João Primo".40 Mas, enfim:

Sem prestígio de família e riqueza, achando-se na idade de 23 anos, apenas advogado por provisão do Tribunal do Desembargo do Paço, era o advogado Rebouças tão somente acreditado por poucas pessoas que o conheciam de perto. Não foi, pois atendido nem estava em posição de dar eficácia à sua reclamação, e, entretanto, lá se foram os militares todos e alguns paisanos descendo as escadas do salão da Câmara, atravessando a praça e entrando para o Palácio do governo. ${ }^{41}$

Parece crível admitir que a instituição formal do "tratamento de Mercê" para com as autoridades constituídas tinha por objetivo mitigar as senhorias, as diferenças hierárquicas, e que à frente dessa iniciativa encontrava-se o secretário do "governo" instalado em Cachoeira. $^{42}$ Isso evidencia, portanto, que, já naquela época, Pereira Rebouças buscava alternativas para assegurar aos mulatos livres ou libertos os mesmos direitos que regiam o mundo dos brancos. ${ }^{43}$

\footnotetext{
${ }^{38}$ Ibidem. p. 460-461. Para Grinberg, ao utilizar esse recurso linguístico, Pereira Rebouças tinha por objetivo emprestar um sentido épico às suas ações, torná-las heróicas. GRINBERG, Keila, op. cit. p. 72. Salienta-se também que Pereira Rebouças, não fez uso do tratamento de patriota para as "pessoas notáveis" que, assim como ele, participaram das "reuniões" e "conferências" e, por fím, da sublevação de 3 de novembro. Reservou essa distinção somente para lideranças que contribuíram para a aclamação da regência e instalação da Junta Conciliatória em Cachoeira ou porque o tratamento de Mercê só fora convencionado com a aceitação da Ata de Instalação da Junta, em 26 de junho, ou não encontrara motivos que justificassem as atuações daqueles seus parceiros anteriores como as mais apropriadas a um patriota. Lembrando novamente, que, ao menos, para com um ex-sublevado, no caso o brigadeiro Gordilho de Barbuda, o autor das Recordações patrióticas veio a ter diferenças consideráveis. Cf. Idem, ibidem. p. 460.

${ }^{39}$ GRINBERG, Keila, op. cit. p. 71-72.

${ }^{40}$ REBOUÇAS, Antônio Pereira, op. cit. p. 462.

${ }^{41}$ Idem, ibidem. p. 463.

${ }^{42}$ Contudo, a menção de "tratamento de Mercê" para as autoridades governamentais parece ter constado tãosomente na ata de criação da Junta Conciliatória e de Defesa. De forma que, passados quase dez anos, o mordaz Cipriano Barata atestava: "Tudo na Bahia são Excelências, Senhorias e Dons, causando riso tanta presunção e orgulho tolo: eu tratei esta gente de bobos (tratamento bem merecido em todo o Brasil)". Manifesto que ao respeitável público apresenta o cidadão Cypriano José Barata de Almeida sobre a sua súbita, tyranna razão na Bahia, e remessa violenta para esta corte, onde se acha prezo. Com várias ideias úteis ao Brazil inteiro, $\& c . \& c .$, op. cit. p. 10 (Grifo do autor).

${ }^{43}$ Para a persistente defesa de Pereira Rebouças contra a discriminação racial, assim como a sua concepção da sociedade escravista fortemente atada ao direito de propriedade, ver GRINBERG, Keila, op. cit. Não se pode
} 
Quanto à justificativa para a criação da Junta Conciliatória e de Defesa, Rebouças considerou-a como o melhor meio "de conciliar os ânimos e de manter a causa da pátria a todo o transe contra quem quer que hostilmente a agredisse". ${ }^{44}$ Entretanto, este "governo" não ficaria restrito a simples defesa dos cachoeiranos, como inicialmente se dizia, visto que uma das suas primeiras ações foi encaminhar mensagens às diferentes vilas e povoações baianas noticiando a aclamação do príncipe regente e o conflito então vivenciado pelos habitantes de Cachoeira decorrente do envio de uma barca de guerra pela capital.

Outras preocupações contribuíram para que um poder governativo fosse logo organizado no Recôncavo, dentre as quais se destacava a apreensão por parte da classe proprietária das contradições da sua resistência para com as autoridades militares da capital que poderiam agudizar as tensões da sociedade escravista, como já referido. Ignácio Accioli também viu no temor de uma "próxima anarquia", a motivação para a rápida instalação de uma autoridade superior em Cachoeira. ${ }^{45}$ Nesse sentido, fica reiterada a hipótese de que a rebeldia da classe proprietária não apenas na Bahia, mas em toda a América portuguesa desse período, esbarrava em uma questão balizar, qual seja: superar a crise sistêmica do Antigo Regime e adentrar na fase de progresso da Era Moderna sem suscitar uma revolução social. ${ }^{46}$ As Recordações patrióticas robustecem a proposição de que o influxo popular acompanhava,

esquecer que, naquele período, começara a vir a público um forte debate envolvendo as questões da escravidão e, por extensão, as do mundo do trabalho. Para esse último caso, o horizonte de expectativa que movia grande parte da classe senhorial era construir, em termos ideológicos, a identidade dos mulatos e demais mestiços - habitantes do Brasil - fundada na disposição natural para o trabalho, pois sabiam que, mais dia menos dia, a depender da pressão internacional, a abolição da escravidão iria concretizar-se. Empenhados nesse debate estavam algumas figuras de proa da chamada geração ilustrada da Independência. Embora não tivesse escrito uma memória sobre o tema, Pereira Rebouças tornou-se, pela sua forte atuação política e parlamentar, um protagonista dessa discussão, destacando-se na defesa de uma perspectiva distinta da hegemônica, posto que alicerçada no mérito pessoal e não em privilégios raciais, como já mencionado. Dentre os principais memorialistas sobre a escravidão nos anos de 1820 e 1830, encontravam-se: COSTA, João Severiano Maciel da. Memória sobre a necessidade de abolir a introdução de escravos no Brasil, sobre o modo e condições com que esta abolição se deve fazer e sobre os meios de remediar a falta de braços que ela pode ocasionar (Publicada em Coimbra no ano de 1821). In: COSTA, João Severiano Maciel da et al. Memórias sobre a escravidão. Introdução Graça Salgado. Rio de Janeiro: Arquivo Nacional; Brasília: Fundação Petrônio Portella, Ministério da Justiça, 1988; SILVA, José Bonifácio de Andrada e. Representação à Assembleia Geral Constituinte e Legislativa do Império do Brasil sobre a escravatura (Publicada no Rio de Janeiro, em 1823). In: COSTA, João Severiano Maciel da et al, op. cit. p. 63-77 e BARRETO, Domingos Alves Branco Moniz. Memória sobre a abolição do comércio da escravatura (Publicada na década de 1830). In: COSTA, João Severiano Maciel da et al, op. cit. p. 79-99. Para a construção ideológica do mundo do trabalho no Brasil oitocentista, ver MATTOS, Ilmar Rohloff de. O tempo Saquarema: A formação do Estado Imperial. 3. ed. Rio de Janeiro: Access, 1994. p. 103 e segs.

${ }^{44}$ REBOUÇAS, Antônio Pereira, op. cit. p. 482.

${ }^{45}$ SILVA, Ignácio Accioli de Cerqueira e, op. cit., v. 3. p. 347.

${ }^{46}$ Sobre a postura política das classes dominantes no processo de formação do Estado nacional brasileiro, ver MOREL, Marco. As transformações dos espaços públicos: Imprensa, atores políticos e sociabilidades na cidade imperial (1820-1840). São Paulo: Hucitec, 2005. Para uma discussão sobre a noção de Progresso e Revolução no contexto da Era Moderna, consultar KOSELLECK, Reinhart. Futuro Passado: contribuição à semântica dos tempos históricos. Rio de Janeiro: Contraponto: Ed. PUC-Rio, 2006. E no que diz respeito à perspectiva revolucionária na Bahia desse período, ver MORTON, F. W. O., 1974, op. cit. 
pari passu, as "mudanças políticas" ocorridas na província baiana de princípios dos anos 1820:

Assim como a barca canhoneira lusitana, estacionada no porto da Vila da Cachoeira, servia de incentivo à propaganda patriótica, também a numerosa ordenança, reunida na mesma Vila da Cachoeira ao comando do capitãomor [José Antonio] Fiuza [de Almeida], no intuito de fazer a polícia preventiva, de qualquer movimento popular, serviu para que os patriotas atraíssem ao seu partido essa multidão de habitantes, vindos de lugares próximos e remotos das roças e [dos] sertões para estarem mal aquartelados e cruzarem alternadamente as ruas, noite e dia, ausentes de todos os seus habituais interesses de cultura dos campos, criação e comércio de aves e gados de diferentes espécies. ${ }^{47}$

Nesse contexto, as vilas de Maragogipe, São Francisco do Conde e Inhambupe todas situadas no Recôncavo - efetivaram concomitantemente as aclamações ao príncipe regente. É significativo também notar que uma parcela importante das classes proprietárias locais tenha se revelado cada vez mais disposta a congregar-se politicamente com as vilas de Cachoeira, Santo Amaro e São Francisco para, em conjunto, formar uma ampla junta governativa com a qual pudesse controlar "a efervescência e confusão que agitava o Recôncavo". ${ }^{48}$ Para o Senado da Câmara dessa última vila, a concorrência de outros projetos políticos no interior da sociedade escravista tornava-se evidente, razão pela qual, em 29 de junho de 1822, registrara:

A tropa e [os] cidadãos desta Vila e [do] seu Distrito, desejando, no deplorável estado de fermentação em que se acha tanto a cidade [Salvador] como o Recôncavo da Bahia, prevenir que algum espírito mal intencionado possa romper em excessos anárquicos, ou desviar-se do sistema monárquico constitucional que temos jurado manter, cujo perigo em verdade é iminente, sendo como estão convencidos de que nenhum outro meio há mais eficaz para tranquilizar o espírito público do que seja satisfazer ao voto geral que tem por fim reverter à regência de S.A.R. e anuir à causa abraçada pela maioria das Províncias do sul e norte do Brasil.

Como já pela Câmara e [pelos] cidadãos desta Vila foi declarado na sessão extraordinária de 20 do corrente mês, em resposta aos quesitos dos nossos ilustres deputados, requerem a este nobre Senado que declare para todo o tempo constar:

$1^{\text {o }}$ que esta Vila e seu Distrito se consideraram desde já unidas à causa adotada pelas Províncias coligadas do Brasil.

$2^{\circ}$ que os seus habitantes reconhecem à S.A.R., o senhor D. Pedro de Alcântara, Príncipe do Reino Unido, como Regente Constitucional do

${ }^{47}$ REBOUÇAS, Antônio Pereira, op. cit. p. 473.

${ }^{48}$ Termo de vereação da Câmara da Vila de S. Francisco para a aclamação do Príncipe Real, regente e defensor perpétuo do Brasil. In: MORAES, Alexandre de Mello, op. cit., t. 2. p. 133-135. A citação encontra-se à página 134. 
Brasil, por seu Augusto Pai, El-Rei o Senhor D. João VI e o reclamam seu perpétuo defensor. ${ }^{49}$

Ainda assim, a Câmara Municipal de São Francisco transmitiria uma cópia autêntica das decisões acima à Junta Provincial instalada na capital, certificando-lhe que "os povos desta Vila e seu termo não alteraram o regime atual e a administração desta Província". ${ }^{50}$ Mas, era evidente que estava a um passo de fazê-lo.

Salienta-se também que naqueles dias o próprio d. Pedro já havia intimado ao brigadeiro Inácio Luís Madeira de Mello para que reunisse toda a tropa sob o seu comando e retornasse com ela a Portugal. ${ }^{51}$ Em seguida, o príncipe cuidou de proclamar aos baianos para tomarem parte na "marcha gloriosa das províncias coligadas" e entoarem com as mesmas os "vivas à Independência moderada do Brasil", ao rei d. João VI, e à "Assembleia Geral Constituinte e Legislativa do Reino do Brasil" (convocada em 3 de junho). ${ }^{52}$ Se Madeira de Mello revelou-se decidido a desobedecer as ordens do herdeiro de Bragança, não tinha porque condescender com as vilas do Recôncavo. Ao contrário, ele tratou logo de informar à Junta Provincial que somente o uso da força contra os sediciosos da província poderia conservar o juramento feito a Constituição. ${ }^{53}$ Tudo isso indicava que os confrontos militares entre as autoridades concorrentes da capital e do interior baiano se tornariam cada vez mais frequentes, o que levava ambos os lados a intensificar suas organizações político-militares.

Em fins de abril de 1822, os dissidentes que tentaram destituir a antiga Junta Governativa da capital se livraram das acusações em Lisboa e, com isso, puderam retornar às suas atividades na Bahia. ${ }^{54}$ Companheiros de sedição e de cadeia, essas lideranças encontravam-se ainda mais articuladas quanto ao projeto político que pretendiam ajudar a implantar no Brasil. A estratégia adotada por eles em seu regresso à província demonstra uma vivacidade e experiência que merece destaque, pois, ao invés de se apresentarem nas áreas do Recôncavo em resistência, o grupo curiosamente dividiu-se em dois.

\footnotetext{
${ }^{49}$ Termo de vereação da Câmara da Vila de S. Francisco para a aclamação do Príncipe Real, regente e defensor perpétuo do Brasil. In: MORAES, Alexandre de Mello, op. cit. t. 2. p. 133-134.

50 Termo de vereação da Câmara da Vila de S. Francisco para a aclamação do Príncipe Real, regente e defensor perpétuo do Brasil. In: MORAES, Alexandre de Mello, op. cit. t. 2. p. 134.

51 Ofício do Príncipe Regente D. Pedro ao brigadeiro Inácio Luís Madeira de Mello, de 15 de junho de 1822. In: SILVA, Ignácio Accioli de Cerqueira e, op. cit., v. 3. p. 333-334.

52 Proclamação do Príncipe Regente D. Pedro aos baianos, de 17 de junho de 1822. Catálogo de decretos do Governo da província. Arquivo Público do Estado da Bahia - APEB. Seção de Arquivo Colonial e Provincial. Data: 17/06/1822. Maço: 626-14.

53 Correspondência do brigadeiro Inácio Madeira de Mello à Junta de Governo da Bahia em 30 de junho de 1822. In: AMARAL, Braz do, 1957, op. cit. p. 215.

${ }^{54}$ Diário Constitucional, n. 32, sábado, 22 de junho de 1822. Tipografia da Viúva Serva e Carvalho, 1821-1822. Exemplar da coleção do IEB/Usp.
} 
O primeiro agrupamento teve, entre seus principais membros, o tenente-coronel Felisberto Gomes Caldeira; o capitão e ajudante de ordens Antonio Maria da Silva Torres; o coronel e ajudante de ordens do governo Salvador Pereira da Costa; o sargento-mor do regimento de artilharia de linha José Elói Pessoa da Silva; os sargentos-mores da legião de caçadores José Gabriel da Silva Daltro e Francisco da Costa Branco; o primeiro-tenente da armada João Francisco de Oliveira (João das Botas) e, finalmente, o cadete de cavalaria Inácio de Matos Teles de Menezes. Depois de trinta e quatro dias de viagem em uma corveta de guerra, esses homens chegaram à cidade de Salvador em 16 de junho, ${ }^{55}$ portando um ofício de d. João VI endereçado à Junta Provincial, o qual dava conta de que as Cortes Gerais "concederam anistia a todas as pessoas que se acharem [sic] compreendidas na devassa a que se procedeu [...] pela tentativa [...] para depor os membros que, então, compunham a Junta Provisória de Governo". 56

Colaborando para dirimir as dúvidas, tanto no que dizia respeito à anulação dessas acusações, quanto no retorno dos militares aos seus antigos postos na guarnição, de tudo deu notícia o Diário Constitucional em sua edição de 22 de junho de 1822. Além do mais, como o regresso dos anistiados pelas Cortes lisboeta não estava completo, havendo outros sobreviventes da malfadada insurreição, divulgou-se na mesma edição do periódico que o restante do grupo aportaria na capital a qualquer momento, por ter ficado em Portugal à espera de "outra embarcação próxima a partir". 57

Possivelmente sob o argumento de que haviam sido injustamente perseguidos em razão de causas políticas, ao desembarcarem em Salvador, os militares dirigiram-se à vedoria geral das tropas para reaver seus soldos, atrasados desde, pelo menos, novembro do ano anterior. Não havendo acusações de outra ordem, certamente tiveram esse pleito, integral ou parcialmente, satisfeito. Mas qual não deve ter sido a exasperação dos que dominavam a capital quando, nos dias seguintes, deram-se conta das deserções desses oficiais, cuja imensa

\footnotetext{
${ }^{55}$ Idem, Ibidem. Para todas as lideranças citadas existem referências documentais acerca dos serviços prestados às tropas que combateram os lusitanos ao longo da Guerra de Independência na Bahia. Por esse critério, seus nomes e postos foram citados no parágrafo acima. Os demais componentes do agrupamento ora analisado, foram o capitão adido ao Estado-Maior João de Souza Neto; o tenente de artilharia montada Francisco Manoel Rodrigues; o capitão de cavalaria Luís Antonio Horta; o ajudante de cavalaria da legião de caçadores Manoel Marquês Cardoso; o segundo-tenente da artilharia montada Herculano Antonio Pereira Lisboa e João Carneiro da Silva Rego. Sobre a participação de boa parte das lideranças assinaladas no processo de Independência, ver SILVA, Ignácio Accioli de Cerqueira e, op. cit., v. 3. p. 363. AMARAL, Braz do, 1957, op. cit. TAVARES, Luís Henrique Dias, 2005, op. cit. e SOUZA FILHO, Argemiro Ribeiro, op. cit.

${ }^{56}$ Ofício de d. João VI à Junta de Governo da Bahia, em 30 de abril de 1822. In: Diário Constitucional, n. 32, sábado, 22 de junho de 1822. Tipografia da Viúva Serva e Carvalho, 1821-1822. Exemplar da coleção do IEB/Usp.

${ }^{57}$ Idem, Ibidem.
} 
maioria logo estaria reunida às classes senhoriais do interior baiano para colaborar na guerra contra os portugueses europeus. ${ }^{58}$

No que diz respeito ao segundo grupo, os indícios são de que seguiu, de início, para a cidade fluminense. Numericamente, era um pequeno grupo, reunindo cinco militares e o feitor da alfândega da Bahia. Em termos da capacidade de liderança política desses homens, é possível acompanhar as atuações do tenente-coronel José Egídio Gordilho de Barbuda e do secretário do $1^{\mathrm{o}}$ regimento de $2^{\mathrm{a}}$ linha Francisco José da Silva Castro. Para esses dois anistiados, pode-se asseverar que, saindo de Lisboa, foram ao Rio de Janeiro, onde não apenas participaram da vida política da corte, como estabeleceram contatos com eminentes autoridades ali reunidas para, somente, então, regressar à Bahia em fins de $1822 .^{59}$

Natural da cidade do Porto, José Egídio Gordilho de Barbuda, futuro visconde de Camamu, dedicou-se aos estudos preparatórios para o Exército e assentou praça na Ilha da Madeira, onde ascendeu ao oficialato em 1808. No ano seguinte, talvez inspirado no exemplo de muitos dos seus conterrâneos, foi habitar na nova e promissora sede do Império português. Na corte fluminense, Gordilho de Barbuda ingressou no primeiro regimento de cavalaria e, em 1810, recebeu a patente de tenente na legião de caçadores da Bahia, indo, então, residir em Salvador. Ainda desconheço se essa promoção e transferência tiveram relação com os duradouros laços de amizade que o futuro visconde de Camamu firmara com o conde dos Arcos, o qual, depois de ter sido vice-rei do Brasil, fora, como já observado, capitão-general da capitania baiana, cujo começo da administração coincide com a chegada de Gordilho de Barbuda à Bahia. O certo, no entanto, é que ele, sempre muito ativo pela ascendência no aparelho burocrático do Estado, logo foi elevado aos postos de major e de capitão, vindo também a ser ajudante de ordens do novo governador. ${ }^{60}$

Depois da repressão aos rebeldes de 1817, Gordilho de Barbuda adquirira fama, seja por ter sido um dos mais sanguinários auxiliares do conde dos Arcos na exterminação dos pernambucanos e demais integrantes das capitanias anexas (Alagoas, Paraíba e Piauí), seja

\footnotetext{
${ }^{58}$ Cf. SILVA, Ignácio Accioli de Cerqueira e, op. cit., v. 3. p. 363 e TAVARES, Luís Henrique Dias, 2005, op. cit. p. 119.

${ }^{59}$ Os demais componentes desse agrupamento foram o capitão ajudante de cavalaria João Antonio Maria; o alferes de cavalaria José Francisco d'Essa e Pinho; o capitão Felipe Justiniano Costa Ferreira e o feitor da alfândega da Bahia José Soares. As informações sobre a conquista das suas liberdades constam do Diário Constitucional, n. 32, sábado, 22 de junho de 1822. Tipografia da Viúva Serva e Carvalho, 1821-1822. Exemplar da coleção do IEB/Usp.

${ }^{60}$ Para informações biográficas e vida político-militar do futuro visconde de Camamu, ver SILVA, Ignácio Accioli de Cerqueira e, op. cit., v. 4. p. 290 e passim; WISIAK, Thomas. A 'Nação partida ao meio': tendências políticas na Bahia na crise do Império luso-brasileiro. Dissertação (Mestrado em História) - Universidade de São Paulo, São Paulo, 2001. p. 79; SOUZA FILHO, Argemiro Ribeiro, op. cit. Consultar o cap. 3; SILVA, Daniel Afonso da, op. cit. p. 25 e SOUSA, Maria Aparecida Silva de. Bahia: de capitania a província, 1808-1823. Tese (Doutorado em História Social) - Universidade de São Paulo, São Paulo, 2009. Caps. 2 e 4.
} 
porque já havia quem supunha que a ambição desse militar correspondia à sua índole de "homem degenerado, ávido de dinheiro e conhecido por exações inauditas". ${ }^{61}$ Com a vitória da Revolução Constitucionalista na Bahia, ele procurou, mais do que depressa, a exoneração do cargo de ajudante de ordens do governador, também exercido na administração do conde da Palma (1818-1821). Mas isso não implicou necessariamente em perda de posição, pois, em maio de 1821, Gordilho de Barbuda dava mais um passo em direção ao topo da carreira militar, sagrando-se tenente-coronel da cavalaria. ${ }^{62} \mathrm{E}$, assim como tantos outros portugueses europeus, via-se recompensado pela vitória do governo constitucional na província. $\mathrm{Na}$ opinião pública em desenvolvimento, porém, a conduta política do futuro visconde de Camamu já era considerada muito controvertida, bem à semelhança do que acontecia com o seu patrono e amigo conde dos Arcos na corte do Rio de Janeiro e cujo procedimento era acompanhado com relativo interesse por muitos habitantes da província baiana.

De fato, sabia-se ali que havia pouco tempo, em abril de 1821, que o conde dos Arcos fora confirmado em um ministério mais promissor - Negócios do Reino e Estrangeiros -, estabelecido por d. João VI para auxiliar a regência no Brasil. ${ }^{63}$ Cultivando desde antes a amizade pessoal com o herdeiro de Bragança, d. Marcos de Noronha e Brito fez mais, tornouse, igualmente, o seu influente conselheiro. ${ }^{64}$ Liberais de diferentes matizes, no entanto, o

\footnotetext{
${ }^{61}$ A citação pertence ao embaixador austríaco no Rio de Janeiro, em 1824, quando considerou o procedimento de Gordilho de Barbuda frente alguns representantes da classe senhorial residentes na Bahia, uma vez que se suspeitava de suas implicações na Revolução de Pernambuco e, mesmo assim, livrando-se da justiça, via a compra de provas documentais em mãos do militar apelidado, por isso, de "Quanto Vale". Apud MONTEIRO, Tobias. História do Império. O Primeiro Reinado. Belo Horizonte: Ed. Itatiaia; São Paulo: Edusp, t. 2, 1982. p. 157. Para a possibilidade de suborno envolvendo o próprio conde dos Arcos que, à época da rebelião em Pernambuco, enfrentava algumas dificuldades financeiras, ver MORTON, F. W. O. The governorship of the Count of Arcos in Bahia, 1810-1818. Enlightened despotism in an age of revolution, Toronto, outubro de 1986 (mimeog.); REIS, João José. Rebelião escrava no Brasil: a história do levante dos malês em 1835. Edição rev. e amp. São Paulo: Companhia das Letras, 2003. p. 93.

${ }^{62}$ Cf. WISIAK, Thomas, op. cit. p. 79.

${ }^{63}$ D. João VI deixava à disposição da regência dois ministérios: o dos Negócios do Reino e Estrangeiros, sob o comando do conde dos Arcos, e o da Fazenda, cujo titular era o conde de Louzã, d. Diogo de Meneses. Com o mesmo propósito, também foram instituídas duas secretarias de Estados interinos: a dos Negócios da Guerra, dirigida pelo marechal-de-campo Carlos Federico de Caula, e a da Marinha, sob responsabilidade do majorgeneral da armada, Manoel Antonio Farinha, depois conde de Souzel. Havia, por fim, mais alguns funcionários subalternos integrando o conselho de regência instituído no Brasil. Para essas nomeações, ver VARNHAGEN, Francisco Adolfo de, op. cit. p. 56-57.

${ }^{64}$ Segundo Isabel Lustosa, a ascendência que o conde dos Arcos exercia sobre o príncipe real propiciara d. João a resistir em nomeá-lo para coadjuvar a regência do Brasil. Situação informada por d. Pedro, em correspondência, ao conde que o mesmo não seria nomeado seu ministro de Estado. No entanto, ficasse certo que, modificada a conjuntura, o viria a chamá-lo para junto de si, pois: "Como eu sei que o conde se interessa por mim, não me quererá fazer ter por homem que precisa ser governado", como parecia crer o seu pai. A sorte do aspirante a ministro, porém, mudaria depois que de sua defesa feita por Silvestre Pinheiro Ferreira perante d. João. Para este conselheiro régio, d. Marcos de Noronha e Brito se distinguia pela competência, a despeito da arrogância que lhe era peculiar. No momento da decisão, o rei finalmente aquiesceu, entregando ao conde a nomeação. LUSTOSA, Isabel. D. Pedro I: um herói sem nenhum caráter. São Paulo: Companhia das Letras, 2006. p. 109-110. A citação da correspondência de d. Pedro ao conde dos Arcos encontra-se à página 109, mas sem a indicação da fonte.
} 
tinham como muito inclinado ao despotismo a merecer cuidadosa atenção. Naqueles dias também se ampliaram as suspeitas de que o conde estava decidido a convencer d. Pedro que chegara o momento de deixar o rei seguir para a Europa, como queriam as Cortes de Lisboa, pois, à frente da regência, o príncipe estaria em condições de fundar no Brasil um império poderoso. ${ }^{65}$ No entendimento de Oliveira Lima, os portugueses europeus queixavam-se:

de que o "depotismo" de Dom Pedro e do Conde dos Arcos visava a desunir os portugueses dos dois hemisférios e reputava outros tantos atentados à união como ele a entendia, sui generis, os ofícios dirigidos do Rio de Janeiro para as províncias do Brasil a fim destas prestarem obediência ao príncipe regente e secundarem a autoridade central executiva criada por elrei ao retirar-se. Os atos mais simples da regência eram interpretados como "maquinações sinistras" e a junta da Bahia, que era ferozmente portuguesa, increpava o governo de Dom Pedro de inteligência com Luís do Rego em Pernambuco e desígnios de atacarem a Bahia para destruírem esse baluarte do constitucionalismo português, que se erguia contra os projetos de independência do reino americano, por aqueles outros favorecidos. ${ }^{66}$

Ainda segundo este autor, o comportamento do conde dos Arcos muito contribuía para que os portugueses europeus o compreendessem como partidário decidido da independência do Brasil, enquanto no cálculo dos filhos da terra o ministro-conselheiro era um genuíno representante dos antigos validos, que preferia a corte fluminense a retornar a Portugal com o velho rei. ${ }^{67}$

Essas desconfianças intensificaram-se quando, em maio, chegaram à Bahia os relatos sobre as violências praticadas no mês anterior contra a assembleia de eleitores de paróquia no Rio de Janeiro. Estas notícias deram conta que ao cumprirem as determinações das autoridades reunidas no Palácio de São Cristóvão, onde estava o príncipe d. Pedro e o conde dos Arcos, os batalhões da divisão auxiliadora cercaram a Praça do Comércio e, sem advertência prévia, efetuaram uma descarga de mosquetaria, seguida de estocadas de baionetas, contra os eleitores e o povo comprimido à sua volta. ${ }^{68}$

\footnotetext{
${ }^{65}$ Para essa hipótese, ver ARMITAGE, John. História do Brasil: desde o período da chegada da família de Bragança, em 1808 até a abdicação de D. Pedro I, em 1831, compilada à vista dos documentos públicos e outras fontes originais formando uma continuação da história do Brasil, de Southey. Belo Horizonte: Itatiaia; São Paulo: Edusp, 1981. p. 40.

${ }^{66}$ LIMA, Manuel de Oliveira. O movimento da Independência: 1821-1822. 5. ed. São Paulo: Melhoramentos; Conselho Estadual de Cultura, 1972. p. 73.

${ }^{67}$ Cf. Idem, ibidem, loc cit.

${ }^{68}$ Concorrida pela volumosa presença da população fluminense, a assembleia dos eleitores de paróquia reunidos na Praça do Comércio teve início na tarde de 21 de abril de 1821, estendeu-se para a noite e madrugada do dia seguinte. Em meio às acirradas disputas políticas, as lideranças liberais mais moderadas viram-se ultrapassadas por deliberações cada vez mais radicais. Impacientes com os possíveis resultados de uma assembleia que ia se mostrando fortemente popular, as autoridades palacianas decidiram pela repressão. Sobre esse acontecimento, ver ARMITAGE, John, op. cit. p. 39-41; VARNHAGEN, Francisco Adolfo de, op. cit. p. 52 e segs. Ao analisar
} 


\section{Ato contínuo, o Semanário Cívico reavaliou a postura elogiosa aos feitos do conde dos Arcos, como já verificado, decidindo-se pelo ataque frontal à sua fidalguia e ao seu projeto político.}

Quem diria que um áulico, que tinha recebido nesta cidade as maiores honras e acolhimento, a quem se havia dado uma avultadíssima quantia que se recolheu ao banco para em perpetuidade receber seus reditos, a quem o corpo dos negociantes havia feito dádiva de uma rica espada, que na casa da Praça do Comércio havia colocado o seu retrato (que já se mandou dali tirar), que este áulico, dizemos, seria o autor desde terrível plano para ver se por este meio podia, à sombra de um jovem e inexperiente príncipe, governar a seu capricho este vasto Reino $!^{69}$

De fato, a suspeição dos planos pouco constitucionais envolvendo o príncipe regente e seu conselheiro-confidente ajuda a compreender a resoluta persistência com que as Cortes Gerais e os mais diferentes defensores do liberalismo preponderante em Portugal - entre eles grandes comerciantes portugueses europeus na Bahia - prefeririam enfrentar uma guerra incerta a reconhecer, sem resistência, a autoridade da regência sob a direção d. Pedro. Por isso, muito se insistiu para que ambos regressassem à Europa naquele período. ${ }^{70}$ Apesar de não obter êxito com relação ao herdeiro de Bragança, ao menos, esses opositores teriam, em breve, a satisfação em saber que o conde dos Arcos não somente acabaria expulso do Brasil, como, em Lisboa, permaneceria preso, por quatro meses, enquanto responderia a um processo de conspiração, do qual, finalmente, foi inocentado. ${ }^{71}$

A despeito do conde dos Arcos, já nos primeiros dias na condução do ministério regencial dos Negócios do Reino e Estrangeiros, ter obtido a aprovação do príncipe regente

as diversas dimensões políticas que envolveram a agenda liberal fluminense de princípios dos anos 1820, Cecília Helena demonstra como a assembleia na Praça do Comércio fez emergir todo um jogo de forças e contradições sociais que nem mesmo os mais conhecidos agentes liberais daquela sociedade quiseram suportar. OLIVEIRA, Cecília Helena L. de Salles. A astúcia Liberal: Relações de mercado e projetos políticos no Rio de Janeiro (1820-1824). Bragança Paulista: Ed. Edusf; Ícone, 1999. Em especial o cap. 3.

${ }^{69}$ Semanário Cívico, n. 18, de 28 de junho de 1821. Apud SILVA, Maria Beatriz Nizza da. Semanário Cívico: Bahia, 1821-1823. Salvador: Edufba, 2008. p. 77-78. Existem indícios de que boa parte dos prêmios recebidos pelo então capitão-general da Bahia deveu-se à sua complacência para com muitos proprietários da Bahia suspeitos de colaborarem para a eclosão da Revolução de 1817 em Pernambuco e demais capitanias anexas. Nesse sentido, ver MORTON, F. W. O., 1986, op. cit.

${ }^{70}$ Varnhagen afirmou que: "A própria esquadra que conduzia el-rei era portadora de muitas cartas dos maiores liberais do Rio de Janeiro [...] pedindo para Portugal a retirada do príncipe e do seu Ministro Conde dos Arcos, acusando a um e outro de tendências ao absolutismo". D. João VI seguiu viagem para a Europa em 24 de abril de 1822. VARNHAGEN, Francisco Adolfo de, op. cit. p. 57. Em termos legais, o pilar dessa resistência foi sistematizado no polêmico decreto de lei de $1^{\text {o }}$ de outubro de 1821 das Cortes de Lisboa, cujas reiteradas tentativas para a sua completa efetivação muito favoreceu para a definitiva ruptura dos laços políticos entre Brasil e Portugal. Análises aprofundadas sobre os efeitos e os contra-efeitos desse decreto estão em ALEXANDRE, Valentim. Os sentidos do Império. - questão nacional e questão colonial na crise do Antigo Regime português. Porto: Afrontamento, 1993 e BERBEL, Márcia Regina, 1999, op. cit.

${ }^{71}$ SILVA, Ignácio Accioli de Cerqueira e, op. cit., v. 3. p. 288, nota 22. 
para uma série de "decretos muito justos" aos princípios constitucionais ${ }^{72}$, ele não obteve aprovação junto à opinião pública nascente. Liberais de diversas matizes - inclusive os comprometidos com os círculos da maçonaria -, continuaram reticentes sobre a controvertida conduta do ministro-conselheiro. E nem mesmo quando ele expediu ofícios para que as províncias prestassem obediência a d. Pedro, "criando no Brasil um centro executivo, como fora resolvido por el-rei", deixou de ser visto como aquele que tão somente queria "usurpar o poder das Cortes e encaminhar o mesmo príncipe para o absolutismo" ${ }^{73}$ Também na Bahia, já bem poucos estavam interessados em hipotecar apoio ao outrora muito prestigiado capitãogeneral.

Havia no horizonte da época o receio de que os projetos acordados entre o herdeiro de Bragança e o seu ministro previssem um governo para o Brasil, onde a Constituição fosse outorgada preservando parte do poder ao rei, à maneira da França de Luís XVIII (1814) e, ao mesmo tempo, facultasse ao conde dos Arcos figurar com atributos de um todo-poderoso primeiro-ministro, como fora o marquês de Pombal para a administração de d. José I. Somadas a essas prerrogativas, d. Pedro deveria manter a possibilidade de assumir a coroa portuguesa em sucessão a d. João VI. ${ }^{74}$ Concepções dessa ordem poderiam, de fato, ser consideradas. À vista da experiência em residir sete anos na corte fluminense, o cônsul francês Jean-Baptiste Maler avaliava, em 24 de março de 1821, que: “[...] le parti du Roi et le parti liberal Brésilien devaient se Réunir contre les Janissaires Lisbonnins, dont le comte dos

\footnotetext{
${ }^{72}$ Em uma "correspondência" publicada no Diário Constitucional de 14 de fevereiro de 1822, afirmava-se aos leitores que "o Príncipe [...] procurou sempre os meios mais profícuos para curar as chagas da antiga Administração; bem entendido, os meios, que estavam em seu Poder; e para mostrar que a sua Administração era e foi sempre Constitucional, basta lermos os seus Decretos, logo depois da ida de S. M., seu Augusto Pai" para Portugal. Diário Constitucional, n. 6, quinta-feira, 14 de fevereiro de 1822. Tipografia da Viúva Serva e Carvalho, 1821-1822. Exemplar da coleção do IEB/Usp.

${ }^{73}$ VARNHAGEN, Francisco Adolfo de, op. cit. p. 76. John Armitage já havia registrado que variados "decretos tendentes a promover o interesse público se promulgaram, e foram abolidos muitos impostos opressivos; porém, cumpre declará-lo, estas mesmas providências foram acolhidas por todos os partidos, mais com suspeitas do que com gratidão, sendo consideradas antes como um ardil para aquisição de popularidade, lançado com o fim de cimentar de novo o vacilante absolutismo". ARMITAGE, John, op. cit. p. 42-43.

${ }^{74}$ Convêm aqui observar, linha a linha, a ponderação de Armitage: “[...] há razões convincentes para se acreditar que ninguém mais desejava a partida de seu augusto pai do que este Príncipe [d. Pedro]. Existia muita indiferença entre eles; D. Pedro havia já frequentemente mostrado sintomas de impaciência por causa do estado subordinado em que se achava; e tanto ele, como o seu principal conselheiro e confidente, o Conde dos Arcos, haviam concebido a maior aversão contra o Ministério então existente. Este fidalgo, ex-governador da Bahia, é geralmente acusado de haver excitado a ambição do Príncipe por um desejo de ser elevado a Primeiro-Ministro, logo que seu patrono tomasse as rédeas do governo; e se tudo isso é verdade o tempo mostrou que os seus cálculos eram bem fundados. Foi muito agradável a D. Pedro a proposição de ser nomeado Regente. Havia saído de muito na infância, com mui pouca saudade do seu país natal, e o Conde dos Arcos inflamou a sua jovem imaginação com a magnificência e recursos do Brasil. Impaciente portanto de obter a esperada dignidade, e temendo que fosse inoportunamente prevenida a retirada de D. João pela obstinação dos eleitores, dizem que adotou a medida arbitrária de dissolver a assembleia da Praça do Comércio com a força armada. Cumpre contudo notar-se que esta hipótese, é, ainda hoje, unicamente baseado [sic] sobre conjeturas." ARMITAGE, John, op. cit. p. 40.
} 
Arcos cherche à devenir le Maître" ${ }^{75}$ Seis meses depois, seria a vez do periódico pró-lusitano, Semanário Cívico, declarar: "Quem conhecer bem o conde dos Arcos há de saber que ele é inimigo de todo o sistema de representação nacional, que ele reconhecia muitos defeitos na antiga administração, porém queria ser ele o reformador". ${ }^{76}$

Então, se ainda havia, em maio de 1821, alguma coisa capaz de realinhar as mais diversas tendências políticas que asseguraram a vitória da Revolução Constitucionalista na província baiana era o forte consenso de que o conde dos Arcos não merecia qualquer tipo de condescendência. Não foi à toa que, ao saber como terminara a assembleia dos eleitores de paróquia da cidade fluminense, os dirigentes da Praça do Comércio da Bahia resolveram marcar bem as suas indisposições com o maior responsável pela existência de todo o conjunto arquitetônico e comercial que lhes davam abrigo e distinção. E, por este motivo, colocaram luto por dois dias. ${ }^{77}$

Apesar de todo o prestígio junto ao príncipe regente, o conde dos Arcos ficou politicamente isolado. Entre seus principais opositores destacaram-se o secretário da Guerra, Carlos Federico de Caula, e o ministro da Fazenda, conde de Louzã, d. Diogo de Menezes. E como ambos possuíssem ascendência na tropa, o apoio militar apresentou-se-lhe igualmente difícil. Foi nesse contexto que, em fins de maio, soube-se na cidade que as Bases da Constituição Portuguesa haviam sido aprovadas pelas Cortes Gerais (em 9 de março). ${ }^{78}$ Ainda que essas notícias contemplassem a maioria das tendências políticas, houve divergências quanto a sua aceitação no Brasil. Na opinião do ministro-conselheiro, como as mesmas Bases declaravam, no artigo 21, que a sua adoção só tornar-se-ia comum aos territórios da América, África ou Ásia "logo que, pelos seus legítimos representantes declarassem ser essa a sua vontade"; caberia exclusivamente aos deputados das províncias americanas declararem, em plenário, a vontade da população do Brasil. ${ }^{79} \mathrm{O}$ próprio d. Pedro assumiu uma postura frente à questão que admite interpretações diversas; posto que, antes de declarar qualquer posição formal, quis primeiro aguardar novas informações de Portugal, admitindo que o desembarque de d. João VI pudesse suscitar novas alterações na política do Império. ${ }^{80}$

\footnotetext{
75 Correspondance Politique du Brésil, despacho de 24/03/1821, v. 1, Archives du Ministre des Affaires Étrangères. Apud MOREL, Marco, 2005, op. cit. p. 69.

${ }^{76}$ Semanário Cívico, n. 18, de 28 de junho de 1821. Apud SILVA, Maria Beatriz Nizza da. A primeira gazeta da Bahia: Idade d'Ouro do Brazil. 2. ed. revista e ampliada. Salvador: Edufba, 2005a. p.331.

${ }^{77}$ VARNHAGEN, Francisco Adolfo de, op. cit. p. 56.

${ }^{78}$ Para a estruturação das Bases da Constituição Política da Monarquia Portuguesa e a sua aprovação pelas Cortes Gerais, ver BERBEL, Márcia Regina, 1999, op. cit. p. 54-56.

${ }^{79}$ Apud VARNHAGEN, Francisco Adolfo de, op. cit. p. 78 (Grifos do autor).

${ }^{80}$ Cf. ARMITAGE, John, op. cit. p. 43.
} 
No torvelinho das indefinições políticas, essa posição vacilante da regência ampliou o receio de que alguma medida contrária à Constituição viesse a ser urdida entre o príncipe regente e o seu ministro predileto, facilitando, por vez, a articulação de um movimento de natureza militar forte o suficiente para forçar o governo a obedecer aos dispositivos legais que norteariam a Constituição da nação portuguesa. Diante da suspeição, o secretário dos Negócios da Guerra, Federico de Caula, conseguiu que diversas proclamações e pasquins aparecessem na cidade dando conta da insatisfação pública. E, assim, no dia 5 de junho de 1821, a divisão auxiliadora marchou para o Largo do Rocio para jurar e também requerer o pronunciamento público das demais autoridades sobre as Bases Constitucionais. Dentre as suas exigências, a tropa solicitou a imediata demissão de d. Marcos de Noronha e Brito do ministério. Constrangido, d. Pedro somente exigiu que se convocassem os vereadores da Câmara Municipal e os eleitores dos deputados para apresentarem-se, pois legitimamente estavam mais capacitados a tão elevadas requisições. ${ }^{81}$

Dois dias depois, diante dos eleitores, dos representantes do Senado da Câmara e da tropa, d. Pedro jurou as Bases da Constituição Portuguesa e instaurou uma Junta Provisória vinculada às Cortes de Lisboa. O conde dos Arcos havendo se recolhido, em companhia de uma filha, no brigue Treze de Maio, partiu do Rio de Janeiro em 10 de junho. Ao passar pela Bahia, no dia 19, tentou desembarcar, porém encontrou sérias oposições. Os membros da Junta Provisória baiana não apenas negaram-lhe a autorização para desembarque, mas também o incriminaram junto às Cortes de Lisboa como sendo "o chefe da mais execranda conspiração contra os interesses da nação e do rei". ${ }^{82}$ Enquanto isso, "um grupo de indivíduos da ínfima classe", nas palavras de Ignácio Accioli, foi até a Praça do Comércio e destruiu um retrato do conde que, em outros tempos, "solenemente havia sido ali colocado". 83 Ao informar aos seus leitores sobre essa tentativa do último vice-rei do Brasil em permanecer entre os habitantes da cidade de Salvador, o redator do Semanário Cívico quis, decerto, expô-lo ao ridículo:

Estiveste fundeado neste porto, rodeado de sentinelas, a bordo de uma pequena embarcação como um prisioneiro, olhando para esta cidade onde outrora imperaste, e encarando para aquela Praça do Comércio na qual havias recebido honras só devidas ao monarca, ou a algum daqueles gênios sublimes que se caracterizam por benfeitores da humanidade! Vai agora a

\footnotetext{
${ }^{81}$ VARNHAGEN, Francisco Adolfo de, op. cit. p. 78-80 e ARMITAGE, John, op. cit. p. 43. Ver também SLEMIAN, Andréa. Vida política em tempo de crise: Rio de Janeiro (1808-1824). São Paulo: Hucitec, 2006. p. $123-124$

${ }^{82}$ Apud LIMA, Manuel de Oliveira, op. cit. p. 76.

${ }^{83}$ SILVA, Ignácio Accioli de Cerqueira e, op. cit., v. 3. p. 288.
} 
Lisboa apresentar-te às Cortes, aquele Soberano Congresso, composto não dos da tua estirpe, mas de sábios e verdadeiros portugueses. Ele restritas contas tomar-te-á da tua conduta política! $!^{84}$

As casas de algumas pessoas vinculadas ao conde passaram a ser vigiadas, com atenção especial para a de seu antigo ajudante, Gordilho de Barbuda. Há também suspeitas de que, ocorrida a Revolução Constitucionalista na Bahia, o futuro visconde de Camamu tenha ido à corte fluminense, dali voltando com a atribuição de promover a união da província baiana com as autoridades do Rio de Janeiro. O certo foi que, em 12 de julho de 1821, ele espalhou pela capital baiana alguns pasquins, os quais prenunciavam para aquela noite o saque da artilharia, bem como denunciava as posturas políticas de Cipriano Barata e do secretário da Junta Governativa, José Lino Coutinho. O primeiro era acusado de "tramar a favor da independência", enquanto o segundo de articular a deposição de alguns dos seus colegas de governo, ${ }^{85}$ o que demonstra a complexa gradação de interesses e concepções políticas mesmo entre aqueles que não se alinhariam ao projeto liberal hegemônico nas Cortes de Lisboa. Ao menos no tocante à separação política, Marco Morel adverte que naquele momento ela podia ser considerada uma imprudência, um crime, pois o projeto liberal era de manutenção do Reino Unido de Brasil e Portugal, inclusive o próprio Cipriano mostrava-se tributário dessa proposta, tanto assim que tomaria parte como deputado nas Cortes de Lisboa. $^{86}$

Pode-se afiançar que a postura de Gordilho de Barbuda a favor do realinhamento político da Bahia ao projeto de união com o Rio de Janeiro só adquiriu uma posição inequívoca depois de ele se livrar da prisão em Lisboa e ter rumado para a corte fluminense em princípios de maio de 1822. Nos meses seguintes, participaria ativamente dos círculos maçônicos e interagiria com a vida política fluminense em um contexto decisivo para os rumos de Portugal e da sua antiga colônia americana. Sem descuidar da carreira militar, o futuro visconde de Camamu alcançou ali mais um posto no oficialato, tornando-se brigadeiro do Exército. Foi aí que a loja Grande Oriente, tendo decidido pela total separação política do Brasil, cuidou de enviar emissários às províncias para que reforçassem os apoios à Independência, aclamando o príncipe regente como imperador constitucional do Brasil. Em função disso, em 15 de setembro de 1822, durante uma sessão da mesma loja sob a presidência de Joaquim Gonçalves Ledo, essa indicação foi aprovada, ocasião em que foram

\footnotetext{
${ }^{84}$ Semanário Cívico, n. 18, de 28 de junho de 1821. Apud SILVA, Maria Beatriz Nizza da, 2008, op. cit. p. 78. ${ }^{85}$ Idem, ibidem, loc cit.

${ }^{86}$ MOREL, Marco. Cipriano Barata na Sentinela da Liberdade. Salvador: Academia de Letras da Bahia: Assembleia Legislativa do Estado da Bahia, 2001. p. 121.
} 
logo recolhidos 450\$000 de contribuições a fim de custear as despesas dos emissários que tratariam da aclamação imperial em suas respectivas províncias. E para ser bem marcado, acordou-se que o ato deveria ocorrer, simultaneamente, nas províncias a 12 de outubro, data do natalício de d. Pedro. Dentre os designados para essa missão, constavam o brigadeiro José Egídio Gordilho de Barbuda para ir à Bahia, o cônego Januário da Cunha Barbosa para Minas Gerais, o capitão João Mendes Viana para Pernambuco e o advogado Lucas José Obes para Montevidéu. $^{87}$

No entanto, Gordilho de Barbuda retornou à Bahia somente em meados de dezembro. Além da missão da Grande Oriente, trouxera uma portaria do então imperador d. Pedro I para que a província realizasse a eleição dos seus deputados à Assembleia Geral Constituinte do Império do Brasil. ${ }^{88}$ Com ele regressara também um de seus antigos companheiros de prisão em Lisboa, o então tenente de milícias Francisco José da Silva Castro. Ambos estavam plenamente integrados à nova ordem política pensada a partir do Rio de Janeiro, tanto assim que portavam "ordens imperiais" para serem empregadas no Exército Pacificador, que vinha logrando sucesso contra as tropas de Portugal, reduzidas cada vez mais ao espaço urbano da cidade de Salvador. ${ }^{89}$

\footnotetext{
${ }^{87}$ BARATA, Alexandre Mansur, op. cit. p.236; LIMA, Manuel de Oliveira, op. cit. p. 235. Para essas decisões da Grande Oriente ver também nota do barão de Rio Branco à História da Independência do Brasil. VARNHAGEN, Francisco Adolfo de, op. cit. p. 136, nota 19.

${ }^{88}$ Atas do Conselho Interino na Cachoeira, 14 $4^{\mathrm{a}}$. Ata de 18 de dezembro de 1882 - O brigadeiro Gordilho de Barbuda, chegado do Rio de Janeiro apresenta ao Governo Interino portaria do Imperador para que se proceda à eleição dos deputados à Assembleia Geral Constituinte. Documentos históricos sobre a emancipação política da Bahia. Revista do Instituto Geográfico e Histórico da Bahia, ano III, v. 3, n. 9. p. 341-343, 1896. Convêm ressaltar que Gordilho de Barbuda se tornaria homem forte na Bahia enquanto o governo centralizado de d. Pedro I foi prestigiado. Depois do movimento de insubordinação das tropas, em 1824, quando soldados do batalhão dos Periquitos assassinaram, em 25 de outubro, o governador das armas da província, Felisberto Gomes Caldeira, dando início à revolta militar que ficaria conhecida como Levante dos Periquitos, Gordilho de Barbuda foi designado pelo imperador a presidir a comissão militar para conhecer e punir os responsáveis pela morte do governador. Suspensas as garantias de segurança pessoal para a província, o futuro visconde de Camamu realizou prisões e processos sumários que levaram a ser fuzilados o major Joaquim Sátiro da Cunha, veterano da Guerra de Independência e comandante do forte de São Pedro durante a sublevação, bem como o tenente do batalhão dos Pitangas, Gaspar Lopes Vilas Boas. Em outubro de 1827, quando a Bahia experimentava muita instabilidade, devido, sobretudo, à circulação da moeda de cobre falsa, Gordilho de Barbuda, reconhecidamente indivíduo do círculo pessoal de $\mathrm{d}$. Pedro I, fora nomeado para a presidência da província e ali permaneceu até o seu assassinato em 28 de fevereiro de 1830. Sobre a trajetória do visconde de Camamu na província baiana, ver, entre outros, SILVA, Ignácio Accioli de Cerqueira, op. cit., v. 4; AMARAL, Braz do. História da Bahia: do Império à República. Salvador: Imprensa Oficial do Estado, 1923; SOUZA FILHO, Argemiro Ribeiro de, op. cit. Cap. 3 e SILVA, Daniel Afonso da, op. cit.

${ }^{89}$ Em 19 de dezembro de 1822 , o Conselho informava que tomaria as providências, conforme determinavam as duas portarias de 15 de outubro daquele ano, sobre o emprego do brigadeiro Gordilho de Barbuda e do tenente de milícias da Bahia, Francisco José da Silva Castro, no Exército Pacificador. Ofício do Conselho Interino para Luís Pereira da Nóbrega de Souza Coutinho, ministro e secretário de Estado dos Negócios da Guerra. Documentos históricos sobre a emancipação política da Bahia. Correspondência oficial do Conselho Interino do Governo na Cachoeira. Revista do Instituto Geográfico e Histórico da Bahia, ano V, v. 5, n. 1. p. 554-555, 1898. Três dias depois, esse governo enviava a Labatut um ofício relatando "que em observância de uma portaria de 15 de outubro [...] expedida pela secretaria de guerra, pela qual Sua Majestade, o imperador, ordenara a este
} 
Desde 1821 havia quem associasse a postura do marechal-de-campo Felisberto Caldeira Brant ao alinhamento político da Bahia ao Rio de Janeiro. Isso porque depois de ter participado da reunião com o conde de Palmela, em dezembro do ano anterior, e de ter enfrentado os promotores da Revolução Constitucionalista, Caldeira Brant não apenas aquiesceu ao ímpeto do movimento na Bahia, como compareceu à sessão da Câmara que definira os primeiros rumos institucionais do novo governo em formação e ali defendeu ideais audaciosos. Ao considerar como fato consumado que a Bahia se desligava politicamente do restante do Brasil para acompanhar a trajetória liberal de Portugal, o futuro marquês de Barbacena teria declarado: "que não pensava que houvesse tanta disposição como a que via manifestar-se por uma nova ordem de coisas, e que assim seria melhor fazer-se logo obra de brasileiro". ${ }^{90}$ Embora tenha sido asperamente admoestado (consta, inclusive, que punhais cortaram o ar do recinto camarário contra o autor daquelas palavras, havendo igualmente quem desejasse atirá-lo por uma das janelas do salão onde se encontrava), Caldeira Brant usou novamente a palavra ao verificar que na ata de proclamação a ser encaminhada para as Cortes de Lisboa constava que a província baiana se desligaria do governo d. João VI, enquanto este não reconhecesse os princípios constitucionais, com "sujeição" a Portugal. Na ocasião, teria alertado "que isso era retrogradar da posição que ocupava a Bahia como parte do Reino Unido do Brasil; que ao menos em lugar de sujeição se dissesse adesão", no que fora acatado. ${ }^{91}$

Suspeitava-se que a proposta do conde de Palmela de uma Constituição com duas Câmaras, anunciada em $1^{\circ}$ dezembro de 1820, havia adquirido forte repercussão junto ao futuro marquês de Barbacena. Após tudo que vivenciara em um único dia, e talvez percebendo que a adesão da Bahia às Cortes lisboeta levaria a importantes mudanças no território do Brasil, esse experimentado funcionário do Estado procurou logo embarcar

governo de incorporar a algum regimento o tenente de milícias, Francisco José da Silva Castro, que tem incorporando este oficial ao batalhão que se mandou organizar em [São José da Barra do] Rio de Contas, a fim de acelerar a prontificação imediata deste corpo e de instruí-lo". Governo Provisório - Correspondência expedida pelo Conselho Interino de Governo. APEB. Seção de Arquivo Colonial e Provincial. Data: 22/12/1822. Maço: 638. Convém ainda observar que Francisco José era irmão do major José Antonio da Silva Castro, o Periquitão, o qual estava à frente do batalhão de $1^{\text {a }}$. linha número 3 (Periquitos), cujos soldados desencadeariam o levante militar ocorrido em Salvador em fins de 1824. Para processar os responsáveis por esse motim, Gordilho de Barbuda assumiu o comando da comissão militar que de forma sumária executou algumas lideranças do movimento. Contudo, o Periquitão saiu pouco prejudicado desse processo, haja vista que somente foi obrigado a abandonar a capital baiana para assumir uma missão militar no Alto Sertão da Bahia. Ressalta-se igualmente que os mencionados irmãos Silva Castro haviam sido, em meados da década de 1810, procurados pela justiça como facínoras depois de terem assassinado o juiz ordinário da vila de Caetité. Para os assuntos aqui abordados, consultar SILVA, Ignácio Accioli de Cerqueira, op. cit., v. 4. TAVARES, Luís Henrique Dias, 2005, op. cit. e DIAS, Alexandre Alves. Facinorosos do sertão: A desagregação da ordem no sertão nordestino na transição da colônia até a independência (1808-1822). Dissertação (Mestrado em História) - Universidade Federal de Pernambuco, Recife, 1997.

${ }^{90}$ REBOUÇAS, Antonio Pereira, op. cit. p. 457.

${ }^{91}$ Idem, ibidem. loc cit. Grifos do autor. 
juntamente com o conde da Palma - ex-governador - para o Rio de Janeiro. Juntos narrariam ao rei e a seus conselheiros as alvissareiras deliberações políticas da Bahia, visto que ali chegaram a bordo da fragata inglesa Icarus, em 17 de fevereiro de $1821 .^{92}$ Nesta ocasião, Edward Thornton, enviado extraordinário da Inglaterra, repassou ao conde de Palmela um despacho de 10 de fevereiro do cônsul inglês na Bahia, William Pennel, dando contas das primeiras notícias desses eventos:

Tenho a honra de participar-vos que esta manhã se proclamou a Constituição e que o governador e as autoridades constituídas aquiesceram a isso. Fez-se a tentativa de suprimir primeiro o movimento, e o marechal Felisberto [Caldeira Brant Pontes Horta de Oliveira], à testa de uma força militar, procurou apoderar-se de uma peça que os revolucionários tinham. Houve em consequência algum fogo, e diz-se que foram mortos um oficial e dez soldados. O governador ordenou que o batalhão $\mathrm{n}^{\circ}$. 12 subisse para sustentar o marechal, mas os soldados não quiseram e se declararam pela Constituição; e temeu-se que fosse baldada qualquer oposição. Tudo está tranquilo, e estão tomando os nossos juramentos. ${ }^{93}$

A conduta política de Caldeira Brant, nessa conjuntura, seria notada de maneira perspicaz pelo redator do Semanário Cívico ao registrar os acontecimentos políticos na Bahia em 3 de novembro de 1821:

Em quanto ao nosso modo de pensar, foi plano combinado com o Rio de Janeiro para fazer uma cisão entre o Brasil e Portugal, plano que haviam estabelecido o conde dos Arcos e o conde de Palmela, e aqui seguido e adotado pelo marechal Felisberto Caldeira e seus satélites. Esta opinião tanta mais força adquire quanto seriamente reflexionamos nos últimos acontecimentos do Rio de Janeiro [...] e que todos os conspiradores são amigos do marechal Felisberto e protegidos e apaniguados do conde dos Arcos. Daqui vem a defesa que faziam estes dos Proteus. O primeiro já era bom patriota, todos estavam arrependidos pelo insultarem no dia 10 de fevereiro [...]. O nosso Governo foi o mais injusto, e caluniador em oficiar para as Cortes contra o incomparável Conde; cometeu o maior atentado em mandar rondar as casas de seus amigos, na noite em que ele aqui chegou do Rio de Janeiro: tal era a linguagem dos conspiradores, e agora estamos vendo que aqueles que foram rondados, naquela noite, entraram muitos nesta conspiração [de 3 de novembro]; e por consequência a medida tomada pelo nosso Governo foi mui acertada.

A cisão entre o Brasil e Portugal era pois o plano dos conspiradores: para o conseguirem antes que chegasse a nova forma de Governo, decretado pelo Soberano Congresso das Cortes; era necessário novo Governo dos da sua facção, que se unisse ao Rio de Janeiro, como estão unidas todas as Províncias do Brasil, à exceção do Pará, Maranhão e a Bahia; Um Reino no

\footnotetext{
${ }^{92}$ LIMA, Manuel de Oliveira, op. cit. p. 45.

${ }^{93}$ Apud BANDEIRA, Luiz Alberto Moniz, op. cit. 375-376.
} 
Brasil separado de Portugal trazia muitas vantagens pessoais aos conspiradores: O Rei dos vastos Sertões despovoados do Brasil os premiaria pelo denodo com que lhes haviam adquirido esta grande, rica e fértil Província. Uma parte dos conspiradores arruinados pelo jogo, sem opinião pública, receosos dos desprezo[s] que iam sofrer, em um Governo Justo, Constitucional, unido a nossos Irmãos de Portugal, que premia o merecimento fundado na virtude, viriam a ser grandes personagens; e para nos servirmos das frases do Redator do Português "Condes de..., Marquêses de..., e Duques de...". Tal era pois os fins dos conspiradores, e as vantagens, que esperavam do seu arrojo e temeridade. ${ }^{94}$

Neste caso, desperta atenção não apenas como Silva Maia percebeu a articulação política entre importantes figuras do Império português na Bahia, mas também por ter vaticinado que muitos dos que contribuiriam para a afirmação da Independência do Brasil e sustentação do governo centralizado de d. Pedro I acabariam agraciados com títulos nobiliárquicos à maneira do Antigo Regime. Denominações honoríficas que, sem dúvida, remontariam continuidades do governo absoluto e cuja Revolução Constitucionalista ambicionara superar. Do mesmo modo, a imagem do regente d. Pedro já era aqui representada negativamente e, à medida que as incompatibilidades com as Cortes Gerais se afirmavam nas províncias do Sul, o herdeiro de Bragança passava a ser tratado, primeiro como pupilo desprovido de experiência que, por isso, deixava-se iludir por quem o rodeava e, após a aclamação deste como imperador do Brasil, seu governo seria descrito como "despótico", sendo mesmo o príncipe um "rebelde".

No que diz respeito especificamente ao influente senhor de engenho e marechal Felisberto Caldeira Brant, cujos investimentos feitos na Bahia destacavam-se: a introdução da primeira máquina a vapor para uso nos engenhos (1815), a participação como um dos principais acionistas e diretor da filial do Banco do Brasil na Bahia (1816), a instalação da barca a vapor ligando a capital baiana ao Recôncavo (1819) e a organização dos Regimentos de Milícias do Recôncavo, o Semanário Cívico dedicou atenção especial. Inicialmente recordou que antes do dia 10 de fevereiro já havia muita desconfiança sobre aquele que tornar-se-ia um dos maiores proprietários na Bahia, pois constava "ter ele dias antes maquinado para frustrar os feitos" que levariam à afirmação da Revolução Constitucionalista em território baiano. Em seguida, Silva Maia sintetizou a trajetória do futuro marquês na expectativa de apontar contradições sobre a conduta constitucional que adotara.

\footnotetext{
${ }^{94}$ Extrato do Semanário Cívico, n. 37, de 7 de novembro de 1821 publicado no periódico $O$ Independente, Suplemento ao n. 4, sábado, 5 de janeiro de $1822 \quad$ In: 〈http://books.google.com.br/books?id=_vovAAAAYAAJ\&printsec=frontcover\#v=onepage\&q\&f=false > (Acesso em 21 de novembro de 2009).
} 
Como desejaria o marechal adotar o novo sistema constitucional quando pelos defeitos do antigo regime é que estava feito marechal, comendador, alcaide-mor, diretor da Caixa de Descontos! Que serviços havia ele feito à nação para adquirir todas aquelas mercês? Ora no novo sistema lhe era muito dificultoso. Quanto mais que era voz pública nesta cidade que o conde de Palmela, o pouco tempo que se demorou nela na sua viagem para o Rio de Janeiro, havia feito persuadir ao marechal os vícios da nova ordem de coisas em Portugal, lisonjeando-o fazê-lo conde para se estabelecer no Brasil o sistema das duas Câmaras, criando para isso alta nobreza que não havia nesta província, de que ele faria parte. ${ }^{95}$

Enfim, o que se observa nas linhas do periódico pró-lusitano é a percepção de como o projeto da aristocracia se fortalecia frente às insuperáveis ambiguidades manifestas nas medidas que as Cortes de Lisboa pretendeu adotar para a América portuguesa. Pelo ângulo de análise de Joaquim José da Silva Maia, os aristocratas ganhariam terreno encampando a Independência do Brasil, seja ao colaborar com um constitucionalismo do tipo inglês, seja envidando esforços para que fosse pactuada uma Constituição conforme o modelo adotado no reinado de Luís XVIII na França em 1814. ${ }^{96}$

\subsection{Disputas internas e reacomodações entre representantes da classe senhorial na Bahia}

Em princípios de julho de 1822, o tenente-coronel Felisberto Gomes Caldeira e o major Antonio Maria da Silva Torres, ex-integrantes dos acontecimentos políticos de 3 de novembro, apresentaram-se no Recôncavo, onde passaram a cumprir importantes serviços às classes proprietárias contrárias às tropas dominantes em Salvador. ${ }^{97}$ Sedentas por ocuparem política e militarmente os espaços de poder existentes, essas lideranças articulariam a organização de um único centro governativo para todo o interior baiano, posto que, em paralelo à instalação da Junta Interina Conciliatória e de Defesa da vila de Cachoeira, que tinha como "comandante-em-chefe de toda a força militar e no exercício das funções de governador das armas" o coronel José Garcia Pacheco de Moura Pimentel e Aragão, outras vilas que proclamaram obediência à regência de d. Pedro também apresentaram suas

\footnotetext{
95 Semanário Cívico, suplemento ao n. 40, de 29 de novembro de 1821. Apud SILVA, Maria Beatriz Nizza da, 2008, op. cit. p. 39 (grifos no original). Um estudo biográfico sobre Caldeira Brant foi feito por CALOGERAS, João Pandiá. O marquês de Barbacena. 2. ed. São Paulo: Companhia Editora Nacional, 1936, p. 18-20. Sobre a sua ascensão durante a fase de melhoramento prático difundido pela Coroa portuguesa, ver o recente artigo de SOUSA, Maria Aparecida Silva de, 2009, op. cit. p. 92 e passim e A Bahia na crise política do Antigo Regime (1808-1815). Revista de História, n. 159, p. 135-166, ago. de 2008 (Disponível em: <http://www.revistasusp.sibi.usp.br/pdf/rh/n159/a06n159.pdf > Acesso em 14 de novembro de 2009).

${ }^{96}$ Cf. SILVA, Maria Beatriz Nizza da, 2008, op. cit. p. 94-95.

${ }^{97}$ Para atuação dessas lideranças nesse período, ver SILVA, Ignácio Accioli de Cerqueira e, op. cit., v. 3 . p. 363 e TAVARES, Luís Henrique Dias, 2005, op. cit. p. 119.
} 
respectivas autoridades militares com "categoria correspondente" à de Cachoeira. Assim, dentre os que concorriam para igual ascensão, encontravam-se ricos proprietários, como o capitão-mor da vila de São Francisco, Joaquim Inácio de Siqueira Bulcão e o capitão-mor Francisco Elesbão Pires de Carvalho e Albuquerque - pertencente ao clã da Casa da Torre e futuro barão de Jaguaripe. ${ }^{98}$ Esse último, havia pouco tempo abandonara o posto de vogal da Junta da capital e emigrara para as suas propriedades em Santo Amaro, sendo certo que desde maio de 1822 se encontrava no Recôncavo. ${ }^{99}$

Diante das recusas de Madeira de Mello e da Junta Provincial em manter qualquer comunicação com as lideranças rebeldes do interior baiano e, até mesmo, propor, no caso do brigadeiro, como única solução para apaziguar os ânimos, que todos os sediciosos depusessem as armas e se entregassem à prisão, a escolha da maior parte da classe senhorial na Bahia foi afastar-se mais e mais da esfera política coadunada pelas Cortes de Lisboa. ${ }^{100} \mathrm{Em}$ razão disso, aos 6 de julho reuniram-se em Cachoeira o bacharel Miguel Calmon du Pin e Almeida (futuro marquês de Abrantes) e os militares Felisberto Gomes Caldeira e Antonio Maria da Silva Torres. Apresentando-se às autoridades cahoeiranas, em nome dos habitantes das vilas de Santo Amaro e de São Francisco, essa "deputação" estava disposta, segundo relatou Antonio Pereira Rebouças, a "impor-lhes condições de existência política”, a fim de "alterar-lhes a própria denominação de Junta Conciliatória e de Defesa, de modo a excluir [dela] toda a suposição de poder exercer atribuições governativas, mesmo na própria vila de Cachoeira". ${ }^{101}$ Entretanto, para não suprimir de vez essa Junta, os três representantes propunham abertamente a sua redução à Comissão Administrativa de Caixa Militar e nada mais do que isso. ${ }^{102}$

Tratava-se, portanto, de um momento crucial para a classe senhorial na Bahia que, a partir do Recôncavo, resistia às determinações das Cortes de Lisboa. A rigor, o que estava em jogo era a própria direção política que a classe dominante visava estabelecer, num momento

\footnotetext{
${ }^{98}$ No que diz respeito a essas disputas, ver REBOUÇAS, Antonio Pereira, op. cit. p. 490. Convêm destacar que Siqueira Bulcão era casado com Joaquina Maurícia de S. Miguel Aragão uma das tias mais moças de Francisco Elesbão, sendo ambos, portanto, aparentados. BANDEIRA, Luiz Alberto Moniz, op. cit. p. 473, nota 45.

${ }^{99}$ No processo de realimento político entre importantes segmentos da classe senhorial da Bahia e do Rio de Janeiro, a própria Junta Provincial da capital, eleita em 2 de fevereiro de 1822, viu-se subtraída de alguns dos seus membros, sendo o capitão-mor Francisco Elesbão Pires de Carvalho e Albuquerque o primeiro a abandonála. A rigor, desde, pelo menos, 27 de março de 1822 os documentos do governo da Bahia não recebiam mais as suas assinaturas. $O$ Constitucional, n. 3 segunda-feira, 15 de abril de 1822. Tipografia da Viúva Serva e Carvalho, 1821-1822. Exemplar da coleção do IEB/USP.

${ }^{100}$ Cf. SILVA, Ignácio Accioli de Cerqueira e, op. cit., v. 3. p. 356-358.

${ }^{101}$ REBOUÇAS, Antonio Pereira, op. cit. p. 490-491.

${ }^{102}$ Sobre a organização da Comissão Administrativa de Caixa Militar e influências de Miguel Calmon, Felisberto Caldeira e Silva Torres no Recôncavo, ver TAVARES, Luís Henrique Dias, 2005, op. cit., especialmente p. 117 119.
} 
em que o processo político no Brasil apresentava contornos cada vez mais complexos. ${ }^{103}$ Segundo o autor das Recordações Patrióticas, os discursos objetivando a persuasão dos componentes da Junta e das demais autoridades cachoeiranas não dispensaram a "ameaça de romper a coalizão, que se considerava inerente a todas as vilas irmãs e, muito principalmente, às próprias de Santo Amaro e S. Francisco para com a Cachoeira". ${ }^{104}$ Pressionadas, as autoridades cachoeiranas aprovaram, por uma votação de "simples maioria", a dissolução da Junta Conciliatória e de Defesa incorporando seus membros na referida Comissão Administrativa de Caixa Militar. ${ }^{105}$

De todo o modo, essa mudança abriria caminho para a expansão do círculo governativo antes concentrado apenas entre os representantes de Cachoeira. Além disso, assegurava, ao menos em parte, uma maior coesão ao governo civil e militar do interior, cujas vilas foram gradativamente se declarando pela proclamação de d. Pedro como defensor perpétuo do Brasil e que, por isso, deveriam estar prontas para evitar que as forças lusitanas da capital, mais bem equipadas, organizadas e treinadas, conseguissem contrariar as suas decisões políticas. ${ }^{106}$

Dalí por diante, os lados favoráveis à prevalência das Cortes de Lisboa e os que defendiam a autoridade do príncipe regente encontraram-se dispostos ao enfrentamento bélico antes de uma possível reconciliação. Enquanto Madeira de Mello recebeu novos reforços militares mandados pelas Cortes lisboeta, batalhões sob a direção da classe senhorial foram organizados e soldados das milícias e voluntariados começaram a ser dispostos em pontos estratégicos para impedir o assédio da tropa inimiga. Ainda no mês de agosto de 1822, os comerciantes do povoado de Nazaré deixaram de enviar à capital sua copiosa produção de farinha de mandioca. Os habitantes das vilas de Rio de Contas e de Caetité, importantes fornecedoras de algodão para exportação e de gado vacum para abastecimento da população

${ }^{103}$ Chama atenção nesse processo de articulação para a redefinição do poder governativo a celeridade dos acontecimentos, visto que o retorno de Gomes Caldeira e Silva Torres à Bahia, depois de cumprirem prisão em Lisboa pelos acontecimentos de 3 de novembro, datava de apenas vinte dias e suas migrações para o Recôncavo de menos de uma semana. A despeito disso, há algum indício de que, pouco antes dessa deputação reunir-se com as autoridades de Cachoeira, o tenente-coronel Gomes Caldeira ainda teve tempo de enviar representação "à vila de Jaguaripe para fazer-lhe alterar a ata de aclamação por constar que nela se reconhecera por Governo a Junta Conciliatória e de Defesa". REBOUÇAS, Antonio Pereira, op. cit. p. 491.

${ }^{104}$ Idem, ibidem. p. 492-493. A citação encontra-se à página 493. Os discursos ficaram por conta do bacharel Miguel Calmon e do major Torres e Silva. Conforme Rebouças, embora a fala do bacharel se distinguisse pelo "talento oratório" e "erudição", ela não deixou de "desenvolver o lugar comum de que a união faz a força, simbolizada no feixe misterioso, recorrendo ao exemplo da fraqueza em que caíra Grécia pela discórdia dos respectivos soldados etc”. Ibidem. p. 492.

${ }^{105}$ Ibidem. p. 494.

${ }^{106}$ Em outro momento demonstrei que esse processo de afirmação de um único órgão governativo para todo o interior baiano encontrou resistências em algumas vilas, a exemplo de Rio de Contas e Caetité, cujas iniciativas de instalação de governos autônomos foram reprimidas pelo Conselho Interino de Governo instalado em Cachoeira. SOUZA FILHO, Argemiro Ribeiro de, op. cit. Cap. 2. 
urbana de Salvador, situadas no Alto Sertão da Bahia, também se decidiram pela aclamação do príncipe regente ficando aptas, portanto, a entabularem novas relações políticas e econômicas com as regiões sublevadas contra as decisões de Portugal. ${ }^{107}$

Intercalada aos círculos maçônicos, às esferas militares e à burocracia governamental, tornou-se considerável a presença dos baianos residentes no Rio de Janeiro que alimentavam a rede de informações com os segmentos sociais reunidos no Recôncavo. Nesse sentido, é importante lembrar que uma comissão de baianos esteve à frente das comemorações fúnebres realizadas no Rio de Janeiro, em 21 de junho de 1822, em desagravo aos violentos combates verificados na cidade de Salvador em fevereiro. ${ }^{108}$ Nas celebrações dessas exéquias, o príncipe d. Pedro e a princesa dona Leopoldina não apenas estiveram presentes, como colocaram luto.

Três dias depois, os principais representantes da comissão foram recebidos em audiência pelo príncipe regente. Provavelmente, o objetivo do encontro visava o fortalecimento da relação política entre interesses da classe proprietária na província e o poder central no Rio de Janeiro que, com efeito, poderia facilitar o alinhamento da Bahia às demais províncias coligadas. Dentre as lideranças baianas que participaram da audiência encontravam-se o conselheiro e desembargador do Paço, Antônio Luís Pereira da Cunha, o desembargador Luís José de Carvalho e Melo, o brigadeiro Domingos Alves Branco Moniz Barreto, o intendente do arsenal do Exército Manoel Carneiro de Campos, o capitão-de-mare-guerra Manoel da Silva Freire e o brigadeiro Manuel Ferreira de Araújo Guimarães. ${ }^{109}$

A despeito de não se dispor de maiores informações sobre o conteúdo dessa audiência, as trajetórias políticas de alguns dos seus participantes indicam que os laços de adesão ao projeto capitaneado pelo príncipe apenas se fortaleceram nos anos seguintes, ampliando os espaços de experiência política forjados no decorrer de um conturbado período de dissolução do Antigo Regime português na América e de emersão do Estado e da nação brasileiros. ${ }^{110}$ É o caso, por exemplo, do desembargador Luís José de Carvalho e Melo que seria eleito deputado na Constituinte de 1823 pela Bahia. Com a dissolução da Assembleia,

\footnotetext{
${ }^{107}$ Idem, ibidem, loc cit.

${ }^{108}$ SILVA, Ignácio Accioli de Cerqueira e, op. cit., v. 3. p. 331.

${ }^{109}$ Idem, ibidem, loc cit.

${ }^{110}$ A categoria histórica espaço de experiência utilizada ao longo desse texto deve ser entendida a partir da discussão de KOSELLECK, Reinhart, op. cit. Cap. 14. Para a formação do Estado e nação brasileiros, ver ainda JANCSÓ, István. A fundação do Estado e da nação brasileiros (C. 1770-C. 1850). In: ARRUDA, José Jobson. FONSECA, Luís Adão. (Org.). Brasil - Portugal: História, agenda para o milênio. Bauru: EDUSC; São Paulo: FAPESP. Portugal: ICCTI, 2001 (Coleção História). p. 365-381 e SLEMIAN, Andréa; PIMENTA, João Paulo G. $O$ "nascimento político do Brasil". As origens do Estado e da nação (1808-1825). Rio de Janeiro: Ed. DP \& A, 2003.
} 
ocupou o $3^{\circ}$ gabinete ministerial do Império do Brasil com a pasta das Relações Exteriores (1823 a 1825), além de ter sido um dos redatores da Carta outorgada de 1824. Pelos serviços prestados, Carvalho e Melo seria agraciado por d. Pedro com o título de visconde de Cachoeira, sendo ainda escolhido para o cargo de senador vitalício em 1826, função não exercida em virtude do seu falecimento neste ano.

Outro que se elegera deputado Constituinte também pela província baiana, foi o brigadeiro e redator Manuel Ferreira de Araújo Guimarães (1777-1838), responsável pelo periódico o Espelho no Rio de Janeiro. ${ }^{111}$ Há fortes indícios de que o próprio imperador tenha publicado ali alguns artigos, especialmente quando quis responder ao periódico Correio do Rio de Janeiro, redigido pelo radical exaltado João Soares Lisboa. ${ }^{112}$ Consta que, em 1781, Araújo Guimarães deixara a capitania baiana para estudar em Portugal. Mas por razões financeiras não ingressou na Universidade de Coimbra, onde pretendia bacharelar-se em Matemática. Em 1798 conseguiu matricular-se na Academia Real de Marinha, diplomando-se com brilhantismo em 1805. Na esteira do melhoramento prático favorecido pela transferência da corte joanina para o Brasil, seguiu para o Rio de Janeiro, onde se tornou um dos primeiros lentes nomeado para a Real Academia Militar (1811), vindo a produzir trabalhos significativos em Matemática. ${ }^{113}$ Ainda na corte, esse quadro formado pela ideologia da ilustração fundou e dirigiu O Patriota, "Jornal Literário, Político, Mercantil etc.", que alcançara algum prestígio devido às variadas memórias publicadas em seus números. De duração um tanto efêmera, existiu entre os anos de 1813 e 1814, O Patriota circulou mensalmente, levando ao conhecimento dos leitores dezoito volumes dedicados a compreender "as últimas descobertas nas ciências e artes". ${ }^{114}$ Simultaneamente, Araújo Guimarães assumiu a redação da Gazeta do Rio de Janeiro, sendo o seu responsável até 1821. E, finalmente, esteve à frente da gazeta o Espelho, defendendo o projeto de Independência encabeçado por d. Pedro.

\footnotetext{
${ }^{111}$ Para as participações desses deputados na Assembleia Constituinte, consultar RODRIGUES, José Honório. A Assembleia Constituinte de 1823. Petrópolis: Ed. Vozes, 1974.

${ }^{112}$ LUSTOSA, Isabel, op. cit. p. 147-148.

113 Cf. SILVA, Circe Mary Silva da. "A variação dos triângulos esféricos” de Manuel Araújo Guimarães: primeiro impresso de Matemática, no Brasil, após a liberação da imprensa em 1810. In: Revista da SBHC, n. 15, p. 53-66, 1996 (Disponível em: 〈http://www.mast.br/arquivos_sbhc/154.pdf> Acesso em 20 de fevereiro de 2010).

114 Conforme as próprias palavras de Araújo Guimarães, o Patriota seria “[...] consagrado às ciências, literatura, política, comércio, agricultura, etc. Quanto à primeira parte, compreenderá as últimas descobertas nas ciências e artes, com preferência as que forem devidas a autores nacionais, observações físicas e metalúrgicas do nosso continente, contando-se nas primeiras, as do termômetro e do barômetro, que servirá para fazer conhecer o Estado da nossa atmosfera em diferentes épocas e ajuizar do nosso clima e temperatura dos mais hábeis engenheiros, indagações geográficas [...]”. Apud SILVA, Circe Mary Silva da, op. cit. p. 55.
} 
A presença do brigadeiro baiano Domingos Alves Branco Moniz Barreto nos círculos liberais e nas associações maçônicas na corte do Rio de Janeiro também deve ser destacada. Influente nesses campos de atuação, atribui-se a ele a proposta apresentada originalmente em sessão da loja Grande Oriente para que fosse dado ao príncipe regente o título de Protetor e Defensor Perpétuo do Brasil. ${ }^{115}$ Deve-se notar que constituía prática desse grupo maçônico - naquele momento de afirmação dos espaços de sociabilidade - discutir as suas proposições políticas antes que fossem apresentadas publicamente. Isso, no entanto, não impediu que d. Pedro fosse surpreendido quando, em 3 de junho, assistiu ao irmão Gonçalves Ledo ler em sua presença uma representação requisitando que uma verdadeira Assembleia Constitucional viesse a ser aprovada, em lugar do Conselho de Procuradores que, apesar de ativo, exercia funções meramente consultivas. Na verdade, a proposta já havia sido anteriormente exposta ao príncipe regente (em 23 de maio de 1822), contudo, a apresentação dela em público pesou, por certo, na decisão do futuro imperador que, incontinente, convocou a Constituinte. ${ }^{116}$

Outro episódio que também se vincula ao brigadeiro Domingos Alves Branco ocorreu no período precedente à aclamação de d. Pedro como imperador constitucional da nação brasileira. A loja Grande Oriente, mais uma vez por meio de Joaquim Gonçalves Ledo, apresentara a proposta de que o herdeiro de Bragança no Brasil deveria ser saudado como "rei e defensor perpétuo". Consta, porém, que o "maçom Domingos Alves Branco Moniz Barreto", subindo em uma mesa, replicara que o príncipe regente deveria sim ser aclamado, não como rei - título próprio das monarquias absolutas -, mas como imperador, visto ser uma representação mais condizente com os princípios de uma monarquia constitucional. $^{117}$

No contexto em que se ampliam as divergências entre os liberais mais exaltados pertencentes à Grande Oriente e os Andrada, responsáveis por uma organização semelhante à maçonaria, conhecida como Apostolado, Domingos Alves Branco proferiu o discurso aclamando d. Pedro, Grão-Mestre da Grande Oriente do Brasil. Nesta sessão, ocorrida em 04 de outubro de 1822, este baiano solicitou que o regente expulsasse os "inimigos", "embusteiros", certamente referindo-se aos membros do Apostolado.

${ }^{115}$ VARNHAGEN, Francisco Adolfo de, op. cit. p. 117. A loja maçônica Grande Oriente Brasílico ou do Brasil instalada no Rio de Janeiro, em 24 julho de 1822, teve na figura do brigadeiro Domingos Alves Branco Moniz Barreto um dos seus fundadores. Este brigadeiro pertencera também à loja maçônica Comércio e Artes, sediada igualmente no Rio de Janeiro. BARATA, Alexandre Mansur, op. cit. p. 175 e 242, nota 107 e MORAES, Alexandre de Mello, op. cit., t. 2. p. 460-461.

${ }^{116}$ VARNHAGEN, Francisco Adolfo de, op. cit. p. 119-120. Sobre a atuação dos círculos maçônicos do Rio de Janeiro enquanto espaços de sociabilidade política nesse período, ver também MOREL, Marco, 2005, op. cit.

${ }^{117}$ VARNHAGEN, Francisco Adolfo de, op. cit. p. 140 (notas 25 e 30). 
Não podendo haver justa liberdade, nem podendo existir algum povo que possa chamar-se livre sem que tenha o direito de petição, e de exprimir as suas ideias e os seus pensamentos, direito que, sendo imprescritível e inalienável, só nos Estados onde rege o despotismo não é respeitado; não posso, portanto, temer perante vós, Senhor, que em tantas e tão diferentes formas tendes manifestado todos os vossos assíduos desvelos e fadigas a prol da liberdade constitucional, e da melhor ventura nacional brasílica, o exprimir sem receio os meus pensamentos [...]

Precavei-vos, respeitável Grão-Mestre, de embusteiros. Não vos abandoneis, a enredos, a vãos caprichos. Atendei que na criação de um Império deveis ter em muita consideração qual é o gênio que o pode conservar ou que o pode destruir. Deus tem visivelmente mostrado que auxilia a nossa justa causa; não trabalhemos para que ele retire a sua onipotente mão, para nos deixar cair nas desgraças e na confusão, apartando-nos dos vínculos que nos unem e das condições do nosso pacto social, tendo por ele o imperador a prerrogativa de fazer todo o bem sem ser responsável pelo mal.

Se mãos ímpias pela intriga pretendem apagar a sagrada tocha que nos alumia, sejam estes sacrílegos lançados para fora do nosso grêmio, e sejam detestados e os seus nomes apagados da tabela que nos honra [...]

Apartai-vos, digno Grão-Mestre, de homens coléricos e furiosos; por mais cientes que eles sejam nunca acham a razão e só propendem para o crime. Vós tendes sabedoria, prudência, comedimento e moderação; portanto não vos deveis abandonar a malvados. Atalhai todo o ulterior progresso da intriga, confiando dos vossos leais mações [...]. ${ }^{118}$

Decerto proposituras dessa natureza causaram impacto muito negativo junto ao futuro imperador, mas o divisor de águas entre esse grupo maçônico/liberal e d. Pedro ocorreu, de fato, quando a Câmara do Senado do Rio de Janeiro, presidida por José Clemente Pereira, quis aprovar uma cláusula pela qual o imperador ver-se-ia obrigado a jurar previamente a Constituição a ser elaborada pela Assembleia. Apoiando-se no ministério dos Andrada, cujas propostas de Império eram, como se sabe, centralista e pouco afeita à soberania popular, d. Pedro autorizou uma perseguição exemplar contra as principais lideranças com ideias acentuadamente liberais. Logo as primeiras vítimas apareceram. E assim, Gonçalves Ledo, mesmo eleito como deputado constituinte pelos fluminenses, só conseguiu escapar à prisão porque se exilou em Buenos Aires e jamais conseguiu se apresentar à Assembleia. ${ }^{119}$

Desfavorável também fora a sorte do brigadeiro Domingos Alves Branco Moniz Barreto que acabara preso e obrigado a responder processo, acusado de participação em uma

\footnotetext{
${ }^{118}$ Apud MORAES, Alexandre de Mello, op. cit., t. 2. p. 461-462. Salienta-se que os liberais aproveitaram da ausência de José Bonifácio para aclamar d. Pedro como Grão Mestre e, simultaneamente, solicitar-lhe a expulsão dos "embusteiros ocultos ou desmascarados". Sobre a conjuntura e o impacto desse discurso, ver também Apud BARATA, Alexandre Mansur, op. cit. p. 236-237.

${ }^{119}$ Cf. VARNHAGEN, Francisco Adolfo de, op. cit. p. 141 e segs.
} 
facção oculta e tenebrosa, descoberta na Corte de furiosos demagogos e anarquistas. ${ }^{120}$ Meses antes ele havia articulado sua nomeação para assumir o comando da Expedição Auxiliadora que d. Pedro enviou à Bahia para coadjuvar a resistência contra as tropas de Madeira de Mello. ${ }^{121}$ Sabe-se também que, aconselhado por José Bonifácio de Andrada e Silva (1763-1838), o regente não o nomeou para o posto pretendido, incluindo-o, todavia, na condição de oficial subordinado ao general francês Pierre Labatut (1768-1849), que assumira o comando da expedição instalada na Bahia com a denominação de Exército Pacificador. Justificando problemas de saúde, Alves Branco não tomaria parte na campanha militar ocorrida na sua província natal, permanecendo, então, no Rio de Janeiro. ${ }^{122}$ Contra Alves Branco pesava também a suspeição de ter estado à frente do motim que pretendeu destituir o comando militar do general Labatut logo depois que esse partira da corte fluminense.

Polemista e escritor de algum prestígio, o brigadeiro Alves Branco fora, sem dúvida, um autêntico representante do pensamento ilustrado. ${ }^{123}$ Dentre os textos de sua lavra, destaca-

${ }^{120}$ O Ministro José Bonifácio fez expedir uma circular enviada aos presidentes das câmaras municipais contra o espírito revolucionário. In: MORAES, Alexandre de Mello, op. cit., t. 2. p. 470-471.

${ }^{121}$ Em 15 de junho de 1822, os procuradores da província do Rio de Janeiro apresentaram uma carta do brigadeiro Domingos Alves Branco Moniz Barreto rogando socorros à Bahia, cujo resultado foi a decisão de d. Pedro de enviar uma força militar para a província baiana. RODRIGUES, José Honório. Independência: revolução e contra-revolução — As Forças Armadas. Rio de Janeiro: Livraria Francisco Alves, 1975, 3 v. p. 208-209.

${ }^{122}$ Segundo Luís Henrique Dias Tavares, uma das razões que levara o brigadeiro Alves Branco ter sido preterido no comando das tropas que a partir do Recôncavo baiano se posicionaram contrárias às disposições das Cortes de Lisboa, deveu-se à suspeição de que teria participado do movimento conspiratório de 3 de novembro de 1821 , bem como o receio de ligações familiares e pessoais com grandes proprietários de terra e escravos na província baiana terminarem contribuindo para a consolidação da autonomia política da classe senhorial ali residente. Salienta-se que a indicação de comprometimento entre Alves Branco e os demais implicados na tentativa de destituição da primeira Junta Governativa avigora a hipótese de que as redes de sociabilidade entre o Rio e a Bahia tornaram-se facilitadoras do alinhamento político envolvendo as duas principais províncias do Brasil, conquanto elas se afastassem efetivamente de um comportamento de tipo monolítico. TAVARES, Luís Henrique Dias, 2005, op. cit. p. 151-152.

${ }^{123}$ Veja, por exemplo, BARRETO, Domingos Alves Branco Moniz. Memória sobre a abolição do comércio da escravatura. In: COSTA, João Severiano Maciel da et al, op. cit. Embora este texto, publicado postumamente (1837), apontasse com rigor os inconvenientes do tráfico internacional de escravos para o desenvolvimento da economia do Brasil recém-independente, à medida que preconizava disposições que, progressivamente, conduzissem à extinção das relações de trabalho fundadas no escravismo, ele não alcançaria nem a radicalidade, nem a repercussão da representação que José Bonifácio dirigiu à Assembleia Geral Constituinte e Legislativa do Império do Brasil, o que, por certo, tornava extremamente delicado definir quem, dentre os contemporâneos, encarnava um projeto mais ou menos liberal para o Estado e a nação brasileiros. Realmente, José Bonifácio foi bem mais enfático do que Alves Branco ao denunciar as impossibilidades de que fossem conciliados conceitos como "Constituição liberal" e escravidão. Por isso, o autor paulista proclamava: “[...] É tempo, pois, e mais que tempo, que acabemos com um tráfico tão bárbaro e carniceiro; é tempo, também, que vamos acabando gradualmente até os últimos vestígios da escravidão entre nós, para que venhamos a formar, em poucas gerações, uma nação homogênea, sem o que nunca seremos verdadeiramente livres, respeitáveis e felizes [...] cuidemos, pois, desde já, em combinar sabiamente tantos elementos discordes e contrários e em amalgamar tantos metais diversos, para que saia um todo homogêneo e compacto, que se não esfarele ao pequeno toque de qualquer nova convulsão política [...]". SILVA, José Bonifácio de Andrada. Representação à Assembleia Geral Constituinte e Legislativa do Império do Brasil sobre a escravatura. In: COSTA, João Severiano Maciel da et al, op. cit. p. 64. Para uma ampla visão sobre a influência desse membro da ilustração paulistana sobre a geração da 
se aqui a defesa que empreendera da sua atividade enquanto maçom, posto que se dissesse perseguido em um contexto no qual o funcionamento de lojas maçônicas na corte fluminense era público. Significava, então, que as atividades dos pedreiros livres fossem, em face das circunstâncias políticas do momento, toleradas e tacitamente aprovadas pelas maiores autoridades do Brasil. Fechada, contudo, a loja Grande Oriente, em 25 de outubro de 1822, por ordem de d. Pedro, o brigadeiro Alves Branco logo seria instado a defender-se dos que o acusavam de pertencer a uma faç̧ão oculta e tenebrosa. Sua resposta pública veio no ano seguinte quando afirmou que:

[...] menos se ignorava que à mesma Corporação se achavam ligados, como Sócios, todos os Ministros, e Conselheiros de Estado de Sua Majestade Imperial, à exceção de um, e que era Presidida, e encaminhada pelas Luzes, Patriotismo, e Probidade do seu Presidente o Exc. Sr. José Bonifácio de Andrada e Silva, na Presença de Quem se tratavam todos os objetos tendentes à prosperidade do Brasil, sua Independência, e Aclamação do Augusto Imperador: o que tudo se conseguiu pelos assíduos trabalhos da referida Corporação, constantemente dirigidos pelo Ilustre Grão Mestre, e com avultada despesa do Cofre Geral, não só para o lustre do Glorioso Dia doze de Outubro, em que entraram cinco arcos triunfais, mas com os Emissários que se mandaram para todas as Províncias, tanto Marítimas, como Centrais, para que nesse mesmo Dia fosse nelas Aclamado o Senhor D. Pedro I, Imperador do Brasil [...]. ${ }^{124}$

Identificado ao grupo liberal exaltado, vinculado a personagens como Gonçalves Ledo, o brigadeiro Alves Branco, em 1823, sentia novamente a necessidade de justificar a importância da maçonaria frente à Independência do Brasil. Do alto da experiência dos 77 anos de idade, a sua declaração servia também de desabafo:

Se a revolução que para isso se fez fosse criminosa, e não merecesse a gratidão pública, então [...] acusaria a Maçonaria, e até lhe imputaria o mau resultado dos seus trabalhos. Como porém a Grande Obra foi bem-sucedida, e mereceu os aplausos públicos, não foi isso devido à Sociedade Maçônica, mas sim aos Brasileiros de todas as Províncias, que não eram Maçons. ${ }^{125}$

De toda forma, fica evidenciado que o comportamento dos baianos residentes no Rio de Janeiro não se prendia a uma única corrente política, visto ter incorporado manifestações dos segmentos mais conservadores, a exemplo do futuro visconde de Cairu,

Independência, ver SILVA, José Bonifácio de Andrada e. Projetos para o Brasil. Organização de Miriam Dolhnikoff. São Paulo: Companhia das Letras, 1998.

${ }_{124}$ Apud BARATA, Alexandre Mansur, op. cit. p. 242.

${ }^{125}$ Apud BARATA, Alexandre Mansur, op. cit. p. 246. 
bem como as dos que se destacariam pela conduta mais liberal como a do brigadeiro Alves Branco. Divergências políticas que na província se manifestariam de maneira mais acentuada.

\subsection{A construção de um espaço de experiência: o Conselho Interino de Governo}

A despeito do desempenho da Comissão Administrativa da Caixa Militar no Recôncavo baiano em fins de julho de 1822, observa-se que, seja na arrecadação e fiscalização dos fundos destinados à despesa da província, seja nas medidas adotadas para melhor resistir às tropas lusitanas, a provisoriedade política característica da dissolução do Antigo Regime português continuou favorecendo a sensação de vazio de poder. Esta situação deu motivo a aparição de críticas e restrições quanto a atuação da Comissão, ${ }^{126}$ razão pela qual, a classe senhorial do Recôncavo viu-se obrigada, mais uma vez, a encontrar uma solução que dirimisse as insatisfações de caráter localista e, simultaneamente, garantisse a sua hegemonia governativa no interior baiano.

Apesar de não terem ocorrido combates militares relevantes nesse período, a campanha estava em curso, sendo que a mobilização e a alimentação da tropa exigiam recursos que não podiam ser reunidos apenas com doações particulares. Acresce-se a isso as notícias de que, em breve, as tropas da capital seriam fortalecidas por novos reforços enviados pelas Cortes de Lisboa. Na expectativa de encontrar alternativas para situações tão inquietantes, o Senado da Câmara de Cachoeira reuniu-se em 31 de julho para apreciar um ofício do coronel de cavalaria José Garcia Pacheco Pimentel de Moura e Aragão, propondo que a mesma Câmara realizasse "um empréstimo em nome da Fazenda Nacional" a ser empregado nas despesas existentes na Caixa Militar. A vereança de Cachoeira, não se sentindo autorizada a assumir tamanha responsabilidade, resolveu convocar "os mais conspícuos cidadãos e proprietários" do seu distrito para opinarem sobre o assunto. ${ }^{127}$

Passados três dias, a Câmara decidiu que seria efetivado um empréstimo suficiente para o pagamento das despesas existentes na Comissão da Caixa Militar até que fosse "embarcada a tropa europeia destacada na capital da província". O levantamento desse fundo seria feito por meio de vales, em nome da Fazenda Nacional, sacados seus valores entre diversos proprietários presentes ou que ali contavam com procuradores. Favorável a assumir esses compromissos, parte dos proprietários ratificou ali mesmo um termo de fiança $e$

\footnotetext{
${ }^{126}$ Cf. TAVARES, Luís Henrique Dias, op. cit., especialmente p. 121.

${ }^{127}$ Termo de vereação do Senado da Câmara de Cachoeira em 31 de julho de 1822. Documentos históricos sobre a emancipação política da Bahia. Revista do Instituto Geográfico e Histórico da Bahia, ano II, v. 2, n. 6, p. 377$378,1895$.
} 
obrigação pelo qual declarou suportar os prejuízos, abrindo mão de "quaisquer privilégios e isenções”, em caso da Fazenda Nacional não reconhecer no futuro o referido débito. ${ }^{128}$

Na relação dos proprietários que assumiram o referido empréstimo encontravam-se: Joaquim Antonio Moutinho, Francisco Antonio Fernandes Pereira, Antonio Teixeira de Freitas Barbosa - futuro barão de Itaparica -, Antonio Lopes Ferreira e Sousa, José de Oliveira Lopes, Felipe Correia Pinto, Domingos da Silva Guimarães, o coronel de cavalaria José Garcia Pacheco de Moura Pimentel e Aragão, José Paes Cardoso da Silva, e este por seu filho, Francisco Paes Cardoso da Silva, o tenente-coronel Manoel Inácio de Lima, Luís Pereira da Rocha, o vereador e alferes José Gomes Moncorvo, o vereador e tenente-coronel Jerônimo José Albernaz, o presidente da Câmara e capitão Antonio de Castro Lima e José Antonio Fiusa de Almeida por seu procurador Feliciano Pereira Castilho. Registrou-se também que o sargento-mor de cavalaria Joaquim de Almeida Arnizau oferecia "os seus soldos vencidos e os que se vencerem até a decisão da causa". Por fim, entre "os cidadãos" presentes, mas que não se comprometeram com o empréstimo, estava o mulato Antonio Pereira Rebouças. ${ }^{129}$

Se administrativamente as soluções para a continuidade da campanha militar contra as tropas lusitanas encontravam paliativos, mesmo que momentâneos e de caráter inegavelmente localista, no campo da política havia muito a concertar tendo em vista que a dinâmica dos acontecimentos internos e externos à província exigia argúcia nas decisões. É bem provável que, devido à rede de informações estabelecida com o Rio de Janeiro, parte da classe senhorial já conhecesse, em princípios de agosto de 1822, as diretrizes gerais traçadas pela regência para apaziguar a Bahia. $O$ certo é que em 21 desse mês esperava "a entrada da

\footnotetext{
${ }^{128}$ Termo de vereação do Senado da Câmara de Cachoeira em 3 de agosto de 1822 e Termo de fiança e obrigação. Documentos históricos sobre a emancipação política da Bahia. Revista do Instituto Geográfico e Histórico da Bahia, ano II, v. 2, n. 6. p. 378-381, 1895.

${ }^{129}$ Idem, ibidem. p. 381-382. Outras decisões temporárias foram tomadas com o fim de sustentar ou, ao menos, prorrogar a prevalência da Comissão da Caixa Militar. Em 7 de agosto, por exemplo, a Câmara de Cachoeira considerou a decisão do coronel de cavalaria José Garcia Pacheco que enviara à vila cento e cinquenta e uma cabeças de gado extraída da Fazenda Nacional e Real com o fim de serem talhadas nos açougues da mesma vila e do porto do povoado de São Félix, "pelo preço de quatro pataca e meia cada arroba, por ser presentemente o preço porque se talham as carnes de boiadas" e cujas rendas seriam revertidas para a Comissão. Termo de vereação do Senado da Câmara de Cachoeira em 7 de agosto de 1822. Documentos históricos sobre a emancipação política da Bahia. Revista do Instituto Geográfico e Histórico da Bahia, ano II, v. 2, n. 6. p. 382 383, 1895. Enquanto o Recôncavo ainda podia praticar o preço de alimentos como a carne bovina nos módicos termos anunciados, a cidade de Salvador que, à época, já sentia a falta de alimentos acarretada pelo crescente isolamento com o interior, consumia o charque do Rio Grande pelo preço exorbitante de 120 patacas (moeda de prata com o valor de 320 réis) a arroba (unidade de medida de peso que atualmente equivale a 14,400 Kg). Para esses dados, ver TAVARES, Luís Henrique Dias, op. cit. p. 121 e GRAHAM, Richard. "Ao mesmo tempo sitiantes e sitiados”. A luta pela subsistência em Salvador (1822-1823). JANCSÓ, István (Org.). Independência: História e historiografia. São Paulo: Hucitec; Fapesp, p. 411-445, 2005.
} 
esquadra, que vem da Corte do Brasil em [...] socorro" das vilas conflagradas, bem como a chegada de um comandante-em-chefe "nomeado por Sua Alteza, d. Pedro de Alcântara. ${ }^{130}$

Ainda no que diz respeito à rearticulação política da província baiana com a corte fluminense, é preciso considerar que os pontos de contato desse processo envolveram, de parte a parte, ressalvas. Afinal de contas, havia pendências políticas mal resolvidas entre a antiga e a recente sede dos vice-reis na América portuguesa. ${ }^{131}$ Não datava muito tempo isso ficara evidenciado quando a Revolução Constitucionalista de fevereiro de 1821 elegera as Cortes de Lisboa como único órgão a merecer obediência, rompendo, assim, de fato e de direito, com as relações administrativas nas duas províncias, cujo efetivo reatamento vinha sendo cuidadosamente costurado. Todavia, a profunda instabilidade política do período demandava, como registrado, celeridade nas decisões.

Por tudo isso, a classe senhorial tinha pressa em fundar um legítimo centro de poder, que não apenas congregasse todo o interior disposto a enfrentar as tropas lusitanas, mas servisse também de anteparo a qualquer investida da regência de d. Pedro que, fortalecido politicamente, estava pessoalmente engajado no envio de emissários de poder para pacificar a Bahia. ${ }^{132}$ Se no aspecto militar a prevalência do comando seria designada a partir do Rio de Janeiro, era imprescindível para a classe senhorial na Bahia assegurar, ao menos, a direção do governo civil. Mas, para isso, era preciso solucionar as disputas internas e, evidentemente, a questão não se constituía tarefa das mais fáceis, pois os interesses e as divergências na condução desse processo variavam, seja no interior das próprias vilas do Recôncavo, seja entre essa região e as áreas interioranas, a exemplo do Alto Sertão. Numa perspectiva de conjunto, Andréa Slemian observou que a irrupção das ideias constitucionais na América portuguesa intensificou a instabilidade política ao criar expectativas de transformações e realocações do poder entre protagonistas dispostos a explorar os espaços públicos em busca

\footnotetext{
${ }^{130}$ Termo de vereação do Senado da Câmara de Cachoeira em 21 de agosto de 1822. Documentos históricos sobre a emancipação política da Bahia. Revista do Instituto Geográfico e Histórico da Bahia, ano II, v. 2, n. 6 , 1895. p. 387 e 390.

${ }^{131}$ A própria decisão da Coroa bragantina em fixar a família real entre os fluminenses, em 1808, sobretaxando as capitanias do Norte para a implantação e a modernização do aparato administrativo e burocrático régio despertou muita desconfiança. O periódico pró-lusitano, Sentinella Bahiense, ao se referir às iniciativas da classe senhorial baiana em requisitar, em 1816, a criação de um corpo militar de 2.000 pedestres para controlar as revoltas escravas, denunciou a sua pretensão de "não conter os negros, mas aclamarem a independência". Sentinella Bahiense, n. 8, quarta-feira de 21 de agosto de 1822. Tipografia da Viúva Serva e Carvalho. Exemplar da coleção do Centro de Estudos Baianos da Universidade Federal da Bahia (grifo do redator). No que respeita à ampliação do descontentamento nas capitanias do Norte que propiciou a Revolução de 1817, consultar MELLO, Evaldo Cabral de. A outra Independência: o federalismo pernambucano de 1817 a 1824. São Paulo: Ed. 34, 2004 e BERNARDES, Denis Antônio de Mendonça, op. cit.

${ }^{132}$ Varnhagen informou que d. Pedro esteve, por algum tempo, ocupado providenciando meios para intervir no conflito envolvendo os baianos. Dentre outras iniciativas do futuro imperador, destacou a autorização para recrutamento das forças que atuariam na província e a resolução que assegurou um empréstimo ao governo de Cachoeira. VARNHAGEN, Francisco Adolfo de, op. cit. p. 125-126.
} 
de afirmação dos seus projetos, situação que, com certa facilidade, poderia marcar as localidades pela violência, não raramente, verificadas nestas disputas. ${ }^{133}$

Para contemplar realidades tão diferenciadas como a prevalecente na província baiana, a classe senhorial no Recôncavo, tendo sob seu controle a quase totalidade das forças de milícias, das municipalidades e, como não poderia deixar de ser, da economia, se dispôs a instituir um novo centro de poder. ${ }^{134}$ Registre-se que o novo órgão extrapolou a experiência das demais juntas provinciais em território do Brasil à medida que arregimentou um maior número de representantes indicados pelas vilas vinculadas à autoridade do príncipe regente. Após acordarem um plano de ação conjunta entre os principais proprietários, novamente com destaque para os residentes em Santo Amaro e em São Francisco, o coronel José Garcia Pacheco apresentou-se em 21 de agosto de 1822 à Câmara da vila de Cachoeira com uma representação, em nome das "pessoas da nobreza e mais Cidadãos conspícuos, e lavradores, todos proprietários desta vila e seu termo", para discutirem a instalação "de um governo geral, não só para o recôncavo e comarca da Bahia, mas também para toda a província". ${ }^{135}$

Essa representação registrou a assinatura das seguintes lideranças da classe senhorial: o coronel e comendador Bento de Araújo Lopes Vilas Boas, o capitão-mor de S. Francisco, Joaquim Inácio de Siqueira Bulcão, o tenente-coronel Felisberto Gomes Caldeira, Manoel de Vasconcelos Souza Bahiana, o major Antonio Maria da Silva Torres, Luís Lopes Vilas Boas, José de Araújo de Aragão Bulcão, Inácio José Aprígio da Fonseca Galvão, Luís Manoel de Oliveira Mendes, o coronel Francisco Maria Sodré Pereira, o juiz de fora Joaquim José Pinheiro de Vasconcelos - futuro visconde de Montserrat -, o bacharel Miguel Calmon du Pin e Almeida, o capitão-mor de Santo Amaro, Antonio Joaquim Pires de Carvalho e Albuquerque (1785-1852) e, finalmente, o desembargador pernambucano Antonio José Duarte de Araújo Gondim - que seria eleito deputado à Assembleia Constituinte de 1823 por sua província natal. Ressalta-se ainda que dentre as justificativas para a criação de um "centro comum de autoridade [...] em nome de S. A. R., o sereníssimo príncipe Senhor D. Pedro de Alcântara, regente e defensor do Brasil, segundo as regras do governo representativo",

\footnotetext{
133 SLEMIAN, Andréa. Sob o império das leis: Constituição e unidade nacional na formação do Brasil (18221834). São Paulo: Hucitec; Fapesp, 2009. p. 73.

${ }^{134}$ Para a capacidade econômica da classe senhorial deste período, consultar SILVA, Eduardo; REIS João José. O jogo duro do dois de Julho: o "Partido Negro" na Independência da Bahia. In: SILVA, Eduardo; REIS, João José. Negociação e conflito: a resistência negra no Brasil escravista. São Paulo: Companhia das Letras, 1989. p. 87.

135 Termo de vereação do Senado da Câmara de Cachoeira em 21 de agosto de 1822. Documentos históricos sobre a emancipação política da Bahia. Revista do Instituto Geográfico e Histórico da Bahia, ano II, v. 2, n. 6, 1895. p. 384-386.
} 
encontrava-se o fato de as vilas de Jacobina e de Valença já terem também, àquela altura, aclamado o príncipe regente. ${ }^{136}$

Bem fundamentada, a representação propunha a instalação de um Conselho Interino de Governo composto por representantes, "eleitos à pluralidade absoluta de votos pelas câmaras e homens bons das vilas coligadas, ou que atualmente têm aclamado a regência constitucional de S. A. R., na razão de um deputado por cada uma das ditas vilas". Seu objetivo era governar a província da Bahia, em nome do príncipe regente, subordinando "as autoridades civis e militares, sem exceção alguma”. Na expectativa de minimizar a carência de recursos, mormente para empregar na campanha militar, esse centro governativo ficaria autorizado a criar "uma comissão de junta de fazenda, para dirigir as finanças"; nomearia também "um comandante-em-chefe interino da força armada da província até que chegue o imediatamente nomeado por S. A. R". Por fim, assumiria o compromisso de dissolver o governo logo que a capital da província aclamasse o príncipe regente e as tropas portuguesas evadissem da capital, deixando instituído, em lugar do Conselho, um governo provincial, isso no caso de o regente não ter, até ali, tomado outra decisão a respeito. ${ }^{137}$ Não sendo registrada qualquer objeção, o plano foi acatado e, assim que apenas cinco representantes se apresentassem em Cachoeira, o governo seria instalado.

Devido aos processos para as escolhas dos representantes locais que tomariam assento no novo órgão governativo, somente aos 6 de setembro o Conselho Interino de Governo da Bahia foi instalado em Cachoeira, vila que se tornava o centro das decisões políticas reativas em razão da ocupação militar de Salvador. Obrigado a encerrar as atividades do periódico $O$ Constitucional em Salvador, para fugir dos portugueses europeus vinculados às Cortes de Lisboa, o bacharel em direito Francisco Gomes Brandão Montezuma refugiou-se no Recôncavo, onde fora nomeado para representar a vila de Cachoeira no Conselho Interino. ${ }^{138}$ Os demais integrantes do novo órgão governativo que tomaram posse no dia 6 foram: o capitão-mor Francisco Elesbão Pires de Carvalho e Albuquerque (pela vila de Santo

\footnotetext{
${ }^{136}$ Idem, ibidem. p. 388. O acordo político que atendesse às especificidades de diferentes realidades interioranas antepunha uma série de obstáculos a serem vencidos. Nesse sentido, enquanto a classe senhorial do Recôncavo propugnava a instalação de um "centro governativo" único para toda a província, as vilas de Valença, no litoral sul, e de Rio de Contas, subordinada à comarca de Jacobina, ao aclamarem o príncipe regente aproveitaram essa ruptura com a autoridade da capital e instalaram juntas governativas circunscritas às situações locais. Em Rio de Contas, por exemplo, a aclamação e a formação do novo órgão governativo ocorreram em 15 de agosto de 1822. Portanto, antes da representação que ora se discute. SOUZA FILHO, Argemiro Ribeiro de, op. cit. Cap. 2.

137 Termo de vereação do Senado da Câmara de Cachoeira em 21 de agosto de 1822. Documentos históricos sobre a emancipação política da Bahia. Revista do Instituto Geográfico e Histórico da Bahia, ano II, v. 2, n. 6, 1895. p. 386-393.

${ }^{138}$ Segundo os dados de F. W. O. Morton, Montezuma fora o único homem de cor nascido na Bahia a se diplomar pela Universidade de Coimbra antes da Independência. MORTON, F. W. O., 1974, op. cit., p. 56.
} 
Amaro); o desembargador Antonio José Duarte de Araújo Gondim (São Francisco); o capitãomor Manoel da Silva Sousa Coimbra (Maragogipe); o capitão Manoel Gonçalves Maia Bittencourt (Jaguaripe) e, finalmente, o padre Manoel José de Freitas Batista Mascarenhas (Pedra Branca). A efetivação deste espraiado centro de poder na Bahia evidenciava, sobremodo, que um grande desafio para a classe senhorial havia sido vencido, pois a ampliação da representação facilitou, ao menos em parte, o entendimento para que os interesses localistas fossem minimamente atendidos e a autonomia da província preservada em uma conjuntura de indisfarçável instabilidade política.

Por outro lado, a novidade do Conselho Interino não estava apenas na quantidade dos seus membros, que alcançaria um total de dezesseis integrantes, mas sobretudo no fato de ser a primeira vez que diferentes representantes locais participavam diretamente das decisões provinciais. ${ }^{139}$ Até ali nenhuma outra forma de governo na Bahia havia propiciado essa experiência, sendo que nem a Revolução Constitucionalista de 1821, precursora das juntas governativas na província, mostrara-se capaz de avançar a participação para além das consagradas estratificações sociais de tipo Ancien Régime fundadas na representação clero, milícia, comércio, agricultura e cidade, situação que permanecera inalterada na segunda Junta Provincial eleita, com aval das Cortes de Lisboa, entre os dias $1^{\circ}$ e 2 de fevereiro de 1822. Essa postura somente seria modificada pela implantação do Conselho que, em paralelo às autoridades da capital, administraria o interior da Bahia por quase nove meses. A despeito da brevidade, esse intervalo de tempo revelar-se-ia suficiente para que fossem processadas mudanças de grande magnitude para o futuro da província e do Brasil.

Também é importante notar que esse tipo de governo ao estilo federado - pois contava com representantes de várias localidades baianas -, só se tornou possível devido à singularidade de uma província dividida por disputas políticas e em meio à Guerra. Prova disso é que aceita a sua autoridade pela maioria das vilas interioranas, a classe senhorial do Recôncavo, que exercia, de fato, maior influência nesse centro governativo, solicitara junto ao imperador nova organização do Conselho Interino nos mesmos moldes das demais juntas. $\mathrm{Ou}$ seja, com apenas sete membros na direção: “[...] até se verificar o método de governo para todas as províncias do Brasil, determinado na constituição, que se fizer a Assembleia Geral Legislativa Constituinte do mesmo Reino, providência que urge ser dada quanto antes, porque

\footnotetext{
${ }^{139}$ Ao contrário do que se registra, a vila de Rio de Contas não enviou o seu representante na pessoa do capitão José Valentim de Souza ao Conselho Interino. Isso porque havia divergências entre o órgão de governo do Recôncavo e outro que havia sido instalado na vila supracitada. Com a ressalva apresentada, ver sobre a composição do Conselho Interino TAVARES, Luís Henrique Dias, 2005, op. cit. p. 124-125. No tocante às dissensões mencionadas, ver SOUZA FILHO, Argemiro Ribeiro de, op. cit. p. 91-94.
} 
o Conselho Interino de Governo não pode subsistir facilmente, atenta à multiplicidade de seus membros". ${ }^{140}$ Havia, por certo, maior necessidade de diálogo e negociação em um órgão federado como o Conselho Interino fora originalmente organizado, o que se constituía, sem dúvida, um desafio para muitos dos representantes da classe senhorial, acostumados a serem prontamente obedecidos em uma sociedade arraigadamente escravista.

Visto por este prisma, as constatações do general francês, Pierre Labatut, considerando o "Recôncavo dividido em pequenos governos ciumentos uns dos outros, cujos Chefes a título de serviços à Pátria satisfaziam suas paixões e interesses, e sem o verdadeiro respeito ao Governo da Província, que não tinha força moral, e muito menos física por que dela não podia usar" possuíam decerto verdades difíceis de serem refutadas. ${ }^{141}$ De qualquer forma, é preciso ressaltar que as lideranças com maior participação nas decisões do Conselho Interino foram desde sempre os representantes das vilas de Santo Amaro, Francisco Elesbão Pires de Carvalho e Albuquerque (presidente); de Abrantes, bacharel Miguel Calmon du Pin e Almeida; de Cachoeira (secretário e responsável pela Fazenda Pública), Francisco Gomes Brandão Montezuma (secretário); de Inhambupe, coronel Simão Gomes Ferreira Veloso e de Valença, padre Teodósio Dias de Castro.

Evidencia-se, então, que, com a declaração da Independência e a formação do Estado e da nação brasileiros, diversas lideranças revelar-se-iam interessadas, ao menos a nível provincial, em formas de poder mais centralizadas, tendência essa que iria distinguir o governo imperial no Primeiro Reinado, cuja participação política da Bahia mostrar-se-ia acentuada. Dessa maneira, a efetivação do Conselho Interino de Governo em Cachoeira pode ser compreendida como a construção de um espaço de experiência que não apenas cumpriria função proeminente na expulsão das tropas lusitanas estacionadas na capital da província, como auxiliaria os representantes da classe senhorial no aprofundamento dos laços políticos com o projeto de monarquia constitucional para o Império do Brasil orquestrado a partir das províncias coligadas.

\footnotetext{
${ }^{140}$ Correspondência oficial do Conselho Interino de Governo na Cachoeira, em 21 de outubro de 1822. Documentos históricos sobre a emancipação política da Bahia. Revista do Instituto Geográfico e Histórico da Bahia, ano IV, v. 4, n. 13, 1897, p. 437-438. O pedido teria a concordância do imperador que, em 5 de dezembro de 1822, expedira um decreto nesta direção. Entretanto, a escolha da nova representação política do Conselho Interino de Governo só ocorreu em 19 de maio do ano seguinte e a sua posse somente foi materializada em 29 de junho. Ou seja, quando já era esperada a breve evacuação da tropa lusitana, ocorrida em 2 de julho de 1823. Presidência da Província - Registro de correspondência expedida. APEB. Seção Colonial e Provincial. Data: 17/12/1822. Maço: 637-2 e MINISTÉRIO DA JUSTIÇA. As Juntas governativas e a independência. Rio de Janeiro: Arquivo Nacional/Conselho Federal de Cultura, 1975, v. 2. p. 791-792, 842.

${ }^{141}$ Declaração franca que fez o general Labatut aos baianos em 02 de janeiro de 1824. In: Revista do Instituto Geográfico e Histórico da Bahia, v. 1, n. 65, p. 45-63, 1939. A citação encontra-se à página 49.
} 
A inserção do ex-integrante da Junta Provincial da capital baiana, Francisco Elesbão Pires de Carvalho e Albuquerque - pertencente ao clã da Casa da Torre -, na função de presidente do Conselho Interino, cujos secretários foram os bacharéis em Ciências Jurídicas Miguel Calmon du Pin e Almeida e Francisco Gomes Brandão Montezuma, delineava uma configuração política pela qual a classe senhorial do Recôncavo passava, em definitivo, a assegurar os principais postos de direção no novo governo da província. ${ }^{142}$ Diligentes na defesa das suas recém-conquistadas autoridades, essas lideranças enviaram circulares aos senados das câmaras interioranas, assim como a todos os coronéis e capitães-mores, exigindolhes o juramento de obediência ao Conselho Interino e à regência constitucional do príncipe d. Pedro. ${ }^{143}$ Daí por diante, toda uma relação de poder passou a ser afirmada com o objetivo de assegurar a subordinação civil, militar e eclesiástica das autoridades interioranas e a coordenação de forças para a expulsão das tropas da capital, sem perder de vista a repactuação dos interesses da província ante a dissolução dos laços políticos com o Império português.

Diante do peso dessa decisão, o cônsul francês Jacques Guinebaud, em 1822, testificou como alguns representantes da classe senhorial souberam alterar as suas posições políticas com o firme propósito de se ajustar às céleres conjunturas que, ao final das contas, conformariam na formação do Estado e da nação brasileiros. Referindo-se, neste caso, ao presidente do Conselho Interino, declarou:

Um dos chefes dos insurretos é membro da [segunda] junta e irmão do coronel senhor da Torre, descendente do famoso português Caramuru, que casou com a filha de um chefe índio e a conduziu à França, à corte de Henrique segundo, onde ela recebeu o batismo da mão de Catarina de Médicis. É o maior proprietário da província. Seu irmão é também muito rico, e tem o hábito de fazer negócios. Ele era secretário geral do governo e capitão-mor hereditário da Bahia no Regime do Rei. Nos últimos dias ele lançou uma proclamação muito enérgica contra Madeira e contra os portugueses, que ele trata como desordeiros e vândalos. Seu nome é Elesbão

\footnotetext{
${ }^{142}$ Não obstante Montezuma ter sido preso e exilado em França até o ano de 1831 devido às posições políticas consideradas por alguns como sendo próprias de um "liberal exaltado" que ingressara na Assembleia Constituinte de 1823, é preciso reconhecer que sua atuação no Conselho Interino não colidia em absoluto com os interesses dominantes da classe senhorial residente na Bahia. Além do mais, quando retornara ao Brasil no período regencial (1831-1840), fez questão, assim como Antonio Carlos de Andrada e Silva, de rever suas posições políticas a ponto de ter sido colocado, até 1834, lado a lado com "conservadores caramurus", os quais não deixariam de ser acusados de planejar reintroduzir d. Pedro ao trono imperial nos moldes de um governo absoluto. No que concerne à atuação política desse baiano no pós-abdicação, ver, por exemplo, MOREL, Marco, 2001, op. cit.

${ }^{143}$ Presidência da Província — Registro de correspondência expedida. APEB. Seção Colonial e Provincial. Data: 25/12/1822. Maço: 1618.
} 
e seu apelido é Santinho [sic]. ${ }^{144}$

No Relatório dos trabalhos do Conselho Interino de Governo da província da Bahia, Miguel Calmon chamaria atenção para a agitação da província entre setembro de 1822 e maio do ano seguinte, salientando a situação de profunda instabilidade política e social, seja pelo fato da capital estar tomada por tropas de Portugal, seja pela indefinição do Reino do Brasil. Segundo o futuro marquês de Abrantes, insubordinações civis, indisciplinas e deserções militares, perseguições aos portugueses europeus, tentativas de levantes escravos e combates a índios sublevados, como se verificaram nas povoações de Aramaris e Água Fria, foram fenômenos relacionados às conturbações próprias de uma província "recheada por inimigos internos" sobre os quais os termos punitivos foram dispostos em gradações variadas. $^{145}$

Por outro lado, é bem sabido que desde sua fundação o Conselho Interino não deixara de se imiscuir nos assuntos militares da província, gerando, assim, sérios atritos entre parte da classe senhorial do Recôncavo e o general Pierre Labatut, comandante do Exército Pacificador. ${ }^{146}$ Porém, pouco se discute sobre a ingerência desse centro governativo em outras esferas de poder. O próprio Miguel Calmon, no entanto, admitiu que para combater o "estado convulso e mal seguro da província" o governo, não raramente, fez "às vezes dos tribunais" e também que amiúde ele se comportou como órgão de "Polícia". ${ }^{147}$ Essas imbricações reforçam o quanto as deliberações tomadas em Cachoeira afetaram o cotidiano da província em uma conjuntura decisiva para os acontecimentos futuros não apenas da Bahia, mas em todo o Império português.

Admite-se não ser acertado assimilar a conduta da classe senhorial como resultado de uma ação conjunta levada a efeito por um bloco monolítico, isso porque, como em

\footnotetext{
${ }^{144}$ Apud ARAÚJO, Ubiratan Castro de. A Guerra da Bahia. Salvador: Ceao/UFBA, 2001 (Série Capítulos). p. 43-44. Houve um equívoco do cônsul francês, visto que Santinho era o apelido do coronel Joaquim Pires de Carvalho e Albuquerque, futuro visconde de Pirajá e não de Elesbão, seu irmão. Cf. BANDEIRA, Luiz Alberto Moniz, op. cit. p. 473-474.

145 Relatório dos trabalhos dos trabalhos do Conselho Interino de Governo da província da Bahia, em prol da Regência e do Império de sua magestade imperial o senhor D. Pedro I e da Independência Política do Brasil, redigido e offerecido ao grande constitucional e defensor perpétuo do Brazil, e ao heróico povo da província da Bahia por Miguel Calmon d' Pin e Almeida. Bahia: Typographia Nacional, 1823 (Disponível em: <http://www.crl.edu/content/brazil/BAH.htm> Acesso em 14 de agosto de 2008).

${ }^{146}$ Cf. AMARAL, Braz do, 1957, op. cit. e RODRIGUES, José Honório, 1975, op. cit.

147 Sobre o funcionamento da Justiça durante esse governo, registram-se, em especial, os direitos e abusos sobre a posse da terra, as medidas adotadas visando a educação do "cidadão", prisões dos portugueses europeus considerados inimigos da causa do Brasil, assim como a administração dos seus bens. Relatório dos trabalhos do Conselho Interino de Governo da província da Bahia, em prol da Regência e do Império de sua magestade imperial o senhor D. Pedro I e da Independência Política do Brasil, redigido e offerecido ao grande constitucional e defensor perpétuo do Brazil, e ao heróico povo da província da Bahia por Miguel Calmon d' Pin e Almeida, op. cit. p. 17-22. Para as prisões, desse período, dos portugueses europeus na província baiana, ver GUERRA FILHO, Sérgio Armando Diniz, op. cit.
} 
qualquer outro corpo social, ela também possuía fissuras e dissensões internas. Relevante, no entanto, é especificar como seus integrantes, em âmbito provincial e, em alguma medida, até junto à corte fluminense, encontraram-se entre os que melhor puderam explorar a vacuidade de poder emergido a partir da dissolução do Antigo Regime português em território americano. As condutas nesse sentido são variadas, conforme se observa no exemplo já citado do rico senhor de engenho e capitão-mor Francisco Elesbão Pires de Carvalho e Albuquerque que, depois de ocupar uma vaga na segunda Junta Provincial da capital, retirou-se para o Recôncavo a tempo de assumir ali nada menos do que a presidência do Conselho Interino.

São indícios como esses que robustecem a hipótese da existência de uma forte articulação intraclasse de caráter senhorial açodada, inclusive, por relações familiares entre residentes na Bahia nos conturbados anos de 1821 e 1823 . Outro dado a ser considerado é o fato de o Conselho Interino não ter registrado uma condenação formal aos integrantes da segunda Junta Provincial de Salvador. Posto que, além de permanecerem em uma cidade militarmente controlada, reconheceram a autoridade e entreteram relações administrativas com o brigadeiro Madeira de Mello que, sem ter assegurado um consenso mínimo entre os habitantes da província, tomou sob sua responsabilidade o governo das armas e declarou guerra aos segmentos rebeldes. Dessa maneira, é crível pensar ter existido, por parte de determinadas lideranças baianas, um acordo tácito para salvaguardar os interesses da classe senhorial, a qual revelar-se-ia disposta a suplantar, não apenas na província, mas igualmente na corte fluminense, a hegemonia dos portugueses europeus nos melhores cargos de mando e subordinação ante o Império do Brasil em formação.

Conforme registrado, a segunda Junta Provincial de Salvador teve como presidente o rico proprietário e senhor de engenho Francisco Vicente Vianna, que na fase seguinte à guerra assumiu o governo da província (1823-1825) e, antes de deixar a administração, obteve o título de barão de Rio de Contas. Outro componente desta Junta que confirmou sua ascensão política foi o grande proprietário e tenente-coronel Manoel Inácio da Cunha e Menezes que ocupou a vice-presidência da província entre os anos de 1826 a 1828, assumindo, interinamente, a presidência do governo da Bahia em três ocasiões distintas, sendo, por fim, mais um agraciado com título nobiliárquico, o de visconde do Rio Vermelho. Trajetórias como essas são indicativas de que mesmo mantendo o poder administrativo em nome das Cortes de Lisboa e sem confrontar abertamente a autoridade das tropas lusitanas, a grande maioria dos componentes da segunda Junta Provincial não deixou de representar os anseios de uma parte da classe senhorial que, por algum tempo, estendeu a sua permanência na capital da província. Em outras palavras, seus integrantes não divergiam dos interesses de classe das 
principais lideranças que ocupavam o poder no Conselho Interino. Não à toa, o redator do periódico Sentinella Bahiense registrava a concepção de "alguns indivíduos" que, em agosto de 1822, admitia que aquele "Governo Civil" era "adido à facção do Rio de Janeiro, e protetor tácito dos revoltosos do Recôncavo". ${ }^{148}$

Importante, então, é notar que enquanto uma parcela da classe senhorial, que tomou assento na segunda Junta Governativa da cidade de Salvador, foi ainda no transcurso da Guerra de Independência reaproveitada na administração provincial, outra parcela seguiu para o Rio de Janeiro, onde, por certo, procurou manter ou mesmo melhorar sua situação política. Nesse sentido, merece atenção a posição do secretário da Junta Francisco Carneiro de Campos. Quando se considera os diversos ofícios que expediu em nome da Junta Provincial, tem-se a impressão que ele convivera bem com as suas funções governativas. ${ }^{149}$ Logo no início da gestão, por exemplo, Carneiro de Campos enviou uma "Circular aos Capitães-Mores das Ordenanças" da província baiana que experimentavam nas vilas sob seus comandos conturbações políticas semelhantes às verificadas na capital. Decidido a garantir o respeito às autoridades constituídas, especialmente às camarárias, o secretário exprimiu-se com rigor as medidas do governo provincial:

Havendo constado a Junta Provisional de Governo desta Província, por diversas representações, que na Villa interior se falta o respeito, e [a] obediência que cumpre tributar às Câmaras, e mais Justiças, pois que na exata observância de seus mandatos consiste a boa ordem, e harmonia dos povos aos quais só compete representar contra as Autoridades constituídas quando estas quebrantando as Leis, se tornam arbitrárias, ou ultrapassam as raias do poder, que lhes foi confiado, e nunca insultar, e desobedecer às mesmas Autoridades, promovendo deste modo a discórdia, que tanto convém apartar: ordena a mesma Junta, que V. M. se desvele em fazer manter nesse distrito o respeito, e [a] subordinação devida à Câmara e [às] mais Justiças; e que pelos Soldados do Terço do seu Comando faça capturar de comum acordo com a referida Câmara, e [às] mais Justiças, e em conformidade da Lei, todo e qualquer amotinador da pública tranquilidade, Deus Guarde a V. M. Palácio do Governo da Bahia aos 12 de Fevereiro de 1822. Francisco Carneiro de Campos. ${ }^{150}$

\footnotetext{
${ }^{148}$ Sentinella Bahiense, n. 9, quinta-feira, 29 de agosto de 1822. Bahia: Tipografia da Viúva Serva e Carvalho. Exemplar do acervo do Centro de Estudos Baianos da UFBA.

149 Por uma contagem parcial realizada em diferentes números do Diário Constitucional e depois O Constitucional, verificou-se que, no decurso dos quatro primeiros meses da segunda Junta Provisória, o secretário Francisco Carneiro de Campos deixara sua assinatura em nada menos do que 42 documentos oficiais. Cf. O Constitucional. Tipografia da Viúva Serva e Carvalho, 1822. Exemplares da coleção do IEB/Usp.

${ }^{150}$ Circular aos Capitães-Mores das Ordenanças. In: Diário Constitucional, n. 9, segunda-feira, 18 de fevereiro de 1822. Tipografia da Viúva Serva e Carvalho, 1821-1822. Exemplar da coleção do IEB/Usp (grifos do redator).
} 
É sabido que, Antônio de Meneses Vasconcelos de Drummond (1794-1865) na condição de correligionário de José Bonifácio, depois de ter permanecido em Recife, entre os meses de fevereiro e junho de 1822 - quando conseguiu que a Junta Provisória de Pernambuco declarasse publicamente sua ruptura com as Cortes de Lisboa e sua adesão ao príncipe regente - seguiu secretamente para a província da Bahia. ${ }^{151}$ Ali os propósitos de Drummond eram igualmente alcançar os sucessos verificados em Pernambuco. O futuro redator do Tamoio chegou a Salvador a bordo de um navio americano, trazendo documentos e dinheiro para facilitar a sua missão. Ainda na embarcação, foi intimado para se dirigir Palácio do Governo diante das denúncias de que seria um agente de d. Pedro. Depois de se apresentar aos membros da segunda Junta Provincial, os quais Drummond classificou como "bons brasileiros, que só tinham o defeito da fraqueza", acrescentou que o influente secretário Francisco Carneiro de Campos era "a melhor cabeça da Junta". Dispensado, o agente ministerial dirigiu-se para a alfândega, na expectativa de reaver sua secreta bagagem. Nesta repartição, encontrou com um irmão do influente secretário da Junta, o guarda-mor da alfândega Joaquim Carneiro de Campos, que possuía um filho em Pernambuco, José Tibúrcio Carneiro de Campos, com quem Drummond havia tido boas relações. Certamente o agente ministerial e o guarda-mor trocaram outras opiniões pois logo Joaquim o convenceu a aceitar a sua hospitalidade enquanto cumprisse seus objetivos em Salvador. Bem relacionado também com a família de Madeira de Mello, o agente do ministério frequentou assiduamente a casa do brigadeiro, aonde, em vão, tentou suborná-lo, oferecendo "uma quantia avultada", para a sua adesão à causa do Brasil. ${ }^{152}$

Mantendo contatos com os membros da Junta da capital, o amigo de José Bonifácio procurou persuadi-los a declararem a Junta coagida pela autoridade militar ocupante da capital baiana e que, por isso, demitiriam das suas funções ou, senão, ao menos, que emigrassem conjuntamente para o Recôncavo. À exceção do ilustrado cônego José Cardoso Pereira de Melo, os demais componentes da Junta apresentaram justificativas atemorizantes. O próprio secretário Francisco Carneiro de Campos ponderou a Drumond que, caso renunciasse, poderia se considerar homem morto, pois cada membro da Junta possuía, naqueles dias, uma sentinela estacionada à porta das suas casas. De fato, havendo rumores de que a Câmara pretendia se declarar obediente ao príncipe regente, em 15 de junho, Madeira de

\footnotetext{
${ }^{151}$ MORAES, Alexandre de Mello, op. cit., t. 2. p. 377. Para atuação desse agente do ministério dos Andrada em Pernambuco, consultar BERNARDES, Denis Antônio de Mendonça, op. cit. Especialmente o capítulo 7; ver também LIMA, Manuel de Oliveira, op. cit. p. 197-198.

${ }_{152}$ MORAES, Alexandre de Mello, op. cit., t. 2. p. 377-379 e TAVARES, Luís Henrique Dias, 2005, op. cit. p. 143-146.
} 
Mello mandou estacionar na Praça do Palácio um piquete de infantaria e outro de cavalaria. Determinou também que entre o Terreiro de Jesus e a Praça do Teatro (atual Praça Castro Alves) sentinelas se pusessem em circulação, conquanto as demais tropas permanecessem aquarteladas. $^{153}$

Todavia, Drummond levou adiante seu plano de promover a definitiva adesão da Bahia ao príncipe regente. Este concerto foi articulado com algumas autoridades do Recôncavo, especialmente com o desembargador Antonio José Duarte de Araújo Gondim. ${ }^{154}$ A expectativa era a de orquestrar um retumbante ato político que impactasse toda a província. A data acordada foi o dia 21 de agosto, quando a classe senhorial no Recôncavo decidiu, como já registrado, pela criação de um "um governo geral que” administrasse a "província em nome de S. A. R., o sereníssimo príncipe Senhor D. Pedro de Alcântara, regente e defensor do Brasil, segundo as regras do governo representativo". ${ }^{155}$ Neste dia também o agente ministerial fez publicar uma longa correspondência, assinada com o pseudônimo de Filelete, no periódico $O$ Constitucional, número 58, que àquela altura dos acontecimentos, tinha em Francisco Corte Real o seu único redator, visto Montezuma já ter se retirado para o Recôncavo. A despeito deste periódico vir, de algum tempo, tecendo críticas ao comportamento militar das tropas europeias reunidas na capital baiana, esse número de $O$ Constitucional, constituiria, sem sombra de dúvida, o grande divisor de água. De fato, o correspondente elegera as ações do brigadeiro Madeira de Mello como alvo predileto, apontando-o como símbolo das desavenças políticas entre a Bahia e o liberalismo dominante nas Cortes de Lisboa. Em um dado momento desatava:

[...] oh desdita! Baldados esforços! A cabala triunfou; e entre os vivas de alegria, novos tiranos reassumiram então o poder; abriram as nossas artérias; esgotaram a nossa paciência; e um cordão do Despotismo circulou a Província inteira, depois de a terem vendido a Portugal desligando-os (como se fosse possível) deste Reino para formar uma Província ultra, de cujos resultados sentimos agora, mais que nunca, os desastrosos efeitos.

[...] Chamará S. Exª inimigos os probos habitantes do Recôncavo, porque aberram do Despotismo, e recusam entregar seus pulsos aos ferros da tirania, porque eles conhecem, que depois de manietados mui tarde se poderão romper a menos que não junquem seus campos com os cadáveres dos seus irmãos e façam [ilegível] com as águas de seus rios o sangue do Portugueses de ambos os hemisfério, que eles prezam muito mais, que os seus caluniadores?

[...] poderá S. Ex ${ }^{\mathrm{a}}$. certificar, que todos os habitantes desta cidade naturais e

\footnotetext{
${ }^{153}$ SILVA, Ignácio Accioli de Cerqueira e, op. cit., v. 3. p. 352-354.

154 TAVARES, Luís Henrique Dias, 2005, op. cit. p. 146.

155 Termo de vereação do Senado da Câmara de Cachoeira em 21 de agosto de 1822. Documentos históricos sobre a emancipação política da Bahia. Revista do Instituto Geográfico e Histórico da Bahia, ano II, v. 2, n. 6, 1895. p. 384-386.
} 
estrangeiros são contentes e aprovam o recrutamento dos pretos forros e cativos, que por ordem de S. Ex ${ }^{\mathrm{a}}$. se faz indistintamente por todas as ruas até nos próprios Domingos, com execranda violação do sagrado Direito de Propriedade? [...] Os escravos dos serviços domésticos no momento em que vão comprar e conduzir para a casa de seus Srs. o próprio alimento diário, presos e conduzidos rigorosamente a serviços que lhe não competem. É muita Constitucionalidade! [...] Os pretos forros, que são homens livres, presos, castigados, e violentados aos trabalhos sem crime, sem culpa formada! Oh Constituição! Oh Lei! sede o verdugo que castigue tantos males! $!^{156}$

O periódico de 21 de agosto foi exclusivamente dedicado a esta e outra correspondência de corte semelhante. A reação, então, da oficialidade europeia se dirigiu contra Francisco Corte Real, comandada pelo tenente-coronel Vitorino José de Almeida Serrão, a tropa lusitana empastelou o periódico, a casa do redator foi vasculhada e os móveis destruídos. Na vindita, até mesmo os proprietários dos estabelecimentos que comercializavam a folha foram maltratados. Prevenido, Corte Real foi se juntar aos demais refugiados no Recôncavo, enquanto Drummond seguiu viagem para o Rio de Janeiro. Em $1^{\circ}$ de setembro já estava prestando conta ao príncipe regente sobre a situação política e militar encontrada na Bahia. ${ }^{157}$

De forma geral, é possível demonstrar que o respeito e acatamento à autoridade representativa das Cortes foram levados a sério nos documentos oficiais da segunda Junta, a qual, no entendimento de Vasconcelos de Drummond, entregou-se ao "defeito da fraqueza". ${ }^{158}$ Condição que também pode ser aferida na recomendação encaminhada em 2 de março a Joaquim Inácio de Siqueira Bulcão, para que este se dirigisse exclusivamente a Madeira de Mello quando quisesse tratar dos assuntos atinentes ao governo das armas da província. Expressamente, o futuro barão de São Francisco ficaria ciente de que:

A Junta Provisória de Governo desta Província [...] julga sem fundamento a dúvida que V. M. entretém acerca do Governador das Armas a quem se deva dirigir, visto que esta mesma Junta [...] lhe participou mui positivamente que o Exmo. Brigadeiro Inácio Luís Madeira de Mello havia entrado no exercício daquele Emprego, para o qual fora nomeado por Sua Majestade El-Rei, o Senhor D. João VI. ${ }^{159}$

\footnotetext{
${ }^{156}$ Constitucional, n. 58, quarta-feira, 21 de agosto de 1822. Tipografia da Viúva Serva e Carvalho, 1821-1822. Exemplar da coleção do IEB/Usp.

${ }^{157} \mathrm{O}$ Sr. Drumond a pedido do Ministro José Bonifácio fornece-lhe novos esclarecimentos a respeito do estado da Bahia. In: MORAES, Alexandre de Mello, op. cit., t. 2. 436-437. Sobre os assuntos aqui tratados ver Idem, ibidem. p. 375-384.

${ }^{158}$ MORAES, Alexandre de Mello, op. cit., t. 2. p. 377.

${ }^{159}$ Para o Capitão Mor da Villa de S. Francisco Joaquim Ignacio de Siqueira Bulcão. In: Diário Constitucional, n. 22, quinta-feira, 14 de março de 1822. Tipografia da Viúva Serva e Carvalho, 1821-1822. Exemplar da
} 
Inquietações populares, que certamente envolviam escravos, foram outros assuntos que exigiram medidas cautelares por parte da segunda Junta Provisional. Em 14 de fevereiro de 1822, portanto, às vésperas de a capital cair sob os domínios das tropas de Portugal, o secretário Francisco Carneiro de Campos e os demais integrantes da administração civil da província encaminharam ao governador das armas uma circular e cópia de uma "representação feita pelos moradores dos lugares do Cabula, [de] S. Bento, Barreiras, Pedrinhas, Pirajá e Batefolha”, localizados nos arredores da cidade, que reivindicam soluções "acerca dos contínuos e numerosos ajuntamentos, que ali há de diversos negros armados, e mulheres que se lhe agregam," cujo propósito consideravam "sumamente pernicioso" e, por isso, a Junta solicitava-lhe "providência", que julgasse "conveniente, a fim de se dispersarem semelhantes reuniões, que têm lugar principalmente nos Domingos e Dias Santos". ${ }^{160}$ Disposições como essa reforçam a hipótese de que os meses seguintes à implementação do constitucionalismo na Bahia foram de profunda instabilidade política que, de cima a baixo, atingiu todas as malhas sociais. Desse modo, o avolumar das tensões entre os defensores do projeto constitucionalista que se afirmava nas Cortes de Lisboa e seus opositores na Bahia prenunciava soluções violentas. ${ }^{161}$

Declarada a Independência política pelas províncias coligadas, culminando na coroação de d. Pedro I como imperador constitucional do Brasil e no aprofundamento das condições para a materialização do Estado e da nação brasileiros, que demandaria a participação de novos atores sociais para a sua consolidação, o desembargador Francisco Carneiro de Campos deixou a secretaria da Junta Provincial e, em janeiro de 1823, escapou da cidade da Bahia ocupada pelas tropas de Portugal em direção ao Rio de Janeiro. É possível conjecturar que, por trás desse novo baiano que trocava sua província pela residência na corte fluminense, houvesse uma planejada articulação política. Afinal de contas, em dezembro de 1822, conforme já mencionado, chegara à Bahia a portaria imperial para que fosse providenciada a eleição dos seus deputados à Assembleia Constituinte, ${ }^{162}$ cujo processo

coleção do IEB/Usp. Este ofício, de 2 de março de 1822, teve as assinaturas de todos os membros da segunda Junta Provincial.

${ }^{160}$ Circular para o Ilmo. e Exmo. Governador das Armas desta Província. In: Diário Constitucional, n. 10, terçafeira, 19 de fevereiro de 1822. Tipografia da Viúva Serva e Carvalho, 1821-1822. Exemplar da coleção do IEB/Usp.

${ }^{161}$ Significativo, sem dúvida, é ter em conta o fato desses acontecimentos consubstanciarem as análises que destacam as possibilidades abertas para a participação de escravos na cena política, conquanto também se saiba que, a despeito da guerra dos senhores, evidentemente melhor armados e assessorados, as tentativas de manifestações vinculadas ao mundo da escravidão foram sistematicamente sufocadas na Bahia. Cf. SILVA, Eduardo; REIS João José, 1989, p. 79-98.

${ }_{162}$ Atas do Conselho Interino na Cachoeira, $14^{\mathrm{a}}$. Ata de 18 de dezembro de 1882 - O brigadeiro Gordilho de Barbuda, chegado do Rio de Janeiro apresenta ao Governo Interino portaria do Imperador para que se proceda à 
eleitoral, que a propósito foi organizado pela classe senhorial dirigente do Conselho Interino, contemplaria, dentre outros representantes, o magistrado Francisco Carneiro de Campos.

Nesse processo de rearticulação política dos quadros da segunda Junta Provincial, deve-se enfatizar a situação do "ilustrado" cônego José Cardoso Pereira de Melo que, pelo menos até dezembro de 1822, permanecera na Junta da capital. No entanto, em março do ano seguinte, José Cardoso - cujo irmão, o coronel Antônio Cardoso Pereira de Melo, comandava uma das colunas do Exército Pacificador - tornara-se um dos escolhidos pelo Conselho Interino para representar o clero na comissão encarregada de redigir as instruções aos deputados da Bahia à Assembleia Constituinte. Outro indício do funcionamento das redes de sociabilidade entre a Bahia e o Rio de Janeiro, ocorrida na complexa tessitura da Independência, pode ser verificado ao se constatar que na relação dos signatários à Felicitação dos Baianos residentes no Rio de Janeiro a S.A.R aparece a assinatura de Francisco Cardoso Pereira de Melo, supostamente um parente do ex-integrante da segunda Junta Provincial da Bahia. ${ }^{163}$

Trajetórias como essas corroboram a hipótese de que a classe dominante alimentava as redes de sociabilidade entre a Bahia e o Rio de Janeiro. Concorrendo aos mais proeminentes cargos no sistema político a ser implementado - à exceção daqueles reservados naturalmente aos herdeiros da dinastia bragantina deixados na antiga América portuguesa -, vários baianos acabariam destacando-se nesse período. Ainda na Assembleia Constituinte, o antigo secretário da segunda Junta Provincial da Bahia iria ter a companhia de seu irmão, o também jurista baiano, José Joaquim Carneiro de Campos, que assegurara o mandato de deputado como representante eleito pela província do Rio de Janeiro.

Alexandre de Mello Moraes registrou que, quando da passagem do príncipe regente d. João em Salvador (1808), o futuro rei não somente confirmou José Joaquim Carneiro de Campos no posto de oficial-maior da Secretaria de Estado dos Negócios do Reino do Brasil, como o agraciou com o ofício de guarda-mor da alfândega de Pernambuco. José Joaquim então - que também havia se graduado em Teologia e Direito pela universidade de Coimbra nomeou como seu serventuário particular o sobrinho José Tibúrcio Carneiro de Campos, o

eleição dos deputados à Assembleia Geral Constituinte. Documentos históricos sobre a emancipação política da Bahia. Revista do Instituto Geográfico e Histórico da Bahia, ano III, v. 3, n. 9, 1896. p. 341-343.

${ }^{163}$ A ata do Conselho Interino, datada de 14 de março de 1823, confirmando a nomeação do cônego José Pereira para a citada comisão encontra-se em: Documentos históricos sobre a emancipação política da Bahia. Revista do Instituto Geográfico e Histórico da Bahia, ano IV, v. 4, n. 12. 1897. p. 175-178. Sobre a saída do cônego José Cardoso Pereira de Melo da cidade de Salvador, ver SILVA, Ignácio Accioli de Cerqueira e, op. cit., v. 3. p. 443. Para a assitatura de Francisco Cardoso Pereira de Melo: Felicitação dos Baianos residentes no Rio de Janeiro a S.A.R, em 15 de janeiro de 1822. In: Constitucional, n. 5, sábado, 20 de abril de 1822. Tipografia da Viúva Serva e Carvalho, 1821-1822. Exemplar da coleção do IEB/USP. 
qual rapidamente assumiu o novo posto em Recife. Este permaneceu ali até 1822, quando "no estado convulsivo que resultava das circunstâncias políticas, que tinham roto todos os laços da antiga obediência" retirou-se de Pernambuco "são e salvo", indo possivelmente para o Rio de Janeiro reencontrar o tio-patrocinador e outros parentes, os quais, como se tem notado, gozavam de prestígio naquela corte fluminense. ${ }^{164}$

A despeito de tudo isso, deve-se ressaltar que a ascensão de várias lideranças nascidas ou residentes em território baiano aos eminentes postos de mando no governo de d. Pedro, não se devia simplesmente à sua homogeneidade ideológica, reforçada pelo treinamento e pela carreira. ${ }^{165}$ Fundamentais nesse processo de direção política rumo ao controle do Estado nacional no Brasil foram os confrontos e as negociações que possibilitaram a diversos representantes da classe senhorial em formação preencher o vazio de poder deixado pela desagregação do Antigo Regime na América portuguesa a partir da confluência de posições políticas necessárias à superação da crise. Nesse sentido, as disputas e as conquistas por cargos de representação, fossem nas juntas governativas, fossem nas primeiras assembleias constituintes - em Lisboa (1821-1822) e no Rio de Janeiro (1823) -, propiciaram a construção de fecundos espaços de experiência com os quais muitas lideranças provinciais alcançaram visibilidade e projeção que facilmente extrapolaram as áreas de influências regionais para se concentrarem na esfera de poder central da nova nação. ${ }^{166}$

A propósito das disputas da classe senhorial para assegurar melhor participação na direção do Estado e da nação brasileiros em formação, deve-se observar como o arranjo político entre a Bahia e o Rio de Janeiro passou por melindrosas negociações, havendo

\footnotetext{
${ }^{164}$ MORAES, Alexandre de Mello, op. cit., t. 2. p. 376-377, nota 214.

165 Segundo José Murilo de Carvalho, a homogeneidade ideológica, consubstanciada pela sociabilização, treinamento e carreira foram os traços definidores de uma elite nacionalizada que se ocupou da construção e direção do novo Estado unitário emergido dos escombros da administração colonial da América portuguesa. Nessa perspectiva, sua conclusão é que: "O núcleo da elite brasileira, pelo menos até um pouco além da metade do século [XIX], era formado de burocratas treinados nas tradições do mercantilismo e absolutismo portugueses, particularmente de magistrados. A educação em Coimbra, a influência do direito romano, a ocupação burocrática, os mecanismos de treinamento, tudo contribuía para dar à elite que presidiu à consolidação do Estado imperial um consenso básico em torno de algumas opções políticas fundamentais”. CARVALHO, José Murilo de. A construção da ordem: a elite política imperial. Brasília. Ed. Universidade de Brasília, 1981 (Coleção temas brasileiros. v. 4). p. 178.

${ }^{166}$ Contrastando com as consagradas interpretações que opõem as classes dominantes regionais às nacionais, Miriam Dolhnikoff tem valorizado o arranjo institucional que permitiu a várias "elites regionais" integrarem a nação. Em vista disso, adverte que: "Para compreender o processo pelo qual se constituiu o Estado brasileiro é imprescindível que a análise não fique restrita à elite articulada em torno do governo central e ao discurso por ela formulado. Torna-se necessário apreender a complexidade das relações entre centro e regiões, examinando tanto um pólo quanto o outro, assim como o arcabouço institucional tal como ele foi efetivamente engendrado, de modo que se inclua na análise o resultado concreto e material da ação e do discurso político, o que permitirá também identificar os limites desse discurso". DOLHNIKOFF, Miriam. Elites Regionais e a construção do Estado nacional. In: JANCSÓ, István (Org.). Brasil: Formação do Estado e da Nação. São Paulo: Hucitec. Ed. Unifuí; Fapesp, 2003. p. 432.
} 
inclusive resistências a algumas das diretrizes que os primeiros representantes do governo de d. Pedro I quiseram implementar na província. Esta assertiva pode ser confirmada, por exemplo, via a reação do Conselho Interino ante as prerrogativas do general Pierre Labatut no comando do Exército Pacificador. Numa perspectiva similar a aqui apontada, Luís Henrique Dias Tavares arrolou algumas evidências sugerindo que, com a ascensão do primeiro ministério encabeçado pelos Andrada, as decisões do Rio de Janeiro chegadas à Bahia sinalizavam que os dispositivos institucionais de afirmação do Estado e nação brasileiros deveriam contemplar o "viés monárquico absolutista". ${ }^{167}$ Para o historiador, indicativo dessa projeção pode ser encontrado nas primeiras declarações de Labatut quando se dirigia ao governo civil instalado no Recôncavo baiano com expressões do tipo: “[...] tendo ordenado [...]”, “[...] passarei ordens [...]”, o que denotava uma linguagem autoritária do primeiro representante de d. Pedro na província. ${ }^{168}$

Aos 19 dias de dezembro de 1822, os integrantes de um levante de escravos, com aproximadamente duzentos africanos, atacou o Exército Pacificador estacionado, justamente, nas imediações de Pirajá (Mata Escura e Saboeiro). Depois de um combate renhido, com algumas baixas para os que lutavam pela Independência, os sublevados foram derrotados. Entretanto, o general Labatut, tendo em vista a afirmação da sua autoridade militar, ordenou a execução sumária de 52 presos e o açoite dos demais sobreviventes. ${ }^{169}$ Essa decisão aprofundou as desavenças entre o general e algumas importantes lideranças do Recôncavo baiano.

Não por acaso, em 23 de dezembro, o Conselho Interino enviou um ofício circunstanciado ao ministro e secretário de Estado dos Negócios do Reino do Brasil e Estrangeiro, José Bonifácio de Andrada e Silva, queixando-se da conduta de Labatut. Logo de início, destacava que o general apossara de parte de uma fortuna em moedas de ouro e prata enterrada por dois grandes proprietários portugueses europeus (nos engenhos Passagens e Cachoeirinha) antes de fugirem para a capital. O Conselho entendia que este recurso deveria ter sido empregado para alinhar a tropa. Foi também solicitada punição sobre as execuções

\footnotetext{
167 TAVARES, Luís Henrique Dias, 2005, op. cit. p. 155-156.

168 Apud TAVARES, Luís Henrique Dias, 2005, op. cit. p.156. As reações preventivas dos representantes da classe senhorial contra um possível tratamento autoritário que a Bahia poderia receber por parte do Rio de Janeiro mereceram todo o desvelo do Conselho Interino de Governo já antes de Labatut aparecer no Recôncavo baiano se auto-intitulando como representante militar que só reconhecia autoridade no próprio príncipe d. Pedro. Sobre o assunto ver: Documentos históricos sobre a emancipação política da Bahia. Revista do Instituto Geográfico e Histórico da Bahia, Ano IV, v. 5, n. 14, 1897. p. 433. Os pernambucanos também expuseram, neste mesmo período, diversos sinais de desconfiança quanto aos rumos políticos que o Rio de Janeiro parecia disposto a legar ao continente do Brasil. Sobre a situação política em Pernambuco no tempo da Independência, ver BERNARDES, Denis Antônio de Mendonça, op. cit., bem como MELLO, Evaldo Cabral de, 2004, op. cit.

${ }^{169}$ AMARAL, Braz do, 1957, op. cit. p. 284-285.
} 
que o mesmo praticara contra alguns paisanos considerados traidores, "não esquecendo a barbaridade com que mandou [...] metralhar aos cinquenta e um [sic] pretos". Para este último caso, importa realçar que o horror da classe senhorial devia-se menos ao sangue derramado pelos sublevados - certamente os mais capazes a todo enfrentamento -, do que pelo entendimento de haver certo desprezo do general francês no tocante às propriedades particulares. Afinal de contas, impingir castigos à escravatura, e, ocasionalmente, um ou outro vir a óbito devido aos sofrimentos ou às mutilações, era tolerado, mas exterminá-los no atacado pressupunha franco desrespeito aos que seriam obrigados a suportar os prejuízos financeiros que, certamente, as peças perdidas iriam tributar-lhes. ${ }^{170}$

No enfrentamento às condutas de escravos rebelados em tempos de profunda divisão interna entre as classes dominantes, a atuação do Conselho Interino revelava-se ainda mais alinhada a premissa de que cabia às autoridades buscarem, dentro do possível, os meios capazes para conduzir os sublevados às prisões e a imediata devolução destes aos "legítimos" proprietários. Esse procedimento pode ser atestado via o ofício enviado ao capitão-mor da vila de Valença com cópia da representação do tenente Miguel Ataíde e Seixas, morador naquela vila, pela qual expunha os "roubos de gados" perpetrados por "vários negros" "fugitivos" e "armados", causando, por essa razão, grandes danos ao suplicante e mais lavradores. Ante a isso, o Conselho solicitava que os escravos fossem presos e "entregues aos seus legítimos senhores" de modo a evitar que "juntando-se em maior número, seja depois muito difícil conseguir sua dispersão e restituir o sossego e tranquilidade daqueles moradores". ${ }^{171}$

Junto com a denúncia que o Conselho Interino encaminhara ao ministro José Bonifácio, recaía sobre Labatut a acusação de haver prendido "influentes" autoridades no Recôncavo, a exemplo do tenente-coronel Manoel Diogo de Sá Barreto e Aragão, o capitãomor interino de Cachoeira, José Paes Cardoso da Silva, o coronel e comendador Manoel José de Araújo Borges e o ajudante de ordens do próprio Conselho Interino, José Garcia Cavalcante. Além dessas denúncias, encontrava-se a das ofensas e perseguições a lideranças

\footnotetext{
${ }^{170}$ Documentos históricos sobre a emancipação política da Bahia. Revista do Instituto Geográfico e Histórico da Bahia, Ano IV, v. 5, n. 14, 1897, p. 559-565. Uma demonstração do quanto a perda generalizada de escravos se afigurava como um verdadeiro desastre pelos que se beneficiavam do mundo da escravidão pode ser percebida na correspondência da senhora de engenho Maria Bárbara Garcez Pinto da França, que noticiou pesarosa ao esposo Luís Paulino Pinto de Oliveira França, então deputado nas Cortes de Lisboa, o ocorrido ao proprietário e comerciante José Inácio Acciovali Brandão e Vasconcelos, visto que "o [seu] administrador, homem forte, segundo dizem, e o feitor foram mortos por alguns negros do [seu] engenho [...], o que não é novo nestes países. Mas, em troca dos dois, o regimento que foi a prendê-los matou-lhe logo 25 [escravos] e prenderam-se-lhe 18. Coitado." FRANÇA, Antônio d'Oliveira Pinto da (Org.). Cartas baianas, 1821-1824: subsídios para o estudo dos problemas da opção na independência brasileira. São Paulo: Nacional; Rio de Janeiro: Núcleo Editorial da Universidade do Estado do Rio de Janeiro, 1980. p. 60.

${ }^{171}$ APEB. Seção Colonial e Provincial. Registro dos ofícios expedidos pelo Conselho Interino de Governo da província da Bahia. Ano: 1823. Maço 632-1.
} 
como o capitão-mor Joaquim Inácio de Siqueira Bulcão, o coronel da Torre Antonio Joaquim Pires de Carvalho e Albuquerque Cavalcante d'Ávila Pereira, o coronel e comendador Bento de Araújo Lopes Vilas-Boas e o capitão-mor de Santo Amaro, Antonio Joaquim Pires de Carvalho e Albuquerque que, indubitavelmente, representavam a fina flor da classe senhorial na Bahia. Em suma, Labatut era acoimado tanto por negar a autoridade do Conselho "para conter os escravos e prevenir alguma sublevação", quanto de promover: "o terror em todas as classes de cidadãos, e principalmente na dos proprietários, de sorte que ninguém se julga seguro e teme ser assassinado a espingarda"; “[...] ele ameaça de matar e enforcar os europeus pacíficos [...] a ponto de ser o Conselho Interino obrigado a publicar" uma "proclamação" visando "tranquilizar" os portugueses europeus residentes nas vilas de Rio de Contas e de Caetité que procuravam abrigo contra as ameaças do comandante-em-chefe do Exército Pacificador. ${ }^{172}$

Por tudo isso, torna-se evidente que as desavenças entre as classes senhoriais e Pierre Labatut, principiadas logo após a sua nomeação no Rio de Janeiro, ampliaram-se em território baiano. Após ter combatido no exército napoleônico e participado da luta de Independência na Venezuela ao lado do general Simon Bolívar, as concepções liberais de Labatut colidiam profundamente com os interesses dos potentados baianos. Não restam dúvidas de que estes últimos não se propunham a abrir mão dos seus privilégios de classe na condução dos melhores postos militares em vantagem da meritocracia pessoal que o general francês parecia disposto a implementar na Bahia. ${ }^{173}$ Aliás, antes mesmo da sua chegada à província baiana, o Conselho Interino rememorava a d. Pedro os feitos dos grandes da terra que desde as lutas contra os holandeses no século XVII, expulsos da Bahia entre os anos de 1624 e 1625 , notabilizaram-se:

Senhor. Os habitantes do Recôncavo e interior da província da Bahia, tão brasileiros como os das briosas províncias do Sul e [de] Pernambuco, reconheceram como eles os ferros, que ainda hoje lhes roxeavam os pulsos e se proclamaram livres.

\footnotetext{
${ }^{172}$ Documentos históricos sobre a emancipação política da Bahia. Revista do Instituto Geográfico e Histórico da Bahia, Ano IV, v. 5, n. 14, 1897, p. 559-565. Sobre os distúrbios políticos envolvendo os portugueses europeus em Rio de Contas e Caetité, ver SOUZA FILHO, Argemiro Ribeiro de, op. cit.

${ }^{173}$ Documentos históricos sobre a emancipação política da Bahia. Revista do Instituto Geográfico e Histórico da Bahia, Ano IV, v. 5, n. 14, 1897, p. 559-565. Em razão das desavenças com Labatut e reiterando o quão intenso foi o trânsito e a articulação da classe senhorial baiana com as autoridades sediadas na corte no contexto da Independência, tem-se o ofício do Conselho Interino de 24 de dezembro de 1822, no qual relata a ida do coronel e ajudante general do Exército Pacificador, Joaquim Pires de Carvalho e Albuquerque (Santinho, futuro visconde de Pirajá) ao Rio de Janeiro com informes sobre os bons serviços que havia prestado à causa do Brasil. Documentos históricos sobre a emancipação política da Bahia. Para José Bonifácio de Andrada e Silva, Ministro e Secretário d'Estado dos Negócios do Império. Revista do Instituto Geográfico e Histórico da Bahia, ano V, v. 5, n. 18, 1898. p. 556-557.
} 
[...] lançaram mãos das armas para com elas sustentarem [...] a Aclamação de Vossa Alteza Real Regente Constitucional deste Reino do Brasil e seu Perpétuo Defensor e Protetor.

[...] Não fraquejou com isso, Senhor, o valoroso espírito dos outrora vencedores dos Batavos; antes sopitado mais e mais a lava patriótica, primeiro rebentada nesta briosa vila da Cachoeira, a tem levado hoje às quinze vilas da comarca da Bahia, às dez da de Ilhéus, às cinco da de Jacobina, à cidade de Sergipe d'El-Rei, e a maioria das vilas de sua comarca $[\ldots] .{ }^{174}$

De maneira semelhante, a felicitação que, em nome do Conselho Interino, os representantes Francisco Gê Acaiaba Montezuma e Simão Gomes Ferreira Veloso levaram pessoalmente à presença d. Pedro em dezembro de 1822, foi produto da mesma forja que amoldava, por um lado, um rasgo patriótico e, por outro, recomendações tímidas sobre as garantias liberais. Na essência, contudo, seu fim não era outro que transacionar os meios sobre os quais a classe senhorial na província baiana visava assegurar a sua participação política no Estado independente. Em vista disso, declaravam:

Senhor. - Defendendo V. M. I. os imprescritíveis direitos do povo brasileiro, levando-o ao gozo de sua política e civil liberdade contra as arrogantes tentativas de Portugal, e por fim constituindo o Brasil nação independente [...]. Tão altos e nunca igualados feitos há muito que anelam os Bahienses vir agradecer a V. M. I., há muito eles têm jurados em seus corações dar a vida por um príncipe cidadão, que soube quebrar-lhes os ferros portugueses e salvá-los do horroroso caos da vil anarquia.

[...] É, porém, o Americano homem livre: decretou assim a natureza ao criar o universo. Os baianos, Senhor, os vencedores dos Batavos, já estão livres [...]. Nos corações baienses não cala, nem calou nunca o monstruoso cisma de divisão das províncias. É base das suas intenções a fraternidade, o respeito, a obediência, a fidelidade ao Augusto Chefe da Nação brasileira, ao primeiro dos imperadores do mundo, o pai da pátria, o defensor do Brasil.

Em todas as eras, grandes, reiterados têm sido os esforços dos sábios políticos para convencerem as nações de que é sempre efêmera a grandeza e prosperidade, que provém de canais alheios e não do essencial de riqueza pública a agricultura, e indústria própria. ${ }^{175}$

\footnotetext{
${ }^{174}$ Correspondência oficial do Conselho Interino de Governo na Cachoeira, em 21 de outubro de 1822. Documentos históricos sobre a emancipação política da Bahia. Revista do Instituto Geográfico e Histórico da Bahia, ano IV, v. 4, n. 13, 1897. p. 437-438.

${ }^{175}$ Felicitação do Conselho Interino a S. M. em dezembro de 1822. Documentos históricos sobre a emancipação política da Bahia. Revista do Instituto Geográfico e Histórico da Bahia, ano IV, v. 4, n. 13, 1897. p. 437-438. Nesse documento, Francisco Montezuma, que já havia incorporado no seu sobrenome a homenagem ao último imperador asteca, substituiu também Gomes Brandão, ambos sobrenomes de origem portuguesa, por Gê Acaiaba, cuja designação Gê, ou Jê indicava indivíduo pertencente ao tronco indígena dos Jês e Acaiaba uma árvore da família das Terebintáceas, mais conhecida como o cedro brasileiro.
} 
No que concernia aos princípios norteadores do "Código político" a ser elaborado pela Assembleia Constituinte, demonstravam-se convencidos de que:

Nem os perturbará a demagogia, ambição e instabilidade das Repúblicas, nem nos definhará a tirania e prepotência das monarquias absolutas. Uma prudente e bem equilibrada divisão dos poderes públicos, guardada a inviolabilidade, e mais direitos próprios da Majestade, e defendidos os sacrossantos [direitos] do cidadão, constituirá para sempre a prosperidade, grandeza e segurança do rico Império do Brasil.

Orientando-se, então, por uma linguagem marcada pelo acatamento e pela "obediência", os representantes do Conselho concluíram a felicitação a d. Pedro com um apelo: "[...] Continuai a ser o nosso defensor, rematai a grande e majestosa obra, que tão heroicamente haveis começado; e praza ao céu que gozes por longos anos [...] um império, que terá por base o amor e a gratidão dos povos". ${ }^{176}$

A presença dos dois representantes do Conselho Interino na corte fluminense não foi decerto suficiente para suplantar os desentendimentos da classe senhorial na Bahia com o general Labatut, visto que este não abria mão de exercer a primazia no comando militar dos corpos das ordenanças de toda a província. Este impasse levou o Conselho Interino, em 16 de abril de 1823, a "se apressa[r] a pintar" para o ministro Bonifácio "o estado político [...] e os acontecimentos mais notáveis" envolvendo o comandante-em-chefe do Exército Pacificador. ${ }^{177}$ Sobre as disputas no trato militar, indagava o Conselho:

Quando aconteceu que em um país em armas se desorganizem corpos formados pelo patriotismo dos cidadãos, que voluntários se ofereceram à defesa de sua pátria?

Quais devem ser as consequências de se ver um cidadão em um dia coronel, ou major, ou capitão, ou outro oficial subalterno e no outro coisa nenhuma; tendo já feito suas despesas para arranjo do mesmo corpo, fardado e prontificado pelos mesmos oficiais? [...]

O general faz mais, despreza os oficiais de primeira linha brasileiros, que amantes de sua Pátria fugiram da cidade [de Salvador] em socorro da província, e os manda embora para empregar portugueses na maior parte dos quais é raro existir amor ao Brasil, para empregar milicianos, seus aduladores [...].

O clamor, Exmo. Senhor, é já mui grande, o clamor reina já nas últimas classes.

Os proprietários, os oficiais milicianos, que em regra são pessoas abastadas e de preponderância, são maltratados por Labatut [...].

\footnotetext{
${ }^{176}$ Idem, ibidem.

${ }^{177}$ Documentos históricos sobre a emancipação política da Bahia. Para José Bonifácio de Andrada e Silva, Ministro e Secretário d'Estado dos Negócios do Império. Revista do Instituto Geográfico e Histórico da Bahia, ano V, v. 5, n. 17 , 1898. p. 363-364.
} 
O descortinar das queixas sobre o comportamento militar de Labatut na Bahia pontilhava todo esse circunstanciado relatório. A falta de um plano e de disciplina na tropa para um ataque decisivo contra os portugueses europeus sob o comando de Madeira de Mello, as deserções, a calamidade nos hospitais do Exército com "mil e cem homens" carecendo de tratamento e medicamentos, as dificuldades para fardar os soldados. Enfim, a repreensão chegara a tal ponto que, conforme ficou registrado, "o general para cavar mais a ruína de nossa Pátria dispensou com os seus horrores a tropa de índios, os primeiros que ganharam louvor na nossa campanha e ensanguentaram naquela posição suas voláteis armas no atraiçoado sangue do coronel lusitano". Razão pela qual não existia mais "um só índio no Exército", enquanto os ocupantes da capital viam-se abastecidos pelos reforços de 1.330 homens vindos de Lisboa, concluindo que: "São estas as crises, em que bem se conhece a fraqueza dos Estados, onde a opinião pública, rainha do universo, não sustenta as autoridades". ${ }^{178}$

Não obstante as amiudadas informações sobre o comportamento militar do general estrangeiro, o Conselho dedicava-se a condenar, com igual destreza, a "sua conduta política". O flanco escolhido era a insistência de Labatut em contemplar as "classes de cor" no interior do Exército Pacificador. Neste sentido, o que mais incomodava era o fato de ter formado um batalhão com os escravos retirados dos engenhos Passagem e Cachoeirinha dos Teixeira Barbosa. ${ }^{179}$ Defendia como sendo "impolítico [...] aprovar um batalhão só de pardos" e, sobretudo, ainda serem "somente pardos os oficiais subalternos e superiores" os responsáveis pelo comando militar de um contingente que, conforme estimou Ubiratan Castro de Araújo, pode ter acomodado "372 escravos mulatos claros". ${ }^{180}$ Evidentemente, as discordâncias do Conselho se davam tanto pela ocupação dos postos diretivos deste batalhão escapar ao monopólio das classes senhoriais - que se queriam brancas e privilegiadas -, quanto por entender que Labatut, ao menos, deveria "dividir" aquelas "praças" pelas distintas repartições do Exército Pacificador. Contudo, em um contexto no qual os inimigos "da causa do Brasil" haviam novamente recebido reforços militares, as razões apresentadas para essa negativa não pareciam muito convincentes.

O Conselho não pode aprovar esta medida, não só por aqueles motivos

\footnotetext{
${ }^{178}$ Idem, ibidem.

179 Documentos históricos sobre a emancipação política da Bahia. Para José Bonifácio de Andrada e Silva, Ministro e Secretário d'Estado dos Negócios do Império. Revista do Instituto Geográfico e Histórico da Bahia, ano V, v. 5, n. 17, 1898. p. 363-364. Sobre o debate entre o Conselho Interino e Labatut relativo ao recrutamento de escravos para o Exército Pacificador, ver GUERRA FILHO, Sérgio Armando Diniz, op. cit. p. 91-97.

${ }^{180}$ ARAÚJO, Ubiratan Castro de, 2001, op. cit. p. 49.
} 
[armar as classes de cor], mas até porque devendo aqueles bens [os escravos libertos pelo ingresso no Exército] pertencerem um dia à Fazenda Pública, muito interessava esta em que fossem conservados e bem administrados; o que não se poderia conseguir sem aqueles braços.

Mas, enfim, deixou passar e cuidou logo de espreitar a opinião pública, e vendo que se declarava contra inteiramente, incumbiu ao brigadeiro José Egídio Gordilho de Barbuda houve de demonstrar ao general o impolítico que era aprovar um batalhão só de pardos, chamados de artilheiros de Sua Majestade Imperial, que desde o começo de nossa regeneração queriam formar, com a clausura de serem somente pardos os oficiais subalternos e superiores; podendo o general dividir as praças, que dele fossem, por todo o Exército.

E quando o general manda um capitão de cavalaria José Gomes Moncorvo com plano para se fazer por toda a província uma contribuição voluntária de escravos pardos, cabras e crioulos e assim reforçar o Exército: e não contente com este oficial, aliás prudente e honrado, dá uma portaria ao capitão dos mesmos libertos, de que já falamos, para fazer uma derrama de escravos dos europeus emigrados, a fim de preencher o mesmo batalhão de libertos já formado. ${ }^{181}$

No âmbito do Conselho Interino, a pedra de toque das desavenças com Labatut consistia no receio de que o espesso contingente de escravos compreendesse como aberta a possibilidade de recorrência às armas em defesa do Estado que, vis-à-vis, corresponderia às conquistas das liberdades civis e políticas dos envolvidos e, possivelmente, ao desmoronamento de todo o sistema escravista. Não por acaso, entre os anos de 1822 e 1823 , um observador e informante anônimo da Coroa portuguesa, concluiu o seu relatório sobre os acontecimentos políticos ocorridos no Brasil com uma observação alarmante, mas que revelava muito sobre o pavor da classe senhorial ante as possibilidades de emancipações dos seus numerosos cativos:

todos os brasileiros, e sobretudo os brancos, não percebem suficientemente, que é tempo de se fechar a porta aos debates políticos, às discussões constitucionais? Se se continua a falar dos direitos dos homens, de igualdade, terminar-se-á por pronunciar a palavra fatal: liberdade, palavra terrível e que tem muito mais força num país de escravos do que em qualquer outra parte. Então, toda a revolução acabará no Brasil com o levante de escravos, que quebrando suas algemas, incendiarão as cidades, os campos e as plantações, massacrando os brancos, e fazendo deste magnífico império do Brasil uma deplorável réplica da brilhante colônia de São Domingos. $^{182}$

\footnotetext{
${ }^{181}$ Documentos históricos sobre a emancipação política da Bahia. Para José Bonifácio de Andrada e Silva, Ministro e Secretário d'Estado dos Negócios do Império. Revista do Instituto Geográfico e Histórico da Bahia, ano V, v. 5, n. 17, 1898. p. 363-364.

${ }^{182}$ MOTT, Luiz. Um documento inédito para a história da Independência. In: Carlos Guilherme Mota (Org.). 1822: Dimensões. São Paulo: Perspectiva, 1972. p. 482.
} 
As matrizes de pensamento do anônimo informante e da classe senhorial baiana possuíam, inegavelmente, um substrato comum. Ambas temiam que o exemplo patriótico contagiasse a escravaria, cujas experiências rebeldes desde fins do Setecentos bem demonstravam o desejo alimentado pelos cativos de se "igualarem as outras classes sociais" existentes à época no Brasil. ${ }^{183}$ Questões dessa natureza demonstram, uma vez mais, que as classes dominantes estiveram muito atentas às tentativas de participação política dos segmentos escravistas, ou mesmos dos descendentes libertos residentes no Brasil. Em julho de 1822, estando em Londres no exercício de missões para o governo do príncipe regente, Felisberto Caldeira Brant - indivíduo que bem caracteriza a mobilidade horizontal da classe senhorial baiana no período - escrevia ao ministro José Bonifácio sobre a instabilidade manifesta nas províncias do Norte:

O ódio contra os Europeus cresceu depois dos acontecimentos da Bahia, e raros são os dias em que algum Português não seja assassinado ou roubado. Não escapam mesmo os Brasileiros suspeitos de alguma adesão aos Portugueses. Sublevações continuadas na Paraíba, e outros pontos da Província, havendo choques de 80 mortos, e mais. Tudo isso é horroroso, e pior ainda que seja dirigido pelos negros e mulatos. ${ }^{184}$

De fato, esse tipo de "consternação" revelava toda a aversão que as classes dominantes devotavam às incursões políticas protagonizadas por aqueles sujeitos históricos, cujas origens étnicas vinculavam-se à escravidão africana. Compartilhando idêntico preconceito, o Conselho Interino demonstraria a sua recusa acerca da "derrama de escravos" que Labatut andava empenhado em concretizar na província baiana. ${ }^{185}$ Além do que, solicitava especial atenção do imperador para uma decisão tida como relevante para o futuro

\footnotetext{
183 Documentos históricos sobre a emancipação política da Bahia. Para José Bonifácio de Andrada e Silva, Ministro e Secretário d'Estado dos Negócios do Império. Revista do Instituto Geográfico e Histórico da Bahia, ano V, v. 5, n. 17, 1898. p. 363-364.

${ }^{184}$ Cartas sobre a Independência, de 1822 a 1823. ARQUIVO NACIONAL. Livro dos termos: homenagens $e$ assentos. Rio de Janeiro: Typografia do Arquivo Público Nacional. 1947. p. 258. Disponível em: < http://www.archive.org/stream/livrodostermosh00bragoog\#page/n13/mode/1up>. Acesso em 15 de maio de 2009. Depois de ter se incompatibilizado com os defensores do vintismo na Bahia, o futuro marquês de Barbacena também não ficou muito tempo na corte fluminense, pois d. João VI tratou logo de despachá-lo para Londres, onde deveria representar os interesses do Império português. Com o retorno de d. João a Lisboa, Caldeira Brant foi nomeado para a função de encarregado dos negócios da regência de d. Pedro na capital britânica e, de bom grado, passou a se corresponder com algumas influentes autoridades do Brasil, especialmente o ministro José Bonifácio de Andrada e Silva. Ao que tudo indica, a transitoriedade do futuro visconde de Barbacena cumprindo funções estratégicas na capital britânica deve-se muito à sua extensa rede de influência que efetivamente assegurava contatos e, em última instância, servia de garantidoras da fidelidade dos indicados à causa a ser empreendida.

${ }^{185}$ Durante a Guerra de Independência, Labatut autorizou igualmente uma "derrama de gado" para forçarem os proprietários a contribuírem com a dieta de carne no Exército, situação que também ocasionou desentendimentos entre o comandante-em-chefe e os criadores de gado vacum na Bahia. SOUZA FILHO, Argemiro Ribeiro de, op. cit. cap. 2.
} 
de uma organização societária ainda indefinida já que o comportamento do general estrangeiro desferia um forte golpe nas tradicionais hierarquias sociais predominantes na sociedade escravocrata.

Na província da Bahia, Exmo. Senhor, existem muito perto de quinhentos engenhos, e um sem número de pequenos proprietários; indo portanto avante o projeto levantar-se-ia, de repente, na província uma força de quatro mil libertos, sem que se tenham esgotado os meios de recrutamento forçado que tanto cumpre primeiro proceder.

Pondere, pois Vossa Excelência, o risco que ia a correr armando assim aqueles que mesmo desarmados procuram quebrar os ferros do cativeiro para se igualarem às outras classes sociais. O Conselho vendo que o general Labatut não tinha feito secreta a proposição, como devera, para depois de bem averiguar ser decidida; e não podendo tomar sobre si a responsabilidade de negócio de tanta importância, quando já pelas ruas em outra coisa não falavam os pardos, cabras e crioulos; finalmente dizendo o mesmo general que se consultassem as Câmaras, incumbiu essa decisão às cinco Câmaras principais para que, convocando proprietários, com eles decidisse o que conviesse, decidindo já a desta vila que dariam a resposta do dia da sessão a trinta dias.

Exmo. Senhor, se este general fosse prudente, não teria o público de se ver assim ameaçado.

Quando aquela medida fosse de conceber-se não era nunca para aventá-la com publicidade; o general devera primeiro consultar, em segredo, o Conselho, e, com o parecer deste, decidir-se o que se devera fazer, nunca incumbindo tal negócio a um capitão dos próprios libertos, que interessado na realização daquele plano, não cessava de conversar com escravos, sendo até pelas ruas cercado por eles.

O Conselho, finalmente, é de parecer que nunca se tome semelhante medida; mas que no caso de assim decidirem as Câmaras, é igualmente de voto que nunca se formem batalhões, nem mesmo companhias de libertos; mas sim que sejam derramados por todo o Exército.

E sendo este negócio da maior importância, o Conselho o recomenda a Vossa Excelência para que o apresente muito especialmente a Sua Majestade Imperial Constitucional para tomar sobre isso uma providência a mais pronta. ${ }^{186}$

Além desse discurso prenhe de significados para conhecimento do imperador, o

Conselho procurara obstar, via a expedição de portarias, o arbítrio de Labatut em questões

\footnotetext{
${ }^{186}$ Documentos históricos sobre a emancipação política da Bahia. Para José Bonifácio de Andrada e Silva, Ministro e Secretário d'Estado dos Negócios do Império. Revista do Instituto Geográfico e Histórico da Bahia, ano V, v. 5, n. 17, 1898. p. 363-364. Analisando as implicações subjacentes à derrama de escravos levada adiante pelo comandante-em-chefe do Exército Pacificador, Hendrik Kraay constatou que no âmbito do Conselho Interino a iniciativa do general francês foi vista como "profundamente preocupante" já que trouxera para o cerne do debate não apenas o "direito de propriedade e o princípio, implícito mas fundamental, da nãointervenção do Estado nos direitos senhoriais", como também dera vazão à questão racial que, como já demonstrado, revelara-se conflitiva para a sociedade baiana já naqueles anos. KRAAY, Hendrik. "Em outra coisa não falavam os pardos, cabras e crioulos." O "recrutamento" de escravos na Guerra de Independência na Bahia (1822-1823). Revista Brasileira de História. ANPUH/Humanitas, v. 22, nº 43, 2002. p. 113.
} 
polêmicas, a exemplo das prisões contra alguns representantes da classe senhorial que se opunham às decisões. "E assim estava mais tranquilo e seguro o cidadão, tanto militar como paisano, quando chegou a portaria do Exmo. Ministro da Guerra, de 22 de janeiro [de 1823]" que reconhecia no general Labatut o comandante-em-chefe de toda força militar obediente ao imperador. $^{187}$

Apesar de não se opor abertamente ao cumprimento desta determinação imperial, em fins de março, o Conselho enviou à corte um legítimo representante da classe senhorial, o abastado coronel Francisco Maria Sodré Pereira, com a missão de "inteirar o ministro do choque da opinião pública com a notícia de que o general Labatut era general das armas, tendo debaixo do seu comando imediatamente toda força de primeira e segunda linha da província". ${ }^{188}$ Ainda na expectativa de uma negociação que atendesse aos interesses das classes dominantes locais, o Conselho resolveu eleger um representante interno para expor ao Imperador o estado da província depois que o comando geral das tropas fora entregue a Labatut. A escolha recaiu sobre Montezuma que, com a maioria de cinco votos, seguiu em viagem novamente para a corte fluminense. Entretanto, na condição de membros do governo, Miguel Calmon, Simão Veloso, Francisco Ayres Freitas e Manoel dos Santos Silva, exigiriam que fosse declarado em ata que foram vencidos "quanto a aprovar-se a indicação de ir na 'crise atual' um deputado ao Rio de Janeiro, declarando mais o mesmo [...] Miguel Calmon de que ele votou no Sr. presidente" Francisco Elesbão para aquela representação. A rigor, são dissensões como estas que desnudam as facções em luta no interior da classe dominante, que,

\footnotetext{
${ }^{187}$ Documentos históricos sobre a emancipação política da Bahia. Para José Bonifácio de Andrada e Silva, Ministro e Secretário d'Estado dos Negócios do Império. Revista do Instituto Geográfico e Histórico da Bahia, ano V, v. 5, n. 17, 1898. p. 363-364,

${ }^{188}$ Documentos históricos sobre a emancipação política da Bahia. Para José Bonifácio de Andrada e Silva, Ministro e Secretário d'Estado dos Negócios do Império. Revista do Instituto Geográfico e Histórico da Bahia, ano IV, v. 4, n. 12, 1897. p. 180-182. Em 21 de fevereiro, o Conselho Interino havia apresentado ao ministro da guerra a proposta organizativa do Batalhão Legião de Honra imperial, "cujo comandante era e ficou sendo o coronel Francisco Maria Sodré Pereira [...], não aprovando [...] o tenente-coronel proposto Antonio Maria da Silva Torres" que, decerto, manifestou interesse neste comando. Na mesma correspondência, o Conselho lembrava a desastrosa iniciativa da Corte de Lisboa em atrelar o governo das armas independente do governo civil, bem como apresentava suas considerações sobre as razões porque a Bahia não deveria proceder como as províncias de Pernambuco, Alagoas e demais do Sul que, segundo as suas palavras, acataram a nomeação de governador das armas pelo imperador. São questões como estas que comprovam o empenho da classe senhorial na Bahia em assegurar uma posição de destaque ante o Estado e a nação que se formavam. Documentos históricos sobre a emancipação política da Bahia. Para José Bonifácio de Andrada e Silva, Ministro e Secretário d'Estado dos Negócios do Império. Revista do Instituto Geográfico e Histórico da Bahia, ano V, v. 5, n. 18, 1898. p. 557-559. Sobre o prestígio do coronel Sodré "entre os líderes da sua classe que chefiavam a guerra contra os portugueses", ver REIS, João José. Domingos Sodré, um sacerdote africano: escravidão, liberdade e candomblé na Bahia do século XIX. São Paulo: Companhia das Letras, 2008. p. 74-75.
} 
de fato, estava longe de se constituir em um todo coeso, cujos membros nutriam posições liberalizantes de tipos distintos. ${ }^{189}$

Em 30 de maio de 1823, o Conselho informava ao ministro José Bonifácio estar ciente da portaria expedida pela Secretária do Estado dos Negócios do Império exigindo que “o secretário do mesmo Conselho, Francisco Gomes Brandão Montezuma, vá a essa corte não só para provar a acusação [...] contra o general Labatut, mas para se defender de outras que lhes fazem". Ou seja, os mais altos dignatários da corte fluminense estavam muito atentos sobre possíveis comportamentos desviantes dos baianos. ${ }^{190}$ Em sua resposta, o Conselho informava que "antes de receber a precitada portaria já havia partido para essa corte, por via de terra, o dito Secretário que se apresenta a Vossa Excelência”. ${ }^{191}$

Os "ciúmes e choques" entre a classe senhorial e o general francês culminaram, como se sabe, na sua destituição do comando do Exército Pacificador em 21 de maio de 1822, sendo preso e encaminhado ao Rio de Janeiro, onde responderia a um Conselho de Guerra. Assegurada ampla defesa, Labatut conseguiu, no ano seguinte, livrar-se das acusações que lhe imputavam as autoridades baianas. No transcurso do processo, fez questão de enfatizar a "indiferença de alguns proprietários [da província baiana] em prestar auxílios ao Exército", razão pela qual foi-lhes solicitado "calvagaduras, gados e outros socorros [...]", conquanto acreditasse não poder ser responsabilizado se oficiais subalternos abusaram dessas suas ordens. No que diz respeito ao arcabuzamento sumário dos "cinquenta e dois" cativos, o resultado não fora diferente, visto que ali também o general francês conseguiu unânime aprovação da comissão do Conselho de Guerra. Os escravos abatidos a tiro foram considerados "inimigos domésticos", verdadeiros "piratas" e "salteadores", cujo extermínio corroborou para que "dali em diante os senhores de engenhos fossem senhores dos seus escravos, o que até ali não sucedia". ${ }^{192}$

\footnotetext{
${ }^{189}$ O Conselho resolve mandar ao Rio de Janeiro o deputado Montezuma para expor ao Imperador o estado da província depois que o ministro da guerra mandou pôr debaixo das ordens imediatas do general Labatut todas as forças militares. In: Documentos históricos sobre a emancipação política da Bahia. Para José Bonifácio de Andrada e Silva, Ministro e Secretário d'Estado dos Negócios do Império. Revista do Instituto Geográfico e Histórico da Bahia, ano IV, v. 4, n. 12, 1897. p. 182-183.

${ }^{190}$ Correspondência oficial do Conselho Interino de Governo na Cachoeira, em 30 de maio de 1823. Documentos históricos sobre a emancipação política da Bahia. Revista do Instituto Geográfico e Histórico da Bahia, ano V, v. 5, n. 17, 1898. p. 374.

${ }^{191}$ Idem, ibidem.

192 Defesa do general Labatut sobre a sua conduta enquanto comandou o Exército Pacificador da Bahia, em resposta aos quatro artigos da sua acusação, que lhe foram comunicados por ordem do conselho de guerra; a que tem já respondido por determinação de S. M. I. Rio de Janeiro: na Typographia de Silva Porto e Companhia, 1824. In: Revista do Instituto Geográfico e Histórico da Bahia, v. 1, n. 65, p. 3-44, 1896. As citações constam do parecer final de tenente general presidente do Conselho de Guerra, Francisco de Paula Maggessi Tavares de Carvalho, Idem, ibidem. p. 36 e 39. Ainda consoante aos escravos exterminados, o general francês levou ao conhecimento dos conselheiros a portaria do imperador, datada de 22 de janeiro de 1823 , que justificava a sua
} 
O comportamento do general francês gerava também desconfianças em representantes do liberalismo exaltado. Em princípios de julho, Cipriano Barata escreveu em sua Sentinela da Liberdade na guarita de Pernambuco, que:

Labatut, passando por esta Vila do Recife, teve a ousadia de dizer que levava Carta Branca para fazer tudo quanto ele julgasse a bem da Bahia. Isto pareceu hipérbole ou jactância do Francês, mas agora se conhece pelo seu comportamento ser verdade e mais que verdade. Labatut matava os homens sem forma de justiça, dispunha dos negócios da Igreja e até dissolveu o Governo Civil de Sergipe d'El Rei, ficando ele despótico em toda aquela Província, e tinha determinado fazer o mesmo à Junta Civil de Cachoeira. Tendo feito algumas tentativas para indispor os povos contra aquela Junta, e não havendo surtido bom efeito, tentou fazê-lo por meio das Tropas, as achando dificuldade na execução do plano pelos Comandantes das Brigadas [Felisberto Gomes Caldeira e o pernambucano José de Barros Falcão de Lacerda], determinou prender a estes para eleger novos a seu contento e levar o projeto avante, que era extinguir a Junta da Cachoeira e ficar de todo Capitão General, como no tempo do antigo despotismo [...]. ${ }^{193}$

Dessa maneira, fica bastante evidente como a classe senhorial na Bahia soube escapar das imposições que o "Gabinete do Rio de Janeiro" - como Cipriano Barata gostava de se referir ao ministério dos Andrada - quis lhe impor, para, de forma suficientemente autônoma, e igualmente exitosa, negociar diretamente com o imperador qual seria a sua inserção. ${ }^{194}$ Daí porque, a queda do general francês no comando militar da Bahia ter sido articulada à maneira de não poder ser facilmente caracterizada como um confronto direto com d. Pedro I, que realmente não estava disposto a entregar aos representantes da classe senhorial baiana o mais importante posto militar da província. Tendo estas melindrosas questões em vista, em 24 de maio, o Conselho Interino nomeou para a direção do Exército Pacificador o coronel José Joaquim de Lima e Silva (1787-1855) que, há cerca de três meses, havia chegado

conduta: "Se o General cometeu alguns excessos, deve pensar o Conselho, que em tempo de Guerra há motivos poderosos, que muitas vezes os minoram, se é que de todo não escusam, e que muitas vezes um mal pequeno cometido salva grandes males". Ibidem, p. 24.

193 Sentinela da Liberdade na Guarita de Pernambuco Alerta!, n. 27, sábado, 5 de julho de 1823. Recife, Tipografia de Cavalcante e Carvalho. In: BARATA, Cipriano. Sentinela da Liberdade e outros escritos (18211835). Organização e edição Marco Morel. São Paulo: Edusp, 2008. p. 312.

194 Neste mesmo período o ministério que tinha à frente José Bonifácio de Andrada e Silva procurou incessantemente minar a autonomia política da província de Pernambuco, usando artifícios bem semelhantes ao que Cipriano Barata denunciava no comportamento de Labatut de tentativa de destituição do Conselho Interino. Atento ao centralismo que a corte fluminense ambicionava implementar já em princípios de 1822, Denis Bernardes registrou que: "Durante a vigência das Cortes, o poder local foi fruto de eleição e teve suficiente autonomia e legitimidade para - sem romper a unidade - discutir, criticar e mesmo recusar cumprir decisões das Cortes - que eram necessariamente assumidas pelo rei - e as do príncipe regente, no Rio de Janeiro. No entanto, antes de realizada a ruptura com as Cortes, já Dom Pedro e José Bonifácio buscavam controlar as juntas locais, destituí-las - como fizeram com Pernambuco - e, assim que puderam, substituí-las por presidentes de província nomeados pelo imperador e, evidentemente, criaturas de seus desejos e ordens". BERNARDES, Denis Antônio de Mendonça, op. cit. p. 630. 
do Rio de Janeiro à frente do Batalhão do Imperador, composto por 800 homens. A despeito de assegurar a autoridade formal, o comandante-chefe empossado não teria condições de unificar "a confederação de destacamentos militares", controlada firmemente pela classe senhorial, com destaque para o coronel baiano Felisberto Gomes Caldeira que exercia grande influência sobre a tropa. ${ }^{195}$

Nesta nova configuração do poder das armas, esboçaram-se os termos de uma negociação possível entre a Bahia e a corte fluminense, cujo próprio d. Pedro I deveria estar cada vez mais consciente de que o arranjo imperial precisaria reservar um espaço privilegiado para acomodar a classe senhorial oriunda da antiga sede dos vice-reis do Brasil. ${ }^{196}$ Não obstante a inserção das províncias coligadas sustentando o projeto político que permitiu o engendramento do Estado e da nação brasileiros, o esgotamento das possibilidades do vintismo não se mostrara suficiente para garantir uma ampla articulação interna entre as partes e o todo constituído pela América portuguesa e que, no segundo semestre de 1822, passou a conformar uma ambiciosa unidade política. ${ }^{197}$ A concreção desta arquitetura exigiria, portanto, a compreensão sobre a organização dos governos provinciais que investigasse e ajustasse as suas relações político-institucionais particulares em relação à corte fluminense, capital do Império que se conformava. ${ }^{198}$ Importa também realçar que o pacto político-social a ser concertado pautou-se tanto na organização do governo monárquico constitucional, como nas reiterações que contemplassem a manutenção da aristocracia da terra e do sistema escravista. Dessa maneira, o aprendizado político subjacente a este intricado processo revelaria que a classe senhorial originária da Bahia, mas transitando ou já instalada no Rio de Janeiro, esteve atenta a cada lance e, devido ao seu peso político, pôde conquistar importantes postos no governo monárquico constitucional encabeçado por d. Pedro I.

Embora não se trate de caracterizar o comportamento político dos primeiros mandatários do sistema representativo em vigor no Brasil em termos de atuação por bancadas parlamentares de caráter regionais - situação que, de fato, não se verificaria, seja nas Cortes

195 ARAÚJO, Ubiratan Castro de, 2001, op. cit. p. 56.

196 A perspectiva aqui defendida não se coaduna com os argumentos dos que compreenderam as "elites" regionais do período como demasiadamente frágeis para elaborarem um projeto nacional. DIAS, Maria Odila Silva. A interiorização da metrópole. In: MOTA, Carlos Guilherme (Org.), 1972, op. cit.

197 SLEMIAN, Andréa, 2009, op. cit. Cap. I. Miriam Dolhnikoff expôs bem a questão ao perceber que "[...] patenteada a impossibilidade de garantir a autonomia provincial sob a direção do governo de Lisboa, a integração ao Rio de Janeiro tornou-se mais atraente, na medida em que este procurava chamar para si os grupos regionais, com o canto da sereia da autonomia. Compreende-se assim a disposição desses grupos em participar da Assembleia Constituinte de 1823 [...], o que pressupunha a aceitação da unidade em torno do governo do Rio”. DOLHNIKOFF, Miriam. O pacto imperial: origens do federalismo no Brasil. São Paulo: Globo, 2005. p. 43.

198 SLEMIAN, Andréa, 2009, op. cit. p. 41-42 e 48. 
de Lisboa, seja na Constituinte de 1823 - convém realçar a forte liderança dos baianos que assumiram funções de relevo nesse momento. ${ }^{199}$ Para além dos mencionados, outras personalidades que chamaram atenção em suas atuações na Constituinte foram o desembargador baiano Antônio Luís Pereira da Cunha, futuro marquês de Inhambupe, eleito também pela província do Rio de Janeiro; o canonista José da Silva Lisboa, o qual assumiria a vaga não ocupada pelo liberal radical Cipriano José Barata de Almeida, o bacharel Miguel Calmon du Pin e Almeida, depois marquês de Abrantes, que assumiria o ministério das finanças, ocuparia uma vaga no senado e revelar-se-ia um dos principais quadros de sustentação do Primeiro Reinado, sob o governo centralista de d. Pedro I e, finalmente, o brigadeiro Felisberto Caldeira Brant que, depois de ter atuado em Londres a serviço do príncipe regente, assumiu a vaga de deputado não preenchida pelo também liberal radical Francisco Agostinho Gomes. Dessa maneira, será significativo examinar as motivações que levaram alguns indivíduos com fortes ligações com a província da Bahia a se inserirem na Assembleia Constituinte, compreendida como o locus da representação da nação, conquanto outras lideranças políticas recusassem ali comparecer. Paradigmático desta postura, o baiano Cipriano Barata, decidiu-se fixar-se em Pernambuco, enquanto se desenrolou o tortuoso e abortado processo da primeira Assembleia Constituinte do Brasil, mas nem por isso deixou de expressar-se como legítimo representante da nação que se formava, visto que os seus escritos jornalísticos reverberaram em importantes e variadas localidades do recém-fundado Império Braziliense. Questões que serão discutidas no capítulo que se segue.

\footnotetext{
${ }^{199}$ A rigor, a atuação política em termos de bancadas parlamentares só se consagra no Brasil com a instauração
} do sistema de governo republicano a partir de 1889. 


\section{Capítulo 4}

\section{Compromissos e acomodações na formação da nação brasileira}

Depois de ter experimentado uma guerra que se estendeu por pouco mais de um ano contra as tropas de Portugal, em 2 de julho de 1823 muitos habitantes da província da Bahia puderam comemorar a Independência visto encontrarem-se, finalmente, livres do inimigo que naquela madrugada afastaram-se da costa. De imediato, as forças militares que, a partir do Recôncavo baiano, mantiveram ativas as linhas de defesa e asseguraram um bem-sucedido assédio à capital, prepararam-se para adentrar a cidade evacuada. Comandados pelo coronel José Joaquim de Lima e Silva, diversos militares administravam como podiam a ansiedade de se apresentar triunfantes pelas ruas de Salvador. Entretanto, nas marchas das tropas em direção à urbe ficaram explicitadas, tanto as hierarquias militares, como as agruras da campanha, manifestas na forma como um considerável número de soldados mal alimentados, e no dizer de Accioli, "quase no estado de nudez e descalços", disputavam aplausos e prebendas que os habitantes improvisavam para recepcionar os bravos defensores da causa da liberdade. ${ }^{1}$

\subsection{Rearranjos político-militares na Bahia pós-Independência}

Considerando que desde meados de maio, os comandos e as tropas de Portugal decidiram pela retirada da província, aguardando tão somente as condições mais oportunas para assim proceder, franquearam-se doravante as condições para entabular negociações capazes de evitar os prováveis atritos entre civis que havia cooperado na permanência de Madeira de Mello no governo das armas e os resistentes àquela posição. Razão pela qual, em fins de junho, diversos negociantes e proprietários portugueses que não pretendiam partir de Salvador enviaram à vila de Cachoeira uma representação solicitando "garantias"

\footnotetext{
${ }^{1}$ SILVA, Inácio Accioli de Cerqueira. Memórias históricas e políticas. Anotada por Braz do Amaral. v. 4. Bahia: Imprensa Oficial do Estado, 1933, p. 55. Sobre a fome e demais privações sofridas pelas tropas contrárias ao domínio de Portugal, tem-se o testemunho ocular do viajante sertanista Antônio Moniz de Souza que registrara ter visto "homens morrerem por falta de se lhes tirarem bichos no meio de milhares de seus semelhantes que os deixavam em abandono". SOUZA, Antonio Moniz de. Viagens e observações de um brasileiro. Organização e notas de Ubiratan Castro de Araújo. 3. ed. Salvador: Instituto Geográfico Histórico da Bahia, 2000 (Coleção do arquivo IGHB, 3). p. 200. Ainda sobre a penúria no exército, ver TAVARES, Luís Henrique Dias. Independência do Brasil na Bahia. Salvador: Edufba, 2005. p. 204-207 e SOUZA FILHO, Argemiro Ribeiro de. A Guerra de Independência na Bahia: Manifestações políticas e violência na formação do Estado Nacional (Rio de Contas e Caetité). Dissertação (Mestrado em História) - Faculdade de Filosofia e Ciências Humanas - Universidade Federal da Bahia, Salvador, 2003. Cap. 2.
} 
de suas vidas e propriedades, tanto por parte do comandante-em-chefe do Exército Pacificador, quanto do Conselho Interino de Governo. A este último, informavam, outrossim, o envio de uma deputação ao Rio de Janeiro visando a atenção do imperador para o firme sucesso da mesma súplica, ao mesmo tempo que, nesta ocasião, aproveitariam para congraçar os "votos de amor e de respeito à sua pessoa, e Imperial dinastia, e de adesão ao sistema de governo constitucional que a nação tem adotado". ${ }^{2}$ Segundo apurou Gladys Sabina Ribeiro, a ampliação da presença de portugueses europeus na corte fluminense entre os anos de 1823 e 1824 deveu-se, tanto pela imigração que continuaram provenientes de cidades como Porto e Lisboa, quanto pelas transferências internas de lusitanos que se sentiam perseguidos, ou simplesmente inseguros, em províncias como a da Bahia e de Pernambuco, onde muito se suspeitavam das condutas dos mesmos. ${ }^{3}$

As evidências são, portanto, de que na conjuntura final da guerra os próprios portugueses europeus residentes na Bahia revelaram-se igualmente aptos na composição das redes de sociabilidade envolvendo o Rio de Janeiro. Esta articulação visava, dentre outros objetivos, assegurar uma anistia geral aos lusitanos residentes na província que, por algum motivo, viram-se enredados nas questões políticas e militares em consonância ao que esperavam as Cortes de Lisboa. E como no decorrer da campanha militar centenas de portugueses acabaram "presos por motivos políticos" sob a alegação de terem "conspirado contra a Causa do Brasil", havendo ainda outros tantos "que a esmo foram sepultados nas Cadeias, sem outro indício mais, que a qualidade de Português", ${ }^{4}$ o momento no qual se

\footnotetext{
${ }^{2}$ SILVA, Inácio Accioli de Cerqueira, op. cit. v. 4. p. 42-45. Nesta representação, seguiam-se quarenta e oito assinaturas. No mesmo dia 30 de junho, o Conselho comprometera-se em tomar todas as providências ao seu alcance para atender aos suplicantes. Idem, ibidem. p. 45, nota 22. Naquele instante, o Senado da Câmara de Salvador também já havia sido autorizado pela Junta Provisória da capital a nomear "alguns homens bons para irem tratar com o comandante das forças Sitiantes a fim de alcançarem dele uma garantia às vidas e fazendas dos Cidadãos [oriundos de Portugal] que ficarem quando se retirar as Tropas destacadas nesta Cidade [...]", o que indica a mobilização dos representantes portugueses em busca de toda a segurança para permanecerem no território baiano. Ata da Câmara de Salvador, em 26 de junho de 1823. Documentos da Municipalidade de Salvador relacionados com a Independência do Brasil. 1821-1823. Salvador: Prefeitura Municipal/Departamento de Cultura da SMEC, 1972. p. 95.

${ }^{3}$ RIBEIRO, Gladys Sabina. A liberdade em construção: identidade nacional e conflitos antilusitanos no primeiro reinado. Rio de Janeiro: Relume Dumará, 2002. p. 71. Para Ricardo Luís de Souza, nem mesmo a adesão explícita dos portugueses europeus ao Império do Brasil e os reconhecimentos destes às autoridades constituídas foram bastante para livrá-los das perseguições promovidas por aqueles que os identificavam como os mais contrários à Independência do Brasil. Dessa maneira, a recusa ao elemento português no pósIndependência não se restringiu à sua postura política, visto que a sua antiga tradição nos domínios econômicos foi igualmente mal tolerada. SOUZA, Ricardo Luís. O antilusitanismo e a afirmação da nacionalidade. Politeia: História e Sociedade/Revista do Departamento de história da Universidade Estadual do Sudoeste da Bahia. Vitória da Conquista - Bahia: Edições Uesb, v. 5, n. 1, 2005. p. 137 e segs.

${ }^{4}$ Relatório dos trabalhos do Conselho Interino de Governo da província da Bahia, em prol da Regência e do Império de sua magestade imperial o senhor D. Pedro I e da Independência Política do Brasil, redigido e offerecido ao grande constitucional e defensor perpétuo do Brazil, e ao heróico povo da província da Bahia
} 
prenunciava o embarque das tropas sob o comando de Madeira de Mello revelou-se igualmente propício à prevenção de futura represália aos lusitanos desejosos em fixarem-se definitivamente na província baiana. Diligente em coadjuvar para a proteção dos naturais de Portugal que ficariam na província, o comandante-em-chefe do Exército Pacificador concitou seu oficialato e demais subordinados sobre a forma como o Exército deveria se comportar na cidade, naquele momento, ainda a ser conquistada.

Soldados [...]! Vós ides entrar na bela capital desta rica província; é chegado o momento de irdes repousar de tantas fadigas, e de pôr o complemento à vossa independência. Soldados [...] ides [...] tornar a ver vossos parentes, amigos e concidadãos. E espero [...] que não mancheis tão pomposo e magnífico dia, com qualquer ato que inculque furor, vingança ou ódio. Vós bem sabeis que a honra, a probidade e a disciplina formam o principal caráter do verdadeiro militar [...] desempenhareis o magnífico título de soldados do bravo exército pacificador, e, sobretudo, dareis uma prova convincente de que sois fiéis executores da augusta vontade do nosso imortal e magnânimo Imperador.

Soldados! Desde hoje nada mais de sangue, ou de vingança; paz, ordem, e a mais rigorosa disciplina [...]. Viva a nossa santa religião, viva o nosso augusto Imperador, viva a assembleia constituinte do Império Brasileiro. ${ }^{5}$

Havendo fortes indícios, desde pelo menos o mês de março, de que a tropa lusitana abandonaria a Bahia, o governo imperial não perdera tempo em transmitir a Lima e Silva as determinações como as que se seguem:

1. ${ }^{\circ}$ Que nenhum indivíduo, ou soldado haja de perturbar o sossego, ou tranquilidade pública, e pessoal, atacando ou ofendendo a qualquer pessoa que seja, por motivo ou pretexto de suas opiniões políticas, porque se diga afeto ao sistema contrário à causa da nossa liberdade e independência, devendo somente pertencer o conhecimento de semelhantes crimes às autoridades competentes, e nunca ao exército, que só deve ser empregado em defender seus concidadãos, ou em auxiliar o governo, em caso que este o requeira.

2. Que seja empregada a maior vigilância sobre a segurança de propriedade, e vidas dos habitantes da cidade, sem que pertença nunca aos indivíduos do exército, ou a outras quaisquer tropas desta província, fazer a seu bom grado e arbítrio distinções, ou diferenças de imputações, competindo unicamente tal conhecimento às autoridades constituídas.

3. ${ }^{\circ}$ Que cumpre bem assim, em execução de suas imperiais ordens (com

por Miguel Calmon d' Pin e Almeida. Bahia: Na Typographia Nacional, p. 1-24, 1823. (Disponível em: <http://www.crl.edu/content/brazil/BAH.htm> Acesso em 14 de agosto de 2008).

5 Apud SILVA, Inácio Accioli de Cerqueira, op. cit. p. 45-46, nota 23. Na mesma ocasião, Lima e Silva expediu uma proclamação aos habitantes da capital baiana, pela qual procurava sossegar os ânimos, ao mesmo tempo em que assegurava que os inimigos fugiriam e que os moradores da capital não deviam temêlos, nem a estes aos "insensatos e desprezíveis anarquistas". Afirmava, por fim, que ele e o Exército garantiriam "a paz, à ordem, à liberdade e independência”. Idem, ibidem, loc cit. 
positiva responsabilidade) a todos os comandantes das divisões, e brigadas, chefes dos diversos corpos do exército, e comandantes das mais tropas desta província, fazer manter a melhor ordem, e disciplina a todos os indivíduos, que estiverem debaixo do seu comando, empregando todos os meios, que estejam à sua disposição, e fazendo conhecer a todos os seus súditos, que pela mínima infração de tão providentes disposições, eles incorrerão nas penas, que as leis irrevogavelmente impõem aos que desobedecem, ou faltam às ordens do Imperador, e dos seus superiores, sendo aliás punidos pelos seus crimes, conforme a sua gravidade. ${ }^{6}$

Prevenções dessa natureza assinalam o quanto as autoridades imperiais estiveram atentas ao que se passava no território baiano. Com efeito, a simples retirada das tropas portuguesas da província não se revelava suficiente para restabelecer o "sossego público", posto que, depois de subsistirem por pouco mais de um ano "aterrados pelos furores da guerra civil", os ramos da economia da província e mesmo a infraestrutura urbana da cidade de Salvador (quartéis militares, repartições públicas e moradias) se encontravam muito deteriorados. Salienta-se que algum tempo antes da libertação da capital, em 29 de maio de 1823, o redator do Semanário Cívico divulgara dados oficiais informando que 9.274 pessoas haviam emigrado de Salvador, conquanto estimasse que esse cálculo pudesse ser fixado em 12.000, pois ninguém desconhecia que as fugas ocultas foram, naquela quadra histórica, bastante rotineiras. ${ }^{7}$ Já Miguel Calmon expunha que para manter o assédio à cidade da Bahia fez-se necessário alimentar diariamente "10.148 bocas", divididas em 9.161 praças combatentes do Exército Pacificador e 987 empregados e serventuários civis dos diferentes ramos do governo, os quais, em 22 de abril de 1823, consumiam nada menos que 253 alqueires de farinha (uma unidade de medida alqueire, hoje em desuso, correspondia a 36,27 litros) e 60 reses bovinas, com média de oito arrobas por animal. Razão pela qual, o futuro ministro das finanças do Império do Brasil concluía que: "Nesta importante Repartição tem [sic] dado entrada desde dezembro do ano passado até maio último: 10.042 cabeças de gado e 153.298 quartas de farinha [a unidade de medida quarta, também em descostume, equivalia a aproximadamente 9 litros]". ${ }^{8}$ Por sua

\footnotetext{
6 Apud SILVA, Inácio Accioli de Cerqueira, op. cit. p. 48-49. Como as graves dissensões políticas envolvendo portugueses e filhos da terra não se circunscreviam aos habitantes da capital e seus arredores, $o$ comandante-em-chefe fez publicar as mesmas determinações, "a toque de caixa, nas divisões do exército, e em todos os distritos da província".

${ }^{7}$ Semanário Cívico, n. 116, de 29 de maio de 1823. SILVA, Maria Beatriz Nizza da. Semanário Cívico: Bahia, 1821-1823. Salvador: Edufba, 2008. p. 164-165.

${ }^{8}$ Relatório dos trabalhos do Conselho Interino de Governo da província da Bahia, op. cit. p. 10. Segundo Miguel Calmon, a necessidade em atender as tropas avançadas de Cachoeira, do Exército e de outros pontos de segurança levou o Conselho Interino a "estabelecer (antes da organização do Comissariado Geral do Exército Pacificador)" a inspeção de munições de boca que, entre $1^{\circ}$ de outubro de 1822 e 20 de maio do ano seguinte, forneceu para as praças destacada e os empregados
} 
vez, o historiador Luís Henrique Dias Tavares contabilizou em 8.686 o contingente de oficiais e soldados de diferentes províncias pertencente ao Exército Pacificador que adentrou em Salvador no dia 2 de julho, sendo estes seguidos pela população civil que, sem tempo a perder, refez o caminho de volta à urbe soteropolitana, encontrada, naquela altura dos acontecimentos, carecida de bens os mais imprescindíveis. ${ }^{9}$

A despeito das medidas adotadas pelas autoridades provincial e central objetivando assegurar a ordem pública na Bahia, o adensamento das tensões pós-guerra era manifesto. Destarte, residia na própria tropa, recém-chegada à cidade, o foco principal de agitação, inclusive porque parte dos fardamentos e dos soldos encontravam-se atrasados. E pior: não havia nenhuma segurança jurídica de que o amplo contingente de homens que ingressou voluntariamente nos batalhões patrióticos seria incorporado ao Exército imperial. Reunindo os escravos alistados que expuseram as vidas em substituições às dos filhos dos senhores convocados, os quais, por este artifício, conseguiram livrar-se da árdua labuta da guerra - ou simplesmente por aqueles cativos que sumiram das supervisões dos proprietários para logo aparecerem no contingente militar -, bem como os libertos negros, pardos ou brancos pobres oriundos de diferentes partes da província, revelou-se expressivo o número dos aspirantes à carreira nas armas como recurso para melhorar de vida. ${ }^{10}$ No entanto, Accioli registrou que, ao menos formalmente e tanto quanto fora possível naquela conjuntura, uma ambiência de relativa paz havia sido assegurada. Diligente, a Junta de Governo transladada em 7 de julho da vila cachoeirana para a capital encaminhou à corte fluminense uma pequena comissão formada pelos majores Luís Lopes Villas-Boas e José

civis, "que em falta dos seus ordenados percebiam Etapa": 11.617 cabeças de gado, provenientes 4.196 de donativo voluntário, 4.905 de compra e 2.501 de empréstimo; 170.606 quartas de farinha; 3.735 quartas de feijão; 5.671 de arroz; 3.903 de milho; 1.679 de sal; 2.325 libras de toucinho e grandes quantidades de galinhas. Frisara ainda o futuro marquês de Abrantes que importante parcela desses víveres fora conseguida devido aos "donativos e, principalmente, empréstimos" angariados em vários pontos da província. Idem, ibidem. p. 8. Para as subscrições pecuniárias e, sobretudo, de víveres para o abastecimento das tropas imperiais encaminhados pelos habitantes do Alto Sertão da Bahia, ver SOUZA FILHO, Argemiro Ribeiro de, 2003, op. cit.

${ }^{9}$ TAVARES, Luís Henrique Dias, 2005, op. cit. p. 220.

${ }^{10}$ Conforme observou Hendrik Kraay, os anos de 1810 a 1820 foram de expansão e de melhora de perspectivas nas carreiras dos que atuavam no exército português. Situação que, por certo, impactara a expectativa daqueles que, havendo tomado armas em devesa da Causa do Brasil, aguardavam incorporar seus nomes entre os novos integrantes do Exército nacional em formação. KRAAY, Hendrik. Race, State and Armed Forces in Independence-Era Brasil, Bahia, 1790's-1840's. Stanford: Stanford University Press, 2002. p. 52. Kátia Mattoso também havia destacado que "o Exército pesava de maneira original nas estruturas de um Estado [aqui ainda o português] que sempre manifestara, diante dos militares sentimentos ambíguos, mesclados de admiração e confiança, receio e ciúmes”. Daí porque todo o interesse dos integrantes das tropas arregimentadas para a expulsão dos portugueses em trilharem carreira nesta consagrada instituição no momento em que a nação em formação tanto dependia da capacidade de manter a ordem interna quanto da defesa de possíveis inimigos estrangeiros. MATTOSO, Kátia M. de Queirós. Bahia, século XIX: uma província no Império. Rio de Janeiro: Nova Fronteira, 1992. p. 224. 
Maria de Sá Barreto que deveria, entre outros objetivos, reiterar os "protestos de fidelidade, amor e respeito" dos habitantes da província baiana à pessoa do imperador e enaltecer "o comportamento do exército pacificador na entrada da cidade, onde se conserva[va] na melhor ordem, e disciplina, mantido o sossego público, e respeitada a propriedade individual". Os mensageiros almejavam igualmente alcançar "a devida cooperação do governo [imperial] [...] para reanimar esta grande cidade, ora carecida de tudo, perfeitamente inanida [despossuída], oferecendo a triste imagem da desolação [...]”. ${ }^{11}$

Depois de informado, o então ministro dos Negócios Estrangeiros do império, o baiano José Joaquim Carneiro de Campos, em 23 de julho, comunicou à Junta da Bahia que

[...] S. M. o Imperador, possuído da maior satisfação e regozijo, por ver aquela capital já livre da opressão [...], congratula-se sobremaneira por este feliz acontecimento [...]. Devendo contudo o mesmo governo entrar agora nos mais sérios cuidados, para restabelecer a dita cidade [...], por em atividade o comércio, e proteger todos os ramos da pública administração; o mesmo Augusto Senhor manda [...] recomendar ao dito governo a maior circunspecção na escolha das providências, que exigir o estado da província, empregando todo o seu zelo e energia em promover a segurança, e propriedade dos seus habitantes. ${ }^{12}$

De fato, a administração da província exigia medidas acertadas de modo a favorecer o equilibro político-social e recuperar as atividades econômicas. Neste último campo o quadro era desolador posto que a Fazenda Pública não conseguira nem, ao menos, quitar os débitos já existentes junto ao Exército. Garantida indistintamente a segurança individual e a propriedade de quem permaneceu na província, Lima e Silva - após ter sido autorizado pelo governo da Bahia - nomeou, em 4 de julho, uma comissão composta pelos negociantes Francisco José Lisboa, Manoel da Silva Friandes, Antonio Vaz de Carvalho, Thomé Affonso de Moura, Domingos José de Almeida Lima, Manoel José de Magalhães e Joaquim José de Oliveira para que "agenciassem um empréstimo" de 444:457\$867 (Quatrocentos e Quarenta e Quatro Contos, Quatrocentos e Cinquenta e Sete Mil e Oitocentos e Sessenta e Sete Réis), correspondente ao citado débito. Ao questionar acerca das "condições sobre as quais deve[ria] ser feito o empréstimo", o comandante-em-chefe sugeriu a comissão que:

\section{[...] consultem Vossas Senhorias suas próprias consciências, e}

\footnotetext{
${ }^{11}$ Apud SILVA, Ignácio Accioli de Cerqueira, op. cit., v. 4. p. 68-69 (grifos meus).

${ }^{12}$ Idem, ibidem. p. 73-74 (grifos meus).
} 
perguntando-lhes sobre a origem dos males, que tem sofrido esta província, e extraordinária despesa, que tem sido obrigada a fazer, ditem Vossas Senhorias a si mesmos as óbvias condições.

O empréstimo deve ser verificado até o último do corrente mês, visto que em o $1^{\circ}$ dia de Agosto aparecerão, no caso negativo, medidas para uma contribuição de guerra, que, a não ser exigida por mim, talvez que não seja bastante o todo o rigor da disciplina para conter soldados ofendidos, e não pagos de seus arriscados trabalhos, de mais de um ano de campanha. $^{13}$

Como já se disse, os pagamentos em atraso aos soldados representava apenas uma parte do problema, já que as incertezas sobre quem seria efetivado ou não no Exército trazia grande apreensão. Motivado por esta hesitação, e especialmente devido a singular circunstância dos escravos alistados no Batalhão dos Libertos, em 16 de julho, Lima e Silva escreveu ao governo central nestes termos: "Nada me parece mais duro do que reverter ao cativeiro homens que expuseram suas vidas, derramaram o sangue, pugnaram pela liberdade e tanto se distinguiram com as armas nas mãos em defesa da Pátria, da Independência e do Império". ${ }^{14}$ Por isso, o futuro visconde de Majé intercedia pela liberdade dos escravos soldados, desde que os legítimos senhores fossem indenizados pelo erário público.

Essa intercessão, contudo, não foi bastante para aplacar as graves tensões manifestas no seio da tropa. Tanto assim, que era possível identificar rusgas internas entre o Batalhão do Imperador - cujo contingente arrostava a exclusividade no pertencimento ao Exército imperial, visto ser o único corpo militar que do Rio de Janeiro saiu organizado como uma expedição vinculada ao Exército - e os demais batalhões, especialmente os arregimentados em territórios baianos. Do mesmo modo, é preciso não perder de vista que, embora a Independência política já estivesse declarada e a Assembleia Constituinte do Brasil encontrasse reunida desde 3 de maio, havia ainda diferenças importantes entre a corte fluminense e as províncias geograficamente mais afastadas deste centro de poder, como era o caso da Bahia. Neste sentido, Luís Henrique Dias Tavares foi ao cerne da questão quando observou a ocorrência de um "desencontro entre a realidade regional e a abstração nacional". Para este historiador, o que existia nos anos imediatos à ruptura

\footnotetext{
${ }^{13}$ Idem, ibidem. p. 74-75.

14 Apud TAVARES, Luís Henrique Dias, 2005, p. 224. Hendrik Kraay concluiu que o recrutamento dos escravos durante a guerra da Independência ameaçou sensivelmente o status dos soldados como homens livres não negros. Situação que pressionara as autoridades que, na primeira oportunidade, instaram pela redefinição da linha de status racialmente absorvida entre o escravo e o soldado, expurgando os pretos e os ex-escravos da guarnição como, de fato, verificou-se durante o rescaldo do Levante dos Periquitos (1824), reconhecido como a primeira sublevação militar importante ocorrida em Salvador no pós-Independência. KRAAY, Hendrik, 2002. Cap. 5.
} 
política com Portugal, ou mais precisamente entre os anos de 1822 e 1825, "era a realidade regional. A Bahia era a Bahia, Pernambuco era Pernambuco. O Rio de Janeiro era o Rio de Janeiro distante e até rival". ${ }^{15}$ Há, de fato, evidências que confirmam esta assertiva pois, como explicar o recorrente interesse da província baiana em enviar representantes à corte fluminense senão a necessidade de vencer os cipoais que embaraçavam a harmônica integração política das duas mais importantes províncias do recém-criado Império do Brasil? Assim, em 16 de julho, foi a vez da Câmara de Salvador encaminhar a d. Pedro I uma pequena delegação composta pelo então deputado constituinte Miguel Calmon du Pin e Almeida e pelo coronel e comendador Bento de Araújo Lopes Villas-Boas, cujo objetivo constituía em assegurar "os devidos cumprimentos à S. M. o Imperador Constitucional [...], tributando ao mesmo Augusto Senhor os nossos votos de fidelidade, homenagem, obediência e amor; e acrescentado os nossos respeitosos agradecimentos pelas sábias, enérgicas e decisivas medidas, que tomou para libertar esta parte do Império", lembrando ainda de reiterar que da Bahia não se devia esperar "avessas intenções". ${ }^{16}$

Todo esse repertório invocativo de obediências e fidelidades podia também explicitar a apreensão entre os habitantes das regiões mais distantes do centro do Império quando às possíveis medidas advindas do Rio de Janeiro em detrimento às autonomias políticas locais que o constitucionalismo fizera emergir, mormente quando se esfumava a ameaça provocada por um disciplinado inimigo como fora as tropas lusitanas. E, ao que tudo indica, a prevenção não fora descabida, tanto é que depois de inteirar-se das circunstâncias nas quais o general Pierre Labatut fora destituído do comando das armas, d. Pedro I tratou logo de nomear seu substituto. Mecanismo que tende a evidenciar a pouca consideração do monarca quanto aos esforços dos baianos em procurarem, dentre os oficiais do Exército, aquele que demonstrasse estar mais organicamente vinculado aos desígnios do paço de São Cristovão, como era o caso do futuro visconde de Majé, abrindo

15 TAVARES, Luís Henrique Dias. Da Sedição de 1798 à Revolta de 1824 na Bahia: Estudos sobre a Sedição de 12 de agosto de 1798, o soldado Luís Gonzaga das Virgens, os escravos no 1798, Francisco Agostinho Gomes, Cipriano Barata e Levante dos Periquitos. Salvador: Edufba; São Paulo: Unesp, 2003. p. 189.

${ }^{16}$ Ata da Câmara de 22 de julho de 1823, de caráter solene, da aclamação de D. Pedro como Imperador Constitucional do Brasil, seguida da assinatura de [aproximadamente 2.000] autoridades e pessoas outras presentes. Documentos da Municipalidade de Salvador relacionados com a Independência do Brasil. 18211823. Salvador: Prefeitura Municipal/Departamento de Cultura da SMEC, 1972. p 103-122. Essa iniciativa de encaminhar representantes camarários para selarem contratos políticos com o imperante não se constituiu uma prerrogativa exclusiva dos habitantes da capital e Recôncavo baiano, visto que a prática fora comum também aos moradores das vilas interioranas, a exemplo do verificado em Caetité e Rio de Contas. SOUZA FILHO, Argemiro Ribeiro de, op. cit. Cap. 2. Ademais, esse tipo de contato tornara-se usual em diferentes províncias, como constatou SOUZA, Iara Lis Franco Schiavinatto Carvalho. Pátria coroada: o Brasil como corpo político autônomo - 1780-1831. São Paulo: UNESP, 1999. p. 148 e segs. 
mão, portanto, de possuírem um filho da terra no mais eminente posto militar da província. Malgrado o empenho, em fins de julho, apresentou-se na capital da Bahia o brigadeiro José Manoel de Moraes como legítimo representante da vontade imperial para assunção no governo das armas da província. Diante disso, em $1^{\circ}$ de agosto, Lima e Silva apresentou seu pedido de exoneração. Entretanto, parte significativa da tropa logo reagiu esboçando resistência à determinação governamental, haja vista um pedido para que Lima e Silva reconsiderasse a transferência de comando. Caso contrário, haveria descontentamento no interior da tropa já bastante afetada quanto a seu futuro no Exército. Uma vez mais a Bahia indicava ao Rio de Janeiro que o pacto político-administrativo a ser acertado passava por negociações que considerassem os interesses de certa autonomia provincial. Após a desistência do brigadeiro Morais do posto designado pelo imperador, Lima e Silva reassumiu o comando das armas, conquanto estivesse consciente de que toda expedição que representasse apenas o Exército arregimentado na corte fluminense era muito mal aceita pelos demais contingentes militares. ${ }^{17}$

Os princípios de agitação não se dissipavam ante o receio da tropa em ver-se a qualquer momento desempregada do Exército, especialmente porque na Fazenda Pública da Bahia não havia recursos financeiros para assegurar os pagamentos futuros de tantos oficiais e soldados reunidos na cidade de Salvador, que havia se declarado livre do inimigo e, portanto, vivendo em tempo de paz. Conforme sugere Accioli, o coronel Felisberto Gomes Caldeira soube aproveitar do irrequieto clima de insatisfação na tropa para forçar a retirada de todo o Batalhão do Imperador em direção à corte, prevendo, com isso, um novo pedido de exoneração de Lima e Silva, para, via seu prestígio entre os militares da Bahia, assegurar a sua nomeação no comando das armas. O certo é que, nos meses seguintes, os soldados da província e a expedição fluminense tiveram alguns encontros violentos. Situação que somente se agravou quando, em 29 de setembro, o futuro visconde de Majé proclamou ser o seu dever de "comandante-em-chefe prevenir o inteiro esgotamento dos cofres" públicos da Bahia, posto que, ainda sem ordens imperiais, decidisse que, dali a dois dias, o Exército fosse

considerado em estado de paz, e em consequência extintas as repartições, e todos os empregos, puramente estabelecido para o serviço da campanha, passando todos os senhores oficiais a perceber seus vencimentos pela tabela dos soldos e gratificações designados por lei para o tempo de paz, e as praças de pret o soldo da tarifa da corte do Rio de Janeiro. [...] excetuadas desta ordem as tropas auxiliadoras das outras

\footnotetext{
${ }^{17}$ SILVA, Ignácio Accioli de Cerqueira, op. cit., v. 4. p. 81-84.
} 
províncias, as quais têm direito aos seus vencimentos ordinários de campanha, até se achem recolhidas às suas respectivas províncias ou quartéis. $^{18}$

O adensamento das tensões sociopolíticas e militares em território baiano já era motivo de preocupações entre as principais autoridades da província. Tanto assim que, em 8 de setembro, o governo provisório adotou uma espécie de código negro, focado em rígidas providências policiais, objetivando coibir os roubos, insultos e assassinatos que novamente se tornaram frequentes na capital e cuja responsabilidade podia, "em grande parte", ser imputada aos "paisanos que tiveram baixa dos corpos de $1^{\text {a }}$ linha, principalmente os pretos, que agregam a si os cativos para cometerem tão horríveis atentados". ${ }^{19}$ Estudioso da instituição militar na Bahia do período, Hendrik Kraay assinalou, com razão, que a milícia expunha a extensão na qual a Independência constituía uma revolução social, visto que os patriotas pretos e pardos desempenharam um papel preponderante, propiciando que os senhores de engenho baianos se decidissem mais facilmente pela Independência. Devido ao número considerável, milicianos pretos, crioulos e pardos ameaçavam dominar a milícia pós-guerra de Salvador, o que espicaçava aos homens de Estado ter sempre em vistas a adoção de medidas que reduzissem as suas influências nos rumos políticos e militares da província. Daí todo o esforço para as desmobilizações e ou transferências interprovincial de alguns contingentes ao longo de todo o Primeiro Reinado. ${ }^{20}$

Com a redução do efetivo militar, a difusa perspectiva de uma revolução republicana voltava à baila, conquanto um dos objetivos desde projeto parecia, uma vez

\footnotetext{
${ }^{18}$ Apud SILVA, Ignácio Accioli de Cerqueira, op. cit., v. 4. p. 94. Só mais tarde foi conhecida na Bahia as portarias imperiais, de 30 de julho e 2 de agosto, determinando a desmobilização do Exército Pacificador, via autorização para que as tropas de Pernambuco e Paraíba retornassem às suas províncias de origem, bem como realizasse o transporte ao Rio de Janeiro, tanto do $4^{\circ}$ regimento de milícias formado pelos fluminenses, quanto do "batalhão ou corpo dos pretos organizados na Bahia". Nestes termos, na Bahia permanecia tão somente o contingente necessário à sua guarnição. SILVA, Ignácio Accioli de Cerqueira, op. cit., v. 4. p. 93, nota 45.

${ }^{19}$ Sobre a íntegra dessa medida coercitiva, ver Idem, ibidem. p. 94-95, nota 46.

${ }^{20}$ KRAAY, Hendrik, 2002, op. cit. Cap. 5. Estudos recentes têm demonstrado como o recrutamento forçado, mormente durante a Guerra da Cisplatina (1825-1828), foi o método privilegiado com o qual as autoridades conseguiram afastar da província baiana expressiva quantidade de homens livres pobres (cuja maioria, sem dúvida, era composta por negros, crioulos e pardos) que se revelavam inclinados a participar do mundo da política em um período no qual os rumos do Estado e da nação brasileiros ainda não estavam consolidados. Neste sentido, ver JUNQUEIRA, Lucas de Faria. A Bahia e o Prata no Primeiro Reinado: Comércio, recrutamento e Guerra Cisplatina (1822-1831). Dissertação (Mestrado em História) - Faculdade de Filosofia e Ciências Humanas - Universidade Federal da Bahia, Salvador, 2005. Para os conflitos envolvendo o recrutamento forçado no Alto Sertão da Bahia nestes anos, ver também SOUZA FILHO, Argemiro Ribeiro de, op. cit. Cap. 3. Algumas vilas sertanejas, como Rio de Contas e Caetité, também receberam parte destes contingentes militares saídos da capital baiana em 1822 e ali permanecendo até o ano de 1831. Idem, ibidem, loc cit.
} 
mais, servir à instrumentalização dos descontentamentos como recurso favorável à definitiva queda de José Joaquim de Lima e Silva do comando das armas. Segundo as suas próprias palavras dirigidas à Junta Provisória da Bahia em 9 de outubro, os expedientes utilizados dando conta da instalação da República apareciam via propagação dos

boatos que corriam a respeito de planos, que se pretendiam, pôr em prática no dia 12 do corrente [outubro], depondo certos empregados; [...] e eu [seria] um dos contemplados nesta deposição; [...] olhando [...] o exemplo de algumas províncias, que inadmitem Governadores de armas [...] era conveniente que eu mesmo me demitisse [...], visto que minha autoridade não tinha o apoio preciso [...]. Novamente repito a Vossas Excelências queiram aceitar a demissão do referido comando, [...] queiram quanto antes, facilitar-me embarcações para me transportar para a corte do Rio de Janeiro [...]. ${ }^{21}$

O governo provincial aquiesceu a solicitação e no mesmo dia o coronel Felisberto Gomes Caldeira recebeu autorização para assumir o comando das armas, com o que se dissiparam os boatos sobre o decantado regime republicano. Em seguida, as expedições militares do Rio de Janeiro, de Pernambuco e da Paraíba retornaram aos seus locais de origem. No entanto, é importante realçar que por essa época já havia alguma articulação em curso na corte fluminense com o intuito de assegurar a nomeação de Gomes Caldeira para o disputado comando, considerando que, em 12 de outubro, o imperador mandou expedir a carta patente que o designava "Governador das Armas da província da Bahia". Sendo assim, fica mais uma vez evidenciado a capacidade de negociação que a classe dirigente da antiga sede dos vice-reis assegurava junto ao governo monárquico, o qual já possuía elementos suficientes para perceber que vantagens haveria de granjear com o expediente da política de concessões mútuas, em se tratando de uma província muito ciosa da sua posição no tabuleiro imperial, como era a situação, naquele período, da Bahia. $^{22}$

Por outro lado, convém considerar que a política da transigência esteve distante de se apresentar como avanço contínuo conduzido pela classe senhorial baiana e a corte fluminense. Isto porque havia a concorrência interprovincial que se revelava igualmente interessada em influir na estruturação do Estado. Ainda no plano das contradições internas centrado no foco de análise para a Bahia, percebe-se com certa facilidade como os diversos setores sociais impactados direta ou indiretamente pela Guerra de Independência

\footnotetext{
${ }^{21}$ Apud SILVA, Ignácio Accioli de Cerqueira, op. cit., v. 4. p. 96-97.

${ }^{22}$ Registro da Patente do Governador das Armas desta Província Felisberto Gomes Cadeira. Documentos da Municipalidade de Salvador relacionados com a Independência do Brasil. 1821-1823, op. cit. p. 135-136.
} 
revelavam igualmente dispostos a ser contemplados no pacto político-social que definiria os rumos do Estado e nação brasileiros. Neste sentido, a dispensa de um amplo contingente de ex-combatentes que abruptamente viram-se privados dos seus vencimentos e de integrarem o aparato do Estado teve o efeito de avivar o denso clima de insegurança que não apenas atingia a cidade de Salvador, mas se espalhava pelas estradas e vilas do interior da província. Realmente, a historiografia aponta que no pós-Independência a Bahia apresentava-se como uma das regiões mais agitadas do recém-fundado Império Constitucional do Brasil, sendo frequentes os distúrbios entre lusitanos e filhos da terra, bem como os saques, os motins militares e as revoltas de escravos. ${ }^{23}$ De resto, o período fora de muita expectativa, pois a materialização do ideário de Independência e de pertencimento a uma nação monárquica constitucional, cujo arcabouço institucional ainda estava em vias de construção, descortinava um tempo novo, gerando um horizonte de expectativa quanto ao futuro de uma coletividade que se afirmava enquanto brasileira, cuja tomada de consciência sob as novas formas de reiteração da vida sociopolítica não surgira instantaneamente.

\subsection{Felisberto Caldeira Brant: visão política em período de crise}

Natural do arraial de São Sebastião, nas proximidades da vila de Mariana-Minas Gerais, mas radicado na Bahia desde 1801, onde conservava parte da sua parentela e considerável influência político-econômica, o marechal Felisberto Caldeira Brant ${ }^{24}$ quanto esteve na capital britânica (1821-1823) restabeleceu correspondência com o baiano José

\footnotetext{
${ }^{23}$ Sobre o assunto, ver, dentre outros, SILVA, Daniel Afonso da. Histórias de Bahia. Histórias de Brasil. Apontamentos para o estudo da crise política do Primeiro Reinado na Bahia (1828-1831). Dissertação (Mestrado em História) - Universidade de São Paulo, São Paulo, 2007; KRAAY, Hendrik, 2002, op. cit; REIS, João José. A elite baiana face os movimentos sociais, Bahia: 1824-1840. Revista de História, São Paulo, Out-dezembro, v. 54, n. 108, ano XXVII, p. 341-384, 1976 e MORTON, F. W. O. The Consertative Revolution of Independence: Economy, society and politics in Bahia (1790-1840). Thesis Submitted to the Board of the Faculty of Modern History in Partial Fulfilment of the Requirements for the Degres of D. Phil, University of Oxford, Oxford, 1974.

${ }^{24}$ Após ter recebido educação militar em Portugal e servido no Exército da metrópole, o tenente-coronel Caldeira Brant chegara à capital da Bahia, onde passou a residir. Ao contrair relações matrimoniais com Ana Constança Guilhermina de Castro Cardoso dos Santos (1783-1817) - filha do português europeu e comerciante matriculado Antônio Cardoso dos Santos -, conseguira permissão real para se engajar nos ramos de comércio, decidido que estava em aprimorar a tradição familiar da sua esposa. Combinando, portanto, as carreiras militar e empresarial, Caldeira Brant foi nomeado Inspetor General da Tropa em 1811. No campo da administração colonial, ocupou a cadeira de vereador na Câmara Municipal de Salvador em três ocasiões diferentes durante os anos de 1806 e 1813. Nos anos de 1819 a 1821, o futuro marquês era reconhecido por possuir interesses econômicos bem alicerçados em uma rede comercial com sócios em Portugal, Inglaterra, França, Hamburgo e Moçambique; era também proprietário de engenhos de açúcar e fazendas de algodão nas capitanias da Bahia e de Sergipe e, por fim, o responsável pelo lucrativo ramo de suprimentos para o Exército e de navegação a vapor na Baía de Todos os Santos. Cf. KRAAY, Hendrik, 2002, op. cit. p. 40-42.
} 
Egídio Álvares de Almeida, barão de Santo Amaro que, como assinalado, gozava de muito prestígio político na corte fluminense. Tratando o destinatário de "meu companheiro e amigo", a motivação deste contato, ocorrido ainda em princípios de 1822 , devia-se à difusão das notícias de que d. Pedro não regressaria à Europa como determinava as Cortes de Lisboa, razão pela qual o missivista buscava os préstimos do barão para levar ao conhecimento do príncipe a sua "obediência e profundo reconhecimento". Previdente, o futuro marquês de Barbacena fez-se logo "ocupado com dois objetos [...] da maior importância para o Governo de S. A. R.", quais sejam: a tomada de "um empréstimo" para livrar o Banco do Brasil "das dificuldades que experimenta" e a aquisição de duas embarcações a vapor capazes de vencer "a comunicação do Amazonas com o Rio de Janeiro unicamente a 15 dias de viagem". Entusiasta das inovações tecnológicas forjadas na Oficina do Mundo, assim como da necessidade de preservar a integridade do território do Brasil em um contexto de elevadas incertezas políticas, Caldeira Brant não deixou de acrescentar que: “[...] Nada pode melhor fazer a união do que uma rápida comunicação entre as Províncias, e a tal perfeição tem chegado ultimamente os Barcos de [sic] Vapor, que fixando o prazo de 15 dias, ficam livres mais de cinco para as escalas de Maranhão, Pernambuco e Bahia”, regiões que, incontestavelmente, constituíam verdadeiros focos de resistência dos portugueses europeus. ${ }^{25}$

Em $1^{\circ}$ de maio desse ano, o futuro marquês de Barbacena travou contato com o ministro José Bonifácio, escrevendo-lhe nos seguintes termos: “[...] dirijo-me a Vossa Excelência nesta particular carta com a fraqueza, e confiança que deve haver entre Pessoas nascidas no mesmo País, talvez ainda com relações de parentesco, e expostas ambas ao castigo e ludibrio dos Portugueses senão conseguir-nos elevar a nossa Pátria à Independência, e prosperidade para que Deus a destinou [...]". ${ }^{26} \mathrm{O}$ intuito de Caldeira Brant era convencer ao interlocutor da sua capacidade em levar adiante uma série de contatos condignos de um abalizado representante para assuntos diplomáticos, ainda que somente extraoficialmente pudesse assim se considerar, seja porque não possuía

\footnotetext{
${ }^{25}$ Cartas sobre a Independência, de 1822 a 1823. In: ARQUIVO NACIONAL, op. cit. p. 240. O conjunto de correspondência de Caldeira Brant em Londres foi analisado por LIMA, Manuel de Oliveira, op. cit. Cap. 20. Sobre a rede de contatos que atesta a influência de Caldeira Brant na Bahia antes mesmo da chegada da família real na América, ver KRAAY, Hendrik, 2002, op. cit. Cap. 2 e SOUSA, Maria Aparecida Silva de, op. cit. Cap. 2.

${ }^{26}$ Cartas sobre a Independência, de 1822 a 1823. In: ARQUIVO NACIONAL, op. cit. p. 241. De fato, há indícios de que os Andrada e Caldeira Brant poderiam ter relações de parentesco, ainda que fossem indiretas. $\mathrm{Na}$ Guerra de Independência na Bahia lutara, no posto de alferes, um sobrinho do futuro marquês de Barbacena de nome José Bonifácio Caldeira de Andrada. A esse respeito, ver BANDEIRA, Luiz Alberto Moniz, op. cit. p. 454, nota 112.
} 
autorização oficial para agir como tal, seja ainda pela simples razão de que, até aquele momento, a conformação política existente era a do Reino do Brasil integrante da nação portuguesa.

Militar experiente, grande proprietário e homem bem relacionado com ingleses e franceses, Caldeira Brant deixou, no entanto, a modéstia de lado para, em linguagem direta, demonstrar ao novo chefe suas habilidades:

[...] Será difícil achar quem como eu dedicando-se inteiramente ao Brasil, tenha ao mesmo tempo na Europa tantas relações e amizades com Militares, Banqueiros e Maquinistas que são as três classes de que ora precisamos. Venha uma ou mais Pessoas completamente autorizadas por S. A. R. para legalizar os ajustes de qualquer gênero, que eu um Agente subalterno farei contente todos os sacrifícios e esforços para bem desempenhar as ordens de Vossa Excelência [...]. ${ }^{27}$

Em seguida, cuidou de fornecer dados sobre os bastidores da política em Portugal, os quais revelam o quanto esteve informado sobre as perspectivas que importantes partes do território do Brasil poderiam, já em princípios de 1822, ter de enfrentar:

[...] Não é possível que Vossa Excelência saiba até aonde chega o ódio e sinistras intenções das Cortes de Lisboa sobre o Brasil. Quiseram primeiramente ceder aos Franceses a margem esquerda do Amazonas a troco de Tropas, que fossem subjugar o Brasil, mas o Governo Francês repeliu toda e qualquer negociação. Quiseram depois renovar o tratado de comércio com Inglaterra, garantindo [a] esta o atual sistema do Governo de Portugal, e todas as alterações que ele fizesse no Brasil, mas esta proposição ainda foi repelida com mais desprezo que fizera o Governo Francês. Projetou agora abandonar Montevidéu, ocupar Santa Catarina, revolucionar as Províncias do Norte, e chegam mesmo à execração de lembrar o levantamento dos negros.

Em um contexto no qual as opções políticas ainda se pautavam pela conciliação dos interesses divergentes entre Portugal e Brasil visando assegurar a "integridade da monarquia" portuguesa, o futuro marquês de Barbacena apresentou as linhas gerais de um projeto político que, por coincidência ou não, fora parcialmente seguido pelo governo de $d$. Pedro, a partir de 3 de junho, quando da convocação da Assembleia Constituinte para o Brasil. Dizia, então, o missivista:

[...] Não proponho a declaração de Independência ou Aclamação de S. A. R. em Soberano do Brasil, porque esta medida tornando-o desobediente a

\footnotetext{
${ }^{27}$ Cartas sobre a Independência, de 1822 a 1823. In: ARQUIVO NACIONAL, op. cit. p. 241.
} 
Seu Pai, e privando-o da herança de Portugal tão bem embaraçaria o reconhecimento dos Soberanos d'Europa, que estimando, e aprovando todos a resolução de ficar S. A. R. no Brasil, não podem fazer ato algum público contra os princípios de Legitimidade garantidos pela Santa Aliança, quando aliás em Regente do Brasil, e fazendo o que adiante lembro, será reconhecido por todos os Soberanos, terá a glória de fundar um novo Império, e mudará a triste sorte de seu Pai, e de Portugal. São pois as medidas seguintes: $1^{\circ}$ Chamar Deputados de todas as Províncias do Brasil. $2^{\circ}$ Declarar a El-Rei em estado de cocção violenta, e as Cortes em manifesta usurpação de Direitos: em conseqüência do que torna-se nulo quanto elas hão feito, e cessa toda a comunicação política, posto que a comercial continue, até que outras Cortes legitimamente eleitas respondam S. M. I. no gozo pleno da autoridade que lhe compete como Rei Constitucional da Nação Portuguesa. $3^{\circ}$ Abrir correspondência com os Soberanos da Europa durante o cativeiro de seu Pai. $4^{\circ}$ Mandar retirar os Deputados do Brasil que se acham em Lisboa, porque vencidos sempre em votos dão involuntariamente sanção às injustiças decretadas contra sua Pátria. $5^{\circ}$ Declarar que não podendo a administração de um Reino tão considerável ser regulada em outro infinitamente pequeno, e distante, haverá no Brasil um Parlamento sem que por isso se entenda desunida a Monarquia. N B [note bem]. O exemplo da Suécia, e Noruega, da Grã-Bretanha, e Hanover provam completamente estes princípios. Logo que a maior parte dos Deputados estiver reunida será o primeiro objeto de seus trabalhos a Constituição do Brasil. Nada há mais fácil, a Constituição Americana com palavras, e fórmulas Monárquicas é quanto nos convém. Quando o Rei estiver em Portugal o futuro sucessor estará no Brasil, e vice-versa. As relações comerciais serão estipuladas por uma conversão. Estas medidas [...] merecerão a aprovação das Nações Civilizadas (exceto Espanha) e o nosso Querido Príncipe sendo agora Regente em breve tempo se assentará em um dos maiores Tronos do Universo [...]. ${ }^{28}$

Diligente com a defesa da unidade territorial do Brasil, Caldeira Brant procurava meios para alocar mercenários dissimulados ou não de colonos para ingressarem nas tropas em defesa das províncias, especialmente as do Sul. Nesse sentido, aduzia:

[...] os Irlandeses são os mais próprios, quer se considere sua atual desgraça, e por consequência necessidade de aceitar ajustes e condições moderadas, quer se considere sua constante ocupação de plantar trigo e salgar carnes, que são as mais próprias para quem deve habitar o Rio Grande. Eles podem ser juntos como lavradores por um determinado tempo a fim do Governo Inglês consentir no seu embarque, e os Oficiais encarregados do alistamento como Administradores. Na França também se pode usar do mesmo meio e na Suíça não é preciso disfarce, mas a despesa será muito maior [...]. Militares mui célebres de mar, e terra ambicionam o serviço de S. A. R., e frequentam a minha casa tanto em

\footnotetext{
${ }^{28}$ Idem, ibidem. Loc. cit (grifos meus).
} 


\section{Londres como em Paris [...]. ${ }^{29}$}

Novamente fornecia informações sobre os planos concertados no Velho Mundo sobre como enfraquecer as relações entre a regência de $d$. Pedro e as províncias mais distantes da corte fluminense. Em razão disso, alertava: “[...] deve Portugal ocupar Santa Catarina e reconhecer todas as formas de Governo que se estabelecerem no Brasil uma vez que por tratados segurem as vantagens do Comércio. Não escondem a intenção de converter as Províncias do Norte em diferentes Repúblicas, dizendo que a sua comunicação é muito difícil com o Rio de Janeiro, e que só precisam de relações Europeias [...]". ${ }^{30}$ Entretanto, não escapava à argúcia do futuro marquês a precária situação econômica do Reino europeu, tanto assim que nesta mesma correspondência ressaltava: "[...] Pode ser que por falta de meios, e não de vontade, todos os projetos hostis das Cortes de Lisboa contra o Brasil senão realizem, mas a prudência aconselha que em tempo se tomem as medidas necessárias". ${ }^{31}$

Em maio de 1823, esse agente voltava a insistir junto a José Bonifácio sobre o projeto dos "regeneradores de Portugal" consistir na convenção de "cada Província [do Brasil] em uma República", conquanto também admitisse que essas perspectivas já se mostrassem "fora de tempo" com a afirmação da monarquia constitucional. Mas, pelo sim pelo não, Caldeira Brant enviou outra correspondência, "secreta e particular", fornecendo dados sobre a suspeição de que o padre Diogo Antônio Feijó (1784-1843) e Antônio Manuel da Silva Bueno, ambos ex-deputados paulistas nas Cortes, seguiram para a cidade de Santos, em São Paulo, na expectativa de difundirem a "propaganda" republicana, "logo

\footnotetext{
${ }^{29}$ Idem, ibidem. p. 244. Em 3 de junho, Caldeira Brant informaria ao ministro Bonifácio que devido à fome e à miséria que a época se verificava na Irlanda, o momento tornava-se bastante propício para exportar parte de sua gente para o Rio Grande, São Paulo e Minas Gerais utilizando-os, por um período pré-estipulado, como servos por dívidas. Nestes termos, resumiu a questão: "Não é preciso fazer-lhes o menor partido, basta adiantar a despesa da passagem que pode ser a $40 \$ 000$ por cabeça, cuja despesa os Irlandeses se obrigam a pagar com o seu trabalho ficando entretanto hipotecados como servos ad glibam addîtcti". Cartas sobre a Independência, de 1822 a 1823. In: ARQUIVO NACIONAL, op. cit. p. 257.

${ }^{30}$ Idem, ibidem. p. 244. Observe-se, uma vez mais, que o recurso sugerido pelo futuro marquês de Barbacena para resolução da comunicação entre as províncias passava pela compra de barcos a vapor aptos a vencer os ventos leste, os quais favoreciam mais facilmente o contato marítimo de algumas regiões do Brasil, como as províncias do Pará e Maranhão, com Portugal do que com o Rio de Janeiro. Embora fosse preciso adiantar em quatros meses a encomenda para que a máquina e embarcação estivessem montadas, Caldeira Brant sabia que: "[...] se pretende vender um que custará 22.000 libras esterlinas, e magnífico, vou ver o que posso fazer e como os meus fundos bastantemente diminuídos por tantas perdas e injustiças não bastam para tamanha empresa, recorrerei a cooperação de amigos, entre os quais se presta de bom grado o Comendador José Marcelino Gonçalves, Brasileiro de cujos sentimentos patrióticos tenho repetidas provas". Cartas sobre a Independência, de 1822 a 1823. In: ARQUIVO NACIONAL, op. cit. p. 244. Sobre as dificuldades que possuíam os habitantes do Pará e Maranhão para estabelecer contato com a corte do Rio de Janeiro devido às dificuldades de navegação, ver MACHADO, André Roberto de A. A quebra da mola real das sociedades: a crise política do Antigo Regime português na Província do Grão-Pará (1821-1825). Tese (Doutorado em História Social) - Universidade de São Paulo, São Paulo, 2006.

${ }^{31}$ Cartas sobre a Independência, de 1822 a 1823. In: ARQUIVO NACIONAL, op. cit. p. 243.
} 
que a revolução" estivesse "segura em Pernambuco". No que diz respeito a esta última província, afiançava que os ex-deputados baianos José Lino Coutinho e Cipriano José Barata de Almeida encontravam-se entre os principais arquitetos da República. ${ }^{32}$

Por tudo isso, era solicitado que o ministério declarasse guerra aos opositores ao governo, porque "sem força não se vencem os inimigos", ressaltando ainda que: "Força sem dinheiro é coisa impossível e que, portanto, seja o cuidado do Excelentíssimo Presidente do Tesouro haver dinheiro, dinheiro e mais dinheiro. Os recursos do Império são tamanhos que nenhuma dívida pode assustar, uma vez que se vença o inimigo, que nos ameaça, quero dizer, a terrível democracia". ${ }^{33}$ Em seguida, anunciava que chegaria às mãos de José Bonifácio “cartas originais de Lino para Lisboa com o tu da revolução Francesa, e o Vos de 1817. Então saberá mais alguma coisa de que me abstenho, porque [...] não

${ }^{32}$ Carta a José Bonifácio de Andrada e Silva, n. 34, em 11 de maio de 1823. Cartas sobre a Independência, de 1822 a 1823. In: ARQUIVO NACIONAL, op. cit. p. 330-331 e Carta a José Bonifácio de Andrada e Silva, secreta e particular (em 11 de maio de 1823!). Idem, ibidem. p. 331-332. É preciso, uma vez mais, ressaltar que os indivíduos citados fizeram parte dos deputados que fugiram juntos de Portugal para não assinar a Constituição elaborada pelas Cortes Gerais e, em Falmouth, deram publicação ao manifesto sobre as razões encontradas para abandonar Lisboa. JANCSÓ, István; PIMENTA, João Paulo Garrido. Peças de um mosaico (ou apontamentos para o estudo da emergência da identidade nacional brasileira). In: MOTA, Carlos G. (Org.). Viagem Incompleta. A experiência brasileira (1500-2000). Formação: histórias. São Paulo: Senac, 2000. p. 129. Em princípios de junho, todavia, Caldeira Brant transmitiu novas notícias ao ministro do Império dando conta da "partida de Bueno e Feijó para o Rio", sendo, portanto, "desmentidas as asserções de[les] seguirem em direitura para Santos". Carta a José Bonifácio de Andrada e Silva, n. 36, em $1^{\circ}$ de junho de 1823. Idem, ibidem. p. 334.

${ }^{33}$ Carta a José Bonifácio de Andrada e Silva, n. 34, em 11 de maio de 1823. Idem, ibidem. p. 331. Proprietário opulento e notabilizado pela extração de riqueza em diferentes empreendimentos, Caldeira Brant dera mais de uma mostra do quanto lhe comprazia o substantivo dinheiro. Em correspondência ao ministro da Fazenda, Martim Francisco de Andrada (1775-1844), em fins outubro de 1822, registrou que "[...] grandes fins não se conseguem sem grandes meios, e estes consistem em três coisas, como dizia um ministro de Luís 14, dinheiro, dinheiro e mais dinheiro. Nunca houve tanta oportunidade para haver dinheiro, a moderado prêmio, como agora, mas se Vossa Excelência não aproveitar o momento, pode sobrevir qualquer guerra na Europa, ou falta de pagamento da parte dos Novos Governos da América Espanhola, e então as condições se tornarão pesadas". Compreende-se como um dos motivos que levara o futuro Barbacena a sentir-se desprestigiado na função de Encarregado de Negócios - nomeação essa que, conforme dizia, não poderia "lisonjear a nenhum Marechal de Campo" - ter sido justamente os emolumentos recebidos, pois "viver[ia] em Londres com seis mil cruzados [mensais], sem casa para morar, sem Secretário etc.”. Em contraste àquela situação: "O Encarregado de Negócios do pobre e velho Portugal tem 12 mil cruzados de ordenado, casas para morar, 2 oficiais de Secretaria, 1 correio etc., tudo pago pelo Tesouro, e menos do que isso não pode ser". Varnhagen também salientou que, seguida a dissolução da Assembleia Constituinte (novembro de 1823), Felisberto Caldeira Brant fora sondado para assumir a pasta da Guerra, mas declinou o convite, posto que, já naquele momento e ainda segundo o autor, ele vislumbrasse o ministério da Fazenda. Ambição esta que, como se verá adiante, concretizar-se-ia em dois momentos distintos, visto que ocuparia a pasta durante dois meses, entre novembro de 1825 e janeiro de 1826, e novamente por um período de oito meses, entre 4 de dezembro de 1829 e princípios de outubro de 1830. Para as duas primeiras citações acima, ver respectivamente: Carta a José Bonifácio de Andrada e Silva, secretíssima e particular, em 7 de novembro de 1822. Idem, ibidem. p. 273-275 e Carta a Martim Francisco de Andrada, em 31 de outubro de 1822. Idem, ibidem. p. 275-277. Cf. VARNHAGEN, Francisco Adolfo de. História da Independência do Brasil: Até ao reconhecimento pela antiga metrópole compreendendo, separadamente, a dos sucessos ocorridos em algumas províncias até essa data. Anotada pelo Barão de Rio Branco e por uma comissão do Instituto Histórico e Geográfico Brasileiro. 4. ed. Revisada e anotada pelo Prof. Helio Vianna. São Paulo: Melhoramentos, 1957. p. 24. p. 228. Para as passagens de Caldeira Brant pelo ministério da Fazenda, ver CALOGERAS, João Pandiá. O marquês de Barbacena. 2. ed. São Paulo: Companhia Editora Nacional, 1936. p. 121. 
desejo falar em Lino e Barata porque são meus inimigos". ${ }^{34}$ Neste caso, pode-se admitir que as hostilidades envolvendo o ex-inspetor das tropas e as citadas lideranças baianas já deviam ser manifestas desde, pelo menos, a Revolução Constitucionalista, em fevereiro de 1821, quando se evidenciaram as graves divergências ante os primeiros rumos daquele processo.

Dentre as várias correspondências daquele que viria a ser o primeiro Encarregado dos Negócios do Brasil na capital britânica, destacam-se algumas em virtude da maneira como foram interpretados os acontecimentos e as conjunturas envolvendo as dissensões políticas entre as Cortes lisboeta e o território do Brasil, ou ainda pelas $\mathrm{p}$

roposições que indicam ter sido apreciadas e, parcialmente, absorvidas pelo governo de d. Pedro. ${ }^{35}$ Em um desses escritos, por exemplo, - provavelmente um anexo das cartas datadas de maio de 1822 -, endereçados ao ministro José Bonifácio, sugeriu-se a negociação para que o almirante inglês Lord Alexandre Thomas John Cochrane, conde de Dundonald e futuro marquês do Maranhão (1775-1860), um dos responsáveis pela então recente Independência do Chile, viesse "com seus navios servir a S. A. R. [...] a tempo de embaraçar a entrada da expedição da Bahia", bloqueando a entrada do porto marítimo da cidade de Salvador, com a vantagem de que "só o seu nome levaria o susto e temor aos nossos inimigos". Para demonstrar a razoabilidade do "convite a Cochrane", Caldeira Brant observava: “[...] Ouço que [o almirante inglês] é muito amigo de dinheiro, que está em discórdia com [José de] San Martin e tudo isso não concorrerá para aceitar o partido?”. Igualmente conhecedor de que o Brasil não possuía boas fragatas de guerra e que a grande maioria do contingente de marinheiros era formada por portugueses europeus, dispostos em simples navios mercantes armados com canhões, o plano do missivista consistia em intercalar esses homens e suas embarcações com as dos mercenários de modo a dar a impressão de se tratar de uma "Esquadra segura". Dando azo à sua astúcia, o futuro marquês arrematara: "[...] Para dizer a verdade, nunca teria completa confiança em marinheiros Portugueses, mas uma vez misturados com Ingleses ou Americanos tudo iria perfeitamente". 36

\footnotetext{
${ }^{34}$ Carta a José Bonifácio de Andrada e Silva, secreta e particular (11 de maio de 1823!). Cartas sobre a Independência, de 1822 a 1823. In: ARQUIVO NACIONAL, op. cit. p. 331.

${ }^{35}$ Caldeira Brant só pôde efetivamente apresentar-se como Encarregado dos Negócios do Brasil a partir de 24 de outubro, quando, finalmente, recebeu um ofício do ministro José Bonifácio, de 12 de agosto, "acompanhado a Credencial de Encarregado de Negócios junto ao Governo Britânico, e as Instruções que [...] devem guiar no desempenho desta comissão”. Idem, ibidem. p. 273.

${ }^{36}$ Idem, ibidem. p. 247.
} 
Hoje, de fato, se conhece que essa tática foi seguida, posto que o Lord Cochrane foi contratado pelo ministério dos Andrada para coadjuvar na "pacificação" das províncias do Norte, tendo como pagamento as presas de guerra capturadas, como era praxe entre os mercenários do período. ${ }^{37}$ Assim, em 25 de abril de 1823, uma divisão naval composta por doze embarcações e comandada pelo mencionado almirante alcançou a Baía de Todos os Santos, o que facilitou o estreitamento do cerco à cidade de Salvador e a consequente expulsão das tropas portuguesas da Bahia. ${ }^{38}$ As incursões de Cochrane foram também decisivas para garantir o bloqueio aos portos pernambucanos, quando o então imperador $\mathrm{d}$. Pedro I enfrentou a mais séria rebelião do seu governo, a Confederação do Equador em 1824. No mesmo ano, a esquadra do futuro marquês do Maranhão, que tinha a seu serviço outros mercenários como o subcomandante inglês John Pascoe Grenfell, atuou na província do Pará com o objetivo de controlar a região, conseguida à custa de muita violência sobre a população local. ${ }^{39}$

Sequioso por se fazer representante de considerável envergadura nos assuntos políticos do Brasil, Caldeira Brant tomou a iniciativa de entreter comunicações com

\footnotetext{
${ }^{37}$ Luís Henrique Dias Tavares aceitou como sendo de Caldeira Brant a sugestão da contratação de Lord Cochrane. TAVARES, Luís Henrique Dias. História da Bahia. 10. ed. rev. e aum. São Paulo: UNESP; Salvador: Edufba, 2001, p. 241. Entretanto, a originalidade dessa ideia parece não ter sido do futuro marquês de Barbacena, visto que no contexto das dissensões manifestas nas Cortes de Lisboa, o Correio Braziliense, n. 165, de fevereiro de 1822, publicado na capital britânica por Hipólito José da Costa Pereira Furtado de Mendonça (1774-1823), alertasse: "Está claro, que procurando Portugal este auxílio da França [para subordinar as províncias da América portuguesa], e ficando a Inglaterra pelo menos neutral, a desejar o Brasil a sua independência, procuraria também auxílio externo, e o acharia muito pronto nas esquadras de Lord Cochrane, e nos exércitos de Columbia, e mais América Espanhola, que se acham agora desocupados, visto que a Espanha já não tem meios de continuar a guerra, e vai reconhecer a independência de suas excolônias". Linha a linha, todas essas possibilidades foram levadas ao conhecimento do Secretário dos Negócios Estrangeiros por Caldeira Brant, conquanto ele não revelasse a fonte. Considere-se também que leitores do periódico baiano $O$ Constitucional conheciam-nas, uma vez que o referido texto de Hipólito fora publicado na província em maio de 1822. Ou seja, nos mesmos dias em que Caldeira Brant anunciava suas proposições ao Rio de Janeiro. $O$ Constitucional, n. 18, segunda-feira, 20 de maio de 1822. Tipografia da Viúva Serva e Carvalho, 1821-1822. Exemplar da coleção do IEB/USP.

${ }^{38}$ Governo Provisório - Registros de correspondência expedida pelo Conselho Interino de Governo. APEB. Seção de Arquivo Colonial e Provincial. Data: 29/04/1823. Maço: 638.

${ }^{39}$ O massacre ocorrido no Bringue Diligente ou "Bringue Palhaço", como ficou conhecido, é, fora de dúvida, um dos episódios mais violentos da Guerra de Independência no Brasil. O caso ocorreu nas proximidades da cidade de Belém. Em outubro de 1823, depois dos integrantes da Junta Governativa do Pará terem solicitado que a divisão marítima comandada por Grenfell evacuasse a cadeia da capital, com a justificativa de que havia pouca segurança e superlotação de presos, 256 indivíduos, entre soldados desertores e civis (a maioria filhos da terra), foram transferidos para o porão da embarcação, cuja escotilha foi quase toda fechada. Padecendo de falta de ar e sob um calor exasperador, não demorou tempo para que um tumulto ocorresse entre aqueles que procuravam ter acesso a pequenas porções de água lançadas no porão pela guarnição vigilante. Sob alegação de que fora preciso usar de alguma violência para controlar os presos, os vigias desferiram disparos de armas de fogo contra os mesmos. Pouco depois, lançou-se sobre seus corpos uma significativa quantidade de cal virgem e a escotilha foi vedada. No dia seguinte, apenas um sobrevivente foi encontrado pelos agentes do imperador. Em estudo recente - de onde estes dados foram extraídos -, André Machado renovou a análise sobre os conflitos políticos nas províncias do Pará e Maranhão durante a Independência. MACHADO, André Roberto de A., op. cit. p. 207.
} 
influentes lideranças, a exemplo dos membros da segunda Junta Governativa de Salvador depois de transcorrida a sua posse, em razão das eleições de fevereiro de $1822 .{ }^{40} \mathrm{O}$ redator de Semanário Cívico havia constatado que dentre os indivíduos que exerceram papel preponderante no fortalecimento dos vínculos da Bahia com a corte fluminense no período da Independência encontrava-se o futuro marquês de Barbacena. Conforme registrara, as cartas que o agente remetera de Londres a algumas lideranças da província conseguiram exaltar "as fofas cabeças dos aristocratas baianos, que todos contavam já serem titulares e membros da Câmara Alta do nascente império brasílico". ${ }^{41}$ De fato, verifica-se que em uma dessas correspondências, datada de $1^{\circ}$ de agosto de 1822, Caldeira Brant havia contatado Francisco Vicente Vianna e Francisco Carneiro de Campos, ambos integrantes do governo da Bahia, na expectativa de estimulá-los a obedecer as resoluções advindas do Rio de Janeiro. Para tanto, anunciava:

A Pátria exige o grande sacrifício de sofrer ainda a ditadura de Madeira, [...] enquanto chegam os socorros mandados pelo Incomparável Príncipe em desempenho do Título que tomou a 13 de Maio = Protetor Constitucional do Brasil = Vossas Excelências e seus Colegas terão sem dúvida combinado como e aonde se reunirão quando aparecer um bloqueio e se verificar o desembarque de Tropas [...], e escusado é lembrar que devem deixar ordens para se fecharem a Alfândega, Junta da Fazenda etc., convocando os chefes destas repartições para junto de si [...]. Não sabendo se a malvada intriga terá mais ou menos desunido os Membros da Junta, tomei o expediente de escrever aos dois, que particularmente me honram com suas amizades, esperando que façam o discreto uso que as circunstâncias exigirem. ${ }^{42}$

Atento ao que se passava no Norte do Brasil, Caldeira Brant também dedicou atenção especial a Pernambuco. Por isso, colocava-se à disposição do presidente da Junta, Gervásio Pires Ferreira, para conseguir, por exemplo, melhorias portuárias e navegações na província. $^{43}$ Entretanto, esse expediente era apenas um pretexto para o arguto correspondente poder em seguida avançar sobre o seu real objetivo: intimidar o presidente

\footnotetext{
${ }^{40}$ Governadores da Bahia, em 4 de maio de 1822. Cartas sobre a Independência, de 1822 a 1823. In: ARQUIVO NACIONAL, op. cit. p. 246. Nessa oportunidade, Caldeira Brant, que se afastara da Bahia em condições adversas, diria a esses correspondentes assegurar "a estimação e confiança de seus Compatriotas [...] foi e será sempre o objeto de meus trabalhos e posto que perseguido de calúnias e ingratidão nem por isso mudo sentimentos". Idem, ibidem, loc cit.

41 Semanário Cívico, n. 89, de 13 de novembro de 1822. Apud SILVA, Maria Beatriz Nizza da. Semanário Cívico: Bahia, 1821-1823. Salvador: Edufba, 2008. p. 137.

${ }^{42}$ Carta a Francisco Vicente Vianna e Francisco Carneiro de Campos, em $1^{\circ}$ de agosto de 1822. Cartas sobre a Independência, de 1822 a 1823. In: ARQUIVO NACIONAL, op. cit. p. 262-263.

${ }^{43}$ Cartas a Gervásio Pires Ferreira, em 2 de fevereiro e 11 de junho de 1822. Idem, ibidem. p. 239 e 254.
} 
e ex-preso político de 1817 para acatar, em definitivo, as diretrizes da corte fluminense.

Por essa razão, diria:

[...] Como porém vagamente se anuncia que Pernambuco não quer unirse as Províncias do Sul, e é já público que o Governo de Lisboa animado pela humilhante conquista da Bahia pretende mandar uma expedição de 6.000 homens para aquela Província, julgo de minha obrigação dar parte a Vossa Excelência da referida expedição [...], pois decerto o primeiro ataque será sobre Pernambuco, e a cabeça que mais se deseja cortar é a de Vossa Excelência. ${ }^{44}$

Sabedor do quanto Pernambuco esforçava-se para, exercer in limite o direito de autonomia administrativa em âmbito local, Caldeira Brant tratou de produzir um discurso concorde à lógica contratualista no qual procurava convencer que o governo do Brasil já admitia a legitimidade localista, via a confederação das suas províncias. Daí concluir que:

[...] garantida a integridade do Brasil, que todos desejam ver dividido, não pode haver a menor dúvida que cada uma das Províncias há de ter sua particular administração, e que os homens de saber e virtude acharão campo vasto para promover a felicidade da Pátria. Neste momento de crise o que sobretudo convém é a estreita união com o Rio, e Vossa Excelência bem conhece quanto embaraça aos Portugueses estar o Herdeiro da Coroa à testa da confederação Brasileira.

[...] A revolução de $1817 \mathrm{fez}$ persuadir a toda gente que os Pernambucanos desejam fazer de sua Província uma República independente, e supondo isso possível que consideração política teria no Mundo? Para os ignorantes não há razão que baste, mas Vossa Excelência de certo conhece as vantagens de um Estado que abrange do Prata ao Amazonas, e por isso espero em Deus que por todos os meios a seu alcance se esforçará por conservar a integridade do Brasil. ${ }^{45}$

Para além da perspectiva republicana que, como se vê, era latente e voltaria a se afirmar com a Confederação do Equador (1824), importa aqui observar que a prerrogativa de maior autonomia na gestão das questões locais, traduzidas na defesa da confederação, aparecia como questão cara à matriz de pensamento liberal nos primeiros anos do Brasil imperial. Tanto assim, que o direito de autogoverno nas questões regionais se constituiria

\footnotetext{
${ }^{44}$ Carta a Gervásio Pires Ferreira, em 11 de junho de 1822. Idem, ibidem. p. 254.

45 Idem, ibidem. Loc. cit. Para as disputas envolvendo a exploração da prerrogativa autonomista em Pernambuco de 1822, ver BERNARDES, Denis Antônio de Mendonça. O patriotismo constitucional: Pernambuco, 1820-1822. São Paulo: Hucitec: Fapesp. Recife: Ed. Universitária da UFPE, 2006. Especialmente o cap. 7. De maneira inovadora, Evaldo Cabral de Mello compreendeu todo o processo político desencadeado em Pernambuco de 1817 a 1824 como substrato de um mesmo ciclo revolucionário que, acima de tudo, propugnava o direito contratualista das relações entre as partes e o centro do império (primeiro a cargo da Coroa portuguesa e depois sob a direção do governo de d. Pedro), razão pela qual defendeu que o processo de Independência tenha durado sete anos para se afirmar em Pernambuco (18171824). MELLO, Evaldo Cabral de. A outra Independência: o federalismo pernambucano de 1817 a 1824 . São Paulo: Ed. 34, 2004.
} 
matéria recorrente nas falas de deputados e senadores até, pelo menos, a instituição das assembleias provinciais por meio do Ato Adicional de 1834. Ao deter-se na análise desse importante processo, Andréa Slemian observou que, se por um lado, a matriz de pensamento conservador defendesse a prerrogativa da Câmara dos Deputados e do Senado como instituições primordiais "no direcionamento dos caminhos a serem trilhados pelo Império, onde estariam reunidos os mais capazes de legislar não para uma, mas para todas as Províncias". ${ }^{46}$ Por outro, estavam os defensores da não ingerência do legislativo nas decisões dos Conselhos provinciais, uma vez que a própria Carta outorgada em 1824 admitia que cada província formulasse as suas leis. ${ }^{47}$

Em 17 de junho de 1822, Caldeira Brant escreveria ao Secretário de Estado dos Negócios Estrangeiros do Brasil prevenindo-o acerca da turbulenta conjuntura política das províncias do Norte, com destaque para a perspectiva autonomista na administração local defendida justamente pelo presidente da Junta de Pernambuco. $\mathrm{Na}$ oportunidade, cuidou também de alertar sobre os juízos que se diziam que os filhos da terra reservavam ao príncipe e ao ministro José Bonifácio:

[...] Se tivéssemos a combater meramente as Cortes, fácil seria a vitória mas temos a vencer dificuldades assustadoras para o Norte do Brasil. Como explicar as frases de que usou Gervásio Pires para Lisboa em consequências do Decreto de 16 de Fevereiro [pelo qual d. Pedro havia convocado o Conselho de procuradores das províncias do Brasil]? Eis aqui mais um testemunho em prova das suspeitas do Ministério Inglês sobre os democratas do Brasil. A intriga trabalha por todos os modos, para o Príncipe escreve-se que não se fie nos Brasileiros que o não amam, que fazem dele escudo para vencer os Portugueses, e que uma vez seguros o rejeitarão porque são todos Democratas: para os Brasileiros escreve-se Vossa Excelência é um Aristocrata que quer restabelecer o despotismo etc. conseguida a divisão entre os Brasileiros qualquer força Portuguesa irá subjugando as Cidades Marítimas. ${ }^{48}$

\footnotetext{
${ }^{46}$ SLEMIAN, Andréa. Sob o império das leis: Constituição e unidade nacional na formação do Brasil (18221834). São Paulo: Hucitec; Fapesp, 2009. Cap. 2. A citação encontra-se à página 171. Para a historiadora, a singularidade dos problemas observados nos primeiros anos do Império do Brasil impõe "a dificuldade em trabalhar com o binômio centralização/descentralização como categoria explicativa para se entender a criação constitucional imperial, por mais que os coevos constantemente o evocassem como poderosa arma no debate político. Por várias razões, é óbvio que a criação das Assembleias provinciais instituiu definitivamente, na ordem constitucional, um espaço de jurisdição local, com Executivo e Legislativo próprios. Entretanto, mantinha-se também sua vinculação, nos mais variados níveis, com a corte, haja vista a pretensão da unidade de todos os territórios americanos anteriormente portugueses". Idem, ibidem. p. 300. No que concerne à capacidade das "elites provinciais" em negociar os seus espaços de atuação no Brasil imperial, ver DOLHNIKOFF, Miriam, 2005, op. cit.

${ }^{47}$ SLEMIAN, Andréa, 2009, op. cit. Cap. 2.

${ }^{48}$ Carta a José Bonifácio de Andrada e Silva, em 17 de junho de 1822. Cartas sobre a Independência, de 1822 a 1823. In: ARQUIVO NACIONAL, op. cit. p. 255-256. Três dias após ter deixado a presidência da Junta Governativa de Pernambuco, deposta em 22 de setembro de 1822, Gervásio Pires Ferreira, em viagem para o
} 
Ainda no tempo do governo regencial, Caldeira Brant percebera que se d. Pedro desejasse a mediação da Inglaterra contra as medidas ostensivas das Cortes de Lisboa, essa intercessão, em boa medida, estaria na dependência de como a eliminação do tráfico de escravo africano seria tratada no Brasil. Após o parlamento inglês abolir esse comércio transatlântico para as suas colônias caribenhas em 1807, os impérios de Portugal e Espanha tornaram-se alvos privilegiados da pressão diplomática para proceder do mesmo modo. Não por acaso, a política antiescravista da Grã-Bretanha em relação aos domínios portugueses manifestou-se ainda no ano de 1810, quando o príncipe regente d. João firmou os primeiros acordos diplomáticos com os agentes britânicos que estabeleciam as restrições iniciais ao comércio de africanos. Em razão disso, o Tratado de Aliança e Comércio (1810) reduzia o tráfico da escravatura às possessões de Portugal em África. Em 1815, durante o Congresso de Viena, nova ofensiva antitráfico adquiriu concretude já que os plenipotenciários portugueses foram persuadidos a ratificar o tratado que proibiu a transação comercial de escravos ao norte da linha do Equador. Sempre à espreita de alcançar a completa cessação do tráfico de africanos, a diplomacia inglesa acresceu seu sucesso, em 1817, quando conseguiu que a Coroa portuguesa acatasse a convenção adicional ao tratado anterior que estipulava a inspeção recíproca dos navios, bem como a instituição de tribunais mistos habilitados a deliberarem sobre as apreensões ocorridas nas costas da África ou nas zonas marítimas. ${ }^{49}$ Atento a tudo isso, o futuro Barbacena admitia que:

uma das primeiras aberturas com o Ministro Britânico será sobre a abolição do comércio da escravatura em 4 anos. Esta abolição sendo necessária para a segurança e prosperidade do Brasil pode felizmente ser feita com vantagens imensas. Não se explica a razão suficiente do espantoso crescimento da Filantrópica sociedade para a abolição do

Rio de Janeiro a bordo do paquete inglês Manchester, foi identificado no porto da capital baiana e retirado da embarcação com o consentimento do Cônsul britânico G. Pinel. Após alguns dias de prisão em Salvador, o ex-presidente foi enviado a Lisboa. Devido às condições em que ocorrera a prisão, Caldeira Brant protestou firmemente junto ao ministro inglês Jorge Canning, por considerar o desembarque de Gervásio um atentado aos que estavam "protegidos pela Bandeira Inglesa". Alguns meses depois, o seu pleito mostrou-se exitoso, uma vez que o governo britânico interveio e, em 4 de março de 1823, o encarregado dos Negócios do Brasil em Londres pôde, finalmente, comunicar a José Bonifácio que: "[...] A propósito de Gervásio, a favor de quem, e por cumprir ordens de Vossa Excelência, solicitei a intervenção Inglesa, avisam-me de Lisboa que estava a ponto de ser solto". Contornado então a ingerência dos defensores de Lisboa sobre os súditos do Brasil, Caldeira Brant não perdia a oportunidade de, nestes termos, alertar: "Muito temo que a volta deste homem seja perniciosa ao Brasil. Desde que deixou Pernambuco, acabaram-se as desordens, e a mais perfeita união, e obediência foi estabelecida. Será portanto prudente evitar que vá a Pernambuco”. De fato, em 5 de junho Gervásio já se encontrava no Rio de Janeiro. Carta a José Bonifácio de Andrada e Silva, em 4 de maio de 1823. Cartas sobre a Independência, de 1822 a 1823. In: ARQUIVO NACIONAL, op. cit. p. 311-312.

${ }^{49}$ RODRIGUES, Jaime. O infame Comércio: proposta e experiências no final do tráfico de africanos para o Brasil (1800-1850). Campinas, SP: Unicamp/Cecult, 2000. 
comércio de escravatura. É raro o Inglês de algum merecimento que não seja membro e o respeitável Presidente [William] Wilbeforce [17591833] com os pés para a cova será o melhor Aliado do Brasil [...]. Por ele, e pela sociedade, tenho quase certeza que o Governo Inglês fará $400 \$ £$ [Quatrocentros Libras Esterlinas] a título de indenização, fixado o prazo da abolição, e talvez facilite a admissão do nosso açúcar o que presentemente solicitam com muito empenho todos os Refinadores de Londres. Qualquer destas concessões por uma coisa que devemos fazer de graça seria bastante para despertar a atenção do Ministério, mas acresce outra vantagem moral que considero da maior importância, e vem a ser recair sobre os Ingleses o odioso desta medida visto que a generalidade os Brasileiros está persuadida que o comércio de escravatura não deve acabar. ${ }^{50}$

Perspicaz e de visão utilitarista, o futuro marquês sugeria aproveitar-se do crescente poder antiescravista britânico a favor da eliminação do tráfico de forma que as autoridades do Brasil não se tornassem as responsáveis por uma medida que, de antemão todos sabiam, desagradaria a prestigiosa classe senhorial e os demais segmentos sociais comprometidos com o trabalho escravo. Em novembro de 1822, quando Londres já conhecia a emancipação política do Brasil, Caldeira Brant informou ao ministro inglês George Canning (1770-1827) que o reconhecimento da Independência por parte da GrãBretanha deveria produzir "no espírito dos Brasilienses mudanças de transcendente vantagem", inclusive porque a conjuntura revelava-se bastante propícia à completa cessação do tráfico africano, especialmente em um contexto geopolítico travejado no qual as ameaças de novas investidas armadas de Portugal pendiam no horizonte. ${ }^{51}$ Diante das

\footnotetext{
${ }^{50}$ Carta a José Bonifácio de Andrada e Silva, em 6 de maio de 1822. Cartas sobre a Independência, de 1822 a 1823. In: ARQUIVO NACIONAL, op. cit. p. 246.

${ }^{51}$ Carta a José Bonifácio de Andrada e Silva, em 14 de novembro de 1822. Idem, ibidem. p. $280-281$. Informado sobre as exigências do governo inglês relativas ao fim do tráfico africano, o ministro José Bonifácio remetera ao Encarregado dos Negócios em Londres as instruções de como regular suas melindrosas negociações. Sob essa perspectiva, admitia-se que o eixo norteador de qualquer convenção deveria prever a disposição do Império do Brasil em colaborar para a abolição gradual da escravatura. Dessa maneira, Caldeira Brant deveria afiançar: "que s. m. i. está intimamente convencido não só da injustiça de semelhante comércio, mas ainda da perniciosa influência que ele tem sobre a civilização e prosperidade do Império; mas não podendo o mesmo augusto senhor tomar medidas algumas decisivas a este respeito, estando a Assembleia Legislativa próxima a instalar-se, manda-me que assegure a vossa senhoria para conhecimento do governo e s. m. i. que os seus sentimentos são os mais liberais possíveis, e que nutre as mais fundadas esperanças dos sentimentos que igualmente animam a Assembleia; de maneira que se conseguirá a abolição gradual do tráfico de escravos, sendo um tempo razoável, e proporcionando à falta de braços ora existente neste país; e principalmente se a Grã-Bretanha, mostrando-se interessada na referida abolição, cooperar para ele sem a menor quebra e sem ofensa da honra, dignidade e interesses legítimos do Império". Carta de José Bonifácio de Andrada e Silva, em 24 de fevereiro de 1823, a Felisberto Caldeira Brant. In: SILVA, José Bonifácio de Andrada e. José Bonifácio de Andrada e Silva. Organização e introdução de Jorge Caldeira. São Paulo: Ed. 34, 2002. p. 172-173. Pouco tempo depois, Canning tivera acesso à correspondência sobre o posicionamento de d. Pedro I relativo à "abolição gradual", expressão que lhe pareceu "mui vaga e suscetível de longa duração", contudo, mereceu ainda a sua atenção as demais considerações do imperador condenando o comércio escravista e, ao final das contas, "mostrou-se mui contente e fez os maiores elogios a Pessoa de S. M. I. [...], chegou a dizer, além de muitas coisas boas, que [o
} 
novidades advindas da América, Caldeira Brant sabia que o momento era o de barganhar, por isso solicitava "atenção" ao ministro "em favor" da sua "Pátria", a "Nação Brasiliense", que se não pudesse contar com o reconhecimento da Grã-Bretanha, certamente, ver-se-ia obrigada a procurar apoio junto aos Estados Unidos, cujo êxito dependeria tão somente em elevá-los às condições de parceiros preferenciais para as futuras trocas comerciais.

Em outra época fora tal abolição impossível, mas hoje será fácil com ligeiras modificações. Nem o Príncipe Regente, nem o Ministério, nem os Brasilienses instruídos desejam de modo algum a continuação daquele infame tráfico da espécie humana, mas a massa geral do povo resiste com obstinação. A obstinação parece algum tanto diminuída depois que as Cortes nos ameaçaram com a sublevação dos pretos, e é de crer, que seja extinta por motivos de gratidão à Sua Majestade Britânica se [a] Nação Brasiliense conseguir imediatamente o reconhecimento de Sua Independência. Que esta se há de conseguir, mais dia menos dia, qualquer que seja a oposição do Velho Portugal, ou Neutralidade das outras Nações, ninguém há que o duvide, assim como de que o pronto reconhecimento adiantando a prosperidade do Brasil, e do Comércio Inglês, também concorrerá para o restabelecimento da ordem em Portugal. Além de todas estas razões, que me parecem bastante para decidir o Gabinete Britânico a favor de S. A. R. ocorre mais que vendose o Príncipe Regente abandonado pelo Melhor, e mais Antigo Aliado da Casa de Bragança, e ao mesmo tempo atacado por Tropas, Esquadras e Emissários dos facciosos de Lisboa, ver-se-á na desagradável, porém forçosa necessidade de lançar-se nos braços dos Estados Unidos da América, que decerto não duvidarão reconhecer a Independência, e mesmo dar algum socorro com a só condição de vantagens comerciais, que talvez no futuro poderão complicar as relações mercantes existentes entre o Brasil e a Grã-Bretanha. ${ }^{52}$

Habilidoso em manejar as conveniências, Caldeira Brant, mesmo sem possuir a "credencial competente" com os "plenos poderes para assinar qualquer convenção" em nome do recém-aclamado imperador d. Pedro, ganharia a simpatia do também perspicaz Canning. No entanto, a celeridade dos acontecimentos verificados no Rio de Janeiro no segundo semestre de 1822 causaram, no primeiro momento, uma impressão de manifesta “volubilidade de princípios" sobre o governo de d. Pedro, alicerçada, entre outras coisas, pela efêmera queda do ministério dos Andrada, em 28 de outubro, e a reintegração dos seus principais integrantes dois dias depois. Segundo o registro do futuro marquês de

Império do Brasil] seria sempre um Bom Aliado contra as repúblicas daquela parte do mundo". Carta a José Bonifácio de Andrada e Silva, em 10 de maio de 1823. Cartas sobre a Independência, de 1822 a 1823. In: ARQUIVO NACIONAL, op. cit. p. 327-328.

${ }^{52}$ Carta a José Bonifácio de Andrada e Silva, em 14 de novembro de 1822. Idem, ibidem. p. 280-281. 
Barbacena, a espessa atmosfera de incertezas quanto aos acontecimentos no Brasil levou o ministro inglês a exigir "a maior circunspeção e cautela em tudo que se houvesse de tratar". Situação que, segundo Caldeira Brant, motivou reclamação por parte do representante do gabinete de St. James (Canning):

Em Agosto declara o Príncipe Regente que não aceitará o Título de Soberano durante a vida e cativeiro de Seu Augusto Pai e, em Outubro, Aclama-se Imperador: Em Setembro, estabelece a Bandeira do Império e a 30 de Outubro ainda tremulava em todas as Fortalezas a Bandeira Portuguesa: finalmente reputo os antigos tratados extintos, e Nomeando um Ministro [Caldeira Brant] para reclamar o reconhecimento e fazer novas convenções e tratados, não recebe este Ministro Plenos Poderes para coisa alguma! Isto não se entende, e portanto o Ministério Britânico usará da descrição que lhe convém, e com muito gosto aproveitará a primeira oportunidade que se oferecer de estreitar sem comprometimento as suas relações com o Brasil. ${ }^{53}$

De mais a mais, a impressão sobre o governo de d. Pedro impactava positivamente os gabinetes conservadores existentes na Europa, sendo que a própria Santa Aliança, como salientara Oliveira Lima, acompanhava com interesse o que ocorria no Império do Brasil, o qual apesar de ser "vazado num molde constitucional", era o único a resguardar o princípio monárquico europeu, tornando, por isso, o elo entre interesses do Velho e do Novo Mundo. ${ }^{54}$ Em razão disso, quando se divulgou a instalação de Assembleia Constitucional no Rio de Janeiro, Caldeira Brant levou ao conhecimento de José Bonifácio o que lhe dissera um eminente diplomata europeu, sem, no entanto, revelar de quem se tratasse:

O Príncipe (disse ele) tem agora bela oportunidade de dar um grande golpe e lição a Portugal. Deve apresentar uma Magna Carta, que sem ofender a essência dos Governos Monárquicos, segure em toda extensão possível os direitos e privilégios do Povo a fim de ser completamente aceita pela Assembleia, a qual longe de perder o tempo em discussões e vaidosa ostentação de eloquência, se ocupará das Leis (segundo os princípios da Carta) para o bem da administração da Justiça e Fazenda. ${ }^{55}$

Tempos depois, em meados de abril de 1823, foi a vez de Caldeira Brant reunirse com o embaixador da Áustria, cujo imperador Francisco I (1768-1835), pai de d. Leopoldina e, portanto, sogro de d. Pedro I, demonstrava alguma dificuldade em assimilar

\footnotetext{
${ }^{53}$ Carta a José Bonifácio de Andrada e Silva, n. 8, em 15 de janeiro de 1823. Idem, ibidem. p. 299.

${ }^{54}$ LIMA, Manuel de Oliveira, op. cit. p. 292.

${ }^{55}$ Carta a José Bonifácio de Andrada e Silva, em 3 de setembro de 1822. Cartas sobre a Independência, de 1822 a 1823. In: ARQUIVO NACIONAL, op. cit. p. 265.
} 
o reconhecimento político requerido pelo Brasil devido ao princípio de legitimidade, uma vez que d. Pedro adotara o título de imperador em detrimento ao de dinastia real. ${ }^{56}$ No entanto, o diplomata deu margem à compreensão de que os ingleses aproveitar-se-iam da contra-revolução que se anunciava tanto em Espanha como em Portugal para persuadir esses governos a serem os primeiros a reconhecer de direito as independências das excolônias americanas, a qual já existia de fato, assegurando, assim, alguma vantagem nas futuras relações comerciais dali por diante acordadas. Enfim, concluía o agente austríaco entendendo que esse tipo solução acabaria também por agradar a Santa Aliança, uma vez que todos conheciam a política da Inglaterra sempre disposta a lançar mãos "de boas palavras, mais ainda de "qualque douce violence" " para assegurar o fim pretendido. ${ }^{57}$

Depois da declaração da Independência e seguidas as preparações para a instalação da Assembleia Constituinte, o Encarregado dos Negócios em Londres passou a dar atenção especial aos ex-deputados que deixaram Lisboa em direção ao Brasil. Um destes contatos se deu com o já eleito deputado constituinte por Pernambuco, o padre Francisco Muniz Tavares (1793-1876). Sem se atentar, talvez propositadamente, que o interlocutor fora um dos revolucionários de 1817 e que, por isso, cumprira pena de três anos na capital baiana até 1821, Caldeira Brant dizia ter nutrido esperanças de conhecê-lo e abraçá-lo na capital britânica, quando soube da sua estada em Falmouth e, por essa razão, o escrevia. Crítico austero do liberalismo constitucional predominante nas Cortes de Lisboa, por considerá-lo excessivamente democrático, o futuro Barbacena registrara que embora não soubesse o quanto o correspondente encontrar-se-ia "contaminado das pestíferas doutrinas do Congresso Lisboense", dirigir-se-ia a ele com franca "abertura". A motivação deste contato visava apresentar concisamente algumas diretrizes à elaboração da "Constituição do Império do Brasil" concedendo amplos poderes ao imperante, daí considerar que:

\footnotetext{
${ }^{56}$ Carta a José Bonifácio de Andrada e Silva, n. 26, em 18 de abril de 1823. Idem, ibidem. p. 323. Sobre o princípio da legitimidade, o barão de Newmen, na condição de representante da Legação Austríaca, teria dito a Caldeira Brant: "Se o príncipe [houvesse tomado sobre si o atributo] de Defensor, Protetor, ou qualquer compatível com a Soberania de Seu Pai [...], estaria a Santa Aliança de acordo em reconhecer a independência do Brasil, mas reconhecer o título de Imperador, isto é, a rebelião contra Seu Pai, é incompatível com os tratados existentes". Todavia, essa dificuldade não incomodava Caldeira Brant, já que supunha ser o gabinete inglês mais maleável em aceitar a designação de imperador para d. Pedro I. E, assim, acreditava que ao assegurar o império do Brasil "a amizade da Inglaterra, quer pública, quer disfarçada, pouco nos importa o resto do mundo". Carta a José Bonifácio de Andrada e Silva, n. 22, em 3 de abril de 1823. Idem, ibidem. p. 321.

${ }^{57}$ Carta a José Bonifácio de Andrada e Silva, n. 26, em 18 de abril de 1823. Idem, ibidem. p. 323 (grifos meus). Em Londres, era dado como certo a queda dos liberais do poder em Portugal. Previsão que, como se sabe, fora confirmada pelos sucessos da Vilafrancada, nome pelo qual a insurreição liderada pelo infante d. Miguel de Bragança iniciada em Vila Franca de Xira no dia 27 de maio de 1823 veio a ser conhecida.
} 
Se tivermos de povoar um território inculto, poderia ser objeto de disputa, qual a melhor forma de Governo, mas quanto a Nossa Pátria já felizmente se decidiu ser a Monarquia temperada, sem dúvida o melhor de todos os Governos para qualquer parte do mundo, e muito principalmente para o Brasil, aonde cada indivíduo tem sido educado como um Pequeno Soberano. Chamar Rei, Imperador, Presidente, Ditador etc. ao Poder Executivo é completamente indiferente tudo está que a Constituição o torne incapaz de prejudicar a Nação! ${ }^{58}$

Nesse vezo pouco afeito à soberania popular, o Encarregado dos Negócios do Brasil despojava-se de qualquer assombro perante o ex-revolucionário pernambucano, pois quando os trabalhos da Constituinte estivessem em curso a sua recomendação era: "Nada de teorias, nada de perda de tempo". "As nações que mais figuram no Velho e Novo Mundo são incontestavelmente a Grã-Bretanha e Estados Unidos, logo aproveitando de suas respectivas Constituições aquilo que convém às nossas circunstâncias, [ao] clima e [aos] costumes desempenhará a Assembleia com facilidade e acerto quanto convém à prosperidade do Brasil". Concluíra salientando que das decisões dos deputados recémeleitos muito dependeria o "[...] Paraíso Brasiliense, uma vez que ali se encontre 'Liberdade de consciência e segurança de propriedade', e eis aqui para onde chamo a atenção de Vossa Senhoria". 59

Com efeito, ao saber da boa impressão que a instalação da Constituinte causara nos ingleses residentes no Brasil, Caldeira Brant, num rasgo de contentamento, comentou:

As cartas inglesas vindas do Rio são uníssonas em certificar que a Constituição do Império será muito semelhante à Inglesa, isto é, que S. M. I. terá o veto absoluto e o direito de convocar e dissolver o Congresso: que haverá duas Câmaras, liberdade de consciência e responsabilidade de Ministros. Ah Grande Deus, seremos tão felizes, que o delírio Peninsular não tenha a menor influência no Congresso!

Seremos, porque de tudo é capaz o Anjo Tutelar, o Imperador do Brasil;

\footnotetext{
${ }^{58}$ Carta a Francisco Muniz Tavares, em 30 de janeiro de 1823. Idem, ibidem. p. 303-304. Entretanto, o agente do Brasil recomendara também ao ministro José Bonifácio sobre a necessidade de persuadir a Europa "que a Nação Brasiliense quer[ia] um Imperador sem despotismo, assim como uma constituição sem as doutrinas democráticas, que fizeram a desgraça de Espanha e Portugal”. Carta a José Bonifácio de Andrada e Silva, n. 36, em $1^{\circ}$ de junho de 1823. Idem, ibidem. p. 333-335.

${ }^{59}$ Carta a Francisco Muniz Tavares, em 30 de janeiro de 1823. Idem, ibidem. p. 303-304. As garantias de liberdade de consciência e segurança de propriedade constituíam os princípios liberais mais apreciáveis ao Encarregado dos Negócios em Londres; tanto assim que repetiria essa fórmula a José Bonifácio, em fevereiro de 1823, posto acreditar que com direitos assegurados constitucionalmente, em breve tempo, o Brasil receberia grande quantidade de emigrantes das nações europeias. Carta a José Bonifácio de Andrada e Silva, n. 15, em 11 de fevereiro de 1823. Idem, ibidem. p. 309. Quando a Assembleia Constituinte discutiu a questão da liberdade religiosa, Caldeira Brant, que conseguira se eleger deputado pela Bahia, declarou-se a favor da tolerância religiosa. Seus princípios, nesta matéria, mantiveram-se coerentes, pois defendeu a perspectiva pragmática, utilitarista, já que continuara convencido de que somente com a liberdade de religião o Brasil atrairia colonos estrangeiros, os quais viriam a favorecer a interrupção do tráfico escravista. RODRIGUES, José Honório. A Assembleia Constituinte de 1823. Petrópolis: Ed. Vozes, 1974. P. 156.
} 
porque tudo sabe e prevê o Imortal Ministro Fundador de Nossa Independência. Aceite Vossa Excelência pois muitos e muitos parabéns por tão felizes acontecimentos em ambos os Mundos e enquanto me não é permitido beijar a Augusta Mão de S. M. I. queira Vossa Excelência, por especial mercê, apresentar os votos de muita obediência, fidelidade e gratidão à Sagrada Pessoa de S. M. e toda Imperial Família. ${ }^{60}$

Afeito ao modelo de governo aristocrático que fornecesse amplos poderes ao imperador, Caldeira Brant aqui não deixou margem à dúvida do quanto lhe aprazia a perspectiva de ser aprovado pela Assembleia Constituinte o veto absoluto e a concessão para o imperante convocar e dissolver o Congresso, o que limitava, na essência, o poder constituinte. Como não se demorou a descobrir, o futuro marquês teve que se contentar com um pouco menos, pois a Carta outorgada em 1824, ao admitir um quarto poder privativo do imperador - o Poder Moderador -, concedeu lhe o privilégio de prorrogar, adiar e dissolver a Câmara de Deputados. Ainda de acordo com artigos 64 e 65 da Carta, o chefe do executivo poderia dispor do direito ao veto "suspensivo somente", sendo que o projeto denegado seria automaticamente sancionado logo após ter sido aprovado por duas legislaturas seguintes a que tomou a iniciativa de assegurar a primeira sanção. ${ }^{61}$

De qualquer forma, Caldeira Brant teria confirmado sua predileção - como já previra, entre outros, o redator do Semanário Cívico -, por um governo monárquico constitucional alicerçado em duas casas legislativas, na qual a Câmara Baixa seria composta de deputados eletivos para mandatos com tempo de duração prefixado e a Câmara Alta, onde nobres e aristocratas com funções hereditárias tomassem assentos. Escrevendo em junho de 1823, ele estava ciente que para este plano se realizar seria preciso vencer as resistências, derrotando, sobretudo, os projetos liberais de cunho mais democrático, incluindo-se aí o de caráter federalista. Isso explica não apenas a aprovação de Caldeira Brant às perseguições políticas promovidas pelos Andrada a partir do Rio de Janeiro, mas a própria recomendação para o influente ministro não dar trégua aos adversários, pois ele era capaz de apontar outros tantos influentes indivíduos de gênios idênticos aos que caíram em desgraça ante ao jovem imperador. ${ }^{62}$

Atento também à imagem da nação brasileira que começava a ser objeto de interesse internacional, em 4 de março de 1823, registrava uma conversa que havia tido com Lord Beresford (1768-1854), na qual a influente autoridade inglesa compreendera

\footnotetext{
${ }^{60}$ Carta a José Bonifácio de Andrada e Silva, n. 40, em 18 de junho de 1823. Idem, ibidem. p. 338.

${ }^{61}$ BRASIL. Carta Constitucional (1824). Constituição Política do Império do Brazil, de 25 de março de 1824. Disponível em: < http://www.planalto.gov.br/ccivil_03/constituicao/constitui\%C3\%A7ao24.htm> Acesso em: 21 mar. 2010.

${ }^{62}$ Carta a José Bonifácio de Andrada e Silva, n. 40, em 18 de junho de 1823. Idem, ibidem. p. 338.
} 
como sendo "um fenômeno inexplicável, mas verdadeiro, que o Povo Português sempre Realista se lançara todo nos braços da mais desprezível democracia [em referência ao ideário de tipo liberal que dominou politicamente as Cortes de Lisboa] e que o Povo Brasiliense sempre propenso para Repúblicas se mostrava Realista, e mesmo um tanto ultra". ${ }^{63}$ Satisfeito com o que acabara de ouvir, esclarecia aos seus superiores no Rio de Janeiro:

Será mui útil para captar a benevolência dos Soberanos da Europa, que em todos os Gabinetes se propague a ideia de que os Brasileiros são Realistas, e muito mais útil será para a futura grandeza do Império, e nossa atual felicidade que os Brasileiros sejam de coração e alma Realistas, mas a este respeito ainda tenho minhas dúvidas. Caíram os Ledos e Clementes [Joaquim Gonçalves Ledo e José Clemente Pereira], mas outros quais tais ainda ocupam altas dignidades. A experiência do referido Ledo deve despertar em Vossa Excelência o maior cuidado e vigilância sobre os outros da mesma escola e seita. ${ }^{64}$

Curioso observar que alguns meses depois, em 2 de junho, o desembargador José Clemente Pereira chegou a Londres, onde travou contatos com o futuro marquês. Ali o súdito banido portou-se com muita humildade e soube bem exprimir um sincero desejo em poder retornar ao Império do Brasil para servir ao imperador. Deixando-se sensibilizar com aqueles contatos, Caldeira Brant se disse convencido da impossibilidade de o magistrado em questão ser um "furioso democrata", e, por isso, intercedeu para o seu breve retorno ao Rio de Janeiro: "Este homem, torno a dizer, não me parece democrata, nem de modo algum perigoso à causa do Império [...]". ${ }^{65}$ Anos mais tarde, porém, em 1830, seria o próprio marquês quem encontraria no português Clemente Pereira um "tenaz inimigo", o qual, segundo João Pandiá Calogeras, aproveitava-se das oportunidades para intrigá-lo

\footnotetext{
${ }^{63}$ Carta a José Bonifácio de Andrada e Silva, n. 17, em 4 de março de 1823. Idem, ibidem. p. 312. William Carr Beresford conhecera de perto a situação de Portugal, pois, como se sabe, assumiu o comando do Exército português, enfrentando com êxito as tropas francesas que haviam ocupado a península com a fuga dos Bragança. Junto a d. João VI, obteve amplos poderes para manter a ordem no Reino europeu, só vindo a perder espaço com o triunfo do movimento vintista que o obrigou a permanecer afastado de Portugal, sob o risco de ser preso.

${ }^{64}$ Carta a José Bonifácio de Andrada e Silva, n. 17, em 4 de março de 1823. Idem, ibidem. p. 313. Em princípios do mês anterior, Caldeira Brant já havia dirigido uma correspondência ao ministro da Fazenda do Império, Martim Francisco Ribeiro de Andrada, parabenizando-o pelo "completo triunfo" que ele e seu irmão José Bonifácio alcançaram sobre "os furiosos Democratas" em referência, dentre outros, aos maçons Joaquim Gonçalves Ledo (carioca), José Clemente Pereira (português europeu) e Domingos Alves Branco Moniz Barreto (baiano) que, na corte fluminense, disputavam os rumos políticos do recém-fundado Império do Brasil. Carta a Martim Francisco Ribeiro de Andrada, em 4 de fevereiro de 1823. Idem, ibidem. p. 307-308.

${ }^{65}$ Carta a José Bonifácio de Andrada e Silva, n. 37, em 2 de junho de 1823. Idem, ibidem. p. 335.
} 
junto ao suscetível d. Pedro I que se encontrava cada vez mais embaraçado com a crescente crise política que assolava o Primeiro Reinado. ${ }^{66}$

Por tudo que tinha observado a partir de Londres nos anos de 1823, Caldeira Brant esforçava-se para servir bem aos interesses dominantes na corte fluminense. Com destreza e desembaraço, as comissões por ele coordenadas seguiram múltiplas direções. Para além de encetar os primeiros ajustes para o reconhecimento da Independência do Brasil por parte da Grã-Bretanha, conseguira enviar às autoridades fluminenses centenas de "marinheiros", dissimulados de "cultivadores", e algumas dezenas de "oficiais" da marinha disfarçados de "feitores". Convêm ressaltar que a conjuntura para esse tipo de aliciamento de pessoal treinado na arte bélica era difícil, pois, além de a prática ser ilegal, havia a expectativa de que uma "sanguinolenta guerra" voltaria ameaçar as potências europeias, como atestavam as crescentes hostilidades entre a França e Espanha. ${ }^{67}$ Sempre à procura do lado vantajoso contido nos mais díspares eventos, o Encarregado dos Negócios em Londres compreendia a iminência de novos conflitos no Velho Mundo como positiva aos interesses do Brasil, já que Portugal ver-se-ia obrigado a concentrar esforços na defesa da integridade do seu território europeu e, com isso, as lideranças americanas ganhariam "tempo e meios de consolidar o Novo Império". ${ }^{68}$ Ademais, também mantivera contatos para a aquisição de fragatas armadas destinadas à estruturação das forças de defesa do Estado e da nação brasileiros. Registre-se ainda que, não obstante o rompimento bélico das relações do Brasil com Portugal, ao menos, uma carta lacrada vinda de Lisboa e sem constar o nome do remetente chegou às suas mãos para ser entregue a d. Pedro I, o que deve ter sido respeitado, pois a correspondência seguira para o destinatário, via o Secretário de Estado dos Negócios Estrangeiros. ${ }^{69}$

66 CALOGERAS, João Pandiá, op. cit. p. 210.

67 Havia, no entanto, diversas dificuldades a vencer, como se percebe no seu desabafo: "Se eu pudera ser indiferente à desgraça de nossa Pátria ficaria mudo e quieto até que viessem novas providências, mas é incompatível com o meu espírito semelhante procedimento e, por isso, sem apego aos restos da minha pequena fortuna mandei no dia 16 do corrente 200 cultivadores e 6 feitores com os quais desembolsei $2.960 £$ [Dois Mil e Novecentas e Sessenta Libras Esterlinas], e cuido de arranjar ainda outra remessa. Com $10.000 £$ [Dez Mil Libras Esterlinas] se arranjava quanto bastava para expulsar Madeira [de Mello], mas eu as não tenho, nem quem seja meu fiador, visto que para as Letras se negociarem é preciso a firma de algum negociante". Carta a José Marcelino Gonçalves, em 18 de fevereiro de 1823. Idem, ibidem. p. 302.

${ }^{68}$ Carta a José Bonifácio de Andrada e Silva, n. 10, em 31 de janeiro de 1823. Idem, ibidem. p. 304-305 (grifos meus).

${ }^{69}$ Carta a José Bonifácio de Andrada e Silva, n. 10, em 31 de janeiro de 1823. Cartas sobre a Independência, de 1822 a 1823. In: ARQUIVO NACIONAL, op. cit. p. 304-305. Apesar de, naquele momento, a Guerra de Independência ainda está em curso, o futuro Barbacena não se importava em entreter alguns contatos extraoficiais com Portugal. Tanto assim, que quando d. Carlota Joaquina se recusou a assinar a Constituição portuguesa que as Cortes de Lisboa terminara de elaborar, ficando, por isso, desautorizada a se afastar de seu aposento real, Caldeira Brant informou ao ministro José Bonifácio: "As Cortes de Lisboa não só privaram a S. M. do Título de Rainha, mas mesmo de Infanta de Espanha e, por isso, a tratam pela Sra. D. Carlota. Está 
Durante sua estada em Londres, Caldeira Brant já começava a colher os frutos pelos serviços prestados ao governo de d. Pedro I. Com efeito, ele fora um dos primeiros contemplados, em $1^{\circ}$ de dezembro de 1822 , com a insígnia de oficial da Imperial Ordem do Cruzeiro, cujo favorecimento atribuía à "intervenção" de José Bonifácio, a quem agradecia. ${ }^{70}$ Nesta época, o Encarregado dos Negócios já havia solicitado dispensa da missão que desempenhava na capital britânica. ${ }^{71}$ Dentre os argumentos utilizados objetivando conseguir esta remoção, estava o de não se sentir preparado para exercer bem o ofício diplomático, justificativa que não convencera muito aos seus superiores no Rio de Janeiro. $^{72}$ Então, novas súplicas seguiram, inclusive porque Caldeira Brant afiançava ter sofrido séria enfermidade durante o rigoroso inverno londrino de $1822 \mathrm{e}$, por isso, apelava até para a possibilidade de remorso que Bonifácio poderia deparar-se, visto insistir que o seu estado de saúde não permitiria passar em Londres outro inverno. Havia, por fim, a nunca sanada falta de credencial e de plenos poderes para estipular relações em nome do império do Brasil pesando fortemente no ânimo do agente que, decididamente, parecia ansiar pelo retorno à sua "Pátria". 73 Consciente de que suas solicitações anteriores referentes à exoneração não lograram sucesso, lançou mão de um recurso penetrante na expectativa de melhor efeito, visto ter empreendido uma dura declaração a José Bonifácio:

Ninguém está mais convencido dos direitos que a Pátria tem a esperar dos seus Filhos todo o gênero de sacrifícios, do que eu estou desde a idade de 20 anos, mas também estou igualmente convencido que o verdadeiro Patriota não deve encarregar-se de uma comissão para o desempenho da qual the faltam os conhecimentos e meios necessários, podendo em consequência, apesar de todo seu zelo e boa vontade, comprometer os interesses da Pátria. Nenhum homem serve para todos os Empregos. Será bem diminuto o número, se acaso existe, dos que possam emparelhar com Vossa Excelência em Ciência e Patriotismo e, contudo, não creio que apesar de tudo isso pudesse bem desempenhar as

S. M. em tal miséria que não tem [recursos financeiros] para o diário sustento. [Marino Miguel?!] Franzine solicitou por ela uma esmola [...] e nada obteve do Congresso. Muito me custa não acudir a S. M., em nome do Imperador [d. Pedro I], mas acho-me sem instruções e também sem dinheiro". Carta a José Bonifácio de Andrada e Silva, n. 18, em 6 de março de 1823. Cartas sobre a Independência, de 1822 a 1823. In: ARQUIVO NACIONAL, op. cit. p. 314.

${ }^{70}$ Carta a José Bonifácio de Andrada e Silva, n. 14, em 7 de fevereiro de 1823. Idem, ibidem. p. 309. Ver também: Relação dos despachos publicados na corte pela Secretaria de Estado dos Negócios do Império no faustíssimo dia $1^{\circ}$ de dezembro de 1822 , da sagração e coroação de S. M. Imperial. In: MORAES, Alexandre de Mello. História do Brasil-Reino e do Brasil-Império. Belo Horizonte: Itatiaia; São Paulo: Ed. Universidade de São Paulo, 1982, t. 2. p. 553-557. A referência ao nome de Caldeira Brant encontra-se à página 554.

${ }^{71}$ Carta a José Bonifácio de Andrada e Silva, em 31 de outubro de 1822. Idem, ibidem. p. 274.

${ }^{72}$ SILVA, José Bonifácio de Andrada e, 2002, op. cit. p.169-170.

${ }^{73}$ Carta a José Bonifácio de Andrada e Silva, n. 20, em 25 de março de 1823. Cartas sobre a Independência, de 1822 a 1823. In: ARQUIVO NACIONAL, op. cit. p. 318. 
funções de General em um dia de batalha.

Ora, decerto, vai menos distância de Vossa Excelência a um General do que de mim a um Diplomático, maiormente quando novos tratados e [novas] negociações de tão superior magnitude devem ser feitas [sic] entre os dois Impérios - Inglês e Brasiliense. Não é, pois, uma falsa modéstia, ou o receio de sacrificar a minha vida no próximo inverno, que me faz insistir na demissão do Emprego Diplomático, é o testemunho da minha consciência, é o meu patriotismo, que novamente me obrigam a pedir com as mãos postas e pelo intermédio de Vossa Excelência a S. M. I. a Graça de conceder-me a demissão. Quando S. M. I. a concedeu [a demissão ministerial, em 28 de outubro em 1822, cuja direção encontrava-se] Vossa Excelência, declarou o justo princípio de que nos Empregos de grande responsabilidade ninguém deve ser conservado contra vontade. Peço a aplicação deste princípio, e conto com o benigno deferimento. ${ }^{74}$

Caldeira Brant recebeu ainda na capital britânica os ex-deputados da Bahia nas Cortes de Lisboa, Pedro Rodrigues Bandeira, Alexandre Gomes Ferrão Castelo Branco e Domingos Borges de Barros. Convencidos da importância do Rio de Janeiro nos rumos do Império, os dois primeiros desejavam partir para ali imediatamente antes de retornar às suas províncias, enquanto o último expressava a intenção em permanecer por mais quatro meses em Londres, sendo um dos nomes recomendados por Caldeira Brant para ocupar o posto diplomático em seu lugar. ${ }^{75}$

Sem possuir maiores informações sobre o avolumar das divergências entre a atuação dos Andrada no interior da Assembleia Constituinte e a vontade de d. Pedro I que, conforme se verificava, não admitia contrariedades, ${ }^{76}$ Caldeira Brant aplicava-se para afinar o discurso concorde aos interesses dominantes no Rio de Janeiro. Numa nova correspondência, "Secretíssima e particular", enviada a José Bonifácio, ficam evidentes as dissensões entre os diferentes projetos do governo aristocrático, posto que o interesse

\footnotetext{
${ }^{74}$ Carta a José Bonifácio de Andrada e Silva, n. 30, em 6 de maio de 1823. Idem, ibidem. p. 318. Certamente, Caldeira Brant não desejava relembrar que à frente da força militar realista na Bahia, em 10 de fevereiro de 1821, ele havia, em poucas horas, sido batido pelos revolucionários. Ademais, ninguém poderia prever que no comando geral do Exército do Brasil, durante a Guerra da Cisplatina, seus homens perderiam a batalha do Passo do Rosário, ocorrida em 27 de fevereiro de 1827, a qual se revelaria a mais importante de um intricado conflito que, ao fim e ao cabo, selou as ambições do Império brasileiro na região platina. Para uma análise bem documentada das elogiáveis funções desempenhadas pelos soldados oriundos, sobretudo, das províncias da Bahia e de Pernambuco, cujos contingentes conformaram a "mordente infantaria imperial, em que predominava a negrada nortista". Apud JUNQUEIRA, Lucas de Faria, op. cit. Cap. 3 (grifos meus). A citação encontra-se à página 147. Ver também CALOGERAS, João Pandiá, op. cit. p. 154 e segs.

${ }^{75}$ Carta a José Bonifácio de Andrada e Silva, n. 31, em 6 de maio de 1823. Cartas sobre a Independência, de 1822 a 1823. In: ARQUIVO NACIONAL, op. cit. p. 327.

76 Tomaram assento na Assembleia Constituinte de 1823 como deputados eleitos pela província de São Paulo os irmãos José Bonifácio, Antônio Carlos e Martim Francisco e o sobrinho destes José Ricardo da Costa Aguiar de Andrada (1787-1846). RODRIGUES, José Honório. op. cit.
} 
doravante das novas lideranças imperiais concentrar-se-ia na consolidação do Estado e da nação brasileiros. Nesse sentido, informava o futuro marquês:

Estou, meu prezadísimo Patrício [...], intimamente convencido que Vossa Excelência conhece em toda extensão a linha de política que convêm à prosperidade de nossa Pátria, e tanto as instruções, e ordens que Vossa Excelência me tem dado, como a fórmula do juramento para os Despachos da Assembleia, não deixam a menor dúvida de que Vossa Excelência de longo tempo meditou, e preveniu as consequências da catástrofe de Portugal. Não temo os talentos do Conde de Palmela [recém-nomeado ministério dos Negócios Estrangeiros], nem a consequência de suas diligências já começadas com a Santa Aliança, Vossa Excelência saberá zombar de tudo isso. Temo as intrigas e seduções do Conde dos Arcos se ele tiver acesso junto ao Nosso Augusto Imperador. As cartas de Lisboa me anunciam que ele fora chamado das Caldas, e que uma Fragata estava pronta para levá-lo ao Rio. Haverá coisa mais desculpável em um Jovem Herói, do que o inocente consentimento de reunir em sua cabeça as Coroas do Brasil e Portugal? Consentimento que será representado como fazendo a felicidade das duas Nações, e admiração do Universo? E manifestando-se em S. M. I. um tal consentimento não perderá ele a força moral que brilhantemente exercita sobre os Brasileiros? E perdida esta força moral não tornarão a surgir as ideias republicanas em algumas Províncias? E não serão os Portugueses mesmo os maiores instigadores de revoluções para estreitar mais a aflição do Imperador com Portugal? Ah Deus nos livre de tal desgraça!! Portugal como inimigo não tem meios de prejudicar ao Brasil, mas como amigo ou há de pouco a pouco reganhar o domínio, ou também pouco a pouco plantar o gérmen da guerra civil. ${ }^{77}$

Revelando-se extremamente preocupado com a situação e, por certo, receando ferir os brios do imperador, o agente em Londres enviou essa correspondência ao Rio de Janeiro por meio do seu filho, Felisberto Caldeira Brant Pontes, como reservado mensageiro. Somente, assim, confidenciava a José Bonifácio - a quem denominava de "10 Ministro do Império" -, que o melhor recurso para evitar os riscos antevistos passava em "não admitir comunicação, convenção ou tratado algum com Portugal enquanto este não reconhecer a Independência do Brasil e o Título de Seu Imperador". Em seguida, aprofundava as sugestões sobre esse procedimento que, em linhas gerais, acabariam assimiladas pelo Rio de Janeiro para lidar com as suscetibilidades entre as coroas de Portugal e Brasil enquanto a Independência não fosse reconhecida:

Ora como a Fragata, e o Conde dos Arcos, ou qualquer outro não leva semelhante reconhecimento, pois que S. M. F. [d. João VI] bem claro

\footnotetext{
${ }^{77}$ Carta a José Bonifácio de Andrada e Silva, Secretíssima e particular, em 4 de julho de 1823. Cartas sobre a Independência, de 1822 a 1823. In: ARQUIVO NACIONAL, op. cit. p. 344.
} 
fala na reunião de toda a família, o caminho curto e seguro será considerar a Fragata Portuguesa como navio empestado, cercando-o de guardas para evitar toda a comunicação, e dando-lhe muito embora os mantimentos necessários fazê-la sair em 24 horas. Isto sem dúvida será o que Vossa Excelência pretende fazer, mas como em seu coração dominam os sentimentos de generosidade, temo que alguma coisa ceda, e seremos perdidos [...].

Sabe-se, no entanto, que, em 7 de setembro de 1823, chegou à corte fluminense os pretensos negociadores portugueses, mas sem o conde dos Arcos. Em seu lugar vieram o conde do Rio Maior (João de Saldanha Oliveira Zuzarte Figueira e Sousa), que no Brasil fora camarista do rei, e o desembargador Francisco José Vieira - ministro da regência de d. Pedro até 9 de janeiro de 1821, dia do Fico -, sendo a finalidade da missão não outra que assegurar que d. João VI fosse "novamente reconhecido como soberano dos reinos de Portugal, Brasil e Algarves". ${ }^{78}$ A importância da Bahia para os projetos da nação portuguesa fora mais uma vez atestada, visto o titubeante rei ter subdivido esta tentativa de reatamento político enviando à província o baiano, marechal-de-campo e ex-deputado das Cortes, Luís Paulino de Oliveira Pinto da França, que era declaradamente a favor da união entre os antigos reinos. Luís Paulino partira na frente dos demais comissários, alcançando a sua terra natal em 6 de agosto. Mas, no dia seguinte, devido a princípios de agitações populares por causa da sua presença na província, a Junta de Governo o compelira a reembarcar e seguir viagem para o Rio de Janeiro. ${ }^{79}$ Ali ele chegara doente, todavia, não pôde desembarcar, pois o clima na Assembleia Constituinte já denotara tensões e vários dos seus ex-colegas de parlamento o taxavam de "brasileiro degenerado" e ainda "traidor". Só a muito custo, o ex-deputado conseguiu obter tratamento medicinal, enquanto o restante da tripulação que o acompanhava, fora obrigada a permanecer a bordo, não estabelecendo comunicações com a cidade fluminense. Em casa de um parente e sob as vistas dos oficiais, Luís Paulino foi examinado e medicado. Nos dias seguintes, os deputados aprovaram a proibição de qualquer negociação com Portugal até que a ex-metrópole declarasse o pleno reconhecimento da Independência e a integridade do Império. O próprio d. Pedro I, agindo de acordo com a Assembleia, igualmente declarara que antes de ser convencionado o reconhecimento preliminar da Independência e integridade do Império,

\footnotetext{
${ }^{78}$ Apud MONTEIRO, Tobias. História do Império. O Primeiro Reinado. Belo Horizonte: Ed. Itatiaia; São Paulo: Edusp, t. 1. 1982. p. 225.

${ }^{79}$ ARMITAGE, John. História do Brasil: desde o período da chegada da família de Bragança, em 1808 até a abdicação de D. Pedro I, em 1831, compilada à vista dos documentos públicos e outras fontes originais formando uma continuação da história do Brasil, de Southey. Belo Horizonte: Itatiaia; São Paulo: Edusp, 1981. p. 79.
} 
não receberia os mensageiros ou quaisquer propostas suas. Os emissários foram, depois disso, intimados a regressar imediatamente a Portugal. Mesmo não restabelecido da enfermidade, Luís Paulino acatou as resoluções: “A obediência sufocou em mim a reflexão sobre o perigoso estado em que se acha ainda a minha vida" ${ }^{80}$ E não restando mais a fazer, reuniu-se à tripulação, considerada inimiga, e embarcou para Europa, vindo a falecer ainda em alto-mar.

Sem conhecer que as tropas portuguesas haviam sido expulsas da capital baiana, Caldeira Brant alertava as autoridades fluminenses: "a soberania do povo está em sua Plenitude na Cidade de Salvador", não faltando ali quem fale de "República". ${ }^{81}$ Certificava, dessa maneira, o fato de as agruras da Guerra de Independência tenderem a corroborar para que o conjunto da população tomasse maior consciência da sua função social e política frente ao Estado e à nação que se formava. Voltando-se para o Velho Mundo, o futuro marquês também informava sobre as impressões que os trabalhos da Assembleia Constituinte adquiriam:

A atenção Europeia está fixa sobre a Assembleia Brasiliense, e geralmente se agoira muito mal supondo-nos inoculados do veneno Peninsular. Em Portugal já não existe a constituição denominada Liberal; em Espanha está limitada a Cádiz com esperança quanto muito de 15 dias de vida, e pode haver Deputado Brasileiro que pretenda uma só Câmara, Ministros fora do Congresso [em referência as duplas atuações de Bonifácio e Martim Francisco como, simultaneamente, representantes da nação e chefes ministeriais] etc. Até quando serão perdidas para os homens as lições da experiência!!. ${ }^{82}$

\footnotetext{
${ }^{80}$ Cf. MONTEIRO, Tobias, 1982, op. cit. p. 227.

${ }^{81}$ Carta a José Bonifácio de Andrada e Silva, n. 45, em 12 de julho de 1823. Cartas sobre a Independência, de 1822 a 1823. In: ARQUIVO NACIONAL, op. cit. p. 346. O futuro marquês de Barbacena não descansava em tomar providências que embaraçassem os projetos políticos mais exaltados. Tanto assim, que, em 19 de agosto de 1823, encontrando-se na Ilha de Madeira em direção à corte fluminense, enviou ordens financeiras a Clemente Álvares de Oliveira Mendes que deveria providenciar passagens para alguns "compatriotas em Lisboa", desejosos de transferirem-se ao Brasil. Mas impunha condições, pois solicitava que o intermediário fosse "escrupuloso na escolha das pessoas, os de mau caráter, os revolucionários, melhor é deixá-los em Portugal porque de tal fazenda já temos bastante cópia nas cidades marítimas do Brasil". Carta a Clemente Álvares de Oliveira Mendes, em 19 de agosto de 1823. Idem, ibidem. p. 351.

${ }^{82}$ Marcando posição antagônica a acima observada, Cipriano Barata admitia ser "a Constituição Portuguesa [...] um esforço do Gênio para aquela Nação, segundo o estado de seu presente abatimento e poderio da Aristocracia e Gente Togada". Certo de que: "Se lhe fizerem algumas reformas nas seguintes Legislaturas, talvez seja esta a melhor de todas as Constituições que se possa dar aos Governos mistos, atentas suas particulares circunstâncias". Manifesto à Bahia de Todos os Santos por um Deputado às Cortes Gerais Constituintes de Portugal. Cipriano José Barata de Almeida. Com algumas Notas. Desengano para Brasileiros e Europeus residentes no Brasil, Recife - Pernambuco: Typographia de Cavalcante \& Companhia!, 18 de fevereiro de 1821. In: BARATA, Cipriano. Sentinela da Liberdade e outros escritos (1821-1835). Organização e edição Marco Morel. São Paulo: Edusp, 2008. p. 135.
} 
Depois de os seus reiterados pedidos de demissão da função desempenhada em Londres terem sido aceitos, Caldeira Brant, antes de partir para o Rio de Janeiro, lançou uma proposta extra-oficial ao ministro inglês Jorge Canning sobre a melhor forma de se convencionar o tratado de cessação do tráfico de escravos com o Brasil. Sua sugestão, feita na condição de "indivíduo", consistia em restringir inicialmente a dez anos a proibição do tráfico transatlântico, compreendendo que:

Esta limitação habilitaria o meu Governo a representar ao Povo tal medida, como de mera experiência para o fim de atrair população Europeia; daria tempo para desfazer os prejuízos das pessoas interessadas neste tráfico, e tiraria aos partidos opostos ao Imperador e a Grã-Bretanha o argumento em que fundam suas intrigas, de que se intenta com a abolição do tráfico da escravatura a repentina e total aniquilação na agricultura do Brasil.

A segunda modificação que me parece dever acompanhar a medida é uma dispensa, ou exceção na Legislação atual Inglesa, para que S. M. I pudesse recrutar no Reino Unido Inglês, ou pelo menos na Irlanda, tantos homens hábeis para o Exército do Brasil, como trabalhadores para a cultura das terras. [...] a contínua emigração [...] seria de dupla vantagem para o Brasil e para a causa da abolição da escravatura, que todos nós desejamos adiantar, porque a introdução de braços livres para a cultura das terras no Brasil lhe daria agradável aumento de povoação de que precisa e provaria ao ponto de convicção, e em breve tempo ainda as pessoas mais prejudicadas, que aquele país pode passar sem escravos. ${ }^{83}$

Sem perder a oportunidade, o futuro marquês juntava àquela proposta a rogativa de facilidades para o Brasil ter acesso a navios ingleses "e seus competentes petrechos, tanto para o transporte, como escolta", facultando, assim, ao governo imperial a disposição de uma "correspondente força naval".

Depois dos serviços prestados ao recém-fundado Império, Caldeira Brant, finalmente, podia reaver o Brasil. Há que se lembrar que não obstante ter se comportado como um legítimo Encarregado dos Negócios, ele despediu-se desta missão sem ter recebido a credencial ou plenos poderes para falar e agir em nome do governo imperial. E, conforme as correspondências aqui analisadas, mesmo tendo que satisfazer os muitos

\footnotetext{
${ }^{83}$ Carta a Jorge Canning, em 3 de agosto de 1823. Cartas sobre a Independência, de 1822 a 1823. In: ARQUIVO NACIONAL, op. cit. p. 348-349. Com muita lucidez e, de certa forma, antevendo os nervosos debates ocorridos na Câmara dos Deputados (nos anos de 1826 e 1827) sobre a melhor forma de convencionar o término do tráfico escravagista, Caldeira Brant deixava claro ao correspondente que os pleitos relativos àquela abolição seriam intensos, razão pela qual não podia afiançar que a medida por ele sugerida seria aceita: "porque o prejuízo a favor da continuação da escravatura é tão geral na gente comum do Brasil; o interesse dos Negociantes de escravos tão poderoso e o temor dos Agricultores de se verem arruinados por falta de escravos tão arraigado em seus espíritos, que será preciso considerável esforço e trabalho para vencer tais dificuldades, apesar das boas intenções e ardentes desejos de S. M. I". Carta a Jorge Canning, em 3 de agosto de 1823. Idem, ibidem. p. 349.
} 
custos que envolviam as atribuições de um cargo de caráter diplomático, o futuro marquês deparou-se com sérias dificuldades para obter recursos financeiros do Rio de Janeiro. Daí não ser raro encontrar exposições de motivos ao Secretário de Estado dos Negócios Estrangeiros do Brasil como as seguintes: "Convencido como estou que Vossa Excelência queira quanto antes salvar a Pátria, e que a falta de formalidade no expediente das ordens era meramente imputável ao oficial da Secretaria, procurei suprir aquela falta solicitando a corporação dos meus amigos, e mesmo dos Banqueiros [...], mas estes homens, como por vezes tenho dito [...], são demasiadamente escrupulosos e qualquer falta de formalidade os embaraçam". ${ }^{84}$ A despeito de contatos e de ser reconhecido como detentor de significativo cabedal, o agente em Londres realmente não teve condições em atender todas as demandas que lhe foram exigidas. Em uma dada ocasião, por exemplo, ele voltou a escrever a José Bonifácio ponderando que: "Conquanto tenha algum crédito não posso deixar de prestar socorros a minha Pátria e [aos] Compatriotas, mas se Vossa Excelência não manda dinheiro ou Plenos Poderes para o haver, será forçoso recolher-me à cadeia, da qual ninguém aqui escapa não pagando em tempo" as dívidas contraídas. ${ }^{85}$ Enfim, o certo foi que Caldeira Brant conseguia retornar prestigiado à América e compreende-se que, em boa medida, as suas súplicas para se licenciar do cargo exercido em Londres devia-se a questões importantes que tinha para resolver no Brasil, especialmente na Bahia de onde se afastara havia dois anos e meio, deixando para trás grande parte das suas vastas propriedades urbanas e rurais. $^{86}$

A despeito dos céleres e complexos eventos que assinalam a dissolução do pacto político entre Brasil e Portugal pelo qual emergira o Estado e a nação brasileiros, houve quem estivesse atento às sutis reentrâncias de representações simbólicas que tentavam esmaecer as perspectivas de soberania popular em favor da distinção nas classes dominantes. É nesse sentido, que Cipriano Barata denunciava o decreto publicado no dia

\footnotetext{
${ }^{84}$ Carta a José Bonifácio de Andrada e Silva, n. 30, em 6 de maio de 1823. Idem, ibidem. p. 326.

${ }^{85}$ Carta a José Bonifácio de Andrada e Silva, n. 33, em 10 de maio de 1823. Idem, ibidem. p. 330.

${ }^{86}$ Nos dias em que deixava de servir aos interesses do governo joanino para obedecer tão somente às determinações da regência no Rio de Janeiro, Caldeira Brant conseguiu, por ordem régia encaminhada à Secretaria de Estado dos Negócios da Justiça em Portugal, "a restituição" do Engenho Santa Anna, situado na Comarca dos Ilhéus, bem como os seus "respectivos rendimentos". Ficava, portanto, anulada a desapropriação que o litigante Manoel Duarte da Silva havia obtido, por meio de uma Portaria expedida pela primeira Junta de Governo da Bahia, em 15 de setembro de 1821. Eis aqui um dos indícios das insistências de Caldeira Brant em retornar ao Brasil, pois, como se sabe, a forma apressada com que abandonara a capital baiana não lhe deu condições para organizar minimamente a administração das suas propriedades. $O$ Constitucional, n. 19, quarta-feira, 22 de maio de 1822. Tipografia da Viúva Serva e Carvalho, 1821-1822. Exemplar da coleção do IEB/USP.
} 
da coroação e sagração imperial de d. Pedro I ( $1^{\circ}$ de dezembro de 1822$)$ instituindo uma nova Ordem de Cavalaria. Indagava o baiano: "Quem diria que os Ministros do Rio de Janeiro abusariam tão depressa da confiança Pública e da do Imperador, apresentando com abominável hipocrisia um Decreto que apenas serve para desmascarar as insidiosas manobras com que a Aristocracia e o Despotismo maquinam levantar de novo o seu trono sobre a singela fé dos iludidos Brasileiros". ${ }^{87}$ Embora o próprio Cipriano fosse um dos muitos contemplados naquele dia com a insígnia de dignatário da Ordem Imperial do Cruzeiro do Sul e dela, posteriormente, acabasse se valendo como antídoto capaz de abrandar a ira das autoridades que incessantemente o perseguiria e o faria subsistir longos anos nas principais prisões imperiais, é deveras interessante perceber como suas formulações apresentavam-se diametralmente opostas à de lideranças como Caldeira Brant. ${ }^{88}$ Desse modo, não há porque duvidar as razões das inimizades entre indivíduos que disputavam concepções tão díspares de como o Estado e a nação brasileiros deveriam ser organizados. Afirmava Cipriano que:

Se os Aristocratas Ministros do Rio de Janeiro não estivessem tão corrompidos e atolados nas antigas maldades, [...] teriam visto que os Povos do Brasil rejeitaram a união com Portugal só porque a Constituição não lhes conveio e que se desejam fazer corpo com o Rio de Janeiro é porque esperam novo sistema e Constituição livre que lhes agrade. Constituição feita sob princípios liberais, que destrua Ordens, Privilégios e Isenções, Classes, Morgados, Comendas etc., que não se lembre de duas Câmaras nem de Veto absoluto [para o imperador], que diminua e corrija os Magistrados, fazendo eleger estes pelo Povo, que deixe toda liberdade à Imprensa, às Ciências e às Artes; que institua

\footnotetext{
${ }^{87}$ Análise do Decreto de $1^{\circ}$ de dezembro de 1822 sobre a criação da Nova Ordem do Cruzeiro com algumas notas. Ilustração ao Brasil e ao nosso Imperador, o sr. D. Pedro I, oferecida ao público pelo desengano. Reimpresso no Rio de Janeiro: Tipografia Nacional, 1823. In: BARATA, Cipriano, 2008, op. cit. p. 139.

${ }^{88}$ Relação dos despachos publicados na corte pela Secretaria de Estado dos Negócios do Império no faustíssimo dia $1^{\circ}$ de dezembro de 1822 , da sagração e coroação de S. M. Imperial. In: MORAES, Alexandre de Mello, op. cit. p. 554. Verifica-se que na extensa lista dos 121 contemplados com a nova ordem honorífica no dia da coroação (sendo dignificados dois grã-cruzes, 34 oficiais e 85 cavaleiros), encontrava-se, além dos já citados Caldeira Brant (oficial) e Cipriano Barata (dignatário), outras lideranças bastante influentes na Bahia, como por exemplo, os dignatários Francisco Elesbão Pires de Carvalho e Albuquerque, Francisco Gomes Brandão Montezuma, José Lino Coutinho, José Egídio Gordilho de Barbuda; os oficiais Joaquim Inácio de Siqueira Bulcão, Joaquim Pires de Carvalho e Albuquerque, José Antonio da Silva Castro, José Garcia Pacheco de Moura Pimentel e Aragão e, por fim, os cavaleiros José da Silva Lisboa, Manuel Ferreira de Araújo Guimarães, Simão Gomes Ferreira Veloso e o Vigário de Saubara na província da Bahia. Idem, ibidem. p. 554-556. Sobre o itinerário político de Cipriano Barata, o qual sobrevivera de cadeia em cadeia ao longo de quase todo o Primeiro Reinado e primeiros anos da Regência, ver MOREL, Marco. Cipriano Barata na Sentinela da Liberdade. Salvador: Academia de Letras da Bahia: Assembleia Legislativa do Estado da Bahia, 2001.
} 
Jurados nos cíveis e crime etc. [...]. ${ }^{89}$

Escudado em sua trajetória de político radical de longa data e profundamente marcado pelos acalorados embates das Cortes lisboeta, Cipriano Barata anunciava que o projeto da classe dirigente que ascendia ao primeiro escalão do poder imperial consistia em “[...] ganhar terreno passo a passo, para breve nos esmagar com Morgado, Barões, Condes, Viscondes, Marqueses e todos quantos formam o cortejo do Despotismo". Não obstante falasse como integrante do campo político que reconhecia na soberania popular a verdadeira legitimidade do governo instituído no Brasil depois da Revolução Constitucionalista de 1821, as denúncias de Cipriano coadunavam com aquelas expostas pelos redatores dos periódicos e panfletos pró-lusitanos na Bahia, quando informaram aos leitores como a administração no Rio de Janeiro inclinava-se a conservar os privilégios e a renovar o poder aristocrático dos grandes proprietários. Neste sentido, é possível extrair daqueles escritos expressões avaliando que para o nascente Império do Brasil: “[...] cada fofo senhor de engenho já conta[va] ser conde, marquês, duque etc", ${ }^{90}$ podendo, assim, satisfazer "[...] sua vaidade e fofice de fitas, títulos, patentes, etc."

Ocorre que já na data da sua coroação, d. Pedro I optara pela distribuição de títulos de nobreza, escolhendo justamente um baiano, Antonio Joaquim Pires de Carvalho e Albuquerque, para dignificá-lo a barão da Torre Garcia d'Ávila. ${ }^{92}$ Com este gesto, o novo imperador retomava a anterior política de cooptações, compensações e compromissos, com a diferença que doravante ela se daria no contexto do Império Constitucional do Brasil. É digno de nota o fato de o primeiro título de nobilitação do Império ter sido inicialmente oferecido a Francisco Gomes Brandão Montezuma, pelo importante papel por ele desempenhado para afirmação do governo de d. Pedro na província baiana, via a publicação e difusão do periódico $O$ Constitucional. Chegado à corte fluminense, em 14 de novembro de 1822, Montezuma soube na véspera do cerimonial de coração que d. Pedro o felicitaria. Cauteloso, e quiçá estranhando o fato de dentre tantas lideranças influentes que habitava ou frequentava a corte fosse ele o escolhido para principiar a nobilitação imperial,

\footnotetext{
${ }^{89}$ Análise do Decreto de $1^{\circ}$ de dezembro de 1822 sobre a criação da Nova Ordem do Cruzeiro com algumas notas. Ilustração ao Brasil e ao nosso Imperador, o sr. D. Pedro I, oferecida ao público pelo desengano, op. cit. p. 142-143.

${ }^{90}$ Diálogo entre um constitucional, um filósofo e um bonifácio, o qual fora publicado na tipografia da Viúva Serva e Carvalho (Salvador) no segundo semestre de 1822. Apud SILVA, Maria Beatriz Nizza da, 2008, op. cit. p. 141.

${ }^{91}$ Semanário Cívico, n. 79, de 5 de setembro de 1822. Apud SILVA, Maria Beatriz Nizza da, 2008, op. cit. p. 138-139.

${ }^{92}$ BANDEIRA, Alberto Moniz. O feudo: A Casa da Torre de Garcia d'Ávila: da conquista dos sertões à independência do Brasil. Rio de Janeiro: Civilização Brasileira, 2000. p. 437.
} 
o então secretário da Junta Governativa de Cachoeira recorreu ao ministro José Bonifácio para convencê-lo acerca dos perigos que a concessão poderia provocar. Depois de muito agradecer a estima do regente pela lembrança de seu nome, chamou atenção para as suscetibilidades capazes de provocar "o ciúme que um tal despacho causaria em uma província que se honrava de ter muitas famílias antigas e ilustres" e das quais ele não pertencia. ${ }^{93} \mathrm{O}$ futuro visconde de Jequitinhonha argumentou ainda que, como a Bahia ainda estava em guerra e sendo ele apenas um mensageiro do Conselho Interino, a aceitação de uma mercê daquela natureza poderia ser mal interpretada na província com o risco de prejudicar a integridade do Estado e da nação que se formava. As evidências indicam que, após esse encontro, ficou decidido que o primeiro súdito do Império do Brasil a ser nobilitado seria o titular do morgado da Torre de Garcia d'Ávila, o qual não se encontrava entre os presentes na corte. De todo modo, é significativo a permanência da concessão para um indivíduo natural da província da Bahia. Por outro lado, Montezuma foi certificado de que seu nome entraria na lista dos contemplados na Imperial Ordem do Cruzeiro. Ele ainda quis escusar, mas logo compreendeu que a recusa o lançaria no rol dos republicanos, por isso não somente recebeu a insígnia, como teve participação ativa nos cerimoniais de coroação e sagração do imperador, sendo um dos oito condutores do rico pálio que protegeu d. Pedro no percurso transcorrido a pé durante a cerimônia de coroação. Por fim, convém considerar que o real motivo para a condecoração nobiliárquica ter sido ofertada a um único súdito, em um dia de tanto fausto, devia-se à precaução, pois, dessa maneira, ganhar-se-ia tempo para conhecer o impacto do gesto junto à população. ${ }^{94}$

\subsection{Deputados baianos na Assembleia Constituinte de 1823}

De acordo os critérios eleitorais à época estabelecidos, os quais valorizavam os eleitores de paróquia, as eleições ocorridas na Bahia para deputados da Assembleia Constituinte do Brasil de 1823 alcançaram 4.382 votos, distribuídos por onze

\footnotetext{
93 Apud MONTEIRO, Tobias. História do Império: A elaboração da Independência. Belo Horizonte: Ed. Itatiaia; São Paulo: Edusp, t. 2, 1981. p. 549, nota 4.

${ }^{94}$ Nos primeiros anos de afirmação do Estado e da nação brasileiros tornou-se evidente o quanto o peso das tradições fora conservado. As marcas indeléveis das práticas de continuidade de tipo Ancien Régime poderiam ser aquilatadas, por exemplo, pelas concessões de condecorações e de títulos nobiliárquicos distribuídos pelo imperador ao longo do Primeiro Reinado, posto que a soma das insígnias das ordens do Cruzeiro, de Cristo e da Rosa contemplara o total de 4.625 cidadãos do Império, enquanto os nobilitados reunidos em um círculo privilegiado compunham apenas 146 agraciados. Cf. MOREL, Marco. As transformações dos espaços públicos: Imprensa, atores políticos e sociabilidades na cidade imperial (1820-1840). São Paulo: Hucitec, 2005. p. 195.
} 
representantes. ${ }^{95}$ Obrigado a organizar o pleito eletivo em meio à Guerra de Independência, somente em 23 de maio de 1823 - quando os trabalhos constituintes já se encontravam em andamento há exatos vinte dias - o Conselho Interino divulgou os nomes e números de votos alcançados por cada deputado, cuja disposição foi: o bacharel em Filosofia Cipriano José Barata de Almeida, que aparece no topo da lista com 612 votos (sendo, por isso, o primeiro deputado eleito com maior votação no Império do Brasil); em seguida, o médico Antônio Ferreira França com 595; o padre e proprietário Francisco Agostinho Gomes com 524; o desembargador Francisco Carneiro de Campos com 477; o bacharel em Direito Manoel Antonio Galvão (1791-1850) com 453; o marechal Felisberto Caldeira Brant com 329; o bacharel em Direito Miguel Calmon du Pin e Almeida com 322; o brigadeiro Manuel Ferreira de Araújo Guimarães com 300; o bacharel em Direito Francisco Gê Acayaba Montezuma com 298; o bacharel em Direito José da Costa Carvalho Júnior (1796-1860), futuro visconde e marquês de Monte Alegre, com 279 e, finalmente, o desembargador Luís José de Carvalho e Melo com 193. ${ }^{96}$ Posteriormente, em cumprimento à portaria imperial de 7 de agosto, o Governo Provisório da Bahia requereu que os eleitores de paróquia da cidade de Salvador realizassem novas eleições para escolha de outro deputado constituinte, sendo eleito, em 7 de setembro, o canonista José da Silva Lisboa que assumiu a vaga de Cipriano Barata, pois, como se sabe, este não tomara assento na Constituinte. $^{97}$ Outro deputado que preferiu ficar em Pernambuco, juntamente com Cipriano, foi o padre e também político radical Francisco Gostinho Gomes, sendo, por isso, substituído pelo suplente de origem fluminense e ex-desembargador da Casa de Suplicação Luis Pedreira do Couto Ferraz, que tomou assento na Assembleia em 6 de agosto. Por fim, a representação da província da Bahia contou interinamente com a atuação do bacharel em Direito Antonio Calmon du Pin e Almeida entre princípios de agosto a 10

\footnotetext{
${ }^{95}$ MINISTÉRIO DA JUSTIÇA. A Junta Governativa da Bahia e a Independência. Rio de Janeiro: Arquivo Nacional, 1973. p. 51. Não obstante a província baiana ter direito a treze deputados para a Constituinte, o número de representantes ficou reduzido a onze, tendo em vista a ocupação das tropas lusitanas que impediu a participação da população da capital baiana. Sobre a quantidade de representantes prevista para cada província e os demais critérios eleitorais para as eleições dos deputados da Assembleia Constituinte de 1823, ver, INSTRUÇÕES de 19 de junho de 1822 referentes ao decreto de 3 de junho do mesmo ano. In: MORAES, Alexandre de Mello, op. cit. 2. v. p. 57-64 e Atas do Conselho Interino na Cachoeira, 14 ${ }^{\mathrm{a}}$. Ata de 18 de dezembro de 1882 - O brigadeiro Gordilho de Barbuda, chegado do Rio de Janeiro apresenta ao Governo Interino portaria do Imperador para que se proceda à eleição dos deputados à Assembleia Geral Constituinte. Documentos históricos sobre a emancipação política da Bahia. Revista do Instituto Geográfico e Histórico da Bahia, ano III, v. 3, n. 9. p. 341-343, 1896.

${ }^{96}$ MINISTÉRIO DA JUSTIÇA. A Junta Governativa da Bahia e a Independência. Rio de Janeiro: Arquivo Nacional, 1973. p. 51.

${ }^{97}$ Idem, ibidem. p. 286.
} 
de outubro, preenchendo a vaga de Caldeira Brant que, no dia seguinte, reclamou e teve direito ao assento como deputado da nação. ${ }^{98}$

A Bahia faria representar-se na Constituinte com uma representação de deputados completamente renovada, uma vez que dentre os eleitos para as Cortes de Lisboa, somente Cipriano Barata e Agostinho Gomes foram reeleitos, mas ao decidirem não comparecer na Assembleia, abriram espaço para o surgimento de novos quadros. Em sua análise sobre os Anais da Constituinte de 1823, José Honório Rodrigues destacou que, ao lado dos deputados de Minas Gerais, a "representação baiana" se distinguiu "como uma das mais poderosas [...] pela força do talento de seus escolhidos e pela homogeneidade". 99 Nesse sentido, o deputado José da Silva Lisboa foi creditado como "uma das maiores figuras da Constituinte". Ombreando com este encontravam-se Carvalho e Melo e Francisco Carneiro da Cunha devido às contribuições jurídicas que legavam aos projetos e artigos aprovados em plenário. A despeito das posições políticas de Montezuma na Constituinte terem sido filtradas pelas lentes do historiador carioca como sendo "quase sempre" "demagógica", ele e Ferreira França mereceram atenção pela combatividade com que sustentavam suas ideias. Por fim, Caldeira Brant, Miguel Calmon e Costa Carvalho, não se afirmando enquanto deputados influentes, seja pela qualidade, seja pela quantidade das intervenções e proposições, sagrar-se-iam como grandes quadros do Império já que os dois primeiros ocupariam pastas ministeriais importantes, em momentos críticos do governo de d. Pedro I; e o último comporia - juntamente com o brigadeiro Francisco de Lima e Silva (1785-1853) e o maranhense João Bráulio Muniz (1796-1835) - a Regência Permanente que, na esteira da abdicação, governaria o Império entre os anos de 1831 e $1835 .^{100}$

É interessante notar que dentre os deputados eleitos pela Bahia, o predomínio fora de indivíduos com trajetórias bem conhecidas na província, a despeito de alguns destes residirem no Rio de Janeiro há anos, como era o caso dos baianos Silva Lisboa, Carvalho e Mello e Ferreira Araújo. Sobressaíram também lideranças jovens, compostas por recém-egressos do curso de Direito em Coimbra, mas que, de volta ao Brasil,

\footnotetext{
98 Não obstante os resultados das eleições tivessem sido divulgados desde fins de maio de 1823, as correspondências de Caldeira Brant, como Encarregado dos Negócios do Brasil em Londres, não fornecem pistas de que ele soubesse da sua eleição à Assembleia Constituinte. Aventa-se, então, a possibilidade de se encontrando na Ilha de Madeira em 19 de agosto com destino ao Brasil, o futuro marquês passou pela província baiana para cuidar dos seus negócios particulares e, só depois disso, seguiu para a corte fluminense, onde tomaria assento como deputado Constituinte.

99 RODRIGUES, José Honório, 1974, op. cit. p. 27.

${ }^{100}$ Cf. DOLHNIKOFF, Miriam, 2005, op. cit. p. 89.
} 
tornaram-se rapidamente protagonistas de alguma relevância nos acontecimentos políticos que culminaram na Independência. Paradigmático deste perfil foram, sem sombra de dúvida, as projeções dos dois secretários do Conselho Interino Montezuma e Miguel Calmon, mas paralelamente observa-se a ascensão de Manoel Antonio Galvão, José da Costa Carvalho, que assumiu o juizado de fora na província de São Paulo nos anos de 1821 e 1822, e Antonio Calmon, irmão mais novo de um dos secretários do Conselho Interino. A exceção do mineiro por nascimento e baiano por adoção Caldeira Brant e do fluminense Luis Pedreira do Couto Ferraz que na condição de suplente ocupou a vaga de Agostinho Gomes na Assembleia, todos os demais deputados tinham como origem a província da Bahia. Por fim, ressalta-se que estes deputados tomaram assento na Assembleia a partir de 21 de junho de 1823.

Característica também marcante dos deputados da província baiana, é que, ao contrário do verificado na representação enviada a Lisboa, eleita unicamente dentre os habitantes da província, ${ }^{101}$ os perfis dos novos deputados constituintes corroboraram não somente a existência, mas a pujança das redes de sociabilidade políticas envolvendo a Bahia e o Rio de Janeiro. Isso porque as instruções eleitorais de 19 de julho de 1822 não condicionaram que os novos deputados fossem exclusivamente indivíduos radicados na esfera provincial, já que alargaram a possibilidade de o futuro representante residir não apenas no território Brasiliense, mas em "qualquer parte da monarquia portuguesa, contanto que te[vesse] 12 anos de residência no Brasil, e, sendo estrangeiro, que te[vesse] 12 anos de estabelecimento, com família, além dos da sua naturalização". ${ }^{102} \mathrm{Na}$ prática, essas medidas foram fundamentais para que alguns baianos residentes na corte fluminense se elegessem deputados da província da Bahia. Do mesmo modo permitiu que entre os próprios representantes eleitos pelo Rio de Janeiro houvesse aqueles cuja origem era baiana. Afinal, dos oito deputados eleitos na corte fluminense, pouco mais de um terço tivera a província baiana como local de nascimento, a saber: José Egídio Álvares de Almeida (barão de Santo Amaro), José Joaquim Carneiro da Cunha (futuro marquês de Caravelas) e Antônio Luís Pereira da Cunha (futuro marquês de Inhambupe). ${ }^{103}$ Ademais,

\footnotetext{
101 Essas escolhas atendiam à complexidade do sistema de eleição dos representantes às Cortes Portuguesa que exigia, por exemplo, que para o "cidadão" ser eleito deputado ele deveria ter necessariamente nascido na província "ou ser domiciliado nela com residência de sete a anos, pelo menos". Apud BERBEL, Márcia Regina. A nação como artefato: deputados do Brasil nas cortes portuguesas (1821-1822). São Paulo: Hucitec, 1999. p. 48.

${ }^{102}$ INSTRUÇÕES de 19 de junho de 1822 referentes ao decreto de 3 de junho do mesmo ano. In: MORAES, Alexandre de Mello, op. cit. 2. v. p. 61.

${ }^{103}$ O jurista baiano José Joaquim Carneiro da Cunha tomou assento na Constituinte como substituto do deputado efetivo Joaquim Gonçalves Ledo que se vira obrigado a fugir para Buenos Aires na esperança de
} 
faz-se necessário não perder de vista que estes indivíduos, juntamente com alguns dos seus conterrâneos, tornar-se-iam os maiores responsáveis pelo arcabouço jurídico não apenas dos artigos e projetos aprovados nos seis meses de trabalhos da Constituinte, como da Carta outorgada pelo imperador em 25 de março de $1824 .{ }^{104}$

No que concerne à Bahia, compreende-se que a mudança de postura política capaz de elevar a representação para indivíduos residentes na corte fluminense deveu-se também às transformações ocorridas na província após o tortuoso e malogrado processo de construção do pacto constitucional com a nação portuguesa. Se por um lado, é difícil precisar o momento exato em que se afirmara a hegemonia da rede de sociabilidade política entre a Bahia e o Rio de Janeiro; por outro, se sabe que essa viragem ocorrera em meados de 1822, quando o projeto político capitaneado pelo príncipe regente passou a expressar-se como o melhor recurso para a Bahia escapar às exigências impostas pelo liberalismo português. Mas, como já discutido no capítulo anterior, esse processo de aproximação não fora algo linear, pois envolveu concessões de ambos os lados e exigiu que as diferenças fossem minimamente equalizadas via uma séria de negociações para que os interesses da Bahia se coadunassem com os das províncias coligadas de onde emergiram o Estado e a nação brasileiros.

Pouco a pouco, lideranças baianas vinculadas à classe senhorial demonstraram habilidades em romper o cipoal que dificultava o acesso aos círculos decisórios reunidos em torno do imperador. Portanto, ainda que se considere o fato de a representação oficial da Bahia conformar tão somente os onze deputados eleitos pela província, não se deve perder de vista que, um ano antes, representantes como José Joaquim Carneiro de Campos e Antônio Luís Pereira da Cunha encontravam-se entre os protagonistas da Felicitação dos Baianos em apoio à decisão do príncipe regente em permanecer no Brasil. ${ }^{105}$ Eleitos pela

escapar às perseguições dos Andrada, mas que, por isso mesmo viu-se sem garantias jurídicas para comparecer à Assembleia. Na verdade, Ledo só retornaria ao Brasil no ano de 1829, quando o governo de d. Pedro já perdera muito da sua credibilidade. Cf. RODRIGUES, José Honório, 1974, op. cit. p. 300-301 e Cf. BETHELL, Leslie; CARVALHO, José Murilo de. O Brasil da Independência a meados do século XIX. In: BETHELL, Leslie (Org.). História da América Latina: Da Independência a 1870. São Paulo: Edusp/Imprensa Oficial do Estado de São Paulo; Brasília: Fundação Alexandre de Gusmão, 2004, v. 3. p. 700.

${ }^{104}$ Desperta atenção o fato de a província do Rio de Janeiro ter elegido para seus representantes na Constituinte lideranças de origens bastante diversas, pois, para além dos baianos mencionados, elegeu-se deputado pela corte: o português europeu e bispo da capital do Império José Caetano da Silva Coutinho (1768-1833); o mineiro e abastado comerciante Manoel Jacinto Nogueira da Gama; o paulista Martim Francisco Ribeiro de Andrada - substituto do deputado efetivo e fluminense Agostinho Correa da Silva Goulão que não tomou posse -; o fluminense Jacinto Furtado de Mendonça (1760-1834) e o catarinense Manuel José de Sousa França (1780-1856). Cf. RODRIGUES, José Honório, 1974, op. cit. p. 300-301.

${ }^{105}$ Felicitação dos Baianos residentes no Rio de Janeiro a S.A.R. In: Constitucional, n. 5, sábado, 20 de abril de 1822. Tipografia da Viúva Serva e Carvalho, 1821-1822. Exemplar da coleção do IEB/USP. Em 24 de 
província do Rio de Janeiro como deputados à Assembleia Constituinte, indivíduos como esses se apresentavam cada vez mais aptos a marcar posições como importantes homens de Estado à medida que se portavam como genuínos interlocutores da classe senhorial junto ao nascente Império do Brasil.

Salienta-se, no entanto, que apesar do programa para as eleições dos deputados constituintes autorizar o envio pelas câmaras municipais das "instruções sobre as necessidades e melhoramentos das suas províncias", ${ }^{106}$ bem cedo os representantes defrontaram-se com a perspectiva de extrapolar estes limites para se concentrar nas aspirações nacionais que, ao fim e ao cabo, direcionaram os trabalhos da Constituinte. ${ }^{107}$ Porém, é preciso esclarecer que esse esforço não fora algo fortuito, haja vista a premente necessidade encampada por distintos protagonistas da Assembleia de $1823 \mathrm{em}$ afastar do centro da disputa as discussões que apontavam para a consideração de um pacto federativo. Como não será acompanhado detidamente as vigorosas, e até violentas, intervenções ocorridas na Constituinte, ${ }^{108}$ propõe-se compreender como a postura dos quadros da ilustração vinculados à classe senhorial baiana revelou-se útil à construção do projeto de governo centralista implementado por d. Pedro I ao longo do Primeiro Reinado.

Há que se lembrar que o ingresso dos representantes da Bahia na Constituinte coincidiu com uma reviravolta importante na conjuntura política imperial. De fato, em 17 de julho de 1823, os irmãos José Bonifácio e Martim Francisco foram oficialmente destituídos das suas funções ministeriais e, a partir daí, passaram a conduzir uma oposição cerrada ao governo, manifesta tanto no Parlamento, quanto na imprensa por meio do

maio de 1822, Pereira da Cunha, na condição de orador da deputação da Bahia, assinaria - "Por todos os Cidadãos Baienses, residentes nesta Corte [Rio de Janeiro]" - uma fala ao príncipe regente d. Pedro. Fala do Orador da Deputação da Bahia. In: LISBOA, José da Silva. História dos principais sucessos políticos do Império do Brasil dedicada ao senhor d. Pedro I. Rio de Janeiro: Tipografia imperial e Nacional, 1927, parte X, Seção II. Nota ao Cap. XVII, p. 45-47.

${ }_{106}$ INSTRUÇÕES de 19 de junho de 1822 referentes ao decreto de 3 de junho do mesmo ano. In: MORAES, Alexandre de Mello, op. cit. 2. v. p. 62.

${ }^{107}$ Nas Cortes de Lisboa, como atestou Márcia Regina Berbel, as proposituras em defesa das vantagens provinciais foram, a princípio, objetivos primordiais das primeiras intervenções de bancadas importantes como a da Bahia e de São Paulo, as quais, gradativamente, deram-se conta de que no horizonte político havia uma concreção de interesse maior, expressa na ideia de Brasil. Foi, portanto, somente a partir deste entendimento que as alianças entre influentes representantes das províncias americanas convergiram para um ideal comum, a defesa do hemisfério brasileiro, tal qual defendera o intrépido Cipriano Barata, ante o hemisfério europeu que se mostrava irredutível em negociar o seu liberalismo constitucional. BERBEL, Márcia Regina, 1999, op. cit. A esse respeito, ver também JANCSÓ, István; PIMENTA, João Paulo Garrido, op. cit. p. 167.

${ }^{108}$ Sobre a importância desses debates, ver SLEMIAN, Andréa. Seriam todos cidadãos? Os impasses na construção da cidadania nos primórdios do constitucionalismo no Brasil (1823-1824). In: JANCSÓ. István (Org.). Independência: história e historiografia. São Paulo: Hucitec. p. 829-847, 2005; RODRIGUES, José Honório, 1974, op. cit. e CONSORTE, Josildeth Gomes. A Contribuição Bahiana à Constituinte de 1823. Revista do Instituto Geográfico e Histórico da Bahia, n. 77. p. 239-269, 1952. 
periódico $O$ Tamoio, que começou a circular no mês seguinte àquelas demissões. Para substituir os Andrada, o imperador decidiu nomear lideranças que desfrutavam, nos últimos tempos, de ascensões políticas prestigiadas no Rio de Janeiro, inclusive como deputados eleitos. Assim, para dar conta dos dois únicos ministérios com poder político efetivo na esfera imperial, d. Pedro convocou o baiano José Joaquim Carneiro de Campos, alçado ao ministério dos Negócios do Reino e Estrangeiros, e o mineiro Manoel Jacinto Nogueira da Gama (1765-1847), futuro marquês de Baependi, responsável pela pasta da Fazenda. No ministério, os recém-ingressos tiveram a companhia do português Caetano Pinto de Miranda Montenegro (1748-1827), futuro marquês de Vila Real da Praia Grande (Justiça), do também baiano Luís da Cunha Moreira (1777-1865), depois visconde de Cabo Frio (Marinha) e, finalmente, do português João Vieira de Carvalho (1781-1847), futuro marquês de Lages (Guerra).

Pertencente à geração ilustrada, Luís da Cunha Moreira foi um daqueles baianos que, ainda muito jovem, seguiu para Portugal em busca de conhecimentos, o que, por certo, ampliavam as oportunidades de futuramente ser aproveitado na máquina administrativa da Coroa portuguesa. Em Lisboa, ingressou no Colégio dos Nobres em 1793. Alguns anos depois, já era um dos poucos americanos a ter acesso aos postos superiores da Marinha portuguesa. Em fins de 1807, Cunha Moreira comandou, na condição de capitão de fragata, uma das embarcações da esquadra que transladou os membros da corte e da família real para o Brasil. ${ }^{109}$ Aplicando-se aos serviços régios, em 1809 este baiano conduzira o bergantim Infante D. Pedro com 18 canhões a bordo, para tomar parte ativa na conquista de Caiena para o governo joanino. Nesta ocasião, fora ferido na cabeça com um golpe de sabre, cuja cicatriz servir-lhe-ia como uma espécie de dístico de honradez e braveza. Na nova possessão portuguesa, tomou sob sua responsabilidade a condução de Vitor Hugues (1762-1826), ex-governador vencido de Caiena, a ser entregue em Morlaix, na França. Em 1822, já bastante experiente nas atividades da Marinha, o futuro visconde de Cabo Frio passou a defender a Independência. E, finalmente, no ano seguinte, encontrando-se no ministério imperial, Cunha Moreira entretinha ampla correspondência com Caldeira Brant, em Londres, a fim de bem desempenhar a inadiável e vital tarefa de organizar a Armada brasileira. ${ }^{110}$

\footnotetext{
${ }^{109}$ Cf. SILVA, Ignácio Accioli de Cerqueira, op. cit. v. 1. Nota 96, p. 295.

${ }^{110}$ Em 2 de julho de 1823, o Encarregado dos Negócios do Brasil, em Londres, já havia despachado ao ministro Cunha Moreira quatro navios fretados, onde se transportavam centenas de toneladas de cabos e mais ferragens para a organização da Armada, ficando para próxima remessa "[...] todo massame que o Arsenal deveria receber em um ano". Em correspondência anterior, Caldeira Brant informara ao mesmo destinatário:
} 
Conhecendo-se que, anteriormente, José Bonifácio dispusera as instruções para a eleição dos deputados de maneira a reduzir a influência dos portugueses na direção interna da Assembleia, também se verifica que, iniciados os debates parlamentares, houve pressões dos segmentos conservadores tentando o esvaziamento das propostas de cunho mais liberalizante, bem como as deliberadas inventivas visando a execração dos seus defensores. Situação que, por exemplo, se evidenciou quando, em 15 de setembro de 1823, a Assembleia principiou a debater o Projeto de Constituição apresentado pelo paulista Antonio Carlos de Andrada e Silva. Para o que aqui se propõe analisar, interessa, sobremaneira, a discussão do artigo $2^{\circ}$ deste projeto que tratava dos limites territoriais do Império. A redação do texto trazia o nome das dezoito províncias, acrescidas das ilhas de Fernando de Noronha e Trindade e suas cercanias, e no final declarava: "e por federação o Estado da Cisplatina". ${ }^{111}$ A apreciação do artigo foi, então, iniciada pelo deputado cearense, e ex-revolucionário de 1817, José Martiniano de Alencar, o qual não teve dúvidas sobre o fato de o Estado da Cisplatina encontrar-se separado do restante do território do Império e, por essa razão, não via como a Assembleia tratar da questão via lei constitucional. Por isso, enquanto o governo não prestasse maiores informações sobre a real situação da Cisplatina, propôs o adiamento da matéria, no que obteve o apoio da maioria.

Mas quando tudo seguia por esse caminho, o deputado baiano Ferreira França apresentou, em 17 de setembro, uma emenda que substituía as palavras "por federação" no final do art. $2^{\circ}$ por uma redação a constar no início do texto: "compreende confederalmente as províncias [...]". ${ }^{112}$ Dali por diante, ninguém mais duvidava que a questão federativa deveria ser apreciada pela Assembleia, razão pela qual encetava um caloroso debate político que, dentre outras situações, punha a descoberto a impossibilidade de pensar a representação da província baiana de 1823 como uma "bancada" no sentido moderno da expressão. Havia, irremediavelmente, divergências políticas entre seus representantes, o

\footnotetext{
"Tenho a satisfação de anunciar a Vossa Excelência que neste momento fixei o ajuste [de preços] com mister Barley, segundo as condições por Vossa Excelência estipuladas, do que já tinha poucas esperanças pela alta dos gêneros navais em consequências dos rumores de guerra [na Europa]. As primeiras 100 toneladas serão remetidas de hoje a 6 semanas, assim ventos contrários não retardem a saída do navio, porque este porto é o pior do mundo; 4 ventos diferentes são precisos para sair do Rio e Canal" . Cartas sobre a Independência, de 1822 a 1823. In: ARQUIVO NACIONAL, op. cit. p. 314 e 342.

111 As províncias eram as mesmas pertencentes ao Reino do Brasil, ou seja: Pará, Rio Negro, Maranhão, Piauí, Ceará, Rio Grande do Norte, Paraíba, Pernambuco, Alagoas, Sergipe d'El Rei, Bahia, Espírito Santo, Rio de Janeiro, São Paulo, Santa Catarina, Rio Grande do Sul, Minas Gerais, Mato Grosso, conformando, portanto, dezoito províncias e mais o Estado da Cisplatina. CONSORTE, Josildeth Gomes, op. cit. p. 246.

112 Apud RODRIGUES, José Honório, 1974, op. cit. p. 113.
} 
que não raramente os colocariam em lados opostos sobre os rumos dos trabalhos da Constituinte. ${ }^{113}$

Montezuma, por exemplo, defendeu vigorosamente a emenda proposta por Ferreira França, entendendo que a admissão da confederação provincial não contrariava os princípios da Assembleia e a expectativa da nação. Todavia, a resposta jurídica e política contrária à federação descobriu-se no discurso ostensivo do também baiano Carvalho e Mello. Dizendo-se assombrado e espantado com o que ouvia em plenário, o futuro visconde de Cachoeira nuançava com cores catastróficas a discussão: "Com que maravilha, torno a dizer, vejo naquela emenda sustentar-se uma doutrina que pode trazer sobre nós imensos males". ${ }^{114} \mathrm{E}$, assim, a linha intimidante avançava, alertando a toda Assembleia que a aprovação da emenda seria o mesmo que declarar: "[...] desmanchem-se os laços que nos ligam, cada uma das províncias separe-se e faça o seu governo". ${ }^{115}$ Em termos mais realistas, no entanto, procurou fazer crer que a ideia de federação era própria de associações e estados independentes, unidos pelos vínculos promovidos por uma constituição geral.

Todavia, a proposta de Ferreira França encontrou no deputado paraibano e proprietário Joaquim Manoel Carneiro da Cunha e no padre cearense José Martiniano de Alencar apoios relevantes. A princípio, defenderam a irrestrita liberdade de opinião e a inviolabilidade dos deputados, ao enfatizarem a aceitabilidade dos ataques somente quando direcionados às ideias, mas, sob nenhum pretexto, às pessoas. Desqualificavam, assim, o ofensivo discurso de Carvalho e Melo. Entretanto, a discussão ganhou desdobramentos importantes quando Alencar inseriu no debate sobre a federação as situações das províncias do Pará e do Maranhão que ainda se encontravam sob o domínio dos portugueses europeus. Em linhas gerais, a sua arguição consistiu em demonstrar à Assembleia que, supostamente, havendo declarado as mesmas províncias uma união à parte com o Império do Brasil na forma federativa, nem o governo, nem ainda a Constituinte teria poder de obrigá-las ao contrário. Nesta mesma linha de raciocínio afirmava que o procedimento das Cortes de Portugal negando as autonomias provinciais levaram-na ao seu descrédito político, portanto, não pretendessem os deputados ir pelo

\footnotetext{
${ }^{113}$ Josildeth Gomes percebeu bem as controvérsias em torno da atuação na Constituinte de representantes como os da Bahia ao informar: "É que o sentido de arregimentação, de unidade de opiniões por província então não existia. Valiam mais as ideias que cada um abraçava a consciência de ideias que cada um possuía". Idem, ibidem. p. 247.

${ }^{114}$ Apud RODRIGUES, José Honório, 1974, op. cit. p. 114.

115 Apud CONSORTE, Josildeth Gomes, op. cit. p. 247.
} 
mesmo caminho, forçando as províncias que ainda não haviam decidido se unir ao Império do Brasil. Daí, porque, apoiava a emenda em pauta. ${ }^{116}$

Montezuma e Ferreira França se revezaram na defesa dos princípios da federação, dizendo-se convencidos que por Estados federados não se deviam compreender Estados independentes, pois todas as províncias seriam dependentes somente no que fosse fundamental à manutenção dos princípios monárquicos representativos adotados pela nação. ${ }^{117}$ Com o avançar do debate, ia tornando-se cada vez mais evidente o quão diverso eram as posições dos representantes da província baiana. Desta feita, foi Silva Lisboa quem fez uso da palavra com o propósito de não apenas aterrar os preceitos federalistas, mas também de defender a conformação do arranjo institucional propício à centralização do poder e à união de todas as províncias ao Império do Brasil. ${ }^{118} \mathrm{Sem}$ rodeios e com um discurso vazado em sólida erudição, o futuro visconde de Cairu tratou de impugnar a emenda, de modo a não deixar dúvidas sobre a sintonia entre seu pensamento e o defendido por Carvalho e Melo. A rigor, as posições entre estes dois baianos já poderiam ser tomadas como aquelas que caracterizariam a conduta da ala conservadora na Assembleia. Embora a discussão continuasse no dia seguinte e incorporasse novos deputados ao debate, prevaleceu a vontade centralizadora, sendo aprovado o art. $2^{\circ}$ como estava originalmente redigido. ${ }^{119}$

Posições acentuadamente divergentes entre deputados constituintes oriundos da Bahia podem ser também percebidas quando, em 23 de setembro, o artigo $5^{\circ}$ foi apreciado. ${ }^{120}$ A proposta inicial da discussão era definir "os membros da sociedade" para o Império do Brasil. O primeiro deputado a se manifestar sobre a matéria foi o paulista Nicolau Pereira de Campos Vergueiro (1778-1859) que apresentou uma emenda para a substituição do termo membro presente na epígrafe do artigo - "Dos membros da sociedade do Império do Brasil" - pela expressão cidadãos. A emenda apresentada por

\footnotetext{
116 Publicado em 1952, o artigo de Josildeth Gomes já suscitava uma importante reflexão ao chamar a atenção para o fato de as capitanias da América portuguesa terem sido sempre governadas verticalmente pela Coroa de Portugal e que somente com a transferência da corte bragantina para o Brasil aquela situação se vira profundamente alterada. CONSORTE, Josildeth Gomes, op. cit. p. 251.

${ }^{117}$ RODRIGUES, José Honório, 1974, op. cit. p. 114-115 e CONSORTE, Josildeth Gomes. p. 248.

${ }^{118}$ RODRIGUES, José Honório, 1974, op. cit. p. 270.

${ }^{119}$ Idem, ibidem. p. 117-118.

${ }^{120}$ Ao analisar a tradição da legislação portuguesa relativa aos direitos de cidadania, Andréa Slemian registrou que, de acordo com aqueles critérios, "todos os homens livres eram entendidos como cidadãos (como moradores da 'cidade') desde que respeitadas as diversas categorias que o diferenciava segundo a concepção de desigualdade entre as ordens anteriormente existentes”. SLEMIAN, Andréa, 2005, op. cit. p. 830 .
} 
Vergueiro não foi aprovada e o debate seguiu com posicionamentos de diferentes deputados sobre a definição de quem poderia ser considerado brasileiro. ${ }^{121}$

Francisco Montezuma demarcou distinções de direitos entre aqueles cidadãos que teriam participação civil e política diferenciada no cômodo da nação. Por esse motivo, declarou: "Ser Brasileiro, é ser Membro da Sociedade Brasílica: portanto todo o Brasileiro é Cidadão Brasileiro: convém sim dar a uns mais direitos, e mais deveres do que a outros: e eis aqui Cidadãos ativos, e passivos". ${ }^{122} \mathrm{O}$ deputado baiano, no entanto, considerou que os índios estavam fora da sociedade imperial, viviam em guerra aberta com esta, mas seria preciso facilitar os recursos de o Império os chamar à civilização. Por isso, propunha que se legislasse para os indígenas em capítulo separado. Quanto aos escravos, mesmo os crioulos - ou seja, os cativos nascidos no Brasil - Montezuma, a quem não se deve esquecer que era mulato, filho de uma mulher negra e de um português, defendeu que devido às "leis os trata[re]m e reconhece[re]m como simples "coisas ou propriedade de alguém", estes só poderiam ser reconhecidos como "habitantes do Brasil", não enquanto cidadãos. $^{123}$

O também baiano Luís José de Carvalho e Melo discordou da posição que vinha se afirmando na Assembleia e, em função disso, manifestou-se favorável a reconhecer como cidadãos brasileiros tanto os nascidos no território da antiga América portuguesa, quanto os que, assim, se tornaram em observância da lei. Resumia, então, a questão da seguinte forma: “[...] reputo Cidadão Brasileiros todos que nasceram no território deste Império, ou que se tornaram tais por força e determinação da Lei. É princípio geral de Direito Público que são Cidadãos todos acima referidos, porque gozam da proteção das Leis, estão a abrigo dela, e formam parte da Cidade ou Sociedade". ${ }^{124}$ Em seguida, Carvalho e Mello recordava que as bases da Constituição aprovadas nas Cortes de Lisboa (1821), e anteriormente as bases da Constituição da Espanha admitida em Cádis (1812), seguiam, de fato, o princípio de primeiro declararem os cidadãos e somente a partir daí marcarem as exceções dos que usufruiriam de certos direitos políticos. Mas reiterava que as distinções privando alguns membros do Império da qualificação de cidadãos revelavamse odiosas e injustas e, por isso, defendia que o artigo $5^{\circ}$ tivesse a sua redação alterada para: "São cidadãos brasileiros", ao invés de somente designar: "São brasileiros", deixando

\footnotetext{
${ }^{121}$ RODRIGUES, José Honório, 1974, op. cit. p. 122.

122 Apud SLEMIAN, Andréa, 2005, op. cit. p. 836.

123 Apud CONSORTE, Josildeth Gomes, op. cit. p. 252-253.

${ }^{124}$ Apud SLEMIAN, Andréa, 2005, op. cit. p. 839.
} 
que um capítulo próprio definisse quem estaria capacitado a exercer os direitos políticos. Sua proposição recebeu apoios importantes, sendo aprovada pela Assembleia. ${ }^{125}$

Os argumentos de Carvalho e Melo foram corroborados pelo seu companheiro da área jurídica e representação provincial, o deputado Francisco Carneiro de Campos que, em termos claros, delimitou a assimetria entre os "cidadãos" e os que poderiam ser considerados "simplesmente Brasileiros":

Ora, por exemplo, os escravos e os estrangeiros também se poderão entender membros no sentido deste Capítulo? Não, por certo; entram na sociedade de homens, mas não na sociedade de homens que gozam dos direitos de cidade conforme a Constituição. O nosso intento é só determinar, quais são os Cidadãos Brasileiros, e estando entendido que [sic] eles são, os outros poder-se-iam chamar simplesmente Brasileiros, a serem nascidos no país, como [os] escravos crioulos, os indígenas, etc. mas a Constituição não se encarregou desses, porque não entram no pacto social: vivem no meio da sociedade civil, mas rigorosamente não são partes integrantes dela. ${ }^{126}$

No que diz respeito aos embates entre os primeiros representantes da província da Bahia na Assembleia, a apreciação do Projeto de Constituição referente ao $\S 2^{\circ}$ do art. $5^{\circ}$ ganhava relevância, posto que admitisse como "Cidadãos Brasileiros": "Todos os portugueses residentes no Brasil antes de 12 de Outubro de 1822", data em que d. Pedro fora aclamado imperador. ${ }^{127}$ Como era de se esperar, a discussão acerca deste tema teriam ilações controversas, pois os desdobramentos em torno do seu enunciado lançariam, irremediavelmente, ao centro do debate um sem número de lutas tácitas, bem como os conflitos abertos e violentos que levaram a profunda ruptura entre a nação de Portugal e o Brasil, os quais, não se podia esquecer, decidiram pela afirmação da Independência política e formação do Estado e da nação brasileiros à revelia dos interesses do Império português. Além do mais, segundo notícias correntes no Rio de Janeiro, as províncias do Pará e Maranhão ainda se batiam contra as tropas portuguesas contrárias às suas emancipações políticas, o que, sem dúvida, embaraçava a proposta do parágrafo posto em discussão. ${ }^{128}$

\footnotetext{
${ }^{125}$ RODRIGUES, José Honório, 1974, op. cit. p. 125. Da forma como foi aprovada, a proposta assegurava a igualdade jurídica para os habitantes do Brasil nascidos livres e os estrangeiros naturalizados. Afinal de contas, reforçava-se a ideia de que a sociedade era naturalmente desigual, conquanto deixasse entreaberta as possibilidades de mobilidade política por meio das capacidades individuais, bem no estilo preconizado pelo modelo de cidadania liberal. Para o aprofundamento desta análise, ver SLEMIAN, Andréa, 2005, op. cit.

${ }^{126}$ Apud SLEMIAN, Andréa, 2005, op. cit. p. 840.

${ }^{127}$ Apud CONSORTE, Josildeth Gomes, op. cit. p. 254.

${ }^{128}$ José Honório Rodrigues registrou que somente em 2 de outubro a Assembleia começou a inteirar-se da Independência do Maranhão e, contados mais vinte e cinco dias, chegaram as primeiras notícias dando conta de que as tropas portuguesas também haviam abandonado a província do Pará. RODRIGUES, José Honório, 1974, op. cit. p. 117.
} 
O eixo de análise aqui objetivará identificar os posicionamentos dos deputados oriundos da Bahia sobre a incorporação dos segmentos sociais de origem portuguesa que continuavam habitando ou tinham interesse em retornar ao Brasil depois de tê-lo abandonado durante os conflitos políticos da Independência. Podendo pautar-se na prática da província, na qual uma parcela significativa da população enfrentara um ano de guerra contra os portugueses, a assimilação dos vencidos no interior da nova sociedade que se erigia demandava a negociação de critérios sobre os quais se pudesse novamente firmar uma harmonia social de convivência recíproca entre as partes. ${ }^{129}$ No campo de experiência baiana, como já registrado, as convenções facilitando as incorporações dos portugueses e de seus capitais à sociedade tornaram-se manifestas dias antes do embarque das tropas inimigas, visto que o Conselho e o Exército, em atenção às orientações da corte, empenharam-se em garantir a integridade física, familiar e a inviolabilidade das propriedades de todos aqueles que desejassem permanecer na província.

Iniciado o debate, Francisco Montezuma inscreveu-se para combater a iniciativa de a Constituição atribuir o título de cidadão aos "portugueses" só porque estes residiam no Brasil antes da aclamação do imperador. Defendia que essa condição não podia ser suficiente para determinar quais destes indivíduos haviam apoiado a causa brasileira. Portanto, o que se deveria assegurar era a assimilação do lusitano que, renunciando ao direito de cidadania portuguesa, expressasse o desejo de pertencer à nação brasileira, posto que a maneira mais simples de eles explicitarem essa vontade seria jurando a Carta fundamental em elaboração pela Assembleia. Neste sentido, apresentou a emenda considerando cidadãos brasileiros: "Todos os portugueses residentes no Brasil que jurarem a Constituição do império". 130

Advogando uma ampla conciliação, Francisco Carneiro de Campos propunha que se alterasse a redação do parágrafo declarando cidadãos brasileiros: “Todos os portugueses residentes no Brasil antes de 12 de outubro de 1822 e que continuaram a residir no Brasil depois daquela época". ${ }^{131}$ Já Carvalho e Mello e Antônio Luís Pereira da Cunha defenderam desabrigadamente que não fossem impostas diferenciações entre os portugueses que aceitaram ou não a ruptura política com Portugal. Partiam do princípio de que em tempos de Revolução nem todos os indivíduos têm discernimentos sobre qual a

\footnotetext{
${ }^{129}$ Esboçava-se ali a perspectiva a ser defendida por lideranças como o futuro visconde de Cairu que compreendia como um dos princípios do liberalismo político a capacidade de integrar os vencidos aos vencedores, tanto assim que anunciara em uma das sessões da Constituinte: "Ninguém de honra insulta prostrados". Apud RODRIGUES, José Honório, 1974, op. cit. p. 263.

${ }^{130}$ Apud CONSORTE, Josildeth Gomes, op. cit. p. 254.

${ }^{131}$ Apud RODRIGUES, José Honório, 1974, op. cit. p. 128.
} 
melhor conduta a ser seguida. Portanto, a Constituição só deveria exigir a obediência dos portugueses após ter sido proclamada a Independência, ficando os seus comportamentos anteriores em irrevogável esquecimento. Neste sentido, Carvalho e Melo pleiteava a dilatação do adjetivo "residente", o qual deveria permitir aos portugueses possuidores de estabelecimentos ou famílias no Brasil - mas que se retiraram devido às convulsões políticas - o direito de retornarem e de ser integrados à cidadania brasileira nos termos estipulados no parágrafo em discussão. ${ }^{132}$

Deputado eleito pela província do Rio de Janeiro, onde, naquela época, se encontrava a mais sólida comunidade de lusitanos do Brasil, ${ }^{133}$ José Joaquim Carneiro de Campos empenhava-se para abrigar os interesses dos portugueses sem dissociá-los dos demais brasileiros, visto considerar que, em termos contratuais, a própria fundação da "Nação" tornava imprescindível a realização de um novo "Pacto Social". Em termos objetivos, esta conciliação fora, assim, defendida pelo futuro marquês de Caravelas: "Deixamos de ser Portugueses, e passamos a ser Brasileiros, desde que pela insurreição do Brasil se dissolveu o antigo Pacto Social que nos ligava à Monarquia Portuguesa [...] pois não é o lugar do nascimento por si só o que constitui, a qualquer Cidadão desta ou daquela Nação, porém sim o Pacto Social expresso, tácito ou presumido". ${ }^{134}$ Eleito igualmente pelos habitantes da capital do Império, Pereira da Cunha estipulava a decisão de se tornar ou não brasileiro quase como uma transação de vantagens, um negócio mesmo, no qual a grande contribuição do que se tornara o Brasil viera de Portugal:

Nós formávamos uma só família Portuguesa: este País não era nosso, ele foi pelos Portugueses conquistados aos Índios seus habitantes Indígenas, aos quais subjugamos por força de armas, e de estratagemas. Dividimos agora em duas Nações, escolha cada um o que mais lhe convier segundo seus interesses, sem ódios, e rivalidades pessoais, impróprias de Povos civilizados. ${ }^{135}$

Entremeado às defesas enaltecedoras do elemento português, da sua contribuição para consolidar o processo civilizacional no Brasil, tornava-se cada vez mais clara a postura entre os deputados que abraçavam a defesa dos interesses do grêmio lusitano, cujo segmento se reaproximava do imperador d. Pedro I e era por ele recepcionado com muita

\footnotetext{
${ }^{132}$ CONSORTE, Josildeth Gomes, op. cit. p. 255.

${ }^{133}$ Para a importância da comunidade portuguesa no Rio de Janeiro à época da Independência, ver RIBEIRO, Gladys Sabina, op. cit.

${ }^{134}$ Apud SLEMIAN, Andréa; PIMENTA, João Paulo G. $O$ “nascimento político do Brasil”. As origens do Estado e da nação (1808-1825). Rio de Janeiro: Ed. DP \& A, 2003. p. 102.

${ }^{135}$ Apud SLEMIAN, Andréa, 2005, op. cit. p. 842.
} 
afabilidade. Afinal de contas, o herdeiro de Bragança também era português de nascimento.

Admite-se, portanto, que depois da demissão dos Andrada e as consequentes ascensões ministeriais do baiano José Joaquim Carneiro de Campos (Império e Estrangeiros) e do mineiro Nogueira da Gama (Fazenda), que teriam como companheiros de gabinete os portugueses Miranda Montenegro (Justiça) e Vieira de Carvalho (Guerra), uma postura a favor dos lusitanos residentes no novo Império revelou-se irrefutável. De sorte que, não obstante a continuidade da guerra envolvendo Portugal e sua antiga colônia americana, a Junta Provisória da Bahia fosse determinada pelo governo a alistar e remeter à corte fluminense "todos os portugueses prisioneiros de guerra, que voluntariamente se quisessem engajar no serviço do Brasil". ${ }^{136}$ Vinculado também ao portuguesismo, o deputado por Alagoas Caetano Maria Lopes Gama (1795-1864) lançou uma proposta sobre a aceitabilidade dos portugueses na categoria de cidadãos brasileiros. Com efeito, a emenda desse pernambucano de nascimento tornou-se vitoriosa na medida em que considerou como "brasileiros todos os portugueses domiciliados no Brasil antes de 12 de outubro de 1822, que expressa ou tacitamente se houvessem ligado à sociedade brasileira"; ${ }^{137}$ Ressalte-se que esta redação seria quase inteiramente aproveitada na Carta outorgada de $1824 .{ }^{138}$ Porém, nem mesmo triunfando em pontos importantes para a conformação de alianças entre a antiga classe dominante, representada pelos grandes negociantes e proprietários portugueses, com a classe senhorial que ascendia ao poder, a ala que se aglutinava em torno do herdeiro de Bragança mostrar-se-ia satisfeita com os rumos da Constituinte, preferindo, por isso, envidar esforços para a sua dissolução. ${ }^{139}$

\footnotetext{
${ }^{136}$ ARMITAGE, John, op. cit. p. 78.

${ }^{137}$ Apud RODRIGUES, José Honório, 1974, op. cit. p. 129.

${ }^{138}$ Estipulava a Carta outorgada por d. Pedro I: "São Cidadãos Brasileiros": "Todos os nascidos em Portugal, e suas Possessões, que sendo já residentes no Brasil na época, em que se proclamou a Independência nas Províncias, onde habitavam, aderiram a esta expressa, ou tacitamente pela continuação da sua residência". Carta Constitucional de 1824, Título 2, art. 6, $\S 4^{\circ}$. BRASIL, 1824, op. cit.

${ }^{139}$ Sobre as reiteradas, e às vezes turbulentas, exigências manifestas na capital baiana para expulsão dos portugueses europeus considerados inimigos do "sossego público", bem como sobre as intervenções das autoridades e de parte da classe senhorial para a proteção dos portugueses e de seus capitais, considerados imprescindíveis à recuperação da economia baiana no pós-Independência, ver: SILVA, Ignácio Accioli de Cerqueira. Memórias Históricas e Políticas da Província da Bahia. Anotado por Braz do Amaral. Bahia: Imprensa Oficial do Estado, 1919-1931, v. 4-6; REIS, João José. A elite baiana face os movimentos sociais, Bahia: 1824-1840. Revista de História. São Paulo, Out-dezembro, v. 54, n. 108, ano XXVII. p. 341-384, 1976; RIBEIRO, Gladys Sabina. A liberdade em construção: identidade nacional e conflitos antilusitanos no primeiro reinado. Rio de Janeiro: Relume Dumará, 2002 e SILVA, Daniel Afonso da. Histórias de Bahia. Histórias de Brasil. Apontamentos para o estudo da crise política do Primeiro Reinado na Bahia (1828-1831). Dissertação (Mestrado em História) - Universidade de São Paulo, São Paulo, 2007, especialmente o capítulo 3.
} 
Revela-se igualmente importante verificar que a despeito de a Bahia distinguir-se como uma das províncias com maior contingente de libertos devido à ampla presença da escravidão e das experiências de sociabilidade compensatórias responsáveis por uma pequena, mas contínua, prática de manumissões, poucos foram os deputados baianos contribuintes na apreciação do $\S 6^{\circ}$ do artigo $5^{\circ}$, que considerava "cidadãos brasileiros" "todos os escravos que obtivessem carta de alforria". ${ }^{140}$ Eivados por controvérsias que desnudavam as discriminações raciais da classe dominante, a primeira resistência ao parágrafo fora porque não apresentava distinções entre "libertos crioulos", a bem dizer os nascidos no Brasil, e os africanos. Razão pela qual, o deputado catarinense Manuel José de Sousa França lançava uma emenda para que apenas "os libertos que forem oriundos do Brasil” pudessem ser contemplados na categoria de cidadãos do Império, não obtendo aprovação.

No entanto, a polêmica sobre o $\S 6^{\circ}$ resvalava para obstrução, especialmente no que dizia respeito à concessão de cidadania ao liberto de origem africana. Havia também os que preferiam aprovar sem discussão a emenda, pois recordando as experiências históricas de constituintes anteriores, como a da Assembleia Nacional Francesa (17891792), prevenia a seus pares acerca dos perigos de retirar do silêncio algumas questões, como a que se detinha na excessiva consideração valorativa sobre a "humanidade" da população negra. De maneira explícita, essa fora a postura do ex-revolucionário de 1817 e padre pernambucano Muniz Tavares ao temer que o exame minucioso da emenda exaltasse os ânimos das ruas e das senzalas Brasil afora. Daí o seu pronunciamento na sessão de 30 de setembro:

[...] lembra-me que alguns discursos de célebres Oradores da Assembleia Constituinte de França produziram os desgraçados sucessos da Ilha de São Domingos, como afirmam alguns escritores que imparcialmente falaram da Revolução Francesa; e talvez entre nós alguns Srs. Deputados arrastados de excessivo zelo a favor da humanidade, expusessem ideias (que antes convirá abafar), com o intuito de excitar a compaixão da Assembleia sobre essa raça de homens, que tão infelizes não só porque a Natureza os criou tostados. ${ }^{141}$

\footnotetext{
${ }^{140}$ Apud SLEMIAN, Andréa, 2005, op. cit. p. 844. Tendo por base a situação da capital baiana ao longo do Oitocentos, Kátia Mattoso registrou que no período da Independência "todos os anos cerca de 2,75\% da população escrava de Salvador recebia sua carta de alforria". O incremento nas manumissões concedidas ou compradas - como se tornara mais comum no último século da escravidão - ampliou-se, pois entre 18391840 essa proporção alcançava 4,40\% e chegaria a 6,62\% entre os anos de 1869-1870. MATTOSO, Kátia M. de Queirós, 1992, op. cit. p. 161.

${ }_{141}$ Apud SLEMIAN, Andréa, 2005, op. cit. p. 845. Em alguma medida, os deputados das cortes de Cádis e de Lisboa esforçaram-se para não aprofundar as discussões sobre os escravos e seus descendentes. No que
} 
Preconceitos religiosos e sociais igualmente foram repisados neste debate. Enquanto o deputado pernambucano Manuel Caetano de Almeida e Albuquerque (17891844) lançou na vala comum dos "pagãos e idólatras" os africanos existentes no Brasil, Pedro José Costa Barros (1779-1839), da província cearense, procurou apresentar as sinonímias entre o ser liberto e o ser vadio. ${ }^{142}$ Tudo estava ainda indefinido quando o baiano Silva Lisboa pronunciou-se. Com oratória envolvente e capaz de amoldar o liberalismo econômico ao conservadorismo político, o deputado revelava a necessidade de a Assembleia realizar pequenas concessões para manter o principal fundamento da estrutura macrossocial do Império que, como se sabe, assentava-se na grande propriedade de terras e na exportação de produtos tropicais. A supressão gradual da escravidão - no sentido mais extensivo do termo - e a inserção dos libertos no interior da sociedade apareciam-lhe como necessárias. ${ }^{143}$ Sob este ângulo, o futuro visconde avaliava como justo e liberal o $\S 6^{\circ}$, conquanto oferecesse uma pequena modificação redacional para evitar interpretações diversas. Como resultado, intercedia para serem aceitos na condição de cidadãos brasileiros: "os libertos que adquiriram sua liberdade por qualquer título legítimo". ${ }^{144} \mathrm{E}$, assim, chamava a atenção dos seus pares:

Para que se farão distinções arbitrárias dos libertos, pelo lugar do nascimento e pelo préstimo e ofício? [...] Uma vez que adquiram a qualidade de pessoa civil merecem igual proteção da lei e não podem ter obstáculo de arrendar e comprar terras, exercer qualquer indústria, adquirir prédio, entrar em estudos políticos, alistar-se na milícia e marinha do império. Ter a qualidade de cidadão brasileiro é, sim, ter uma denominação honorífica, mas que só dá direitos cívicos e não direitos políticos [...]. Os direitos cívicos se restringem a dar ao homem livre o jus a dizer: tenho uma pátria, pertenço a tal cidade, não sou sujeito à vontade de ninguém, mas só ao império da lei. ${ }^{145}$

Silva Lisboa também teve que combater os discursos do deputado mineiro João Severiano Maciel da Costa (1769-1833), que se posicionava asperamente contra a assimilação do ex-escravo africano enquanto cidadão brasileiro. Para o futuro marquês de Queluz, se a Constituinte negava aos demais estrangeiros o estatuto da cidadania, era

concerne aos posicionamentos das Cortes de Lisboa sobre a temática, ver BERBEL, Márcia Regina, 1999, op. cit. Para uma recente abordagem sobre como as classes dominantes no Brasil trataram os impasses relativos à temática da escravidão ante a crescente pressão britânica para a cessação do tráfico internacional escravista, ver: BERBEL, Márcia; MARQUESE, Rafael; PARRON, Tâmis. Escravidão e política. Brasil e Cuba: 1790-1850. São Paulo: Hucitec, 2010.

${ }^{142}$ RODRIGUES, José Honório, 1974, op. cit. p. 131-132 e SLEMIAN, Andréa, 2005, op. cit. p. 844-845.

${ }^{143}$ Cf. RODRIGUES, José Honório, 1974, op. cit. p. 268 e segs.

144 SLEMIAN, Andréa, 2005, op. cit. p. 845.

${ }^{145}$ Apud RODRIGUES, José Honório, 1974, op. cit. p. 132. 
espantoso como se revelava sobejamente liberal com o africano que, um dia ainda cativo e noutro obtendo "carta de alforria", passaria automaticamente a pertencer ao "grêmio da família brasileira". ${ }^{146}$ Em contrapartida, o deputado baiano voltava-se para a ferocidade do sistema escravista que depois de explorar detida e sistematicamente o trabalho do cativo lhes deixava, quando o fazia e sempre em pequeno número, com a posse da liberdade formal; e, por isso, concluía que não se devia compará-lo aos demais estrangeiros livres, os quais desejando sempre encontrariam recursos e facilidades para retornarem às suas pátrias. Ao final, a Assembleia ficou com a solução proposta por Silva Lisboa que, em última instância, visava a estabilidade de uma sociedade reconhecidamente heterogênea, mas que admitia a mobilidade como possibilidade tangível para aqueles capazes de reunir às condições propícias às superações das barreiras sociais.

Um dos pontos nodais que levaria à profunda divisão na Assembleia Constituinte foi, como ressaltou José Honório Rodrigues, a discussão do projeto sobre a arrematação da fazenda dos defuntos e ausentes, cuja indicação coube ao deputado de Minas Gerais, e exinconfidente de 1789, José Resende da Costa. ${ }^{147}$ Apresentada à comissão de legislação em 4 de julho, a sua proposta consistia em encontrar um meio legislativo de dar acesso aos exauridos cofres da nação a uma exuberante soma de mais de dois milhões de cruzados que, nominalmente, tinha posse os tesoureiros e oficiais dos juízos das provedorias, muitos dos quais sabidamente dilapidavam as fortunas que deveriam zelar. Funcionário graduado e experiente do ministério da Fazenda, o deputado estava bem informado. E, logo, todos sabiam que estes recursos pertenciam, originalmente, aos variados herdeiros ausentes em Portugal, bem como aos portugueses que se retiraram do Brasil à época da Independência que, declarados inimigos, tiveram seus bens sequestrados. ${ }^{148}$ Resende da Costa solicitava ainda a anulação da Provisão de 28 de dezembro de 1754, destinada a impedir pagamentos das dívidas por escrituração pública contraídas pelos finados a limites superiores a $200 \$ 000$ e as demais em até $100 \$ 000$, ficando a execução do restante na dependência dos herdeiros e ausentes em Portugal ou em outras partes das possessões da nação portuguesa.

Por atingir os interesses econômicos de diversos portugueses, que naquele período voltavam a frequentar as rodas seletas da corte fluminense, a reação ao projeto elaborado foi imediata. Antigo habitante do Rio de Janeiro e habituado aos círculos

\footnotetext{
${ }^{146}$ Idem, ibidem. p. 134.

${ }^{147}$ Idem, ibidem. p. 174 e segs.

${ }^{148}$ De fato, os cofres públicos encontravam-se esgotados, seja pela extração dos recursos que os ministros de d. João realizaram antes da partida do rei para a Europa, seja devido às despesas para as expulsões das tropas portuguesas do território do Brasil promovidas pelas guerras de Independência.
} 
palacianos, o deputado baiano Carvalho e Melo foi o primeiro a defender na Constituinte que o projeto não devia passar a segunda discussão. Dirigindo-se à tribuna duas vezes por esta ocasião, os argumentos jurídicos do futuro visconde de Cachoeira visavam demonstrar a pouca utilidade prática do que se apreciava. Defendia também que a matéria tratava-se de legislação particular e, por isso, deveria ser examinada pela Assembleia regular. Não obstante o esforço, o projeto passou para a segunda discussão, iniciada em 12 de agosto. Novas intervenções seguiram, enfatizando Resende Costa os princípios anteriormente explicados. O projeto, finalmente, entrou na terceira discussão, começada em 16 de agosto. Carvalho e Melo retornou à tribuna, mas as suas considerações jurídicas quase não avançam em novidades. Não via urgência na modificação do regimento dos ausentes e defuntos naquele momento. No futuro, este poderia ser reformado por uma lei geral que possibilitasse a arrecadação das heranças jacentes, tal qual determinava os códigos modernos. E, por isso, voltava a apelar para a Assembleia conservar a lei e a prática, não incorrendo em reformas parciais e aceleradas. ${ }^{149}$

A discussão continuava incerta, pronunciando-se, então, Maciel da Costa. Com razão, José Honório Rodrigues observa que a fala deste futuro marquês era a melhor expressão do antireformismo e ultraconservadorismo na Constituinte. ${ }^{150}$ Nenhum argumento dos que solicitaram a reforma do regimento dos ausentes e defuntos o convenceu da emergência e inevitabilidade da providência sugerida. Compreendia que a Constituinte deveria se dedicar a outros trabalhos, pois a continuar como estava só tenderia a encontrar complicações, ampliar os males, desassossegar os povos, extenuando o pendor moral, como fizeram outras assembleias que acabaram dissolvidas. Ainda que indiretamente, o recado foi dado aos deputados e na época da dissolução ninguém menos do que Maciel da Costa era o presidente daquela Assembleia Constituinte.

Interpretando, mas não se acovardando frente à ameaça que lhes fora lançada, os deputados levaram adiante o debate e as discussões se estenderam pelas sessões seguintes. Dentre os representantes da Bahia que se pronunciaram nesta fase, encontrar-se-iam o exsecretário da segunda Junta da capital baiana, Francisco Carneiro de Campos, que, sem afastar-se da ala conservadora que se conformava no interior da Assembleia, tecia considerações importantes para o entendimento do assunto a ser deliberado. Para tanto, expressava:

\footnotetext{
${ }^{149}$ RODRIGUES, José Honório, 1974, op. cit. p. 177-178.

${ }^{150}$ Idem, ibidem. p. 179.
} 
Se eu houvesse de votar em geral sobre esta matéria, diria que convinha extinguir-se absolutamente o juízo dos ausentes, por ser um juízo excepcional e de privilégio muito odioso, que estabelece distinção absurda entre os direitos e [as] vantagens do credor e devedor, antepondo o ausente que não se sabe quem seja, ao qual dá executivo para cobrar tudo quanto possa pertencer-lhe, ao presente, a quem não permite cobrar senão mínimas quantias e sem aquele privilégio da execução; além de que a simples inspeção do regimento do juízo dos ausentes mostra que ele é um dos ferretes do sistema colonial, destinado só para a Guiné, Mina, Brasil e Açores, e mais partes ultramarinas, das quais se pretendia facilitar a saca [exportação] de capitais para estes se irem acumular no reino de Portugal, calculando-se pouco com os inconvenientes e embaraços a que ficavam sujeitos os moradores do ultramar que haviam transigido com os antecessores dos ausentes, sendo portanto evidente que aquele regimento, além dos defeitos e desigual legislação que compreende, é já incompatível com a declaração de nossa independência, como monumento de um sistema que se acha proscrito. ${ }^{151}$

Por isso, o jurista baiano votaria a favor do projeto com as emendas indicadas pela comissão, pois compreendia como necessária a reforma que assegurasse tanto os direitos das partes envolvidas, como permitisse as transações capazes de mitigarem as inseguranças e atenuarem as objeções do embolso por aqueles de direito.

Miguel Calmon falou no sentido de não se empreender a reforma, posto que entendesse ser infindável o debate que se propusesse destruir aquela legislação. Silva Lisboa também defendia que não se devia alterar o regimento, conquanto adiante afirmasse: “[...] Não digo isto para impugnar absolutamente o projeto de lei, pois estou persuadido que talvez o dito juízo mereça extinção, ou ao menos radical e reverendíssima extinção". Carvalho e Melo mais uma vez se pronunciava com o objetivo de demonstrar que, debalde o esforço a ser realizado pela comissão de redação do projeto, o resultado não deixaria de "ser um monstro que em vez de estabelecer doutrina clara, regular, útil, apresentará conclusões sem nexo, discordantes e até contraditórias". O parecer da comissão apresentado pelo seu relator Maciel da Costa, de fato, traduzia esses embaraços, pois, assim, dispunha a questão: “a lei, por minguada em providências, parece não encher nem a indicação que se fez, nem os fins importantes que a mesma augusta Assembleia se propôs neste ramo interessante da administração". O projeto não tinha salvação, portanto, estava reprovado. ${ }^{152}$

Salienta-se que, a exceção do mineiro Maciel da Costa (relator), os demais membros da comissão que examinaram e rejeitaram o projeto sobre o juízo dos defuntos e

\footnotetext{
${ }^{151}$ Ibidem. p. 181.

152 Apud RODRIGUES, José Honório, 1974, op. cit. respectivamente às páginas 184 e 186.
} 
ausentes eram os baianos: Carvalho e Melo, Miguel Calmon, Francisco Carneiro de Campos e Silva Lisboa. No plenário, havia ainda os conterrâneos José Joaquim Carneiro de Campos, o barão de Santo Amaro e Pereira da Cunha, todos pertencentes ao grupo daqueles que estiveram sempre a postos para obstruir qualquer tentativa de revisão legislativa desfavorável aos portugueses ou aos seus interesses econômicos. As posturas em favor deste continuísmo seriam bem gratificadas, já que todos eles preencheriam funções proeminentes na vida pública ao longo do Primeiro Reinado.

A despeito de ter obstruído o projeto que ambicionou liberar os recursos financeiros empatados por meio do antigo método das cartas régias do tempo do Brasil Colônia, o grupo político e econômico que substituiu o gabinete dos Andrada e passou a sustentar os interesses dos portugueses, não se deu por satisfeito. Houve mesmo a insinuação de que o poder legislativo da Assembleia muito espantava. E, com efeito, não faltou quem cooperasse de maneira ativa, ou simplesmente pela letargia, para a dissolução do primeiro Congresso brasileiro. Muito atento a esta possibilidade, o baiano Cipriano Barata, que, nas palavras de Marco Morel, escolhera o papel impresso e a circulação deste para exercer fora do recinto parlamentário o mandato de deputado constituinte, escrevia aos seus leitores sobre os perigos que rondavam a Assembleia:

[...] se conclui facilmente a razão por que os Reis e seus Sequazes, acostumados a dominarem a Sociedade, lutam para acabar o sistema de Cortes Liberais ou livres; e forcejam para estabelecer a convocação de Cortes Suplicantes; ou ao menos darem Carta a seu arbítrio e [a sua] vontade; nas Primeiras, que são as nossas, o povo prepondera e é o Soberano verdadeiro; nas Segundas, o Rei usurpa o poder Soberano e diz que é o Senhor; e quando se vê apertado recorre para o ardil da Carta, que vem a ser o mesmo que Cortes Suplicantes ou quase Suplicantes. ${ }^{153}$

Dessa maneira, distinguiam-se, no primeiro plano, as cortes gerais típicas do Antigo Regime, onde a soberania era açambarcada e personificada no poder majestático e, em segundo, as assembleias constituintes da fase liberal, resultantes do poder soberano residente no povo e que, por isso, nasciam e permaneciam legítimas. Pressupunha, no entanto, que o mesmo povo devesse vigiar e garantir a autonomia da Constituinte e, sob hipótese alguma, aceitar a imposição de uma Carta. Nesta primeira infância dos poderes

${ }^{153}$ Gazeta Pernambucana, n. 16, 14 de julho de 1823. Recife, Tipografia de Cavalcante e Carvalho. In: BARATA, Cipriano, 2008, op. cit. p. 169. Não se deve deixar de observar que esse alerta de Cipriano ocorreu justamente no período em que os deputados debatiam o juízo de defuntos e ausentes, propiciando Maciel da Costa mencionar o alvitre de uma possível dissolvência da Assembleia. Para a interpretação de Marco Morel sobre as funções desempenhadas por Cipriano Barata enquanto transcorriam as atividades da Constituinte, ver BARATA, Cipriano, 2008, op. cit. p. 162. 
constitucionais organizados a partir do Brasil, Cipriano Barata advertia que ao imperador cabia estudar política e outras práticas de bem governar e nelas se contentasse, uma vez que: "A sua insígnia não é espada é cetro". ${ }^{154}$ Pouco depois dessa fala, quando a Assembleia Constituinte iniciava seus trabalhos na corte fluminense, em 3 de maio, Cipriano bradara da sua sentinela na guarita de Pernambuco:

Ó do Brasil, alerta! Fora o sistema do terror. Fora Carta de Constituição! Não se deve aceitar senão Constituição liberal segundo aquelas bases juradas que devem ter efeito. Este foi o ajuste que as Províncias fizeram com o Rio de Janeiro; é preciso cumpri-lo. Os povos não devem ser enganados. As Províncias são livres. Ninguém deve querer a escravidão. Ó das Províncias, Alerta! ${ }^{155}$

Em 18 de junho, saiu na Sentinela da Liberdade uma análise a respeito da famosa Fala do Trono, produzida pelo imperador na abertura dos trabalhos da Constituinte. $\mathrm{O}$ viés discursivo ali sustentado objetivava novamente a demonstração de que a soberania da nação residia no povo, o qual de posse deste direito "imprescritível" decidira delegar o poder executivo a d. Pedro que, em última instância, também estaria sujeito a cumprir as suas atribuições, de acordo com as leis, como qualquer outro "Cidadão". De sorte que, Cipriano indagava sobre as razões pela quais se difundiam os receios relativos aos

[...] Ilustres Deputados se acovard[ar]em à vista da fala feita por Sua Majestade Imperial, em que declara que se deve fazer uma Constituição digna dele. Como se a Constituição fosse ordenada ou dirigida ou feita por ele. E, se, pelo contrário, ele não fosse obrigado a obedecer a Constituição, como um Cidadão escolhido pela graça do povo para exercer certas funções. Parece que Sua Majestade está persuadido que ele é que dá Constituição ao povo, quando é o contrário, pois o povo é que dá Constituição ao Imperante. O Brasil agora é que se está Constituindo, o povo é o verdadeiro Soberano. ${ }^{156}$

A luta dos radicais exaltados e demais defensores dos ideais liberais próprios da Era das Revoluções e em prol de uma Constituição elaborada pelos legítimos representantes da nação brasileira que se formava fora, de fato, desproporcional. Isto porque, assegurada a ruptura política com Portugal, a classe senhorial havia alcançado o

\footnotetext{
${ }^{154}$ Sentinela da Liberdade na Guarita de Pernambuco Alerta!, n. 5, quarta-feira, 23 de abril de 1823. Recife, Tipografia de Cavalcante e Carvalho. In: BARATA, Cipriano, 2008, op. cit. p. 194.

${ }_{155}$ Sentinela da Liberdade na Guarita de Pernambuco Alerta!, n. 9, sábado, 3 de maio de 1823. Recife, Tipografia de Cavalcante e Carvalho. Idem, ibidem. p. 209. Como observa Marco Morel, devido à publicação do conteúdo desse número do jornal, Cipriano Barata foi submetido a processo por crime de imprensa. Idem, ibidem. Nota 1, p. 207.

${ }^{156}$ Sentinela da Liberdade na Guarita de Pernambuco Alerta!, n. 22, quarta-feira, 18 de junho de 1823. Recife, Tipografia de Cavalcante e Carvalho. In: BARATA, Cipriano, 2008, op. cit. p. 284-285.
} 
seu projeto político-econômico principal que era libertar o Brasil das amarras do estatuto colonial, ter a seu dispor a liberdade de comércio e garantir a autonomia administrativa, inclusive com o alargamento na gestão da coisa pública. No mais, estava disposta a negociar os termos da Independência. ${ }^{157}$ Os homens de Estado desta nova fase efetivamente não desejavam uma luta continuada com os grandes negociantes e demais representantes portugueses que inegavelmente cederam-lhes o posto de classe dominante por excelência, mas que saberiam manter, por muito mais tempo, suas capacidades de interação com o poder, visando vantagens a serem transacionadas com o mínimo de atrito na esfera imperial. Por certo, havia aqueles que sonhavam ainda com a possibilidade de realinhamento político com a nação portuguesa ou, ao menos, com o governo absoluto via o herdeiro de Bragança, mas inexoravelmente o senso de realidade sobressairia e estes cederiam às conquistas do tempo.

No contraponto da Sentinela da Liberdade, os redatores dos periódicos fluminenses Atalaia, do baiano Silva Lisboa, e Estrela Brasileira, cuja direção encontravase um poeta e aventureiro de nacionalidade francesa Jean-Baptiste Aimé de Loy, ${ }^{158}$ favoreciam a difusão das ideias legitimistas com as quais o imperador procurou se valer para levar adiante o projeto de desbaratar a Assembleia e, em seguida, outorgar uma Carta Constitucional à nação brasileira. A rigor, a perspectiva de dissolução adquiria densidade à medida que o grupo português se via fortalecido em torno do herdeiro de Bragança. A isto, acrescenta-se o fato realçado por Varnhagen, que a possibilidade de o imperador dissolver a Constituinte teria sido apresentada, inicialmente, pelo ministro José Bonifácio a d. Pedro como recurso a ser aplicado em caso extremo. ${ }^{159}$ Situação que parece ainda mais veraz quando se sabe que o então ministro da Justiça Diogo Feijó, tempos depois, em sessão de 21 de maio de 1832 da Câmara dos Deputados, declarou ter ouvido de um dos Andrada provavelmente referindo-se a Antonio Carlos -, quando estes ainda controlavam o gabinete, o seguinte: "Se a Assembleia não fizer o que o imperador quer, ele a dissolverá. Se a nova não der uma Constituição digna dele, ele a tornará a dissolver e dará ao Brasil uma Constituição". ${ }^{160}$ Por sua vez, Tobias Monteiro atribuiu que a atuação "do partido

${ }^{157}$ COSTA, Emília Viotti da. Da Monarquia à República: momentos decisivos. 8. ed. rev. e amp. São Paulo: Ed. Unesp, 2007. p. 60.

${ }^{158}$ Cf. LUSTOSA, Isabel. Insultos impressos: a guerra dos jornalistas na Independência (1821-1822). São Paulo: Companhia das Letras, 2000. p. 384. Ao menos no que respeita ao redator do periódico Estrela Brasileira, corria a notícia de que d. Pedro I repassava-lhe recursos financeiros para ser divulgados conteúdos favoráveis aos ideais dominantes na corte fluminense naquele período. Idem, ibidem loc cit.

${ }^{159}$ VARNHAGEN, Francisco Adolfo de, op. cit. p. 224.

160 Essa informação encontra-se, em nota de Rio Branco, na abra de Varnhagen sobre a Independência. VARNHAGEN, Francisco Adolfo de, op. cit. Nota 132, p. 224. 
andradino, ligado a elementos dirigidos por Felisberto Caldeira Brant", embalara uma expectativa de renovação do ministério, encampado somente pelos brasileiros natos, os quais receberiam os apoios dos Andrada e de Caldeira Brant e teriam, assim, campo aberto para procederem a dissolução e a outorga de uma Carta. ${ }^{161}$

Por tudo isto, se compreende que a dissipação da Assembleia e a imposição de uma Carta de Constituição, ocorrendo sob dadas condições, encontrariam apoios ativos, ou ainda tácitos, em parte não desprezível dos deputados. Entretanto, durante o desenrolar dos acontecimentos verificados na Constituinte, quando, em 8 de novembro de 1823 pôs-se em apreciação o requerimento do boticário David Pamplona Corte Real solicitando providências sobre a segurança pública e individual dos cidadãos, o processo de usurpação dos direitos da Constituinte passou, indubitavelmente, à articulação e execução das tropas imperiais diretamente subordinadas a d. Pedro I, cujo comportamento, naquela conjuntura, seria largamente aprovado pelos segmentos associados ao portuguesismo. ${ }^{162}$

O requerente Pamplona pedia à Assembleia providências contra as condutas dos militares de origem portuguesa, no caso o major José Joaquim Januário Lapa e o capitão Zeferino Pimentel Moreira Freire, os quais, depois de o confundirem como sendo o autor das cartas impressas que levava a assinatura de "Brasileiro Resoluto", deram-lhe uma sova com bengalas; não obstante o fato dele também ser português nascido no Açores. ${ }^{163}$ Iniciados os debates na Assembleia sobre o requerimento em pauta, elegeu-se, em plenário, uma comissão especial de justiça para examiná-lo composta por Pedro de Araújo Lima (1893-1870), futuro marquês de Olinda, Caldeira Brant, o barão de Santo Amaro Nicolau Vergueiro e José Bonifácio. Na sessão do dia seguinte, 9 de novembro, a comissão concluiu o parecer opinando que a petição não era de competência legislativa, mas sim judiciária, devendo o ofendido impetrar os recursos ordinários que as leis demarcavam para o caso. ${ }^{164}$

\footnotetext{
${ }^{161}$ MONTEIRO, Tobias, 1981, op. cit. t. 2, p. 757. A formação deste ministério ficaria restrita a convocação de quadros externos à Assembleia pois, após as exceções concedidas ao baiano José Joaquim Carneiro de Campos (Império) e ao mineiro Nogueira da Gama (Fazenda) para assumirem pastas ministeriais sem interromper suas atividades parlamentares, os deputados, por medida de lei, vedaram o acúmulo simultâneo de cargos ou funções públicas entre seus membros. Idem, ibidem. Loc. cit.

${ }^{162}$ Cf. ARMITAGE, John, op. cit. p. 80-81.

${ }^{163}$ VARNHAGEN, Francisco Adolfo de, op. cit. p. 211. Consta que as cartas do "Brasileiro Resoluto", combatendo justamente a admissão dos portugueses no Exército e reputando os mencionados oficiais lusitanos à condição de contrários à Independência, foram publicadas no periódico Sentinela da Praia Grande que juntamente com o Tamoio faziam oposição ao governo. RODRIGUES, José Honório, 1974, op. cit. p. 201-202.

${ }^{164}$ VARNHAGEN, Francisco Adolfo de, op. cit. p. 216.
} 
Nestas sessões, que se mostrariam decisivas à Assembleia, interessa observar, mais uma vez, o comportamento dos deputados que representavam diretamente a Bahia ou ali haviam nascido. Disposto a trazer mais elementos para a discussão sobre o requerimento em pauta, Montezuma exigiu a leitura dos documentos anexos para, somente assim, expor seu voto. Escudado nas divergências políticas com os lusitanos que, conforme se deduz, eram latentes desde a sua saída forçada de Salvador em direção ao Recôncavo, ocorrida logo depois de 20 de agosto de 1822, o deputado baiano declarou: "Eu vejo que dois oficiais portugueses foram atacar a casa de um cidadão brasileiro, e como eu tenho aqui falado a favor da minha pátria e contra tudo que é lusitano, receio que qualquer dia me façam o mesmo". ${ }^{165}$ Dessa maneira, reiniciava na Assembleia o embate sobre a competência ou não de se instaurar um processo contra oficiais portugueses o que, em última instância, daria azo ao imperador e aos seus aliados, reunidos a partir do palácio de São Cristóvão, a por em ação o nunca desprezado plano de aniquilar de uma vez a Constituinte.

Em considerável quantidade, o povo compareceu à sessão da Assembleia, em 10 de novembro, ocupando rapidamente todas as galerias. E, como ainda havia pessoas aguardando o acesso ao interior da Casa, Martiniano de Alencar propôs que parte delas fosse realocada no vão restrito detrás das cadeiras dos deputados. Como esta concessão não era prevista pelo regimento, Silva Lisboa reclamou do procedimento. Para ele, a alteração da ordem era devida à maneira desordenada com que o povo adentrara na sala, dando, no entanto, ensejo à exclamação de Antonio Carlos: "O que me admira é haver tanto medo do povo e tão pouco da tropa! No meio do povo brasileiro nunca podemos estar mal", ao que deputados e público manifestaram apoios entusiasmados. ${ }^{166}$ Ainda assim, Carneiro de Campos e Martim Francisco advertiram que o povo não poderia extenuar sinais nem de aprovação, nem ainda de repulsão ao que seria analisado.

Quando efetivamente principiou o debate sobre o parecer da comissão especial acerca do requerimento de Pamplona, Antonio Carlos e Martim Francisco, hostis, como declaradamente eram, à indiscriminada admissão dos lusitanos no Exército, denunciaram as agressões como exemplo de continuado casuísmo por parte do oficialato português com diversos cidadãos brasileiros. Neste sentido, realçaram que o ataque tinha por alvo certo o "Resoluto Brasileiro" e, extensivamente, dizia respeito ao "Povo do Brasil". Antonio Carlos instava a Maciel da Costa, então presidente da Assembleia, ao observar:

\footnotetext{
${ }^{165}$ Apud RODRIGUES, José Honório, 1974, op. cit. p. 201.

${ }^{166}$ Apud MONTEIRO, Tobias, 1981, op. cit. t. 2, p. 774.
} 
[...] Ainda é tempo, Sr. Presidente, de prevenirmos o mal, enquanto o vulcão não arrebenta; desaprove-se o parecer da Comissão, reconheça-se a natureza pública agravante do ataque feito ao Povo do Brasil, punam-se os temerários que ousaram ultrajá-lo, abusando da sua bondade, não poluam mais a sua impura presença o sagrado solo da liberdade, da honra e do brio; renegue-os o Império, e os expulse de seu seio [...]. ${ }^{167}$

Diante do discurso, era quase impossível o público não se manifestar, inclusive com aplausos, os apoiados que diferentes deputados hipotecaram ao orador. O presidente Maciel da Costa, no entanto, diligenciou um novo pedido de silêncio, mas como as vozes do povo se misturavam às dos deputados, decidiu-se, sem mais, interromper a sessão, declarando-a suspensa. Resolução que serviria de pretexto para o imperador declarar que a Assembleia tornara-se tumultuária e anarquizada, favorecendo ao seu fechamento. ${ }^{168}$

De fato, nesse mesmo dia 10, d. Pedro havia organizado o terceiro gabinete imperial, entregue ao fluminense Francisco Vilela Barbosa (1769-1846), depois marquês de Paranaguá, o posto de ministro do Império e Estrangeiros; ao português Sebastião Luís Tinoco da Silva (1758-1839) o da Fazenda; ao baiano Clemente Ferreira França, depois marquês de Nazaré, a pasta da Justiça; ${ }^{169}$ ao fluminense José de Oliveira Barbosa (17531844), futuro visconde do Rio Comprido, o ministério da Guerra; e, por fim, manteve no comando da Marinha o baiano Luís da Cunha Moreira que, segundo consta, não se destacava pela atuação política. Sobre as razões dos afastamentos dos também deputados José Joaquim Carneiro de Campos e Nogueira da Gama dos ministérios, a historiografia diverge. No entanto, é plausível o argumento de que estas demissões obedeciam ao princípio de se nomear pessoas estranhas à Assembleia que não deveriam perder na apreciação de suscetibilidades sobre haver legitimidade ou não na dissolução da

\footnotetext{
${ }^{167}$ Tamoio, 11 de novembro de 1823. Apud Sodré, Nelson Werneck. História da imprensa no Brasil. 4. ed. Rio de Janeiro: Ed. Mauad, 1999. Nota 42, p. 80.

${ }^{168}$ Servidor experiente do Antigo Regime, Maciel da Costa já havia exercido o cargo de desembargador do Paço no Rio de Janeiro, governara a Guiana Francesa entre os anos de 1809 e 1815, quando esta possessão da França ficou sob o domínio de Portugal; em 1821 retornou com d. João VI à Europa e de volta ao Brasil elegeu-se deputado constituinte; por duas vezes o futuro marquês de Queluz preenchera importantes funções ministeriais no governo de d. Pedro I, posto que assumisse, logo após a dissolução da Constituinte, o ministério do Estado dos Negócios do Império (1823-1824) e adiante, em 1827, o ministério da Fazenda; esteve entre os escolhidos pelo imperador para compor o Conselho de Estado que elaborou a Carta outorgada; em 1825, quando a província baiana experimentava novos períodos de agitações políticas, Maciel da Costa foi o homem de confiança escolhido para governá-la; no ano seguinte, finalmente, d. Pedro I o chamou ao Rio de Janeiro para assumir uma vaga no Senado pela província da Paraíba. Cf. COSTA, Emília Viotti da, op. cit. p. 60.

${ }^{169}$ Como demonstrado, Clemente Ferreira França foi um dos que pertencera à comunidade de baianos residentes no Rio de Janeiro que subscreveram a felicitação entregue a d. Pedro. Felicitação dos Baianos residentes no Rio de Janeiro a S.A.R. In: Constitucional, n. 5, sábado, 20 de abril de 1822. Tipografia da Viúva Serva e Carvalho, 1821-1822. Exemplar da coleção do IEB/USP.
} 
Constituinte pelas tropas imperiais. ${ }^{170}$ Passados mais de meio século daquelas substituições (em 18 de março de 1776), o conde de Baependi, filho de Nogueira da Gama, registrou em uma correspondência a Varnhagen que a alteração ministerial do dia 10, em que seu pai fora um dos expoentes, atendeu: “[...] a uma necessidade indeclinável da situação, a fim de demonstrar ao país que não era contra os membros responsáveis do poder executivo e sim contra o chefe irresponsável do mesmo poder que se levantava na Assembleia a mais anárquica oposição, dirigida pelos Andradas [...]". 171

Na manhã de 11 de novembro, os deputados foram informados de que grande quantidade de tropas, inclusive a artilharia, estava reunida em São Cristóvão por ordem de d. Pedro I, o que explica o fato de alguns deles não comparecerem à sessão da Constituinte naquele dia. Dentre estes havia, por certo, os que temiam pelas suas seguranças pessoais, bem como os que conheciam, direta ou indiretamente, os planos em andamento para nulificar a Assembleia, prender algumas das suas lideranças mais insubordinadas, converter os moderados em aliados e atingir o objetivo primaz com o reforço do projeto de concentração de poder na corte imperial. Salvo os acontecimentos da região da Cisplatina, com as expulsões das tropas portuguesas dos territórios da Bahia, Pará e Maranhão, o governo de d. Pedro certamente possuía informações para avaliar que o fechamento da Assembleia deveria ser suportado, sem maiores transtornos, por todas as províncias do Brasil.

A situação de Pernambuco, sem dúvida, demandava cuidados, mas o próprio afastamento do político radical Cipriano Barata, e a consequente desaparição, por vários anos, da Sentinela da Liberdade, com a sua prisão e deportação para a capital do Império, em 17 de novembro, serviam, indiscutivelmente, à consecução do projeto de poder centralizado em andamento no Rio de Janeiro. Com efeito, a própria Assembleia trabalhou pela saída do redator da Sentinela da província pernambucana, já que requereu o seu comparecimento no "Congresso" reunido na capital fluminense, onde deveria tomar "parte nos seus gloriosos trabalhos como Deputado à mesa da Assembleia pela Província da

\footnotetext{
${ }^{170}$ Sobre as controvérsias concernentes às quedas dos dois mais influentes ministros do segundo gabinete, há os que compreenderam que aquelas alterações obedeceram às comodidades de se afastar possíveis influências dos ministros-deputados nas discussões intestinas na Constituinte sobre o projeto de liquidação da Assembleia, como, por exemplo, Tobias Monteiro. José Honório Rodrigues admite posição distinta ao salientar que, particularmente, para o caso do futuro visconde de Cachoeira, a opção de pedir demissão do governo adveio da recusa em referendar, no ministério, o ato da dissolução. Ver respectivamente, MONTEIRO, Tobias, 1981, op. cit. t. 2, p. 770 e RODRIGUES, José Honório, 1974, op. cit. p. 223.

${ }^{171}$ Correspondência transcrita na íntegra em nota de Rio Branco na obra de VARNHAGEN, Francisco Adolfo de, op. cit. Nota 116, p. 213.
} 
Bahia". ${ }^{172}$ Dez dias antes de ser preso, o experimentado Cipriano Barata teria apresentado ao Rio de Janeiro as motivações para não acatar aquela exigência:

Porque tenho opiniões livres, que vão quase todas de encontro com o Projeto de Constituição [...]. E não poderei salvar a minha Pátria das garras do preparado Governo Absoluto, no meio de um partido infinitamente grande contrário aos princípios que adoto.

Porque existem no Congresso muitos Deputados meus Inimigos declarados.

Porque vejo a Soberana Assembleia cercada de mais de sete mil baionetas. Tropas formadas de grande número dos nossos Inimigos Portugueses, além de um Batalhão de Estrangeiros, aparato este todo reforçado de violência pela poderosa circunstância de ser V. M. o imperador Comandante do Exército. Eu sou Deputado livre e não posso discutir uma Constituição liberal e sustentar os sagrados Direitos dos meus Constituintes entre o estrondo da artilharia e com as espadas na garganta.

Porque tendo havido já tentativas para eu ser assassinado, chegando a aparecerem pasquins pelas esquinas em que se prometiam 400 rs a quem embebesse o ferro no meu coração [...].

Porque servindo eu à Pátria em geral, mesmo daqui posso espalhar luzes, [ilegível] o Projeto de Constituição, e posso concorrer para a liberdade do Brasil, cumprindo desta [ilegível] com os fins para que fui eleito pelos meus Constituintes, aos quais darei cabal satisfação em tempo competente. $^{173}$

Verifica-se, dessa maneira, que o imperador e os seus principais interlocutores envidaram esforços bem-sucedidos para o estreitamento do círculo de reação, permitindo, com isso, o relativo controle político dos que se posicionavam contrários ao projeto de centralização do poder.

Ainda na manhã do dia 11, os deputados que compareceram ao prédio reservado aos trabalhos da Constituinte iniciaram normalmente a sessão. Dentre os representantes da Bahia, encontravam-se Montezuma, Silva Lisboa, Caldeira Brant, Miguel Calmon e Francisco Carneiro de Campos. Após informar sobre o estado de inquietação na cidade do Rio de Janeiro devido ao movimento, por toda noite, das tropas, Antonio Carlos propôs que a Assembleia se declarasse em sessão permanente, enquanto uma deputação iria até o

\footnotetext{
172 Ofício da Soberana Assembleia assinado pelo deputado José Ricardo da Costa Aguiar, de 30 de Agosto de 1823. In: Sentinela da Liberdade na Guarita de Pernambuco Alerta!, n. 66, quarta-feira, 19 de novembro de 1823. Recife, Tipografia de Cavalcante e Carvalho. BARATA, Cipriano, 2008, op. cit. p. 584-585.

${ }^{173}$ Resposta de Cipriano Barata de Almeida ao ofício da Soberana Assembleia, em 7 de novembro de 1823. In: Sentinela da Liberdade na Guarita de Pernambuco Alerta!, n. 66, quarta-feira, 19 de novembro de 1823. Recife, Idem, ibidem. p. 585-586. Registra-se que também o deputado Francisco Agostinho Gomes, igualmente refugiado em Pernambuco, havia a mesma exigência para comparecer à Assembleia. Entretanto, depois que a Junta pernambucana decidiu prender e deportar Cipriano, nada mais foi feito no sentido de coagir o outro deputado constituinte baiano a embarcar para o Rio de Janeiro. Sobre os meandros desse processo em Pernambuco, ver MELLO, Evaldo Cabral de, 2004, op. cit. p. 154 e segs.
} 
imperador obter informações sobre aqueles acontecimentos. Não tardou, porém, para os deputados serem surpreendidos com o ofício do ministro do Império e Estrangeiros Vilela Barbosa, comunicando, em nome de d. Pedro I, que as insatisfações nas tropas deviam-se aos insultos sofridos pelos oficiais do Exército por parte de alguns constituintes. Ainda segundo este documento, os oficiais queixaram-se igualmente da falta de decoro com que alguns redatores de periódicos e seu partido se dirigiam ao imperador. Depois disso, a comissão especial aprovou a medida para a Assembleia declarar-se em sessão permanente até que novos esclarecimentos junto ao governo de d. Pedro I fossem obtidos.

Somente no início da noite chegou o ofício contendo as respostas do governo sobre as indagações dos deputados. Nele se dizia que todos os oficiais eram insultados pela Assembleia; acusava os jornais Tamoio e A Sentinela da Praia Grande como ofensivos ao imperador, além de denunciar os três deputados Andrada José Bonifácio, Antonio Carlos e Martins Francisco, “[...] editores do primeiro jornal, colaboradores do segundo, e chefes de um partido sedicioso [...]". ${ }^{174}$ No final da manhã seguinte, dia 12, o ministro do Império e Estrangeiros, Vilela Barbosa, sem atender ao pedido de despojar-se da sua espada para ter acesso ao salão, apresentou-se à Assembleia. Em sua presença, alguns deputados insistiram por esclarecimentos sobre a reunião das tropas, considerando as respostas evasivas dadas pelo governo. Montezuma quis saber quais as deliberações da Constituinte que efetivamente satisfariam os descontentes, obtendo como resposta que, em primeiro lugar, fosse imediatamente restringida a liberdade de imprensa e, em segundo, "que fossem expulsos da Assembleia os Srs. Andradas, como redatores do Tamoio e colaboradores da Sentinela". ${ }^{175}$ Um verdadeiro interrogatório a Vilela Barbosa irrompeu, mas, na essência, não se alteraram as respostas e, então, o ministro decidiu deixar o recinto.

Montezuma ainda considerou ser necessário ouvir o ministro da guerra para saber das condições em que as tropas retornariam aos seus quartéis. Silva Lisboa advertiu sobre o perigo de o poder legislativo contrapor-se ao militar. Também não via como a Assembleia decidir que só deliberaria quando as tropas retornassem aos seus locais de origem ou transferindo as sessões para o interior do Império, como defenderam os deputados Antonio Carlos e Martiniano de Alencar. Em razão disso, inquiria: "Em que lugar? Estamos no mundo da lua? Andaremos de capa em colo em busca de pouso? A quem daremos ordens? Quem as executará?" 176 Ao se deparar com um impasse, os

\footnotetext{
${ }^{174}$ Apud ARMITAGE, John, op. cit. p. 81.

175 Apud RODRIGUES, José Honório, 1974, op. cit. p. 218.

${ }^{176}$ Apud VARNHAGEN, Francisco Adolfo de, op. cit. p. 217.
} 
deputados decidiram mais uma vez consultar a comissão especial, quando difundiu-se a notícia que a tropa deixara São Cristóvão e, pelo visto, marchava em direção à sede da Assembleia.

Tobias Monteiro registrou que, desde as primeiras horas da manhã do dia 12, a resolução do fechamento da Assembleia por d. Pedro já era conhecida de algumas autoridades. Isso porque, a exceção de Vilela Barbosa que forara ao encontro dos deputados constituintes, os demais ministros encontravam-se reunidos em São Cristóvão. O imperador apresentou-lhes o decreto que selaria a sorte da Assembleia, exigindo, no entanto, o referendo ministerial. Recusando-se a se tornarem igualmente responsáveis por aquela alta deliberação, o baiano Cunha Moreira (Marinha) e o português Tinoco da Silva (Fazenda) foram demitidos, conquanto seus colegas de gabinete o fluminense Oliveira Barbosa (Guerra) e o baiano Clemente Ferreira França (Justiça) decidissem pela chancela ao decreto que liquidaria a primeira Assembleia Geral Constituinte e Legislativa da nação brasileira. $^{177}$

Depois de ter sido recusado, na Bahia, como governador das armas nomeado pelo próprio imperador, coube justamente ao brigadeiro José Manoel de Moraes, português americano, a função de interromper a sessão permanente para apresentar aos deputados o decreto de dissolução da Assembleia, com a rubrica imperial e as assinaturas ministeriais. ${ }^{178}$ D. Pedro I e o grosso das tropas encontravam-se estacionados ali próximo, no Campo de Santana. Era uma hora da tarde do dia 12 de novembro e todo o trabalho constituinte sucumbia ao menoscabo das baionetas imperais. Antonio Carlos, um dos mais destemidos representantes, encerrou sua participação na Assembleia com a resignada constatação dita aos presentes: "Já não temos que fazer aqui. Resta-nos cumprir o que Sua Majestade ordena". ${ }^{179} \mathrm{Na}$ saída do prédio, foram imediatamente presos em nome do governo imperial, os ex-deputados paulistas Antonio Carlos e Martim Francisco, o baiano Francisco Montezuma, os mineiros padre Belchior Pinheiro de Oliveira (1775-1856) e José Joaquim da Rocha (1777-1868) e, em casa, o paulista José Bonifácio. Todos seguiram para o exílio somente retornando ao Brasil a partir de 1829, quando uma profunda crise

\footnotetext{
${ }^{177}$ MONTEIRO, Tobias, 1981, op. cit. t. 2, p. 778-779. Consta que o desembargador Sebastião Luís Tinoco da Silva nasceu em Viana, Portugal. Em 1803, teria registrado, em correspondência ao príncipe regente, possuir de dez para onze anos de serviço na América. Cf. < http://www.fazenda.gov.br/portugues/institucional/ministros/dom_pedro004.asp> Acesso em: 31 de Abril de 2010 e teria vindo para o Brasil, em 1803, ocupar o posto de juiz de fora.

${ }^{178}$ Cf. RODRIGUES, José Honório, 1974, op. cit. p. 221-222.

${ }^{179}$ Apud MONTEIRO, Tobias, 1981, op. cit. t. 2, p. 780.
} 
convulsionava o Império e que, dois anos depois, levaria à abdicação do imperador d. Pedro I. ${ }^{180}$

O desaparecimento da Assembleia Constituinte de 1823 não deve, de fato, ser reduzido às vontades e aos caprichos despóticos, arbitrários, tirânicos e mesmo pessoais de um imperador que ambicionava recobrar o controle de uma situação que lhe esquivava ao domínio. A rigor, a atuação de d. Pedro I diante da Assembleia atendia, indubitavelmente, a conciliação de interesses coletivos, politicamente articulados e que, por isso, foram vantajosamente representados não apenas no Rio de Janeiro, mas a partir deste importante centro decisório que constituía a corte imperial. ${ }^{181}$ Portanto, o "pacto social" a ser forjado no interior da nação brasileira ainda em formação deveria levar em conta, tanto os interesses da classe senhorial que se tornava dominante, como a não desprezível força socioeconômica e política dos portugueses. Ao reconhecer e mesmo valorizar a força dos senhores da terra, e simultaneamente se aproximar do imperador, os portugueses imigrados revelavam toda disposição em negociar as antigas posições, desde que fosse mantida a sua participação no comércio, na produção e na administração, o que incluía a partilha do poder coercitivo do Estado, por meio do acesso aos postos de comando militares. $^{182}$

O redesenho nas esferas de poder público e privado envolvendo os portugueses europeus e os filhos da terra, vinha se esboçando de maneira mais acentuada desde 1808. Visto assim, os segmentos representativos dos grandes comerciantes, negociantes de grosso trato, traficantes de escravos e controladores das navegações de cabotagem passaram, naqueles anos, por reconfigurações, nas quais as presenças dos portugueses americanos se tornaram cada vez mais frequentes. O momento de singular expansão vivido pela economia na América portuguesa, datado desde fins do Setecentos (1790) e ampliado com a transferência da corte para o Rio de Janeiro e, especialmente, com o fim do exclusivismo colonial (1808), revelou-se decisivo para que estas transformações se dessem de forma a evitar maiores choques entre os antigos e os novos competidores. ${ }^{183}$ Para os

\footnotetext{
180 Francisco Gê Acaiaba Montezuma somente retornara ao Brasil, em 1831, depois da abdicação do imperador. MATTOSO, Kátia M. de Queirós, 1992, op. cit. p. 274.

181 SLEMIAN, Andréa; PIMENTA, João Paulo G., 2003, op. cit. p. 106.

182 Sobre este intricado jogo de interesses em volta da administração, do mercado e da política, ver OLIVEIRA, Cecília Helena L. de Salles. A astúcia Liberal: Relações de mercado e projetos políticos no Rio de Janeiro (1820-1824). Bragança Paulista: Ed. Edusf; Ícone, 1999. p. 298.

183 Acerta dessas transformações, ver FRAGOSO, João Luís Ribeiro. Homens de Grossa Aventura. Acumulação e hierarquia na praça mercantil do Rio de Janeiro (1790-1830). 2. ed. Rio de Janeiro: Civilização Brasileira, 1998 e LENHARO, Alcir. As tropas da moderação: o abastecimento da Corte na formação política do Brasil, 1808-1842. São Paulo: Símbolo, 1979.
} 
envolvidos, "a unidade do Brasil correspondia à própria geografia dos seus negócios particulares, não mais restritos a apenas uma província ou a um pequeno grupo dela", ${ }^{184} \mathrm{o}$ que explica ter a corte fluminense se tornado a principal rota migratória não somente para os baianos, mas para os mais diferentes súditos do Império português. Entretanto, o processo de Independência e a própria realização da Assembleia Constituinte e Legislativa da nação brasileira trouxeram para o primeiro plano as tensões e divergências entre os envolvidos. Afinal de contas, a disputa não se daria mais por meio de políticas de concessões de espaço e poder para os filhos da terra, como até então a modernização ilustrada tinha promovido, e sim na definitiva quebra nos predomínios jurídicos, comerciais e administrativos que ainda se constituíam os maiores patrimônios que os portugueses europeus possuíam sobre o território brasiliense.

No dia imediato à suspensão dos direitos da Assembleia Constituinte, d. Pedro I viu-se obrigado a reorganizar o gabinete ministerial, convocando alguns deputados que se destacaram na defesa dos interesses predominantes na fase de concentração de poder na corte imperial. Dentre os baianos, entregava a Luís José de Carvalho e Mello a pasta dos Estrangeiros e mantinha Clemente Ferreira França na Justiça. ${ }^{185} \mathrm{Na}$ ocasião (13 de novembro), o imperador também nomeou os membros do Conselho de Estado, que seriam responsáveis pela elaboração do novo projeto de Constituição prometido pelo próprio d. Pedro para ser "duplamente mais liberal" que o elaborado pela Casa legislativa cassada. Das dez vagas existentes neste Conselho, cinco foram ocupadas pelos baianos, a saber: José Joaquim Carneiro de Campos, Luís José de Carvalho e Mello, barão de Santo Amaro (José Egídio Álvares de Almeida), Antônio Luís Pereira da Cunha, Clemente Ferreira França, todos com formação e experiências jurídicas. ${ }^{186}$ Para Varnhagen, estas lideranças formavam uma "turma compacta" que, para além da confiança e do prestígio que desfrutavam junto ao imperador, prestavam-se mútuo apoio no ministério e Conselho de Estado. $^{187}$

${ }^{184}$ SLEMIAN, Andréa; PIMENTA, João Paulo G., 2003, op. cit. p. 106.

${ }^{185}$ Os demais ministros que formavam o quarto gabinete, anunciado em 14 de novembro, foram Pedro de Araújo Lima (Império) Mariano José Pereira da Fonseca (Fazenda), Pedro José da Costa Barros (Marinha) e Francisco Vilela Barbosa (serviria interinamente como ministro da Guerra). MORAES, Alexandre de Mello, op. cit., t. 2. p. 563.

${ }^{186}$ Os outros conselheiros foram João Severiano Maciel da Costa, Manoel Jacinto Nogueira da Gama, Mariano José Pereira da Fonseca, João Gomes da Silveira Mendonça e Francisco Vilela Barbosa.

${ }^{187}$ VARNHAGEN, Francisco Adolfo de, op. cit. p. 234. Em pesquisa de mestrado recém-concluída, Eder da Silva Ribeiro examinou a atuação do Conselho de Estado durante o governo de d. Pedro I, procurando reconstruir as trajetórias individuais, as relações familiares e de sociabilidade daqueles quadros nomeados para a iminente função de conselheiro, a qual, sem dúvida, se constituía no principal aporte que o imperador lançara mão para auxiliá-lo na administração do Império. RIBEIRO, Eder da Silva. "O Conselho de Estado 


\subsection{Da Bahia para representantes da nação}

Com a extinção da Assembleia Constituinte, a trajetória subsequente de alguns desses homens de Estado nascidos na Bahia informa sobre a continuidade das suas ascensões e consolidação política. Percursos que, não restam dúvidas, foram cheios de nuances, pois muitos deles constituíram pontas de lança nos gabinetes ministeriais, formando com outras importantes lideranças da sua geração, os intelectuais orgânicos do governo centralizado, no qual d. Pedro I era o monarca, chefe do executivo, cuja responsabilidade do poder, ainda que não admitida, dividia com os seus ministros. ${ }^{188}$

Nesse sentido, principia-se por observar que a despeito de algumas desses quadros políticos pertencentes à comunidade baiana residente na corte terem se revelado aptos a se eleger representantes do Rio de Janeiro, não significa dizer que abandonaram as redes de sociabilidade com a sua província de origem. Prova disso foi que, durante as eleições gerais ocorridas na Bahia em 1824, os baianos, acompanhados aqui, obtiveram votações expressivas para o Senado imperial, como atesta um extrato do Diário Fluminense, reproduzido no periódico português, a Gazeta de Lisboa. ${ }^{189}$ Além do mais, quando se conhece os resultados destas mesmas eleições para a província do Rio de Janeiro, verifica-se igualmente o prestígio que parte significativa desses indivíduos continuava usufruindo junto aos habitantes da capital do Império, evidenciando as capacidades de algumas dessas lideranças em se articular politicamente em mais de uma província.

no tempo de D. Pedro I": um estudo da política e da sociedade no Primeiro Reinado (1826-1831). Dissertação (Mestrado em História) - Universidade Federal Fluminense, Niterói, 2010.

${ }^{188}$ Utilizo aqui intelectuais orgânicos no sentido conceitual formulado por Antônio Gramsci. GRAMSCI, Antônio. Concepção materialista da história. 3. ed. Rio de Janeiro: Civilização Brasileira, 1978.

${ }^{189}$ Gazeta de Lisboa, n. 277, terça-feira, 23 de novembro de 1824. Lisboa: Impressão Régia. p. 1309. Disponível: <http://books.google.com.br/books?id=XREwAAAAYAAJ\&pg=RA1PA1309\&lpg=RA1-

PA1309\&dq=\%22 Gazeta+de+Lisboa22+22Cunha+Moreira22\&source=bl\&ots=bq7Nt36wAF\&sig=04J5OJR wMsI2N58QYv83sx1 x6XY\&hl=ptBR\&ei=Gp3WTLLQAoKB8gaJrpCxCg\&sa=X\&oi=book_result\&ct=resu

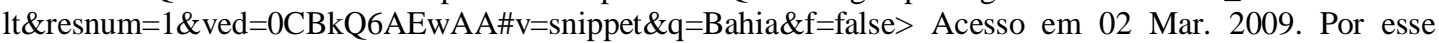
periódico, sabe-se que o Diário Fluminense divulgou, em agosto de 1824, os resultados das eleições para a Câmara de Deputados e o Senado imperial ocorridas na Bahia e no Rio de Janeiro. Portanto, presume-se que estas eleições ocorreram entre abril e julho daquele ano, posto que atendessem ao decreto imperial de 26 de março de 1824, o qual determinava a realização das eleições dos deputados e senadores da Assembleia Geral Legislativa e dos membros dos Conselhos Gerais das Províncias. Cf. RODRIGUES, José Honório. Independência: revolução e contra-revolução. Rio de Janeiro: Livraria Francisco Alves, 1975, v 1, p. 353354 e LUSTOSA, Isabel. D. Pedro I: um herói sem nenhum caráter. São Paulo: Companhia das Letras, 2006. p. 224. 
TABELA 2

\section{Resultados da eleição para o Senado Imperial na Bahia e no Rio de Janeiro - 1824}

\begin{tabular}{|c|c|c|c|}
\hline Votados & Votos BA & Votos RJ* & Naturalida \\
\hline Francisco Carneiro de Campos & 150 & $* *$ & Bahia \\
\hline José Joaquim Carneiro de Campos & 144 & 211 & Bahia \\
\hline José da Silva Lisboa & 135 & 146 & Bahia \\
\hline Manoel Ferreira da Câmara & 131 & $* *$ & Minas Gerais \\
\hline Felisberto Caldeira Brant & 123 & $* *$ & Minas Gerais \\
\hline Antonio Luís Pereira da Cunha & 122 & 178 & Bahia \\
\hline barão de Santo Amaro - José Egídio Álvares de Almeida & 123 & 161 & Bahia \\
\hline Luís José de Carvalho e Mello & 113 & 157 & Bahia \\
\hline Antônio [sic] Ferreira França $* * *$ & 111 & $* *$ & Bahia \\
\hline Domingos Alves Branco Moniz Barreto & 100 & $* *$ & Bahia \\
\hline Antonio Augusto da Silva & 100 & $* *$ & Bahia \\
\hline Alexandre Gomes Ferrão & 87 & $* *$ & Bahia \\
\hline Domingos Borges de Barros & 86 & $* *$ & Bahia \\
\hline Antonio José Duarte de Araújo Gondim & 82 & $* *$ & Pernambuco \\
\hline Joaquim Inácio da Silva [sic] Bulcão $* * * *$ & 81 & $* *$ & Bahia \\
\hline Luís da Cunha Moreira & 81 & $* *$ & Bahia \\
\hline Pedro Rodrigues Bandeira & 73 & $* *$ & Bahia \\
\hline José Bonifácio de Andrada e Silva & 73 & $* *$ & São Paulo \\
\hline bispo Capelão Mor - José Caetano da Silva Coutinho & $* *$ & 267 & Rio de Janeiro \\
\hline Mariano José Pereira da Fonseca & $* *$ & 198 & Minas Gerais \\
\hline João Severiano Maciel da Costa & $* *$ & 165 & Minas Gerais \\
\hline Francisco Vilela Barbosa & $* *$ & 162 & Rio de Janeiro \\
\hline Manoel Jacinto Nogueira da Gama & $* *$ & 125 & Minas Gerais \\
\hline conde da Palma - Francisco de Assis Mascarenhas & $* *$ & 123 & Lisboa \\
\hline monsenhor Vidigal - Francisco Correia Vidigal & $* *$ & 123 & Rio de Janeiro \\
\hline
\end{tabular}

Fonte: Gazeta de Lisboa, n. 277, terça-feira, 23 de novembro de 1824. Lisboa: Impressão Régia. p. 1309.

* O fato de as votações para a província do Rio de Janeiro ter sido, para os casos aqui verificados, mais expressivas do que a da Bahia deve-se ao percentual maior da população na capital do Império

** O número de votos só aparece para uma província

*** O senador eleito pela Bahia e que tomaria posse em 1826 seria Clemente Ferreira França e não o exdeputado constituinte Antônio Ferreira França, reeleito pela Bahia para a Câmara dos Deputados nas legislaturas de 1826-1829; 1830-1833 e 1834-1837

**** Joaquim Inácio de Siqueira Bulcão 
Não obstante o imperador procrastinar para autorizar as instalações da Assembleia Legislativa e do Senado imperial, verifica-se que os baianos José Joaquim Carneiro de Campos (futuro marquês de Caravelas), Silva Lisboa (barão e depois visconde de Cairu), Pereira da Cunha (futuro marquês de Inhambupe), José Egídio Álvares de Almeida (barão e futuro marquês de Santo Amaro) e Carvalho e Mello (visconde de Cachoeira) encontravam-se com suas trajetórias políticas consolidadas, ao menos, nas duas principais províncias do Império do Brasil; sendo, nestes anos, nobilitados pelo imperador. $^{190}$

Merece igual atenção o fato de que mesmo residindo na corte, estes indivíduos obtivessem votações mais expressivas na província da Bahia, durante o processo eletivo de 1824, do que outras lideranças ali radicadas e cujas participações nas esferas políticas aguardavam, certamente, oportunidades. Dentre estes se encontravam os ex-deputados pelas Cortes de Lisboa Alexandre Gomes Ferrão e Pedro Rodrigues Bandeira - o opulento negociante da capital baiana -, ou ainda o proprietário, e típico representante da classe senhorial no Recôncavo baiano, Joaquim Inácio de Siqueira Bulcão, os quais, como se vê pelos dados da tabela 2, estiveram entre os que concorreram a uma vaga senatorial. ${ }^{191} \mathrm{E}$ Curioso também constatar o fato de os eleitores da Bahia terem depositado uma significativa votação para o exilado político José Bonifácio, mas deixassem de lado o compatrício desterrado Francisco Montezuma. ${ }^{192}$ Finalmente, há ainda que considerar o

${ }^{190}$ Reproduzindo o extrato do periódico o Independente, publicado na Bahia, a Gazeta de Lisboa divulgava a relação dos senadores nomeados pelo decreto imperial de 22 de janeiro de 1826. Para a província baiana foram, então, indicados senadores: José Joaquim Carneiro de Campos; Carvalho e Mello; Clemente Ferreira França; Silva Lisboa; Domingos Borges de Barros (visconde de Pedra Branca) e Francisco Carneiro de Campos. Gazeta de Lisboa, n. 112, sábado, 12 de maio de 1826. Lisboa: Impressão Régia, op. cit. p. 450. Disponível

<http://books.google.com.br/books?id=xw8wAAAAYAAJ\&pg=PA454\&dq=\%22Gazeta+de+Lisboa $\% 22+\%$ $221826 \% 22+\% 22$ senador\%22\&hl=pt-

BR\&ei=XoncTKSGHsGC8gaKsaGaCQ\&sa=X\&oi=book_result\&ct=result\&resnum=1\&ved=0CC8Q6AEw

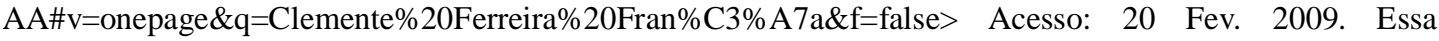
disposição devia obedecer ao artigo 41 da Carta de Constituição de 1824 que estabelecia: "Cada Província dará tantos Senadores, quantos forem metade de seus respectivos Deputados, com a diferença, que, quando o numero dos Deputados da Província for impar, o número dos seus Senadores será metade do número imediatamente menor, de maneira que a Província, que houver de dar onze Deputados, dará cinco Senadores". Carta Constitucional (1824). Constituição Política do Império do Brazil, de 25 de março de 1824. Para os dados dos senadores eleitos e que assumiram vaga pela província da Bahia, ver ainda MATTOSO, Kátia M. de Queirós, 1992, op. cit. Nota 11, p. 281e 682.

${ }^{191}$ Gazeta de Lisboa, n. 277, terça-feira, 23 de novembro de 1824. Lisboa: Impressão Régia, op. cit. p. 1309. Ressalta-se, uma vez mais, que o ex-deputado das Cortes lisboeta, Alexandre Gomes Ferrão Castelo Branco, havia, entre os anos 1805 e 1815, ocupado a cadeira de vereança em Salvador.

${ }^{192}$ É possível que José Bonifácio devesse os votos recebidos na Bahia à articulação política de Caldeira Brant que desde 1822 - quando cumprira missões para o ministério em Londres - dava mostras de amizade e, quiçá, houvesse se tornado, naquelas eleições, correligionário do mais famoso dos Andrada. Essa hipótese é robustecida na medida em que se observa que nem Bonifácio, nem Caldeira Brant aparecem na lista dos bem 
comportamento dos representantes da Bahia que sugere empenho na conquista de espaços políticos na alta cúpula imperial, pois, afora o observado para o ex-ministro Andrada, o pernambucano e senhor de terras no Recôncavo baiano Araújo Gondim e o mineiro radicado na província Caldeira Brant, a votação para o Senado na Bahia foi majoritariamente direcionada aos conterrâneos, contrastando, dessa maneira, claramente com o verificado no Rio de Janeiro. ${ }^{193}$

Antigo conselheiro régio e desembargador do Paço no período joanino, Carvalho e Mello era, por certo, um dos homens de Estado que após os serviços prestados na Assembleia Constituinte veria facilitado o acesso aos principais postos que d. Pedro I dispunha para agraciar os seus súditos mais distintos. Como já informado, o futuro visconde de Cachoeira ocupara o ministério dos Negócios Estrangeiros do Brasil no quarto gabinete organizado pelo imperador, em 14 de novembro de 1823 . Nomeado membro do Conselho de Estado, tributam-se a ele e ao conterrâneo José Joaquim Carneiro de Campos as atribuições de principais redatores da Carta de Constituição de 1824. Pouco depois, Carvalho e Mello foi nomeado senador pela Bahia, mas não permaneceu na vaga vitalícia, em razão de uma enfermidade que causaria a sua morte em 1826.

Muito prestigiado no governo joanino, e depois de ter sido eleito deputado constituinte pelo Rio de Janeiro, José Joaquim Carneiro de Campos teve, como se viu, o privilégio e a responsabilidade de substituir José Bonifácio no ministério dos Negócios Estrangeiros, a pasta mais importante do Império. Seus conhecimentos jurídicos são reconhecidos por historiadores como José Honório Rodrigues, para quem não somente o futuro visconde de Cachoeira, mas também Francisco Carneiro de Campos, Carvalho e Mello, Pereira da Cunha e Silva Lisboa (este último formado em Cânone), foram "os grandes juristas da Assembleia Constituinte" de $1823 .{ }^{194}$ Também se sabe que o futuro visconde de Cachoeira defendera genuinamente naquela primeira Casa legislativa os princípios do Poder Moderador, apregoando que o imperador, dentre os integrantes da nação, era a "[...] primeira autoridade vigilante, guarda dos nossos direitos e da constituição". E, por isso: “[...] Esta suprema autoridade que constitui a sua pessoa sagrada e inviolável e que os mais sábios publicistas deste tempo têm reputado um poder soberano, distinto do poder executivo por sua natureza, fim e atribuições, esta autoridade, digo, que

votados para o Senado pela província do Rio de Janeiro, onde, sabidamente, ambos guardavam inimigos influentes, a exemplo, do português José Clemente Pereira.

${ }^{193}$ Ver tabela 2, cujos dados, já se disse, foram extraídos da Gazeta de Lisboa, n. 277, terça-feira, 23 de novembro de 1824. Lisboa: Impressão Régia, op. cit. p. 1309.

${ }^{194}$ RODRIGUES, José Honório, 1974, op. cit. p. 273. 
alguns denominam Poder Neutro ou Moderador, e outros tribunício, é essencial nos governos representativos [...]”. O arremate, então, se apresentou com idêntica resolução: “[...] Estas considerações deram nascimento ao poder moderador, que é o baluarte da liberdade pública e a mais firme garantia para a nação de que nós, que somos os seus legítimos representantes, e os que nos sucederem em outras assembleias, jamais nos transformaremos em seus senhores e tiranos". ${ }^{195}$

São ainda de Honório Rodrigues, que além de historiador era bacharel em Direito, estas palavras sobre a liderança que o visconde de Cachoeira exercera no cenário imperial:

Carneiro de Campos crescerá com o tempo, e se em 1823 ele era, sem favor, uma das maiores figuras da Assembleia, de 1826 até sua morte, em 1836, será um dos grandes Senadores de todos os tempos. Sua exposição sobre o Poder Moderador confirma sua autoria da Constituição de 1824, seu principal redator, e por si só é suficiente para elevá-lo como um dos maiores mestres do direito público brasileiro. ${ }^{196}$

A solidez desta formação se devia ao bom proveito que não apenas o futuro marquês de Caravelas, mas diversas lideranças da geração da Independência souberam tirar do profícuo aprendizado propiciado pelo movimento da ilustração no Império português de fins do Setecentos e princípios do século seguinte.

Joaquim José Carneiro de Campos retornou ao ministério entre 1825 e 1827, responsabilizando-se pela condução da Justiça e do Império, ou acumulando as duas pastas simultaneamente como se verificou no $10^{\circ}$ gabinete organizado naquele último ano. Eleito senador, tanto por sua província natal, como pelo Rio de Janeiro, ainda em 1826 d. Pedro o nomeou para a assunção da vaga senatorial pela Bahia. Adiante, seria lhe mais uma vez entregue o ministério do Império, assumido entre dezembro de 1829 e agosto de $1830 .{ }^{197}$ Por ter destacada presença como representante dos interesses das classes dirigentes radicadas na influente província do Norte, bem como da própria corte fluminense, o doravante marquês de Caravelas assumiu, juntamente com o liberal Nicolau Vergueiro e o general do Exército Francisco Lima e Silva, a Regência Provisória, nos dois meses após a

195 Apud RODRIGUES, José Honório, 1974, op. cit. p. 65-66 (os grifos não são meus).

${ }^{196}$ RODRIGUES, José Honório, 1974, op. cit. p. 274. Embora não integrasse o Conselho de Estado, alguns historiadores, como o próprio José Honório, indicam que Francisco Carneiro de Campos também coadjuvara na redação final da Carta de 1824. Idem, ibidem, p. 251. De maneira ainda mais enfática, Kátia Mattoso afirmou: "[...] Aliás, Francisco [Carneiro de Campos] foi considerado o verdadeiro redator da Carta de 1824, atribuída a José Joaquim”. Questão que deve ser mais bem investigada. MATTOSO, Kátia M. de Queirós, 1992, op. cit. p. 285. Informações biográficas de vários destes quadros políticos oriundos da Bahia encontram-se neste trabalho, especialmente o capítulo 17.

${ }^{197}$ MORAES, Alexandre de Mello, op. cit., t. 2. p. 556 e segs. 
abdicação de d. Pedro I, em 7 de abril de $1831 .{ }^{198}$ E, assim, experimentou os principais postos que o Império parecia reservar aos cidadãos que se colocaram às voltas do poder monárquico instalado no Brasil.

Embora também estivesse entre os indivíduos mais bem votados ao Senado imperial, simultaneamente na Bahia e no Rio de Janeiro, Antonio Luís Pereira da Cunha foi nomeado por d. Pedro I para a vaga senatorial pela província de Pernambuco, já que ali conseguira angariar votos suficientes para aparecer na lista tríplice que dava condições àquela contemplação. ${ }^{199}$ Como alguns dos seus colegas e compatrícios que compunham o Conselho de Estado do imperador, o futuro marquês de Inhambupe seria muito lembrado para compor as pastas ministeriais, em diferentes momentos do Primeiro Reinado. Assim como ocorreu com Carneiro de Campos, houve ocasiões de ele estar à frente de dois ministérios, como se verifica no $9^{\circ}$ gabinete nomeado a 20 de janeiro de 1826 , em que respondeu pela pasta dos Estrangeiros e da Fazenda. Por fim, no apagar das luzes do Primeiro Reinado, em 5 de abril de 1831, foi o escolhido para preencher o ministério do Império. Dois dias depois abandonou a cadeira ante a abdicação do imperador. ${ }^{200}$

Possuindo, do mesmo modo, votos suficientes para ser eleito senador por sua província de origem, o imperador decidiu que o conselheiro de Estado José Egídio Álvares de Almeida ocupasse, a partir de 1826, a vaga senatorial pelo Rio de Janeiro. Além do mais, o visconde de Santo Amaro foi escolhido, entre seus pares, para exercer a primeira presidência do Senado imperial. $^{201}$

Outra personagem de relevo fora o mineiro de origem, mas residente nas duas últimas décadas na Bahia, o marechal Felisberto Caldeira Brant. Entre os sobrados da velha São Salvador, o futuro marquês encontrara os caminhos da fortuna e do preenchimento de postos estratégicos na administração governamental, posto que, em 1823, pudesse ser considerado um talhado homem de Estado, como parece ter notado o conde de Palmela (ver Capítulo 2). ${ }^{202}$ Transcorrida a liquidação da Assembleia Constituinte, o futuro marquês de Barbacena recusou todos os pedidos para que assumisse o ministério da Guerra. Preferiu seguir para a Bahia, juntamente com Miguel Calmon du

\footnotetext{
${ }^{198}$ DOLHNIKOFF, Miriam, 2005, op. cit. p. 89.

${ }^{199}$ Cf. RIBEIRO, Eder da Silva, op. cit., p. 21.

${ }^{200}$ A estreia de Pereira da Cunha no ministério se deu, de fato, no gabinete anterior, visto que a partir de 18 de janeiro de 1826 passou a responder pela pasta dos Estrangeiros. MORAES, Alexandre de Mello, op. cit., t. 2. p. 565.

${ }^{201} \mathrm{O}$ visconde de Santo Amaro esteve no comando do ministério dos Estrangeiros entre 21 de novembro de 1825 e 18 de janeiro do ano seguinte. Idem, ibidem loc cit.

${ }^{202}$ Sobre a ascensão social e a atuação administrativa de Caldeira Brant na Bahia, ver, sobretudo, KRAAY, Hendrik, 2002, op. cit. e SOUSA, Maria Aparecida Silva de, 2009, op. cit.
} 
Pin e Almeida, onde, interagindo com o também ex-deputado pelas Cortes de Lisboa José Lino Coutinho, prestaram importante auxílio a d. Pedro ao defenderem o projeto de Constituição que o governo imperial mandava para ser apreciado e jurado pela Câmara Municipal da capital baiana. ${ }^{203} \mathrm{Na}$ ocasião, diversas autoridades locais se reuniram em um conselho na Câmara de Vereadores de Salvador e, com alguns ajustes políticos, aprovaram o projeto. Importante também é saber que, de acordo com o periódico Grito da Razão, o próprio Lino Coutinho defendeu a imediata aceitação do projeto de Constituição, devendo as pequenas alterações ficar a cargo "da primeira Assembléia ordinária e Legislativa, para que houvesse por bem fazer as requeridas emendas [...]". ${ }^{204}$

Colaborando como pôde para neutralizar a província ante a centralização do poder na corte, ${ }^{205}$ Caldeira Brant cuidou, em seguida, de reiterar acerca de prejuízos que, segundo dizia, a guerra e os desmandos portugueses causaram em suas propriedades, dentre estas relacionava engenhos e safras inteiras de açúcar perdidas, sobre os quais reclamaria indenizações por parte do Erário Público. Somente depois de tudo isso, foi que, finalmente, tomou embarcação marítima para Londres, aonde seguia munido de credenciais e poderes para transacionar o reconhecimento da Independência junto às autoridades britânicas. Ao retornar da Europa, o futuro marquês iniciou suas atividades ministeriais. Estreava, em fins de 1825, na condução da pasta do Império, mas esta experiência revelar-se-ia efêmera, de apenas 12 dias (entre 9 a 21 de novembro), pois foi essa a duração do $7^{\circ}$ gabinete substituído, novamente, pelo imperador. ${ }^{206}$ Aproveitado ainda na composição do novo ministério, Caldeira Brant tornou-se o responsável da Fazenda; ali ficou somente de 21 de novembro de 1825 a 19 de janeiro do ano seguinte.

Dentro da política de compensações tão utilizada por seu pai, d. Pedro I utilizou o mesmo recurso para retribuir os seus súditos mais próximos. Como Caldeira Brant havia obtido boa votação nas já conhecidas eleições senatoriais ocorridas na Bahia, o imperador

\footnotetext{
${ }^{203}$ A reunião desse conselho ocorreu em 10 de fevereiro de 1824, quando, justamente, se comemorava os três anos da adesão da Bahia ao constitucionalismo. Grito da Razão, n. 2, 17 de fevereiro de 1824, terça-feira. Tipografia da Viúva Serva e Carvalho. Exemplar do Apeb - Setor de microfilmagem; filme 48.

${ }^{204}$ A narrativa desse encontro público entre Caldeira Brant e Lino Coutinho, a quem o futuro marquês de Barbacena registrara, anteriormente, que não queria conversa, pois dizia se tratar de seu inimigo particular, foi documentada e publicada no periódico. Idem, ibidem. No que concerne às intervenções oposicionistas do deputado Lino Coutinho na Câmara dos Deputados, ver PEREIRA, Vantuil. "Ao Soberano Congresso": Petições, requerimentos, representações e queixas à Câmara dos Deputados e ao Senado - Os direitos do cidadão na formação do Estado Imperial brasileiro (1822-1831). Tese (Doutorado em História) Universidade Federal Fluminense, Niterói, 2008 e SLEMIAN, Andréa, 2010, op. cit. Cap. 2.

${ }^{205}$ Sobre o impacto da dissolução da Assembleia Constituinte na Bahia possuo um artigo: SOUZA FILHO, Argemiro Ribeiro de. Autonomia política e centralização: a província da Bahia no Primeiro Reinado. In: COSTA, Wilma Peres; OLIVEIRA, Cecília Helena Salles de (Org.). De um Império a outro: Formação do Brasil, séculos XVIII e XIX. São Paulo: Hucitec; Fapesp. p. 297-312, 2007.

${ }^{206}$ MORAES, Alexandre de Mello, op. cit., t. 2. p. 564-565.
} 
alçou-lhe ao posto de senador, nomeando-o pela província de Alagoas. O futuro marquês podia, finalmente, fazer coro junto aos seus colegas de ofício: não mais falava em nome dos interesses regionais, ou apenas locais. Ao ingressar no Senado imperial, era, doravante, representante da nação. ${ }^{207}$ Inquieto, porém, Caldeira Brant quis por a prova seus conhecimentos militares. E, por isso, assumiu nada menos que o comando do Exército imperial, ingressando, todavia, na desastrosa Guerra da Cisplatina (1825-1828).

No campo de batalha platino, o ex-inspetor das tropas da capital baiana recebeu contingentes de homens com frio e mal alimentados. A maioria dos soldados havia sido recrutada nas províncias do Norte, especialmente na Bahia e em Pernambuco, onde os governos locais e central encontraram um meio útil de se ver livres daquela "negrada". Expressão esta que aparece na documentação da época e bem esclarece sobre o tratamento que os homens de cor encontraram no Exército depois das pelejas pela Independência e de terem também combatido, ou ainda participado, da Confederação do Equador (1824). Como a guerra na Banda Oriental do Rio da Prata já se aproximava de quase dois anos e as dívidas com os gastos no Exército se confundiam com a situação crônica das finanças do Império, Caldeira Brant, dando pouca importância às condições de seus subordinados, procurou, logo na primeira oportunidade, acossar o inimigo, mas acabou surpreendido. Depois de horas de cerrado combate, as tropas imperiais começaram a recuar e a debandada só não fora completa devido à intrepidez dos soldados nortistas, como reconhecera o próprio Barbacena. O Exército imperial perdia a famosa batalha do Passo do Rosário (ou Itunzaingó), ocorrida em 20 de fevereiro de 1827, e Caldeira Brant retornava às atividades senatoriais no Rio de Janeiro. ${ }^{208}$

Concluída a guerra e confirmada a vitória dos platinos, que declararam seu território livre e fundaram a nação uruguaia, o então marquês de Barbacena foi o homem escolhido por d. Pedro I para formar um gabinete composto só de brasileiros. A tentativa era de contornar a crítica situação enfrentada por seu governo, seja a oposição na Câmara dos Deputados, autorizada a funcionar em 1826, seja a crescente insatisfação da opinião pública manifesta especialmente por meio da imprensa. ${ }^{209}$ À frente do ministério da

\footnotetext{
${ }^{207}$ Em defesa do seu biografado, Pandiá Calogeras assevera que o marquês de Barbacena havia sido uma dos maiores senadores do seu tempo, a quem o próprio regente Feijó recorrerá para o seu governo, mas, como Caldeira Brant já se encontrava com a saúde fragilizada, colheu apenas os seus conselhos de versado político. CALOGERAS, João Pandiá, op. cit. p. 235-236.

${ }^{208}$ Para o resumo desses eventos, tomo como base a bem documentada pesquisa de JUNQUEIRA, Lucas de Faria, op. cit.

${ }^{209}$ Para o contexto político que levara d. Pedro I renovar os quadros no ministério para tentar mitigar as críticas da oposição na Câmara dos Deputados concernente à crise política que tomava conta do Primeiro Reinado, ver PEREIRA, Vantuil, op. cit. p. 156 e segs.
} 
Fazenda, Caldeira Brant ficou à vontade para montar o ministério, anunciado em 4 de dezembro de 1829. Dando crédito àquela autonomia administrativa, os deputados e os jornais abrandaram a crítica ao governo central. ${ }^{210}$ Entretanto, isso não foi suficiente para superar as contradições que marcavam o governo centralizado de d. Pedro I.

O Imperador não somente demitiu todo o gabinete, em princípios de outubro de 1830, como deu a conhecer que o ministro da Fazenda havia se locupletado com os recursos da nação, quando do contrato do seu segundo casamento com a princesa Amélia de Leuchtenberg, o qual negociara em viagem à Europa entre outubro de 1827 e dezembro de 1829. De considerável amigo de d. Pedro, o marquês de Barbacena tornou-se seu desafeto. ${ }^{211}$ Mas este não deixou por menos, pois escarafunchou um assunto que devia ser bem penoso aos Bragança, lembrando ao imperante a possibilidade dele padecer da mesma doença que, no passado, atormentara alguns dos seus antecedentes. Em carta de 15 de dezembro, destinada a d. Pedro I, o marquês, teria escrito: “Um dos tios-avós de V. M. I. acabou seus dias em uma prisão em Sintra. V. M. I. poderá acabar os seus em alguma prisão de Minas a título de doido [...]". ${ }^{212}$

Deixemos de lado as suscetibilidades de d. Pedro I e do marquês de Barbacena para dar atenção ao ex-secretário do Conselho Interino, Miguel Calmon du Pin e Almeida. A despeito da atuação discreta que teve na Assembleia Constituinte, sua adesão ao grupo político ligado ao imperador era evidente. Tendo, anteriormente, administrado a Fazenda Pública da província baiana durante a Guerra de Independência, o futuro marquês de Abrantes foi requisitado para preencher o ministério da Fazenda em um momento muito delicado para as finanças do governo central. De fato, em 1827, os recursos monetários do Império encontravam-se profundamente empenhados, seja pela grande difusão da moeda de cobre falsa que circulava em importantes províncias, como era o caso da Bahia, seja por causa dos gastos decorrentes das despesas com a Guerra da Cisplatina. ${ }^{213}$ Foi justamente neste cenário que o baiano Miguel Calmon passou a integrar o primeiro escalão do governo de d. Pedro I, atuando como ministro da Fazenda entre novembro de 1827 e junho de 1828

\footnotetext{
${ }^{210}$ Cf. Idem, ibidem, p. 157-158.

${ }^{211}$ Pandiá Calogeras argumenta que uma das razões para o afastamento do marquês de Barbacena residia nos ataques formulados pelos portugueses palacianos insatisfeitos com a política do ministério. CALOGERAS, João Pandiá, op. cit.

${ }^{212}$ Apud LUSTOSA, Isabel, 2006, op. cit. p. 19.

${ }^{213}$ Sobre a "enxurrada" de moedas de cobre falsas que circularam na Bahia na década de 1820, ver SILVA, Daniel Afonso da, op. cit. Cap. 2 e SOUZA FILHO, Argemiro Ribeiro de, 2003, op. cit. Cap. 3.
} 
e, passados mais dois meses, voltou a assumir o mesmo o ministério, entre setembro de 1828 e dezembro de $1829 .^{214}$

Viabilizando-se enquanto experiente homem de Estado naqueles anos, o futuro marquês de Abrantes sagrar-se-ia como uma das poucas lideranças que, após tornar-se proeminente no crítico governo de d. Pedro I, conseguiria transitar nas cúpulas administrativas tanto no período das Regências (1831-1840), como durante o Segundo Reinado (1840-1889). A pasta da Fazenda estaria sob sua direção em mais quatro ocasiões distintas. Nos anos de 1837 e 1839, preencheu o ministério, retornando àquelas funções entre 1841 e 1843, pouco tempo após o início do governo de d. Pedro II. Mais tarde, em 1854, com a ascensão do famoso Gabinete da Conciliação (1853-1856) capitaneado por José Honório Hermeto Carneiro Leão (1801-1856), o marquês de Paraná, novamente Miguel Calmon seria responsável pela pasta da Fazenda, tornando-se então um dos prestigiados coadjuvantes do ministério das capacidades. ${ }^{215}$ Finalmente, entre os anos de 1863 e 1864, o quase septuagenário marquês de Abrantes ainda emprestaria sua experiência na condução das finanças imperiais.

Outra figura influente na dinâmica de consolidação política do Brasil Império fora o baiano Francisco Gê Acaiaba Montezuma. Regressando do exílio somente após a abdicação, o ex-secretário do Conselho Interino reavaliou sua posição política durante a Assembleia de 1823, considerando-a imatura. Dessa maneira, seu ângulo de visão se encontrava, uma vez mais, com o dos irmãos Andrada, que também avaliaram as suas participações na primeira Constituinte do Brasil como negativa. Pode-se dizer que Montezuma tornara um Caramuru, pois defendia o retorno de d. Pedro ao trono imperial, situação que o alinhava aos políticos conservadores. Com a aprovação do Ato Adicional, em 1834, e a posterior eleição de Diogo Feijó para a Regência no ano seguinte, o futuro visconde de Jequitinhonha, aproximou-se novamente dos liberais. Nos meses finais da Regência comandada pelo padre paulista, Montezuma foi nomeado para o ministério da Justiça, onde permaneceu entre maio e setembro de 1837. Posteriormente, fundou a Ordem dos Advogados do Brasil (OAB), em 1843. Elegeu-se também deputado provincial pelo Rio de Janeiro (1847-1850). Desfrutando de grande prestígio como político e advogado, o mulato Montezuma integrou o Conselho de Estado, em 1850, na condição de conselheiro

\footnotetext{
${ }^{214}$ MORAES, Alexandre de Mello, op. cit., t. 2. p. 565 e segs.

${ }^{215}$ Do famoso Gabinete da Conciliação participaram, além de Miguel Calmon (Fazenda), Bernardo Pereira de Vasconcelos (Justiça); Rodrigues Torres (Marinha), Sebastião do Rego Barros (Guerra) e Maciel Monteiro Araújo Lima (Negócios Estrangeiros), o marquês de Olinda. Cf. RODRIGUES, José Honório. A política de conciliação: História cruenta e incruenta. In: RODRIGUES, José Honório. Conciliação e reforma no Brasil: um desafio histórico-cultural. Rio de Janeiro: Civilização Brasileira, p. 23-111, 1965.
} 
extraordinário e, no ano seguinte, conseguiu, finalmente, ser nomeado senador por sua província de origem. ${ }^{216}$

No campo liberal, à exceção de Cipriano Barata que, coerente com os seus princípios radicais, foi obrigado a suportar as perseguições políticas nas masmorras imperiais devido não abrir mão de fustigar um governo fortemente apegado às feições dinásticas e aristocráticas, somente José Lino Coutinho e Antônio Ferreira França empolgaram o poder, em 1826, na condição de líderes entre os deputados imperiais. ${ }^{217}$ De fato, estes dois baianos estiveram entre as principais lideranças da oposição parlamentar ao governo centralizado durante os anos finais do Primeiro Reinado. ${ }^{218}$ No âmbito da Câmara dos deputados, não se deve deixar de mencionar também a atuação do ex-deputado da Assembleia Constituinte, o baiano José da Costa Carvalho, que integrou a legislação de 1826-1829 e sendo novamente indicado para o segundo mandato como deputado eleito pela Bahia, acabou renunciando ao posto parlamentar, indo assumir a direção da Faculdade de Direito de São Paulo. Em 1839, Costa Carvalho foi nomeado senador por Sergipe, seguindo, desde então, as orientações do partido conservador. ${ }^{219}$ Outros quadros foram eleitos como deputados pela província da Bahia na primeira legislatura, mas, ao que tudo indica, pouco conseguiram intervir nos rumos políticos do Primeiro Reinado, a exemplo dos juristas Antônio da Silva Teles e Luís Paulo de Araújo Bastos.

Como seria de se esperar, a vida política no Rio de Janeiro seguia, pouco a pouco, modificando as relações sociais e, especialmente, as familiares de vários dos indivíduos que se tem aqui analisado. De fato, a corte imperial se consolidava como rota migratória preferencial para todos aqueles que desejassem usufruir das vantagens que a formação e a consolidação do Estado e da nação brasileiros poderiam oferecer. Aos

\footnotetext{
${ }^{216}$ Kátia Mattoso forneceu dados bibliográficos que bem sumarizam a trajetória advocatícia e política de Montezuma. MATTOSO, Kátia M. de Queirós, 1992, op. cit. p. 273-274.

${ }^{217}$ Lino Coutinho alcançaria a direção do ministério da Justiça, em julho de 1831, três meses após a abdicação de d. Pedro I. MORAES, Alexandre de Mello, op. cit., t. 2. p. 571. Na segunda legislatura (18301834), a população da Bahia elegeu o mulato Antônio Pereira Rebouças que, com perfil liberal, atuaria nas seguintes legislaturas: 1830-1833, 1834-1837 e 1843-1844. Todavia, Rebouças não adquiriria status de líder da oposição. Sobre a atuação política desse baiano na Câmara dos Deputados, ver GRINBERG, Keila. $O$ fiador dos brasileiros: cidadania, escravidão e direito civil no tempo de Antônio Pereira Rebouças. Rio de Janeiro: Civilização Brasileira, 2002.

${ }^{218}$ Sobre as contribuições de José Lino Coutinho e de Antônio Ferreira França no combate ao governo centralizado ver PEREIRA, Vantuil, 2008, op. cit. p. 161. Entretanto, o verdadeiro aliado de Lino Coutinho na oposição, a partir da Câmara dos Deputados, seria o jovem mineiro Bernardo Pereira de Vasconcelos (1795-1850) que se tornara deputado aos 26 anos de idade e logo se destacaria naquela Casa legislativa. Idem, ibidem. p. 192 e segs.

219 Para a trajetória de José da Costa Carvalho, que no decurso do Segundo Reinado se portaria como suporte político ao grupo dos "intransigentes defensores do princípio conservador" na província de São Paulo, ver MATTOS, Ilmar Rohloff de. O tempo Saquarema: A formação do Estado Imperial. 3. ed. Rio de Janeiro: Access, 1994. p. 102. A citação acima encontra à página 235.
} 
primeiros que migraram para a nova órbita do poder, acresciam, para além da família nuclear (esposa e filhos), irmãos, sobrinhos, afilhados ou outros agregados pertencentes à vasta parentela que, por decênios a fio, sobreviveu ao Brasil colonial. Como exemplo dessa mobilidade, que se tornaria muito comum naqueles anos, encontra-se o caso do ex-ouvidor da comarca de Ilhéus e desembargador da relação da Bahia Baltazar da Silva Lisboa (17611840). Nos dias em que a sua província se convulsionava com a Guerra de Independência, o sexagenário Baltazar partiu para a corte, indo viver próximo ao seu irmão, o futuro senador visconde de Cairu. Logo, adquiriu o posto de ouvidor sindicante do Rio de Janeiro, e como tantos outros migrantes, passou os anos finais da sua vida habitando a corte fluminense.

Com efeito, tornava-se cada vez mais constante a integração de novos personagens aos círculos dos negócios, das relações familiares, bem como da política, daqueles baianos que, pioneiramente, haviam se transferido da província em busca de melhores oportunidades no centro do Império que, de português, subvertera-se em brasileiro. A despeito das mudanças políticas no decorrer do Oitocentos, decerto demoraria algum tempo para que se notasse alterações nas redes de sociabilidade entre os indivíduos oriundos da Bahia e os habitantes da corte imperial. Antes disso, a presença numerosa de baianos em postos políticos importantes no governo imperial - ministérios, diplomacia, conselhos e tribunais superiores - sobretudo na primeira metade do século XIX, atestava o lugar de relevo ocupado pela província nos anos fundamentais de conformação da nação brasileira. ${ }^{220}$ Ademais, não se pode esquecer que laços políticos e uniões afetivas não raras vezes fortaleceram ainda mais interesses comuns entre os membros de poderosas famílias, imbricando a complexa modelagem da estrutura social. ${ }^{221}$

Se no campo das estruturas econômicas, assegurou-se a permanência das relações escravistas e das suas condicionantes, algumas modificações, inclusive na composição dos organismos políticos, não passaram desapercebidas a olhares mais atentos. Em 1834, o diplomata francês Saint-Priest, em visita ao novo Império, viu no espaço senatorial a oportunidade para alguns "mulatos" ostentarem as suas ascensões político-sociais, a exemplo dos senadores Carvalho e Mello e Felisberto Caldeira Brant. Para tanto, dizia:

\footnotetext{
${ }^{220}$ PINHO, Wanderlei. A Bahia, 1808-1856. In: HOLANDA, Sérgio Buarque de. História Geral da Civilização Brasileira. O Brasil Monárquico. Dispersão e Unidade. 5. ed. São Paulo: Difel, 1985. p. 302.

${ }^{221}$ Os espaços da política, dos negócios e dos interesses familiares se encontraram, por exemplo, quando, em fins dos anos de 1820, foi celebrado na corte imperial o enlace matrimonial entre José Carlos de Almeida e Ana Constança Brant Pontes, respectivamente, o filho do primeiro presidente do Senado, o marquês de Santo Amaro e a filha do marquês de Barbacena (Caldeira Brant), tornando mais ubíqua a pujança daquelas famílias que, deixando suas províncias de origem, refaziam as mais diversas alianças na capital do Império.
} 
"Les mulâtres ne forment point une classe à part, il y a eu beaucoup de mulâtres dans les clubs, mais non des clubs de mulâtres. Ils sont mêlés, confondus avec tour le monde: on en trouvé dans l'esclavage, dans les plus vils métriers, mais on en trouve aussi dans le monde et au Sénat". 222

Pandiá Calogeras registrou que ao se anunciar a composição do gabinete de 4 de dezembro de 1829, que além do marquês de Barbacena (Fazenda), contava também com os baianos marquês de Caravelas (Império) e Miguel Calmon (Estrangeiros), o maranhense visconde de Alcântara (Justiça), o fluminense marquês de Paranaguá (Marinha) e o português conde de Rio Pardo (Guerra), houve, na corte, quem disso desdenhasse. Isto porque o amigo português do imperador, o Chalaça (Francisco Gomes da Silva - 17911852), referia-se ao novo gabinete como o ministério de cinco crioulos, deixando de fora somente o conde de Rio Pardo, seu compatrício europeu. ${ }^{223}$ Era o sinal dos tempos, uma nova classe dirigente se afirmava no Império e por mais que pretendesse se distanciar dos segmentos sociais menos favorecidos a quem deveria representar, a epiderme mestiça, como a da maioria da população do Brasil, denunciava as origens miscigenadas de uma geração que se definiria como brasileira.

${ }^{222}$ Apud MOREL, Marco, 2005, op. cit. p. 292.

${ }^{223}$ CALOGERAS, João Pandiá, op. cit. p. 213. Era o visconde de Alcântara, o maranhense João Inácio da Cunha (1781-1834) e o conde de Rio Pardo o português Tomás José Pereira Valente (1790-1849). 


\section{Conclusão}

Dotada de condições geográficas, materiais e humanas que lhe garantia papel de destaque na consecução dos projetos com que a Coroa portuguesa intentou superar a crise do Antigo Regime em fins do século XVIII, a capitania da Bahia beneficiou-se da política de modernizações, compensações e cooptações levada adiante pelo governo bragantino. Assegurou-se, assim, o incremento da pauta agroexportadora, bem como das importações de mão-de-obra escrava africana para atender as novas exigências. Diversos também foram baianos que seguiram para a Europa em busca de titulação acadêmica, estimulados pela possibilidade de participarem mais ativamente dos negócios da administração, entre outras funções disponíveis na rígida estrutura do governo imperial. Todavia, a potencialização da crise política que assolou as monarquias absolutas no mundo ocidental e, em particular, as ibéricas, exigiria muito mais do que programas reformistas para a sua superação. A transferência do centro de poder do Império português para a América, em 1808, dimensiona a gravidade da situação enfrentada pelos Bragança e é no interior desse quadro político que reside a complexa tessitura entre os antigos e os novos padrões de comportamento compartilhados a partir de então pelos habitantes do vasto território da América portuguesa. Se, por um lado, a presença da corte em terras americanas possibilitou o fortalecimento dos laços de adesão entre os súditos e o príncipe regente, através de variados canais de beneficiamentos e concessões. Por outro, permitiu também o aprofundamento das contradições políticas e a emersão de novas críticas, particularmente em se tratando das capitanias do Norte, insatisfeitas com a posição privilegiada do Rio de Janeiro, novo lócus do poder central.

Apesar disso, não restam dúvidas que para uma parcela dos habitantes da Bahia, mormente os que detinham posições de mando na estrutura político-econômica da capitania, os anos finais do Antigo Regime foram de significativas realizações. A bem

dizer, o reordenamento do Império português na América revigorou as condições de mediação com as classes proprietárias locais sem, todavia, encontrar soluções que assegurassem a estabilidade política do sistema que com o advento do constitucionalismo se veria profundamente alterada. As formas consagradas de resolução dos conflitos entre as instituições governamentais e a população não mais correspondiam às exigências postas pelo movimento liberal, perdendo, em definitivo, a sua operacionalidade. Compreende-se, portanto, que, entre os anos de 1821 e 1823, a Bahia experimentou um período de grande 
agitação política que envolveu amplos segmentos sociais e permitiu a construção de distintas alternativas de encaminhamento da crise, fornecendo concretude a projetos coletivos e individuais. Além do mais, o que desperta a atenção na dinâmica histórica desses anos é a extrema rapidez com que as mutações políticas se manifestaram.

De fato, a intensidade dos eventos que marcaram a conformação da nação independente em território baiano redundara em um quadro político complexo capaz de exprimir antagonismos e fortes tensões, seja entre os segmentos de baixa extração social e as classes dominantes, seja entre as próprias facções no interior desta última. Como resultante, os arranjos políticos regionais que possibilitaram a deflagração, manutenção e o desfecho da Guerra de Independência fizeram emergir os pólos de rivalidades entre poderes paralelos organizados na Bahia por esse período. Expressão e símbolo da autonomia provincial, a Junta Governativa de Salvador, vinculada às Cortes de Lisboa, não conseguiu impedir a criação de outros governos parciais no interior da província baiana. De outro modo, a atuação do Conselho Interino, situado na vila de Cachoeira, desnuda a violência com que esse órgão governativo impôs a sua vontade em detrimento dos demais interesses concorrentes. Torna-se perceptível as dificuldades para se fixar convergências em torno de um projeto político que satisfizesse as demandas de um amplo arco de alianças. No plano externo, os desdobramentos dos conflitos ameaçavam a garantia da unidade territorial e, internamente, as classes proprietárias viam-se atemorizadas ante o alargamento do espaço público, exigindo o concerto de novas soluções. Não à toa, o Senado da Câmara da vila de São Francisco se posicionara, em 29 de junho de 1822, justificando a necessidade de aproximação com a regência de d. Pedro, como meio de "prevenir que algum espírito mal intencionado" pudesse "romper em excessos anárquicos, ou desviar-se do sistema monárquico constitucional que temos jurado manter, cujo perigo em verdade é iminente [...]".

A despeito de as classes dominantes não se constituírem um grupo monolítico, haja vista a própria Guerra de Independência que dispôs em lados opostos indivíduos detentores de condições socioeconômicas similares, as graves dissensões revelaram-se essenciais na rearticulação de posições conciliatórias entre parte das classes dirigentes e o poder central. É plausível admitir que, se por um lado, a proclamação da Revolução Constitucionalista na Bahia produziu, oficialmente, o rompimento político e financeiro da província com a corte fluminense, por outro, as inter-relações políticas, comerciais e

\footnotetext{
${ }^{1}$ Termo de vereação da Câmara da Vila de S. Francisco para a aclamação do Príncipe Real, regente e defensor perpétuo do Brasil. In: MORAES, Alexandre de Mello, op. cit. t. 2. p. 134.
} 
familiares entre os habitantes desses dois eminentes centros de poder não esvaneceram. De forma que vindo à tona as primeiras frustrações americanas com as Cortes de Lisboa, já em fins de 1821, aliadas às graves conturbações e às incertezas experimentadas na América portuguesa neste período, uma proeminente articulação envolvendo autoridades residentes no Rio de Janeiro e na Bahia adquiriu densidade, a ponto de se mostrar essencial aos rumos de Portugal e do Brasil a partir de 1822.

Desse modo, o profundo aprendizado político no decorrer dos conflitos na província foi fundamental para forjar novas lideranças capazes de intermediarem negociações em torno de um projeto unitário de Estado independente, monárquico e constitucional para o continente do Brasil. Foi neste contexto que as redes de sociabilidade entre a Bahia e a corte fluminense adquiriram singular importância não somente na prevenção de uma possível radicalização do processo político, como também na definição do arcabouço jurídico-institucional do governo centralizado conduzido por d. Pedro I. O elenco desta intricada e célere modelagem fora, assim, percebido por Cipriano Barata:

[...] hoje tudo tem sido obrado nas Províncias por movimentos necessários, segundo os tempos e as circunstâncias e necessidades públicas, acomodadas as causas e boas razões políticas que nos têm acompanhado. Daqui se vê que todos os fenômenos políticos aparecidos no Brasil, revoluções, guerras, Independência, Imperador, Ministros de Estado, Instituições novas, arranjos, Ordem do Cruzeiro, Deputados, Cargos e Dignidades, Batalhões, Postos militares, Generais, tudo em uma palavra tem sido efetuado por uma rápida promoção e criação, salto e movimento extraordinário segundo se tem julgado preciso para conservação e duração da nova Ordem de coisas que os Brasileiros fizeram criar em benefício da pátria e fidelidade desta porção do Gênero Humano nascidos nestas Plagas bem-aventuradas que Deus deu em partilha exclusiva aos Homens cor de cobre ou caboclos e a seus descendentes, misturados e únicos herdeiros e naturais Senhores. ${ }^{2}$

Enquanto a aceleração do tempo histórico fornecia indicativo sobre o soterramento do Antigo Regime na América portuguesa, intensificavam-se as lutas entre os defensores da preservação de elementos de arcaicas estratificações e os que se apegavam às rupturas coerentes com o futuro que desejavam ver implementado. Disso resultaria um movimento de Independência de caráter ambíguo e contraditório: Foi liberal, ao livrar-se de algumas persistentes amarras da dominação colonial, conquanto não deixasse de ser conservador, pois preservava a instituição escravista e reforçava o poder da classe

\footnotetext{
${ }^{2}$ Sentinela da Liberdade na Guarita de Pernambuco Alerta!, n. 25, sábado, 22 de junho de 1823. Recife, Tipografia de Cavalcante e Carvalho. In: BARATA, Cipriano, 2008, op cit. p. 296.
} 
senhorial. Permitiu, ademais, a criação da "nação" sob a hegemonia da ideologia do senhoriato que permaneceria profundamente avessa a flexibilizar sua dominação social e política. ${ }^{3}$

Do ponto de vista historiográfico, a perspectiva da pesquisa que ora se conclui procurou reforçar os estudos mais recentes que têm rompido com a visão do processo de formação do Estado e da nação brasileiros centrados a partir do Rio Janeiro. Tomando a província da Bahia como objeto de análise, o esforço aqui empreendido objetivou compreender a abrangência das articulações entre a província e o poder central. Disputando espaços políticos em meio à formação do Estado imperial, emergem nesse cenário indivíduos como os irmãos Carneiro de Campos, Luís José de Carvalho e Mello, Antônio Luís Pereira da Cunha, José da Silva Lisboa, José Egídio Álvares de Almeida, Felisberto Caldeira Brant, Miguel Calmon du Pin e Almeida, entre outros, cujas trajetórias constituíram, quando vistas em conjunto, no principal esteio de sustentação do governo centralizado que d. Pedro I implementara no Brasil, além de expressiva participação na Regência e em princípios do Segundo Reinado. A rigor, no decorrer dos vinte gabinetes ministeriais organizados entre a Independência e o Gabinete da Conciliação (1853-1856), a Bahia só deixou de ter representantes em apenas oito, como registrara Wanderley Pinho. ${ }^{4}$

Dessa maneira, admite-se que enquanto o profundo aprendizado político de parte das classes dirigentes no processo de superação da crise do Antigo Regime e do Sistema Colonial serviu como experiência para aprimorar os meios de exercício do poder. Para os segmentos que reconheciam na soberania popular a única fonte de legitimidade da nação iniciava-se um tortuoso processo na busca por um projeto político autônomo.

\footnotetext{
${ }^{3}$ NOVAIS, Fernando Antônio; MOTA, Carlos Guilherme. A independência política do Brasil. 2. ed. São Paulo: Hucitec, 1996. p. 13.

${ }^{4}$ PINHO, Wanderley. A Bahia, 1985, op. cit. p. 302.
} 


\section{Fontes Documentais e Bibliográficas}

\section{Documentos Digitalizados}

- Relatório dos trabalhos do Conselho Interino de Governo da província da Bahia, em prol da Regência e do Império de sua magestade imperial o senhor D. Pedro I e da Independência Política do Brasil, redigido e offerecido ao grande constitucional e defensor perpétuo do Brazil, e ao heróico povo da província da Bahia por Miguel Calmon d' Pin e Almeida. Bahia: Typographia Nacional, 1823. Disponível em: <http://www.crl.edu/content/brazil/BAH.htm> Acesso em: 14 ago. 2008.

- BRASIL. Carta Constitucional (1824). Constituição Política do Império do Brazil, de 25 de março de 1824. Disponível em: < http://www.planalto.gov.br/ccivil_03/constituicao/constitui\%C3\%A7ao24.htm> Acesso em: 21 mar. 2010.

- Ministros do Império do Brasil. Disponível em: < http://www.fazenda.gov.br/portugues/institucional/ministros/dom_pedro004.asp>. Acesso em: 31 Out. 2010.

- Gazeta de Lisboa, ano 1824, edições 1-151. Disponível em: $<$ http://books.google.com.br/books?id=xw8wAAAAYAAJ\&pg=PA454\&dq=\%22Gaz eta+de+Lisboa\%22+\%221826\%22+\%22senador\%22\&hl=pt-

BR\&ei=XoncTKSGHsGC8gaKsaGaCQ\&sa=X\&oi=book_result\&ct=result\&resnum= $1 \&$ ved $=0 \mathrm{CC} 8 \mathrm{Q} 6 \mathrm{AEwAA \# v}=$ onepage $\& \mathrm{q}=\mathrm{Clemente} \% 20$ Ferreira $\% 20 \mathrm{Fran} \% \mathrm{C} 3 \% \mathrm{~A} 7 \mathrm{a} \&$ $\mathrm{f}=$ false $>$ Acesso em : 02 Fev. 2009.

- Gazeta de Lisboa, ano 1826, edições 153-309. Disponível: <http://books.google.com.br/books?id=XREwAAAAYAAJ\&pg=RA1PA1309\&lpg=R A1-

PA1309\&dq $=\% 22$ Gazeta + de + Lisboa22 +22 Cunha + Moreira22 \&source $=$ bl\&ots $=b q 7 \mathrm{Nt}$ 36wAF\&sig=04J5OJRwMsI2N58QYv83sx1 x6XY\&hl=ptBR\&ei=Gp3WTLLQAoKB $8 \mathrm{gaJ} r \mathrm{CxCg} \& \mathrm{sa}=\mathrm{X} \&$ oi=book_result $\& \mathrm{ct}=$ result\&resnum $=1 \& \mathrm{ved}=0 \mathrm{CBkQ} 6 \mathrm{AEwAA \# v}$ $=$ snippet\&q=Bahia\&f=false $>$ Acesso em: 20 Mar. 2009.

- O Independente, n. 9, sábado, 9 de março de 1822 [p. 526]. Disponível em: <http://books.google.com.br/books?id=_vovAAAAYAAJ\&printsec=frontcover\#v=on epage $\& q \& \mathrm{f}=$ false $>$. Acesso em: 21 nov. 2009.

\section{Documentos Manuscritos}

\section{Arquivo Público do Estado da Bahia - APEB (Salvador)}

\section{Fontes}

\section{Manuscritas}

Seção de Arquivo Colonial e Provincial

Série Colônia

- Catálogo de decretos Governo da província. Maço: 626-14 
Série Governo (Governo Provisório)

- Registro de correspondência expedida pelo Conselho Interino de Governo. Maços: $637-2$ e 638

Presidência da província (Governo)

- Registro de correspondência expedida pelo Conselho Interino de Governo. Maço: 1618

Setor de microfilmagem

Periódicos

- Idade d'Ouro do Brazil (1820-1823)

- O Constitucional (1822)

- Diário Constitucional (1822)

- O Grito da Razão (1824-1825)

Documentos e Correspondências

- Requerimento dos vivandeiros, condutores e mais habitantes de diversas classes de Cidadãos da Bahia, dirigido ao Príncipe Regente, contra a falta de economia pública e contra os abusos pelos quais sofrem vexames. Bahia, 31 de julho de 1807. 1 documento. APEB. Setor de Microfilmes (Fontes do catálogo 68 - constantes do acervo da Biblioteca Nacional do Rio de Janeiro - Documento, 905).

\section{Fundação Clemente Mariani (Salvador) - FCM/BA}

\section{Fontes}

Impressas

- O Diário Constitucional/depois/O Constitucional. Salvador, Tipografia da Viúva Serva e Carvalho, 1821-1822 - FCM/BA

- Manifesto que ao respeitável público apresenta o cidadão Cypriano José Barata de Almeida sobre a sua súbita, tyranna razão na Bahia, e remessa violenta para esta corte, onde se acha prezo. Com várias ideias úteis ao Brazil inteiro, \&c. \&c., Rio de Janeiro, 20 de julho de 1831. Rio de Janeiro: Typographia de Torres, anno de 1831 - FCM/BA.

- Desengano ao Público ou Exposição dos Motivos da Minha Arbitrária Prisão na Província da Bahia, Rio de Janeiro, 20 de julho de 1831. Rio de Janeiro: Typographia de Torres, anno de 1831.

\section{Centro de Estudos Baianos da Universidade Federal da Bahia. Biblioteca Frederico Edelweiss}

- Sentinella Bahiense, $n^{o}$. 1-15 (1822) (Periódico). 


\section{Memórias, relatos de viajantes e documentos impressos}

AMORIM, Deolino. A Independência do Brasil e as Câmaras do Recôncavo baiano. Revista do Instituto Geográfico e Histórico da Bahia, n. 74, Bahia. p. 213-222, 1947.

Anais da Biblioteca Nacional do Rio de Janeiro. Inventário dos documentos relativos ao Brasil existentes no Arquivo de Marinha e Ultramar de Lisboa. Bahia, v. 301 (1909), 302 (1910), 304 (1912), 307 (1918);

ARMITAGE, John. História do Brasil: desde o período da chegada da família de Bragança, em 1808 até a abdicação de D. Pedro I, em 1831, compilada à vista dos documentos públicos e outras fontes originais formando uma continuação da história do Brasil, de Southey. Belo Horizonte: Itatiaia; São Paulo: Edusp, 1981.

Cartas sobre a Independência, de 1822 a 1823. ARQUIVO NACIONAL. Livro dos termos: homenagens e assentos. Rio de Janeiro: Typografia do Arquivo Público Nacional. 1947. p. 258. Disponível em: < http://www.archive.org/stream/livrodostermosh00bragoog\#page/n13/mode/1up >. Acesso em 15 de maio de 2009.

Atas da eleição dos deputados da província da Bahia às Cortes da nação portuguesa em 02 de setembro de 1821. Revista do Instituto Geográfico e Histórico da Bahia, ano VI, v. 6, n. 19. p. 85-90, 1889.

Atas do Conselho Interino na Cachoeira, $14^{\mathrm{a}}$. Ata de 18 de dezembro de $1882-\mathrm{O}$ brigadeiro Gordilho de Barbuda, chegado do Rio de Janeiro apresenta ao Governo Interino portaria do Imperador para que se proceda à eleição dos deputados à Assembleia Geral Constituinte. Documentos históricos sobre a emancipação política da Bahia. Revista do Instituto Geográfico e Histórico da Bahia, ano III, v. 3, n. 9. p. 341343, 1896.

Ata do Conselho Interino na Cachoeira de 14 de março de 1823. Documentos históricos sobre a emancipação política da Bahia. Revista do Instituto Geográfico e Histórico da Bahia, ano IV, v. 4, n. 12. p. 175-178, 1897.

BARATA, Cipriano. Sentinela da Liberdade e outros escritos (1821-1835). Organização e edição Marco Morel. São Paulo: Edusp, 2008.

BRITO, João Rodrigues de. Cartas Econômico-políticas: sobre a agricultura e comércio da Bahia. Lisboa: Imprensa Nacional, 1821 (Reeditada pelo Governo do Estado da Bahia no ano de 1924).

Correspondência oficial do Conselho Interino de Governo na Cachoeira, em 16 de abril de 1823. Documentos históricos sobre a emancipação política da Bahia. Revista do Instituto Geográfico e Histórico da Bahia, ano V, v. 5, n. 17. p. 363-364, 1898.

COSTA, João Severiano Maciel da et al. Memórias sobre a escravidão. Introdução Graça Salgado. Rio de Janeiro: Arquivo Nacional; Brasília: Fundação Petrônio Portella, Ministério da Justiça, 1988.

Documentos da Municipalidade de Salvador relacionados com a Independência do Brasil. 1821-1823. Salvador: Prefeitura Municipal/Departamento de Cultura da SMEC, 1972.

FERREIRA, Silvestre Pinheiro. Memorias e cartas biográficas (?) sobre a revolução popular, e o seu ministério no Rio de Janeiro desde 26 de fevereiro de 1821 até o regresso de S. M. o Sr. d. João VI com a corte para Lisboa, e os votos dos homens d'Estado que acompanharam a S. M. Carta I. In: Annaes da Bibliotheca Nacional do 
Rio de Janeiro. 1876-1877, v. 2, fascículo n. 1. Rio de Janeiro: Typ. G. Leuzinger \& Filhos, 1877.

FRANÇA, António d'Oliveira Pinto da (Org.). Cartas baianas, 1821-1824: subsídios para o estudo dos problemas da opção na independência brasileira. São Paulo: Nacional; Rio de Janeiro: Núcleo Editorial da Universidade do Estado do Rio de Janeiro, 1980.

FUNDAÇÃO PETRÔNIO PORTELLA. Memórias sobre a escravidão - João Severiano Maciel da Costa et all. Rio de Janeiro: Arquivo Nacional; Brasília: Ministério da Justiça, 1988.

MINISTÉRIO DA JUSTIÇA. As Juntas governativas e a independência. Rio de Janeiro: Arquivo Nacional/Conselho Federal de Cultura, 1975, v. 2.

. A Junta Governativa da Bahia e a Independência. Rio de Janeiro: Arquivo Nacional, 1973.

Ofício do Conselho Interino para Luís Pereira da Nobrega de Souza Coutinho, ministro e secretário de Estado dos Negócios da Guerra. Documentos históricos sobre a emancipação política da Bahia. Correspondência oficial do Conselho Interino do Governo na Cachoeira. Revista do Instituto Geográfico e Histórico da Bahia, ano V, v. 5, n. 1. p. 554-555, 1898.

REBOUÇAS, Antonio Pereira. Recordações Patrióticas. 1821-22. Revista do Instituto Geográfico e Histórico da Bahia, n. 48. p. 455-506, 1923.

SOUZA, Antonio Moniz de. Viagens e observações de um brasileiro. Organização e notas de Ubiratan Castro de Araújo. 3. ed. Salvador: Instituto Geográfico Histórico da Bahia, 2000 (Coleção do arquivo IGHB, 3).

Recurso e adendo ao mesmo que as soberanas Cortes de Portugal dirigem mil e cinquenta e dois constitucionais da notável, e sempre fiel cidade da Bahia, por seu emissário o cidadão Francisco Mendes da Silva Figueiró. Revista do Instituto Geográfico e Histórico da Bahia, v. 58. p. 295-317, 1932.

Revista do Instituto Histórico Geográfico e Brasileiro. "Memórias políticas sobre os abusos gerais e modo de os reformar e prevenir a revolução popular redigidas por ordem do Príncipe Regente no Rio de Janeiro em 1814 e 1815 (por Silvestre Pinheiro Ferreira)" RIHGB, 1884, tomo 47.

SIERRA Y MARISCAL, Francisco de. Idéias gerais sobre a Revolução do Brasil e suas consequências. Anais da Biblioteca Nacional. v. 43-44. p. 51-81, Rio de Janeiro, 1931.

SILVA, Ignácio de Accioli Cerqueira e. Memórias Históricas e Políticas da Província da Bahia. Anotado por Braz do Amaral. Bahia: Imprensa Oficial do Estado, 19191931, v. 3 e 4.

SILVA, José Bonifácio de Andrada e. José Bonifácio de Andrada e Silva. Organização e introdução de Jorge Caldeira. São Paulo: Ed. 34, 2002.

. Projetos para o Brasil. Organização de Miriam Dolhnikoff. São Paulo:

Companhia das Letras, 1998.

Termo de vereação do Senado da Câmara de Cachoeira em 31 de julho de 1822. Documentos históricos sobre a emancipação política da Bahia. Revista do Instituto Geográfico e Histórico da Bahia, ano II, v. 2, n. 6. p. 377-378, 1895. 
Termo de vereação do Senado da Câmara de Cachoeira em 3 de agosto de 1822 e Termo de fiança e obrigação. Documentos históricos sobre a emancipação política da Bahia. Revista do Instituto Geográfico e Histórico da Bahia, ano II, v. 2, n. 6. p. 378381, 1895.

Termo de vereação do Senado da Câmara de Cachoeira em 7 de agosto de 1822. Documentos históricos sobre a emancipação política da Bahia. Revista do Instituto Geográfico e Histórico da Bahia, ano II, v. 2, n. 6. p. 382-383, 1895.

Termo de vereação do Senado da Câmara de Cachoeira em 21 de agosto de 1822. Documentos históricos sobre a emancipação política da Bahia. Revista do Instituto Geográfico e Histórico da Bahia, ano II, v. 2, n. 6. p. 384-393, 1895.

VILHENA, Luís dos Santos. Recopilação de notícias soteropolitanas e brasílicas. Bahia: Imprensa oficial do Estado, 1921, v. 1 e 2.

\section{Bibliografia:}

- Artigos/Dicionários/Livros

ALEXANDRE, Valentim. Os sentidos do Império. - questão nacional e questão colonial na crise do Antigo Regime português. Porto: Afrontamento, 1993.

AMARAL, Braz do. História da Independência na Bahia. Salvador: Progresso, 1957.

. História da Bahia: do Império à República. Salvador: Imprensa Oficial do Estado, 1923

ARAS, Lina Maria Brandão de. A Santa Federação Imperial: Bahia, 1831-1833. Tese (Doutorado em História Social) - Universidade de São Paulo, São Paulo, 1995.

ARAÚJO, Ubiratan Castro de. A Guerra da Bahia. Salvador: Ceao/UFBA, 2001 (Série Capítulos).

. A política dos homens de cor no tempo da independência. In: DOMINGUES, Carlos Vasconcelos et al (Orgs.). Animai-vos, Povo Bahiense! A conspiração dos Alfaiates. Salvador: Omar G. Editora. p. 100-113, 1999.

ARAÚJO, Valdei Lopes de. A experiência do tempo: conceitos e narrativas na formação nacional brasileira (1813-1845). São Paulo: Hucitec, 2008.

ARRUDA, José Jobson de Andrade; NOVAIS, Fernando Antônio. Prometeus e Atlantes na forja da Nação. Revista Economia e Sociedade, Campinas, v. 12, n. 2, p. 225-243, jul./dez. 2003 (disponível em <http://www.eco.unicamp.br/docdownload/publicacoes/instituto/revistas/economia-esociedade/V12-F2-S21/05-Novaes\%20Jobson.pdf> Acesso em 12 de novembro de 2009).

. O Brasil no comércio colonial, 1796-1808. São Paulo: Ática, 1980.

BANDEIRA, Luiz Alberto Moniz. O feudo: A Casa da Torre de Garcia d'Ávila: da conquista dos sertões à independência do Brasil. Rio de Janeiro: Civilização Brasileira, 2000. 
BARATA, Alexandre Mansur. Maçonaria, sociabilidade ilustrada e independência do Brasil. Juiz de Fora: Ed. UFJF; São Paulo: Annablume, 2006.

BARICKMAN, Bert J. Um contraponto baiano: açúcar, fumo, mandioca e escravidão no Recôncavo, 1780-1860. Rio de Janeiro: Civilização Brasileira, 2003.

BENEDICT, Anderson R. Pioneiros crioulos. In: BENEDICT, Anderson R.

Comunidades Imaginadas: reflexões sobre a origem e a difusão do nacionalismo. São Paulo: Companhia das Letras. p. 84-106, 1998.

BERBEL, Márcia Regina. A nação como artefato: deputados do Brasil nas cortes portuguesas (1821-1822). São Paulo: Hucitec, 1999.

; MARQUESE, Rafael; PARRON, Tâmis. Escravidão e política. Brasil e Cuba, c.1790-1850. São Paulo: Hucitec, 2010.

BERNARDES, Denis Antônio de Mendonça. O patriotismo constitucional: Pernambuco, 1820-1822. São Paulo: Hucitec: Fapesp; Recife: Ed. Universitária da UFPE, 2006.

BLACKBURN, Robin. A queda do escravismo colonial 1776-1848. Rio de Janeiro/São Paulo: Record, 2002.

BETHELL, Leslie; CARVALHO, José Murilo de. O Brasil da Independência a meados do século XIX. In: BETHELL, Leslie (Org.). História da América Latina: Da Independência a 1870. São Paulo: Edusp/Imprensa Oficial do Estado de São Paulo; Brasília: Fundação Alexandre de Gusmão. p. 695-769, 2004, v. 3.

CALMON, Pedro. História do Brasil. Século XIX, o império e a ordem imperial. v. 4, 1959.

CALÓGERAS, João Pandiá. O marquês de Barbacena. 2. ed. São Paulo: Companhia Editora Nacional, 1936.

CÂNDIDO, Antonio. Radicalismos. Estudos avançados, v. 4, n. 8, São Paulo, p. 418, jan./abr. 1990.

CARVALHO, José Murilo de. A construção da ordem: a elite política imperial. Brasília. Ed. Universidade de Brasília, 1981 (Coleção temas brasileiros; v. 4).

CAVALCANTE, Zélia. O processo de Independência na Bahia. In: MOTA, Carlos Guilherme (Org.). 1822: Dimensões. São Paulo: Perspectiva. p. 231-250, 1972.

CHUST, Manuel. La cuestión nacional em lãs Cortes de Cádiz (1810-1814). Valencia: Centro Francisco Tomás y Valiente UNED Alzira-Valencia, Fundación Instituto Historia Social, 1999 (Col. Biblioteca História Social).

COELHO, Hilton Barros. "Authoridades" e "Anarchistas" no "Império da desordem": conflitos e reconfigurações do poder dominante na Bahia da guerra à consolidação da Independência. Dissertação (Mestrado em História) - Universidade Federal da Bahia, Salvador, 2003.

CONSORTE, Josildeth Gomes. A Contribuição Bahiana à Constituinte de 1823. Revista do Instituto Geográfico e Histórico da Bahia, n. 77. p. 239-269, 1952.

COSTA, Emília Viotti da. Da Monarquia à República: momentos decisivos. 8. ed. rev. e amp. São Paulo: Ed. Unesp, 2007.

. Introdução ao estudo da emancipação política. In: MOTA, Carlos Guilherme. Brasil em Perspectiva. 19. ed. Rio de Janeiro: Ed. Bertrand Brasil. p. 64-125, 1990. 
COSTA, Wilma Peres. Do domínio à nação: os impasses da fiscalidade no processo de Independência. In: JANCSÓ, István (Org.). Brasil: Formação do Estado e da Nação. São Paulo: Hucitec; Ed. Unifuí; Fapesp. p. 143-193. 2003.

DIAS, Alexandre Alves. Facinorosos do sertão: A desagregação da ordem no sertão nordestino na transição da colônia até a independência (1808-1822). Dissertação (Mestrado em História) - Universidade Federal de Pernambuco, Recife, 1997.

DIAS, Maria Odila Silva. A interiorização da metrópole. In: MOTA, Carlos Guilherme (Org.). 1822: Dimensões. São Paulo: Perspectiva. p. 160-184, 1972.

DOLHNIKOFF, Miriam. O Pacto Imperial: origens do federalismo no Brasil do século XIX, 2005.

Elites Regionais e a construção do Estado nacional. In: JANCSÓ, István (Org.). Brasil: Formação do Estado e da Nação. São Paulo: Hucitec; Ed. Unifuí; Fapesp. p. 430-468, 2003.

FERNANDES, Florestan. A sociedade escravista no Brasil. In: IANNI, Octávio (Org.). Florestan Fernandes: sociologia crítica e militante. São Paulo: Ed. Expressão popular. p. 349-423, 2004.

GODECHOT, Jacques. Independência do Brasil e a Revolução do Ocidente. In: MOTA, Carlos Guilherme (Org.). 1822: Dimensões. São Paulo: Perspectiva, p. 27-37, 1972.

GRAHAM, Richard. "Ao mesmo tempo sitiantes e sitiados". A luta pela subsistência em Salvador (1822-1823). JANCSÓ, István (Org.). Independência: História e historiografia. São Paulo: Hucitec; Fapesp, p. 411-445, 2005.

GRINBERG, Keila. O fiador dos brasileiros: cidadania, escravidão e direito civil no tempo de Antônio Pereira Rebouças. Rio de Janeiro: Civilização Brasileira, 2002.

GUERRA FILHO, Sérgio Armando Diniz. O povo e a Guerra: Participação das camadas populares nas lutas pela Independência do Brasil na Bahia. Dissertação (Mestrado em História) - Universidade Federal da Bahia, Salvador, 2004.

GUERRA, François-Xavier. Modernidad e independências: Ensayos sobre las revoluciones hispánicas. México: Fondo de Cultura Económica, 1995.

FRAGOSO, João Luís Ribeiro. Homens de Grossa Aventura. Acumulação e hierarquia na praça mercantil do Rio de Janeiro (1790-1830). 2. ed. Rio de Janeiro: Civilização Brasileira, 1998.

; FLORENTINO, Manolo. O arcaismo como projeto: Mercado Atlântico, sociedade agrária e elite mercantil no Rio de Janeiro, 1790-1840. Rio de Janeiro: Editora Diadorin, 1993.

FREYRE, Gilberto. Casa-grande \& senzala: formação da família brasileira sob o regime da economia patriarcal. 30. ed. Rio de Janeiro: Record, 1995.

FURTADO, Celso. Formação econômica do Brasil. 17. ed. São Paulo: Ed. Nacional, 1980.

GRAMSCI, Antônio. Concepção materialista da história. 3. ed. Rio de Janeiro: Civilização Brasileira, 1978.

HOBSBAWM, Eric J. A Era das revoluções: Europa 1798-1848. 16. ed. revisada. São Paulo: Paz e Terra, 2002. 
HOLANDA, Sérgio Buarque de. A herança colonial - sua desagregação. (Org.). História Geral da Civilização Brasileira. 6. ed., tomo II. São Paulo: Difel, 1985, v. 1, p. 9-39.

Raízes do Brasil. 26. ed. São Paulo: Companhia das Letras, 1995.

IZARD. Miguel. El miedo a la revolucion: La lucha por la libertad em Venezuela (1777-1830). Madrid: Editoria Tecnos, 1979.

JANCSÓ, István. Brasil e brasileiros: notas sobre modelagem de significados políticos na crise do Antigo Regime português na América. Estudos avançados. v. 22, n. 62, São Paulo, p. 257-274, jan./abr. 2008.

2005.

.(Org.). Independência: História e historiografia. São Paulo: Hucitec; Fapesp,

. Independência, independências. In: (Org.). Independência: história e historiografia. São Paulo: Hucitec; Fapesp. p. 17-48, 2005.

(Org.). Brasil: Formação do Estado e da Nação. São Paulo: Hucitec; Ed. Unifuí; Fapesp, 2003.

- A construção dos Estados Nacionais na América Latina: Apontamentos para o estudo do Império como projeto. In: SZMRECSÁNYI, Tamás; LAPA, José Roberto do Amaral (Orgs.). História Econômica da Independência e do Império. 2. ed. revista. São Paulo: Hucitec/Associação Brasileira de Pesquisadores em História Econômica/ Edusp /Imprensa Oficial. p. 3-26, 2002.

. Bahia 1798: A hipótese de auxílio francês ou a cor dos gatos. In: FURTADO, Júnia Ferreira (Org.). Diálogos oceânicos: Minas Gerais e as novas abordagens para uma história do Império Ultramarino Português. Belo Horizonte: ed. UFMG. p. 361387, 2001.

. A fundação do Estado e da nação brasileiros (C. 1770-C. 1850). In: ARRUDA, José Jobson; FONSECA, Luís Adão (Org.). Brasil - Portugal: História, agenda para o milênio. Bauru: EDUSC; São Paulo: FAPESP; Portugal: ICCTI. p. 365-381, 2001 (Coleção História).

. A sedução da liberdade: cotidiano e contestação política no final do século XVIII. In: SOUZA, Laura de Mello e (Org.). História da vida privada no Brasil: cotidiano e vida privada na América portuguesa. São Paulo: Companhia das Letras. p. 387-437, 1997, v. 1.

. Na Bahia, contra o Império: História do ensaio de sedição de 1798. São Paulo: HUCITEC; Salvador: EDUFBA, 1996.

; PIMENTA, João Paulo Garrido. Peças de um mosaico (ou apontamentos para o estudo da emergência da identidade nacional brasileira). In: MOTA, Carlos G. (Org.). Viagem Incompleta. A experiência brasileira (1500-2000). Formação: histórias. São Paulo: Senac. p. 127-175, 2000.

JUNQUEIRA, Lucas de Faria. A Bahia e o Prata no Primeiro Reinado: Comércio, recrutamento e Guerra Cisplatina (1822-1831). Dissertação (Mestrado em História) Faculdade de Filosofia e Ciências Humanas - Universidade Federal da Bahia, Salvador, 2005.

KANTOR, Iris. Esquecidos e Renascidos: Historiografia acadêmica luso-americana, 1724-1759. São Paulo: Hucitec; Salvador: Centro de Estudos Baianos/UFBA, 2004. 
KENNEDY, John Norman. Bahian Elites, 1750-1822. Hispanic American Historical Review - Hahr, v. 53, n. 3. p. 415-439, 1973.

KOSELLECK, Reinhart. Futuro Passado: contribuição à semântica dos tempos históricos. Rio de Janeiro: Contraponto: Ed. PUC-Rio, 2006.

KRAAY, Hendrik. Muralhas da independência e liberdade do Brasil: a participação popular nas lutas políticas (Bahia, 1820-1825). In: MALERBA, Jurandir (Org.). A independência brasileira: novas dimensões. Rio de Janeiro: Ed. FGV. p. 303-341, 2006.

. Identidade racial na política, Bahia, 1790-1840: o caso dos henriques. In:

JANCSÓ, István (Org.). Brasil: formação do Estado e da Nação. São Paulo: Hucitec; Ed. Unifuí; Fapesp. p.521-546, 2003.

. Race, State and Armed Forces in Independence-Era Brasil, Bahia, 1790's-

1840's. Stanford: Stanford University Press, 2002.

. "Em outra coisa não falavam os pardos, cabras e crioulos." O "recrutamento" de escravos na Guerra de Independência na Bahia (1822-1823). Revista Brasileira de História. ANPUH/Humanitas, v. 22, no 43. p. 109-126, 2002.

LENHARO, Alcir. As tropas da moderação: o abastecimento da Corte na formação política do Brasil, 1808-1842. São Paulo: Símbolo, 1979.

LIMA, Manuel de Oliveira. O movimento da Independência: 1821-1822. 5. ed. São Paulo: Melhoramentos; Conselho Estadual de Cultura, 1972.

LISBOA, José da Silva. História dos principais sucessos políticos do Império do Brasil dedicada ao senhor d. Pedro I. Rio de Janeiro: Tipografia imperial e Nacional, 1927.

LYNCH, John. As origens da Independência da América Espanhola. In: BETHELL, Leslie (Org.). História da América Latina: Da Independência a 1870. São Paulo: Edusp/Imprensa Oficial do Estado de São Paulo; Brasília: Fundação Alexandre de Gusmão. p. 19-73, 2004, v. 3.

LYRA, Maria de Lourdes Viana. A utopia do poderoso império: Portugal e Brasil: bastidores da política, 1798-1822. Rio de Janeiro: Sette Letras, 1994.

LUGAR, Catherine. The Merchant community of Salvador - Bahia 1780-1830. These (doctorate). University of New York at Stony Brook, 1980.

LUSTOSA, Isabel. D. Pedro I: um herói sem nenhum caráter. São Paulo: Companhia das Letras, 2006.

. Insultos impressos: a guerra dos jornalistas na Independência (1821-1822).

São Paulo: Companhia das Letras, 2000

MALERBA, Jurandir (Org.). A independência brasileira: novas dimensões. Rio de Janeiro: Ed. FGV, 2006.

MAURO, Frédéric. A Conjuntura Atlântica e a Independência do Brasil. In: MOTA, Carlos Guilherme (Org.). 1822: Dimensões. São Paulo: Perspectiva. p. 38-47, 1972.

MORAES, Alexandre José de Mello. História do Brasil-Reino e do Brasil-Império. Belo Horizonte: Ed. Itatiaia; São Paulo: EDUSP, tomos 1 e 2. 1982.

MATTOSO, Kátia M. de Queirós. Bahia, século XIX: uma província no Império. Rio de Janeiro: Nova Fronteira, 1992. 
Ser escravo no Brasil. São Paulo: Brasiliense, 1982.

Os escravos na Bahia no alvorecer do século XIX (Estudo de um grupo social). Revista de História. São Paulo, Jan-março, v. 47, n. 97, ano XXV. p. 109-135, 1974.

MATTOS, Ilmar Rohloff de. O tempo Saquarema: A formação do Estado Imperial. 3. ed. Rio de Janeiro: Access, 1994.

MAXWELL, Kenneth R. A geração de 1790 e a ideia do império luso-brasileiro. In: Chocolate, piratas e outros malandros. Ensaios tropicais. São Paulo: Paz e

Terra. p. 157-207, 1999.

- A Devassa da devassa: a Inconfidência Mineira: Brasil e Portugal 1750/1808. 3. ed. Rio de Janeiro: Paz e Terra, 1985.

MELLO, Evaldo Cabral de. A outra Independência: o federalismo pernambucano de 1817 a 1824. São Paulo: Ed. 34, 2004.

MONTEIRO, Tobias. História do Império. O Primeiro Reinado. Belo Horizonte: Ed. Itatiaia; São Paulo: Edusp, tomos 1 e 2. 1982.

. História do Império: A elaboração da Independência. Belo Horizonte: Ed. Itatiaia; São Paulo: Edusp, t. 2, 1981.

MOREL, Marco. As transformações dos espaços públicos: Imprensa, atores políticos e sociabilidades na cidade imperial (1820-1840). São Paulo: Hucitec, 2005.

Cipriano Barata na Sentinela da Liberdade. Salvador: Academia de Letras da Bahia: Assembleia Legislativa do Estado da Bahia, 2001.

MORTON, F. W. O. The Consertative Revolution of Independence: Economy, society and politics in Bahia (1790-1840). Thesis Submitted to the Board of the Faculty of Modern History in Partial Fulfilment of the Requirements for the Degres of D. Phil, University of Oxford, Oxford, 1974.

. The governorship of the Count of Arcos in Bahia, 1810-1818. Enlightened despotism in an age of revolution, Toronto, outubro de 1986 (mimeog.).

MOTA, Carlos Guilherme. A ideia de revolução no Brasil (1789-1801): Estudo das formas de pensamento. 4. ed. São Paulo: Ática, 1996 (Série Fundamentos, 116).

. Nordeste 1817: estruturas e argumentos. São Paulo: Perspectiva, 1972.

MOTT, Luiz. Um documento inédito para a história da Independência. In: Carlos Guilherme Mota (Org.). 1822: Dimensões. São Paulo: Perspectiva. p. 465-483, 1972.

NEVES, Erivaldo Fagundes. Estrutura Fundiária e dinâmica mercantil: Alto Sertão da Bahia séculos XVII e XIV. Salvador: EDUFBA; Feira de Santana: UEFS, 2005.

. Uma comunidade sertaneja: da sesmaria ao minifúndio (um estudo de história regional e local). Salvador: Edufba; Feira de Santana: UEFS, 1998.

NEVES, Lúcia Maria Bastos Pereira. Corcundas e Constitucionais: A cultura política da Independência (1820-1822). Rio de Janeiro: Ed. Faperj; Revan, 2003.

Liberalismo Político no Brasil: Ideias, Representações e Práticas (1820-1823).

In: GUIMARÃES, Lúcia M. Pascoal e PRADO, Maria Emília (Orgs.). Liberalismo no Brasil imperial. Origens, conceitos e prática. Rio de Janeiro: Revan/UERJ. p. 73-101, 2001. 
NOVAIS, Fernando Antonio. Aproximações: estudos de história e historiografia. São Paulo: Casacnaify, 2006.

. Portugal e Brasil na crise do Antigo Sistema Colonial (1777-1808). 2. ed. São Paulo: Hucitec, 1983.

; MOTA, Carlos Guilherme. A independência política do Brasil. 2. ed. São

Paulo: Hucitec, 1996.

OLIVEIRA, Cecília Helena L de S. A astúcia Liberal: Relações de mercado e projetos políticos no Rio de Janeiro (1820-1824). Bragança Paulista: Ed. Edusf; Ícone, 1999.

PEREIRA, Vantuil. "Ao Soberano Congresso": Petições, requerimentos, representações e queixas à Câmara dos Deputados e ao Senado - Os direitos do cidadão na formação do Estado Imperial brasileiro (1822-1831). Tese (Doutorado em História) - Universidade Federal Fluminense, Niterói, 2008.

PIMENTA, João Paulo Garrido. Estado e Nação no fim dos Impérios Ibéricos no Prata (1808-1828). São Paulo: Hucitec; Fapesp, 2002.

. A política hispano-americana e o Império Português. In: JANCSÓ, Jancsó

(Org.). Brasil: Formação do Estado e da Nação. São Paulo: Hucitec; Ed. Unifuí; Fapesp. , p. 123-139. 2003.

PINHO, Wanderlei de A. A Bahia - 1808-1856. In: HOLANDA, Sérgio Buarque de (Org.). História Geral da Civilização Brasileira. 6. ed. São Paulo: Difel. p. 242-311, tomo II. 1985, v. 2.

. A Abertura dos Portos: Cairu, os ingleses, a Independência. Salvador:

Publicações da Universidade da Bahia, 1961.

PONTES, Kátia Vinhático. Mulatos: Políticos e Rebeldes Baianos. Dissertação (Mestrado em História) - Universidade Federal da Bahia, Salvador, 2000.

PRADO JÚNIOR, Caio. Formação do Brasil contemporâneo. 22. ed. São Paulo: Brasiliense, 1992.

. Evolução Política do Brasil. 6. ed. São Paulo: Brasiliense, 1966.

REIS, João José. Domingos Sodré, um sacerdote africano: escravidão, liberdade e candomblé na Bahia do século XIX. São Paulo: Companhia das Letras, 2008.

. Rebelião escrava no Brasil: a história do levante dos malês em 1835. Edição rev. e amp. São Paulo: Companhia das Letras, 2003.

. A elite baiana face os movimentos sociais, Bahia: 1824-1840. Revista de

História. São Paulo, Out-dezembro, v. 54, n. 108, ano XXVII. p. 341-384, 1976.

RIBEIRO, Eder da Silva. "O Conselho de Estado no tempo de D. Pedro I": um estudo da política e da sociedade no Primeiro Reinado (1826-1831). Dissertação (Mestrado em História) - Universidade Federal Fluminense, Niterói, 2010.

RIBEIRO, Gladys Sabina. A liberdade em construção: identidade nacional e conflitos antilusitanos no primeiro reinado. Rio de Janeiro: Relume Dumará, 2002.

ROCHA, Antonio penalves. Economia Política e Política no Período Joanino. In: SZMRECSÁNYI, Tamás; LAPA, José Roberto do Amaral (Orgs.). História Econômica da Independência e do Império. 2. ed. revista. São Paulo:

Hucitec/Associação Brasileira de Pesquisadores em História Econômica/ Edusp /Imprensa Oficial. p. 27-43, 2002. 
. A economia política na desagregação do Império português. In: CARDOSO, José Luís (Coord.). A economia política e os dilemas do Império luso-brasileiro (17901822). Lisboa: Comissão nacional para as comemorações dos descobrimentos portugueses. p. 149-197, 2001 (Coleção Outras Margens).

Introdução. CAIRU, Visconde de. Visconde de Cairu. Organização e introdução de Antonio Penalves Rocha. São Paulo: Ed. 34. p. 7-50, 2001.

MARTINS, Rocha. O último vice-rei do Brasil. Lisboa: Edição do autor, s.d.

RODRIGUES, Jaime. O infame Comércio: proposta e experiências no final do tráfico de africanos para o Brasil (1800-1850). Campinas, SP: Unicamp/Cecult, 2000.

RODRIGUES, José Honório. Independência: revolução e contra-revolução. Rio de Janeiro: Livraria Francisco Alves, 1975, 3 e 5 v .

. A Assembleia Constituinte de 1823. Petrópolis: Ed. Vozes, 1974.

. A política de conciliação: História cruenta e incruenta. In: RODRIGUES, José Honório. Conciliação e reforma no Brasil: um desafio histórico-cultural. Rio de Janeiro: Civilização Brasileira, p. 23-111, 1965.

RUY, Affonso. A primeira revolução social brasileira (1798). 2. ed. São Paulo: Ed. Nacional, 1978 (Brasiliana; v. 217).

História política e administrativa da cidade de Salvador. Evolução histórica da cidade de Salvador. Salvador: Tipografia Beneditina Ltda (Publicação da Prefeitura Municipal do Salvador; Comemorativa do IV Centenário da Cidade), 1949.

SANTOS FILHO, Licurgo. Uma comunidade rural do Brasil Antigo (aspectos da vida patriarcal no Sertão da Bahia nos séculos XVIII e XIX). São Paulo: Companhia Editora Nacional, 1956.

SCHWARTZ, Stuart B. Segredos internos: Engenhos e escravos na sociedade colonial - 1550/1835. São Paulo: Companhia das Letras, 1995.

SILVA, Eduardo; REIS João José. O jogo duro do dois de Julho: o "Partido Negro" na Independência da Bahia. In: Negociação e conflito: a resistência negra no Brasil escravista. São Paulo: Companhia das Letras. p. 79-98, 1989.

SILVA, Luís Geraldo, Aspirações barrocas e radicalismo ilustrado. Raça e nação em Pernambuco no tempo da Independência (1817-1823). In: JANCSÓ, István (Org.). Independência: história e historiografia. São Paulo: Hucitec; Fapesp. p. 915-934, 2005.

SILVA, Maria Beatriz Nizza da. Semanário Cívico: Bahia, 1821-1823. Salvador: Edufba, 2008.

. A primeira gazeta da Bahia: Idade d'Ouro do Brazil. 2. ed. revista e ampliada. Salvador: Edufba, 2005a.

. Ser nobre na Colônia. São Paulo: Editora da Unesp, 2005b.

. D. Pedro e o Processo de Independência do Brasil. In: Estudos em homenagem a Luís António de Oliveira Ramos, Faculdade de Letras da Universidade do Porto, p. 1011-1018, 2004, Biblioteca Digital. Disponível:

$<$ http://ler.letras.up.pt/site/default.aspx?qry=id015id1128id2143\&sum=sim> Acesso em: 12 fev. 2010.

.Movimento constitucional e separatismo no Brasil (1821-1822). Lisboa: Livros Horizonte, 1988 (Coleção Horizonte Histórico). 
SILVA, Circe Mary Silva da. "A variação dos triângulos esféricos" de Manuel Araújo Guimarães: primeiro impresso de Matemática, no Brasil, após a liberação da imprensa em 1810. In: Revista da SBHC, n. 15. p. 53-66, 1996. Disponível em: < http://www.mast.br/arquivos_sbhc/154.pdf> Acesso em: 20 fev. 2010.

SLEMIAN, Andréa. Sob o império das leis: Constituição e unidade nacional na formação do Brasil (1822-1834). São Paulo: Hucitec; Fapesp, 2009.

; PIMENTA, João Paulo G. A corte e o mundo: Uma história do ano em que a família real portuguesa chegou ao Brasil. São Paulo: Ed. Alameda, 2008.

. Vida política em tempo de crise: Rio de Janeiro (1808-1824). São Paulo:

Hucitec, 2006.

. Seriam todos cidadãos? Os impasses na construção da cidadania nos primórdios do constitucionalismo no Brasil (1823-1824). In: JANCSÓ. István (Org.). Independência: história e historiografia. São Paulo: Hucitec. p. 829-847, 2005.

; PIMENTA, João Paulo G. $O$ “nascimento político do Brasil”. As origens do Estado e da nação (1808-1825). Rio de Janeiro: Ed. DP \& A, 2003.

SOUSA, Avanete Pereira. Poder local e cotidiano: a Câmara de Salvador no século XVIII. Dissertação (Mestrado em História) - Universidade Federal da Bahia, Salvador, 1996.

SOUSA, Maria Aparecida Silva de. Bahia: de capitania a província, 1808-1823. Tese (Doutorado em História Social) - Universidade de São Paulo, São Paulo, 2009.

. A Bahia na crise política do Antigo Regime (1808-1815). Revista de História, n. 159, p. 135-166, ago. de 2008. Disponível em: <http://www.revistasusp.sibi.usp.br/pdf/rh/n159/a06n159.pdf > Acesso em: 14 nov. 2009.

SOUZA FILHO, Argemiro Ribeiro de. Autonomia política e centralização: a província da Bahia no Primeiro Reinado. In: COSTA, Wilma Peres; OLIVEIRA, Cecília Helena Salles de (Org.). De um Império a outro: Formação do Brasil, séculos XVIII e XIX. São Paulo: Hucitec; Fapesp. p. 297-312, 2007.

. A guerra de Independência na Bahia: Manifestações políticas e violência na formação do Estado nacional (Rio de Contas e Caetité). Dissertação (Mestrado em História) - Universidade Federal da Bahia, Salvador, 2003.

SOUZA, Iara Lis Franco Schiavinatto Carvalho. Pátria coroada: o Brasil como corpo político autônomo - 1780-1831. São Paulo: UNESP, 1999.

SOUZA, Ricardo Luís. O antilusitanismo e a afirmação da nacionalidade. Politeia: História e Sociedade/Revista do Departamento de história da Universidade Estadual do Sudoeste da Bahia. Vitória da Conquista - Bahia: Edições Uesb, v. 5, n. 1, p. 133-151, 2005.

TAVARES, Luís Henrique Dias. Independência do Brasil na Bahia. Salvador: Edufba, 2005.

. Da Sedição de 1798 à Revolta de 1824 na Bahia: Estudos sobre a Sedição de 12 de agosto de 1798, o soldado Luís Gonzaga das Virgens, os escravos no 1798, Francisco Agostinho Gomes, Cipriano Barata e Levante dos Periquitos. Salvador: Edufba; São Paulo: Unesp, 2003. 
História da Bahia. 10. ed. rev. e aum. São Paulo: UNESP; Salvador: Edufba, 2001.

VARNHAGEN, Francisco Adolfo de. História da Independência do Brasil: Até ao reconhecimento pela antiga metrópole compreendendo, separadamente, a dos sucessos ocorridos em algumas províncias até essa data. Anotada pelo Barão de Rio Branco e por uma comissão do Instituto Histórico e Geográfico Brasileiro. 4. ed. Revisada e anotada pelo Prof. Helio Vianna. São Paulo: Melhoramentos, 1957.

VILLALTA, Luis Carlos. "O que se fala, o que se lê: língua, instrução e leitura". In: MELLO e SOUZA, Laura de (Org.). História da vida privada no Brasil. Cotidiano e vida privada na América portuguesa. (Coleção dirigida por Fernando A. Novais). São Paulo: Companhia das Letras. p. 332-385, 1997.

WISIAK, Thomas. A 'Nação partida ao meio': tendências políticas na Bahia na crise do Império luso-brasileiro. Dissertação (Mestrado em História) - Universidade de São Paulo, São Paulo, 2001. 